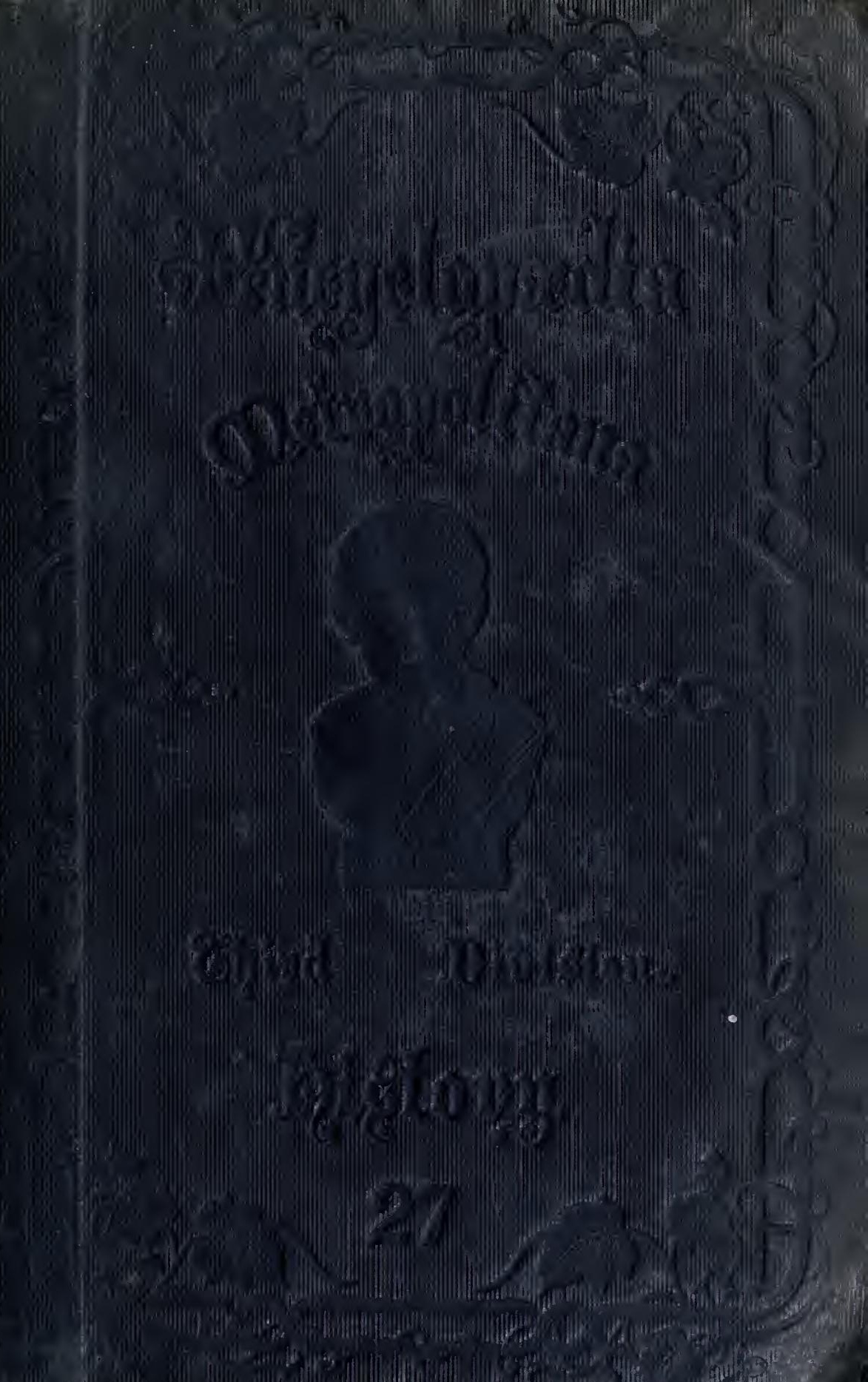




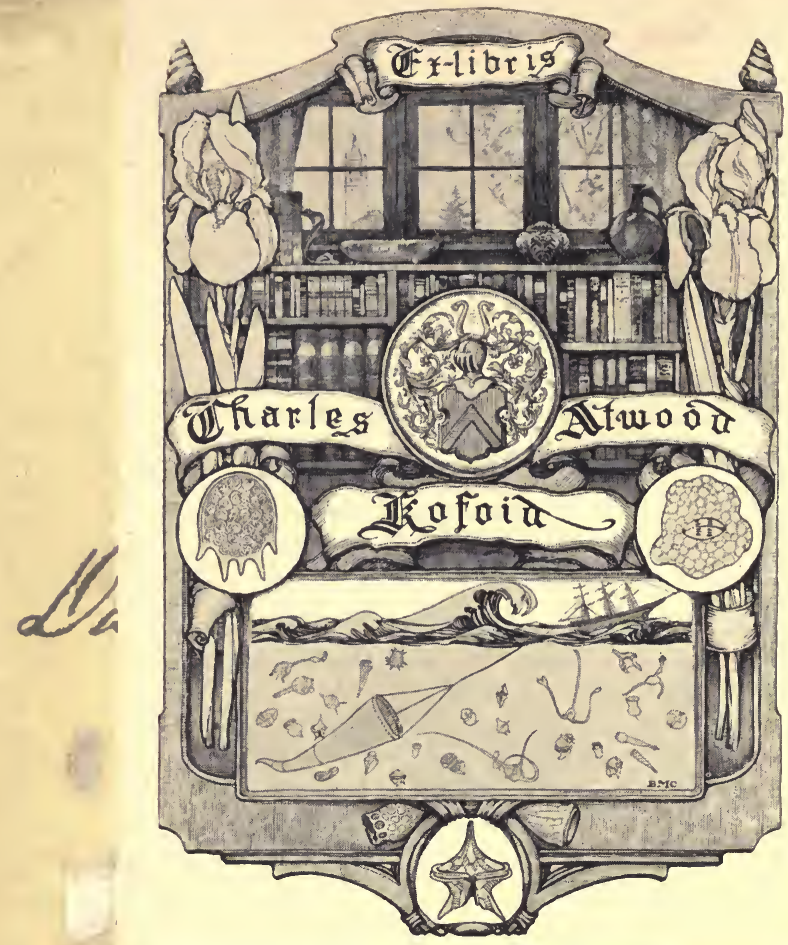



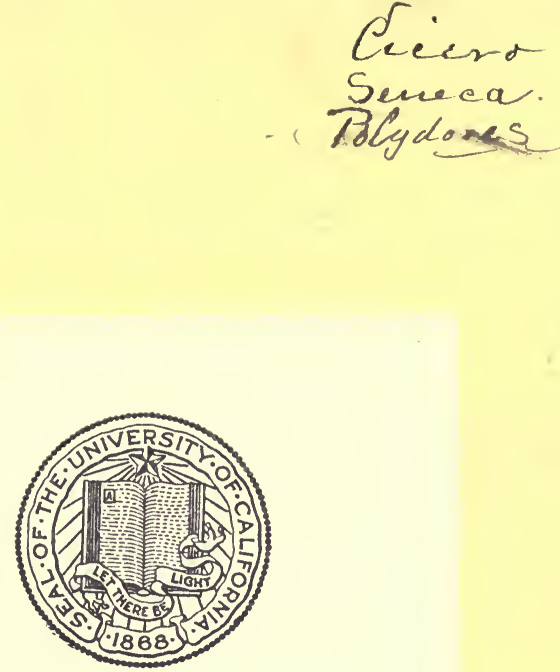

THE LIBRARY $\mathrm{OF}$

THE UNIVERSITY OF CALIFORNIA

PRESENTED BY PROF. CHARLES A. KOFOID AND MRS. PRUDENCE W. KOFOID. 



\title{
NEW WORKS
}

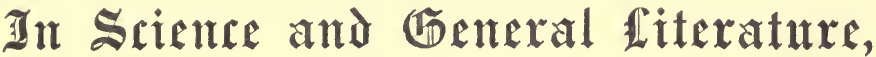

\author{
PUBLISHED BY
}

RICHARD GRIFFIN AND COMPANY,

Peblishers to the University of Glascow,

5 Warwick Square,

PATERNOSTER ROW,

LONDON.

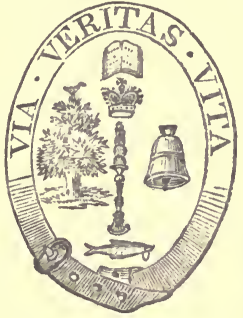

Prince of Wales Buildings,

B U C H A N N - STREET,

GLASGOW.

\section{UIassifiey Enox.}

Agriculture, Botany, and Natural History.

Balfour's Manual of Botany, Book of Nature,

Davy's A gricultural Chemistry,

- Encyclopedia of Natural History.

Mlustrations of Zoology,

Ramsay's Geology of Arran.

White's Natural History of Selborne

Arts and Manufactures.

Book of Trades,

Encyclopæedia of Fine Arts,

$$
\text { Manufactures. }
$$

Graham's Compositor's Guide,

Kerr on the Manufacture of Sugar,

Napier's Manual of Dyeing,

- Electro Metallurgy,

Phillips's Metallurgy.

Treatise on Gold-Mining,

Shier's Directions for Testing Cane-Juice, Biography.

Child's (Mrs.) Good Wives.

Cyclopedia of Modern Religious Biography, smyth's Worthies of England. History and Antiquities.

Campbell's Naval History,

Cox's Biblical Antiquities,

Sacred History.

Eadie's Oriental History,

Ecclesiastical History-Early Christianity,

Ferguson's Roman Republic,

Hale's History of the Jews,

Hinds's Rarly Christianity,

History of Greece,

History of Greece and Macedonia,

History of the Jews,

History of Rome

Jeremie's Church History,

Pococke s India in Greece,

Potter's Grecian Antiquities,

Ramsay's Roman Antiquities,

Stoddart's Introduction to History,

Universal History.

Language and Metaphysics.

Coleridge on viethod.

D'Orsey's S pelling by Dictation,

Bncyclopædia of Mental Philosophy.

History of Greek Literature.

Greek and Roman Philosophy. Roman Literature,

Importance of Literature to Men of Business,

Maurice's Moral Philosophy, -

Mental Science.

Stoddart's Universal Grammar.

Whately's Logic,
Page 2

Encyclopadia of the Medical Sciences, -

- Page 6

Spooner's Veterinary Art, : $:-\div:-8$

Mercantile.

Gilmer'

Reehorst's Com-Keeping, -

Marine Dictionary,

\section{Miscellaneous.}

Encyclopædia Metropolitana, Library Edition, - 5 Ditto, new octavo edition, $\quad-\quad-4$ Griffn's Juvenile Library, - - - - - 5 Popular Library, - - - : Marriage Offering. - - - - - 6 Mitchison's Scottish Song, - - - - - 6 Polson's Law of Nations, - - - - $\quad 7$ Pope's Poetical Works and Translations, - - ? Senior's Political Economy, - - - - - 7

Abbott's Works,

Religious and Moral. Cox's Biblical Antiquities, - - - : : - Geography and Natural History of Palestine, 2 - Manners and Customs of the Israelites, Cyclopædia of Religious Anecdotes, - - - 2 Religious Biography, Cruden's Concordance, Eadie's Biblical Cyclopædia, - - - - - 3 - Biblical Dictionary, - - - - Kingsley's National Sermons, - - - - - 5

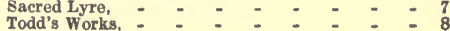

The Sciences and Mathematics.

Airy's Contributions to Encyclopædia Metropolitana, 2 Book of Nature.

Davy's Agricultural Chemistry, - - - -

Encyclopedia of Astronomy, - - - - -2 Experimental Philosophy, - - 3 Mathematics. - - - $\quad 6$ Mechanical Philosophy, $-\quad-6$ Griffin's Crystallography, - - - - - 5 - Scientiflc Catalogue. - - - - 5 Ferschel's Contributions to Encyclop.Metropolitana, 5 Hunt's Photography, - - - 5 Schoedler and Medlock's Scientific Treatises, : Von Kobell's Mineralogy, 
ABBOTT.-MORAL AND EDUCATIONAL WORKS:

Comprising the Young Christian, Teacher, Way to do Good, \&c. 8vo, 5s. cloth. AIRY.-CONTRIBUTIONS TO THE ENCYCLOP EDIA METROPOLITANA : viz. Trigonometry, Figure of the Earth, and Tides and Waves. One Volume, 4to, 10s. 6d. cloth.

ANECDOTES-CYCLOP ADIA OF RELIGIOUS ANECDOTES; A vast Collection of Facts, Narratives, and Examples, with Copious Index, With Introductory Essay by Rev. Dr. CHEever. To which is added a Complete Series of Scriptural Texts illustrated by the Anecdotes. 4th edition. Cr. 8vo, 5s. cl. ASTRONOMY.

THE ENCYCLOP EDIA OF ASTRONOMY.-Plane Astronomy, (Professor BArLow,) Nautical Astronomy, (Captain KATER.) Physical Astronomy, (Sir J. HerscheL, Figure of the Earth, (Professor AIRY,) Tides and Waves, (Professor AIRY.) With 21 Plates, 4to, 14s. cloth.

BALFOUR.-A MANUAL OF BOTANY;

An Introduction to the Study of the Structure, Physiology, and Classification of Plants. By JoHN H.BALFour, F.R.S.E., Professor of Botany in the University of Edinburgh. Numerous Illustrations, Second Edition, crown 8vo, 12s. 6d. cloth.

BOOK OF NATURE:

THE BOOK OF NATURE; a Comprehensive INTroduction to the NATURal and Physical Sciences. From the German of Professor SchoedleR, with numerous Additions, by HenRy Medlock, F.C.S., Senior Assistant in the Royal College of Chemistry, Assistant Secretary of the Chemical Society. With Copious Index, and illustrated by above 500 Engravings, post 8vo, cloth, 10s. $6 \mathrm{~d}$.

First Division-Comprehending Physics, Astronomy, and Chemistry. With above Two Hundred Engravings, Second Edition, post 8vo, cloth, 5s.

Second Division-Comprehending Mineralogy, Geology, Botany, PhyslolOGY, and ZoolOGY. With above 300 Engravings, post 8vo, cloth, 5 s.

BOOK OF TRADES;

Or, Circle of the Useful Arts. Illustrated by Engravings and Woodcuts, Tenth Edition, 16mo, 4s. 6d. cloth.

BUNYAN.-THE PILGRIM'S PROGRESS;

New and beautiful Edition. With numerous Engravings by Harvey, Martin, and Corbould, post 8vo, 7s. cloth.

CAMPBELL.-BRITISH NAVAL HISTORY.

Lives of the British Admirals and Naval History of Great Britain from the 1)ays of Cæsar to tne Present Time. New Edition, with numerous engravings, foolscap 8vo, 3s. 6d. cloth, or 4s. extra gilt.

CHILD (MRS.)-BIOGRAPHIES OF GOOD WIVES.

By the Author of the Mother's Book. Foolscap 8vo, 4s. cloth, richly gilt.

COLERIDGE.-A TREATISE ON METHOD.

Introductory Dissertation to the Encyclopædia Metropolitana on the Science of Method, with a Synopsis. By Samuel Taylor Coleridge. Crown 8vo, 2s. cloth. COX.-BIBLICAL ANTIQUITIES.

BIBLICAL ANTIQUITIES, OR ILLUSTRATIONS OF THE HOLY SCRIPTURES. By the Rev. F. A. Cox, D.D. LL.D. With Maps and nearly 200 Illustrations, crown 8vo, 7s. 6d. cloth.

COX.-PALESTINE.

The Geography and Natural History of Palestine. By F. A. Cox, D.D., LL.D. Numerous Engravings, crown 8vo, 2s. 6d. cloth gilt.

COX.-SACRED HISTORY AND BIOGRAPHY,

From the Antediluvian Period to the Time of the Prophet Malachi. Edited by Rev. F. A. Cox, D.D., LL.D. Crown 8vo, 6s. cloth. COX.—THE ISRAELITES.

The Manners and Customs of The Israenites in relation to their Religion, Civil Polity, and Occupations. By F. A. Cox, D.D., LL.D. Numerous Engravings, crown 8 vo, 2s. 6d., cloth gilt.

CRUDEN.-A COMPLETE CONCORDANCE

To the Holy Scriptures. Condensed and Revised fróm the larger Work of Cruden. By the Rev. Professor EAdIE, D.D., LL.D. Thirteenth edition, 8vo, 5s. cloth. 
DAVY.-AGRICULTURAL CHEMISTRY.

ELEMENTS OF AGRICULTURAL CHEMISTRY. By Sir H. DAVY,

Bart, P.R.S., \&c. New edition, thoroughly Revised, by JoH SHIER, A.M., LL.D., Agricultural Chemist to the Colony of British Guiana. Engravings, 8vo, 3s.6d. cl. D'ORSEY.—SPELLING BY DICTATION;

A Series of Progressive Exercises in English Orthography, Illustrated by 1500 Quotations. By Rev. A. J. D. D'Orsex, High School, Glasgow. Fourth edition, $18 \mathrm{mo}$, 1s. cloth.

EADIE.-A BIBLICAL CYCLOP无DIA ;

Or, Dictionary of Eastern Antiquities, Geography, Natural History, Sacred Annals and Biography, Theology, and Biblical Literature. By the Rev. Professor EADIE, D.D., LL.D. With Maps and numerous Pictorial Illustrations, third edition, 8vo, 10s. 6d. cloth.

EADIE.-A DICTIONARY OF THE BIBLE,

For the Use of Young Persons. By the Rev. Professor Eadie, D.D., LL.D. With 120 Illustrations, second edition, $18 \mathrm{mo}, 3 \mathrm{~s} .6 \mathrm{~d}$. cloth.

EADIE.-EARLY ORIENTAL HISTORY ;

Comprising the History of Egypt, Assyria, Persia, Media, Phrygia, and Phœnicia.

By Rev. Prof. EA DIE, D.D., LL.D. Numerous Illustrations, crown 8vo, 8s. cloth. ECCLESIASTICAL HISTORY.

First Division.-RISE AND EARLY PROGRESS OF CHRISTIANITY. By Right Rev. Samuer Hinds, D.D., Bishop of Norwich, to which is added a Dissertation on Miracles, by Rev. J. H. NEwMAN. D.D. Crown 8vo, 6s. cloth.

SECOND DIVISION. - HISTORY OF THE CHRISTIAN CHURCH IN

THE SECOND AND THIRD CENTURIES. By JAMES A. JEREMIE, D.D., Regius Professor of Divinity in the University of Cambridge. Crown 8vo, 4s. cloth. EXPERIMENTAL SCIENCE.

THE ENCYCLOP EDIA OF EXPERIMENTAL PHILOSOPHY.-Magnetism, Electro-Magnetism, Electricity, Galvanism, Heat, Chemistry, Meteorology, By Professor Barlow, Rev. F. Lunn, Dr. P. M. Roget, and G. HARVEY, Esq. With 39 Plates, 4to, £1. 1s. cloth.

FERGUSON.-HISTORY OF THE ROMAN REPUBLIC.

HISTORY OF THE PROGRESS AND TERMINATION OF THE ROMAN REPUBLIC. By AdAM FERGUSON, LL.D. 8vo, 3s. 6d. cloth.

FINE ARTS.

THE ENCYCLOP EDDIA OF THE FINE ARTS.-Architecture, Sculpture, Painting, Heraldry, Numismatics, Poetry, Music, and Engraving. By NARRIEN, IV EStMacotT, Bishop JaMes, Green, Hughes, GWilt, and LiNdSAY. With 55 Engravings, 4to, £I ls. cloth.

GILMER.-INTEREST TABLES.

Tables for the Calculation of Interest on any Sum for any Number of Days at all Rates, from $\frac{1}{2}$ to 6 per Cent. By RoBERT GILMER. Third Edition, Corrected and Enlarged, royal $18 \mathrm{mo}, 5 \mathrm{~s}$. bound.

GRAHAM.-COMPOSITOR'S GUIDE.

THE COMPOSITOR'S TEXT BOOK; or, Instructions in the Art of Printing.

With Essay on Punctuation. By JoHN Gra HaM. 12mo, 2s. 6d. cloth.

GREECE.-HISTORY OF.

History of Greece from the Earliest Period to the Close of the Peloponnesian War. By E. Pococke, Esq., Rev. J. B. OTtlex, M.A., Sir THomas N. 'TALFOURD, D.C.L., and the late J. T. Rutr, Esq. With One Hundred and Fifty Illustrations." Crown 8 vo, 9 s. cloth.

GREECE AND MACEDONIA-HISTORY OF.

History of Greece from the Age of Xenophon to the absorption of Greece in the Roman Empire, including the Age of Alexander the Great. By WILLIA M ROE LYali, D.D., Rev. J. H. B. Mountain, D.D., Rev. G. C. RenouaRd, B.D., and others. Illustrated by numerous Wood Engravings. Crown 8vo, 8s. cloth.

GREEK LITERATURE.-TALFOURD, \&c.

A HISTORY OF GREEK LITERATURE. By Sir T. N. TALFOURD, Right Rev. Dr. Blomfield, E. Pococke, Esq., Rev. H.'Thompson, M.A., and other Contributors. With Chronological Tables and Index. Crown 8vo, 7s. 6d. cloth.

GREEK AND ROMAN PHILOSOPHY AND SCIENCE.

HISTORY OF GREEK AND ROMAN PHILOSOPHY AND SCIENCE. By the Rev. DR. Blomfield, William Lowndes, Esq., M.A., Q.C., Rev. S. W. Blakesley, M.A., Andrew Findlater, A.M., Rev. Professor Jeremie, Rev. Professor WheweLL, and other Contributors. Crown 8vo, 6s. cloth. 
ENCYCLOP EDIA METROPOLITANA, NEW AND REVISED EDITION. The Second Edition of the Encyclopædia Metropolitana will be handsomely printed in a Series of Cabinet Volumes, in Loug Primer type, in crown 8vo. The work will be thoroughly revised, many new Treatises added, the Articles all provided with comprehensive Indexes, or Analytical Tables of Contents, and abundantly illustrated by Maps, Wood-cuts, and Engravings. It will be published in Volumes, each containing a Complete Treatise.

Vol. 1.-COLERIDGE'S (S. T') DISSERTATION ON THE SCIENCE OF METHOD, revised. With a Synopsis, 2 s.

2.-STODDART'S (SIR JOHN) UNIVERSAL GRAMMAR, or the Pure Science of Language, competely Re-written, 5 s.

3.-WHATELY'S (ARCHBISHOP) LOGIC. With a New Synopsis and Index, 3 s.

4.-WHATELY'S (ARCHBISHOP) RHETORIC. With a New Synopsis and Index, 3s. $6 \mathrm{~d}$.

5.-HINDS'S (BISHOP) HISTORY OF EARLY CHRISTIANTY. Revised, to which is added, NEWMAN'S DISSERTATIUN ON MIRACLES, 6s.

6.-SENIOR'S (NASSAU W.) POLITICAL ECONOMY, $4 \mathrm{~s}$.

7.-HALE'S (ARCHDEACON) HISTORY OF THE JEWS. From the Time of Alexander the Great to the Destruction of Jerusalem, revised, 2s. $6 \mathrm{~d}$.

8.-SACRED HISTORY AND BIOGRAPHY. From the Antediluvian Period to the Time of the Prophet Malachi. Edited and partly written by the Rev. F. A. Cox, D.D., LL.D., revised, 6s.

9.-HISTORY OF GREEK LITERATURE. By Sir THOMAS N. TALFOURD, Right Rev. DR. BLOMFIELD, Bp. of London, \&c. Revised, 7s. $6 \mathrm{~d}$.

10.-MORAL AND METAPHYSICAL PHILOSOPHY. By Professor MAURICE. Part First, the Ancient Systems of Philosophy, re-written, 58 .

11.-INTRODUCTION TO UNIVERSAL HISTORY. By Sir JoHN Stoddart, LL.D., re-written, 5s.

12.-ROMAN ANTIQUITIES. By WILLIAM RAMSAY, M.A., Professor of Humanity in the University of Glasgow. Numerous Engravings, 8s. 6d.

13.-BOTANY. By John Hutton Balfour, F.R.S.E., Professor of Medicine and Botany in the University of Edinburgh. Numerous Engravings, 12s.6d.

14.-ELECTRO-METALLURGY : Containing an..Account of the most Improved Methods of depositing Copper, Silver, Gold, and other metals. With numerous Illustrations. By JAMES NAPIER, F.C.S. 3s. 6d.

15.-HISTORY OF GREECE from the Earliest Periods to the Close of the Peloponnesian War. By Sir Thomas N. TALFourd, D.C.L., Rev. J. B. OtTley, A.M., E. Pococke, Esq., and other Contributors. With One Hundred and Fifty Illustrations, 9s.

16.-PHOTOGRAPHY, embracing Daguerreotype, Calotype, \&c. By RoBERT Hunt, Professor of Mechanical Science in the Museum of Practical Geology, London. Third edition, 54 Wood-Engravings, 6s.

17.-VETERINARY ART, by W.C. SFooner. Fifty-one Engravings, 3s.

18.-EARLI ORIENTAL HISTORY, comprising the History of Egypt, Assyria, Persia, Media, Phrygia, and Phœuicia, by Rev. Professor EAdE, D.D., LL.D. With numerous Illustrations, 8s.

19.-HISTORY OF THE ROMAN REPUBLIC. By the Rev. Thomas ARnold, D.D., Sir Thomas N. Talfourd, D.C.L., the Rev. Professor JEREMIE, and others. With numerous Illustrations, $8 \mathrm{~s}$. $6 \mathrm{~d}$.

20.-BIBLICAL ANTIQUITIES AND GEOGRAPHY. By Rev. F. A. Cox, D.D., LL.D. With Maps and numerous Illustrations, 7s. 6d.

21.-ME'TALLURGY. A Practical Treatise on the Chemistry of the Metals; containing an Account of Assaying, Mining, Smelting, \&c., by John Arthur Phillips, F.C.S., with nearly 200 engravings, 12s. 6d.

22.-HISTORY OF THE CHRISTIAN CHURCH IN THE SECOND AND THIRD CENTURIES; including a Biographical and Critical Account of the Ecclesiastical Writers and Heretics of that Period. By James AmirauX Jeremie, D.D., Regius Professor of Divinity, Cambridge, $4 \mathrm{~s}$.

23.-HISTORY OF GREECE AND MACEDONIA, from the Age of Xenophion to the Absorption of Greece in the Roman Empire. By Dr. LYALL, Dean of Canterbury, Rev. G. C. RenouaRD, B.D., \&c., \&c.. W'ith numerous Illustrations, $8 \mathrm{~s}$.

24.-HISTORY OF ROMAN LITERATURE. By Rev. Thomas ARNol., D.D., Rev. Henry Thomson, M.A., Rev. Dr. Newman, Rev. J. B. OtTley, M.A., and Rev. J. M. NeAle, Warden of Sackville Coll. 10s.6d.

25.-HISTORY OF THE ROMAN EMPIRE. By the Rev. ThOMAS ARNold, D.D., of Rugby, \&c. With numerous Illustrations, 10s. $6 \mathrm{~d}$.

26.-HISTORY OF THE DECLINE AND FALL OF THE ROMAN POWER. By Bishop RUSSEL, \&c., with numerous illustrations, 10s. 6d. 
Excyclopedia Metropolitana, continued.

Vol.27.-HISTORY OF GREEK AND ROMAN PHILOSOPHY AND SCIENCE. By Right Rev. DR. Blomfield, Rev. Professor WHEWELL, Rev. Professor JEREMIE, and others, 6 s.

ENCYCLOPADIA METROPOLITANA, OR UNIVERSAL DICTIONARY OF KNOWLEDGE. Quarto Library Edition.

Complete Sets of the Encyclopædia Metropolitana, (published at $£ 61$ 19s. in parts,) bound in 30 Volumes, 4 to, half-bound Russia extra, in best London binding, $£^{\prime} 25$.

The Large Paper Edition, with Proof Impressions of the Plates, (Published at $£ 1064 \mathrm{~s}$., in Parts, ) in 30 Volumes roval 4 to, half-bound Russia, £30.

GRIFFIN'S JUVENILE LIBRARY, Beattifully Illustrated. JANE SEATON, or the Cornelian Cross, 18mo, 1s. 6d. cloth.

LIFE OF SIR WILLIAM WALLACE, the Scottish Hero, 18mo, 1s. 6d. cloth. LADY SANDFORD'S STORIES from the History of Rome, 18mo, 1s. 6d. cloth. SCRIPTURE SCEN ES, or Views of the Lands of the Bible, 18mo, 1s. 6d. cloth. STORIES OF THE SEA, or Narratives of Battle and Peril, 18mo, 13. 6d. cloth. BOOK OF WONDERS, 18mo, 1s. 6d. cloth.

GRIFFIN.-SCIENTIFIC CATALOGUE.

Illustrated Catalogue of Chemical and Philosophical Apparatus of every description, Cabinets of Minerals, Rocks, \&c. With 1200 Engravings, 8vo, 2s. sewed.

GRIFFIN.-SYSTEM OF CRYSTALLOGRAPHY;

With its Application to Mineralogy. By JoHn J. GrIfFin, F.C.S. 8vo, 12s. cloth. HALE.-HISTORY OF THE JEWS,

From the Time of Alexander the Great to the Destruction of Jerusalem by Titus. By Archdeacon HaLE, Master of the Charter House. Crown 8vo, 2s. 6d. cloth.

HERSCHEL.-CONTRIBUTIONS TO THE ENCYCLOP ÆDIA METROPOLITANA: viz. Physical Astronomy, Light, and Sound. One Volume, 4to, cloth, 21s.

HINDS.-HISTORY OF EARLY CHRISTIANITY.

THE RISE AND EARLY PROGRESS OF CHRISTIANITY. By Right Rev. Dr. Hinds, Bishop of Norwich. New Edition, Revised, crown 8vo, 6s. cloth. HOOPER. - A MEDICAL DICTIONARY.

Eighth Edition, Enlarged. By KLein Grant, M.D. 8vo, 30s. cloth. HUNT.-PHOTOGRAPHY.

A Treatise on the application of the chemical changes produced by Solar Radiation to the production of Pictures from Nature-embracing the Daguerreotype, Calotype, and all the published Photographic processes. By RoBERT HUNT, Esq., Professor of Mechanical Science in the Museum of Practical Geology. Third edition, enlarged. With numerous Engravings, crown 8vo, 6s. cloth.

JAMIESON.-RELIGIOUS BIOGRAPHY.

POPULAR CYCLOP EDIA OF MODERN RELIGIOUS BIOGRAPHY.

By the Rev. Robert JAMIESON, D.D. Second Edition, crown 8vo, 5s., cloth.

JEREMIE.-CHURCH HISTORY.

HISTORY OF THE CHRISTIAN CHURCH IN THE SECOND AND

THIRD CENTURIES; including a Biograplical and Critical Account of the Ecclesiastical Writers and Heretics of that Period. By JaMeS AMIraUX JEREMre, D.D., Regius Professor of Divinity, Cambridge. Crown 8vo, 4s. cloth. JEWS-HISTORY OF.

Brographical Annals of the Hebrew Nation, from the Earliest Period to the Destruction of Jerusalem under Titus. By the Venerable ARCHDEACON HALE Rev. Dr. Cox, Dr. MASON GOoD, and others. With Landscape Illustrations, Crown 8vo, antique cloth binding, 8 s.

KERR.-MANUFACTURE OF SUGAR ;

A Practical Treatise on the Cultivation of the Sugar Cane and the Manufacture of Sugar. By Thomas KerR, of Barbadoes. Crown 8vo, 5s. cloth.

KINGSLEY.-NATIONAL SERMONS.

By the Rev. Charles Kingsley, Canon of Middleham, and Rector of Eversley, author of Y east, Alton Locke, \&c. Foolscap 8vo, 5s. cloth.

LITERARY STUDIES.

The Importance of Literature to Men Engaged in Business. A Series of Addresses by the Duke of Argyll-Earl of Carlisle-A rchbishop Whately-Sir David Brewster-Sir John Herschel-Sir A rchibald Alison-Lord Mahon-Charles Knight-Hon. B. D'Israeli, M.P.-Sir T. N. Talfourd, \&c. fcap. 8vo. 5s. cloth. 
MANUFACTURES AND MACHINERY.

THE ENCYCLOP EDIA OF ARTS, MANUFACTURES, AND MACHINERY. By Professor BARLOW. With an Introductory Dissertation, by Professor BABBAGE. New edition, illustrated by 87 Pages of Engravings by Lowry, 4to, 42s. half russia, or emblematical cloth binding.

MATHEMATICS.

THE ENCYCLOP EDIA OF PURE MATHEMATICS, comprehending a complete Course of Mathematical Science. By Professors AIRx, BARLow, DE Morgan, Hali, Hamilton, Levy, Moseley, Dr. Lardner, F.R.S., and Rev. Dr. PEacock, Dean of Ely. With 17 Engravings, $£ 1$ 1s. cloth.

MARRIAGE OFFERING;

A Compilation of Prose and Poetry. Foolscap 8vo, 4s. cloth, richly gilt.

MAURICE.-MORAL AND METAPHYSICAL PHILOSOPHY :

ANCIENT PHILOSOPHY, comprising the Hebrew, Egyptian, Hindoo, Chinese, Persian, Grecian, Roman and Alexandrian Systems of Philosophy. By Rev. F. D. MAURICE, Chaplain to Lincoln's Inn, Professor of Ecclesiastical History, King's College, London. Crown 8vo, 5s. cloth.

MODERN PHILOSOPHY, comprising the Philosophy of the First Six Centuries, the Middle Ages, and the Modern Systems. Crown 8vo. In the Press.

MECHANICAL PHILOSOPHY.

THE ENCYCLOP EDIA OF MECHANICAL PHILOSOPHY.-Mechanies, Hydrodynamics, Pneumatics, Sound, Optics, Light, illustrated by 78 Plates. By Professor BarLow and Sir JoHN Herschel. 4to, £1 11s. 6d. cloth.

MEDICAL SCIENCE.

THE ENCYCLOP EDIA OF THE MEDICAL SCIENCES.-Anatomy, by J. F. South, Esq., F.L.S., and F. LE Gros Clark, Esq.; Surgery, by W. Bowman, Esq., F.R.S.; Materia Medica, by G. JoHnson, Esq., M.D.; Elementary Principles of Medicine, by R. WILlia MS, Esq., M.D.; Veterinary Árt, by W. C. SPOoNER, Esq., with 18 Engravings, 14s. cloth.

MENTAL SCIENCE.

THE ENCYCLOP EDIA OF MENTAL PHILOSOPHY, by S. T. COLERIDGe, Sir J. Stoddart, LL.D., Archbishop Whately, R. JEbB, Esq., A. Polson, Esq., Professors Maurice, Graves, and Corrie, and the Rev. Dr. Rose. 4to, 14s. cloth.

MENTAL SCIENCE.

Samuel Taylor Coleridge on METHOD ; Archbishor Whately's TreaTISES ON LOGIC and RHETORIC. In One Volume, forming a Section of the Encyclopedia Metropolitana, crown 8vo, 5s. cloth.

MITCHISON.-HAND-BOOK OF SCOTTISH SONG.

A HAND-BOOK OF THE SONGS OF SCOTLAND, containing the best Songs of Burns, \&c. Set to Music. With Notes, and Life of Wilson. By WiLliam Mitchison. Crown 8vo, 2s. 6d. cloth.

MORRISON.-BOOK-KEEPING ;

A Complete System of Practical Book-keeping by Single Entry, Double Entry, and a New Method. By C. Morrison, Accountant, Glasgow. Eighth edition, 8vo.. 8s. half-bound.

NAPIER.-DYEING.

A Manual of Dyeing, Practical and Theoretical, by James Narier, F.C.S. With Engravings. Post 8vo, 7s. 6d., cloth.

NAPIER.-ELECTR0-METALLURGY;

Containing an Account of the most Improved Methods of depositing Copper, Silver, Gold, and other metals, with numerous Illustrations. By JAMES NAPIER, F.C.S. Second edition, revised and enlarged. Crown 8vo, 3s. 6d. cloth.

NATURAL HISTORY.

THE ENCYCLOP EDIA OF NATURAL HISTORY.-Botany, Zoology, Physiology, Crystallography, Mineralogy, and Geology. With 131 quarto Plates. By ThoMAS EDWARDS, Esq., F.L.S.; GEORGE DoN, Esq., F.L.S.; J. H. BROOKE, E'sq.; J. F. South, Esq.; and Profs. PhILLIPS and DA UBENY. 4to, £1 15s. cloth.

PHILLIPS.-METALLURGY ;

A Mandal of Metallurgy: being an Account of Assaying, Mining, Smelting, \&c., by J.A. Philbips, F.C.S., late Professor of Metallurgy at the College for Civil Engineers. With nearly 200 engravings. Crown $8 v 0,12 s .6$ d. cloth. 


\section{PHILLIPS.-GOLD MINING;}

A POPULAR TREATISE on GOLD-MINING, and the ASSAYING and VALUATION of NATIVE GOLD, with an Account of the Processes of Gold. Washing, Amalgamation, Cupellation, Parting, Fusion of Gold into Ingots, \&c. By J. A. PHillips, F.C.S., late Professor of Metallurgy at the College for Civil Engineers. Numerous Illustrations, second edition, foolscap 8vo, 2s. 6d. cloth. POCOCKE._INDIA IN GREECE,

Or, TRUTH IN MYTHOLOGY, containing an Account of the Sources of the Hellenic Race, the Colonisation of Egypt and Palestine from India, the Wars of the Grand Lama, and the Bud'histic Propaganda in Greece. By E. Pococke, Esa. Illustrated by Maps of India and Greece, post 8vo, 12s. cloth.

POLSON.-PRINCIPLES OF THE LAW OF NATIONS,

With Practical Notes on the Law of Blockade, and on Contraband in War. By Archer Polson, Esq., Lincoln's Inn. To which is added DIPLOMACY. By Thomas Hartwell Horne, B.D. Crown 8vo, 3s. 6d. eloth.

POPE.-POETICAL WORKS.

COMPLETE POETICAL WORKS and TRANSLATIONS of ALEXANDER POPE. Portrait and Vignette. New Edition, 8vo, 5s. cloth.

POPULAR LIBRARY;

A Miscellany of Amusement and Instruction, illustrated by numerous Engravings. $12 \mathrm{mo}, 5 \mathrm{~s}$. cloth.

POTTER.-GRECIAN ANTIQUITIES:

THE ANTIQUITIES OF GREECE. By John Potter, D.D., late Archbishop of Canterbury. New edition, edited by Dr. BoY D, High School, Edinburgh, with numerous Illustrations. $12 \mathrm{mo}, 4 \mathrm{~s}$. $6 \mathrm{~d}$. cloth.

RAMSAY.-ROMAN ANTIQUITIES;

a Mandal of Roman Antiquities. By William Ramsay, M.A., Professor of Humanity in the University of Glasgow, with Map, numerous Engravings, and very copious Index. Second edition, crown Svo., 8s. 6d. cloth.

RAMSAY.-THE GEOLOGY OF THE ISLAND OF ARRAN, From Original Survey. By A. C. RAMsay, F.R.S., F.G.S., Professor of Geology in the Museum of Economic Geology, London. Engravings, 8vo, 2s. 6d. cloth. REEHORST._POLYGLOTT COMMERCIAL DICTIONARY,

In Ten Languages. English, Dutch, German, Danish, Swedish, French, Italian, Spanish, Portuguese, and Russian. With Table of Coins, Weights, Measures, \&c. By K. P. TER REeHorst, Oblong 8vo, 3s. cloth.

REEHORST.POLYGLOTT MARINE DICTIONARY,

In Ten Languages. English, Dutch, German, Danish, Swedish, French, Italian. Spanish, Portuguese, and Russian. Comprehending upwards of 5000 Technical Terms. By K.P. Ter ReeHorst. Oblong 8vo, 7s.6d. cloth.

RELIGIOUS DENOMINATIONS.

A CYCLOP EDIA OF RELIGIOUS DENOMINATIONS. An Authentic Account of the various Religions prevailing throughout the World, written by Members of the respective Bodies. Second Editioll, crown 8vo, 5s. cloth.

ROME-HISTORY OF.

HISTORY OF ROME, from the Foundation of the City of Rome to the Extinction of the Western Empire. By the Rev. Thomas Arnold, D.D., the Rev. J. A. Jeremie, D.D., Sir Thomas Noon Talfourd, D.C.L., and others. Illustrated by numerous Engravings. Three Volumes, crown 8vo, cl. extra, $£^{\prime 1} 9 \mathrm{~s} .6 \mathrm{~d}$.

1. The Roman Refublic, 150 Engravings, 8s. 6d. clotl.

2. The Roman EMPIRE, 10s. 6d. cloth.

3. The Decline and Fall of the Roman Power, 10s. 6d. cloth.

ROMAN LITERATURE.-ARNOLD, THOMPSON, \&c.

A HISTORY OF ROMAN LITERATURE. By the late Dr, ARnold, Rev. Henry Thompson, M.A., Rev. J. H. Newman, D.D., the Rev.J. M. Neale, and other Contributors. Crown 8vo, 10s. 6d. cloth.

SACRED LYRE;

Comprising Poems Devotional, Moral, and Preceptive, including many Original Pieces. Fifth edition, medium $32 \mathrm{mo}$, 1s. 6 d. cloth, gilt.

SENIOR.-POLITICAL ECONOMY ;

The Science which Treats of the Nature, Production, and Distribution of Wealth, forming part of the Encyclopædia Metropolitana. By NASSAU W. SENIOR, late Professor of Political Economy, Oxford. Crown 8vo, 4s. cloth. 


\section{SCHOEDLER AND MEDLOCK'S SCIENTIFIC TREATISES,}

Crown 8vo, cloth.

ASTRONOMY. Second Edition. With 51 Engravings. 1s.6d.

BOTANY. With 121 Engravings. 1s. 6d.

CHEMISTRY. Second Edition. With 50 Engravings. 2s.

MINERA LOGY and GEOLOGY. With 128 Engravings. 2s. 6d.

NATURAL PHILOSOPHY. Second Edit. With 150 Engravings. 2s.6d. ZOOLOGY and PHYSIOLOGY. With 84 Engravings. 2s.

SHIER-MANUFACTURE OF SUGAR.

Directions for 'Testing Cane Juice, with Practical Instructions for conducting the process of Clarification. By JoHN SHIER, LL.D., Agricultural Chemist to the Colony of British Guiana. Twenty-seven Cuts, crown 8vo, 3s. cloth.

SMYTH.-WORTHIES OF ENGLAND;

Or, Memoirs of Eminent Men, whose actions have shed a lustre on the History of their Country. By George Louis Smyth. Portraits, medium 8vo, 5s, cloth.

SPOONER.-VETERINARY ART.

A Practical Treatise on the Diseases of the Horse. By W. C. Spooner, Esq. With 50 Engravings, forming part of the Encyclopædia Metropolitana, crown 8vo, 3s. cloth. STODDART.-INTRODUCTION TO HISTORY;

Two Dissertations-FIrst: On the Uses of History as a Study. SEcond: On the Separation of the Early Facts of History from Fable. By Sir JoHN STODDART, LL.D. Crown 8vo, 5s. cloth.

STODDART.-UNIVERSAL GRAMMAR,

Or, the Pure Science of Language. By Sir JoHn Stoddart, LL.D. Second edition, crown 8vo, 5 s. cloth.

STODDART.-GLOSSOLOGY,

Or, the Historical Relations of Languages. By Sir JoHN StoddaRT, LL.D. Crown 8vo, cloth. Nearly ready.

TODD.-COMPLETE WORKS ;

Comprising the Sabbath School Teacher, Student's Manual, \&c. 8vo, 7s. cloth.

UNIVERSAL HISTORY,

Ancient and Modern, from the Earliest Periods of Mankind to the Peace of 1818. By upwards of Forty Contributors, comprising the most Eminent Men of the day. Illustrated by Maps, 5 vols. 4to, £5. 5s. half russia.

USEFUL ARTS.

THE ENCYCLOP EDIA OF THE USEFUL ARTS.-Agriculture, Horticulture, Commerce, Political Economy, Carpentry, Fortification, and Naval Architecture. By GEorge DoN, Esq., F.L.S., JosePH Low, Esq., NASSAU William Senior, Esq., \&c., with 19 plates, 4to, 14s. cloth.

VON KOBELL.-MINERALOGY:

Instructions for the Discrimination of Minerals by Simple Chemical Experiments. By Franz Von Kobeld, Professor of Mineralogy in the University of Munich. Translated by R. C. Campbell, 8vo, 2s. sewed.

WHATELY.-LOGIC.

Original Edition, complete, forming part of the Encyclopædia Metropolitana. With Synopsis and Index. Crown 8vo, 3s. cloth.

WHATELY.-RHETORIC.

Original Edition, complete, forming part of the Encyclopædia Metropolitana. With Synopsis and Index. Crown 8vo, 3s. 6d. cloth.

WHITE.-THE NATURAL HISTORY OF SELBORNE.

THE NATURAL HISTORY OF SELBORNE, with Observations on various parts of Nature, and the Naturalist's Calendar. By Rev. GilbERT W Hite, A.M. New edition, greatly enlarged by Captain THomas BRown, F.L.S., \&c. With coloured Illustrations, foolscap $8 \mathrm{vo}$, cloth, $3 \mathrm{~s}$. 6d., or richly gilt, $4 \mathrm{~s}$.

ZOOLOGY-ILLUSTRATIONS OF.

A Series of Ninety Engravings, comprehending about a Thousand Figures of Quadrupeds, Birds, Fish, Reptiles, Mollusca, Insects, Crustacea, Polyps, \&c., engraved by J. W. Lowry and Thomas Landseer, after Sowerby, Charles Landseer, and others. The Descriptions, selected from articles contributed to the Encyclopædia Metropolitana, by JoHN FLiNT Soutr, Esq., F.L.S., J. E. GraY, Esq., F L.S., J. F. StefHens, Esq., F.L.S., F.Z.S., and others. Imperial 4to, 31s. 6d. cloth, gilt edges, or $42 \mathrm{~s}$. half-morocco, gilt edges. 


\title{
ENCYCLOPEDIA METROPOLITANA;
}

or,

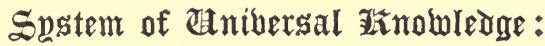

\author{
ON A METHODICAL PLAN
}

PROJECTED BY SAMUEL TAYLOR COLERIDGE.

SECOND EDITION, REVISED.

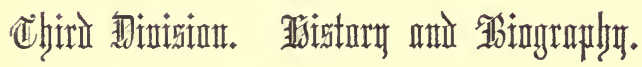

\section{GREEK AND ROMAN \\ PHILOSOPHY AND SCIENCE.}

LONDON AND GLASGOW:

PUBLISHED BY RICHARD GRIFFIN AND COMPANY, PUBLISHERS TO THE UNIVERSITY OF GLASGOW. 
LONDON : PRINTED BY WILLIAM CLOWRS ANJ SONS, STAMFORD STREET. 


\section{HISTORY}

oF

\section{G R E E K A N D R 0 II A N}

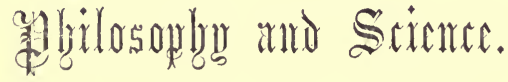

BY

CHARLES JAMES BLOMFIELD, D.D. BISHOP OF LONDON;

WILLIAM LOWNDES, Esq., M.A., Q.C. BRAZENOSE COLLEGE, OXFORD;

Rev. J. W. BLAKESLEY, M.A. VICAR OF WARE, LATE FELLOW AND TUTOR OF TRINITY COLLEGE, CAMBRIDGE;

ANDREIV FINDLATER, A.M. JOHN HENRY NEWMAN, B.D. FORMERLY FELLOW OF ORIEL COLLEGE, OXFORD;

JAMES AMIRAUX JEREMIE, D.D. REGIUS PROFESSOR OF DIVINITY, CAMBRIPGE;

W. WHEIVELL, D.D., F.R.S. MASTER OF TRINITY COLLEGE, AND PROFESSOR OF MORAL PHILOSOPHY, CAMBRIDGE;

PETER BARLOW, Esq., F.R.S. PROFESSOR AT THE ROYAL MILITARY ACADEMT, WOOLWICH;

AND

The late FRANCIS LUNN, M.A. ST. JOHN'S COLLEGE, CAMBRIDGE. 
.

\section{.}




\section{$B 111$ 457 1853}

\section{P REFACE.}

Ir is difficult to picture the succession of events that compose the history of a nation in any other way than by associating them with the fortunes of individuals. Hence the common complaint that, instead of the histories of peoples, we have only the lives of kings and military leaders. Historians find that this is the readiest way to connect the events, and render them easily remembered.

The same expedient is, perhaps, still more necessary in tracing the progress of human opinions. The history of thoughts is best understood and remembered in connection with the history of the thinkers. Those 'airy nothings' can hardly become fixed objects in the memory, but by giving them 'a local habitation and a name;' and a necessary commentary on the writings or doctrines of a philosopher, is a knowledge of the character and environment of the man.

It is on this principle that, in the present volume, the History of ancient Philosophy and Science is associated with Biographical notices of the leading thinkers and writers. As it is hardly to be supposed that one man should be equally conversant with all the parts of so extensive a subject, the several sketches that compose the volume have been contributed by different hands. Owing to this, and to the circumstance that they stood originally in a different connection, they unavoidably involve some degree 
of repetition and of variation in the plan of execution. Nor is it pretended that they furnish a complete and uninterrupted history of philosophy. Still it is believed that the reader, while making himself acquainted with the lives of some of the most remarkable men of ancient times, will acquire a tolerable notion of the chief phases that speculative opinion presented in the ancient world; and that what the picture thus loses in point of uniformity and continuity, it gains in reality and clearness.

It is almost unnecessary to speak of the important place that Greek and Roman Philosophy holds in the history of intellectual progress. Whatever has been done since had its spring in the speculative energy of Greece; and the present position of philosophy cannot be rightly understood without making ourselves acquainted with the speculations of the men with whom it originated.

The intelligent reader will perceive the deficiencies and errors of the different systems of doctrine here sketched without having them pointed out to him at every step; nor will he less recognise and admire the genius of the men, though they advanced many things that, in the light of the nineteenth century of the Christian era, may seem wrong or were ridiculous. 


\section{O N T E N T S.}

ESOP

Precepts - - - - - - - - - 11

\section{SOCRATES :}

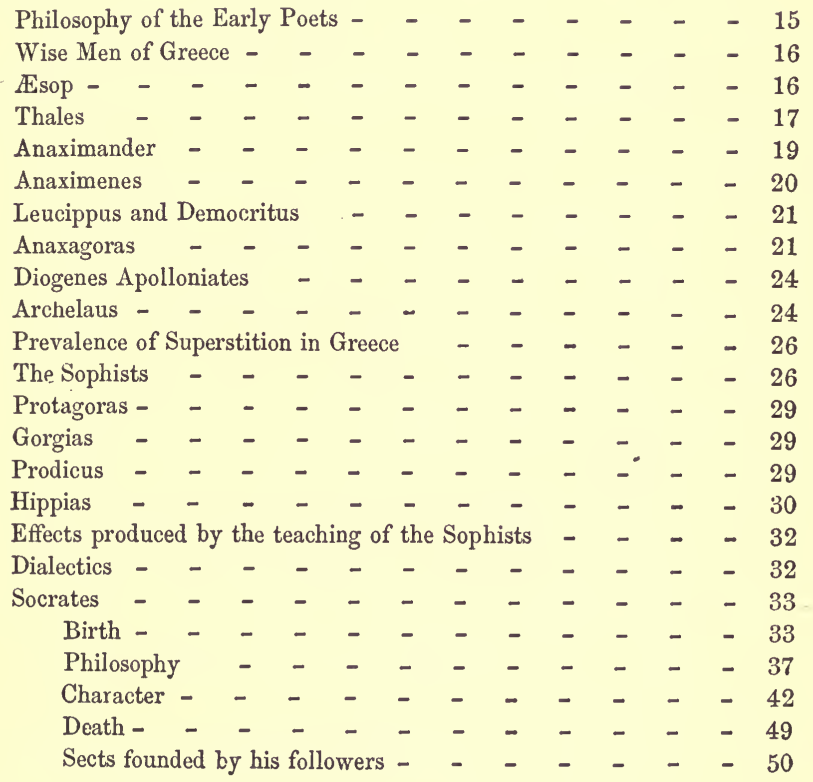

PLATO :

Birth - - - - - - - - - - - - - 53

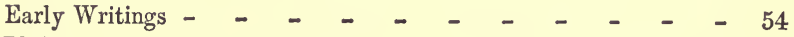

Philosophy of Italy-Heraclitus _ _ _ _ _ _ 57

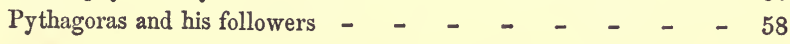


PLATO-continued.

Death

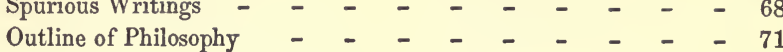

Successors - _ _ _ _ _ _ _ _ - 88

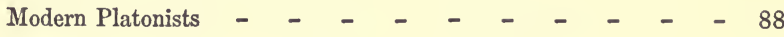

ARISTOTLE :

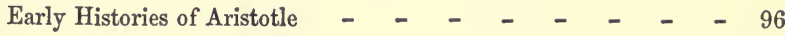

Summary of his Life - _ _ _ _ _ _ _ - 101-147

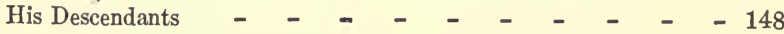

Fate of his Works - _ _ _ _ _ _ _ _ - 150

Ancient Commentators on Aristotle - _ _ _ _ _ -155

Nature of the Exoteric Writings - _ _ _ _ - -159

Nature of the Politics and Poetics - _ _ - _ - -170

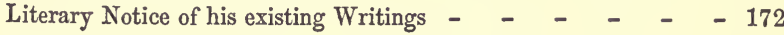

EPICURUS :

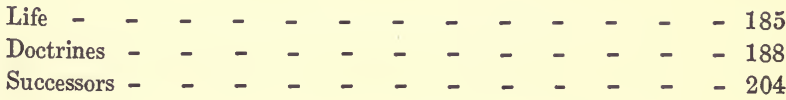

\section{CICERO :}

Character of his Philosophical Writings - _ - _ $~-~ 207$

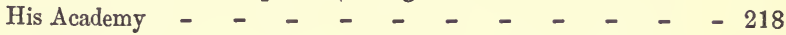

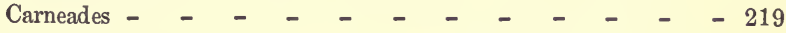

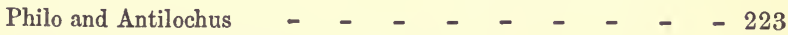

Mixed Philosophy of Cicero _ _ _ _ _ _ $-\quad$ - 223

Rhetorical Works _ _ _ _ _ _ _ _ _ - 227

Moral and Physical Writings - _ _ _ _ _ _ -230

Poetical and Historical Works - _ _ _ _ _ _ - 235

Orations - _ - _ _ _ _ - _ - - - 235

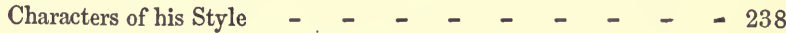

Roman Eloquence - _ _ _ _ _ _ _ _ - 240

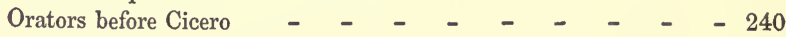

Ciceronian Age - _ _ _ _ _ - _ - _ - 241

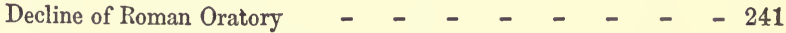

MSS., Editions, \&c., of Cicero's Works - _ _ _ _ -242

SENECA.-The Stoical Philosophr.

Progress of Philosophy in Rome - _ - _ - $-\quad 249$

Cynicism the Parent of Stoicism - _ - - _ - -249

Antisthenes - - _ _ _ _ - _ - - 250

Diogenes - - - _ - _ - _ - - 251

Onesicritus - _ - - - - - --252

Monimus - - _ _ - _ _ - - - 252

Crates - - - - - - - - - - 252 
CONTENTS.

SeneCa.-Tine Stoical Philosophy-continued.

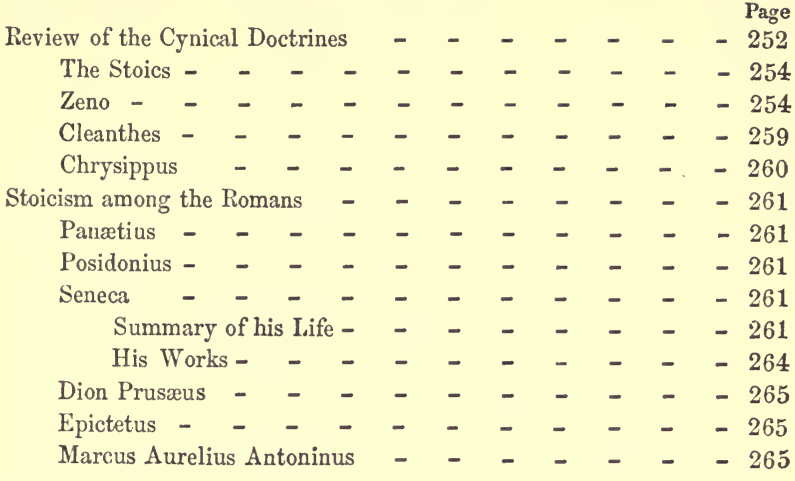

SextUs EMPIRICUS.-The Sceptical Philosophy.

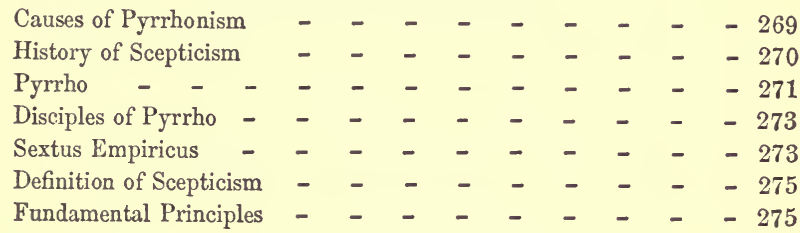

Plotinus.-The Eclectics, or Later Platonists.

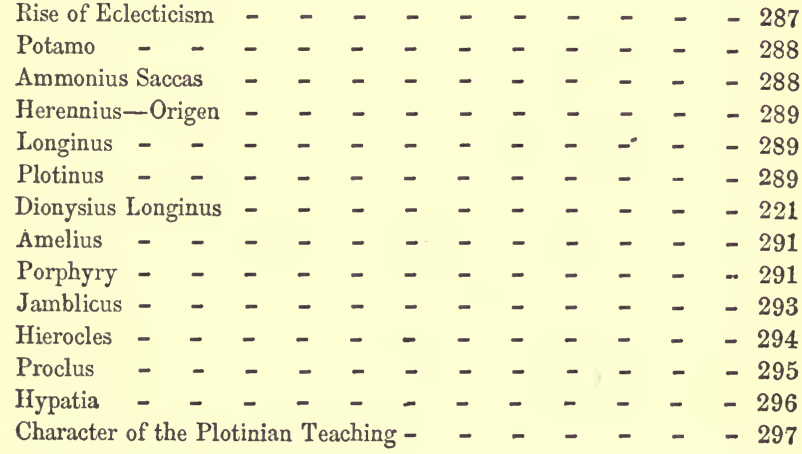

ARCHIMEDES.-GReEK Mathematics.

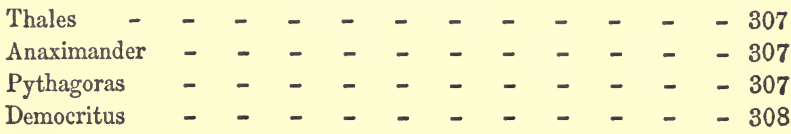


ARCHIMEDES.-Greek Mathematics-continued.

Page

Anaxagoras

Hippocrates

Archytas -

Menechmus

Eudoxus -

Plato - -

Zenodorus -

Autolycus -

Euclid

Aristillus -

Timocharis

Aratus

Aristarchus

Archimedes

Mathematical Treatises

Mechanical Treatises -

Ctesibius

Eratosthenes

Apollonius -

$$
\begin{array}{rrrrr}
- & - & - & - & - \\
- & - & - & - & - \\
- & - & - & - & - \\
- & - & - & - & - \\
- & - & - & - & - \\
- & - & - & - & - \\
- & - & - & - & - \\
- & - & - & - & - \\
- & - & - & - & - \\
- & - & - & - & - \\
- & - & - & - & - \\
- & - & - & - & - \\
- & - & - & - & - \\
- & - & - & - & - \\
- & - & - & - & - \\
- & - & - & - & - \\
- & - & - & - & - \\
- & - & - & - & - \\
- & - & - & - & -
\end{array}
$$

\section{GREEK PHYSICS.}

Astronomi

Claims of the Chaldeans, \&c. -

Thales

Anaximander

Anaximenes

Anaxagoras

Pythagoras

Philolaus -

Eudoxus - - _ -

Calippus - - - -

Autolycus - - - -

Euclid - - - - -

Aristarchus

Eratosthenes

Archimedes

Hipparchus

Ptolemy

Greeks posterior to Ptolemy - $\quad$ - $\quad$ - $-\quad-345$

\section{Mechanics :}

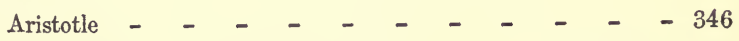

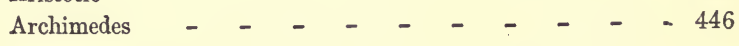

\section{HydROSTATICS :}

Archimedes 
GREEK PHYSICS - continued.

Pneumatics :

Page

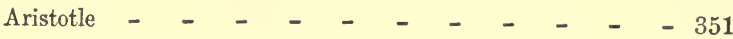

Optics :

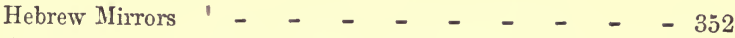

Aristotle - - - - _ - _ - - - - 353

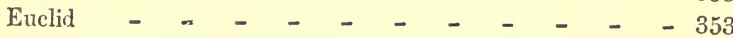

Numa - - - - - - - - - - 355

Archimedes' Mirrors - _ _ _ _ _ - _ - 355

Ptolemy Euergetes - _ _ _ _ _ _ - - 357

Ptolemy the Astronomer - _ _ _ _ _ _ -357

Pliny - - - - - - - - - - - 361

\section{ELECTRICITy :}

Thales

- - - - - - - - - 362

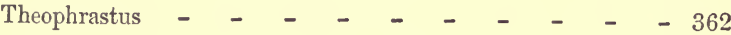

Pliny - - - - - - - - - - - - 362

Solinus - - - - - - - - - - - 362

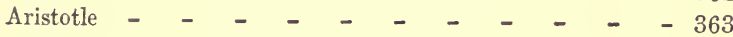

Oppian - - - - - - - - - - - 363

Claudian - - - - - - _ - - - -363

Scribonius Largus - $\quad$ - $\quad$ - $\quad$ - $\quad$ - -363

Galen - - - - _ - - _ - - - - 363

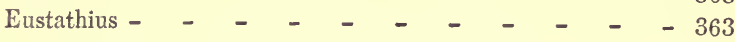





\section{A S 0 P.}

REPRINTED FROM THE ORIGINAL EDITION.

[G. R. P.] 



\section{AS OP.}

FLOURISHED ABOUT B. C. 560 .

THE use of the allegory or fable, as a means of instruction, appears to have been one of the earliest dictates of enlightened reason; and has been resorted to, in a greater or less degree, by the moralists and philosophers of all ages and countries. Hence it is, that throughout the classical historians we meet so often with the name of Esop, perpetuated for no other reason than that he was the most famous of ancient fabulists; or, as some writers have alleged, the very inventor of this mode of instruction. His life is totally unconnected with any public events of importance; his family were utterly obscure; no kingdoms were conquered by him, or settled in legislation; on the contrary, human nature appears in complete degradation in his person and circumstances : in condition a slave, and deformed, it is said, in person, even to the excitement of disgust in those who beheld him, he yet sustains a high rank amongst the sages of ancient times, and certainly more for his method of teaching than for anything extraordinary which he communicates. Indeed, what were his particular sentiments as a philosopher can now be very faintly traced: his fables, in which all his precepts appear to have been conveyed, are considerably mutilated; and the majority of those which bear his name are the fabrication of a later period. In those which can with any degree of certainty be traced to Esop as their author, his exact meaning is not always obvious; and the occasion of their composition, which must have given a much greater propriety to their application, is, for the most part, unknown. The celebrity of Esop is, perhaps, still more remarkable, as it appears to have been originally unconnected with any recommendation from the form of his compositions, or the mode of publishing them : they were not adorned by the graces of poetry, nor do they appear to have been delivered with eloquence. Their novelty, their liveliness, and their strict analogy to real life, appear to have been their only attraction; features of the genuine fable which, under every form of its development, are a tribute to the imperishable charms of truth.

Several countries dispute the honour of giving birth to Esop: he Uncertainty is sometimes called a Thracian, and by other writers a Samian; but try. the more commonly-received opinion is, that he was born in the town of Ammonius, in the Greater Phrygia. Perhaps these indications of the uncertainty, serve only to prove the meanness of his origin: of 
the names of his parents we hear nothing. His person, as we have already noticed, was deformed in the highest degree; an immense

Person and complexion.
Slave of

Xanthus. protuberance of the back threw his head forward, and appears from early life to have utterly stopped his growth : his complexion is said to have been swarthy; and hence some writers have supposed the name of Esop to be a corruption of Ethiop. In addition to these disadvantages, he had so serious an imperfection in his speech, that for a considerable period of his life he was unable to articulate any sounds distinctly. Camerarius, a learned German critic, to whose researches we shall be much indebted in this paper, mentions a tradition, to which, however, he refuses credit, that Essop liad the good fortune in his youth to relieve certain travelling priests of his country who were exhausted with hunger and had lost their wav; when, in requital of his kind offices, by virtue of their prayers to the gods, they first brought him to the use of his tongue. This is all we hear of his early life. And we next meet with him at the period of his being offered as a slave to his third master, Xanthus (or, as Herodotus calls him, Jadmon), of the island of Samos. He was carried by a factor to Ephesus, together with some other slaves, for the chance of sale, or on business for his master. As our future sage was feeble in his body, his companions allowed him his choice as to which of their different packages he would undertake to carry, and he, to their astonishment, selected the largest and heaviest, containing the provisions of the party; an instance of what they deemed his folly, which excited no little merriment. In the morning Esop bore their ridicule and his own burden with patience. At noon, however, the basket of provender was considerably lightened, by the hearty meal which the slaves then made, and Essop was, of course, considerably relieved from the weight of his charge. In a few hours more, another meal completely consumed the food, and left the provident weakling entirely at his ease for the remainder of the journey. Upon his arrival at Ephesus with his slaves, the merchant soon disposed of them all by private bargain, excepting three, stated to have been a musician, an orator, and our poor neglected fabulist, of no apparent accomplishments, and of no profession. These he took to the open market, as the only place in which he was likely to dispose of them; the two former accoutred with the implements of their profession, and the latter making little better appearance that that of a deformed idiot; when Xanthus, a Samian philosopher, entering the area, was attracted by the appearance of Esop's companions, and inquired 0 the merchant his price for them. Objecting to this as exorbitant, the philosopher was on the point of quitting the market, when some 0 the pupils, by whom he was attended, pointed out Essop to his notice. At their solicitation, and jocularly, more than with any serious intention, he put the accustomed question to the despised captive, of " What he could do?" "Nothing at all," replied Esop; " for I have just overheard my companions answer your question, by 
affirming that they could do everything; therefore there is nothing left for me to do." Xanthus, delighted with this answer, now entered into conversation with this unattractive wit, and became fully sensible of his superior powers. In answer to a question respecting the deformity of his person, Essop boldly remarked, "that a philosopher like Xanthus should appreciate a man according to the vigour of his mind, and not to the appearance of his body ;" an observation upon which that philosopher immediately acted. The factor being asked the price of his deformed slave, declared that could he obtain from the purchaser a proper sum for the other two, he would cheerfully part with Essop for nothing. This offer was accepted; Xanthus at once paid the price to which he had first objected for the musician and the orator, and returned home with all three of the slaves. Esop here found his master in more hopeless bondage than himself, to a wife of a most furious and jealous temper. On his first appearance amongst Anecdotes. the domestics, as her husband's slave, she asked, in scorn, of Xanthus, " whether it were a beast or a man that he had now brought home?" when Assop, unable to repress a similar disposition, is said to have exclaimed, "From the mercies of fire, water, and a wicked woman, great gods deliver us!" 'This of course awoke the vehement temper of his mistress, and Essop, with difficulty, brought himself through this awkward reception, by pretending that he only recited some lines of the poet Euripides, and observing, how practicable it was for her whom he addressed to make herself " as glorious in the rank of good women." This story, however, cannot be correct in its entire details, for the murder of Esop, in Delphi, occurred at least eighty years before the Greek tragedian was born. It is stated, however, that the aptness of Esop's reply on this occasion conciliated the favour of the incensed lady.

Esop had not been long in the service of the Samian philosopher, when the latter took his newly-acquired slave to a gardener for the purpose of purchasing some herbs; the agriculturalist, observing Xanthus in the habit of a plilosopher, inquired tlie reason why those plants which grew of themselves, and without any artificial aid, should come up so fast and thrive so well, whilst others, though never so carefully cultivated, could scarcely be preserved from perishing. "Now," continued the gardener, " you who are a philosopher, pray disclose to me the meaning of this." Xanthus was, however, utterly at a loss for a satisfactory answer, and was obliged to content himself witl saying, " That so Providence had ordered it to be." Here Asop interfered; and, after a sarcasm upon the imperfection of the school of philosophy in which Xanthus was bred, requested to be permitted himself to give the solution. "For what," said the slave, "signifies a general answer to a general question, but an acknowledgment of complete ignorance on the subject proposed ?" To this Xanthus readily consented, observing to the gardener, that it was beneath the dignity of a philosopher to answer minutely such a trivial question. "The earth, then," said 
Assop, " may be considered as in the nature of a real mother to that which she brings forth out of her own bowels; but she is only a stepdame in the production of those plants that are cultivated and assisted, nay, sometimes even forced under her care, by means of the sheer industry of another. It is natural for her to withdraw her nourishment from the one, and to lavish her powers upon the other kind of plants." This solution of the gardener's question is said to have so delighted him, that he not only refused to take money for the herbs that had been bought, but welcomed Æsop to the produce of his garden in future.

Esop had to bear with all the oppressions of slavery; and many anecdotes, of dubious authority, are told of this part of his life. He is said to have interpreted an obscure inscription, which had utterly foiled his master; and, emboldened by his success, to have demanded of him what reward he would offer, if he were to point out to him a considerable hidden treasure? "One-half of it and your liberty," said Xanthus. Possessed of the property, however, the faithless Samian conveniently forgot the conditions upon which he acquired it, and returned to the defenceless Assop menaces and blows; though he is said to have been fearful lest he should betray the matter to king Dionysius, who was entitled to the advantage of the discovery. On another occasion, the wife of Xanthus having eloped from her husband, notwithstanding the acerbity of her disposition, he was desirous of recalling her, and Esop undertook the task of fulfilling his wishes. He prepared a plentiful feast, and gave it publicly abroad, that his master's first wife having separated from him, this entertainment was prepared for a second marriage. The effect was as he had imagined, the lady immediately ordered her chariot to be prepared, and returned to the house of her husband. At another time Xanthus, in a moment of inebriety, had made a considerable wager that "he would drink the sea dry," and, on becoming sober, applied to \#sop to extricate him from the difficulty into which he had involved himself. "Sir," said the slave, "be careful of Bacchus; it is the humour of this god first to make men cheerful, then to make them drunk, and lastly to make them mad." He exhorted him, however, to take courage, and pursue his advice. Xanthus, accordingly, appeared next day on the sea-shore, attended by the man with whom he had made the ridiculous agreement. "And now," said he, " am I ready to drink the sea dry, but it is you who must first stop all the rivers which run into it."

Esop's 1iberation.

A circumstance, however, at last occurred, which not only liberated Esop from his undeserved degradation, but so attracted the attention of the Samians as to elevate him highly in the public esteem. He appears, in this instance, to have been a little more wary in his communications for the benefit of others, and determined to assert that station in society for which his acute and comprehensive mind so admirably qualified him. In common with all the surrounding states in this semibarbarous age, these people were strongly addicted to the 
practice of augury. On a day of peculiar solemnity amongst them, an eagle had snatched away a ring upon which the arms of the town were engraven, and, after having carried it to a consiaerable distance, dropped it at last into the bosom of a slave. To explain this mysterious omen the philosophers of Samos were consulted, and, amongst others, Xanthus, the master of Esop, who immediately applied to him for assistance. When all the sages of the island had been completely perplexed, Xanthus arose, at the instigation of Esop, in an assembly of his countrymen, confessing his ignorance, and recommending them to his long-tried slave, as a man peculiarly gifted by the gods with wisdom, for a solution of the augury. Assop was accordingly summoned to the assembly, but declined to enter upon the subject. He alleged the unworthiness of his condition, and the serious effects of his master's permanent displeasure against him, should the interpretation of the augury interfere with any of his designs. This objection was of course overruled, by his immediate manumission through the interference of the assembly, on which he is reported to have addressed them as follows: "The eagle," said Essop, " is a royal bird, and signifies a great king; the dropping of your signet into the bosom of a slave, or one who has no power over himself, denotes the loss of your liberties: if you are not particularly vigilant in the conducting your affairs, this omen will but too shortly be realized." The event was answerable to Assop's solution of the augury; for, shortly after, Crœsus, king of Lydia, commissioned ambassadors to demand a tribute, as a token of submission to him, from the Samians; and the successful interpreter of the oracle was called to the debate, which such a demand naturally produced. "The path of liberty," observed His honours. the now honoured sage, "is narrow and rugged at the entrance; but the further you advance on it, the plainer and the smoother it shall be found." 'This noble sentiment decided the Samians : a defiance was pronounced against the Lydian monarch, and his embassy dismissed with contempt. When Crœsus learnt these circumstances,-and that one man, recently a slave, had, by a few words only, induced the boldness of this measure, he sent to the Samians, offering them peace and independence, on condition of their delivering up Esop, the instigator to the threatened war. To this the sage himself offered his instant acquiescence, but first admonished the Samians on the improvidence of purchasing peace by sending away those counsellors in whom consisted their chief defence; and on this, it is said, he first introduced the well-known fable of the Wolves and the Sheep who gave up their only defenders, the Dogs. This apologue, so well applied, determined the people again to resist the demands of Crœsus; a tribute of regard for Esop which emboldened him to a patriotic step for the future stability of their state, which is not exceeded in personal courage or address in all history. He suddenly departed from Samos, and presented himself at the Lydian camp. "I come success at not here, great king," said he to Crœsus, "in the condition of a man the Lydian 
abandoned or given up by his country, but of my own will appear before you, with this only request, that you will vouchsafe me the honour of your royal ear before you condemn me." He then addressed the monarch in the elegant fable of the Captive Grasshopper, who begged for life upon this simple plea: "that all her business was her song, and that her death could bring no possible advantage to her possessor." The generous monarch felt the force of the appeal, and not only pardoned the petitioner, but desired him to ask any further favour within his wishes. Essop was not forgetful of those who had been his deliverers from slavery, and might almost be called his countrymen.; he implored the king's goodwill toward the Samians; and obtained them a grant of permanent peace and favour under the royal signet. Assop hastened to Samos with the welcome news, and a statue was decreed to his honour in return for his important services. He then returned to the court of Lydia, and entered upon a still more extensive career of fame; he became a public counsellor of the state, In favour and the distinguished and permanent favourite of Crœsus; under whose with Cresus. patronage, and for whose instruction and amusement, he composed many of those apologues that have been handed down, under his name, from age to age, and through the languages of all civilized countries, to the present day.

Esop now, easy in his circumstances, thirsted for new opportunities of observation, and obtained leave to travel. His ultimate and principal object was to visit the famous city of Babylon, then in its meridian splendour, and to the king of which he had procured a recommendation from Crœsus, who was in alliance with him. In the way

His travels. to Babylon, Essop traversed the rising states of Greece, and called forth the admiration of several of the cities where he abode. At the villa of Periander, near Corinth, he met the Seven Sages, whose fame was at that time at its zenith, and contended with them on the question of the best form of government, EEsop alone preferring a monarchy to that of any other. With Solon he appears to have been previously acquainted, upon the visit of that legislator to the court of Crosus, when he is said to have advised him (on his being neglected at court) "to make his visits to kings as pleasant, or as seldom as possible," to which the more rigid Grecian philosopher replied, "or, rather as seldom, or as profitable as possible." When he visited Athens, then under the dominion of Pisistratus, he admonished the discontented citizens that they should rather bear the slight evils of which they complained, than seek an unknown and perhaps an intolerable change; and on this occasion was it that he related the famous tale of the ' Frogs wanting a King,' and who, discontented with their harmless log-sovereign, were punished by Jupiter for their oscillatory disposition by the tyranny of the direful stork.

Settles at

Babylon.

Æsop at last reached the dominions of Labynetus, king of Babylon, where his talent at solving enigmas and auguries produced him ample rewards and reputation. Secure of a comfortable subsistence, he next 
sought for an equivalent to the natural affections of life, by the substitution of an artificial connection, not uncommon in those days. $\mathrm{He}$ adopted as his son and heir a promising youth of the name of Ennus, who appears, however, to have treated him with peculiar ingratitude. Ennus forged his adopted father's name and seal to a paper containing the plan of a plot against the king of Babylon," who, giving way instantly to his rage, and not imagining the falsehood of the accuser, immediately ordered the execution of Asop. From death, however, the sage was rescued by some noble friends, who yet were obliged to conceal him from the public vengeance by a close confinement. Labynetus soon had reason to repent his rashness in depriving himself of so useful a counsellor, without having given him the chance of acquittal by a hearing; for Amasis, king of Egypt, having sent to Babylon requesting to be supplied with an architect "who could build a tower which should hang in the air, and with a philosopher who could resolve all difficult questions" (this kind of practice forming at that time one of the principal amusements of a court), Labynetus was immediately remincied of the qualifications of Esop, whom he esteemed capable of performing all the wishes of his Egyptian ally. On expressing sorrow for his unknown fate, the friends of the sage produced him to the joyful and repentant monarch in the rags and squalid appearance of a prison, and Esop quickly cleared himself from all suspicion of guilt. Labynetus, in just revenge, would now have sacrificed his treacherous accuser, but Essop procured his pardon, and even again restored him to his own wonted favour. Asop then departed for Egypt with the ambassadors of Amasis; but although he seems readily to have undertaken the obscure offices required-in which way he performed them we are not told-he appears to have soon returued to Babylon, where he was much occupied in the educaof Ennus. Amongst his precepts we find the following fragments of no common mind: "Worship God, my son," said he, "with care, His precepts. with reverence, and with a sincerity of heart, void of all hypocrisy or ostentation; for know that he is omnipotent as he is true. Have a care even of your most private actions and thoughts; for God always sees you, and against you your conscience is always ready to bear witness. Prudence, as well as nature dictates, that while you do all the good in your power to all persons whatever, you should pay the same honour to your parents which you expect your children should pay to you; and prefer your relations before strangers in the exercise of your good offices. Nevertheless, where you cannot be beneficial be not ruinous to any one. Words signify actions and thoughts; there must be no impurity in either. Be careful of childish or impotent affections; but follow the dictates of your reason, and you are safe. Be still assiduous to learn, as long as anything is left unknown to you; and value wisdom before money. The human mind requires cultivation as do the plants of the field; the improvement of our reason assimilates us to angels; the neglect of it changes us into beasts. 
Wisdom and virtue are the only permanent and inviolable good; but the study of these, without the practice, is nothing. Think not, however, that asperity of aspect necessarily designates wisdom; for wisdom makes us serious, but not severe. It is one degree of virtue not to be vicious. Keep thy faith with all men; and avoid a lie to man, for that is an offence to God. Measure your words: for great talkers have no respect for either honesty or truth. Frequent the society of good men, for the sake of their manners, as well as their virtues. Be careful of the worldly maxim that there is sometimes good in evil; for profitable knavery and starving honesty is a mistake; virtue and justice are ever eventually productive of good and profit. Admit not that restless passion, curiosity for the affairs of others, but attend to your own business. Speak ill of no one; and no more indulge in the hearing of calumnies than be the instrument of reporting them; for those who love the one, commonly practise the other. Intend honestly, and leave the event to God. Despair not in adversity, and exult not in prosperity, for everything is changeable. There are three things of which you will never repent-being early and industrious at your business; learning good things; and obliging good men. Remember that is done best which is done in season; watch therefore for opportunities of doing good. Love and honour kings, princes, and magistrates; for they who punish the guilty and protect the innocent form the band which holds society together." Such are the lessons of morality and wisdom which are attributed to Assop in his adopted character as a parent; but the object of his anxious cares appears to have ill requited them: his life was a scene of rebellion and debauchery, although he is said to have been at last a penitent, and to have died in all the bitterness of remorse for his ingratitude to Esop.

In well-earned prosperity, a favourite with the monarch, and loved and respected by his private connexions, Esop now appears to have passed many years at Babylon; and when he at last obtained a forced Last journey permission to revisit Greece, it was only on the express condition of to Greece. an early return to that city. As he again passed through the various cities of the peninsula, he resumed his former habit of delivering his sentiments by way of fable, until he is said to have been barbarously assassinated by the inhabitants of Delphi.

The object of the Phrygian sage in visiting this city in his last journey is related differently by different historians. Some have stated, that, satisfied with his travels, he arrived at length at the court of his first patron and protector, Crœsus, intending to make Lydia his future home; and that when resettled there, and under the accustomed favour of the king, he was deputed by him to consult the oracle at Delphi on some important occasion, a circumstance according with the well-known fact of the unusual partiality and liberality of Crosus to this famous oracle. Others report, that his own curiosity and thirst for general knowledge led our fabulist thither, and a desire to consult the oracle on some personal affairs. But, whatever were 
his objects, his disappointment at the barbarous manners of the people, and at the oracle itself; his consequent sarcasms, and his death, are uniformly related. On his arrival at Delphi, then a place held sacred throughout Greece, he found the inhabitants, whom he had expected to see deserving of the reputation they had acquired for piety, wisdom, and learning, deeply immersed in pride, avarice, and barbarism. Unfortunately for himself, he did not conceal his sentiments concerning them, but allowed his contempt and aversion to become publicly apparent, although clothed in his usual allegory. "I find," said he, "the curiosity that brought me hither to be exactly similar to the expectation of those who, whilst standing on the shore, see something at a distance which the wind and the waves are floating towards them; they imagine it to be of considerable bulk or value; but upon its approaching nearer, they discover it at last to be nothing more than a heap of floating sticks, weeds, and rubbish." This censure, it slould seem, was levelled not at the lower class of the Delphian people only, but likewise at the magistracy, and perhaps at the juggles of the famous oracle itself; the cheats and extortions attendant upon which cannot be supposed altogether to have escaped the penetrating intellect of Asop.

Jealous of their reputation, and well knowing the credit with which the fabulist was received by princes and states of the first importance, and those bv whom the Delphian oracle was, until then, highly reverenced, the magistracy of the city, and perhaps the priests of the temple, resolved to silence the censures of Esop by depriving him of life. It was necessary, however, that he should appear to the public eye to deserve the ignominious death they meant to inflict on him, and the philosophic traveller had already quitted Delphi to depart, when he was seized only a few miles from the town, on a charge of sacrilege. Assop at first ridiculed the accusation; but the conspirators had laid their plot too sure. They had secreted amongst his baggage, for no benevolent design, a golden cup which belonged to the temple, and there, on inspection, it was found. This apparent proof of Esop's guilt was not exhibited to the people in vain: they were much enraged; and the court at which he was afterwards regularly tried, condemned him to be thrown headlong from a rock. Esop, to whom kings, states, and cities of the greatest celebrity had listened with admiration, could now with considerable difficulty obtain a hearing for the few words in which he endeavoured to expose the artifice under which his character was for the first time impeached. But in vain : he was hurried to execution. On the road, however, he is said to have succeeded in diverting their attention for awhile from its immediate object; and, evading those who held him, to have escaped to a neighbouring altar. From hence, however, he was dragged, with the remark, that those who robbed their sanctuaries were not entitled to protection from them; when he made another and final attempt to move their compassion or awaken their justice, in the fable of the 
Eagle, the Hare, and the Beetle; and to prove to them that injustice always meets with its due punishment, though practised by the strong upon the weakest of creatures. "Nor are you," continued the unhappy sage, "to flatter yourselves that the profaners of the holy altars, and the oppressors of the guiltless, can ever ultimately avoid the vengeance of the gods." All this served but the more to enrage his already exasperated judges, and the furious and unthinking multitude. They dragged him forward to the fatal spot, and the last words he uttered were characteristic of his history. He likened his miserable lot to that of an old man who had fallen into a pit, together with some asses : both he and the beasts having been beaten out of their road by the violence of a tempest, the animals, when they found themselves precipitated into this cavern, and confined to its narrow boundaries, began to kick the aged traveller, and gave him his death-wounds. "Unhappy wretch that I am," exclaimed Essop, in the person of this old man, " since die I must, it is doubly hard to die by means of, and surrounded by, these asses, the most senseless of beasts! To suffer death unjustly were enough calamitous, but for it to be inflicted by the hands of a barbarous and ignorant people, alike devoid of humanity, honour, hospitality, or justice;-ye gods, permit not my innocent death to pass unavenged !" In the midst of this harangue, the impatient multitude precipitated him from the rock, and he fell lifeless His death. at its base. Thus perished, as he had lived, the sage and celebrated Esop, mixing wisdom with wit, entertainment with instruction.

The veneration with which the character of Esop has been generally regarded by the historians of his time, cannot, perhaps, be more strongly exemplified than in their ascribing a dreadful plague, with which the Delphians were shortly afterwards visited, to the outrage thus committed on the hospitality peculiarly due to great men, and their impiety to the gods. This the Pythoness herself declared to be but justice upon them for their crime, and directed a public atonement to be made for it. Accordingly we find that this clamorous and capricious people, soon after his death, erected a pyramid to the memory of $\mathbb{E}$ sop. It was also a tradition of the best times of Greece, that the conspirators by whose wicked contrivance he fell, so severely suffered the stings of conscience, that they slew themselves in remorse;-a circumstance which is reported to have given pleasure to the more civilized nations of the Greeks around. Socrates is said to have amused and consoled himself, in several of the serious hours he spent in prison, shortly before he suffered, by rendering several of the compositions of Esop into familiar verse. 


\section{SOCRATES.}

BY

\section{CHARLES JAMES BLOMFIELD, D.D.,} BISHOP OF LONDON.

REPRINTED FROM THE ORIGINAL EDITION. 


\section{SOCRATES.}

Froy B. C. 469 TO B. C. 399 .

THE biography of this remarkable person, who occupies so conspicuous a station in the history of the human mind, will be conveniently introduced by a short sketch of the previous history of philosophy in Greece.

The earliest philosophy of the Greeks, which was derived to them Philosophy through Ionia, from Asia, consisted in devising both names and of the early attributes for the various deities, who were supposed to preside over the different departments of the universe; and in conveying to a simple people a system of theology and ethics in allegorical poems. Many fragments of these were incorporated into the works of Homer and Hesiod; and some are to be found in the more ancient oracular verses which are quoted by the Greek historians. 'The 'Theogonia' of Hesiod was no doubt taken, as to its principal features, from the cosmogony of some more ancient philosophical poet; and it is to be remarked, that this philosophy, such as it was, and from whatever source derived, was coeval with the language in which it was taught; for the names of the deities are not borrowed from the oriental mythology, which probably supplied many of the deities themselves; but are Greek names, significant of the attributes which they were intended to personify. Thus, void space is termed Xáos, from the verb Xáw,

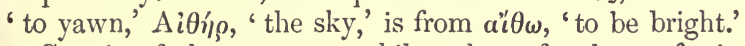

Certain of these poets or philosophers, for the professions were not then distinct, were employed professionally by some of the Grecian states, to compose useful mythological poems and hymns, appropriate to the worship of various deities: in particular we may mention Pamphus, and Orpheus, an imitation of whose hymns was in after ages forged by some falsary. ${ }^{1}$

These were the masters of wisdom to the earliest Greeks, who for many ages had no philosophical writings in prose. Theognis consigned his moral and political precepts to elegiac verse; and the same kind of composition afforded even to Solon a vehicle for instruction of the most important kind to his fellow-citizens. It was not till history

${ }^{1}$ It is amusing to see so grave a writer as Brucker seriously deducing a summary of the Orphic philosophy from these spurious fragments, many of which are of a date but little, if at all, anterior to the Christian era. An attempt was made in the fifth century before Christ to revive what was pretended to be the philosophy of Orpheus; and certain mystagogues seem to have made the initiation of votaries a gainful trade. But it appears, from some expressions in Euripides, that the credit of this sect was, even in his time, at a very low ebb. 
had descended from the car of poetry, that didactic philosophy submitted to deliver her doctrines in the sober language of common life; and it is very uncertain to what extent those philosophers, who first bore the name, committed the results of their speculations to writing. The verses of Orpheus, and Linus, and Musæus, were undoubtedly preserved by oral tradition. The persons who are commonly known

The Wise Men of Greece.

Esop. by the name of the Seven Wise Men of Greece, seem, with the exception of Thales, to have been indebted for that honourable distinction, either to their political sagacity, or to their talent of expressing, with an oracular brevity, the most important maxims of morality. They are known to us chiefly by a few of their sayings; and even of these the individual property is not very clearly ascertained. It may perhaps be contended, that a wise legislator is the greatest of all practical philosophers: and on this account Solon occupies the very highest station amongst those illustrious men, who have applied their wisdom and experience to the great ends of promoting public virtue and happiness. But, in the common acceptation of the term, Thales is the only one of the seven sages, who can be considered as one of the real fathers of Grecian philosophy. And it does not appear that he left any writings behind him. Even Assop, the celebrated inventor of moral apologues, probably committed none of his fables to writing. Many of them were traditionally preserved, and mentioned by later writers; and furnished a basis for various superstructures, which were afterwards raised, and dignified with his name.

Since neither Thales, nor any of the earlier teachers of wisdom in Greece, left any works to posterity, it is obviously very difficult to form anything like an accurate notion of the state of philosophy in Greece in the period during which they flourished. As from the time of Thales there was a continued succession of philosophers, it would of course happen in after times, that what the scholar had said was attributed to the master ; sometimes perhaps even by the scholar himself, when he was desirous of conciliating respest to his dogmas, by stamping them with the authority of a greater name than his own.

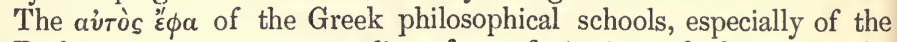
Pythagorean, was a compendious form of citation, which gave to the founder of a sect the credit of many opinions of which he had never dreamed.

But for the whole account of the earlier philosophers, and for any knowledge whatever of their doctrines, we are of course obliged to trust to writers of a more recent date, who were probably not very careful to discriminate between the claims of different individuals, nor to separate the primitive philosophy of their earliest teachers from the refinements of a later age. Indeed the principal sources from which our knowledge of these subjects is derived, must be confessed to be very corrupt. As far as we can collect our notions of the earlier systems from the writings of Plato, we may feel ourselves tolerably secure, although it is more than probable that the outlines are occasion- 
ally distorted, or the features too strongly marked, by the brilliant and inventive genius of that wonderful man. Even upon the testimony of Aristotle we cannot depend with certainty; for he was notorious for his misrepresentations of the tenets of his predecessors. It is only in the deficiency of more authentic sources of information, that we can trust ourselves to the accuracy of such a writer as Plutarch; and we can never rely with satisfaction upon the relation of Diogenes Laertius, unless his accounts be either corroborated by less doubtful writers, or bear in themselves the marks of consistency and credibility. Amongst the later authors, Cicero is the most trustworthy source of information concerning the Greek philosophers; yet even he lived at so great a distance of time from the earlier masters of wisdom, that it is more than probable, that their doctrines descended to him much altered and corrupted, through the channels of the more modern philosophy.

It is commonly said of Socrates, that he was the first person who brought down philosophy from the skies, and introduced her into the commerce of civil life. But although in his time the title of philosopher was almost entirely confined to those who busied themselves in physical researches, or speculated upon abstract notions; yet at an earlier period the wise men of Greece (for the name of philosopher was not then invented) seem to have directed their attention to the laudable objects of improving the science of legislation and government; in pursuit of which, they travelled into the more ancient and flourishing kingdoms of Egypt and the East. It is related by Herodotus (1.29) that the court of Crœsus was visited by all the Sophistæ, ${ }^{1}$ at that time living in Greece.

Thales, however, appears to have merited the appellation chiefly by Thales, born his skill in astronomy and geometry, and by his theories upon the formation of the universe; they are the real foundations of his fame; for as to his speculations upon the divine nature and government, it is extremely difficult, from the causes above mentioned, to ascertain what were really the doctrines of Thales.

One instance will serve to illustrate this difficulty. We read in Aristotle (de $A n$. 1. 5.) that Thales thought the universe to be full of gods. Diogenes Laertius says, Thales taught that the universe was animated, and full of dæmons. But now comes Cicero, and tells us that Thales admonished mankind to bear in mind that the gods perceived all things, for that all things were full of them. Valerius Maximus goes one step farther, and asserts that Thales, being asked whether the actions of men escaped the notice of the gods, replied, Not even their thoughts; "Nec cogitata, inquit. Ut non solum manus, sed etiam mentes puras habere vellemus; cum secretis cogitationibus

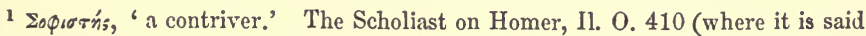

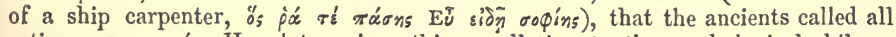
artizans $\sigma \circ \varphi \sigma \sigma \tau \alpha i$. Herodotus gives this appellation to the mythological philosophers before spoken of, and to Pythagoras. Thucydides applies it to the teachers of rhetoric and logic.

[G. R. P. $]$ 
nostris caleste numen adesse credidissemus." It is obviously very probable that Thales broached simply the absurd notion, that the universe was filled with gods in every part, by way of accounting for the various operations of nature; and that the moral deductions were afterwards appended to it by later philosophers. And what renders this still more probable is, that the answer of Thales, recorded by Valerius Maximus, is by Plutarch attributed to Pittacus. We may remark by the way, that a strong instance of the uncertainty, under which we labour generally, as to the tenets of the earlier philosophers, is the confusion which prevails, as to the real authors of many sayings recorded by ancient authors. For example, the celebrated apophthegm,

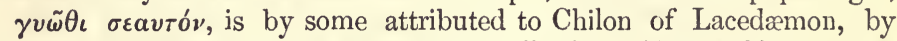
others to Thales, and by some to Apollo himself. M $\eta \delta \dot{\varepsilon} \nu$ ä $\gamma a \nu$ is assigned by Aristotle to Chilon, but by many to Pittacus. This lastmentioned philosopher is also recorded to liave said to a person, who inquired of him whether he had better marry a rich wife, or one suited

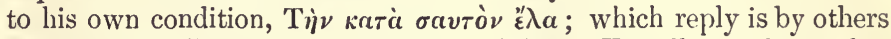
attributed to Solon, and by some to Chilon. Tertullian relates, that Thales, when asked by Crœsus what he thought of the gods, after much deliberation could return no answer. Now older and more trustworthy authors relate the same story of Simonides. From these, and from many similar instances which might be adduced, appears the difficulty of ascertaining and marking out the precise property, which belongs to each of the ancient philosophers, in the wide range of physical and moral speculation, which is spread through the writings of many ages.

His leading It is, however, agreed upon all hands, that the leading doctrine of doctrine. Thales was this, that water was the origin of all things; which some persons have considered to refer to the reappearance of all things from the deluge. Whether he taught that water was the material, and that the Deity formed the universe out of it, seems to admit of doubt. It is certain that he was not an atheist, and that he believed in the existence of an incorporeal Deity; but as it is justly observed by Bayle (art. Thales), the opinions of the heathen philosophers were so little connected, that it did not follow as a necessary consequence, from the hypothesis of the existence of a God, that he was the creator of the universe; but many of them believed the gods to be the governors of the world, having been themselves produced from chaos.

It is far from improbable, that both. Thales and Pythagoras may have obtained a great part of their mathematical knowledge, and some of their notions respecting the Deity and his operations, from the Chaldæan philosophers. It is going too far to suppose, as some have done, that they were acquainted with the Mosaic writings; but they were probably not ignorant of that traditional knowledge, which had descended from the earliest ages of the world, and was preserved amongst the inlabitants of Egypt, Phœnicia, and Assyria. It is observed by Diodorus Siculus (who perhaps had not much better 
means of knowing the fact than we have), that Lycurgus and Solon, as well as the poets Orpheus, Musæus, Melampus, and Homer, and the philosophers, Pythagoras and others, had drawn most of their knowledge from Egypt. And Dingenes, asserts, upon the authority, as he salys, of Hecatæus and Aristagoras, that the Egyptians had tanght, from the remotest antiquity, that the world had a beginning; that the earth was spherical, and the stars of the nature of fire; and that the soul was immortal.

Whoever will take the trouble of considering the passages which Bp. Stillingfleet has collected in his 'Origines Sacræ,' b. iii. c. 3, will readily recognise, in the physics of Thales, some traces of the Mosaic cosmogony. The water, which according to Thales was the primitive form of matter, corresponds to the chaotic mass which "was without form and roid."

'To return to the theology of Thales: amidst the conflicting accounts which later writers have given of his opinions as to the formation of the world, it seems not unreasonable to conclude that he delivered no express dogma on the subject, but tacitly supposed the existence of a God:

With regard to his notions on the subject of natural history, we may remark, that he held the monn to be a solid body, like the earth, and to receive its light from the sun; that the earth is spherical, in the centre of the universe ; that eclipses of the sun are caused by the intervention of the moon between the sun and the earth. His knowledge of astronomy was sufficient to enable bim to predict eclipses of the sun; this we know, upon the testimony of Herodotus; but with what degree of precision, whether to the assigning of the exact hour, we cannot determine. ${ }^{1}$ Proclus tells us, and most probably his assertion is true, that 'Thales derived his mathematical knowledge from Egypt; and that amongst other geometrical problems he discovered the following, which were afterwards inserted in the 'Elements of Euclid:' 1. That a circle is bisected by its diameter. 2. That the angles at the base of an isosceles triangle are equal to each other. 3. That two straight lines intersecting one another make the vertical angles, at the point of intersection, equal. Thales also introduced into Greece an improved distribution of the year, which he divided into 365 days.

Anaximander, who taught publicly the opinions which Thales Anaximanhad broached in private, was born about the 42 nd Olympiad. He der, born has been frequently confounded with Anaximenes, and sometimes with Araxagoras. He was the first person that constructed a geogra-

${ }^{1}$ It is impossible to reconcile this fact with the account which is given of the notions of Anaximander, that eclipses were caused by the stopping up of the orifices through which the fire of the sun and moon exhaled. If Thales did really predict an eclipse, he must either have known the obliquity of the ecliptic, and possessed a far more accurate knowledge of astronomy than his scholar, or he must have obtained some information of an expected eclipse from the Egyptian or Babylonian astronomers, which perhaps is not an improbable conjecture. 
phical map. We find Aristagoras, not many years afterwards, in possession of a map of the world, engraven on brass. (Herod. v. 49.) $\mathrm{He}$ is said to have invented the gnomon, not the sun-dial used to distinguish the hours of the day, but an instrument for deternining the times of the equinoxes and the meridian line. It seems doubtful whether the division of the day into hours was known in Greece till two centuries after the time of Anaximander. (See Ernesti 'Opusc. Philol.' p. 23.)

His Anaximander held that the origin and element of all things was rò

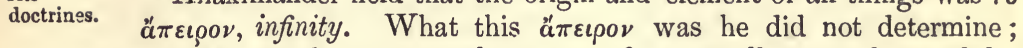
whether anything material, or an infinite intelligence: later philosophers explained it of the former ; and in consequence Anaximander has been classed amongst the atheists. According to Cudworth, Thales was a theist; but Anaximander, Anaximenes, Hippo, and others, were atheistical, who lield that matter devoid of life and understanding was the first principle. But, in point of fact, so little is really known of the doctrines of these philosophers, that it is not easy to say whetler they were believers in the existence of a God or not. One thing should be remembered, that many of them, in all likelihood, may have broached opinions concerning the formation of the world which ultimately conducted their followers to atheism, without being sensible at the time of their tendency.

Anaximenes. The successor of Anaximander was AvAximenes, who taught that

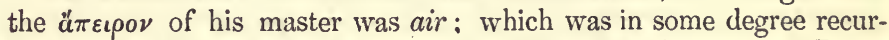
ring to the mythology of the poets, who identified the supreme Deity with Ether, the atmosphere. Anaximenes, however, maintained that the gods had their origin from this eternal and infinite air. $\mathrm{We}$ may here remark, that these philosophers, when they spoke of the

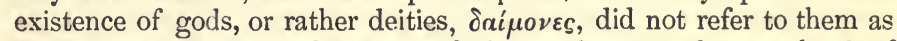
the creators or original causes of things, but merely as a kind of beings greatly superior to man, and possessing authority over them. So that a belief in their existence was perfectly compatible with a real and philosophical atheism. The grand doctrine of atheism is this : that the substance of matter, or extended body, is the only real entity, and therefore the only unmade thing, which is neither gene-

The eternity rable nor to be created, but self-existent from all eternity. But it of matter. does not follow that every philosopher who asserted the eternity of matter thereby intended to deny the eternity of God. On the contrary, some appear to have thought that an eternal cause must have had an eternal effect; as, for instance, Aristotle, who maintained the eternal existence of the world, says, "If there were nothing but matter in the world, there would be no original cause, but an infinite succession of causes." Others, again, entertain the contradictory hypothesis that matter was eternal and self-existent, and that the Deity was coexistent with it; in short, that the artificer of the universe and his materials were both self-existent. So that it remains very doubtful whether the philosophers of the Ionic school did really 
intend to exclude a supreme intelligence from their theories of the formation of the universe. "It plainly appears," says Dr. S. Clarke, "how little reason modern atheists have to boast either of the authority or reasons of those ancient philosophers who held the eternity of the world. For since these men neither proved, nor attempted to prove, that the material world was original to itself, independent, or self-existent; but only that it was an eternal effect of an eternal cause, which is God; it is evident that this their opinion, even supposing it could by no means be refuted, could afford no manner of advantage to the cause of atheists in our days; who, excluding supreme mind and intelligence out of the universe, would make mere matter and necessity the original and eternal cause of all things."

The great difference between the theists and atheists before the Ancient time of Aristotle was, that the former affirmed the world to have been Theists and made by God; the latter, by the fortuitous motion of eternallyexistent matter; and this theory was not the doctrine of the Ionic school.

The atomic theory is attributed by Plato to Protagoras; but its Atomic real authors (as applied to the purposes of atheism) were Leucippus and Democritus, who lived about 460 B.c. They made the two great Leucippus principles of nature to be the Plenum and the Vacuum, the one ö $\nu$, the critus. other $\mu \grave{\eta} o^{\prime} \nu$. 'They taught that everything was made by the fortuitous concourse of atoms, or individual corpuscles, some of which were round, some angular, some curved and hooked. These were called by Xenocrates $\mu \varepsilon \gamma \varepsilon \dot{\theta} \theta \eta$ aiocai $\rho \varepsilon \pi a$, “indivisible magnitudes ;" by

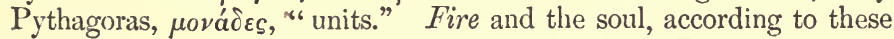
philosophers, consist of spherical corpuscles, which Democritus compared to the motes in the sunbeam. According to this hypothesis, all things are materially and mechanically necessary; but the older atomists (i.e. those who believed in the formation of the world from atoms, but did not exclude spiritual essence, or rather incorporeal substance) were generally theists; as, for instance, Pythagoras and Parmenides.

A determined opponent of Democritus was Axaxagoras, the Anaxagoras, successor of Anaximines, and the most remarkable of the Ionic school, whose philosophy is a subject of more immediate interest to us, inasmuch as he took up his abode in Athens, and became the instructor of Pericles and Euripides, and the source from which Socrates derived his knowledge of natural philosophy. Anaxagoras discovered that there were inequalities in the moon's surface; and asserted that the sun was a mass of burning matter. He maintained that snow was black; and that the eyes were not capable of discovering the true colours of objects. Or the reasons which induced him to maintain these opinions, the ancient writers give but an indifferent account. It would appear that Anaxagoras had adopted a leading notion of the old materialists, which has been revived by modern philosophers, that the qualities of bodies which strike our senses have no real existence without us, but are images and appearances within us. With regard 
to the opinions of Anaxagoras, we fortunately possess some unexceptionable documents in the poetry of his disciple Euripides, who, it is well known, was called the philosopher of the stage, and who introduced into many of his dramas the leading tenets of his master, particularly into his 'Chrysippus.'

Taught a Divine Creator of the World.

The founder of the Ionic school had taught that the Deity was the mind of the universe ; a notion very nearly, if not exactly, coinciding with that of the Hylozoick philosophers, who said that matter was endowed with a kind of reason. But Anaxagoras was the first who

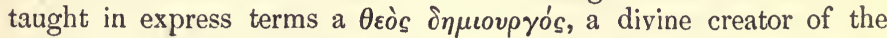
world. According to him, all things were a shapeless and inert mass, which the divine intelligence endued with motion, form, and beauty.

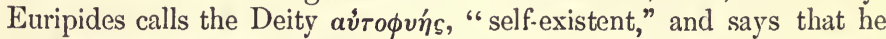
" interwove nature with the ethereal circle or orb." In other passages he represents the Anaxagorean doctrine of the divine mind imforming matter by the poetical union of Ether with the Earth :-

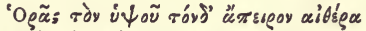

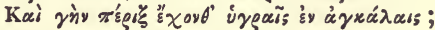

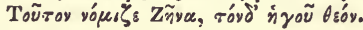

See'st thou on high this rast expanse of air,

Encircling in its liquid arms the earth ?

This, this is Jove, revere the present God!

Hence we find, in the surviving plays of Euripides, frequent invocations to Jove and the earth. This part of the poetical mythology of the Greek drarna is fully illustrated by Valckenaer in his 'Diatribe on the Fragments of Euripides,'who conjectures that Anaxagoras derived his notion of the two principles of animal life from Egypt, the great nursery of Greek philosophy; since Procopius (a very late writer, it must be confessed) mentions Anaxagoras of Clazomene as one of those who travelled into Egypt for the sake of acquiring a more exact knowledge of physics and theology.

Another dogma of Anaxagoras was, that nature consisted in the repeated union and dissolution of the same particles; agreeably to what Lucretius says (ii. 1001) :-

$\mathrm{Nec}$ sic interimit mors res, ut materiai

Corpora conficiat, sed coetum dissupat ollis.

\section{And Ovid-}

Nec perit in tanto quicquam (mihi credite) mundo;

Sed variat, faciemque novat.

It was upon the strength of this doctrine that Socrates afterwards asserted that the souls of men, when fieed from their temporary union with the body, returned to their native heaven.

His doctrine of similar particles.
The most curious and abstruse of his notions was that of the

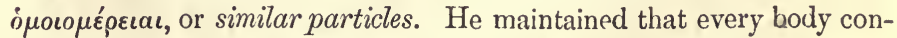
sisted of particles similar to itself; for instance, gold consists of atoms of gold; a bone, of minute bones, and so on. (This doctrine is 
detailed and refuted by Lncretius, i. 830.) $\mathrm{He}$ considered that everything was of a mixed nature except mind, which animated and moved the universe. Anaxagoras himself was called Noṽs, "Mind," probably from this dogma. It appears, however, that he supposed

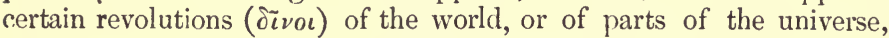
which were quite independent of this mind. Moreover, he attributed mind to animals of every kind, which he designated by the same appellation as that which he applied to the supreme intelligence.

It being agreed on all hands that Anaxagoras supposed the chaotic mass of particles to have been reduced into order by the divine intelligence, it may appear strange that Irenæus should have branded him with the imputation of atheism. The following passage of that father is quoted by Bayle (art. Anaxagoras, p. 212) : "Anaxagoras autem, qui et Atheus cognominatus est, dogmatizavit facta animalia decidentibus e cœlo in terram seminibus, quod et hi ipsi in matris suæ transtulerunt semina, et esse hoc semen seipsos statim confitentes apud eos qui sensum habent, et ipsos esse quæ sunt Anaxagoriæ irreligiosi semina."

The fact seems to be that Irenæus confounded Anaxagoras the Clazomenian with Diagoras the Melian, who was called, by way of distinction, the Atheist.

Anaxagoras was sensible of the difficulties which embarrass all the speculations of human reason upon the final causes of things; he complained that all things were surrounded with darkness. In the mathematical sciences he found a greater degree of certainty, although even in this department of knowledge he seems to have indulged in speculations upon abstruse points. He is said to have treated of the speculations. quadrature of the circle, of the nature of comets, of the milky way, earthquakes, winds, thunder, eclipses, and the annual overflowing of the Nile : a constant source of perplexity to the ancient naturalists. $\mathrm{He}$ is related to have foretold the fall of a stone from the sun, which did actually fall into the Goat's River in Thrace, and was there venerated as having come from heaven. This is a curious incident. Of course it is impossible that Anaxagoras should have predicted the fall of the stone : the fact probably is, that having heard of the circumstance, he said that the stone had fallen from the sun, agreeably to his own hypothesis of the sun's being an ignited mass of stone. This, we believe, is the first distinct mention of an aerolite, or meteorolite, which occurs in ancient bistory ; and the account given by Anaxagoras of the stone in question, is pretty nearly as probable as the theory of La Place, who supposes these meteorolites to be projected from a volcano in the moon, and having passed the sphere of lunar gravitation, to pursue their course to the earth's surface.

A mongst the opinions of Anaxagoras on points of natural history, His opinions the most remarkable are these:-

on natural history.

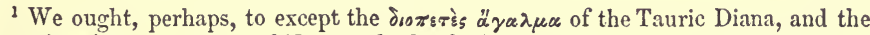

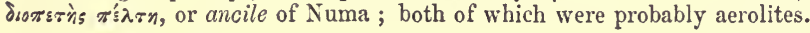


1. That sleep is an affection merely of the body, not of the mind.

2. That the cause of winds is the rarefaction of the air by the sun's rays. His successors, not contented with this simple and true account of the matter, had recourse to much more complicated and improbable causes.

3. That earthquales are caused by air confined in subterraneous caverns.

4. That the rainbow is occasioned by the reflection of the sun's rays in a dense cloud, opposite the sun. (Brucker says, "by the

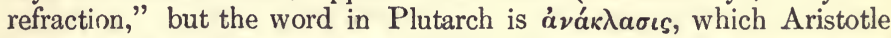
uses of the reflection of light. The philosophers of that age knew nothing of refraction: and when Pliny speaks of the rainbow, although he uses the word refringi, he seems to mean reflexion.)

Anaxagoras committed to writing some of his lucubrations; Socrates is represented by Plato as expressing the dissatisfaction which he experienced, upon the perusal of a work of Anaxagoras, at finding that he proceeded no further, in accounting for the actual state of things, than mechanical causes; instead of assigning moral causes, such as the fitness of things, the principles of order, \&c. Bayle defends Anaxagoras, upon the ground, that, having once admitted a first moving cause, he had no occasion to recur to it in his explanation of the separate phenomena of nature. It appears, from this account, that Socrates was not a scholar of Anaxagoras.

Diogenes The principles of Anaxagoras were taken up by Drogenes ApolA polloniates. LONIATES, the next philosopher of the Ionic school, who made, however, this important change, that he supposed the air not only to be the first principle of all things, but also the efficient and moving principle.

Archelaus Diogenes was succeeded by Archelaus, both of them having been hearers of Anaxagoras. Archelaus was called, by way of eminence, o $\phi v \sigma \iota c_{s}$, " the natural philosopher." Some writers have attributed to him the honour, which is most commonly assigned to Anaxagora;, began teach- of having been the first to import philosophy from Ionia into Athens. ing in It is not unlikely that Archelaus might have been the first who about 450 B.c. established a regular school of philosophy in that city; for Anaxagoras perhaps only taught some occasional disciples. But the method by which Bayle endeavours to reconcile the two accounts, is this:-The ancient writers say nothing more than that Archelaus first transported the Ionic school of philosophy from Ionia to Athens, which is strictly true; for during the temporary residence of Anaxagoras in Attica, the chair of philosophy in Ionia was not vacant; whereas, when Archelaus came to Athens, he left no successor behind him in Ionia.

Where Archelaus altered the dogmas of Anaxagoras in physics, it seems to have been for the worse, and the same may be said of his moral philosophy; since he maintained the dangerous position, that there is no such thing as natural right; that all actions are in themselves indifferent; and that their moral quality depends solely on the 


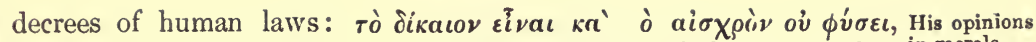
$\alpha \lambda \lambda \grave{a} v o ́ \mu \omega$, " that justice and turpitude are not such by nature, but in morals. by law." This sentiment is nearly the same as that which was put by Euripides into the mouth of one of the characters in his Aolus :-

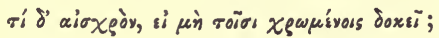

What is base, which does not seem so to those who do it?

For there is nothing either good, or bad,

But thinking makes it so.

Shakspeare-Hamlet.

In opposition to this sentiment, Diogenes the Cynic is related to have said,

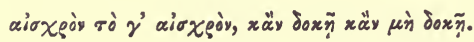

What is base, is base, whether it be thought so or not.

Possibly, however, Archelaus intended merely to deny the existence of a moral sense; and consequently of any distinction between right and wrong, independently of the will of the legislation: we cannot pronounce him guilty of impiety, till it can be determined whether by vómos, he meant human laws, or the declared will of the Deity.

In closing this brief account of the Ionic school, we have one remark to make, which will throw light upon some transactions in the life of Socrates. It was a leading principle of the received mythology of those times, that all the different operations of nature were performed by the agency of genii, an inferior class of deities, at whose will the lightning flashed, the earth quaked, the stars withdrew their light. Earth, air, and sea were peopled with these imaginary agents, who were subject to the order and control of the superior gods. All the phenomena of the heavens were referred to their respective powers; and when any portent alarmed an ignorant people, it was attributed to the anger of some offended deity.

Now the new philosophy, which pretended to assign "natural and Effects of material causes for these various phenomena, went to pluck up by material the roots this superstition (emphatically termed by the Greeks, causes of

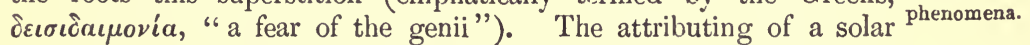
eclipse to the periodical interposition of the moon between the sun and the earth, instead of considering it as a portent sent by some superior power, for the purpose of announcing some approaching calamity, was, in the eyes of the vulgar, nothing less than depriving their deities of a legitimate privilege. And, besides, there was a numerous tribe of people in Greece, called ' $\dot{\xi} \xi \eta \gamma \eta \tau a i$, or expounders, whose trade it was to explain portents, omens, and presages of every kind; and it was an art productive of no inconsiderable gains to its professors. He, therefore, who undertook to show that these phenomena, which resulted from the established and unerring laws of nature, could never be the prognostics of contingent events (inasmuch as they will certainly happen, whether the events themselves happen 
or not), aimed a deadly blow at the lucrative calling of the whole tribe of exegetæ and soothsayers.

The example of Nicias, as represented by Thucydides in his account of the Athenian expedition against Sicily, affords a striking Prevalence of proof of the hold, which this superstition had obtained upon the minds superstition in Greece.

even of the higher classes in Greece; while, on the other hand, Pericles was a remarkable instance of the advantage which a man of powerful mind acquires over his contemporaries, by divesting himself of the superstitious notions of the age in which he lives. The following is the observation of Plutarch: "Pericles not only derived this benefit from his intercourse with Anaxagoras, but he seems to have been rendered superior to that kind of superstitious fear, which astonishment at the phenomena of the heavens excites in those who are ignorant of the causes of them, and by reason of their inexperience, are disturbed, and like persons possessed in religious matters: from which superstition natural philosophy emancipates a man, and inspires him with a firm piety, accompanied by pleasing hopes, in the room of this terrifying and feverish superstition." The same author, speaking of the eclipse of the moon, which induced Nicias to defer his retreat, says, that eclipses of the sun were then pretty well understood by the common people to be occasioned by the moon; but an eclipse of the moon itself was much more incomprehensible, and a subject of great alarm. For Anaxagoras, the first philosopher who had written clearly on the subject, had not publicly divulged his opinions ; but his scholars kept them close amongst themselves through fear of the people, who could not endure those philosophers who treated of natural causes, but called them in contenıt $\mu \varepsilon \tau \varepsilon \omega \rho \circ \lambda \varepsilon \sigma^{\prime} \chi^{\alpha \iota}$, or " persons who prose about things in the sky;" being jealous of their attributing to natural causes, that which belonged to the gods alone ; for which reason Protagoras was banished from Athens, and Anaxagoras put into prison; from which he was with great difficulty liberated by Pericles.

It was obviously the interest of all the expounders and soothsayers above mentioned to forment the popular jealousy of these studies, and to raise the cry of atheism against the new philosophy. Anaxagoras was accused of impiety, because he asserted that the sun was a mass of ignited stone, thereby degrading that luminary from the order of gods; and when Aristophanes, some years afterwards, endeavoured to fix the popular odium on Socrates, he represented him as a minute philosopher, prying into the secrets of nature. It was well observed by Justin Martyr, "Those persons before the Christian era, who endeavoured by the strength of liuman understanding to investigate and ascertain the nature of things, were brought into the courts of justice as impious and over-curious."

The Sophists. We have before observed, that the name which was applied to these persons who inquired into the secrets of nature, or studied

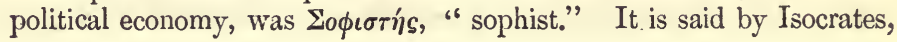


that Solon was the first who assumed this title; that is, probably, the first Athenian. About the time of Socrates this appellation began to be applied to those professors of wisdom, who dogmatised with confidence upon every subject, and taught philosophy as a perfect science, for pay; while the modest inquirers after truth contented themselves

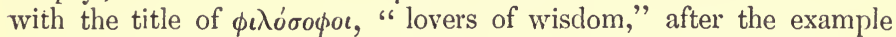
of Pythagoras. By degrees, these two classes of men became distinct from, and opposed to each other, chiefly through the influence of Socrates; but in his time the distinction was not established. About that period, however, the sophists began to assume a tone of greater confidence, and professed to teach the principles of natural and moral philosophy as matters, not of investigation, but of certainty; and seeing the success which had attended the lectures of Anaxagoras, by whose advice Pericles had been enabled to obtain the control and direction of the Athenian republic, they joined the arts of logic and eloquence to the study of morality and natural history, and pretended to be masters and teachers of the whole circle of human knowledge. In reading the history of those times, as it regards the progress of philosophy, we must be careful not to confound the sophists of the Socratic age with those of a later period, who confined themselves to the art of rhetoric: such were the sophistæ whose lives were written by Philostratus. That the sophists of Athens combined natural philosophy with eloquence and politics, appears from the following sentiments of Socrates, as reported by Xenophon. "No person ever saw or heard an irreligious or impious action or word of Socrates : for he was not accustomed to discourse concerning the nature of all things, as most of his contemporaries did, considering how that, which the

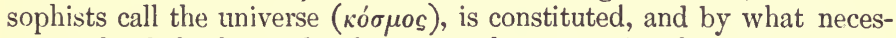
sity each of the heavenly phenomena happens; but he used to prove the folly of those who busied themselves about such things; and he used to inquire, in the first place, whether they applied themselves to these pursuits, having previously obtained a complete knowledge of everything relating to man; or whether they could reconcile it to their notions of propriety and duty to omit all consideration of human affairs, and study only divine things. And he expressed his surprise at their not clearly perceiving, that these things are not discoverable by the human intellect, since even those who most prided themselves upon discoursing on these subjects, did not think alike, but differed with one another like so many crazy people; for some crazy persons are not afraid, even of things which are really formidable, while others see fear where there is none: some again make no scruple of saying or doing anything, even in a crowd, while others cannot bear even to appear in public: some respect neither temple nor altar, nor anything pertaining to the gods, while others worship sticks, and stones, and beasts. So amongst natural philosophers: some think that there is only one entity, others an infinite multitude; some hold that all things are continually in motion, others that nothing can be moved; some 
assert that all things are generated and destroyed, others that nothing can be generated or destroyed." - "The older sophists," says Philostratus (i.e. those of the age of Socrates), "discoursed largely upon all philosophical questions; for instance, concerning fortitude, justice, heroes, and gods, the formation and figure of the universe; whereas the more recent sophists (not the latest of all, but those of a middle age) delineated characters, and discussed questions relating to indi-

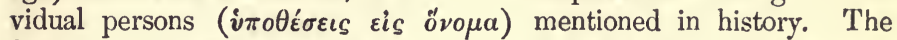
first of the older sophists was Gorgias of Leontium; of the second class, Eschines, the son of Atrometus, who professed the art in Caria and Rhodes, after his political failure at Athens." He gives the following account of the different modes pursued by the philosopher and the ancient sophist in their teaching. "The old sophistic art may properly be termed a philosophising rhetoric, for it discusses the same topics as the philosophers; but what they propose in the form of questions, advancing step by step, and professing not to know with certainty; of all this the old sophist professes a perfect knowledge. $\mathrm{He}$ begins his discourses with $I$ know, and $I$ understand, and $I$ have thoroughly considered, ${ }^{1}$ and nothing is certain to man ( $\beta \varepsilon ́ \beta a \iota \nu \nu ~ ' \iota \nu \theta \rho \omega ́ \pi \omega$ ov $\delta \varepsilon$, this seems to refer to the universal doubt of the sceptics)."

It is a common remark, that Socrates was the first who transferred philosophy from the contemplation of natural history to the manners of men: but this is not literally true; for although the Ionic school was chiefly employed in physiological researches, the sophists, who came to Athens about the time of Socrates, professed, at least, to combine ethics and politics with the more abstruse studies of nature. The principal merit, however, to which they laid claim, was that of communicating to their disciples a ready off-hand kind of knowledge, which might enable them to talk speciously and fluently upon all subjects whatever $;^{2}$ and to impart to them that pernicious skill in dialectics, by which they might baffle their adversary, whether right or wrong, and " make the worse appear the better cause." In his celebrated dialogue, entitled 'The Sophist,' Plato has exposed the manners and arts of the sophists of his time, against whom Socrates declared interminable war. So successful were these pretenders to wisdom, in their endeavours to impose upon their countrymen, that the most eminent of them moved from city to city, attended by a vast

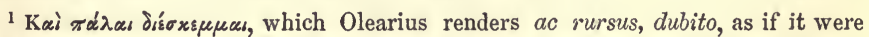

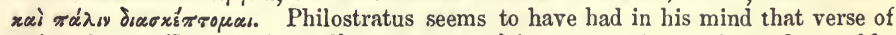

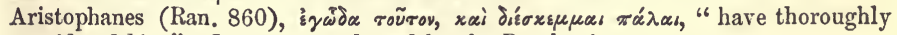
considered him." It was a word used by the Pyrrhonists.

${ }^{*}$ When Socrates professed his desire to ask some questions concerning the art which Gorgias professed, Callicles says to him, "There is nothing like asking the man himself, Socrates; for this is one part of his public exhibition : it was only just now that he desired any one of the party to ask him any question he pleased, and declared that he would give an answer to all." Upon which Chærephon asks Gorgias whether this be true; to which he replies, "It is quite true, Chærephon: I did make this promise; and, moreover, I say that nobody has put a new question to me for these many years." Plato, Gorg. p. 447. 
train of scholars, who paid large sums, for the inestimable advantage of being taught the art of deceiving and overreaching their fellowcitizens: and, indeed, Xenophon tells us that Socrates applied the term sophist exclusively to those who sold wisdom for money, and

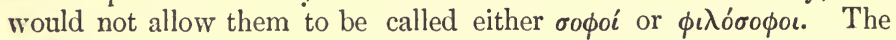
sophist is described in the dialogue above-mentioned, as-1st, a mercenary hunter of rich young men; 2 nd, a wholesale trafficker in metaphysical knowledge; 3rd, a retail trader in the same; 4th, one who sells his own manufactures; 5 th, one practised in the gymnastics of litigious eloquence; 6th, one, who himself contradicts, and teaches others to contradict, and be contentious in questions relating to divine things, to the phenomena of nature, and to political science ; 7 th, a kind of conjurer, or juggler, who, with the semblance of truth, persuades young men that he knows everything, whereas, in fact, he has only a delusive show of wisdom, without the substance. The dialectic subtlety of these men is exposed by Plato, in his 'Euthydemus :' but it must be confessed, that, by their minute cavils and objections, by their divisions and subdivisions, they led the way to a truer and more exact system of logic than had heretofore been known.

The great leader of the sophists was Protagoras, of Abdera, or of Protagoras. Teos, a scholar of Democritus, who, having commenced the custom of demanding a fee for admission to his lectures, amassed more money, says Socrates, in Plato, than Phidias, and any ten sculptors besides. This gainful trade he pursued for forty years, and, when he died, left a great reputation behind him. He was not, however, the earliest sophist; for Socrates is made to say in the same place ('Menon.,' p. 373 , ed. Bib.) that many others had followed the same profession before lim. He was, however, the first who gave lectures for pay.

Amongst the scholars of Protagoras, the most remarkable were Gorgias; Gorgias, of Leontium, who was chiefly celebrated for his eloquence Prodicus. (whom Philostratus calls the Aschylus of sophists), and Prodicus, of Ceos; in the number of whose hearers were Euripides, Isocrates, Xenophon, and Socrates himself, who is represented by Plato, as saying to Meno, "You and I, Meno, it seems, are but poor creatures ; Gorgias has given an indifferent education to you, and Prodicus to me." It appears, however, from a passage in Plato's 'Cratylus,' that Socrates could not afford to pay the sum, which Prodicus exacted of those who were desirous of knowing the more recondite mysteries of his craft. He speaks of a lecture, ${ }^{2}$ the price of which was

1 Plato remarks, in the character of Thextetus, that, unless the sophists had professed to communicate political knowledge, no one would have conversed with them. This is a remarkable circumstance, inasmuch as it develops the real object which their auditors had in view, viz.- to acquire so great a proficiency in the adroit management of affairs as might enable them to take the lead in the commonwealth. Gorgias professed to communicate to his scholars the summum bonum, viz.-the art of persuasion, "by which men obtain the government over others in their respective states." Plato, Gorg. p. 452.

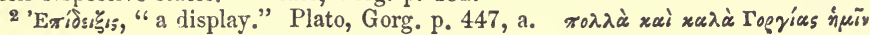


fifty drachms; while he himself had only paid one drachm. Prodicus first made his appearance at Athens, as an ambassador from his native island, and gained great applause by his eloquence. Most of our readers are acquainted with his celebrated apologue, of the 'Choice of Hercules,' which Socrates quotes at length in the 'Memorabilia,' of Xenophon, and says that it was very popular.' Prodicus was accused, as Socrates afterwards was, of corrupting the youth of Athens by inculcating irreligious opinions, and was condemned to drink " the cold Socratic draught." 2

Hippias. Another celebrated sophist was Hippias, of Elis, who boasted at the Olympic games, that there was nothing, in the whole range of the arts and sciences, which he did not know; and that he was not only a perfect master of the liberal arts, geometry, music, poetry, \&c., but that the ring which he then wore, his robe, and his buskins, were all manufactured by his own hand. Plato has introduced him as a speaker in the two dialogues which are entitled 'Hippias Major,' and 'Hippias Minor ;' the first of which throws so much light upon the character and practices of the sophists, that we shall here present our readers with such parts of it as may serve to place in the clearest point of view the mode of philosophising, against which Socrates waged unceasing war. The two persons of the dialogue are Socrates and Hippias.

So. Why Hippias, worthy ${ }^{3}$ and wise sir, what a long time it is since you visited us at Athens!

Hr. Very true; for I have had no leisure, Socrates. For the state of Elis, when it wants to negotiate anything with another city, always comes first to me, to choose me for its ambassador, thinking me to be the most competent judge and interpreter of the proposals made on the part of the respective cities. I have therefore frequently gone as ambassador to other cities, but most frequently, and upon affairs of the greatest moment, to Lacedæmon; for which reason, that I may answer your inquiry, I don't come very often into these parts.

So. Such a fine thing it is, Hippias, to be a truly wise and perfectly accomplished man. You, for instance, are able, in your private ca-

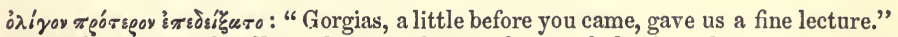
Aristophanes describes Euripides as making a rhetorical display of this sort to the

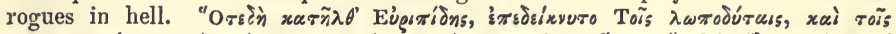

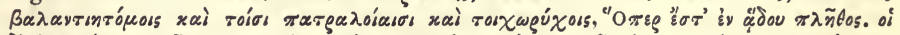

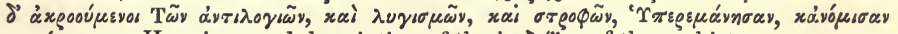

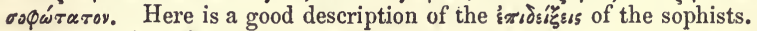

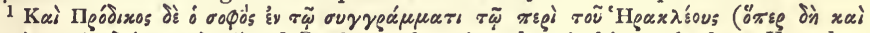

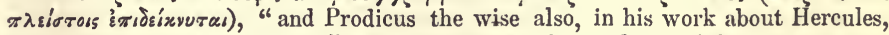
which he recites to everybody." No commentator has understood the precise meaning of this parenthesis. See the preceding note. Philostratus says, that Gorgias ridiculed Prodicus for repeating the same discourse or lecture over and over again, and professed himself to speak extemporaneously.

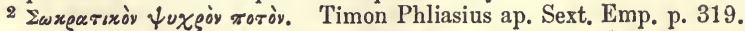

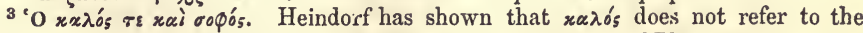
personal appearance of Hippias, as Sydenham, the translator of Plato, supposes. It answers perhaps most nearly to the bellus of the Latins, and to our fine. 
pacity, while you receive lange sums from the young men, to give them in return more than their money's worth; and in your public character, to benefit your country, as every man must, who would not be despised, but thought highly of by people in general. But pray tell me, Hippias, what can be the reason, why those ancient worthies, who are so celebrated for wisdom, Pittacus and Bias, and Thales of Miletus, and his successors down to Anaxagoras, all, or most of them, appear to have kept aloof from political transactions ?'

Hr. What other reason, d'ye think, Socrates, than their inability, and incompetency to master, by the force of their understanding, the arts both of public and private life?

So. Do you mean to say then, that as the other arts have advanced, and the ancient professors of them have been far surpassed by those of our days; so the art which you sophists profess, has improved, and that the old philosophers are nothing compared to you?

H. You have exactly hit upon the truth.

So. I am ready to testify with you, that what you say is true; and that, in fact, your art has so far improved, as to combine the management of public with that of private affairs. For Gorgias, the sophist of Leontium, came hither, on a public embassy from his native country, as being the best qualified of the Leontines to manage the affairs of the commonwealth; and he had the credit of being an excellent speaker in the assemblies of the people; and in private gave lectures, and associated with young men, and by that means made a great deal of money out of this city. Again, if you prefer this instance, our old companion Prodicus, has often come hither in a public character upon other occasions, and upon his last visit, which was very lately, having come from Ceos, he acquired great credit by a speech in the council; and giving lectures in his private capacity, he got a prodigious sum of money. But not one of those ancient gentlemen ever thought of exacting money as a price, nor of making a display of his wisdom to all sorts of people, so simple were they, and ignorant of the great value of money. Whereas, each of those moderns makes more money by his wisdom, than the professors of any other art whatever; and the same was done by Protagoras before them.

Hr. The fact is, Socrates, that you know nothing of the fine things I could tell you on this subject. If you knew how much money I have made, you would indeed be surprised. To mention no other instances-having arrived in Sicily upon a certain occasion, Protagoras being at that time residing there, in high reputation, and somewhat advanced in years, $I$, being much younger, made in a very short time more than one hundred and fifty minæ; and more than twenty out of one very small town, named Inycum. This I carried

1 Socrates says this in compliance with the common opinion. of the sophists of his time, who laid claim to the invention of managing the state by philosophy; and said that Pittacus, and others of the same stamp, interfered in politics, not as philosophers, but as tyrants and intriguers. 
home and gave to my father, to the great surprise and astonishment of himself and his fellow-citizens. And I rather think I have made more money than any two whatever of the other sophists.

He then goes on to tell Socrates, that in Lacedæmon, where he had been most frequently, he had made no money at all; and when pressed for a reason of this, he says, "It is not the custom of that country to disturb the existing laws, nor to introduce any novel practice in the education of their sons." He confesses that the Lacedæmonians would not listen to any discourses on astronomy, geometry, nor arithmetic ; nor upon grammatical questions ; but " concerning the genealogies of heroes and men, and the original foundation and colonization of towns, and upon antiquarian subjects. And I got great credit by discoursing upon the different pursuits which a young man ought to follow. For I have a very charming little work on this subject, well drawn up in all respects, but particularly in point of language. The subject is this. Troy being taken, I suppose Neoptolenıus to ask of Nestor, what are the most becoming pursuits for a young man who wishes to gain credit by them? Then Nestor speaks and suggests to him a great many very orderly and honourable precepts. This discourse I delivered there, and intend to do the same here the day after to-norrow, in the school of Pheidostratus, and to add to it a great deal more worth hearing."

Effects on Greek society produced by the teaching of the sophists.

These extracts afford a fair specimen of the vanity and ostentation of the sophists, and of the effect which they produced upon the tone of society at Athens, with respect both to literature and morality. Multitudes of young men attended these pernicious teachers, and paid them every kind of honour; struck with astonishment at the facility and splendour of their eloquence, as well as at the dialectic subtlety of their reasoning; and, what was far worse, captivated by the easy morality which confounded all the limits of right and wrong, and placed the summum bonum in the attainment of political distinction. We have given an account, somewhat minute, of these misnamed philosophers, because it is impossible to understand the character of Socrates, or to appreciate his excellencies, without being previously acquainted with the state of society in which he found himself upon his entrance into life. The example of Pericles had inflamed the ambition of the youth of Athens; and to obtain, like him, an unlimited influence over the people, was the one great object of their desires. To the pursuit of this, all other studies were made subservient. The sophists saw this ruling passion, and took advantage of it; and in the course of their instruction, having run through a certain system of natural philosophy, founded upon the principle of materialism, they directed their chief attention to those arts of reasoning, or rather to that abuse of reason, which they called by the name

Dialectics. of dialectics. By the help of this instrument, the youthful catechumen was enabled readily to perplex the understandings and judgments of a popular auditory; to argue plausibly on either side of a question, as 
might be most agreeable to his hearers, and therefore most conducive to his own purposes; in the accomplishment of which he would be restrained by no feelings of honour or moral delicacy, having been taught that there was no inherent nor essential difference between right and wrong.

"That might made right," says Mr. Mitford, the able historian of Greece, " especially in public transactions, was a tenet very generally avowed; the incalculable mischiefs of which were checked only by the salutary superstition, which taught to respect the sanction of oaths, in the fear that immediate vengeance from the gods would follow the violation of it as a personal affront to themselves. It appears, however, in the remaining works of the great comic poet of the day, that this salutary superstition was fast wearing away. It is evident from the writings of Xenophon and Plato, that, in their age, the boundaries of right and wrong, justice and injustice, honesty and dishonesty, were little determined by any generally-received principle. There were those who contended that, in private as in public affairs, whatever was clearly for a man's advantage, lie might reasonably do: and even sacrifice was performed, and prayer offered to the gods for success in wrong."

Such was the state of things at Athens, when Socrates appeared Socrates. upon the stage of public life. Before we proceed to detail his biography, a few words must be said concerning the sources from which we derive our information respecting him. It is well known that the two authors, from whom this information is principally drawn, were his scholars and admirers. Of these, Plato has rather been studious to raise an immortal monument to his own wisdom and eloquence, than to give a faithful delineation and portraiture of his illustrious master. He has made Socrates the principal personage in his truly dramatic dialogues; but he has rather employed him as the organ of his own philosophical opinions, than represented, in their native simplicity, the doctrines of the great teacher himself. We are assured by Aristotle, that Plato was addicted, in his earlier years, to the notions of Heraclitus; and Socrates complained that, even during his lifetime, Plato corrupted his doctrines by mixing with them the tenets of other philosophers. This conduct gave great offence to the other disciples of Socrates, and especially to Xenophon, between whom and Plato there appears to have subsisted a considerable dislike. It is very plain, from the style of Plato's dialogues, that they are not to be depended upon as faithful records of the life or sayings of Socrates. Athenæus relates, that Gorgias, upon reading the dialogue inscribed with his name, exclaimed, "How well does Plato understand the art of lampooning!" $\mathrm{He}$ added, that he had never heard Socrates utter a syllable of what Plato puts in his mouth. Timon of Phlius, the writer of Silli, who lashed all the philosophers, had a verse to the following effect:- "How skilfully did Plato invent his admirable fictions!"

[G. R.P.] 
Some of the persons, whom Plato introduces as conversing with Socrates, could never have seen him; and Xenophon says, that as it was perfectly well known that Socrates confined himself wholly to moral philosophy, those writers who put into his mouth long discussions upon subjects relating to physics, were guilty of a palpable imposture. This remark was evidently aimed at Plato. The Abbé Garnier has endeavoured to exonerate Plato from these charges, but without success.

The genius and ambition of Plato having thus disqualified him for the office of a faithful historian of the philosophy of Socrates, we must be cautious how we impute to that extraordinary man any opinion or practice, upon the authority of Plato, unless we have the concurrent testimony of Xenophon, whose amiable candour and simplicity irresistibly claim our belief. His 'A Memoirs ${ }^{1}$ of Socrates, are our text-book, in investigating the opinions of his master.

The life of Socrates was written by Aristoxenus, Demetrius, Phalereus, and several others, whose works have perished; but we find notices from them in the writings of later authors; in some instances contradicting one another, and requiring the judgment of sound criticism to decide upon their comparative credibility.

Socrates born 468 в. с.

Socrates was born in the fourth year of the seventy-seventh Olympiad, on the sixth of the month Thargelio, at Alopece, a demus or borough, of Attica. His father, who was a statuary, was named Sophroniscus; his mother, who was a midwife, Phænarete. Socrates Learns his was instructed by his father in his own art, which he exercised with father's art of some skill and success: Pausanias says, that he made the statues of
statuary.

Mercury and the Graces, which stood at the entrance of the Acropolis. His father having died, left him an inheritance of eighty minæ, which he lost by the treachery of a relation, to whom he had lent it upon interest. Being thus reduced to the necessity of working at his profession, he contented himself with doing just enough to bring him in a bare subsistence, and employed his leisure time in the study of philosophy. ${ }^{2}$ Crito, a rich Athenian, is said to have furnished him with the means of procuring for himself such instruction as he desired.

Becomes a scholar of Archelaus. At the age of seventeen, he became a hearer and favourite scholar of

1 This book is usually called the Memorabilia. Gellius describes it as " a treatise concerning the actions and sayings of Socrates :" $\dot{\alpha} \pi$ \%

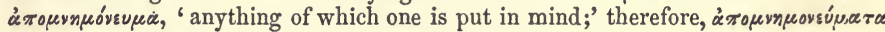
are probably Memoirs. Boswell's Life of Johnson would be exactly designated by this word. We must here observe, that some critics have doubted whether the Memorabilia be the genuine production of Xenophon or not.

2 Brucker makes a ludicrous mistake on this subject. He says, "Quare necessitate compulsus, non Athenis tantum, sed et Duris statuariam exercuit." $\mathrm{He}$ found in the Latin version of Diogenes these words: "Porro Duris serviisse illum ait, et sculpsisse lapides;" i. e., "Duris also relates that he was a slave, and cut statues." Whereas Brucker, not consulting the Greek, where there is the nominative $\Delta$ overs, mistook Duris for the ablative, and fancied it to be the name of a place. 
Archelaus. He received lessons in music from Damon, a celebrated professor of that science; but did not learn to play on the lyre till he had arrived at a much later period of his life. For the precepts of eloquence he had recourse to Prodicus; for those of poetry to Euenus, of Paros, a celebrated elegiac poet; geometry he learned from Theodorus. To these graver studies, he sought to add an acquaintance with the delicacies of language and of thought; and with that view, he frequented the society of the most accomplished females at Athens, particularly Aspasia, the mistress, and afterwards the wife, of Pericles; and Diotima, from whom he professed to have imbibed the philosophy of love.

He pursued these methods of obtaining knowledge, in preference to the course which had been followed by most of his predecessors, who had thought it necessary to visit Egypt and the east, $\theta \varepsilon \omega \rho i \eta s$

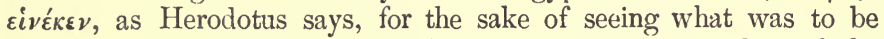
seen, and of obtaining some insight into the recondite wisdom of the priests and magi; whereas Socrates used to boast that he had never left Athens, except on the service of the state. When he was called upon, in his civil capacity, to discharge any of the offices imposed upon him by the laws, he was active, conscientious, and disinterested. He served as a soldier at the siege of Potidæa, (OL. lxxxvi. 3), and Alcibiades, who was his comrade, testified that he surpassed all his fellow-soldiers in his endurance of labour, hunger, and thirst; and that he united the most perfect sobriety with great convivial cheerfulness. Alcibiades himself, when wounded, was rescued from the most imminent danger by his friend and preceptor. After the conflict, the prize of valour having been adjudged to Socrates, he prevailed upon the umpires to transfer it to Alcibiades. His second campaign was in OL. lxxxix. 1, when he distinguished himself at the battle of Delium in Bøotia (where the Athenians were defeated) by his valour in defence of Xenophon; who having lost his horse in the flight, and lying wounded on the ground, Socrates, who wås on foot, carried him on his shoulders to a considerable distance, walking deliberately and firmly, and displaying a courage which deterred the enemy from attacking him. He served again, the same year, in the expedition against Amphipolis. Athenæus endeavours to deprive Socrates of the credit of these military achievements, taking for his text a saying of Democrates, "that one could as easily make a lance of a stalk of savory, as a perfect soldier of a Socrates;" and he attempts to prove, partly by chronological computations, and partly on the ground of improbability, that the account given by Plato is untrue. But Plato is supported by the testimony of Xenophon and Antisthenes; both of whom lived so near the time when these occurrences are said to have taken place, as to render it in the highest degree improbable that they should have ventured to impose a false account upon persons who knew the real state of the case. The cavils of Athenæus have been satisfactorily refuted by Isaac

Serves as a Soldier. 
Casaubon, in his animadversions upon that learned, but injudicious writer.

Socrates, partly from a dislike of politics, and partly, perhaps, from the obscurity of his station, did not fill any civil office till he was considerably advanced in years, when he was elected into the

His conduct as member of a Court of Justice. council: and being one of the Prytaneis when the six generals were tried for having neglected to rescue from the waves those who had been wrecked, and the dead bodies of those who had fallen in the sea-fight at Arginusæ, he resisted singly the iniquitous attempts of their accusers, and the fury of the people, and refused to put the question to the vote. Afterwards, under the rule of the Thirty, being deputed one of five to arrest Leo of Salamis, for the purpose of putting him to death, he resolutely declined the office, at the hazard of his own life, which would probably have been sacrificed to the resentment of the tyrants, had they not shortly afterwards been deprived of their power.

Socrates is said to have taken advantage of a law of Solon, which permitted an Athenian citizen to have two wives; and to have marHis marriage. ried first Xanthippe, and afterwards Myrto, the daughter of Aristides (not the Just), whom he is related to have taken into his house from motives of pity, when she was a widow and in distress. This story rests upon the authority of Plutarch, Demetrius, Phalereus, Aristoxenus, and Satyrus the Peripatetic. But there are many reasons for doubting the fact. In the first place, there is no good authority for asserting that there was any law of Solon which permitted bigamy. In the second place, neither Plato nor Xenophon make any allusion to such a circumstance in their master's life; nor Aristophanes, who certainly would not have let slip so fair an opportunity of a joke against Socrates. And lastly, Plutarch, who is the earliest author extant that mentions the story, says that Panætius, in his book on Socrates, "has abundantly refuted the assertions of those writers who propagated the story." The fact probably was, that Socrates did receive Myrto into his house from motives of charity and kindness, and that hence originated a report of his having married her. The reader may see the question discussed at length in Bentley's 'Diss. on the Socratic Epistles ;' Mahne's 'Diatribe de Aristoxeno.'

Xanthippe,

With regard to the character of Xanthippe, his undoubted wife,

her characier there is a great diversity of opinion. She is commonly believed to have been a woman of loose manners, and of violent temper. For the first of these charges, however, there seems to be no gocd authority. Neither Plato, Aristotle, nor Aristophanes, make any allusion to it; and it is inconsistent with the account which Plato gives of the kind and affectionate behaviour of Xanthippe towards her husband in his last moments. But it is quite clear that she was of a violent and untractable temper; for Socrates professed to have married her because he knew that if he could put up with her caprice and passion, he would be able to bear with patience the ill humour of 
others. Lamprocles, the son of Xanthippe, declares, in Xenophon, that the fierceness of a wild beast would be more tolerable than the temper of such a mother. At the same time, however, he confesses that she had performed towards him all the offices of a kind and careful parent.

Socrates appears to have been at all times in a state of great indi- Socrates' gence; nor was he solicitous to increase his means. He was wholly poverty. intent upon correcting the gross defects which he perceived in the religion, the morality, and the government of his country; and made the pursuit of this object the sole business of his life. He was gifted with an extraordinary share of sagacity and common sense, and a great facility of expressing his sentiments in easy and perspicuous language. Instead of following the example of the sophists, who proclaimed their readiness and ability to communicate to others every kind of knowledge, he professed himself, what, in fact he was, a sincere and ardent inquirer after truth; and imparted to others the wisdom which he seemed to be seeking, not in the way of a dogmatic lecture, nor of precept, but by proposing questions, which led his hearers insensibly His method to just and indisputable conclusions.

As Socrates was well aware that the most effectual way of producing a reform in the opinions and habits of his countrymen, was by communicating a proper bias to the minds of those young men who were likely to have a share in the management of public affairs, he took every opportunity of mixing, but in an easy and natural way, in the company of the opulent and popular Athenians, of those who sought to distinguish themselves by their eloquence, their elegance, or their manly pursuits. With this view he was continually in public. No man, perhaps, ever lived so long and so much in the eyes of the world as Socrates. Early in the morning he went to the public walks and gymnasia, or schools for athletic exercises; and when the Agora (i. e., the public bazaar or exchange) was most thronged, which was about noon, Socrates was always one of the crowd; and he generally accepted of some invitation to pass the rest of the day where he was likely to meet the largest company. In these parties he was usually the principal speaker. Although a very patient hearer, he mostly contrived to give the conversation a tirn to some interesting and important subject, which he enlivened by his ingenuity and cheerfulness, and concluded by convincing his hearers, without even distinctly asserting the opinion which he wished them to embrace.

When his reputation was established, and he was followed by great numbers of young Athenians, he could never be induced to relieve his poverty by accepting any reward for his instructions given in public; and in private, properly speaking, he gave none.

He did not, however, confine his peculiar method of philosophising to men of rank and property ; but took frequent opportunities of conversing with those artists and mechanics who were most eminent in their respective departments. He judged that it was an important 
service to his country, to inspire every class of citizens with just and correct notions of the best method of practising their callings, and of discharging the duties incident to them. ${ }^{1}$ Indeed, this was an object of which he never lost sight; rightly thinking, that upon the conscientious and diligent behaviour of each individual in his particular station and calling, depended the safety and prosperity of the whole commonwealth. In the same strain he taught his hearers, that he who was the best manager of his own affairs, was likely to be the best administrator of the affairs of the republic.

We have before observed, that Socrates did not deliver lectures like the sophists, but conducted his discourses upon subjects of practical philosophy in the way of question and answer. His usual method was, to apply to the person, whom he wished to bring over to his own opinion, with a pretended ignorance, as one who desired to obtain information; and without asserting anything himself, he would put to him, in succession, a series of questions, which admitted but of one answer; and so, by degrees, would bring him to acknowledge the truth which Socrates wished to establish. He always began by gaining the assent of his adversary to some unquestionable propositions: these he artfully connected with some of a more dubious kind, and then, by tying down his opponent to his former concessions, he proved his own point.

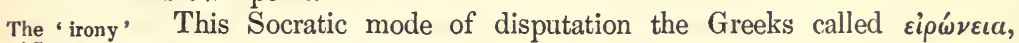
of Socrates. "irony," from $\varepsilon$ ' $\rho \omega \nu$, " a person who dissembles his real knowledge or opinions;" one who pretends to know nothing of what he really does know. ${ }^{2}$ Horace calls a person of this sort dissimulator opis proprice. To this ironical or bantering mode of disputation the Athenians in general seem to have been partial; in the case of Socrates it gave so much offence to some, that they called him " the Attic buffoon, or jester." Aristotle contrasts the boasting pretender, who, for the sake of fame or profit, affects accomplishments which he does not possess, with the $\varepsilon^{\prime \prime} \rho \omega \nu$, him who dissembles his powers, and disparages his own qualifications, "for the sake of appearing more amiable and pleasing; for," he observes, "persons of this description seem to speak, not for the sake of gain, but from a wish to avoid ostentation. And in particular, they reject all pretences to fame; as was the case with Socrates."

Being well aware that the sophists were a principal cause of that deterioration in the character of his countrymen which he so often

1 He carried this custom so far, as not only to give advice to Parrhasius, the celebrated painter, and Clito, the sculptor, upon the best method of communicating to their representations of the human form an expression of moral sentiment; but he conversed with Theodote, a courtesan, upon the most efficacious methods of alluring lovers.

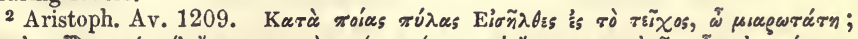

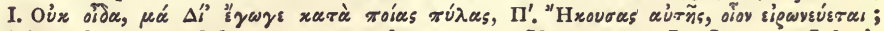
"By what gates did you get into the city, you "baggage? I. I protest I don't know by what gates. P. D' ye hear how she banters us?" 
complained of, he applied himself to undermine their credit, and to open the eyes of their disciples. With this object in view, he pursued He opposes a line of conduct, in all respects, the reverse of that which distinguished himself to the sophists. Instead of appearing in the places of public resort in a gorgeous robe, he was remarkable for the meanness of his dress, and of his whole appearance. Instead of professing the talent of haranguing copiously and elegantly, he declared himself wholly ignorant of such arts; and instead of delivering at length lectures upon given subjects, he conversed in the way of short questions and answers. $\mathrm{He}$ used to make his appearance, as it were by accident, amidst the numerous tribe of Athenians who were listening to Gorgias, or some other famous sophist; and professing his admiration of such talents and eloquence, lamented the straitness of his means, which debarred him from the advantage of becoming a scholar of so able a master. $\mathrm{He}_{\mathrm{e}}$ would then, with seeming diffidence, propose a simple question to the sophist, to which an eloquent but diffuse reply would be given. Upon which, Socrates requests him so far to humour his infirmity and slow comprehension, as to proceed step by step. When this was done, he soon manifested the clearness and justice of his own ideas, and the confused and inconsistent notions of the sophists; reducing him by a series of simple, but closely-connected questions, to admit the truth which Socrates desired to prove. It was in vain that the sophist ridiculed or found fault with his opponent for descending to minutiæ, and arguing in detail, to the exclusion of all eloquence and commonplace; in vain did he treat with contempt the maxims of common sense and of plain downright morality, which were at variance with his own notions as to the best methods of prospering in life. Socrates returned with coolness and temper to the charge; and by a series of such attacks, closely followed up, he exposed the shallowness and inconsistency of those pretenders to wisdom.

It does not appear very clearly, at what period of his life Socrates began to attract public notice as a teacher of philosophy, nor how long a period of time he continued his attacks upon the sophists, before he produced a strong impression upon the public mind. For some time he was himself considered to be one of that class of teachers; and when Aristophanes introduced him upon the stage, he was probably just risen into eminence, although it should seem, from the representation given of him in 'The Clouds,' that his real character and mode of philosophising were not known to the great comic poet. Socrates was then about forty-six years of age. To this subject we shall revert presently.

We may probably refer to his ironical mode of teaching the cele- The 'demon'

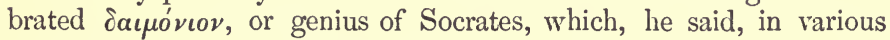
emergencies, admonished him what course to pursue, and enabled him to predict, in many cases, what was about to happen. It was, in fact, neither more nor less than common sense or right judgment; a faculty which he possessed in an eminent degree, and which he made the 
guide of his life. Other philosophers called this "opinion;" Socrates chose to speak of it as his attendant genius. At the same time, it must be confessed, we are told by some authors that this $\delta a \iota \mu o$ vıov made itself heard only in those questions which were not determinable by human prudence. It is evident that most of those who have mentioned the genius of Socrates, including his immediate scholars, have understood it literally to have been a being of a superior nature; a very natural opinion for those who were acquainted with the doctrines of the older philosophers, who maintained the existence of a race of spiritual beings, intermediate between the gods and men. Socrates, who had full confidence in the conclusions of that judgment which he had cultivated with so much care, and was convinced that it would not mislead him in matters cognisable by human reason-yet studious at the same time to avoid an appearance of laying down the conclusions of his own reason, as the sophists used to do, for infallible truthschose to speak of them as the suggestions of this invisible friend; being at all times very careful not to exalt too highly the powers of the human mind; and being aware, that even the dictates of right reason might, without impropriety, be referred to the inspiration of a superior power. It is even possible, that, convinced as he was of the existence of a supreme intelligence, and accustomed to find, that when he acted upon the suggestions of his reason, without having sought for them by laborious induction, he was always in the right-it is possible, we say, that he might have referred them to the immediate influence of a spiritual adviser, as the enthusiasts of modern days are too apt to do, oftentimes with less reason. But it is truly surprising that any Christian writer should have been found to adduce the genius of Socrates, in order to prove the truth of the Scripture doctrine of angels. It appears, that the great master himself would never vouchsafe to his

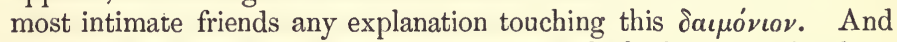
it is very probable, that the fer instances which they record, where Socrates appeared to have determined rightly rather from divination than from the inductions of reason, are not related agreeably to the real facts. Every explanation which has hitherto been given of this curious subject has its difficulties. It appears to us, that the most probable solution of the knot is that which we have proposed in the last place. We cannot, at any rate, coincide in opinion with Brucker, who thinks that Socrates enjoyed "a certain faculty or presentiment, approaching to divination." But, on the other hand, it will not be enough to conclude, with Plutarch, P. Simon, and others, that this genius was no other than common sense; unless at the same time we suppose that Socrates himself, struck by the justice and promptitude of his own conclusions in emergencies, which gave no scope to deliberation, did actually refer to the inspiration of a divine monitor, what were in fact the dictates of his own singular natural good sense. For many years he had been an attentive observer of human nature, and had narrowly scrutinised the motives and watched the consequences of actions; the 
result of which was a matured and solid experience, and a degree of aagacity, which seemed at times to be almost more than human. The cracle which is said to have been delivered by the Pythian priestess, declaring Socrates to be the wisest of mankind, is well known: but there is good reason to suspect that it was a forgery, probably invented by Chærephon, or by some other disciple of Socrates, after his master's death. It was, however, reported very soon after that event; and at any rate serves to show the prevailing opinion in Greece respecting the superior wisdom of the deceased philosopher. Great, howerer, as that wisdom was, it was not greater than his modesty. The following observations, which Cicero has put into the mouth of Varro in his first book of 'Academic Questions,' place in a strong light the good sense and modesty of Socrates :- "It is agreed on all hands, and, I think, justly, that Socrates was the first person, who called away philosophy from the study of occult things, purposely concealed by nature herself, in which all the philosophers before him had been occupied, and introduced her to common life: making virtue and vice, good and evil, the objects of his inquiry ; but esteeming the higher branches of natural philosophy (coelestia) far removed from our cognizance, or at all events, if they were ever so well understood, of no importance towards living well. In all his discourses, which lave been committed to writing by those who heard him, with great variety and copiousness of language, his method of disputing is, to affirm nothing himself, but to refute others: he professes to know nothing, except the fact itself of his knowing nothing: and says, that in this respect he excels other men, who fancy that they know that which they do not know; whereas all his own knowledge consisted in the consciousness of knowing nothing; and he supposes that Apollo had pronounced him to be the wisest of mankind,' because the whole of true wisdom consists in a man's not thinking himself to know that of which he is ignorant. This being the constant tenor of his discourses, and lis fixed opinion, all his eloquence was expended in praising virtue, and in exhorting all men to the study of virtue; a fact sufficiently evident from the writings of the Socratic philosophers, and especially of Plato." It need hardly be remarked that this confession of ignorance, on the part of Socrates, was very different from the universal doubt and uncertainty professed by the sceptics; his object being simply to inspire mankind with a distrust of that intuitive kind of knowledge to which the sophists laid claim, and to teach them that the road to true wisdom must be pursued through all the successive steps of patient investigation.

With regard to his religious opinions, Socrates appears to have been His religion. firmly convinced of the existence of a Supreme Being, and of his superintending providence over the affairs of men. He was never heard, says Xenophon, to say anything which savoured of impiety;

1 These words, it must be remembered, are put into the mouth of Socrates by Plato, and afford one proof, amongst many, that it is unsafe to place much reliance upon the accuracy of his representations. 
but every part both of his conversation and his conduct was such, as might be expected from a man, deeply sensible of the truth and importance of religion. Upon these subjects, however, he found it necessary to speak with a certain degree of caution and reserve; and even with all his care he did not escape the charge of impiety. It need hardly be proved that he disbelieved the popular mythology of his time; and he appears to have admitted the existence of an intermediate race of spiritual beings, between the Supreme Deity and men. It is, however, not unreasonable to suspect, that when Socrates referred to his friends, in questions not to be resolved by human sagacity, to auguries and divinations, he complied with what he considered to be a harmless superstition, without intending to assert his own belief in it. At the same time that he maintained the purity and spirituality of the Supreme God, and strongly denied the weaknesses and vices imputed by the poets to the deities of the Pantheon, he practised himself, and recommended to others, a regular compliance with the established forms of worship, and even consulted oracles. At the same time he seems to have intimated his sense of the impropriety of addressing the Deity by any particular name, by his custom of introducing into his colloquial asseverations sometimes the name of Heré (Juno) and sometimes that of a dog or a goose. The last words which Socrates uttered before his death, were to put his friends in mind, that he was indebted to Asculapius a cock, which he had vowed, but never sacrificed. Such an expression, used at a moment when he was perfectly aware of his approaching dissolution, might seem to indicate an actual belief in the existence of the inferior gods. But it has been conjectured, and not improbably, that when those wordis were uttered, the poison which he had taken had affected his reason. Whatever may have been the language which he held in his public discourses, the sagacity of Aristophanes did not fail to perceive, that he rejected in fact the popular superstitions of his country.

His moral character.

His firmness of mind, in refusing to act contrary to the dictates of his conscience; his temperance and frugality, have been already mentioned. The concurrent testimony of all antiquity proves him to have been one of the most irreproachable characters of the heathen world. And the virtues, for which he was most remarkable, will appear more worthy of admiration, if we reflect that he was destitute of those lights and helps which are possessed by the Christian moralist. "The singular merit of Socrates," observes Mr. Mitford, "lay in the purity and usefulness of his manners and conversation; the clearness with which he saw, and the steadiness with which he practised, in a blind and corrupt age, all moral duties; the disinterestedness and the zeal with which he devoted himself to the benefit of others; and the enlarged and warm benevolence, whence his supreme and only pleasure seems to have consisted in doing good. The purity of Christian morality, little enough indeed seen in practice, nevertheless is become so familiar in theory that it passes almost for obvious and even congenial 
to the human mind. Those only will justly estimate the merit of that near approach to it which Socrates made, who will take the pains to gather, as they may from the writings of his contemporaries and predecessors, how little conception of it was entertained before his time; how dull to a just moral sense the human mind has really been; how slow the progress in the investigation of the moral duties, even where not only great pains have been taken, but the greatest abilities zealously employed; and, when discovered, how difficult it has been to establish them by proofs beyond controversy, or proofs even that should be generally admitted by the reason of men. It is through the light diffused by his doctrine, enforced by his practice, with the advantage of having both the doctrine and practice exhibited to the highest advantage, in the incomparable writings of disciples, such as Xenophon and Plato, that his life forms an era in the history of Athens, and of man."

Our readers are well aware that one imputation has been cast upon Calumnies the moral character of Socrates, of the most disgraceful kind: but it respecting has been by writers of an age much more recent than that of Socrates, and chiefly by Porphyry, and some fathers of the Christian church. The authorities upon which it rests have been collected by Mr. Cumberland in the 'Observer,' or rather by Dr. Bentley, whose papers his grandson is now known to have pillaged without scruple. But these authorities may justly be considered as destitute of weight, when put in competition with the total absence of any aspersion of the kind in 'The Clouds' of Aristophanes, and with the direct and united testimony of Plato and Xenophon to the purity and integrity of Socrates. These charges, as Mr. Mitford justly observes, carry every appearance of having originated in the virulence of party-spirit; and they have been propagated by writers in the profligate ages that followed: a propensity to involve men of the best report, in former times, in the scandal of that gross immorality which disgraced the fall of Greece and Rome, is conspicuous among some of the writers under the Roman empire. There cannot be a stronger negative argument to rebut the charge of scandalous immorality, than the silence, both of Aristophanes, (who scrupled at no indecency of expression or of representation ${ }^{1}$ ) and of the accusers of Socrates, who were not deterred from calumniating the object of their hatred, by any regard for truth. (The reader may see this question discussed more at length in a dissertation by the Abbé Fraguier, 'Choix des Mémoires de l'Académie Royale,' t. iii. p. 29). The wisdom of Socrates, his benevolence, and the purity of his morals, were so remarkably superior to those of his contemporaries, that some Jewish and Christian writers have maintained, with more zeal than judgment, that he derived his knowledge of divine things from an acquaintance with the Scriptures of the Old Testament; while some of the defenders of natural religion affect to contrast the ethics of Socrates with those which are inculcated in the Gospel. But even if

1 The classical reader, who calls to mind the representation which the comic poet has given of Euripides, will consider this argument as almost conclusive. 
we admit the justice of those commendations which are bestowed upon his moral precepts, we find the great and pervading deficiency, which revelation alone could supply, that of motive; necessarily resulting from a state of uncertainty as to the retribution of a future life.

His doctrines Socrates taught that the divine attributes might be inferred from compared
with those of the works of creation; a notion asserted also by St. Paul. He main-

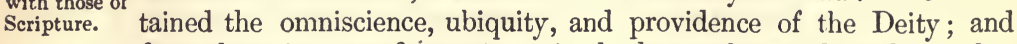
from the existence of conscience in the human breast, he inferred that man is a moral agent, the object of reward and punishment; and that the great distinction between virtue and vice was ordained by the Deity. This is the sum of those theological doctrines which Socrates taught with plainness and simplicity; but which Plato expanded and corrupted with his own refined and abtruse speculations. It is easy to perceive how far superior, both in point of reasonableness and in their moral tendency, these doctrines were, to the metaphysical speculations of the Ionic school.

The soul of man, according to Socrates, is given him by the Deity, whom it resembles in its powers and properties; consequently it is immortal, and will receive, after the death of the body, the rewards of virtue. If Socrates expressed any doubt on this head, it related to the place of the soul in another life, not to its existence or happiness.

The justness of his notions, upon these important subjects, naturally exalted and purified his moral system. The chief happiness of life he placed in a practical knowledge of virtue, of the ends which man is intended to answer, and of the right methods of pursuing them. This knowledge, when complete, teaches him that in every case that which is just is expedient; and that the purest pleasures are those which spring from an habitual rectitude of conduct. The great secret of obtaining this desirable wisdom is to know ourselves; a secret which Socrates, in his daily conversations with those who had the greatest reputation for wisdom, proved to be little understood.

His moral precepts.

Socrates taught that "to obey is better than sacrifice;" that the most acceptable service to the gods is to perform their commands: that man ought simply to ask the gods to give what is good for him ; for that they know, far better than he does, what is really to his advantage: that the gods are to be worshipped, according to the institutions of our country; a precept which is also attributed to Pythagoras. He said that besides the written laws of men, there are certain unwritten laws, ${ }^{1}$ ordained by the Deity, such as those which enjoin the

1 "A rea posvónor. This notion was not first entertained by Socrates. We find it expressed by Sophocles, in his Antigone, v. 453.

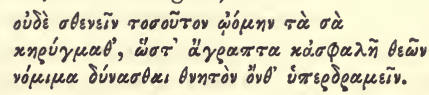

Nor judged I thy decrees of such avail, As that a mortal might transgress the gods'

Unwritten and immutable behests.

Thucydides, in the funeral oration spoken by Pericles, distinguishes between the 
worship of the gods, and the reverence due to parents; that it is reasonable to conclude that these laws have the divine sanction, because the violation of them carries with it its own punishment, a provision surpassing the wisdom and power of a human legislator. (This argument is insisted upon by Bishop Butler, in the second chapter of his 'Analogy').

In the course of a life spent in disseminating the principles of truth His Politics. and morality, as discoverable by the light of nature, Socrates delivered maxims and rules for the conduct of men in every relation of civil and social life. Those which are recorded by Xenophon are marked by that sound and practical common sense which was the leading feature of his philosophy. With regard to politics, the peculiar constitution of the Athenian polity, and the temper of the times, made him cautious in delivering his sentiments. Yet he said enough, at different times, to make his countrymen suspect that he disliked the existing constitution of Athens. He remarked (at least Elian tells us that he remarked) that democracy is tyrannical, and abounds with the evils of monarchy. It was urged by his enemies that he rendered his hearers disaffected towards the democracy; and indeed, althongh he was too good a citizen to promote sedition and political violence, it was not possible that he should approve of the manner in which the Athenian government was conducted. He wished, as Mr. Mitford has remarked, for wholesale changes by gentle means; and it seems to have been an object which he never lost sight of, in all his teaching, to infuse those principles into the Athenian youth, which might insensibly produce the wished-for change. Although he took no part in politics himself, he endeavoured to obtain an influence over those young men, who were most likely, from their wealth, their talents, and their ambition to bear sway in the popular assemblies. Thus employed, and courted as he was by many of the richest and most powerful of the Athenian youth, it is no wonder, if the vulgar demagogues considered him as a dangerous rival, and were desirous of exciting popular jealousy against him.

Socrates was about forty-six years of age when he was introduced socrates held by Aristophanes in his comedy of 'The Clouds,' and held up to up to deripublic derision. It is well known, that what is called the old comedy, Clouds of the leading writers of which were Eupolis, Cratinus, and Aristophanes, introduced, without scruple, living personages upon the stage, not only exhibiting the peculiarities of their moral and political characters, but representing, by means of masks and dresses, their personal appearance. The great object of the comic poets was, to please a popular audience, and to obtain their suffrages for the prize awarded to the most deserving. But they not unfrequently had a higher object in view : Aristophanes in particular directed his wit against the mischievous, but too popular demagogues of his time, with the truest patriotism; laws enacted for the common good, and the unwritten laws, the violation of which brings with it acknowledged disgrace. So also Demosthenes, de Coron. $\S 83$. 
and with a courage, which nothing but a confidence in his own surpassing abilities, and the justice of the cause which he espoused, could have inspired. Whatever he conceived to be at variance with that free and manly spirit, which had once distinguished his countrymen, but which in his time was nearly destroyed by political chicanery, and the flagitious doctrines of the sophists, he assailed with all the powers of ridicule: and although in many cases, as was to be expected, the innocent suffered with the guilty, and defamation usurped the place of legitimate satire; yet, upon the whole, it is evident, that the object of Aristophanes was, to bring his countrymen to a right way of thinking, and to open their eyes to the artifices, by which they had been so long imposed upon. It is not easy to assign a satisfactory reason for the injurious representation which Aristophanes has given of Socrates, in the comedy before mentioned. But we may probably conjecture, that wishing to attack the sophists in general, of whom Socrates at that time was considered to be one, he took him as a representative of the whole body, and attributed to him that species of philosophy, which it was the constant object of Socrates to decry and discredit.

The object of the comic poet in 'The Clouds,' is to show how the sophistry of the schools may be employed to the perversion of justice and morality. He ridicules, by the way, certain new and fanciful notions touching the relation of children and parents; and introduces the clouds, as the deities of the new philosophers, who acknowledged no such divinity as Jupiter, or his associate gods. Mr. Cumberland has justly remarked, that although Socrates is exhibited in a very ridiculous point of view, as hoisted up in a basket, to pursue his astronomical studies, and measuring the space over which a flea can skip, yet he lays down no principles of fraud or injustice, as parts of his own system. It is not the teacher who recommends, but his disciples who pervert his instructions to the evil purpose of defrauding their creditors. The son in the play beats his father on the stage, and he quotes in his own justification the maxims of Socrates; but he does not quote them as positive rules and injunctions for an act so atrocious; he only shows that sophistry may be turned, to defend that or any other thing equally violent and outrageous.

It is undoubtedly true, that the schools of the sophists, which the government of Athens thought it necessary to put down by a public decree, were no unfit subjects for dramatic ridicule; but still the great difficulty recurs, why should Socrates have been selected by the poet, as the representative of that mischievous tribe, rather than Gorgias, or Hippias, or Polus, or some well-known member of the fraternity? Perhaps it was, as some modern critics have supposed, that some of the disciples and friends of Socrates, rather than the philosopher himself, were the real objects of dislike to Aristophanes; and that he introduced the teacher himself upon the stage, for the purpose of ridiculing his school. Three, at least, of the followers of Socrates, were 
just objects of satire: the rapacious Simon, the cowardly Cleonymus, and the dissolute Theorus, of whom Aristophanes says- "O Jupiter, if thy bolt is aimed at perjury, why has it not consumed Simon, nor Cleonymus, nor 'Theorus, all perjured as they are?" An intimate friend of Socrates was Euripides; against whom, as the inculcator of an ambiguous morality, and the debaser of genuine tragedy, Aristophanes entertained a peculiar antipathy. And besides, accustomed as the Athenians were to see their public men ridiculed and reviled in the grossest manner upon the stage, it did, perhaps, no great harm to the character of Socrates, that his philosophy should be jocosely burlesqued; for, be it remembered, there is little or nothing of calumny and ill-nature in the delineation which Aristophanes gives of Socrates himself. It must have been so exceedingly and palpably unlike the original, that one is almost tempted to suspect the poet of having made it so on purpose, that the spectators might at once perceive it to be intended for a good-natured caricature of Socrates, with whose real mode of life they were all perfectly well acquainted; and whose prosing discourses, most of them probably thought, as Eupolis did, very tiresome. The singularity which Socrates affected in his manners and dress, going barefoot, and, at times, standing for a whole day together in the same attitude of meditation, rendered him a tempting subject for ridicule. The poet says in 'The Clouds,' "We could not think of attending to any other of the sophists of the present day, except Prodicus, to him, on account of his wisdom and good sense; but to you (Nocrates) because you swagger in the streets, and roll your eyes about, and go barefoot, pretending to put up with many annoyances, and wear a solemn countenance towards us." Aristophanes represents Socrates as taking a fee for his instructions, although the contrary was notoriously the fact. It appears, however, that at the first representation 'The Clouds' did not take with the audience, but was condemned, owing, as it is said, to Alcibiades, and a party of the friends of Socrates. The following year it was reproduced, in an amended state, with better success. The story told by Elian, of the poet's having been bribed by Anytus and Melitus to write 'The Clouds,' in order to pave the way for their criminal accusation, has been long ago exploded: this comedy is known to have been acted more than twenty years before the trial and condemnation of Socrates. Yet it is far from impossible, that the ridicule cast upon him in that play, may have contributed to the popular prejudice, which, many years afterwards, became so fatally strong. We are not informed by Xenophon or Plato, whether Socrates had given any cause of offence to Aristophanes; indeed, Plato represents them as becoming familiar companions at a subsequent period. Upon the whole, our readers may still be disposed to adhere to the notion first suggested, that Aristophanes, when he wrote 'The Clouds,' knew but little of Socrates, whom he, perhaps, imagined to be a quibbling sophist, like the others of that profession.

About two or three-and-twenty years after the first representation 
of 'The Clouds,' a young man, named Melitus (or rather Melētus) delivered to the archon an information against Socrates, to the follow-

Socrates accused of reviling the gods, and of corrupting the youth. ing effect: "Melitus, son of Meletus, of the borough of Pitthos, makes this charge upon oath against Socrates, son of Sophroniscus, of the borough of Alopece: Socrates is guilty of reviling the gods acknowledged by the state, and of preaching other new gods; moreover, he is guilty of corrupting the youth. Penalty, death." Melitus, who was a poet, and a man of no consideration, was associated in this affair with Lycon, an orator of eminence, and Anytus, a man in high esteem, who had commanded with credit in the Peloponnesian war, and was afterwards an ally of Thrasybultus in restoring the democracy. It was urged against Socrates, by his prosecutors, that he was disaffected to the democracy, and that he had instilled similar principles into his followers, especially Critias and Alcibiades. Indeed, it seems very likely, that his intimacy with Alcibiades was one principal cause of the suspicion and dislike with which he was viewed by the popular party. Socrates himself, as Plato makes him speak, did not deny his disapprobation of the existing government: the whole of his defence, as reported by his illustrious scholar, was calculated to irritate, rather than to conciliate, his judges.

His trial. No advice of his friends could persuade him, when put upon his defence before the Heliastæ, ${ }^{1}$ to say a word in the form of supplication. He told his judges, that he was pleading for them, to save them the guilt of an unjust condemnation. Being persuaded of the soul's immortality, he considered the prospect of a dismissal from the body, at his age, to be a subject of rejoicing. Death might be an introduction to the highest degree of happiness; it could not bring anything worse to a good man than a cessation of being: and therefore he looked with no apprehension to a sentence, which would consign him to the easiest of deaths; for such the Athenian mode of execution, by a draught of prepared hemlock, was reputed to be.

The judges were so much incensed by the tone which Socrates took in his defence, that they refused to hear Plato, who would have spoken in his behalf, and immediately found him guilty. It being then permitted him to say what fine ought to be imposed upon him, he would not suffer his friends to contribute anything towards a pecuniary mulct; but told the court, that he considered himself worthy of the highest honours and reward. Still further irritated by this reply, a majority Iscondemned of the judges, still greater than the former one, condemned him to to death. death; and he was accordingly conducted to prison, after having shown the injustice of his sentence. He concluded his address to the judges with these words: "But it is time that we should depart; I to die, you to live : but which for the greater good, God only knows."

The condemnation of Socrates happened on the eve of the day appointed for the ceremony of placing a sacred chaplet upon the ship,

1 The largest court of judicature at Athens was the 'H Hsaid, consisting of from

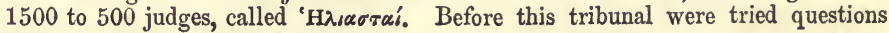
concerning religion. 
which carried the annual offerings to the gods worshipped at Delos. And no execution could take place at Athens from the crowning of the galley till its return from Delos. Thus the death of Socrates was respited for thirty days. His friends took advantage of this delay, to concert means for his escape. The jailer was bribed, and a vessel prepared to convey Socrates to some friends in Thessaly. But no Refuses to persuasion could induce him to use the opportunity. Having all his life recommended obedience to the laws of his country, he would not now set an example of the breach of them; arguing, that unjust as his sentence was, wrong would not justify wrong. Plato has given us a beautiful representation of the manner in which Socrates employed himself during this painful interval, in discussing subjects of the highest nature with his favourite disciples. But there is too much reason to apprehend that these representations are more striking than faithful. It is, however, agreed on all hands, that when the sacred ship returned (of which he professed to have been forewarned by a dream), he drank the fatal cup with perfect composure, and died with a degree of tranquillity, which would have been still more admirable, had it not been alloyed by a mixture of ill-timed facetiousness. He was, at his death, His death, which happened OL. xciv. 1, in the 70th year of his age. B. C. 399 .

The disciples of Socrates, after having paid the last honours to their departed master, and testified their grief and indignation in the most public manner, quitted Athens for some time, for fear of the faction which had procured his condemnation. A general sentiment of indig- Revulsion of nation prevailed in the Grecian states, at the news of this event; and it was not long before the Athenians themselves, being made sensible of the injustice of their proceedings, turned their anger against the accusers of Socrates; of whom Melitus is said to have been condemned to death, and Anytus banished from Athens. The friends of the murdered philosopher were recalled, and a statue erected to his honour. A pestilence which happened not long afterwards, was considered to be a just punishment for their grosis violation of justice; and it is not a little remarkable that, from that time, the affairs of Athens grew continually worse.

The grammarian who wrote the argument to that oration of Isocrates, which is called the Encomium of Busiris, relates, that when the 'Palamedes' of Euripides was acted at Athens, and the chorus uttered the following words : "O Greeks, ye have killed the wisest, sweetest songstress of the Muses, who injured no one, the best of the Greeks," the whole theatre shed tears, perceiving the allusion to Socrates. But Diogenes Laertius, after having observed, that Euripides intended, in the words above quoted, to reproach the Athenians with their injustice towards his illustrious friend, adds, "but Philochorus (a writer on the antiquities of Attica) says that Euripides died before Socrates ;" which is perfectly true; for the poet died, OL. xciii. 1, the philosopher in OL. xciv. 1. But as the 'Palamedes' was brought upon the stage nine years after the first representation of 'The Clouds' of Aristophanes, Valck- 
enaer thinks it probable that Euripides might intend to shadow out, in the story of 'Palamedes,' the ingratitude and injustice of the citizens of Athens towards their illustrious teacher, and to point to the probable result of the popular outcry against him. As to the story of the commiseration expressed by the audience at the lamentation of the chorus, if it ever took place at all, it was, perhaps, at a second representation of the 'Palamedes,' after the death of Socrates.

Left no

writings.

Person of Socrates.

Sects founded by his followers.

Socrates never committed any of his speculations to writing: those which have been attributed to him have been abundantly proved not to have been his productions; especially the epistles, which go by his name, but which Bishop Pearson and Dr. Bentley have shown to be the forgery of a sophist of later times. He is reported to have assisted Euripides in writing some of his tragedies, for which rumour there was, prohably, no foundation but the intimacy which subsisted between them.

The person of Socrates is so well known to our readers, that it need hardly be described. Its resemblance to the representation usually given of Silenus, in the works of ancient art, is so strong, that he was called, with an allusion to the convivial excesses of his friend, the Silenus of Alcibiades.

As Socrates, instead of addicting himself to any set of philosophical principles as a system, with which every moral and political phenomenon must be made to square, passed his life in the investigation of truth, and delivered, in plain and unaffected language, the result of patient observations and inquiry, it is not to be wondered at, if some of his followers, who were not superior to the ambition of systemmaking, instead of treading in the footsteps of their master, struck off in different directions, and became the founders of different sects in philosophy. Such were Plato, the father of the Academic sect, Aristippus of the Cyrenaic, Phædo of the Eliac, Euclid of the Megaric, and Antisthenes of the Cynic; all of whom, widely as they differed from one another, pretended to ground their notions upon the authority of their master.

In the foregoing account of Socrates, we have endeavoured to observe a just impartiality. It is not to be denied, that in some parts of his conduct there was an affectation of singularity, unworthy of so wise a man; and that he sometimes bestowed much unnecessary labour upon the elucidation of a very common and obvious truth; but he was undoubtedly the author of a far more genuine and practical philosophy than the Greeks had before been masters of; and taught a system of morality, which, with a very few exceptions, was defective only in its motives. And it is a strong argument of the necessity which existed, before the time of our Saviour, of a divine revelation, that a philosophy, so pure and rational as that of Socrates, enforced as it was by the ablest and most eloquent writers of antiquity, had but little effect in improving the religious or moral character of the most acute and ingenious people of the heathen world. 


\section{PLATO.}

BY

WILLIAM LOWNDES, EsQ., M.A., Q.C. BRAZENOSE COLIEGE, OXFORD. 


\section{PLATO.}

FROM B. C. 428 TO B. C. 348 .

OuR readers have been already presented with the particulars of the life of Socrates, whose moral worth illustrated the age in which he lived, and whose pupils and admirers branched out into so many separate families or schools, that he has been very justly entitled the great patriarch of Grecian Philosophy. The first of those schools, that of the earlier Academics, as they have been called, was founded by the subject of the present memoir. Plato, the pupil of Socrates, who was one of his country's highest ornaments, and whose works remain as the great model of Athenian genius, elegance, and urbanity.

Our memoir will contain a bare outline of the principal facts of the life of Plato, as far as they can be authenticated by the concurrent testimonies of Cicero, Apuleius, and Diogenes Laertius. We shall reject all fables; and think it unnecessary, for instance, to trouble our readers with the tale that Plato was born of a virgin mother, and that he had the honour of Apollo for his father, though Diogenes and A puleius, and Plutarch and Lucian, concur in the story; nor do we think it worth while to stay and inquire whether the fable might not originate in some circumstance of illegitimate birth, or in the fact that Plato was born on one of Apollo's festivals. In like manner, we cannot dwell on the account that a swarm of bees gathered round the cradle, and settled on the infant's lips, though Cicero, ${ }^{1}$ in one passage, assumes the fact. We prefer relating what may be credited, and trust that our readers will approve our caution, though it may. deprive us of some amusing materials.

Our narrative will be interspersed with brief abstracts of some of those Dialogues of Plato, which we think contain the best views of his sentiments, or in which we suspect the characters and objects of the speakers to have been generally misapprehended. To the narrative we shall subjoin a general outline of Plato's doctrines, with a few general reflections on the bearings of his philosophy; and here we shall maintain the same reserve as in our relation of facts. We shall state Plato's own doctrines from his own writings, and we shall not trouble ourselves with the consideration of notions (and of such there is abundance) which are generally attributed to him, but of which we do not find the slightest trace in his own writings.

Plato was born of Athenian parents, in the island of Agina, in the His birth,

1 Platoni cum in cunis parvulo dormienti apes in labellis consedissent, responsum B. c. 428 . est, singulari illum suavitate orationis fore, ita futura eloquentia provisa in infante est.-De Divinat. lib. i. 36. 
Becomes a disciple of Socrates.

His early writings. first year of the eighty-eighth Olympiad (B.c. 428). In his early life he devoted himself much to poetry, and is said to have produced an epic poem, which he committed to the flames, and a drama, which was represented. When about the age of twenty, he became a disciple of Socrates, and continued with him for eight years, till that great and amiable philosopher fell a sacrifice to the rancour of party, disguised under the pretext of zeal for the national religion. Plato attended his master during his trial, was one of those who offered to speak in his defence (though the judges would not allow him to proceed), and to be bound as a surety for the payment of his fine; and after the fatal sentence, waited on him in prison, and was present during his last moments.

It appears that Plato had written one or two dialogues in the lifetime of Socrates; and there is much reason to believe that if those dialogues exist in the present collection of his works, they are 'The Lysis,' 'Phædrus,' 'The Banquet,' and perhaps the ' Protagoras.' All these bear strong marks of youthful fancy. In the three first the dramatic character so completely predominates, that the, arguments seem only introduced as illustrative of the manners and temper of the individuals. 'The Banquet' is a perfect comedy. The choice phrases and pretty turns of Lysias, the grandeur and affected antitheses of Gorgias, covertly represented in the speeches of their respective admirers, Phædrus and Pausanias, are finely contrasted with the plain severity of Pericles's style, in the speech of Eryxamachus; and the broad humour and wild ribaldry of Aristophanes are but a foil to the less prominent but more significant irony of Socrates. It is to be lamented that the subject of the dialogue, Love, leads to illustrations from the grossest sensuality and vilest depravity; but Socrates has evidently aims of a high moral cast in the part which he takes in the conversation. Indeed, Alcibiades, whilst he does justice to his preceptor's moral character, has introduced an admirable description of the manner by which Socrates in general proceeded from the most familiar subjects, and from trite and obvious topics to insinuate reflections of a graver nature, and to lead his hearer's mind into a train of useful thought. ${ }^{1}$

The object of 'The Protagoras' seems to be, in a great degree, to

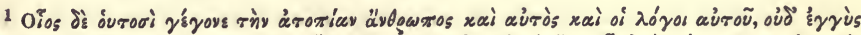

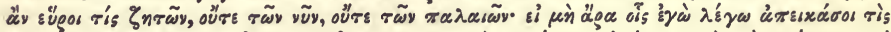

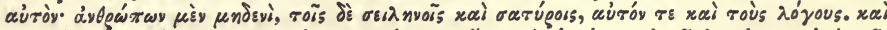

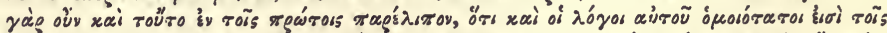

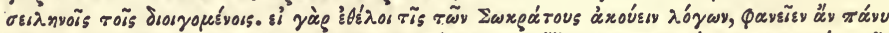

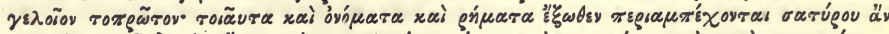

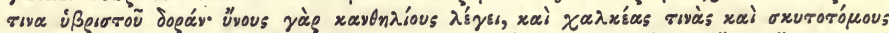

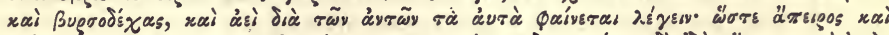

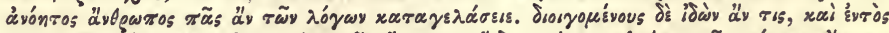

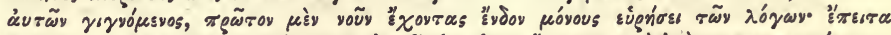

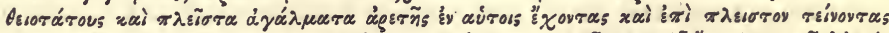

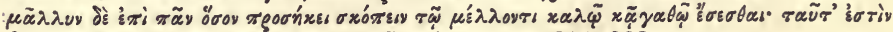

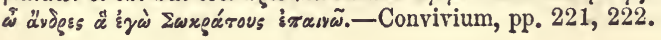


represent the style and doctrines of that ingenious and eloquent declaimer in contrast with those of Socrates. The dialogue, though intending an exposure of the artifices of rhetoric, and of the trickery of exterior pomp, is written in a grave and dignified style; and the poetical imagery with which it is ennobled is of the highest cast. It is altogether one of the most elegant of Plato's dialogues ; and a more plausible or beautiful harangue cannot be imagined than the fine speech delivered by Protagoras. It is a masterpiece of the kind. But the lordly declaimer is much embarrassed by the close mode of combat practised by Socrates; and, the first moment he can disengage himself, expatiates afresh in that amplitude of discourse where the colourings of the imagination can be best used to dazzle and delude, and in which ingenious hypothesis and splendid illustrations may be substituted for proofs with the greatest chance of success. For an outline of this dialogue, sketched by the hand of a master, we would beg to refer our English readers to Mr. Gray's posthumous works, published by Mr. Matthias $;^{1}$ and we only regret that our limits will not permit us to insert an abstract, which is at once so just in the statement of the arguments, and gives such fine glimpses of the original in the colour of the diction.

Another circumstance which makes it probable that these dialogues were written at that period of Plato's life is, that the poetical splendour with which they abound is rather of a mythological than a metaphysical cast. They are entirely destitute not merely of the subtilties and of the refined discussions which appear in some of the other productions of Plato, but of those grand and noble reveries into which his soul at a maturer age delighted to throw itself, when he had refuted the Sceptics by a logic of his own, still more subtle than theirs, and when his own system of intellectual existences had been formed and completed. The poetry in these dialogues, on the contrary, is rather popular than philosophical.

Soon after the death of Socrates, Plato retired to Megara ; and it is Retires to generally believed that he there composed those three simple and beautiful dialogues connected with the fate of his master; "The Defence,' 'The Crito,' and 'The Phædo.' The dramatic parts of these dialogues, and particularly that of 'The Phædo,' abound with pathetic The Phædo. touches; and there is such an air of nature throughout, that the reader is impressed with a share of the author's sensibility, and is at once present and interested in the scene described. The last conversation of the great patriarch of Grecian philosophy is recorded by his affectionate pupil with every circumstance which can indicate the writer's devoted veneration and deep regret, or which can conciliate the reader's esteem and admiration. The plain integrity, the cheerful and even playful temper, the genuine intrepidity of Socrates on the eve of death, are so simply and forcibly represented, that we feel that whether imagination or memory supplied the particulars of the conver-

'In quarto, 1814, vol. ii. p. 387. 
sation recited, all the manners of the dialogue, the attitudes, and tones, and gestures of the speaker must have been drawn from life; and every little circumstance speaks the language of a heart retracing its fondest recollections.

Immortality

The argument discussed is suitable to the occasion, the Immortality of the Soul. of the Soul. Upon this momentous subject, which should seem to defy and to confound the powers of human reason unenlightened by revelation, Socrates is represented as urging that the soul cannot be a modification of the body, for the soul gives life to the mass which it informs, it controls and regulates the functions of the perishable frame with which it is connected.

The conditions in which beings exist are but a succession of changes and an alternation of extremes. Heat succeeds cold, and weakness strength; and the existence of one state infers the succession of its opposite. Life, as it precedes, so it will prokrably succeed death ; and a state of insensibility and inaction is merely to be looked upon as a necessary state of transition to its opposite. But the human soul is capable of contemplating the eternal relations of things, which exist independently of those accidental combinations and mere casual phenomena which are presented to the senses. The soul has powers of meditating objects unconnected with time or space, and of a nature imperishable; and, it should therefore seem, must be itself as imperishable as the objects which it is its divine prerogative to be able to contemplate. The general principles with which the mind is fraught, and which, so far from being acquired in this life by any collection from particulars, are the tests which the mind from our earliest infancy applies in the arrangement of particulars ; that inborn and inherent knowledge, which study and investigation do not create, but only develop, as they are strong arguments to show some preexistent state, so also are they to be considered as indelible attestations of the divine original of the mind. Upon the whole, the particles of the visible world undergo not any destruction, but merely a transformation : the powers and faculties of the mind embrace those universal essences which have a far higher nature than the accidents of this visible world: they bear with them strong marks of a preexistent state, and are endowed with a divination and strange presentiment of some future state.

What the condition of individuals may be in that future state must be but matter of conjecture; but the good will safely rely upon the conviction, that in doing what is right they have done what is acceptable to the Deity; and, in the distribution of future conditions, it is not to be apprehended that those will be reduced to a lower state who have done all in their power to deserve a higher. But these difficulties can only be met by conjecture.

Some of these arguments bear the cast of doctrines which are prevalent in those writings of Plato which are acknowledged to be the productions of a much later period in his life. And though 'The 
Phædo' might be sketched at Megara, it probably received touches from the author's hand at a much more advanced stage of his life than his residence in that state.

We should be inclined to attribute to an early period of Plato's life The Alci-? 'The Alcibiades' (generally termed 'The First Alcibiades'). It is biades. written with much simplicity; and, at the same time that it inculcates the necessity of gaining thorough information of the details of public affairs before a young man enters into political life, it intimates, in many marked passages, the coincidence between true policy and virtue, and may be read by the students of Plato's works with great propriety, as introductory to and illustrative of the 'Books on the Commonwealth.' 'The notion that virtue is the perfection of a state, just in the same manner that it is the perfection of an individual, is developed in those books at great length; but the great principle, that the duty of justice is invariable and eternal, and that whatever is productive of disorder is as noxious to the exorbitant individual as it is to society; or, in the case of a state, equally prejudicial to itself as it is encroaching on its neighbours, is glanced at in this dialogue in a manner very forcible. 'The vanity of Alcibiades is pleasantly flattered by Socrates in the beginning of the dialogue. His spirit and readiness are very characteristic ; but his self-sufficiency gradually abates, and he is, before the conclusion, in a manner, rebuked and abashed. But a certain liveliness is preserved throughout, and the reader cannot help feeling an interest for the frank and ingenuous youth in spite of all the embarrassment into which he is thrown, and which is a just punishment for his forwardness and self-complacency.

From Megara, Plato proceeded on a course of travels; and first he Plato visits visited Italy: and perhaps we shall be excused if we premise here a brief sketch of the opinions which seem to have prevailed in Italy at the time of Plato's visit. In his progress through life he introduced and ingrafted on the doctrines of Socrates many notions, of which we find no account in Xenophon, as having been entertained by that philosopher; and many of his dialogues, on the other hand, are occupied in controverting other classes of opinions, the nature and bearings of which cannot indeed be understood without particular examination.

The philosophy of Italy seems to have been at this time divided The Philobetween the opposite schools of Heraclitus and Pythagoras. The sophy of former, whilst they reduced all the operations of the mind ultimately Ieraclitus. to sense, and considered sense as produced by the impression of external species on the animal frame, fixed their attention upon the changes of external phenomena, and the fluctuations and alterations taking place in the animal frame itself; and concluded that there was nothing permanent or settled in nature; that abstract science was a mere pretence, experimental philosophy an arrangement of dreams, sensation itself an illusion; for how could there be any reality when the things which seemed to impress the body were but the exuviæ or fleeting shadows of objects which were themselves shadows equally 
unsubstantial; and when the feeling arising from the impression depended on the momentary and accidental state of the body impressed?

Pythagoras and his followers.

The followers of Pythagoras pursued a directly-opposite course in their investigations. Perceiving that, from certain definitions, if the properties assumed were considered as the essential properties of figures, all the other properties might be deduced by an easy method, and a connected system might thus be formed of demonstrable truths, they satisfied themselves that such assumed properties were really original and primary; and that in the course of nature, in like manner as in the course of their studies, the other properties flowed from them as their source. Numbers seemed with them to have been taken for something elementary. These the earlier Pythagoreans considered not only as the essences but as the causes and originative producers of all things; and though their theory admitted of divinities, these seem only to have been higher natures, some harmonious products, as it were, of numbers, in the same manner as the visible world was a less harmonious product of the same causes. By what ingenuity the early Pythagoreans could have derived all the qualities of the visible world from combinations of mere numbers, Aristotle confessed himself incompetent to conceive. It is scarcely, therefore, to be hoped that this mystery of antiquity can be solved when the materials for information are still more deficient. Other followers of Pythagoras seemed to have reasoned in a manner less subtle, and to have arrived at some conclusions of the highest moment. These perceived or imagined in the external world, amidst its varying phenomena, the existence of certain substances of a more permanent nature. They perceived that whilst individual objects perish, the classes of objects still remain; that whilst some qualities are transformed by attrition, or fusion, or other operations of nature or art, other properties appear to be inherent and unchangeable. They concluded, therefore, that there exist in nature two distinct classes, one of variable qualities, and the other of eternal essences. But as their principal attention was directed to mathematical studies, and as they found that in the external world no materials could be found exactly corresponding to their notions of quantity, whether continuous or discrete ; that physical squares or circles always involved some disproportion; and that musical instruments, however formed, could never adequately give, through the medium of sense, the relations of their musical scales, though these last were formed of perfect consonances, they inferred that essences exist in some manner independent of phenomena, and that phenomena are but imperfect representatives of essences. They judged that the relations of things are eternal, but the things related fluctuating and accidental. They deemed that there is a perfect intellectual world discoverable by intellect; and also a visible world, which is but a semblance and approximation to the other, the proper object of mere sense. 
Whilst these schools, of the physical analysts and annihilators of existence on the one hand, and of the metaphysical realists and assertors of eternal relations on the other, were in full vogue and in daily collision, Plato paid his visit to Italy. He embraced the doctrines of Plato modiHeraclitus as far as they related to physics; but the sceptical inferences fies and comwhich were attempted to be drawn from those doctrines, met in him systems of with a decided and unwearied opponent. He adopted the notions of Heraclitus the Pythagoreans as to the permanence of essences, but he modified goras. the doctrine considerably, by incorporating with it those notions of a moral system and of an organizing Providence, which he had inherited from Socrates, as part of the purer creed of Anaxagoras. In another very important particular too, he qualified the metaphysical system of Pythagoras: he considered the intellectual world as being in some degree embodied in the visible one. Instead of inferring, as the Pythagoreans had done, that things related were a semblance of the abstract relations, he thought that they participated in those relations. ${ }^{1}$ Some other differences subsisted between his notions and those of the Pythagoreans, on the origin and the nature of numbers, which are involved in considerable obscurities. ${ }^{2}$ They seem to have merged sensible objects in numbers, or in some manner to have identified them; he, on the contrary, insisted on their separate existence from numbers. In these, as in many other particulars of ancient philosophy, it is to be feared that we must be satisfied with glimpses of meaning, and must be careful of introducing our own conjectures as expositions of what we cannot clearly apprehend. But it may be remarked as singular, that in one case Plato is represented as allowing a greater affinity between sensible objects and their essences, than the Pythagoreans did; and in the other, that he made greater distinctions than they did between sensible things and numbers, when it is admitted by all that the Pythagoreans at least identified numbers with essences.

From Italy, the general account is, that Plato proceeded to visit He visits Egypt; but we have no information which can be depended upon, either as to the circumstances of his visit, or the length of his stay in that country. Some accounts state that this journey was undertaken for the sake of merchandise, and that Plato was there trafficking in oil. $^{3} \quad$ But nothing can be more improbable than such a circumstance. Others relate that he there visited the priests, and was initiated in their most profound mysteries. ${ }^{4}$ But Plato himself acquaints us with the reserve maintained in Egypt towards strangers with regard to the peculiar institutions of the country; and assures us, that so far from their mysteries being accessible to foreigners, "the animals of the

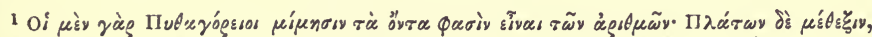

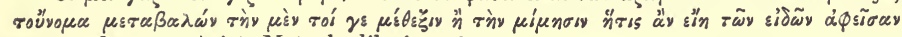

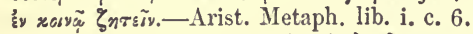

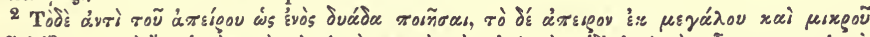

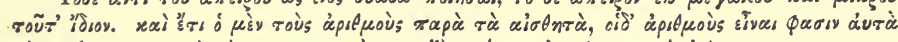

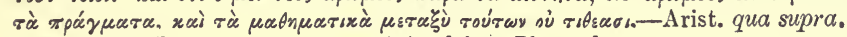

3 Diogenes Laertius.

* Apuleius. Plutarch. 
Nile used to drive foreigners away by their meats and sacrifices, and rude proclamations." 1 The most probable ground for his visit, besides general curiosity, is the one stated by Cicero, ${ }^{2}$ that he went for the purpose of completing his mathematical studies, and becoming master of their astronomical systems. We must attribute to the ignorance and ranity of the Alexandrians of a later period, the fiction, that during Plato's stay in Egypt the germ of all his knowledge was formed; and that he was indebted to the sages there for those treasures of moral and political wisdom which he afterwards imparted to his countrymen. On this head we have the express authority of Plato, that although some of the abstract sciences flourished in Egypt, the other liberal sciences were in his day but at a low ebb there. At the close of his 'Fifth Book on Laws,' after descanting on the advantages to be derived to the mind from the study of arithmetic, he remarks, that such studies produce other tendencies, which require to be counteracted, and that the knowledge of numbers may degenerate into mere cunning. "And this," says he, "is the case with the Egyptians and Phœnicians, and in many other countries, from the meanness of their other institutions and acquirements; whether this circumstance is to be attributed to the ignorance of their legislators, or to untoward occurrences, or to some inherent and physical defect."s

Some writers mention Plato's visit to Italy as occurring after his visit to Egypt ; ${ }^{4}$ and others suppose that he visited Italy twice, both on his way to, and on his return from, Egypt. ${ }^{3}$ It seems pretty well established that he visited Italy when he quitted Megara; whether he returned to it or not, when on his way homeward from Egypt, must remain a matter of doubt. But it seems probable that he did so.

On his return to Greece, Plato took possession of a small house

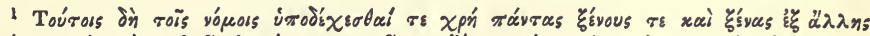

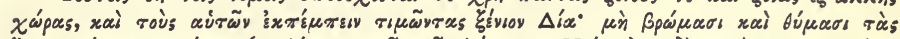

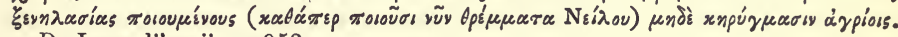
-De Legg. lib. xii. p. 953. e.

2 "Cum Plato Egyptum peragravit ut a sacerdotibus barbaris numeros et cœlestia acciperet?"-De Finibus, v. 29. It is strange how this passage has been misinterpreted, and what latitude has been given to the term colestia here, even by some writers who were acquainted with another passage of Cicero, which is the best commentary on this, if indeed it stood in need of any:- " Socrates mihi videtur, id quod constat inter omnes, primus a rebus occultis, et ab ipsa natura involutis, in quibus omnes ante eum philosophi occupati fuerant, evocavisse philosophiam, et ad vitam communem adduxisse, ut de virtutibus et vitiis, omninoque de bonis rebus et malis quæreret; cœlestia autem vel procul esse a nostra cognitione censeret, vel si maxime cognita essent, nihil tamen ad bene vivendum conferre."

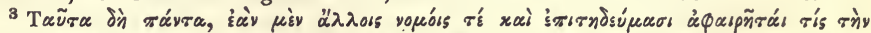

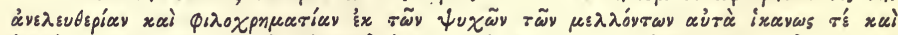

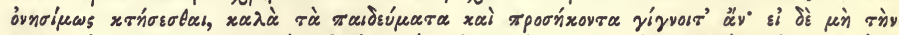

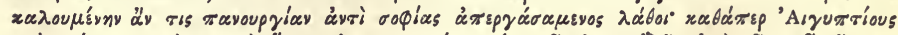

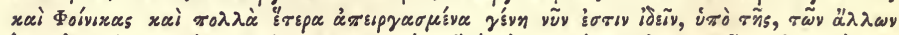

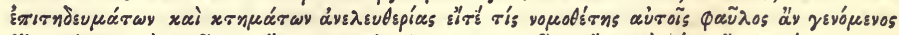

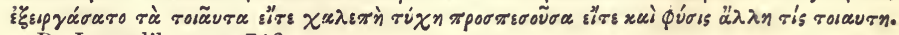
-De Legg. lib. v. p. 746.

* Diogenes Laertius. 5 Apuleius. 
and garden, adjoining to the groves and grounds which had been Opens a pubbequeathed by Academus or Ecademus to the public, and indeed as it Athens. seems within one common enclosure; and here he opened a public school for disputation and instruction in philosophy, where he was attended during the remainder of his life by a large concourse of auditors. As His Diathe earliest productions of Plato after his return from his travels, we should be disposed to mark 'The Euthydemus,' 'Gorgias,' 'Cratylus,' 'Io,' 'Theætetus,' 'The Sophist,' and 'The Parmenides.' 'The Euthydemus' and 'Gorgias' may be considered as satirical dramas upon the fashionable sophists and declaimers of the day. In the first of these dialogues the folly of verbal wranglings is admirably exposed, by introducing Socrates as fighting these retailers of subtilty with their own weapons. Absurdities are heaped on absurdities, until the conceited champion of sounds is reduced to a proper sense of his own insignificancy, and that of his art. In 'The Gorgias,' the same method is pursued, to show the vanity of that art which was taught for rhetoric in the days of Plato. The inutility of words and set phrases, and balanced sentences, without sterling sense and real knowledge, is shown in the amplest manner. Sentences of the fairest structure, with all the changes of cadencies that can be wrung upon them, and crowded with galaxies of imagery, are sifted and subverted by a few plain and direct remarks; and a homely logic soon strips off the splendid trappings of declamation; and exposes all the beautiful turns and elegant contrasts of words, as mere jugglers' tricks, which mislead the understanding by tickling the senses.

The antipathy of Plato to the substitution of sound for sense, and to the artificial mechanism of rhetoric, is well known to have been inveterate. The style of Lysias seems to have been the object of his particular aversion: he parodied it in his 'Phædrus,' and in 'The Gorgias ;' and it has been conjectured, with great plausibility, that he pursued the same end covertly in 'The Menexenus.'

'The Cratylus' is another dialogue, written in exposure and confutation of the sophists; but the solemn banter and grave irony used throughout this dialogue in the part of Socrates, have given rise to much misapprehension amongst critics and commentators. The dialogue is throughout refutative of those wranglers, who, as they addicted themselves only to the study of words, had propagated with some complacency a theory of philosophical etymology, and were pleased to think that no names whatever were of arbitrary imposition, but that every word had a sort of mystical propriety. Socrates com- Ridicules the bats this doctrine by adopting it, and by producing the most absurd etvmologies etymons which had been then promulgated. He proceeds, too, in an Sophists. indirect attack on the vulgar mythology, by showing the suitableness 'of the names of the heathen gods and goddesses to the actions generally imputed to them. He intersperses hyperbolical eulogies on the sophists, with which his hearers are represented to be gratified, as indeed they were rather repetitions of, than parodies upon, the pre- 
tensions of that fraternity. Socrates closes his attack in a manner more direct, by asking the perplexing question, how, if words were first established from a knowledge of things, and a knowledge of things could be only acquired by the study of words, language could ever have been formed at all. Such seems to be the scope of this dialogue. Socrates, in an early part, after throwing out a few whimsical and mystic derivations, hints that he must have a fit of inspiration on him, which he can only attribute to the benefit of a conversation he had recently had with Euthyphro.' He derives the word hero from ( $\varepsilon \rho \omega s)$, the love of the gods to mortal damsels or to goddesses; or else from ( $\varepsilon^{\prime}(\rho \varepsilon \imath v)$, the art of speaking, so as to be synonymous with rhetorician or sophist. He brings a confirmation of the doctrine of Heraclitus, from the origin of the word Tethys. He proves Pluto to be the very model of a sophist and a philosopher. He affects to be rather shy of going on with the etymology of divinities, but begs all his auditors will try the mettle of Euthyphro's horses in any other particular. He then says that he thinks the inventors of names, from the difficulty of the subject, became giddy and sea-sick, and as their heads swam round, they fancied all the objects before them in motion. He illustrates this by showing how things remote in nature are related in language, till at last he finds a strange affinity between duty ( $\tau o$ ó $\delta$ '́ $\nu$ ), and mischief ( $\tau \grave{o} \beta \lambda a \beta \varepsilon \rho o ̀ \nu)$. He observes, that the Greek of his day may probably be as different from the original as from a foreign language; that where any words cannot be traced with ease, it may be convenient to look upon them as of foreign extraction. Socrates, upon being complimented by Cratylus, repeats that he must have been inspired by Euthyphro, and that he could not help wondering at the wisdom he had himself been uttering. He proceeds in tracing verbal affinities, till he finds guilt and intelligence, intemperance and science, altogether synonymous. Although Socrates is well known to have indulged in great latitude of irony; although there is scarcely a page throughout the dialogue which does not bear some intimation of banter, and the above passages are obvious, and in a manner casually extracted, almost every annotator has made up his mind to consider the dialogue as a serious and solemn discussion; and the most ridiculous among the etymons have been quoted by grave authors ${ }^{2}$ with particular approbation.

' The Io' is throughout a banter on the imposture and the extravagant pretentions of the rhapsodists, interspersed with some oblique insinuations on the inspiration of the poets.

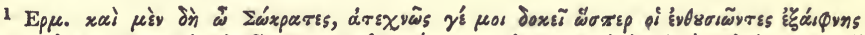

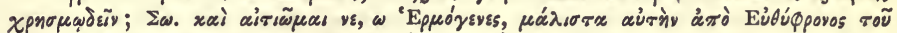

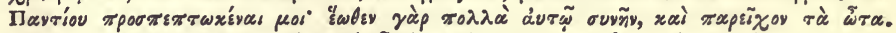

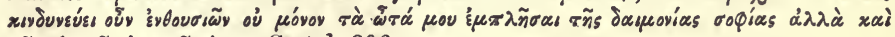

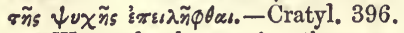

2 We need only mention the names of the learned and very ingenious Bryant, and of Taylor, to suggest to our readers the extent to which the sigwesia of Socrates in this dialogue has been misunderstood. 
' The Parmenides' is altogether the most mysterious and incomprehensible of Plato's dialogues. The resolution of all things into one, and the sameness of that one through the changes of all are the grand topic. Great disputes have been maintained about this unity of Parmenides, and some have been willing to identify his notions with the Spinozism of later days. The opinion of Aristotle, ${ }^{1}$ independently of other considerations, seems conclusive on this point, and whatever Parmenides might mean, he certainly did not mean any unity of matter.

It seems well established that Plato at some period visited the Visits court of Dionysius at Syracuse. One visit only of his is mentioned Dionysius at by Diodorus Siculus; but the spurious letters which have passed under the name of Plato, have given rise to very circumstantial accounts of three different visits. ${ }^{2}$ Of that visit which really took place, little can be satisfactorily said; and instead of dwelling on the fictions with which Plato's biographers have embellished their accounts of his stay in Sicily, we turn to the further consideration of Plato's dialogues.

'The Philebus' bears throughout marks of a judgment strengthened by experience, and of an imagination and feelings mellowed by age. To a student unacquainted with Plato's writings, and desirous of obtaining a full view of the moral doctrines of his mature years, it deserves to be recommended, both for the graces of the composition, and the sanctity of the precepts which it contains. It is a mass of moral wisdom, inculcated with every charm of manner and sentiment, which can captivate the imagination and interest the heart. It is serious and earnest and affecting.

' The Commonwealth,' or, as it is perhaps more properly entitled, 'The Dialogue on Justice,' was the production of Plato's mature years, and indeed seems to have been continually revised by him till the last hour of his life. The grand object of this dialogue is to prove His doctrine that moral virtue is the excellence of human nature; that moral conduct of virtue. independently of the accidents of rewards and punishments is suitable to the constitution of man. In the first part he shows that what is just, is not constituted such by arbitrary enactments, for then what was just in one state might be unjust in another, and besides no enactment would then be considered unjust. Inferring that there must be some other test, he proceeds to consider the human mind, and discovers in it three several faculties; the desire of pleasure, the defensive faculty, or the principle of irritation, and Reason. And, as it might be difficult to proceed with the consideration of these, as each balancing the other, or as severally gaining the ascendency in a single mind, he proceeds to examine the analogous parts as they display themselves in that large animal, a commonwealth. The sketch, therefore, of an ideal commonwealth which is introduced, is merely by

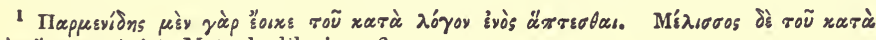

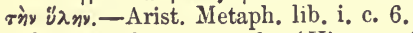

2 See Mitford's remarks, 'History of Greece,' rol, viii. 
way of illustration; and the several deviations from that perfect form, as exhibited in a tyranny, an oligarchy, and a democracy, though displayed at great length, and with admirable graphical effect, are, in reality, only larger exemplars brought in to evince the disproportions and confusion which must ensue, from allowing an ascendency either to the appetite for pleasure, or to the irritable propensities, in that microcosm, the human mind. The dialogue, in short, is throughout of a moral cast, and the political details are merely auxiliary and subsidiary to the moral end. The author shows that Reason must be the sovereign legislator, and that the inferior faculties of the mind must be regulated by the mandates of their Queen; and that happiness is secured to the individual in proportion as the higher faculty is well exercised and enlightened, and as the subject-propensities maintain their due and orderly allegiance.

Independently then of external circumstances, a certain regularity of conduct is required for the peace and harmony of the system within us ; but the' author proceeds to show that virtue, besides bearing its own reward here, in the content and self-complacency and happiness which it inspires, has, as far as tradition or conjecture may reach, the fairest chance of a continuance of happiness when this life is closed. In illustration of which a very beautiful fable is introduced.

Whilst Plato considered morality to be founded in the governance of Reason, and government to have its grand aim in the promotion of morality, it is not to be wondered at, that he thought the nature of man and of public societies would mutually illustrate one another; but we think the remark of a learned foreign critic $^{1}$ (in a work which is the best commentary that has yet been published on the design and conduct of this dialogue of Plato) particularly just, that the excursive and illustrative portions of the dialogue have in a manner overtopped those devoted to the principal and direct subject of discussion, partly from the disproportionate extent of those excursive portions, and more particularly from the singularity of some of the theories adopted in them. It is agreed by all, that Plato had great merit in forming to himself the notion of a perfect commonwealth; and in considering not merely existing institutions, but in endeavouring to create some form of ideal excellence, which might serve as a model, and as a constant example not of the practicable but of the desirable. It has, however, been the misfortune of his system to be judged of, not in the view with which it was formed, but to have its particular parts anatomized without reference to the whole, but as detached principles; and when so taken, their unsuitableness to society, as it exists, has been proved with much dexterity, and, indeed, by conclusive argu-

Plato's idea of a Commonwealth. ments. But the object of Plato was to conceive one perfect model to which human institutions might in some remote degree approximate. If the perfection of human nature is the annihilation of every selfish feeling, and the entire ascendency of a sense of duty, it is to be con-

1 Caroli Morgenstein, De Platonis Republicâ Commentationes tres. 
sidered, what in existing states of society are the causes that impede that perfection, that men may at least learn not to abandon themselves to those propensities, whatever they may be, the indulgence of which is so adverse to their real interests. If free devotion to general good is impeded by the love of lucre, and by the partialities of families and kindred; if avarice is admitted to be vicious, and favour and personal regards mischievous to the public, it seems to result, that in a perfect state all property should belong to the state, and that individuals should ratier be members of the great family of the state than of private households. On these grounds, amongst other regulations for citizens educated in a particular manner, brought up in a strict discipline of the passions, Plato modified rather than invented institutions, which had subsisted in some degree among the Cretans and Spartans," and projected a community of property and of wives. Marriages were to be performed with due ceremonies at seasons to be appointed by the public functionaries; but the nuptials, instead of effecting an appropriation for life, only sanctioned a temporary cohabitation; so that the offspring might not be claimed as the exclusive property of its individual father, but as the offspring of the state. Indeed the remark of Lucian is very just, that Plato's community of wives was quoted as a justification for the vilest prostitution and profligacy, by many persons who never suspected the real meaning of the author, or observed the particular guards and regulations with which Plato had encompassed this rule, even in a state of beings supposed to be exalted by every opportunity and preparation for moral and intellectual excellence.

Connected with this dialogue are two others, 'The Timæus' and ' The Critias,' the latter of which is left unfinished. 'The 'Timæus' contains a singular history of the Cosmogony. In this dialogue His CosmoTimæus is introduced, first making the usual distinction between gony. essences, which are the subject of knowledge, and accidents which are the subjects of opinion, and then stating that the divinity found a mass of inordinate and turbulent materials, which he organized and reduced to system. The opposite elements of fire and earth, he consorted by the media of air and water, and a proper temperament was produced by mixing them together in harmonious proportions. One world was the result; which, as it comprehended in itself all the ingredients in existence, and could therefore be subject to no external attrition or concussion, must remain undecaying and imperishable; and, as it comprehended all living beings, must be of that figure which is most perfect, and comprehends within itself all other figures, namely, a sphere. A soul or principle of motion was also created by the eternal intelligent Divinity, with which he caused the universal mass to be pervaded and invested. But Timæus expressly observes, that though in the order of our notions, this soul is conceived as pro

' See on this head Cardinal Bessarion's work, Contra Calumniatorem Platonis, lib. iv. c. 2 ; Venet. 1516, p. 69 ; and Morgenstein's Commentatio.

[G.R.P.] 
duced subsequently to the mass which it informs, yet that, in fact, this animating principle, as it is more noble in its nature, so must it have been more ancient in its existence. To produce a connexion between essences and accidents which seem of opposite natures, the Supreme Artificer introduced the medium of similarities and differences, and by this medium many admirable ratios were effected.

Time and Eternity.

Time was produced at the same time with the world, and is, in a manner, a shadow or fleeting image of eternity. It is not, as it were, a particle discerped from eternity, for eternity is one ever-present thing; and our ordinary expressions applicable to time as the past, the future, and the present, so far as used in reference and in contradistinction to the others, are entirely inapplicable to eternity. Eternity is the mighty and the real essence of which time is the unsubstantial image, which was born with this visible world, and is accommodated to its unsubstantial nature. And to mark the grand periods of time the Supreme Being produced the sun, and moon, and planets, and allotted them their positions and appropriate revolutions.' of a month was produced when the moon had completed her circle, and a year when the sun had perfected his revolution. The courses of the other planets are equally regular and significant; but the negligence or incapacity of men, has caused them hitherto to fail in rendering a perfect description of their periods. Out of each of the Creation of four elements, the Supreme Being created living beings; from the living beings fire, the gods or beings indued with self-motion; the revolving souls of the starry sphere, the soul of the earth, which Timæus asserts to be the first and most ancient of the created gods. The origination of demons or demi-gods, though stated with some detail, is prefaced by a declaration that it is founded solely on tradition; and that, as it was given by the personages themselves, it is therefore deserving of credit. The soul of man was next produced, but its high or fiery nature was commingled with desire and anger, and their concomitant passions; of a nature indeed imperishable; but which to attain its perfection must purge off the dross and defilements of these its meaner ingredients, and become purified from the adherence of every gross and sensual tendency. The Supreme Being created all these souls, but indued the inferior gods with the power of accommodating them to their several perishable and material vehicles. Timæus relates with great minuteness, how with cramps and bonds of adamant invisible to human eyes, material and immaterial substances became connected, and the soul incorporated. The nature of the senses, and the reason of the position of the head and body, are explained at length; and some profound remarks are interspersed on the benefit which the intellect derives, even in its most abstract speculations, from the suggestions of sight; and grand philosophic excellences are discovered in melody and

1 For the ablest dissertation which has yet appeared on this intricate subject, we would refer our readers to a short tract of Böckh, De Astronomiæ Philolaicæ verâ indole. 
rhythm. Timæus proceeds to distinguish the qualities of the externa world from the essences to which they assimilate, or of which, at most, they only participate. A singular definition is then given of Space. ${ }^{1}$

As all bodies were resolved into the four elements, so the element- Properties of ary bodies themselves are now resolved into figures. The different sorts of watery, aerial, earthy, and fiery substances are enumerated; and definitions are given of the opposite properties of heat and cold, hardness and softness, heaviness and lightness, smoothness and roughness, and of the sensations of pleasure and pain. A description ensues of the different senses, and of the whole animal economy; and the subject of divination is transiently glanced at in a manner ambiguous at least, if not ironical.

Several medical observations ensue, particularly on the preferableness of diet and regimen to violent medicines. The distempers of the mind are incidentally touched upon, as sometimes connected with physical causes, and as at other times originating in the defects of early education, in which case the parents or guardians are much more blameworthy than the unfortunate subject of the malady. The ascendency of reason is asserted to be something divine; and the pure enlightened reason is designated as a demon or superior spirit. The dialogue closes with a scale of the animal creation.

It is somewhat difficult to conjecture for what reason Plato has formed so strict a connexion between his 'Dialogue on Justice' and 'The 'Timæus,' except, perhaps, it might be his intention to intimate to his disciples the course in which he wished such studies to be pursued, and that he would have them perfect themselves in morals before they proceeded to the study of these sublime metaphysical investigations.

The scope of 'The Critias' seems to have been to introduce the peculiar political sentiments set forth in the 'Dialogue on Justice,' and to familiarize them to the Athenians by a sort of popular romance. By assuring his countrymen that his ideal commonwealth once existed, and that their own was the favoured country in which such political institutions had flourished in days of which the memory had long since passed, he might think to propitiate in favour of his scheme, those national vanities and prepossessions, which he before probably offended.

Plato attempted a work of more practical utility, when he wrote his System of 'System of Laws.' The five first books of these, besides containing many profound speculations on the general principles of laws-on the duties of a legislator, on the propriety of accompanying laws with a statement of the reasons which produce them, of visiting offences with proportionate punishments, and of considering punishments as exemplary and admonitory, rather than vindictive-abound with more pithy and pregnant apophthegms of moral wisdom than any equal portion

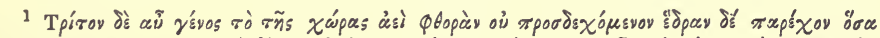

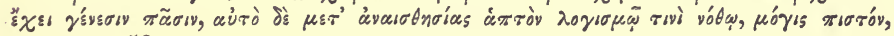

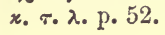


in the works of Plato. The other books contain a system both of municipal and international laws, written with so much comprehensiveness of understanding, and illustrated by so much copiousness and distinctness of reasoning, that whatever helps we may suppose Plato to have received from writings of his predecessors which are now lost, it is impossible to read them without admiration of the author's sagacity and judgment and genuine humanity. As this was the work of Plato's mature years, it may be considered as his last thoughts as a moralist and politician. As a statesman, and speaking with practical views, he never thinks of recommending any community of goods or wives; but he proposes many excellent regulations, considering the condition of females at that time in Greece, for the education and elevation of that sex from the comparative servility in which they lived.

'The Minos' which is generally prefixed as introductory to the 'Book of Laws,' has been shown to be spurious by an eminent foreign critic; and although Plato did write an 'Epinomis,' or supplemental close to his Laws, yet the same learned critic holds the dialogue which we now have under that title to be spurious also.

Platu's death, Plato died at Athens in the first year of the hundred and eighth в. с. 318. Olympiad, as it seems, of a general decline, at the advanced age of eighty-one years. A monument was raised to his memory" in the Academy, inscribed with an epitaph written by his pupil Aristotle, in terms of gratitude and enthusiastic reverence.

Certain dialogues generally introduced in the editions of Plato, have

Spurious writings. been long ago admitted to be spurious by general consent. These are ' The Axiochus,' 'Demodochus,' 'Eryxias,' 'Sisyphus,' ' Clitopho,' and the two short dialogues on Justice and Virtue. Other dialogues generally received as genuine, the 'Hipparchus,' 'The Minos,' 'The Epinomis,' 'The Latter Alcibiades,' 'The Rivals,' 'Clitopho,' and 'Theages' bear strong marks of spuriousness. The dialogues last enumerated are accordingly rejected by Böckh, ${ }^{1}$ Bekker, ${ }^{2}$ and Von Ast. $^{3}$ Bekker and Von Ast also reject the Letters. Bekker in like manner condemns ' The First Alcibiades,' 'The Lesser Hippias,' and ' The Io.' Von Ast not only concurs in this judgment, but goes much greater lengths. He questions the genuineness of 'The Meno,' 'Euthydemus,' 'Charmides,' 'Lysis,' 'Menexenus,' 'Laches,' 'The Greater Hippias,' 'Io,' ' Euthyphro,' 'The Defence of Socrates,' 'The Crito,' and the 'Books of Laws.' In the two 'Hippias' it is true that the gravity and importance of the sophist are caricatured with almost too great boldness and freedom of pencilling, and that the touches of satire are not of that more reserved and delicate cast which generally prevails in Plato's style. But we know not any sufficient reason for

I See Böckh's excellent critical tract, entitled Commentatio in Platonis qui vulgo fatur Minoem, ejusdemque libros priores de Legibus, Hal. Sax. 1806.

2 In his edition of Plato, Berlin, 1818.

${ }^{3}$ In his Platons Leben und Schriften, als einleitung in das studium des Platon, Lips. 1816, 8vo. 
questioning their authenticity. 'The Io' is undoubtedly genuine. But the banter is so admirably disguised, and so well kept up under an appearance of gravity and even solemnity, that critics and commentators have been as much imposed upon, as 'Io' was intended to

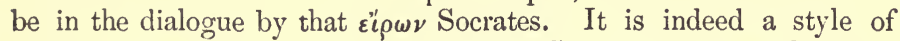
irony the most covert and insidious; and Socrates practises that very method which is said occasionally to have been adopted by a moralist ${ }^{1}$ in more recent times, of the most virtuous character and amiable disposition, "when he found any man invincibly wrong, to flatter his opinions by acquiescence, and sink him yet deeper in absurdity." The resolution of all poetry into a divine inspiration actuating a being otherwise in no respect superior to his fellow-creatures, and in a manner unconscious of the fine phrensy which he is in, and the magnetic process by which the contagion of enthusiasm is communicated, are conceived in the happiest style of humour and ridicule. The interpreter of the poets is played upon throughout the dialogue so skilfully and with such fine effect, that he seems to be flattered by compliments, which reduce not only his art, but that of the objects of his idolatry to phantasy and illusion; and he departs with a conviction, readily adopted, of the peculiar favour of heaven, and with every feeling of self-importance mightily increased and confirmed. 'The Laches' is probably spurious. 'The Euthyphro' is very questionable, but may have been written by Plato at an early period of his life, and before he had become master of the address which he afterwards attained in his mode of attacking vulgar superstitions. 'The Crito' and 'The Defence of Socrates,' approve themselves genuine by the interesting manner in which they are written, and by the simplicity and elegance of the style. On the same ground we should admit the 'First Alcibiades,' the 'Charmides,' and 'Lysis.' The 'Alcibiades' is full of good sense. The 'Charmides' and 'Lysis' though less weighty in argument, abound with delicate raillery, and with exquisite touches of manners. They have not, indeed, the same body with the 'Alcibiades,' but they bear with them the same genuine smack and raciness. 'The Menexenus' is, we think, a satire on the Rhetoricians, and a parody on Lysias. All the topics, the connective particles, the modes of transition from one topic to another, the antithesis, the measured clauses, have something technical and puerile about them, and are completely alien from the manner and arrangement and general style of Plato. If 'The Menexenus' is to be looked upon as a serious performance, we admit at once that it is no production of Plato; but we are inclined to believe that it is genuine, and intended for a parody. With regard to the ' Books of Laws,' it is well established that they were not pub- Books of lished in the lifetime of Plato, but were given to the world after his death by $P$ hilip the Opuntian; and this circumstance is a sufficient reason with Laws, their us for the difference which appears between them and the generality of the finished productions of Plato. The dramatic parts are very slightly

${ }^{1}$ Addison. See his life by Johnson. 
sketched. Von Ast, indeed, considers the characters Megillus, the Athenian stranger, \&c., as fictitious; but we see no reason for supposing that they may not have been real personages, and that a further development would have been given to these points, and a general proem prefixed, if the work had received the last touches of the author's hand. 'The other arguments of Von Ast relating to the 'Books of Laws,' originate, we think, in a misapprehension of Plato's object in his 'Commonwealth ;' the direct object of which was, as we before observed, of a moral nature, and the political discussions only elucidatory. In a commonwealth, where the individuals had by education been disciplined to a high state of moral perfection, many details might be impertinent or irrelevant, which would not only find their place, but would be absolutely necessary in a political treatise of a practical nature, and in framing a code of laws to be used by men, constituted as men are, and not such as they might be fancied to become. The notion that the 'Books of Laws', whoever they were written by, were intended by the author as supplemental, and to be accommodated to the inhabitants of Plato's ideal commonwealth, is surely not only a gross mistake of the nature of that commonwealth, but a perversion of the object of the 'Books of Laws,' as declared and explained by the author himself.

Such are our reasons for considering these dialogues genuine, though doubted or rejected by Mr. Von Ast. And, in our opinions of the object and turn of several of these dialogues, we are sensible that we trench very much upon a certain formal definition, which a writer ${ }^{1}$ of most fastidious taste and timid genius has laid down for the ancient philosophic dialogue. This learned and scrupulous critic defines it to be, "an imitated and mannered conversation between certain real, known, and respected persons, on some useful or serious subject, in an elegant and suitably adorned, but not characteristic style." And the same author attributes to the Promethean genius of Lucian, the "creation of a new species, the merit of which consists in associating two things not naturally allied together, the severity of the philosophic dialogue, with the humour of the comic." That the ancient dialogue was not always on serious subjects, and not always in a style not characteristic of the speakers, will perhaps be sufficiently obvious to any one who studies 'The Banquet,' which is admitted on all hands to be a genuine production of Plato. The characters of the style of the different speakers are there preserved in the closest manner, and were always so understood by the ancients; and, in one place, to set out the buffoon Aristophanes to the very life, his wild rambling wit is thrown into strong relief by preliminary incidents of the most ludicrous nature; for Plato was bent, says Athenæus, ${ }^{2}$ upon comedizing

1 See Hurd's Preface to his Moral and Political Dialogues, p. 53, 4th edition.

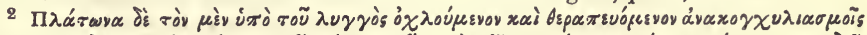

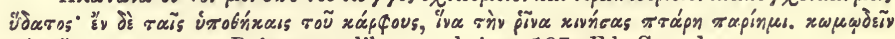

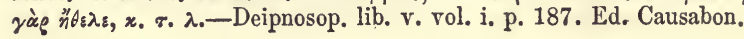


and scoffing the comedian. That Plato parodied Lysias, and mocked his artificial and balanced sentences, his formal antithesis and set cadences, we may rest assured on the evidence of Plutarch, who mentions it as an ingenious way of dealing with an adversary, to surpass him in his own style, as Plato did Lysias. But we are, perhaps, arguing this point too seriously, and too much at length, since all that the critic probably intended, was to give a definition of his own dialogues; and, as applied to those refined and most elegant compositions of his, the definition is perfect.

In attempting an outline of Plato's philosophy, we fully admit the Outline of justice of Wyttenbach's remark, that no abstract can give an adequate Plato's Philonotion of the merits of the original. Plato has two great excellences in the highest degree, which any attempt to represent to the reader in the course of an abstract must entirely fail. The first, is his method of opening and investigating his subject, so that unforeseen truths are elicited, in a manner at once surprising and satisfactory, from the most obvious premises, and from axioms which every understanding recognises. The other is, that his diction, figurative as it is, is in the greatest degree proper and philosophical; what is called his poetry, is, in fact, a chain of continued argument, and of animated illustration. So that his writings, extensive as they are, are really much more incapable of abridgment or condensation, than many persons are inclined to imagine from a first view of their expanded diction and dialogue form. We must honestly confess, therefore, that we can present our readers with a little more than a sketch of the most prominent points of Plato's philosophy, which we have collected, however, not from previous compendiums, but from the original works of our author. To enable our learned readers to judge how far we are borne out by the original, we shall support our sketch by quotations or references to the passages upon which we principally rely. One or two translations of a larger nature we shall intersperse, that our English readers may be brought aequainted in some degree with the peculiar manner in which the subject sought is evolved in Plato's dialogues. But the more we study the subject, the more we are convinced of the truth of a remark made by the learned and amiable foreign critic just mentioned, that Plato's system can only be adequately learned by a full and thorough perusal of his dialogues in the original; and that those who wish to master the subject, must have recourse to that means alone, and must not rely upon compendiums, the best of which cannot but be extremely imperfect. We shall be well pleased if the following outline serves the purpose of stimulating curiosity, and of promoting the study of an author, whose merits and beauties have not, we think, of late been sufficiently appreciated in this country.

Philosophy was divided by Plato into three parts: Morals, Divisions of

1 See his Epistola Critica ad Van Heude, prefixed to Van Heude's Specimen Criticum in Platonem. Lugd. Bat. 1818. 
Physics, and Dialectic. Under Morals he comprehended Politics; and under Physics, that science which was afterwards distinguished by the name of Metaphysics.

Plato's Moral Of Plato's moral doctrines the most important are, that, indeDoctrines. pendently of other ends, virtue is to be pursued as the proper perfection of man's nature ;' that vice is a disease of the mind, originating in some delusion or misapprehension of our proper interests $;^{2}$ that the real freedom of a rational being consists in his being able to regulate his conduct by the determinations of his Reason; that every person who is not guided by his Reason, encourages insubordination in the faculties of his mind, and becomes the slave of caprice or passion;" that a course of virtuous conduct, independently of its advantages to society, is beneficial to the individual practising it, as insuring that regularity of imagination, that tranquillity and internal harmony which is the mind's proper happiness. ${ }^{4}$

The earnestness of a virtuous mind in the attainment of truth, and the propriety of pursuing the ordinary gratifications of life, only so far as they are subservient to, or at least compatible with, man's higher and nobler duties, ${ }^{5}$ are topics insisted upon and adverted to with peculiar force and frequency. But, perhaps, a more complete

summary. summary cannot be given of the principal points of Plato's Morals, than is contained in the following passage, extracted from his own writings. It is at the commencement of his fourth 'Book of Laws,' and the remarks with which it closes on the coincidence of the precepts of morality with the conclusions of prudence and enlightened self-love, though written in a more popular manner than most of Plato's moral dissertations, are very happily conceived.

"It remains to consider by what mode of life a man may best consult his own interests, so that he may not be merely restrained by the necessity of obeying the laws, and by a fear of punishment, but may be influenced by a kindly regard towards the laws, as being sensible that what is established is for his benefit. This point then we proceed to consider. Truth, in the sight of heaven and of man,

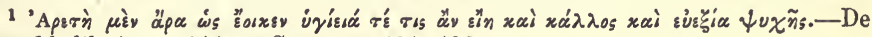
Republ. lib. iv. p. 444. et Gorg. pp. 491, 492.

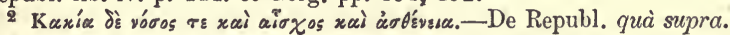

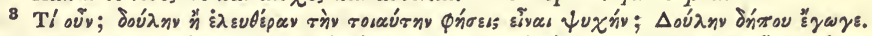

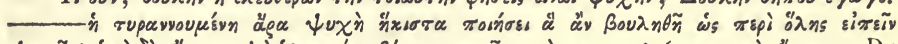

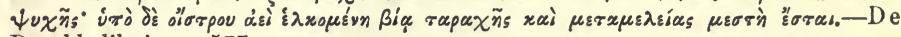
Republ. lib. ix. p. 577.

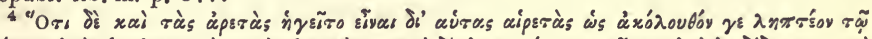

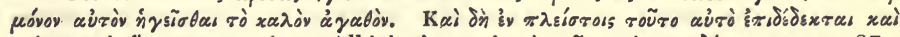

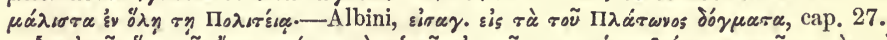

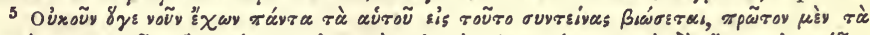

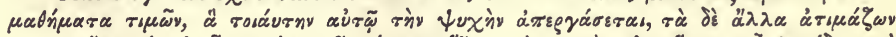

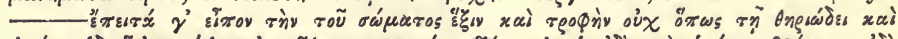

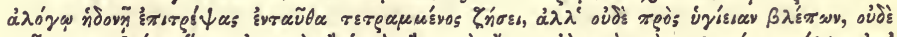

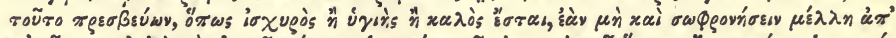

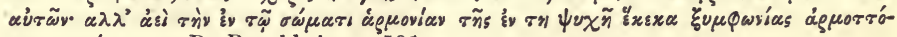
$\mu \varepsilon v o s$ Qaívnraı.-De Republ. ix. p. 591. 
is the noblest good; and a man who would enjoy happiness, is desirous at the earliest moment to partake of Truth, that he may spend as much of his time as possible in the course of sincerity, for such an one is a sincere character. But he is insincere who practises voluntary falsehood; and he is simple who practises it involuntarily. Nor is either of these conditions to be admired. For every insincere and simple person is friendless, and his true character being detected in course of time, he ends his days in dreary solitude. Since, whether his family and acquaintance still live or not, his life is almost equally lonely. That man is to be respected, who is guilty of no injustice himself, but doubly or more than doubly does he deserve respect, who will not allow injustice to be committed by others.

"Let that man who assists the magistrates in punishing vice, be proclaimed a great and perfect character, and let him receive the crown of virtue. And let the same praise be given respecting temperance and wisdom, and all other good qualities which a man not only possesses in himself, but is able to impart to others. The person able so to impart, should be respected in the highest degree; and next to him, he who, though unable, is at least willing to impart. But the man of an envious nature, who would grudge to others the blessings which he himself enjoys, deserves reprehension. Nor ought we to disparage any virtue which is misapplied, but rather to be desirous to attain it if we can. And let every one enter on a course of virtuous emulation, but devoid of envy. For, by such conduct, while men improve themselves, instead of engaging in calumnies and detraction against others, they benefit the community. But an envious character, who seeks to raise himself by depreciating others, not only makes no advances himself towards real virtue, but by his aspersions, he does, as far as he has power, discourage others from the pursuit of excellence, and checks the advance of his country towards real eminence.

"It is also right that a man should be at once courageous and mild; for it is impossible to rid oneself of the severe, and extreme or irremediable injuries of others, otherwise than by struggling against them, and by overcoming them, and executing exemplary vengeance. And such a struggle cannot be entered upon without courage and resolution. On the other hand, with regard to such injuries as are remediable, we ought to reflect first of all, that injustice originates not. in any perverseness of the will, but in a defect of the understanding; for the perpetrator of evil does the greatest mischief to his own mind; and no one voluntarily and intentionally seeks what is mischievous to himself, least of all, when it is mischievous in the highest degree. But a man's mind, as we before observed, is that which is deserving of the greatest respect. Now, in that part of himself which is deserving of the greatest respect, no one would voluntarily bring on the greatest evil, when that evil too would continue through life. But a man who is unjust, and who is possessed with evil propensities, is 
truly an object of commiseration; and we ought to pity such a being while the malady is remediable, and restrain our sentiments of resentment, and not be carried off with the violence and zealous indignation of the weaker sex. But, where a man is incurably mischievous, and irretrievably wicked, we ought then to administer justice unmingled with mercy. And for this reason it was, we said, that a virtuous character ought at once to be resolute and mild. But the greatest evil is that which takes deepest root in the heart of man, and for which, whilst each shows some indulgence to himself, no cure can be devised; and this proceeds from that self-love which is supposed to be innate in man's nature, and which, under proper regulations, is itself an important duty. But the excess of this is the source of all crimes, for affection blinds the judgment in this, as in all other cases ; and the man who, instead of regarding the real relations of things, is constantly observing his own situation, will very imperfectly discern what is just, or honourable, or proper. For a man who would be really great, ought not to attach his regard to self or his orvn vulgar interests, but to virtue; whether the results lead to his own personal gratification, or to that of other's. But it is from an error on this point that many deem their own folly to be wisdom, and whilst in a state of the grossest delusion believe themselves in a manner omniscient. From the same cause we sometimes undertake what we are incapable of performing, because we will not allow those to perform it who are capable; and would rather blunder ourselves than admit that others are better informed, whilst in truth we ought to feel no shame in following and imitating those who are really our superiors. There are other points too, which, though they are of less importance than those which we have touched upon, and of a very trite nature, may yet be equally serviceable, and which it may be well to recall to mind. For the stream of knowledge, as it seems constantly to flow away from the miud, should be constantly replenished; and recollection is but the reflux of ebbing knowledge. All extremes in the expression of joy and grief are to be avoided, and the excesses of the passions themselves are to be restrained; so that we may acquire and maintain a dignified moderation, whether our fortunes are successful and our guardian spirit seems to 'smile upon us, or whether the spirits of nature seem to be engaged in opposition to us, compelling us to surmount by our own virtue the arduous and steep ascent. We should then rely on the favour which Providence always shows to the good, that he will smooth the path of pain, and requite grief with gladness, and that the day of prosperity will follow the night of sorrow. Every man should support himself under trials with such hopes; and, whether in serious or in cheerful mood, each should revolve in his own mind, and communicate to those around him, such cheering and such consolatory views of the dispensations of Providence.

"So far with regard to models of excellence, and the perfection of 
the human character. But, since perfection is, in fact, not attainable by man, we must proceed in a less elevated strain, and consider what is practicable, and give such rules as may be of use in the regulation of conduct. Man's sensations and desires form a very considerable part of his constitution. By these he is influenced in all he does, and upon the nature of these his happiness, in a great degree, depends. We certainly ought to commend the most virtuous sort of life, not merely because it is most conducive to good character, but because, if steadily and uniformly pursued from youth upwards, it far exceeds any other in those particulars which are the objects of universal desire, in the attainment of pleasure, and in the exemption from pain. This, indeed, is evidently the case where a man's desires are well regulated. But by what means this just regulation of desire is effected, whether by the power of some inherent and connate faculties, or by the light of experience, may require some consideration. But we may form a comparative estimate of the pleasurableness or painfulness of some modes of life upon the following grounds. We wish to partake of pleasure, but pain we neither prefer nor desire. A state of indifference we do not wish for, as compared with pleasure, but yet we prefer it to pain. Nor can we say that we wish to have an equal share of pleasure, if attended with equal pain. In number, therefore, and magnitude and intensity, pleasures and pains surpass or equal, or are less one than another, as objects whether of desire or of aversion.

"Such being the state of things, a life, in which there are many of both sorts, and these great and intense, but where the pleasures predominate, we should wish, but where the contrary, we should not wish. So again, a life in which there were few of each sort, and these small and moderate, but where the pains exceeded, we should not wish; but where the contrary, we should wish. So that where there is an equilibrium of pleasures and pains, the mind feels a kind of indifferency; it would wish a course of life where the objects of desire preponderate, and would decline a course of life where the objects of aversion preponderate.

"These are all the different modes of life; and if we imagine there are any others besides these, we only imagine such things from an ignorance and inexperience of the nature of things. It may be well, therefore, to arrange and classify the different modes of life, that each man, by selecting that which is best calculated to produce a more unalloyed succession of pleasures, or a greater uniformity and permanence of satisfaction, may so best insure his own general happiness.

"We may term one sort of life a life of temperance, another of prudence, another of valour, another of health. To these we may oppose four others, a life of folly, of cowardice, of intemperance, of disease. Whoever is acquainted with a life of temperance, knows that it is moderate in all particulars, that it affords moderate pleasures, moderate desires and affections. That an intemperate man is violent in all 
these particulars; that his pains and pleasures are in excess, that his desires are tempestuous, and his affections frantic and irregular. That in a temperate life the pleasures exceed the pains ; but that in an intemperate life, the pains exceed the pleasures, in extent, in number, and in intensity. According to the constitution of nature, therefore, one of these modes of life is more agreeable and the other more painful; and no man who desires to live a life of real enjoyment, would voluntarily prefer a life of intemperance. If this be so, every intemperate man is such not by the exercise of a free will; but either from some defect in their understandings, or from the unruliness of their passions, or from a concurrence of these circumstances, the mass of mankind pass their lives destitute of temperance. With regard to a life of disease or of health, we must form the like reflections; that they both have their pleasures and their pains; that in a state of health the pleasures exceed the pains, but in a state of disease the pains exceed the pleasures. Now the object of our selection with regard to the modes of life, was not one in which pain predominates; but, on the contrary, we agreed that was preferable in which the pain was surpassed by the pleasures. But a temperate man surpasses an intemperate one, a prudent man an imprudent one, inasmuch as the pains which he has are fewer, and less intense, and of shorter continuance. The modes of life then of the temperate, the brave, the prudent, and the healthy, are far more desirable than those of the dastardly, and the intemperate, the imprudent, and the diseased. So that, to sum up all, the man who has any excellence, whether bodily or mental, so far passes a more agreeable life than the man who has any infirmity or depravity. And besides this direct agreeableness, such excellence is preferable on account of its comeliness, its consistency with nature, its serviceableness to others, and the character which accompanies it. So that one who is blessed with virtuous habits, passes a life more happy than one under opposite circumstances in every particular whatsoever."

Plato as a

Politician.

As a politician, Plato considered that the great object of laws was to provide for the natural accommodation of the members of the community, as subsidiary and in subordination to the cultivation of their moral virtues. ${ }^{1} \mathrm{He}$ considered the perfection of the state to consist not solely in the health, beauty, strength, and wealth of the individuals composing it, but also in their prudence, temperance, justice, and fortitude. ${ }^{2}$ He complains that legislators in general had only attended to the inferior qualities, and had neglected all the superior, with the exception of fortitude. In Crete and in Sparta, prudence and justice were notoriously disregarded, and temperance was only so far considered, as the practice of it was necessary to one species of fortitude. ${ }^{3}$ Plato illustrates with great ability the decline and decay of states from that momentary elevation and meridian of grandeur which success in 
arms had obtained, in consequence of sacrificing to vulgar conceptions of interest and policy, and to an overweening ambition, the duty of self-command and the eternal principles of justice. ${ }^{1}$

Plato perceived the inconveniences resulting from the Cretan and Lacedæmonian system of public messes and of naked exercises ; yet he seemed to think that convivial meetings under proper directions might be of great service both in promoting humanity and fellowship, and in discovering the true characters of individuals. ${ }^{2}$ He defined education to be that which qualifies men to become good citizens, and renders them fit to govern or to obey. ${ }^{3}$ He thought it most important that the early principles instilled into the minds of youth should be those of strict moral virtue, and considered that if poems and fables early taught were able to impress the mind through life with a belief of the most improbable fictions, that the same means might be applied with not less success for inculcating realities and important truths. ${ }^{*}$ Wine, he was so far from prohibiting, that he recommended the moderate use of it from eighteen to forty, and after that age a more free indulgence. ${ }^{5}$ He considered idleness as the bane of all virtue, and urged to industry as the grand source not only of wealth but of happiness. ${ }^{6}$ He perceived with great clearness the advantages resulting from the subdivision of labour, and pointed out the necessity and natural progress of such subdivision in proportion as civilization advances. ${ }^{7}$ As to crimes, Plato considered them as originating in a love of pleasure, in passion, or in ignorance and folly. ${ }^{8}$ He esteemed it the duty of every citizen to respect the established religion of the country, and he recommended that the religious ceremonies should be accompanied with festivities, and be enlivened by the association of songs and dances. ${ }^{9}$ It may, however, be incidentally remarked, as a strong argument against the opinions which many have entertained in modern times of the nature of the Orphic and Bacchic mysteries, that Plato misses no opportunity of animadverting on the verses which were current under the name of Orpheus, ${ }^{10}$ and that he excludes the Bacchic dance, as something unaccountable and unsuited to any purpose of policy, from any new state that may be established, and barely tolerates it in any old state, in which it may happen already to exist among ancient usages. ${ }^{11}$ Plato observes, too, on the necessity of accommodating laws to the character and prevailing temper of the inhabitants, and remarks that
${ }^{1}$ De Legg. lib. ii.
4 Ibid. lib. ii.
2 Ibid. lib. viii.
5 Ibid. lib. ii.
7 De Republicâ, lib. i.
${ }^{8}$ De Legg. lib. ix.
10 De Republicâ, lib. ii.
3 Ibid. lib. ii.
6 Ibid. lib. vii.
${ }^{9}$ Ibid. lib. ix.

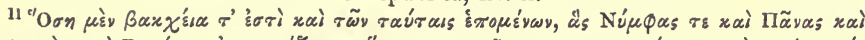

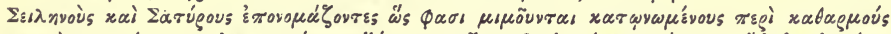

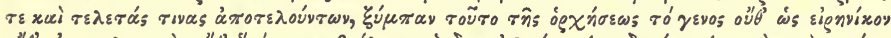

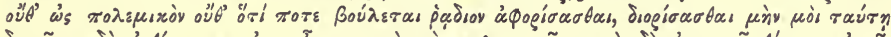

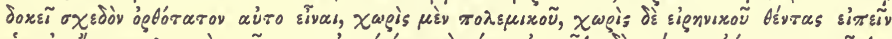

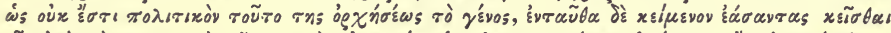

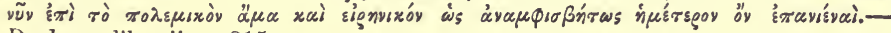
De Legg. lib. vii. p. 815. 
there is a great and striking difference between the characters of the inhabitants of different countries, whether the circumstance is to be attributed to the climate, or to some peculiar constitution, or to whatever other cause. ${ }^{1}$ Against trade and navigation Plato entertained considerable prejudice. Like all statesmen of old times, he interfered unnecessarily in the detail of personal economy, and proposed the establishment of numerous and trivial sumptuary laws. $\mathrm{He}$ considered, too, a part of the human race as necessarily destined to slavery, but his regulations in regard to the slaves are full of consideration and humanity.

But Plato's moral and political system received its completion from His Natural his doctrines of natural theology. The Supreme Being was considered Theology. by him as a being of perfect benevolence, who willed the good of the system which he had organized, and whose providence was constantly engaged in its superintendence. Negligence, or love of ease, or some other weakness is generally the cause of human indifference or neglect; but such imperfections are inconsistent with the first notions of God. ${ }^{2}$ He thought that to suppose God intent only on affairs of great moment, and indifferent about minor concerns and petty details, is a mere error, originating in like manner from our imputing to a higher intellect the shortsightedness and distractions incident to ourselves, and from the difficulty of our apprehending the nature of a perfect being. ${ }^{3}$ Plato urges too, that it is a mark of a narrow and contracted mind to infer from any disasters or misadventures which seem to befall individuals, that the world is out of order, and that there is no wise superintending providence. The system of the universe is regulated by general principles, and as far as the nature of the materials would allow, everything is adjusted so as to produce the highest good both of the whole and of the parts. But particular must give way to general interests; and each individual should consider that the world was not framed for him alone, but that his good is in a sense merely relative, and to be viewed in subordination to the good of the whole system. ${ }^{4}$ Nevertheless, the virtuous man has no ground for doubt as to the conduct he should pursue, or for despair in whatever difficulties he may be cir-

1 De Legg. lib. v. p. 746. b.

2 Ibid. lib. x. p. 900, et seq.

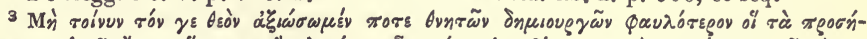

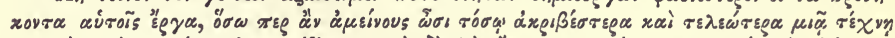

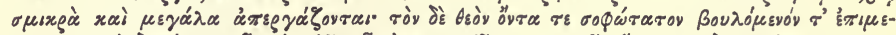

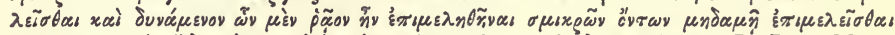

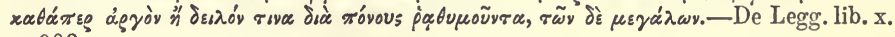
p. 902 .

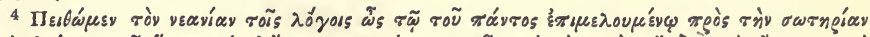

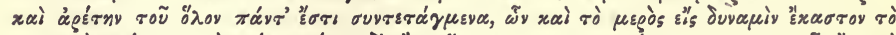

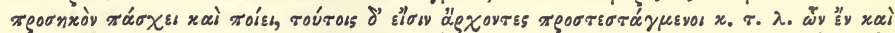

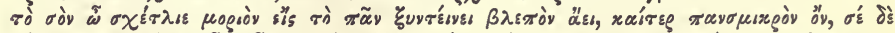

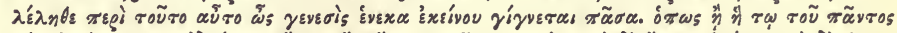

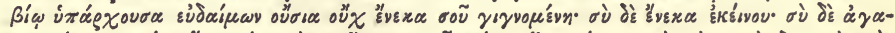

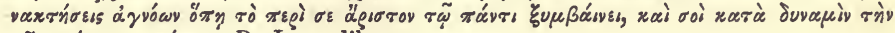

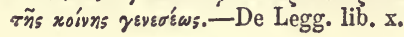


cumstanced. For the human mind is so constituted, that virtue brings with it its own satisfactions and consolations; and indeed, the course of human affairs, irregular as it may seem, is so tempered, that virtue will sooner or later prevail, whilst vice brings with it not only its own stings, but also inherent seeds of decay and downfal. ${ }^{\prime}$ To despair under any circumstances is a mark of self-willedness and of disloyalty to Providence. The good being will never eventually desert that spirit which has aspired as far as its faculties would permit, to assimilate itself in goodness to its great original, or suffer it when thus purified and advanced to a congenial nature, to undergo any real calaniity. The virtuous, therefore, may rely in confidence, that, whatever the appearances of things may be, real worth will never prejudice its possessor; for that it is a general law of nature, that the destinies of men are, in some respect or other, accommodated to their deficiencies or to their qualifications. The virtuous must ultimately attain conditions where their virtues will have suitable scope and energy; and the vicious may congratulate themselves if visited with speedy punishment, that they are provided with early means and opportunities of being reclaimed from their errors, and disciplined to better babits; but those, on the other hand, are deserving of commiseration who have the misfortune to succeed in purposes of mischief, and who become rooted in the delusion of vice. ${ }^{2}$ For it is an eternal and imnutable law, the operation of which pervades the entire universe, and from which no created being can soar so high as to escape by his elevation, or shrink so low as to screen himself by his obscurity. That virtue will eventually be rewarded and vice punished. ${ }^{3}$

It is very difficult to obtain a clear view of Plato's physical system. His Physical He seems to have considered all the qualities of the visible world as compounded of two different and, indeed, opposite ingredients : permanent and invariable essences, and fleeting accidents. His essences seem to have been endued by him with some inherent powers of motion, and his accidents with the property of being acted upon. All

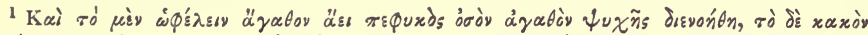

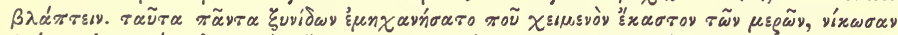

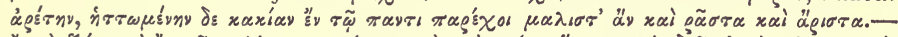

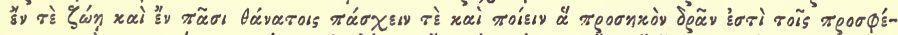

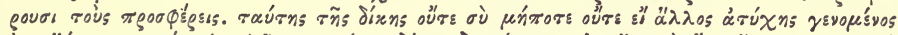

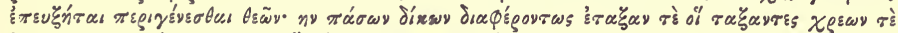

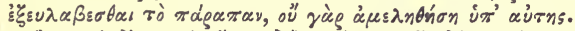

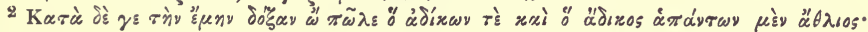

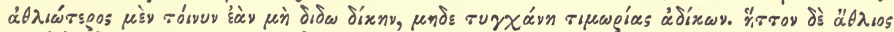

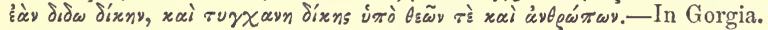

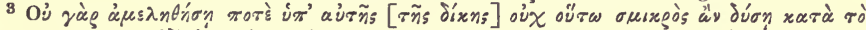

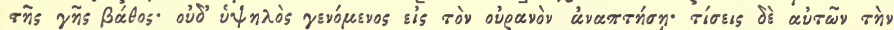

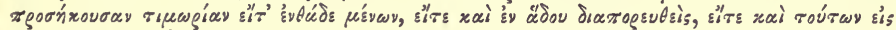

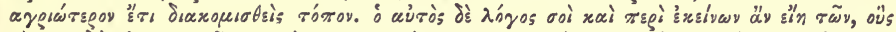

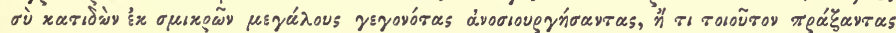

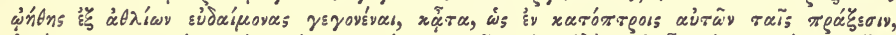

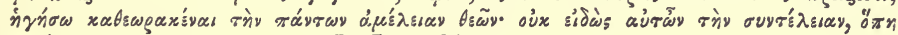
$\pi \circ \tau \dot{s} \tau \tilde{j} \pi \alpha \nu \tau i \zeta_{\nu \mu \beta \alpha} \alpha \lambda \varepsilon \tau \alpha \iota .-D e$ Legg. lib. x. p. 905.
} 
qualities, he thought, might be reduced to the four elements of fire, air, water, and earth; the two first he considered as active, the two latter as passive elements. But even in these, again, he seemed to find certain common properties, till by a further analysis he arrived at some original and primeval thing, ${ }^{1}$ which, itself destitute of all qualities, might yet serve as a groundwork or common vinculum for all qualities. This universal recipient and primary component, which is indefinable except by negatives, is what was afterwards by Aristotle termed $\boldsymbol{v} \lambda \eta$, and is with us in general called matter.

Matter eternal.

Essences and In uniting essences with fleeting accidents, Plato found great diffiAccidents.

This matter he seems to have considered as eternal and selfexistent; and that an eternal mind reduced those ingredients, which after wards constituted qualities, and which were originally inordinate, by his sovereign will into system and harmony. Creation, therefore, was in his view the organisation by mind of an elementary chaos; and he considered the power of the Supreme Being over matter as not entirely absolute, but as limited in some degree by the perverseness or resisting nature of the subject to be actuated. And whether we are to attribute the supposition to some irregularities or occasional deviations, which the ancient philosophers imagined in the motion of the heavenly bodies, or to whatever other cause we are to impute the singular position, so it is that Plato held the inberent and permanent stubbornuess of matter to be such, that at stated and periodic intervals the Supreme Being intermitted his regular and progressive agency, and the sphere of the universe revolved in a retrograde motion, until the excess of unruliness was exhausted, and the system had reverted to a point where it could resume its orderly obedience, and again revolve in suljection to its mighty Ruler. ${ }^{2}$

culty in reconciling such opposite subjects, and therefore devised a medium, which he described as being neither uniform in its nature, like the one, nor incapable of permanence, like the other, but in some respect compound and stable. It is very difficult to collect what Plato meant by these intermediate or connecting materials. And it may, perhaps, rather obscure than elucidate the subject to remark, that in many passages of Plato, ${ }^{3}$ and in some of Aristotle, ${ }^{4}$ connected

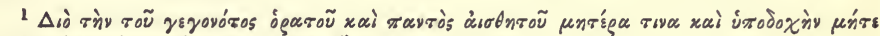

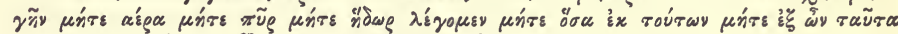

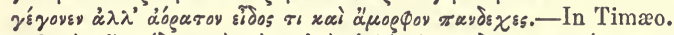

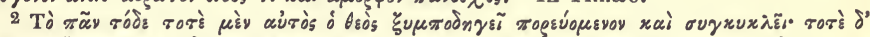

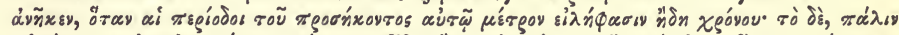

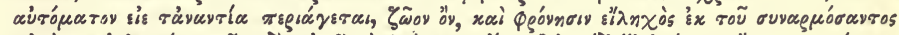

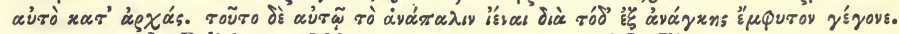
- . в. $\lambda$. In Politico, p. 269.

3 In Timæo.

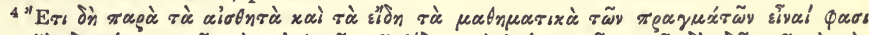

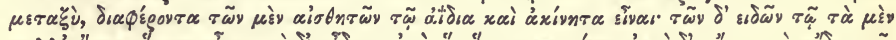

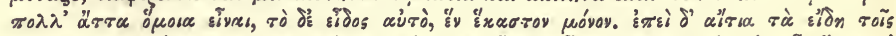

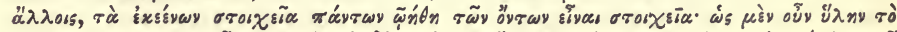

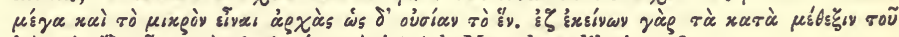

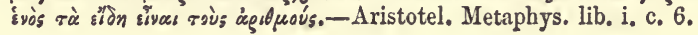


with this point, the term essences seems to be applied to numbers, and these intermediate materials to quantities. The notion, however, Matter inof some inherent power in matter of itself tending to confusion and herently inordinate, and only restrained and subjected to certain rules by a inordinate. Supreme intelligence, and by a coercing and counteracting Providence, was a fixed part of Plato's system, and is glanced at in his moral writings, as well as insisted upon where physical subjects are more directly the subject of his investigation. But wherever complete order prevailed, and regularity was observed in the movement of any body or systen,, it was inferred by Plato that that order must have been produced by the infusion of some part of the divine mind; and by the continuing and predominant energy of such infused spirit, overruling the untoward propensities of the material body or system which it informed. Such infused spirits he supposed to regulate the movements of the heavenly bodies, and he inferred them to be akin to the soul of man, when the soul had attained its highest perfection, and had reduced the appetites and passions of the body under its absolute control. ${ }^{1}$

No trace is to be found in Plato of the existence of malignant spirits. His doctrine of the resistance of matter may, perhaps, be looked upon as an ingenious theory, adopted in an imperfect state of knowledge, to solve the great problem of the existence of evil. In the sense which we have explained, Plato taught the existence of actuating spirits or divinities; but the passages in which he seems to adopt, in the number of these, the deities of the popular mythology, are generally prefaced by words of reserve; and may, perhaps, be justly considered as instances of cautious, if not honourable, accommodation to popular superstition. With the fate of Anaxagoras and of Socrates but too strongly impressed on his memory, Plato may perhaps be excused for not openly defying and exposing the vulgar polytheism.

The more gross and practically-mischievous effects of the supersti- Reprobates tion that prevailed among his countrymen, he reprobates on every occasion. He incessantly ridicules that weakness which, instead of the offering of a pure heart, would attempt to propitiate a perfect being by gifts and sacrifices, and would make such bargains with an all-just God as would be an insult if proposed to any of their fellow-

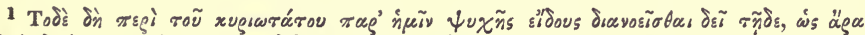

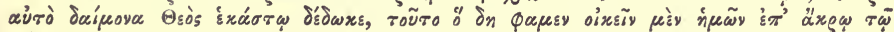

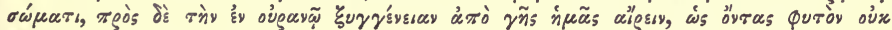

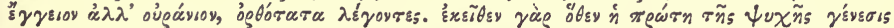

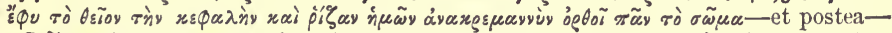

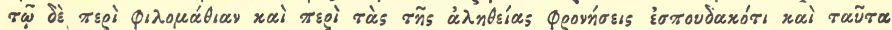

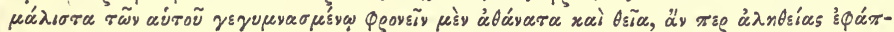

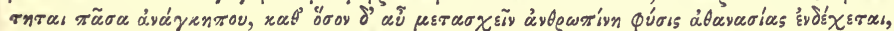

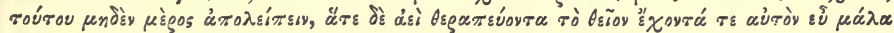

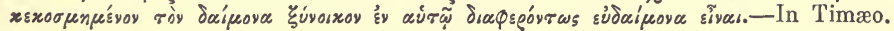
p. 90. These passages seem strongly illustrative of the nature of Socrates' docmon, at least as understood by Plato.

[G. R.P.] 
creatures.? He rebukes the poets for creating or giving popularity to the idlest and most impure fictions of the ancient mythology. If Plato considered the gods of his country as having permanent existence, as embodied powers of nature and tutelary divinities, or as having had a mortal existence, as departed heroes and benefactors of mankind, he

Did he believe in polytheism?

His opinions on Logic and Rhetoric.

at least did not, at the same time, consider that beings so superior were or had been capable of the grossest crimes and of the greatest inconsistency of character. But we confess it seems to us most probable that Plato entirely disbelieved the whole mass of the current fictions; and the difference of style observable in his writings upon this subject, so distinguishable from his solemn and earnest manner when discoursing on the Supreme divinity, seems strongly to confirm our opinion of his disbelief in the polytheism of his countrymen even in a modified sense. ${ }^{2}$

The art of communicating knowledge, or the science of language and reasoning, is intimately connected with philosophy, or the art of acquiring knowledge. As knowledge, according to Plato's doctrine, consisted in rejecting accidental particulars, and in contemplating those essences or general principles which always existed in the mind, but which only required the suggestion of particular occasions to unfold and develop them at large; so he considered the art of communicating knowledge to consist in exciting the power of abstraction, and in awakening in the understanding those inherent but dormant notions which only require proper excitement to become expanded in their due proportions. As the objects of knowledge can only be clearly distinguished from one another, by separating their permanent natures from their accidental circumstances and combinations, he considered definitions as the grand instrument for communicating knowledge; since, by means of them, we can limit the subject of inquiry to a distinct point; and by words defined and adhered to in the sense given as a definition, can at once explain what we consider the permanent and inherent properties of anything, and can also converse of them as separated from their accidental adjuncts. ${ }^{8}$

With men, indeed, of sound understandings and candid tempers, plain and direct reasoning is the most proper mode of proceeding, and knowledge is best communicated by simple methods, and with as little of the circuits and perplexities of language as the nature of the subject will admit. But with different tempers, and on different occasions, other methods of communicating knowledge, and leading

1 De Legg. lib. x. and lib. xii.

2 "Sciendum est tamen non in omnem disputationem philosophos fabulosa admittere, sed his uti solent cum vel de animâ, vel de aeriis, ætheriisve potestatibus vel de cæteris Dîs loquuntur: cæterum cum ad summum et principem omnium Deum tractatus se audet attollere, nihil fabulosum penitus attingunt."-Macrobius in Somn. Scip. lib. i. c. 2.

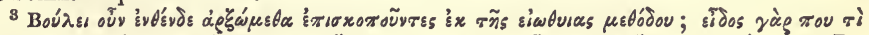

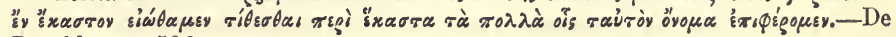
Republ. x. p. 596. 
on to just sentiments, must be adopted. Some minds must be first cleared and purified from idle prepossessions, from vain conceits, from the arrogant imagination that they are already in possession of that very knowledge from which their hearts and understandings are, in fact, entirely alien. The subtile must be met with subtilty, the fantastical must be indulged a little in their whimsies, and be enticed and allured to more substantial entertainment. The art of conviction is very closely connected with the art of persuasion. And although without a true and sound logic no man can acquire knowledge worth imparting, so, on the other hand, without proper rhetorical skill, the most important knowledge of a practical nature must remain unimparted or imparted to little purpose.

Such seem to have been Plato's general notions on the subjects of logic and rhetoric. But it has so happened that his animadversions on the technical refinements, the jingling tricks and fopperies of contemporary rhetoricians, have been misconceived, as if they involved a general and indiscriminate censure on the art of rhetoric. The object of Plato was very different, as will appear to any one who carefully studies his dialogues connected with that subject. He merely endeavours to inculcate that the faculty of using words without a real knowledge of the subjects discussed, is but empty babbling; and that any art which would attempt to show that the opposite sides of every question are equally capable of argument and proof, must be grounded either in the ignorance or in the imposture of its professors.

That the view which we have taken of Plato's doctrine on this head is the just one, will be seen at once from the following abstract or condensed arrangement of the principal arguments used in the 'Phædrus,' for which we are principally indebted to an essay by Mr. Geddes, on the composition of the ancients, which contains, amongst other things, some very valuable illustrations of Plato.

"I ask you," says Socrates, "does not eloquence allure and persuade Abstract of the mind, not merely in courts of justice, and other public assemblies, but in private parties likewise, where men discuss topics of more or less importance? Is it not for their honour to deliberate justly in matters of snall as well as of great moment? By Jove, answered Phædrus, I never heard that oratory was displayed anywhere else than Oratory. at public trials, or in speeches addressed to the people.-What then, Phædrus, is it the opposite parties do in courts of justice? Do they not contradict one another? They do.-With regard to what is just, and to what is unjust? Yes.-He who does this by art can make the same things appear just to the same persons at one time, and at another unjust? He can. And in a public oration, he can represent the same things useful to the public this day, and the next, injurious? This art then of debating or contradicting being in fact one and the same, may not only be exercised in public meetings, and the business transacted there, but likewise in every other affair? Answer me, then, and say, whether does a deception happen in things which differ 
widely, or things which differ but little? In the latter.-If, in going from a thing to its opposite, you proceed gradually, will not the transition be more insensible than if made suddenly? Certainly.- - He, therefore, who would impose upon another, without being himself deceived, must have an accurate knowledge of things which resemble, and things which do not resemble one another? He myst.-Is it possible for a person who is ignorant of the truth, in any one thing, to judge of its greater or less similitude with other things? By no means.-Consequently, those who are deceived, and who form opinions contrary to the nature of things, are led astray by false appearances or similitudes? They are.-Well, then, is it in the power of any man who does not himself understand the nature of things, artfully and insensibly to draw off his hearers by delusive resemblances from truth to falsehood? Not at all.-Whoever, therefore, my friend, is ignorant of truth, and guided by opinions, must appear ridiculous, and unacquainted with his art when he attempts to persuade; he, who would excel in oratory, ought first, to form just notions, and to understand the true character of every species of things, and hence be enabled to judge when the people are likely to be deceived, and when not? $\mathrm{He}$ would be a happy man, Socrates, who possessed that knowledge.Moreover, when he has to describe anything, none of its properties ought to escape him, but he ought at one glance to discover to what species his subject belongs : an oration ought in its composition to resemble an animal, which has its own body, head, and feet, and its middle extremities, and every member and part correspondent to each other, and to the whole. It ought not to be a matter of indifference, whether what is said'first might as well be last, or the contrary. These observations, Phædrus, are not, however, so important as the two following ones. What are these? First, it would be well for us if we could collect many remote qualities, and reduce them into one kind; and by defining everything, give a distinct idea of the subject: in this manner we have endeavoured to define love, and ascertain its meaning.-Well, what is the other? It is this. To be capable of subdividing each species into its natural and peculiar division without, like an unskilful artizan, breaking any of its parts. I am in love, Phædrus, with such divisions and compositions, as by them I am enabled to reason, and to speak justly; if I find a person, who can discover one and many, as they are in nature, I follow him step by step as a kind of Deity: God knows if I am right for esteeming those so highly who argue in this manner, and in calling them as I do, masters in the dialectic. But we have not yet discovered what rhetoric is.- - How do you mean, Socrates? We must pronounce what remains to be said upon oratory.-You know, Socrates, there are many famous treatises written upon this subject? Well suggested.-The proem is the first part of an oration, and is frequently adorned with great art? It is. - The second part contains a narration ${ }_{8}$ with the evidence of the facts; the third and fourth parts consist of conjectures and presump- 
tions, arguments and confirmations. I might also take notice of those, who have taught how a plaintiff and defendant are to manage their accusations and defences, replies and rejoinders; and those who invented panegyric and invective. We dismiss 'Lysias' and 'Gorgias,' who prefer an appearance of truth to the reality, and by the force of their eloquence can make small things look great, old things new, and the contrary; value themselves, sometimes on conciseness, at other times on prolixity; at which Prodicus laughed heartily one day, and said, this art neither required very long nor very short sentences, but moderate ones. He was right.-Polus ought also to be praised, for having added several graces to oratory. Protagoras likewise was very elegant in his discourses; Chalcedonius excelled in moving our pity and compassion, in raising or calming our anger, and in raillery and repartee; they all agreed as to the nature of the conclusion which some call a recapitulation.-You mean, Socrates, one ought to sum up the whole of his arguments in the end of his speech? I do.Well, continued Phædrus, I see you look on all these precepts of these rhetoricians as no more in effect than the first rudiments; but pray inform me how shall one become perfect in the true art of persuasion? Perhaps, Phædrus, 'tis possible to become a master in this as well as any other exercise: nay, you cannot fail if nature has bestowed a genius, and you take care to cultivate it right.

"In acquiring this art I am not for following the method of Lysias and Thrasymachus, but another.-What other? Pericles my friend seems to be reckoned the most perfect orator.-Why? The more excellent arts demand constant meditation, and an accurate inquiry into the powers of nature; hence we acquire true grandeur of mind, and a capacity of performing everything in the best way. Pericles had a fine natural genius, and improved it to the utmost by these studies; he was a constant companion of Anaxagoras, heard his lectures on natural philosophy, on the temper of the human mind and its disorders, became well acquainted with both, and drew from this fountain the noblest helps to eloquence.-How so? The art of medicine and rhetoric are, in this respect, the same.-In what? You must attentively consider the nature of the body in the one, of the mind in the other : this, I say, you must do, if you are resolved, not empirically but scientifically, to confer health and strength on the body by diet and medicine: and by reason, and legitimate discipline to instil virtue into the mind, and gain it by persuasion. - That is highly probable, Socrates. Do you think you can understand the nature of the human mind, without knowing the nature of the whole? If we believe Hippocrates, the successor of Esculapius, we cannot know the nature of the body, without applying to that study.-His notion is just, Phædrus : let us hear, then, in our researches into nature, what Hippocrates and right reason suggest. Are not we to consider the nature of everything in this manner? First, whether what we ourselves desire to know, and teach others, be simple or various; if simple, we must learn its 
active and passive powers of operation ; if compound, we must enumerate its different kinds, and accurately distinguish the virtues of each, how they operate, and by what they are affected? So I think.Without this method, our progress will be like that of a blind man. Now he, who performs anything, according to art, cannot be compared to the blind or the deaf: is it not therefore evident, whoever speaks with true art must understand well the nature of that which he addresses? Now this is the mind. Undoubtedly.-Does not the whole labour of the pleader tend to this, that he may persuade the hearer? Yes.-It follows from all this, that Thrasymachus, or any other teacher of rhetoric, ought with the utmost assiduity to investigate and declare, whether the mind is by nature simple and uniform, or compound, as the body; this is what we mean by explaining nature. I understand you.--Secondly, he is to show, how the mind acts, and how it is acted upon. Right.--Thirdly, having regularly taught the different kinds of speech, and various passions of minds, and examined the motive, which influence them, he is to adapt the one to the other, and teach how, and for what reason, a mind of such a temper is necessarily persuaded by such an argument, while another one is not in the least moved by it. A noble method, indeed, Socrates.-Believe me, neither the art of rhetoric, nor any science whatever, can be taught, or explained to advantage any other way than this; our modern rhetoricians, whom we daily hear, are men of shrewd parts, they keep to themselves their knowledge of the human heart, and will not communicate it to the world: but till they teach and write in the manner we have mentioned, I shall never be convinced they are skilful in their art.-What manner do you mean? It will not be easy, Phædrus, to explain this fully; but I shall briefly intimate, what method the true teacher of this science is to follow.-Pray let me hear it. Since eloquence is nothing else than pleasing and convincing the mind, a good orator ought surely to know how many sorts of minds there are, so many of one, so many of another quality; whence men are of opposite tempers and characters: these distinctions being made, 'tis next to be observed, there are different kinds of speech too; each of which has its own peculiar quality. Some men will be persuaded by one kind of speech and motives, which will hardly have any influence on others. One of a ready capacity, who has been taught this art, will be able, on proper occasions, to bring it readily into practice, and see at first sight when and how to apply it; if he cannot, he will be little wiser for his knowledge of the theory; but if he knows that such a person will be prevailed on by such a speech, and can in practice penetrate into the mind, and discern at once, that now occurs the character which is to be persuaded, by such an argument to such an action; he, I say, who is master of this art, and nice discernment, and can, in an easy and elegant manner introduce the different ornaments and figures of diction, the pathetic, sublime, and rehement, is the consummate orator! Whoever is defective in any of these respects, 
either as a speaker, writer, or teacher, and says he is good in his art, is mistaken."

In criticising the philosophy of Plato, it is but just to advert to the General exuncertain state of knowledge at the time when he wrote. If the plain cellence of and sober sense of Socrates had struck out some sterling truths of on moral submorality, and had struggled to catch at some general principles, and to lay a firm groundwork for human virtue, it is the merit of Plato to have followed up the same track, and to have directed the great powers of his understanding and of his imagination, and the prodigious acquirements of long and varied research, to the illustration of the proper end and aim of man. There is scarcely a dialogue of his, however different its principal or professed object may be, in which something is not adduced or insinuated in relation to this important subject. It is this circumstance indeed beyond all others, which gives that apparent uniformity and coherence and system to all the writings of Plato; they all, in a greater or less degree, tend to elucidate the problem, what is the true happiness of man, and what are the best means of attaining it, considering the constitution of human nature, and the circumstances in which man is placed? His ultimate views on this subject are, perhaps, the most just that unassisted reason can arrive at. His arguments and his conclusions have been adopted by Lord Shaftesbury in his 'Inquiry concerning Virtue and Merit,' the ablest and most unexceptionable of his performances. They have been explained and illustrated with more precision and perspicuity by Bishop Butler, in his three admirable sermons ' On Human Nature;' and that learned writer has successfully combated the most ambiguous and noxious of Hobbes's positions, by girding on the armoury of ancient lore, and proving against all the cavils of the advocates for confusion, that man is naturally a law to himself. The conclusions indeed of Plato and other ancient writers, on the fundamental questions of morality, are so clear and satisfactory, that whilst we feel the greatest admiration of the reasoning process by which they arrived at such truths, yet we should be almost inclined to say, that the primary distinctions of virtue and vice, when once expounded, are in a manner self evident to human reason, ${ }^{1}$ if we did not see the characters of Polus and Euthydemus revived in almost every age among mere speculative inquirers.

Upon Plato's physical system, or the mysteries of his numbers, we His physical have little to observe in addition to the remarks we have before inci- system often dentally made. We frankly confess, that there is much in these parts gible. of his writings that we do not understand; and, indeed, that his grand periodical revolutions and calculations ${ }^{2}$ which he has introduced, as

1 "Nam neque tam est acris acies in naturis hominum et ingeniis ut res tantas quisquam nisi monstratas possit videre: neque tanta tamen in rebus obscuritas ut eas non penitus acri vir ingenio cernat si modo aspexerit."-Cicero.

2 Schneider, however, is of a different opinion, and we have studied the explanation which he attempts, but without becoming converts. See Schneider's Commentationes duæ de Numero Platonis. Wratislaviæ, 1821, quarto. 
connected with political subjects, seem to us utterly incapable of solution.

His dia-

On his dialectics we have but one remark to make; that the diffi-

lectics.

culty experienced by Plato, whenever he has occasion to advert to the mere arrangement of arguments and the process of reasoning, confirms us in an old opinion, which indeed we never doubted, but which of late years some attempts have been made to shake, that Aristotle was strictly correct in announcing himself as the author of that logical system which he afterwards communicated to his countrymen. The same persons who are sagacious enough to discover the essences of Plato in the reveries of Eastern sages, may be somewhat perplexed to account why he did not at the same time borrow that logical system which they will have it prevailed among the same sages, and why it should be left to Aristotle to introduce that verbal machinery, of which he forsooth falsely claimed the invention.

Little known Such was the life, and such seem to have been the doctrines of as to his per- Plato: and we feel it a matter of sincere concern, that so little has
sonal character. been handed down, that can be depended upon, relating to the personal character of so illustrious a man. The idlest inferences have been drawn from misinterpretations of particular passages in his works; and tales of jealousy and rivalship have been invented by the scandalmongers of antiquity, and retailed by the moderns. By some writers he has been described as vain and ostentatious, and as one who was bloated up to pride and arrogance by the attentions he received at the court of Syracuse. By some he has been represented as the tyrant's parasite; by others, as a political intriguer and factionary. That he was not a vain man, however, sufficiently appears from the course of his writings; where, with an amiable devotedness, he attributes to Socrates not only the simple truths of that excellent man's plain and sound morality, but all the rich and rare illustrations which his own genius, and the amplitude of his research had discovered, or the prodigality of his fancy bestowed. And this respect for his master was, if we may place any faith in Plutarch, exemplified also in his life, in an assimilation of manners, in his equanimity of temper, and in that uniformity of character, which is the best proof of sincerity and integrity. "Plato," says he, " was the same person in the Academy and at Syracuse, and exhibited the same character towards Dionysius and towards Dion."

His successors.

The doctrines of Plato were, after his death, expounded in the Academy by his nephew Speusippus, who continued his duties as a public "professor for eight years, when he resigned in favour of Xenocrates, who had been one of Plato's most esteemed pupils. The integrity of Xenocrates is well known, and his personal chastity has been celebrated by the retailers of anecdotes ${ }^{2}$ in a particular tale connected

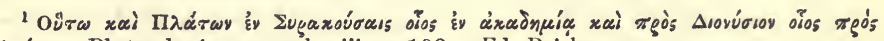
$\Delta$ เ́́yo. - Plutarch. in opp. vol. viii. p. 193. Ed. Reiske.

¿ Diogenes Laertius, Valerius Maximus, Bayle. 
with the courtezan Lais. Neither Speusippus nor Xenocrates appear to have deviated in the slightest degree from the general system of Plato. But Polemo, who succeeded Xenocrates, atoned for a youth of intemperance, by rushing in his more sedate years into an extreme bordering on asceticism. The austerities of his own practice, the strictness of his sense of duty, and the ambiguous language which he seems to have employed as to the soul of the universe, almost make one imagine that he anticipated the system of Zeno. Polemo was succeeded by his intimate friend Crates, who had long been connected with him by congeniality of disposition, but who died after a short sway in the Academy. It is not improbable, indeed, that the positive and dogmatic manner of Polemo and Crates produced that revulsion which ensued upon the death of the latter, and occasioned their successors to indulge in greater latitude of speculation, and in more of that temperate and modest suspense of judgment, which is content to consider the conclusions of practical reason as merely approximations to certainty; but is at the same time willing to act upon probabilities, since man must act somehow or other, and it is most reasonable to act according to such semblances of truth as the mind can arrive at.

Such was the course of the old Academy. The history of the new Academy, (for we agree with Middleton in rejecting the distinction of a middle Academy), beginning with Arcesilas, will be connected with the history of its great ornament, Cicero. Some account of the later Platonists will be presented to our readers in the life of Plotinus, who wasted a genius of the highest order in idle reveries, and whose writings, clouded as they are with mysticism and the spirit of ascetical illusion, occasionally glow with the fervour of the richest imagination, and with an exuberance of philosophic imagery. Indeed, without a powerful genius, he could never have affected that wonderful change in the Platonic school which he did effect, though to us it appears a Modern lamentable corruption. From this time, Plato has seldom been studied except with the aid of the commentaries, or in conjunction with the treatises of this later school; and at the revival of learning, the learned Florentine, Ficino, who procured the printing of Plato, performed the same service for the illustrious leaders of the later school, and illustrated his edition of Plato with many commentaries, in which he showed himself at least an equal adept in the mysteries of Plotinus and Porphyry, as in the sense of Plato. Cardinal Bessario was a Platonist of more discrimination, and one whose intercourse with the world had perhaps given him more tact and address in selecting the practical works of Plato, and in illustrating those of a more obscure cast, than the learned but recluse Florentine. Bessario's work, in reply to George of Trebizond, "the calumniator of Plato," is a very masterly performance, but its celebrity has not continued equal to its merit. Bessario has there fully developed many of those arguments which have been used of late years by the admirers of Plato, particularly 
among the German controvertists. Serranus has conferred great obligations by his excellent edition of Plato; and as the paging of that edition has been universally adopted by scholars for reference, it has been very judiciously continued in the margin of the Bipont edition, and of the edition published by Mr. Bekker. The abstract of Plato's 'Dialogues,' by Mr. Tiedemann, annexed to the Bipont edition, is executed with considerable ability; but the author is somewhat too fond of deviating into mystical disquisitions, and has rendered the work less intelligible and less generally useful than it otherwise would have been, by a constant reference to the philosophy which then prevailed in Germany.

In Germany, indeed, Plato has uniformly been the favourite of the ablest philosophers; and whether the mystic Reuchlin, or Leibnitz, ${ }^{1}$ or Kant, brought their own theories to light, they all equally acknowledged Plato to be the great object of their admiration among ancient

English translations of Plato. writers. In Britain, the professed translators of Plato have been Sydenham, Spens, and Taylor. Of Sydenham's translation, every scholar will speak with respect, and every man of taste with regard and fondness. Its imperfect and unfinished condition bears with it a deep interest as a memorial of Sydenham's melancholy fate; when a man of the highest talents, and the most elegant accomplishments, after struggling with the inequalities of fortune, and suffering mortifications not the less galling because concealed and uncommunicated, gave way to the sudden impulse of his indignant spirit, and quitted a world which he disdained to flatter. Spens' work bears marks of being a version from the French, and not from the original. It is impossible to speak otherwise than with respect of Mr. Taylor, as a self-taught scholar, and a student of unwearied industry; but his translation of Plato is in every higher quality a lamentable contrast to the work of his predecessor Sydenham. It is written without spirit, without taste, without, as it should seem, even a suspicion of the lighter shades of language, and it is disfigured throughout with the unintelligible jargon of the Alexandrian school.

His admirers Among the British admirers of Plato, besides the cabalists Gale in Britain. and More, and the indefatigable and eloquent pupil of the Alexandrian school, Cudworth, we may mention several of our ablest philosophers and poets. Bacon never speaks of the political or moral works of Plato without marked respect. Berkeley's enthusiastic admiration is well known, and his dialogues are, perhaps, the only productions in the lan-

1 The testimony of Leibnitz is very explicit. In one letter to Bierling, after making some remarks on Cicero's 'Dialogues,' he continues thus :- "Platonis dialogi paulo minus accommodati sunt ad ingenium nostri sæculi. Mihi tamen vix quicquam in illis spernitur; adeo multa agnosco consideratione profundiore digna." And in another letter, in reply to some vague remarks made by the same correspondent, he observes, "De Platone non sentio tam contemtim. Meditationes ejus mihi et profundæ passim et utiles videntur. Et habeo Ciceronem non malum judicem mecum sentientem. Non ita pridem didicimus plus Platonem in recessu. habere quam vulgo apparet."-Leibnitii Epistol. in opp. vol. v. p. 368. 
guage which can give to a mere English reader a sense of the art, the dignity, and the gracefulness of his Athenian model. Lord Shaftesbury's essays on the contrary, though written more with the air of a professed imitation, have about them an inflation and a stilted grandeur, which never deforms the serious works of Plato. The minds, both of Milton and Gray, were thoroughly imbued with the spirit of Plato's writings. The whole of the 'Comus,' and particularly the beautiful eulogy upon Philosophy, the solemn introduction of the unsphering Plato's spirit in the 'Penseroso,' and the express praise of the remnants of the Socratic school in the 'Tractate on Education,' and 'The Answer to Smectymnus,' show at once how fully Milton's mind had been stored with the sublimer parts of Plato's philosophy, and how great his admiration was of the plainer and more practical parts. His larger poems breathe everywhere, as it were, inadvertently, intimations of the deep fountains of ancient wisdom, in which his genius had delighted to refresh and invigorate itself; and every casual turn displays glances of the sky robes of the Athenian sage, and drops rich distillations of the choicest dew from Hymettus. The poems of Gray, in like manner, bear a strong tincture from their author's studies; and the intelligent, to whom they are addressed, ${ }^{1}$ would need no further evidence than the colour of the language, and imagery with which they abound, to satisfy them that Plato was Gray's favourite author. This point, however, has been put out of all question by the publication of his posthumous works before referred to; which show, not only his earnest study of Plato's own writings, but his minute and laborious research into other writers of antiquity, to procure illustration even of the most petty particulars of dates or characters anywise connected with them.

But we perceive that we are dwelling too long upon details, which at best can be considered but as an appendage to a sketch of Plato's life. The neglect, however, with which Plato's writings are in the present day indiscriminately treated, even among persons of general learning and intelligence, must be our excuse for resting on the names of any who have entertained a different opinion of his writings, although they were not themselves deficient in genius, or accustomed to any servile admiration of antiquity. But upon this head, of the disregard shown to Plato in our public schools and universities, upon which it might seem impertinent or presumptuous for us to enlarge further, we willingly shelter ourselves under the authority of Berkeley, and close our sketch with recommending the perusal of Plato's writings, in the words of that learned and virtuous dignitary:-

"It might very well be thought serious trifling to tell my readers, that the greatest men had ever an high esteem for Plato; whose writings are the touchstone of a hasty and shallow mind; whose philosophy has been the admiration of ages; which supplied patriots, magistrates, and lawgivers to the most flourishing states, as well as fathers to the church, and doctors to the schools. Albeit, in these days, the depths 
of that old learning are rarely fathomed, and yet it were happy for these lands, if our young nobility and gentry, instead of modern maxims, would imbibe the notions of the great men of antiquity. But in these freethinking times, many an empty head is shook at Aristotle and Plato, as well as at the Holy Scriptures. And the writings of those celebrated ancients are by most men treated on a foot with the dry and barbarous lucubrations of the schoolmen. It may be modestly presumed there are not many among us, even of those who are called the better sort, who have more sense, virtue, and love of their country than Cicero, who, in a letter to Atticus, could not forbear exclaiming, 'O Socrates et Socratici viri! Nunquam vobis gratiam referam.' Would to God many of our countrymen had the same obligations to those Socratic writers." - 'Siris,' in Berkeley's Works, vol. ii. p. 613. 


\section{ARISTOTLE.}

BY

The Rev. J. W. BLAKEsley, M.A., VICAR OF WARE,

LATE FELLOW AND TUTOR OF TRINITY COLLEGE, CAMBRIDGE.

REPRINTED FROM THE ORIGINAL EDITION. 



\section{A RISTOTLE.}

FROM B. C. 384 TO B. C. 323.

Is the account which we are about to give of the founder of the Peripatetic school, we shall confine ourselves strictly to the province of the biographer. ${ }^{1} \quad$ We shall enter more into detail respecting the documents which exist for our purpose than has been done in the lives of Plato and Socrates, and in the sketch of the earlier philosophers of Greece, because an acquaintance with this subject is absolutely necessary for estimating the value of any information relative to the lives of these remarkable men, and the existing sources of all our possible knowledge in any one case, are very nearly the same as those for every other.

If the acquaintance we possessed with the private life of individuals were at all proportioned to the influence exerted by them on the destinies of mankind, the biography of Aristotle would fill a library; for without attempting here to discuss the merits of his philosophy as compared with that of others, it may safely be asserted that no man ever yet lived who exerted so much influence upon the world. Absorbing into his capacious mind the whole existing philosophy of his age, he reproduced it, digested and transmuted, in a form of which the main outlines are recognised at the present day, and of which the language has penetrated into the inmost recesses of our daily life. Translated in the fifth century of the Christian era into the Syriac language by the Nestorians who fled to Persia, and from Syriac into Arabic four hundred years later, his writings furnished the Mohammedan conquerors of the East with a germ of science which, but for the effect of their religious and political institutions, might have shot up into as tall a tree as it did produce in the West; while his logical works in the Latin translation which Boethius, "the last of the Romans," bequeathed as a legacy to posterity, formed the basis of that extraordinary phenomenon, the philosophy of the schoolmen. An empire like this, extending over nearly twenty centuries of time, sometimes more, sometimes less, despotically, but always with great force, recognised in Bagdat and in Cordova, in Egypt and in Britain, and leaving abundant traces of itself in the language and modes of thought of every European nation, is assuredly without a parallel. Yet of its founder's personal history all that we can learn is to be gathered from meagre compilations, scattered anecdotes, and accidental

1 For an analysis of Aristotle's philosophical doctrines, see the volume of this Encyclopedia on 'Moral and Metaphysical Philosophy.' 
notices, which contain much that is obviously false and even contradictory, and from which a systematic account, in which tolerable

Early histories of Aristotle and other philosophers.
Indirect information in ancient writers on the subject. confidence may be placed, can only be deduced by a careful and critical investigation. It is not, however, to the indifference of his contemporaries, or to that of their immediate successors, that the paucity of details relating to Aristotle's life is due. Ptolemy Philadelphus, the second of the Macedonian dynasty in Egypt, not only bestowed a great deal of study upon the writings of the great philosopher, but also is said to have written a biography of him. ${ }^{1}$ About the same time Hermippus of Smyrna, one of the Alexandrine school of learned men, whose research and accuracy are highly praised by Josephus, composed a work extending to considerable length, 'On the Lives of Distinguished Philosophers and Orators,' in which Aristotle appears to have occupied a considerable space. ${ }^{3}$ Another author, whose date there is no direct means of ascertaining, but who probably is to be placed somewhere about the end of the third century before the Christian era, ${ }^{4}$ Timotheus of Athens, is also to be added to the number of his early biographers. But independently of such works as these, antiquity abounded in others which contained information on this subject in a less direct form. Aristoxenus of Tarentum, who, during a part of his life, was himself a pupil of Aristotle, in his biographies of Socrates and Plato had frequent occasion to speak of the great Stagirite. Epicurus, in a treatise which is cited under the title of 'A Letter on the Pursuits and Habits of former Philosophers,' related several stories to his disparagement. ${ }^{5}$ The same, perhaps, was the case with Aristippus (apparently the grandson of the founder of the Cyrenean school) in his work 'On the Luxury of Antiquity.' And yet more valuable materials than were furnished by the two lastmentioned works, of which at least the former appears to have been composed in the vulgar spirit that delights in finding something to degrade to its own level all that is above it, ${ }^{7}$ probably were contained in the treatises of Demetrius the Magnesian, and Apollodorus the Athenian. The first of these was a contemporary of Cicero and his

1 David the Armenian, in a commentary on the Categories, cited by Brandis, in the Rheinisches Museum, vol. i. p. 250, and since published from two Vatican

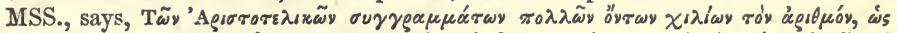

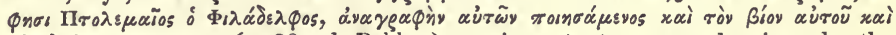

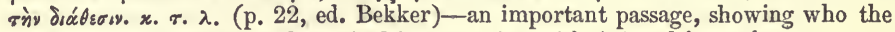
Ptolemy was that is elsewhere cited in connexion with Aristotle's works.

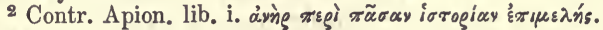

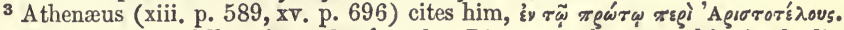

4 This seems to follow from the fact that Diogenes only quotes him in the lives of Plato, Speusippus, Aristotle, and Zeno of Cittium. He is, therefore, no authority for anything later than the time of the last. Zeno was an old man B.C. 260 (Diog. Laert. vii. 6). Timotheus's work is quoted under the title IIsgi Bíwy.

5 Ap. Athen. Deipnosoph. p. 354.

- Diog. Laert. ii. 23, v. 3.

7 See the stories which he related in it of Protagoras, also mentioned by Athenæus, loc. cit. 
celebrated friend Atticus, ${ }^{1}$ and appears to have exercised his acumen in detecting such erroneous stories prevalent in his time as arose from the confusion of different poets and philosophers who had borne the same name $;^{2}$ a cause which with us would hardly be adequate to produce any great effect, but formerly, in the absence of hereditary surnames, and under the operation of many motives for falsification, was much more fertile in its results than can now be easily imagined. ${ }^{3}$ The second is an authority, who, for the purposes of the modern biographer of Aristotle, is the most important of all. He, like Hermippus, was an Alexandrine scholar, and pupil of the celebrated editor and commentator of the Homeric poems, Aristarchus." Among his voluminous works was one 'On the Sects of Philosophers,' which no doubt contained much that was interesting on our subject; but what renders him valuable above any other of these lost writers, and makes us treasure up with avidity the slightest notices by him which have come down to us, is his celebrated 'Chronology', a composition in

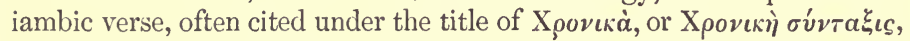
by that compiler whose treatise is unfortunately the most ancient systematic account of Aristotle's life which has escaped the ravages of time. These citations are invaluable, not merely for the positive information which we gain from them, but because they serve also, as we shall have occasion to observe in the sequel, for a touchstone of anecdotes whose authority is otherwise uncertain. ${ }^{5}$

The foregoing list of authors, which might be yet further enlarged Gradual did we not fear to exceed the due limits of this occasion, abundantly of the shows that in the beginning of the first century before Christ there literature on were materials for compiling a biography of Aristotle as detailed as jects. one of Newton or Young could be in the present day. This, however, soon afterwards ceased to be the case. When the only means of obtaining the copy of a book was by the laborious process of transcription, the expense necessarily confined its acquisition to comparatively few persons, and when to this drawback we add those arising from voluminous size and but partially interesting subject, the circulation would be very limited indeed. It may be questioned, perhaps, whether some of the works we have noticed ever found their way beyond the walls of the royal library at Alexandria, except in the shape of extracts. If this were the case, the destruction of the whole or a great part of that library ${ }^{6}$ in the siege of the city by Julius

${ }^{1}$ Cicero, Brut. 91 . He is alluded to in Epp. ad Attic. iv. 11; but in viii. 11, ix. 9, xii. 6, it is Demetrius the Syrian, a rhetorician, who is referred to. This latter is also spoken of in Brut. 91.

2 Diog. Laert. v. 3.

3 See Galen, Comment. in Hippocr. de Nat. Hom. ii. pp. 105, 109, and in Hippocr. de Humor. i. p. 5, ed. Kuehn.

4 Suidas, sub v. 'A $\pi 0 \lambda \lambda \circ \delta$ w

5 See, with reference to Apollodorus and his works, Voss, De Historicis Græcis, p. 132, et seq.; Heyne, ad Apollodori Bibliothec. vol. i. pp. 385, 457; and Brandis in the Rheinisches Museum, vol. iii. p. 110; in whose opinion the chronology of Apollodorus is founded on that of Eratosthenes.

6 Aulus Gellius, Noctes Atticæ, vi. 17.

[G.R.P.] 
Cæsar (в.c. 48), would very probably cause their annihilation. At all events, in the subsequent times, when Rome was the centre of civilization as well as of empire, works of such a description became

Literature fashionable in Rome. totally unfit to satisfy the wants of the age. A certain acquaintance with Greek literature, Greek philosophy, and Greek history, became an essential accomplishment for the fashionable Roman; but this acquaintance was nothing like the one which Cato and Scipio, which Atticus and Cicero possessed. It was expected to be extremely comprehensive, ${ }^{1}$ and, as all comprehensive knowledge must be when popularized, it was proportionally superficial. To feed this appetite for general information was the work of the needy men of letters under the empire. In the time of the early Ptolemies and of the kings of Pergamus their energies had been directed by the munificence of those monarchs to the accumulation of vast stores of erudition on particular subjects. 'The number of monographies, and the minute subdivision of intellectual labour which prevailed under their patronage, is scarcely equalled by the somewhat similar case of Germany at the present day. Homer, a sacred book for the Greeks, was the principal subject of their labours; but indeed there was no classical author and no literary or scientific question which did not employ the abilities of a crowd of antiquarians or commentators. The prodigious stores thus accumulated ${ }^{2}$ formed the stock from which the littérateurs of Rome

1 See Juvenal, Satir. vii. 229 - 236, of the masters of his time:-

Vos sævas imponite leges,

Ut præceptori verborum regula constet,

Ut legat historias, auctores noverit omnes

Tanquam ungues digitosque suos; ut forte rogatus

Dum petit aut thermas aut Phœbi balnea, dicat

Nutricem Anchisæ, nomen patriamque novercæ

Anchemori; dicat, quot Acestes vixerit annos,

Quot Siculus Phrygibus vini donaverit urnas.

Make it a point that all, and every part

Of their own science be possessed by heart;

That general history with our own they blend,

And have all authors at their fingers' end:

That they may straight inform you, should you meet,

And ask them at the bath, or in the street,

Who nurs'd Anchises? from what country came

Archim'rus' stepmother, and what her name?

How long Acestes flourished? and, in short,

With how much wine Eneas left his court?

Gifford's Version, p. 264.

2 The number of volumes at Alexandria, in the time of Callimachus (about 259 B. C.) amounted to 532,000 , or, according to the explanation of Ritschl (Die Alexandrinischen Bibliotheken, p. 28), 432,000. At the time of the destruction of the great part by fire they had reached 700,000. The difference was caused, in a great measure, by the accumulation of commentatorial or antiquarian works. Thus Aristarchus is said to have written more than 800 volumes of commentaries alone. (Suidas, sub v.) Some are said to have spent their whole lives on the elucidation of single questions relative to Homer. (See Wolf, Prolegomena in Homerum, sec. 45, 51.) Under Ptolemy Philadelphus an immense number of original works 
derived materials for the new species of intellectual repast demanded by the taste of their times. In the first generation of compilations Compilawhich were composed for this purpose, the writers of course made tions. use of the existing sources of information, and fortified their statements by citations of their authority in each particular instance. But as the real love for literature declined before the debilitating influence of luxury, while at the same time the fashion of literary accomplishments remained, it became necessary that information should be furnished in a more generally palatable form. Hence, out of the first crop of compilations, a new generation of writers composed a sort of Omniana, Miscellanies.

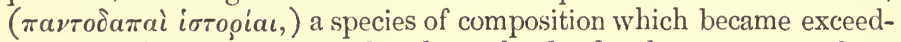
ingly popular as it combined a loose kind of information on those points of which everybody was expected to possess some knowledge, with the piquancy of memoirs, and the variety of subject which is so pleasant to a frivolous and indolent reader. It very soon overlaid and destroyed the learned labours of the preceding age; and from the time at which it began to prevail, it becomes very questionable whether a writer, when he quotes an authority of a date earlier than the empire, ever has cast eyes upon him, or even wishes his readers to believe that he has done so. One of the earliest as well as most original works of this description was the production of a female hand. Pamphila, a lady of Egyptian extraction, in the time of Nero, had Pamphila. married at a very early age a person of considerable literary tastes and attainments, whose house was the resort of many persons distinguished for the same, either for the purposes of education or of social intercourse. During thirteen years she states that she was never separated from her husband's side for an hour, and that it was her habit to take notes of anything which she might learn either from him or from any of his literary circle, which appeared worth recording. Out of these materials, together with extracts made by herself from authors which she had read, she composed eight books of miscellaneous historical memoirs ( $\sigma \dot{v} \mu \mu \iota \kappa \tau a ~ i \sigma \tau о \rho \iota \dot{c} \dot{v} \pi о \mu \nu \dot{\eta} \mu \alpha \tau \alpha$ ), purposely abstaining from anything like an arrangement according to subjects, that her readers might enjoy the pleasure arising from the variety. 'This work Photius, from whom we have taken this notice of it, describes as being "a most useful one for the acquirement of general information."1

Phavorinus, a native of Arles, who flourished in the reign of the Phavorinus.

were collected, and the arrangement, description, and illustration of these became the principal business of men of letters under his successors. Under Ptolemy the accumulation was so rapid that there was no time for this. Galen relates that when any merchant-vessels put into the harbours of Egypt, all manuscripts which happened to be on board were taken to the royal library, and transcripts of them sent back to the owners. In default of time to examine what the originals were,

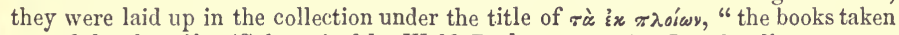
out of the ships." (Galen, cited by Wolf, Proleg. sec. 42.) It is hardly necessary to remark that the word "volume," in reference to this time, applies to the papyrus rolls, of which none perhaps contained more than a couple of closely printed octavo sheets, while some were rery much less.

1 Photius, Biblioth. p. 119, ed. Bekker. 
emperor Hadrian, was the compiler of another work of the same description, but not composed under such interesting circumstances.

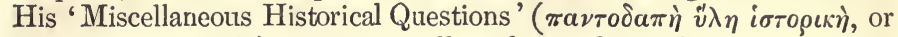

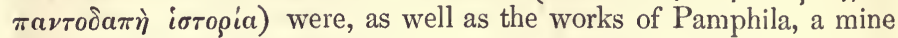
much worked by subsequent writers. But the degenerate taste which had caused the production of such works as these, or at least as the latter, did not stop here. Still declining, it called for yet more meagre and worthless compilations, which were furnished by drawing from the confused and turbid 'Miscellanies' those parts which referred to any particular subject on which the writer thought proper to make

Later com. pilations.

Criterion of the relative value of the later writers. collections. To this stage belongs the work of Diogenes Laertius, a part of which forms the nucleus of all modern biographies of Aristotle, as well as of Plato and most of the early Greek philosophers; and to a yet later period, after the processes which we have been describing had been again and again repeated, the lives by the pseudo-Ammonius and his anonymous Latin translator and interpolator.

If we were to estimate the relative importance of these later authorities by the quantity of critical discernment or sound erudition which they display, there would be little to choose between the contemporary of Severus and his followers of some centuries later. But Diogenes, although devoid of all historical or philosophical discrimination, although sometimes contradicting himself within the limits of a single biography, and confusing the tenets of Peripatetics and Epicureans without the least consciousness of his own indistinct views, ${ }^{1}$ is distinguished by the circumstance that in his narrative the names of the earliest authorities still appear, while from the rest they have in most cases dropped out. With the use, therefore, of due caution and diligence, we are frequently enabled to arrive at the views entertained on a given point by individuals of four centuries earlier date, who possessed both the wish and the means to ascertain truth where the later writers were deficient in both. This is particularly the case with certain classes of facts. Anecdotes illustrative of individual character or habits of life readily spring up and have a rapid growth, if the smallest nucleus of truth exist as a foundation for them. But dry and uninteresting statements, such as the date of an insulated event, will very rarely be falsified except by accidents attending transcription, or unless their determination is distinctly felt to affect the decision of some more obviously important question. When, therefore, such statements, coupled with the name of an early authority, have been preserved, there is a fair presumption that we have firm standing ground; and other notices of uncertain origin will possess a greater or less claim to our consideration as they appear more or less adapted to make parts of that body of which, as it were, a few fossil bones have been preserved. These we shall first present collectively to the view of our readers, and then proceed step by step in the process of redintegration.

'See Casaubon's Note on Diog. Laert. v. 29. 
On the authority, then, of Apollodorus, ${ }^{1}$ we may fix the birth of Summary of Aristotle in the first year of the ninety-ninth Olvmpiad (в.с. 384-3), Aristotle's and his arrival at Athens as a scholar of Plato when seventeen years authority of old. After remaining there twenty years he visited the court of Apollodorus. Hermias (a prince of Asia Minor, of whom we shall say more in the sequel), in the year after his master's death, Theophilus being then archon (i.e., B.c. 348-7), and stayed there for three years. In the archonship of Eubulus, the fourth year of the hundred and eighth Olympiad (в.с. 345-4), he passed over to Mytilene. In that of Pythodotus, the second year of the hundred and ninth (в.c. 343-2), he commenced the education of Alexander the Great at his father's court; and in the second year of the hundred and eleventh, returned to Athens and taught philosophy in the school of the Lyceum for the space of thirteen years; at the expiration of which time he crossed over to Chalcis in Eubœa, and there died from a disease in the archonship of Philocles, the third year of the hundred and fourteenth Olympiad (B.c. 322-1), at the age of about sixty-three, and at the same time that Demosthenes ended his life in Calauria.

Stagirus (or, as it was later called, Stagira), the birthplace of one Birthplace of of the most extraordinary men, if not the very most, that the world Aristotle. has ever produced, was a petty town in the north of Greece, situated Its situation. on the western side of the Strymonic gulf, just where the general line of coast takes a southerly direction. It lay in the midst of a picturesque country, both in soil and appearance resembling the southern part of the Bay of Naples. Immediately south a promontory, like the Punta della Campanella, and nearly in the same latitude, ran out in an easterly direction, effectually screening the town and its little harbour Capros, formed by the island of the same name, from the violence of the squalls coming up the Egean, a similar service to that rendered by the Italian headland to the town of Sorrento. In the terraced windings, too, by which the visitor climbs through the orange groves of the latter place, he may, without any great violence, imagine the "narrow and steep paths" by which an ancient historian and chorographer describes those who crossed the mountains out of Macedonia as descending " into the valley of Arethusa, where was seen the tomb of Euripides and the town of Stagira." 2 The inhabitants pos- Civilization. sessed all the advantages of civilization which Grecian blood and Grecian intercourse could give; the city having been originally built by a colony of Andrians, and its population subsequently replenished by one from Chalcis in Eubœa. ${ }^{3}$ The mouth of the Strymon and the

1 Ap. Diog. Laert, Vit. Arist. sec. 9. Compare Dionysius of Halicarnassus, Epist. i. ad Ammæum, pp. 727, 728, whose account agrees with that of Diogenes, and is itself probably based on the chronology of Apollodorus. See Clinton's Fasti Hellenici, 2, 320 B. c. col. 3.

2 Ammianus Marcellinus, xxvii. 4. The similarity in the name of the island Capri, which lies off sorrento, is curious, and seems to favour the account of Frontinus, that Surrentum was originally colonized by Greeks.

3 Thucyd. ir. 88; Dionys. Halic. Ep. i. ad Amm. p. 727. 
important city of Amphipolis was within three hours' sail to the

Fate. north; and every part of the Chalcidic peninsula, a district full of Greek towns, ${ }^{1}$ among which were Olynthus and Potidæa, was readily accessible. With the former of these Stagirus appears to have been leagued as a humble ally ${ }^{2}$ in that resistance to the ambitious designs of Philip which terminated so calamitously. In the year 348 B.c. it was destroyed by him, ${ }^{3}$ and the inhabitants sold as slaves.

Aristotle's childhood.

Aristotle, however, did not share the misfortunes of his native town, to which it is probable he had been for many years a stranger. His father, Nicomachus, one of the family or guild of the Asclepiads, in which the practice of medicine was hereditary, had taken up his residence at the court of Philip's father, Amyntas, to whom he was body surgeon, and whose confidence he appears to have possessed in a high degree. ${ }^{4}$ He did not confine himself to the empirical practice of his art, for he is related to have written six books on medical and one on physical "subjects, ${ }^{5}$ which latter head would in that age include every department of natural history and physiology, no less than those investigations of the properties of inorganic matter to which the term is appropriated in the present day. Now this circumstance is much more important in its bearing upon the intellectual character of Early 'educa- Aristotle than may at first appear. In his writings appears such a
tion. fondness for these pursuits as it seems impossible not to believe must have been imbibed in his very earliest years, and most probably under the immediate superintendence of this parent. For although he was an orphan at the age of seventeen (and how much earlier we cannot say), yet it is well knawn that education in the "art and maistery of healing," and such subjects as were connected therewith, was commenced by the Asclepiads at a very early age. "I do not blame the ancients," says Galen, " for not writing books on anatomical maniptlation; though I commend Marinus, who did: for it was superfluous for them to compose such records for themselves or others, while they were from their childhood exercised by their parents in dissecting just as familiarly as in writing and reading; so that there was no more fear of their forgetting their anatomy than of their forgetting their alphabet. But when grown men as well as children were taught, this thorough discipline fell off; and the art being carried out of the family of the Asclepiads, and declining by repeated transmission, books be-

1 Demosthenes (Philipp. iii. p. 117) says that Philip destroyed thirty-two there. Some of these were doubtless mere hamlets.

2 Dio Chrysost. Or. ii. p. 36.

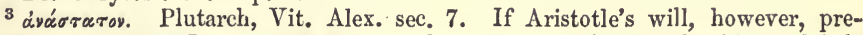
served by Diogenes Laertius, be genuine, this term must be considerably qualified; for in it he speaks of his $\pi \alpha \tau \rho \omega_{\alpha}^{\prime}$ oixia in Stagirus. One naturally expects the description of Demosthenes (loc. cit.) to be overcharged.

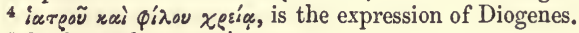

5 Suidas, sub v. Nixópaxos.

- Cited and translated by Whewell, History of the Inductive Sciences, vol. iii. p. 385. See also Plutarch, Vit. Alex. sec. 8. 
came necessary for the student." And we have another, although slighter, presumptive evidence that the childhood of the great philosopher was spent with his father at the Macedonian court, in the circumstance of his being selected by Philip, at a period long subsequent, to conduct the education of Alexander. This we shall find an opportunity of reverting to in the sequel. Whatever influence, however, was exercised by Nicomachus over the future fortunes of his son, he had not the happiness of living to be a witness of its effects. $\mathrm{He}$, as well as his wife Phæstis, a descendant of one of the Chalcidian colonists of Stagirus, died while Aristotle was yet a minor, leaving him under the guardianship of Proxenus, a citizen of Atarneus in Asia, who appears to have been settled in the native town of his ward. How long this person continued in the discharge of his trust we have no means of determining; it was sufficiently long, however, to imbue the object of it with a respect and gratitude which endured throughout life. At the age of seventeen, however, it terminated; and Aristotle, master of himself and probably of a considerable fortune, came to Comes to Athens, the centre of the civilization of the world, and the focus of Athens. everything that was brilliant in action or in thought. It is not probable that anything but the thirst for knowledge which distinguished his residence there was the cause of its commencement. Plato was at that time in the height of his reputation, and the desire to see and enjoy the intercourse of such a man would have been an adequate motive to minds of much less capacity and taste for philosophy than Aristotle's to resort to a spot, where, besides, every enjoyment which even an Epicurean could desire was to be found. ${ }^{1}$ It was reserved for Absurd the foolish ingenuity of later times, when all real knowledge of this accounts of period had faded away, to invent the absurd motive of "a Delphic oracle, which commanded him to devote himself to philosophy." 2 For another account, scarcely less absurd, the excuse of ignorance cannot be so easily made. Epicurus, in the work we have before spoken of, Calumny of related that Aristotle, after squandering his paternal property, adopted the profession of a mercenary soldier, and, failing in this, afterwards that of a vender of medicines; that he then took advantage of the free manner in which Plato's instructions were given to pick up a knowledge of philosophy, for which he was not without talent, and thus gradually arrived at his views. ${ }^{3}$ It is at once manifest that this story Refuted. is incompatible with the account of Apollodorus, according to which Aristotle attached himself to the study of philosophy under Plato before he had completed his eighteenth year. Independently of the difficulty of conceiving that a mere boy should have already passed through so many vicissitudes of fortune, it is obvious that he could

${ }^{1}$ See Xenophon, Rep. Ath. cap. ii. sec. 7, 8.

2 Pseudo-Ammonius, Vit. Arist.

3 Athenæus, Deipnosoph. viii. p. 354 ; Elian, Var. Hist. v. 9. That these two accounts are derived from the same source appears no less from their similarity of phrase than from the remark of Athenæus, " that Epicurus was the only authority for this story against Aristotle." 
not before that time have squandered his property, except through the culpable negligence of his guardian, Proxenus ; and any supposition of this sort is precluded by the singular respect testified for that individual in his ward's will, the substance of which-or perhaps a codicil

Aristotle's affection for his guardian. to it-has been preserved to us by Diogenes Laertius. ${ }^{1}$ In it he directs the erection of a statue of Proxenus and of his wife, he appoints their son Nicanor (whom he had previously adopted) to be joint guardian, with Antipater, of his own son Nicomachus, and also bestows his daughter upon him in marriage. It is impossible to conceive that such feelings could have been aroused in the ward by a negligent or indiscreetly-indulgent guardian; and we should hardly have reverted to the story in question, except to remark how the very form of the calumny seems to indicate that the favourite studies of Aristotle, in the early part of his life, were such as his father's profession would naturally have led him to, Physiology and Natural History. ${ }^{2}$ Indeed, nothing is more probable than that he might have given advice to the sick; science and practical skill being in those times so inseparably connected, that the Greek language possesses no terms which formally distinguish them-and from this circumstance the report may have arisen, that he attempted medicine as a profession.

Other discordant accounts.

There are some other accounts equally discrepant with the chronology of Apollodorus, which we have taken as our standard. One of these is, that Aristotle did not attach himself to Plato until he was thirty years of age: another, that on his first arrival at Athens he was for three years the pupil of Socrates. ${ }^{3}$ 'The first of these, which rests on the sole authority of one Eumelus, ${ }^{4}$ a writer of whom nothing more whatever is known, may perhaps be a feature of the story of Epicurus which we have just discussed: it has been conjectured, however, with great appearance of probability, that its sole foundation is the well-known maxim of Plato, that the study of the ligher philosophy should not be commenced before the thirtieth year. The second, as it stands, is absolutely unintelligible, Socrates having been

1 Vit. Arist. sec. 11-16. The genuineness of this document is confirmed by the notice which Athenæus (xiii. p. 589) gives from Hermippus, relative to the provision for Herpyllis, which quite agrees with what we find in it. Compare, too, the author of the Latin Life (ad fin.), from whom it appears that Ptolemy and Andronicus had each of them inserted a testament of Aristotle in their works.

2 Athenæus tells the story, after mentioning several tenets of Aristotle on matters of natural history, in reference to which he calls him "the medicine-vendor"

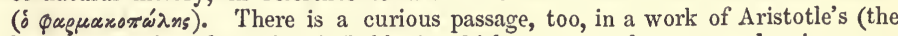
Politics, p. 1258, line 12, ed. Bekker), which seems to have some bearing upon this matter. It may almost be taken as an explanation of his conduct, if it was such as we have supposed. Timæus of Tauromenium related, that at a late period

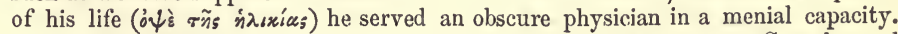
(Aristocles, ap Euseb. xv. 2.) For the character of Timæus, see Casaubon ad Diog. Laert. x. 8.

8 Pseudo-Ammonius.-Vita Latina.

4 Ap. Diog. Laert. Vit. Arist. sec. 6. All other accounts are unanimous in representing him as becoming Plato's disciple while very young. 
put to death in the archonship of Laches (B.c. 400-399), that is, fifteen years before the birth of Aristotle. But it has been ingeniously remarked, ${ }^{1}$ that at the time when Aristotle first came to Athens, Plato was absent in Sicily, from whence he did not return till Olymp. ciii. 4 , the third year afterwards $;^{2}$ so that if Aristotle was then introduced to the philosophy of the Academy, it must have been under the auspices of some other of the Socratic school, whom the foolish compilers of later times mistook for its founder. Under this natural explanation, the absurd story becomes a confirmation of the account of Apollodorus, which we have followed-a coincidence the more satisfactory as it is quite undesigned.

We shall now proceed, as well as the scanty information which has Aristotle at come down to us will allow, to sketch the course of Aristotle's life Athens, B. c. during the ensuing period of nearly twenty years which he spent at Athens. It appears to have been mainly, although not entirely, occupied in the acquisition of his almost encyclopædic knowledge, in collecting, criticising, and digesting. Of his extraordinary diligence His industry. in mastering the doctrines of the earlier schools of philosophy we may form some notion from the notices of them which are preserved in his works, which indeed constitute the principal source of our whole knowledge upon this subject. That this information should have been acquired by him during this part of his life is rendered likely both by the nature of the case and by the scattered anecdotes which relate that his remarkable industry and intelligence elicited the strongest expressions of admiration from Plato, who is said by PseudoAmmonius to have called Aristotle's house " the house of the reader." The Latin translator adds, that in his absence his master would exclaim, " that the intelligence of the school was away, and his audience but a deaf one!"3 A treatise on Rhetoric, not that which works of has come down to us, but one which, as we shall have occasion to this time. show in the sequel, was probably written during this period of his life, is described by Cicero as containing an account of the theories of all his predecessors upon this subject, from the time of Tisias, the first who wrote upon it,- - so admirably and perspicuously set forth, that all persons in his time who wished to gain a knowledge of them, preferred Aristotle's description to their own. We may take occasion

1 Stahr, Aristotelia, i. p. 43.

2 Corsini (De die n. Platonis) cited by Ast. Platons Leben und Schriften, p. 30. Heraclides of Pontus presided in the school of Plato during his absence. But Xenocrates, who is known to have been an intimate associate of Aristotle in after life, may possibly have been the means of drawing his attention to intellectual philosophy; the social intercourse in which this might be effected would to later ages appear in the light of formal instruction, and, when this was the case, the name Xenocrates would readily, by the carelessness or meddling criticism of a transcriber, be altered into Socrates.

$\mathbf{3}$ "Intellectus ab est; surdum est auditorium." This story is probably only an expansion of a saying of Plato's, recorded by Philoponus (De Eternitate, Mundi, vi.

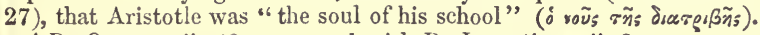

${ }^{4}$ De Oratore, ii. 38, compared with De Inventione, ii. 2. 
to remark by the way that this taste for reading could not have been gratified without very ample means. A collection of books was a luxury which lay within the reach of as small a portion of the readers of that day, as a gallery of pictures would of the amateurs of this. ${ }^{1}$ This circumstance, then, is calculated to throw additional discredit on the story told by Epicurus of Aristotle's youth. A bankrupt apothecary could never have been a book collector. Another work of Aristotle's, which is unfortunately lost, was compiled during this same

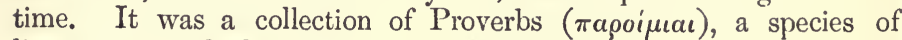
literature to which he, like most other men of reflection, attached great value. Two other most important works, both of which are likewise lost, we may, from what we know of their nature, probably refer to the same period, at least as far as their plan and commencement are concerned. The first of these was a work on the fundamental principles on which the codes of law in the States of his time were severally based. ${ }^{2}$ The second was an account of no less than one

1 The facilities for obtaining the copy of a book were very much increased after the extensive manufacture of papyrus at Alexandria under the Ptolemies, and when transcription had become a profitable and widely-practised profession. Yet we find Polybius (iii. 32) at some pains to take off the objection to his work arising from its costliness. But in the time of Aristotle's youth, the expense must have been far greater. He, probably in the latter part of his life, possessed a very large library (Athenæi. Epitom. p. iii.), which he left to his successor, Theophrastus. (Strabo, xiii. p. 608.) The philosophers after him appear likewise to have made collections. We know this for certain of Theophrastus, Strato, and Lycon (Diog. Laert. v. sec. 52, 62, 73); and such were probably used under greater or less restrictions by their respective scholars. But nothing of this sort is related of the earlier philosophers, whose systems indeed did not require (at least to anything like the extent of Aristotle's) any previous historical investigation. And Plato, if he really did purchase the work of Philolaus, as he was said by Satyrus, and Timon the Sillographer (Aulus Gellius, iii. 17.; Diog. Laert. iii. 9, viii. 15, 85), to have done, and to have reproduced the philosophy of it in his Timæus, certainly had no intention of communicating it to his scholars. Hence, it appears unlikely that Aristotle could have obtained the use of the greater part of the works which the plan of his studies required by other means than purchase.

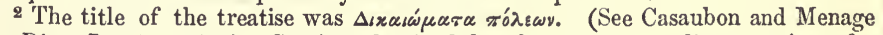
on Diog. Laert. v. 26.) Grotius, deceived by the corrupt reading, $\pi 0 \lambda_{\varepsilon}^{\prime} \mu \omega \nu$ for

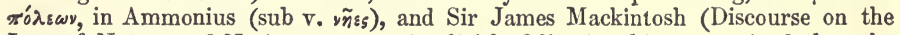
Law of Nature and Nations, p. 16), implicitly following him, conceived that the work was "a treatise on the laws of war." But any one who will peruse attentively the third book of the Politics, will see that it would be much more accurately described by calling it "a treatise on the spirit of laws." In the small states of Greece it was not difficult to reduce all the existing laws, or at any rate those which related to the political constitution, to some one axiom, which was regarded as the generative principle, the idée-mère of the whole code. For this axiom, whether explicitly stated, or only to be gathered from the common and statute law, the technical term in Aristotle's time was ro dixusov, "the rule of right."

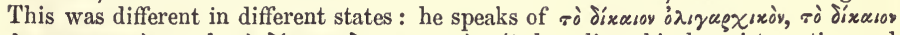

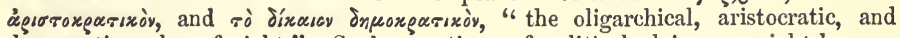
democratic rules of right." Such assertions of political claims as might be considered obvious applications of these fundamental axioms were called by the name $\delta_{i x \alpha \iota \omega} \mu_{\alpha} \tau \alpha$, " prerogatives," or " pleas of right," being, in fact, embodiments of some principle of equity in a maxim. Thus, in our own country, the right of the crown to dissolve parliament; that of the subject to be tried by jury, and to be 
hundred and fifty-eight (according to others one hundred and seventyone or two hundred and fifty-five) States, which, judging from some fragments which have been preserved, involved their history from the earliest known times to his own. ${ }^{1}$ Of this invaluable work a great many scraps remain. On those which relate to Athens, Sigonius is said to have based his account of that commonwealth. ${ }^{2}$ And another, (or the draught of it,) for which this apparently formed the foundation, the 'Politics', has come down to us in all probability in the state in which it was left at the moment of the author's death. We may conclude the evidence which these productions afford of their writer's activity and industry with an anecdote preserved by Diogenes ("Vit. Arist.' sec. 16). Apparently to prevent the remission of attention which results from nature insensibly giving way under the pressure of extremely laborious study, he was accustomed to read holding a ball in one hand, under which was placed a brazen basin. On the slightest involuntary relaxation of the muscles, the ball would fall, and by the sudden noise which it made, at once dissipate the incipient drowsiness of the student.

But this intense love of knowledge had not the common effect of His geniality converting him into a mere bookworm. In his works we see nothing like an undue depreciation of the active forms of life, or even of its pleasures. And this is the more remarkable as we know that his frame was delicate, and his constitution weakly, and that in the latter part of his life he suffered much from bad health, ${ }^{3}$ - circumstances which in general lead to an under-estimate of those pursuits for which a certain robustness of body is a necessary condition. His attention to neatness of person and dress was very considerable; indeed, it is said that he carried it to an extent which Plato considered unworthy of a philosopher." Whether this account be true or not, it is certain that his habits and principles were the reverse of cynical, that he enjoyed life, and was above any unnecessary affectation of severity. "Not apathy, but moderation," is a maxim ascribed to him by Diogenes. ${ }^{5}$

We have seen that Plato felt and testified the highest admiration Plato's sen-

held innocent of any charge till found guilty; that of the peers to demand an towards him. audience of the sovereign, and to be the ultimate court of appeal in civil cases, are

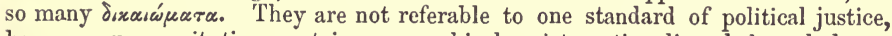
because our consitution contains monarchical, aristocratic, oligarchal, and democratic elements. But the Greek states were almost always pure oligarchies or pure democracies.

1 Diog. Laert. Vit.; Pseudo-Ammon. and Vit. Lat. Compare Cicero, De Fin. v. 4, 10; Varro, De L. L. vii. 3.

\& Nunnez, ad Vit. Pseudo-Ammon. p. 59.

3 Censorinus, De die natali, cap. xiv. "Aristotelem ferunt naturalem stomachi infirmitatem crebrasque morbidi corporis offensiones, adeo virtute animi diu sustentasse, ut magis mirum sit ad annos lxiii. eum vitam protulisse, quam ultra non pertulisse." Compare Gellius, xiii. 5 .

4 Alian, Varia Historia, iii. 19 ; Diog. Laert. Vit. Arist. init.

5 Vit. sec. 31. 
for the talents of his pupil. But it appears that in spite of this there was by no means a perfect congeniality in their feelings. Aristotle is said to have offended his master not only by the carefulness respecting his personal appearance which we have just spoken of, but by a certain sarcastic habit ( $\mu \omega \kappa i \boldsymbol{a}),{ }^{1}$ which showed itself in the expression of his countenance. It is difficult to imagine that he should have indulged this humour in a greater degree than Socrates is by Plato himself represented to have done. However, a vein of irony which would appear very graceful in the master whom he reverenced, and whose views he enthusiastically embraced, might seem quite the reverse in a youthful pupil who promised speedily to become a rival.

His reputed ingratitude to Plato.

An anecdote is related by $\mathbb{E}$ lian, ${ }^{2}$ from which we should infer that overt hostility broke out between them. Aristotle, it is said, taking advantage of the absence of Xenocrates from Athens, and of the temporary confinement of Speusippus by illness, attacked Plato in the presence of his disciples with a series of subtle sophisms which, his powers being impaired by extreme old age, had the effect of perplexing him and obliging him to retire in confusion and shame from the walks of the Academy. Xenocrates, however, returning three months after, drove Aristotle away, and restored his master to his old haunts. On this or some other occasion it is said that Plato compared his pupil's conduct to that of the young foals who kick at their dam as soon as dropped. ${ }^{3}$ And the opinion that Aristotle had in some way or other behaved with ingratitude to his master certainly had obtained considerable currency in antiquity; but it is probable that this, in a great measure, arose from the false interpretation of a passage in the biography of Plato by Aristoxenus the musician, whom we have noticed in the early part of this essay. ${ }^{4}$ This writer had related that "while Plato was absent from Athens on his travels, certain individuals, who were foreigners, established a school in opposition to him." "Some," adds Aristocles, the Peripatetic philosopher, ${ }^{3}$ after quoting this passage, " have imagined that Aristotle was the person here alluded to, but they forget that Aristoxenus, throughout the whole of his work, speaks of Aristotle in terms of praise." Every one who is conversant with the productive power of Greek imagination, and the rapidity with which anecdotes in that fertile soil sprang up and assumed a more and more circumstantial

1 Elian, loc. cit.

2 Ibid.

8 Klian, Var. Hist. iv. 9.

4 Page 96.

5 Ap. Eusebium, Præparatio Evangelica, xv. 2. Aristocles, a native of Messina, was the preceptor of the virtuous emperor, Alexander Severus, not of Alexander Aphrodisiensis, and consequently lived in the first half of the third century of the Christian era. The work from which Eusebius extracts a passage of some length, relating to Aristotle, was a kind of History of Philosophy, in ten books. Eusebius's extract is a part of the seventh. The learning and discrimination of the writer are very great. He traces the stories which he has occasion to mention up to their earliest origin, and refutes them in a masterly manner. There is a literary notice of him in Fabricius's Bibliotheca Græca, iii. c. viii., where see Heumann's note. It is curious that in the Latin Life Aristocles is cited, together with Aristoxenus, as an authority for the very story which he is concerned to refute. 
character on repetition, will not wonder that in the course of the five centuries which intervened between Aristoxenus and Elian, the vague statement of the first should have bourgeoned into the circumstantial narrative of the second.' Indeed, independently of the vulgar in- Refutation of solence with which this story invests the character of Aristotle, $-a$ the story. quality of which there is not a trace in his writings,- - there is much * about it which may render us extremely suspicious of receiving it. In the first place, other stories of equal authority represent his feelings towards his master as those of ardent admiration and deep respect. His biographer informs us that he dedicated an altar (by which he probably means a cenotaph) to Plato, and put an inscription on it to the purport that Plato " was a man whom it was sacrilege for the bad even to praise." There is certainly not much credit to be attached to the literal truth of this story $;^{2}$ but its character may be considered to indicate the view which the authority followed by the biographer took of Aristotle's sentiments towards his master. Still better evidence exists in the way in which Plato is spoken of in the works of his pupil that have come down to us. His opinions are often controverted, but always with fairness, and never with discourtesy. If he is sometimes misapprehended, the misapprehension never appears to be wilful. In one rather remarkable instance there is exhibited a singular tenderness and delicacy towards him. The passage in question is near the commencement of the Nicomachean Ethics. ${ }^{3} \quad$ To the doctrine of Ideas or Archetypal Forms, as maintained by Plato, Aristotle was opposed. It became necessary for him, in the treatment of his subject, to discuss the bearing of this doctrine upon it, and he complains that his task is an unwelcome one, from the

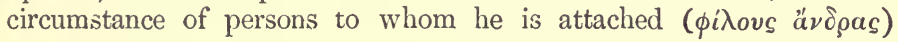

1 The literary men of the declining period considered it a part of their duty to supply all the details which their readers might desiderate in the more general notices of the classical writers. An amusing instance of this kind of writer is Ptolemy, the son of Hephæstion, whose book is described by Photius (Biblioth. p. 146-153, Bekker), and strongly praised by him for its utility to those who

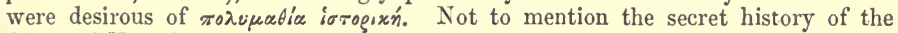
death of Hercules, Achilles, and various other celebrated characters, we are informed of the name of the Delphian, whom Herodotus abstains from mentioning (i. 51), and of that of the queen of Candaules, which latter it seems was Nysia. The reason of Herodntus abstaining from giving it was, that a youth, named Plesirrhoüs, to whom he was much attached, had fallen in love with a lady of that appellation, and, not succeeding in his suit, had hanged himself. This Ptolemy related in his fifth book. In the third he had informed his readers that this very Plesirrhoüs inherited Herodotus's property, and wrote the preface to his history, the commencement of it, as left by the author, having been with the words Is $\sigma \sigma^{\prime} \omega_{y}$ oi $\lambda$ óyos. He probably knew that the readers for whom he wrote, even if they read both anecdotes, would have forgotten the first by the time they reached the second. Yet the age whose taste could render books of this description popular, was no more recent than that of Hadrian, at whose court Elian and Phavorinus lived and wrote.

2 The phrase in question is also found in an elegy to Eudemus, cited by Olympiodorus, Comment. ad Platon. Gorgiam.

${ }^{8}$ P. 1096, col. 1, c. 11, ed Bekker.

(Bekker, p. 53.) 
having originated the theory. "Still," he adds, "it seems our duty even to slay our own flesh and blood,"--an allusion to such cases as those of Iphigenia, Polyxena, and Macaria,-- "where the cause of truth is at stake, especially as we are philosophers; where we love both parties, it is a sacred duty to prefer the truth." The delicacy which prompted such a preface as this would surely have restrained its author from such coarseness as is attributed to him in Elian's story.

The way in which Xenocrates is mixed up with this affair is not to be overlooked. He is represented as the vindicator of his master's honour, and the punisher of the insolence and vanity of his rival. But we shall see presently this same Xenocrates in the character of Aristotle's travelling companion during the three eventful years of his life which immediately followed the death of Plato, consequently at no long period after the alleged insult took place and was revenged; a circumstance which certainly is very far from harmonizing with that conduct of the two philosophers towards each other which Elian's narrative represents.

We must not forget either that Aristotle, although probably possessed of considerable wealth, and perhaps also of some influence from his Macedonian connexions, was still only a METIC, or resident alien. How sensitive the pride of the Athenian citizen was to any appearance of pretension on the part of these, is notorious. ${ }^{1}$ In certain public festivals duties of an inferior, not to say menial, character were assigned to them. ${ }^{2}$ They could hold no land; they could not intermarry with citizens, nor even maintain a civil action in their own persons, but were obliged for this purpose to employ a citizen as their patron or sponsor

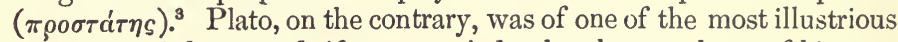
families in Athens, and, if we may judge by the anecdotes of his connexion with Chabrias and Timotheus, possessed friends among the most influential public characters of the day. ${ }^{4}$ It is scarcely credible, therefore, even had all better motives been wanting, that fear of making a powerful enemy should not have restrained Aristotle from behaving to his master in the way which has been described.

Uncongeniality of Plato and A ristotle

It is not difficult to imagine how such stories grew up. There is a most marked contrast observable in the modes of thought of the two philosophers, such a difference indeed as seems incompatible with congeniality, although quite consistent with the highest mutual admira-

1 Eurip. Suppl. 892.

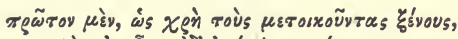

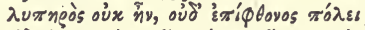

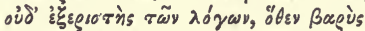

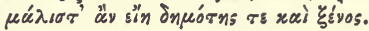

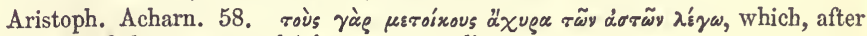
all, was doubtless meant and taken as a compliment.

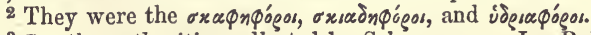

${ }^{3}$ See the authorities collected by Schoemann. Jus Publicum Græcum, p. 190.

${ }^{4}$ Diog. Laert. Vit. Plat. sec. 1, 23; Elian, Var. Hist. iị. 18. 
tion and respect. It manifests itself in their very style; Aristotle's being the dryest and most jejune prose, while that of Plato teems with the imagery of poetry. The one delights to dress his thoughts in all the pomp of as high a degree of fancy as one can conceive united to a sound judgment ; the other seems to consider that the slightest garment would cramp their vigour and hide their symmetry. In Aristotle we find a searching and comprehensive view of things as they present themselves to the understanding, but no attempt to pass the limits of that faculty-no suspicion indeed that such exist. Plato, on the contrary, never omits an opportunity of passing from the finite to the infinite, from the sensuous to the spiritual, from the domain of the intellect to that of the feelings; he is ever striving to body forth an ideal, and he only regards the actual as it furnishes materials for this. Hence, he frequently forgets that he violates the conditions to which the actual world is subjected; or, perhaps, we should rather say, he disregards the importance of this. A striking exemplification of the essential difference between the two great philosophers is afforded by the Republic of Plato compared with the criticism of it by Aristotle. ('Pol.' ii.) The former seems to have grown up out of a wish to embody an ideal of justice, and is the genuine offspring of a vigorous and luxuriant imagination reviewing the forms of social life and seeing in all analogies to the original conception which it was the aim of the artist to set forth. But from this point of view it is never once contemplated by its critic. Essentially a picture, it is discussed by him as if it were a map. ${ }^{1}$ The natural consequence of these different bents is, that Aristotle's views always form parts of a system intellectually complete, while Plato's harmonize with each other morally: we rise from the study of the latter with our feelings purified, from that of the former with our perceptions cleared; the one strengthens the intellect, the other elevates the spirit. Consistently with this opposition it happened that in the early centuries Christianity was often grafted on Platonism, and even where this was not the case, many persons were prepared for its reception by the study of Plato; while in the age of the schoolmen - an age when religion had become theology-Aristotle's works were the only food which the philosophy of the time could assimilate.

The difference which is so strikingly marked between the matured philosophical characters of these two giant intellects is of a kind which

1 The sacred subjects, as they were treated by the early Italian painters-indeed down to the time of Raffaelle and Correggio-present an analogy to this work. There is in them a certain dominant thought, which it is the artist's problem to embody, and which all the details, however incongruous they may be in all other respects, assist in bringing out more fully and clearly. Thus in the celebrated Vierge au Poisson there is a real unity of feeling to which each of the particulars contributes its share. But a spectator who misses this will at once remark on the glaring absurdity of the evangelist, an old man, reading his gospel to the subject of it, an infant in arms ; and of 'Tobias presenting a fish of the size of a mackerel, as that one which " leaped out of the river and would have devoured him." Exactly on such principles does Aristotle's critique on the Republic proceed. 
must have shown itself early. Neither could have entirely sympathised with the other, however much he might admire his genius; and this circumstance may very well have produced a certain estrangement, which by such of their followers as were of too vulgar minds to understand the respect which all really great men must entertain for each other, would readily be misinterpreted. Difference of opinion would, if proceeding from an equal, be represented in the light of hostility,if from a former pupil, in that of ingratitude. The miserable spirit of partisanship prevailing among the Greeks, which is so strongly reprobated by Cicero, ${ }^{1}$ rapidly gave birth to tales which at first probably were meant only to illustrate the preconceived notions which they were in course of time employed to confirm. And so, if Plato had ever made a remark in the same sense and spirit as Waller's epigram to a lady singing one of his own songs, ${ }^{2}$ this might very easily in its passage through inferior and ungenial minds have been distorted into the bitter reflection we have noticed above.

Hostility between Aristotle an Isocrates.

Respecting the relation between Aristotle and another celebrated contemporary of his, there can be no manner of doubt. All accounts agree with the inference we should draw from what we find on the subject in his works, that between him and Isocrates the rhetorician, there subsisted a most cordial dislike, accompanied, on the part of the former at least, with as cordial a contempt. Isocrates was, in fact, a sophist of by no means a high order. He did not possess the cleverness which enabled many of that class to put forth a claim to universal knowledge, and under many circumstances to maintain it successfully. He professed to teach nothing but the art of oratory; but his want of comprehensiveness was not compensated by any superior degree of accuracy or depth. Oratory, according to his view, was the art of making what was important appear trivial, and what was trivial appear important-in other words, of proving black white and white black. He taught this accomplishment not on any principles even pretending to be scientific, but by mere practice in the school, ${ }^{3}$ like fencing or boxing. Indignation at this miserable substitute for philosophical institution, and at the undeserved reputation which its author had acquired, found vent with Aristotle in the application of a sentiment which Euripides in his 'Philoctetes,' a play now lost, put into the mouth of Ulysses. He resolved himself to take up the subject, and his success was so great that Cicero appears to regard it as one of the

1 "Sit ista in Grœcorum levitate perversitas, qui maledictis insectantur eos, a quibus de veritate dissentiunt."-De Finibus, ii. 25.

2 The eagle's fate and mine are one,

Who, on the shaft that made him die,

Espied a feather of his own,

Wherewith he wont to soar so high.

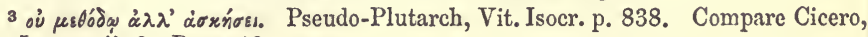
De Invent. ii. 2; Brut. 12.

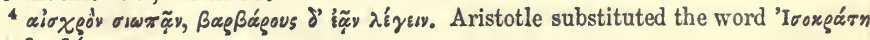

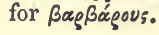


principal motives which induced Philip to entrust him with the edu- Aristotle cation of Alexander.' The expressions which Cicero uses in describing gives lecture Aristotle's treatment of the subject imply rather lectures, combined with rhetorical practice and historical illustration, than a formal treatise. ${ }^{2}$ And this is an important point, inasmucl as it proves that Aristotle assumed the functions of an instructor during this his first residence at Athens. However, such part of his subject as embraced the early history of the art, and might be regarded in the light of an introduction to the rest, would very likely appear by itself; and this is exactly the character of the work so highly praised by Cicero, but unfortunately lost, to which we have before alluded (p. 105.) It was purely historical and critical, and contained none of his own views. These were systematically developed in another work, ${ }^{3}$ perhaps the one which we possess, which was certainly not written at this early period." Apparently, in this lost work the system of Isocrates was attacked and severely handled. The assailed party does not seem to have come forward in person to defend himself; but a scholar of his, Cephisodorus, in a polemical treatise of considerable length, did not Cephisodorus confine himself to the defence of his master's doctrines, but indulged in the most virulent attacks upon the moral as well as intellectual character of his rival. ${ }^{5}$ Upon this work, Dionysius of Halicarnassus, His book perhaps sympathising with a brother rhetorician, passes a high enco- against mium. ${ }^{6}$ But from the little which we know of it, there is but scanty room for believing that its author carried conviction to the minds of many readers not predisposed to agree with him. One of the grounds on which he holds his adversary up to contempt is the having made a collection of proverbs, an employment, in the opinion of Cephisodorus, utterly unworthy of one professing to be a philosopher. Such as have not, like Cephisodorus, an enemy to overthrow, by fair means or foul, will be inclined to smile at such a charge, even if indeed they do not view it in something like the contrary light. " Apophthegms," says Bacon, "are not only for delight and ornament, but for real búsinesses and civil usages ;" for they are, as he said, "secures aut mucrones verborum, which, by their sharp edge, cut and penetrate the knots of matters and business; and occasions run round in a ring, and what was once profitable may again be practised, and again be effectual,

' De Orat. iii. 35.

2 "Itaque ornavit et illustravit doctrinam illam omnem, rerumque cognitionem cum orationis exercitatione conjunxit . . . Hunc Alexandro filio doctorem accivit, a quo eodem ille et agendi acciperet præcepta et eloquendi."'-Cicero, loc. cit.

3 "Cujus [Aristotelis] et illum legi librum, in quo exposuit dicendi artes omnium superiorum, et illos, in quibus ipse sua quædam de eâdem arte dixit." -De Orator. ii. 38 .

${ }^{4}$ See Clinton, Fasti Hellenici, a. 334.

5 Aristocles ap. Euseb. loc. cit.; Athenæus, p. 60.

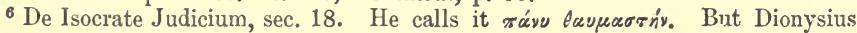
utterly fails where he attempts literary criticism. Witness the absurd principles on which he proceeds in his comparison of Herodotus and Thucydides.

[G. R.P.] 
whether a man speak them as ancient or make them his own." Proverbs are the apophthegms of a people; and from this point of view Aristotle appears to have formed his estimate of their importance. He is said to have regarded them as exhibiting in a compressed form the wisdom of the age in which they severally sprang up; and, as in many instances, having been preserved by their compactness and pregnancy through vicissitudes which had swept away all other traces of the people which originated them. ${ }^{1}$

Aristotle at the court of Hermias.

We now pass to another stage in the life of Aristotle. After B. C. a twenty years' stay at Athens, he, accompanied by the Platonic philosopher Xenocrates, passed over into Asia Minor, and took up his residence at Atarneus or Assos (for the accounts vary), in Mysia, at the court of Hermias. ${ }^{2}$ Of the motives which impelled him to this step we have, as is natural, very conflicting accounts. His enemies imputed it to a feeling of jealousy, arising from Speusippus having been appointed by Plato, who had died just before, as his successor in the school of the Academy. ${ }^{3}$ Others attributed it to a yet more vulgar motive, a taste for the coarse sensualities and ostentatious luxury of an oriental court. ${ }^{4}$ But the first of these reasons will seem to deserve but little credit when we consider that the position which Plato had held was not recognised in any public manner; that there was neither endowment nor dignity attached to it; that all honour or profit arising from it was due solely to the personal merits of the philosopher; that in all probability Aristotle himself had occupied a similar position before the death of Plato; and that, if he felt himself injured by the selection of Speusippus (Plato's nephew), he had every opportunity of showing by the best of all tests, competition, how erroneous a judgment had been formed of their respective merits. And with regard to the second view, it will be sufficient to remark, that for the twenty years preceding this epoch, as well as afterwards, he possessed the option of living at the court of Macedonia, where he probably had connexions, and where there was equal scope for indulging the tastes in question. We shall, therefore, feel no scruple in referring this journey to other and more adequate causes. The reader of Grecian

${ }^{1}$ Synesius, Encom. Calvitii, p. 59, ed. Turneb.

2 Strabo, xiii. p. 126, ed. Tauchnitz. Diodorus Siculus, xvi. 53.

${ }^{3}$ Elian, Var. Hist. iii. 19. Eubulides (ap. Aristocl. Euseb. Præp. Ev. xv. 2) alleged that Aristotle refused to be present at Plato's deathbed.

4 To this the epigram of Theocritus of Chios (ap. Aristocl. loc. cit.) perhaps alludes:-

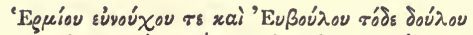

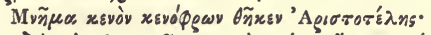

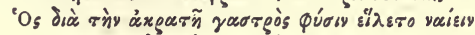

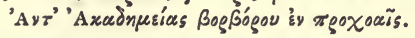

although Plutarch applies it to his residence in Macedonia. The cenotaph spoken of in the second line is probably the foundation for the "altar" to Plato, of which the latter writers speak. Theocritus of Chios was a contemporary of Aristotle. The Syracusan poet of the same name, in an epigram ascribed to him, protests against being identified with him. 
history will not fail to recollect that the suspicions which the Athenians had for some time entertained of the ambitious designs of Philip received a sudden confirmation just at this moment by the successes of that monarch in the Chalcidian peninsula. The fall of Olynthus and the destruction of the Greek confederacy, of which that town was the head, ${ }^{1}$ produced at Athens a feeling of indignation mixed with fear, of which Demosthenes did not fail to take advantage to kindle a strong hatred of anything belonging to Macedon. The modern example of France will enable us readily to understand how dargerous must have been the position of a foreigner, by birth, connexions, or feelings in the slightest degree mixed up with the unpopular party, especially when resident in a democratic state, in which the statute laws were every day subject to be violated by the extemporaneous resolutions ( $\psi \eta \phi i \sigma \mu a \tau a)$ of a popular assembly. Philip, indeed, was accustomed - or at any rate by his enemies believed - to make use of such aliens, as from any cause were allowed free ingress to the states with which he was not on good terms, as his emissaries. ${ }^{2}$ It is scarcely possible under these circumstances to conceive that the jealousy of party hatred should fail to view the distinguished philosopher, the friend of Antipater, and the son of a Macedonian courtphysician, with dislike and distrust, especially if, as from Cicero's description appears highly probable, political affairs entered considerably into the course of his public instructions.

Here, then, we have a reason, quite independent of any particular motive, for Aristotle's quitting Athens at this especial time. And others, little less weighty, existed to take him to the court of Hermias. For some time before, the gigantic body of the Persian empire had Revolt of exhibited symptoms of breaking up. Egypt had for a considerable Persian the experiment had produced the revolt of Phœnicia. The cities of Asia Minor, whose intercourse with Greece Proper was constant, naturally felt an even greater desire to throw off the yoke, and about the year 349 before the Christian era, most of them were in a state of open rebellion. Confederacies of greater or less extent for the purpose of maintaining their common independence were formed among them; and over one of these, which included Atarneus and Assos, one Eubulus, a native of Bithynia, exercised a sway which Eubulus. Suidas represents as that of an absolute prince. ${ }^{3}$ This remarkable man, of whom it is much to be regretted that we know so little, is described as having carried on the trade of a banker ${ }^{4}$ in one of these towns. If this be true, the train of circumstances which led him to the pitch of power which he seems to have reached was probably such a one as, in more modern times, made the son of a brewer of

1 Above, p. 102.

2 The case of Anaxinus (see Eschines c. Ctes. p. 85; Demosth. De Cor. p. 272) may serve as one instance among many.

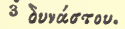

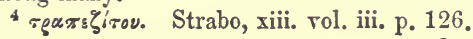


Ghent regent of Flanders, and the Medici dukes of Tuscany. A struggle for national existence calls forth the confidence of the governed in those who possess the genius which alone can preserve them, as unboundedly as it stimulates that genius itself; and there appears no reason why the name of tyrant or dynast should have been bestowed upon Eubulus more than upon Philip van Artevelde or William of Orange. He was assisted in the duties of his government, Hermias. and afterwards succeeded, by Hermias, who is termed by Strabo his slave,- - a term which a Greek would apply no less to the vizier than to the lowest menial servant of an Asiatic potentate. He is also described as an eunuch; but, whether this was the case or not, he was a man of education and philosophy, and had during a residence at Athens attended the instructions of both Plato and Aristotle.' By the invitation of this individual the latter, accompanied by Xenocrates, passed over at this particular juncture into Mysia; and it will surely not seem an improbable conjecture that the especial object for which their presence was desired was to frame a political constitution, in order that the little confederacy, of which Hermias may perhaps be regarded as the general and stadtholder, might be kept together and enabled to maintain its independence in spite of the formidable power of the Persian empire. Ably as such a task would doubtless have been executed by so wise a statesman as even the fragmentary political work that has come down to us proves Aristotle to have been, it was not blessed with success. Fortune for a time favoured the cause of freedom, but the barbarian's hour was not come. The treachery of a Rhodian leader of condottieri in the service of the revolted Egyptians enabled the Persian king, Artaxerxes Ochus, rapidly to overrun Phœnicia and Egypt, and to devote the whole force of his empire to the reduction of Asia Minor. Yet Hermias made his ground good, until at last he suffered himself to be entrapped into a personal conference with the Greek general Mentor, the traitor whose perfidy had ruined the Egyptian cause, and who now commanded the Persian army that Death of - was sent against Atarneus. In spite of the assurance of a solemn Hermias. oath, his person was seized and sent to the court of the Persian king, who ordered him to be strangled. The fortresses which commanded the country surrendered at the sight of his signet; and Atarneus and Aristotle flies Assos were occupied by Persian troops. ${ }^{2} \quad$ The two philosophers were

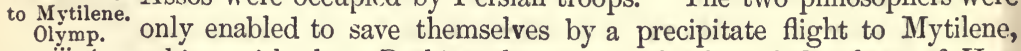
cviii. 4. B.c. $345-4$. taking with them Pythias, the sister and adopted daughter of Hermias. ${ }^{3}$ It is singular that Aristotle's intercourse with the prince of Atarneus, and more especially that part which related to his connexion with this woman, whom he married, should have brought more calumny upon him than any other event of his life; and the strangest thing of all, according to our modern habits of thinking, is that he himself should have thought it necessary, for the satisfaction of his

${ }^{1}$ Strabo, loc. cit.

2 Ibid. loc. cit. Diodorus, svi. sec. $52,53,54$.

${ }^{3}$ Aristocles, ap. Euseb. loc. cit. 
own friends, to give a particular explanation of his motives to the marriage. In a letter to Antipater, which is cited by Aristocles,' he Marries relates the circumstances which induced him to take this step; and P'ythias. they are calculated to give us as high an opinion of the goodness of his heart as his works do of the power of his intellect. The calamity which had befallen Hermias would necessarily have entailed utter misery, and in all probability death, upon his adopted daughter, had she been left behind. In this conjuncture, respect for the memory of his murdered friend, and compassion for the defenceless situation of the girl, induced him, knowing her besides, as he says, to be modest and amiable, ${ }^{2}$ to take her as his wife. It is a striking proof of the utter want of sentiment in the intercourse between the sexes in Greece, that this noble and generous conduct, as every European will at once confess it to have been, should have drawn down obloquy upon the head of its actor; while, if he had left the helpless creature to be carried off to a Persian harem, or sacrificed to the lust of a brutal soldiery, not a human being would have breathed the slightest word of censure upon the atrocity. Even his apologists appear to have considered this as one of the most vulnerable points of his character. When Aristocles ${ }^{3}$ discusses the charges which had been made against him, he dismisses most of them with contempt as carrying the marks of falsehood in their very front. "Two, however," he adds, " do appear to have obtained credit, the one that he treated Plato with ingratitude, the other that he married the daughter of Hermias." And, indeed, the relation of Aristotle to the father furnished a subject for many publications ${ }^{4}$ in the second and third centuries before Christ, and appears to have excited as much interest among literary antiquarians of that day, as the question who wrote 'Icon Basilike,' or the 'Letters of Junius,' might do in modern times. The treatise of Apellicon of Teos, a wealthy antiquary and bibliomaniac contemporary with Sylla, was regarded as the classical work among them. We shall have occasion, in the sequel, to say something more, about this personage. Aristocles ${ }^{5}$ speaks of his book as sufficient to set the whole question at rest, and silence all the calumniators of the philosopher for ever. Indeed, if we may judge of the whole of their charges from the few specimens that have come down to us, a further refutation than their own extravagance was hardly needful. The hand of Pythias is there represented as purchased by a fulsome adulation of her adopted father, ${ }^{6}$ and a subserviency to the most loathsome vices which human nature in its lowest state of depravity can engender; and the husband is said, in exultation at his good fortune, to have paid to his father-in-law a service appropriated to the gods alone,

1 Ap. Euseb. loc cit.

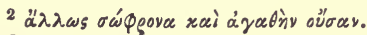

${ }^{8}$ Ap. Euseb. loc. cit. ${ }^{4}$ Aristocles, loc. cit. ${ }^{5}$ Ap. Euseb. loc. cit.

6 She is in some accounts represented, not as his sister, but as his concubine. Others, not considering him an eunuch, call her his daughter. One, probably to

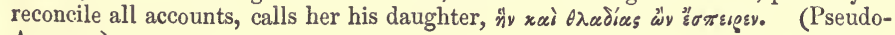
Ammon.) 
singing his praises, like those of Apollo, in a sacred pæan. Fortunately this composition has come down to us, and turns out to be $a$ common scolium, or drinking song, similar in its nature to the celebrated one, so popular at Athenian banquets, which records the deserts of Harmodius and Aristogiton. It possesses no very high degree of poetical merit; but as an expression of good feeling, and as a literary curiosity, being the only remaining specimen of its author's powers in this branch, it perhaps deserves a place in the note. ${ }^{1}$ The perfection of the manly character is personified as "a virgin, for whose charms it is an enviable lot to die, or to endure the severest hardships. The enthusiasm with which she inspires the hearts of her lovers is more precious than gold, than parents, than the luxury of soft-eyed sleep! For her it was that Hercules and the sons of Leda toiled, and Achilles and Ajax died! her fair form, too, made Hermias, the nursling of Atarneus, renounce the cheerful light of the sun. Hence his deeds shall become the subject of song, and the Muses, daughters of Memory, shall wed him to immortality when they magnify the name of Jupiter Xenius (i.e. Jupiter as the protector of the rights of hospitality), and bestow its meed on firm and faithful friendship !" By comparing this relic with the scolium to Harmodius and Aristogiton, which Athenæus has preserved on the page preceding the one from which this is taken, the reader will at once see that Hermias is mentioned together with Achilles and Ajax, and the other heroes of mythology, only in the same manner as Harmodius is; yet not only did this performance bring down on its author's head the calumnies we have mentioned, but many years after it was even made

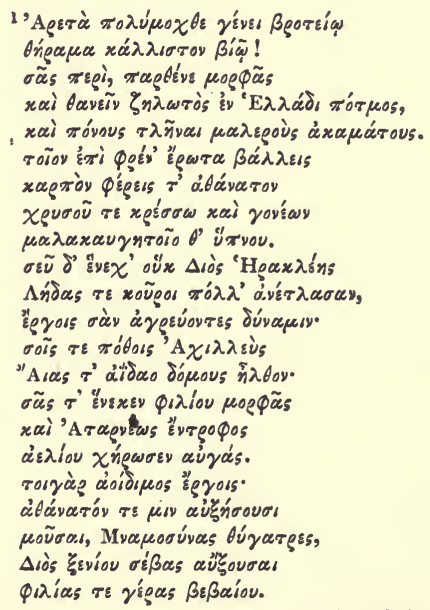

This Scolium is preserved in Diogenes Laert. Vit. Arist. sec. 7 ; Athenæus, p. 696; and Stobæus, Serm. i. p. 2. From the first (sec. 27) we learn that Aristotle also composed some epic and some elegiac poetry. 
the basis of a prosecution of him for blasphemy: such straws will envy and malice grasp at!

The respect of the philosopher for his departed friend was yet further attested by the erection of a statue, or, as some say, a cenotaph, to him at Delphi, with an inscription, in which his death was recorded "as wrought in outrage of the sacred laws of the gods, by the monarch of the bow-bearing Persians, not fairly by the spear in the bloody battle-field, but through the false pledge of a crafty villain!" And " the nearer view of wedded life" does not seem in any respect to have diminished the good opinion he had originally formed of his friend's daughter. She died-how soon after their marriage we cannot say-leaving one orphan daughter; and not only was her memory honoured by the widower with a respect which exposed him, as in the former instance of her father, to the charge of idolatry, ${ }^{2}$ but, in his will, made some time afterwards, he provides that her bones should be taken up and laid by the side of his, wherever he might be buried, as, says he, she herself enjoined. ${ }^{3}$

At this epoch of Aristotle's life, when the clouds of adversity ap- Aristotle peared to be at the thickest, his brightest fortunes were about to goes to appear. He had fled to Mytilene an exile, deprived of his powerful educate to friend, and apparently cut off from all present opportunity of bringing Alexander. his gigantic powers of mind into play. But in Mytilene he received an invitation from Philip to undertake the training of one who, in the cix. 2 . B.c. $343-2$. world of action, was destined to achieve an empire, which only that of his master in the world of thought has ever surpassed. A conjunction of two such spirits has not been yet twice recorded in the annals of mankind; and it is impossible to conceive anything more interesting and fruitful than a good contemporary account of the intercourse between them would have been. But, although such a one did exist, we are not fortunate enough to possess it. The destroying hand of time has been most active exactly where we should most desire information as to details; and almost all the description we can give of this period is founded upon the scanty notices on the subject furnished by Plutarch in his biography of the great conqueror.

How far the mere personal character of Aristotle contributed to Philip's procuring him the invitation from Philip, it is difficult to say. Cicero $\begin{gathered}\text { probable ac- } \\ \text { quaintance }\end{gathered}$ represents the king as mainly determined to the step by the reputation with Arisof the philosopher's rhetorical lectures. ${ }^{4}$ A letter preserved by Aulus totle. Gellius (ix. 3), which is well known, but can scarcely be genuine, would induce us to believe that, from the very birth of Alexander, he was destined by his father to grow up under the superintendence of his latest instructor. It is, indeed, not unlikely that, at this early period, Aristotle was well known to Philip. We have seen that, in all probability, his earliest years were passed at the court, where his father possessed the highest confidence of the father of Philip. More-

\footnotetext{
1 Diog. Vit. sec. 6.

${ }^{3}$ Ibid. sec. 16.
}

2 Ibid. sec. 4.

4 De Oratore, iii. 35. 
over, he is said, although neither the time nor the occasion is specified, to have rendered services to the Athenians as ambassador to the court of Macedon. ${ }^{1}$ But if this letter be genuine, how are we able to account for the absence of the philosopher from his charge during the thirteen years which elapsed between its professed date and the second year of the 109th Olympiad, in which we know for certain that he entered upon his important task? For that it was not because he considered the influences exerted upon this tender age unimportant, is clear from the great stress he lays upon their effect in the eighth book of his 'Politics,' which is entirely devoted to the details of this sub-

Alexander's early masters ject. ${ }^{2}$ And although Alexander was only thirteen years old when his connexion with Aristotle commenced, yet the seeds of many vices had even at that early period been sown by the unskilful hands of former instructors; and perhaps the best means of estimating the value of Aristotle's services is to compare what his pupil really became with what he would naturally have been had he been left under the care of these. Two are particularly noticed by Plutarch, ${ }^{3}$ of totally opposite dispositions, and singularly calculated to produce, by their combined action, that oscillation between asceticism and luxury which, in the latter part of his life especially, was so striking a feature in Alexander's

Leonidas. character. The first was Leonidas, a relation of his mother Olympias, a rough and austere soldier, who appears to have directed all his efforts to the production of a Spartan endurance of hardship and contempt of danger. He was accustomed to ransack his pupil's trunks for the purpose of discovering any luxurious dress or other means of indulgence which might have been sent by his mother to him: and, at the outset of Alexander's Asiatic expedition, on the occasion of an entertainment by his adopted mother, a Carian princess, he told her that Leonidas's early discipline had made all culinary refinements a matter of indifference to him; that the only cook he had ever been allowed to season his breakfast was a good night's journey; and the only one to improve his supper, a scanty breakfast. ${ }^{4}$ An education of which these traits are characteristic might very well produce the personal hardiness and animal courage for which Alexander was distinguished; it might enable him to tame a Bucephalus, to surpass all his contemporaries in swiftness of foot, to leap down alone amidst a crowd of enemies from the ramparts of a besieged town, to kill a lion in single combat ; ${ }^{5}$ it might even inspire the passion for military glory, which vented itself in tears when there was nothing left to conquer ; ${ }^{6}$ but it would be almost as favourable to the growth of the coarser vices as to the development of these ruder virtues; and we learn that, to the day of his death, the ruffianly and intemperate dispositions which belong

${ }^{1}$ Diog. Vit. sec. 2.

${ }^{2}$ See especially p. 1334 , col. 2 , line 25 , et seq.; p. 1338, col. 1 , line 5 , et. seq. ed. Bekker.

${ }^{3}$ Vit. Alex. sec. 5.

4 Plutarch, Vit. sec. 22.

5 Ibid. $6-40, \& c$.

$6 \quad$ Unus Pellæo juveni non sufficit orbis,-Juv, Sat. x. 168. 
to barbarian blood, and which the influences of Leonidas had tended rather to increase than diminish, were never entirely subdued by Alexander. ${ }^{1} \quad$ The character of Lysimachus, the other instructor espe- Lysimachus. cially noticed by Plutarch, was very different, but hardly likely to have produced a much more beneficial effect. He was by birth an Acarnanian, and an expert flatterer, by which means he is said to have gained great favour. His favourite thought appears to have been to compare Alexander to Achilles, Philip to Peleus, and himself to Phœnix, as the characters are described in the epic poetry of Greece; and this insipid stuff it was his delight to act out in the ordinary business of life. At a later period, this passion for scene-making nearly cost poor Phœnix and his master their lives $;^{2}$ and to it is probably due, in a great measure, the cormorant appetite for adulation which is the most disgusting feature in the history of the latter. To neither, then, of these two individuals-and if not to these, of course much less to the crowd of masters in reading, writing, horsemanship, harp-playing, and the other accomplishments included by ancient

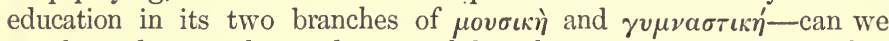
ascribe a share in the production of that character which distinguishes Alexander from any successful military leader. But to Aristotle some of the ancients attribute a degree and kind of merit in this respect which is perfectly absurd. Plutarch says that his pupil gained from him more towards the accomplishment of his schemes than from Philip. $^{3} \quad$ Alexander himself was accustomed to say, that he honoured Aristotle no less than his own father; that to the one he owed life, but to the other all that made life valuable: $:^{4}$ and it is very likely that the misinterpretation of such phrases as these led to the belief that the conqueror had received from his instructor direct advice for the accomplishment of the great exploit which has made him known to posterity. But the obligations to which he really alluded were probably of a totally different kind. Philip is said to have perceived, at a very early age, that his son's disposition was a most peculiar one, sensible in the highest degree of kindness, and tractable by gentle measures, but absolutely ungovernable by force, and consequently requiring, instead of the austerity of a Leonidas, or the flattery of a Lysimachus, the influence of one who could, by his character and abilities, com-

1 " Leonidas Alexandri pædagogus, ut a Babylonio Diogene traditur, quibusdam eum vitiis imbuit, quæ robustum quoque et jam maximum regem ab illâ institutione puerili sunt prosecuta."-Quintilian, Inst. Or. i. 1, 8. Is it not probable that Aristotle, in the seventh book of his Politics (p. 1324, col. 1, line 23, et seq., and p. 1333, col. 2 , line 10, et seq.) has a particular reference to the views of Leonidas?

2 Plutarch, Vit. sec. 24.

3 Plutarch, De Fortun. Alexandri. See Ste. Croix, Examen Historique, p. 84. Such expressions as these led later writers to yet more extravagant ones; such as Roger Bacon's, " per vias sapientiæ mundum Alexandro tradidit Aristoteles;" and probably to the same source is to be traced the romance of the philosopher having personally attended his pupil in his expedition.

4 Plutarch, Vit. Alex. sec. 8. 
His literary mand respect, and by his tact and judgment preserve it. Such qualitastes.

His mental cultivation.

Rapidity of his education fications he found in Aristotle, and the good effects seem to have speedily shown themselves. From a rude and intemperate barbarian his nature expanded and exhibited itself in an attachment to philosophy, a desire of mental cultivation, and a fondness for study. So completely did he acquire higher and more civilized tastes, that being at the extremity of Asia, in a letter to Harpalus he desires that the works of Philistus the historian, the tragedies of Eschylus, Sophocles, and Euripides, and the dithyrambs of Telestes and Philoxenus, should be sent to him. Homer was his constant travelling companion. A copy, corrected by Aristotle, was deposited by the side of his dagger, under the pillow of the couch on which he slept ; ${ }^{1}$ and, on the occasion of a magnificent casket being found among the spoils of Darius's camp, when a discussion arose as to how it should be employed, the king declared that it should be appropriated to the use of containing this copy. ${ }^{2}$ But his education had not been confined to the lighter species of literature; on the contrary, he appears to have been introduced to the gravest and most abstruse parts of philosophy, to which the term of acroamatic was specifically applied. We shall, in the sequel, examine more fully what exact notion is to be attached to this term $:^{3}$ in the mean time it will be sufficient to observe that it included the highest branches of the science of that day. In a letter, then, preserved by Plutarch and Aulus Gellius, ${ }^{4}$ Alexander complains that his preceptor had published those of his works to which this phrase was applied. "How," he asks, "now that this is the case, will he be able to maintain his superiority to others in mental accomplishments-a superiority which he valued more than the distinction he had won by his conquests?" Gellius likewise gives us Aristotle's answer, in which he excuses himself by saying, "that although the works in question were published, they would be useless to all who had not previously enjoyed the benefit of his oral instructions." Whatever may be our opinion as to the genuineness of these letters, which Gellius says he took from the book of the philosopher Andronicus (a contemporary of Cicero's, to whom we shall on a future occasion again revert), it is quite clear that if they are forgeries, they were forged in accordance with a general belief of the time, that there was no department of knowledge, however recondite, to which Aristotle had not taken pains to introduce his pupil.

But the most extraordinary feature in the education of Alexander is the short space of time which it occupied. From the time of Aristotle's arrival in Macedonia to the expedition of his pupil into Asia there elapsed eight years (i.e.,) from Olymp. cix. 2. to Olymp. cxi. 2.) But of this only a part, less than the half, can have been devoted to

1 Plutarch, Vit. sec. 7, 8.

2 Plutarch, Vit. sec. 26 ; Strabo, xiii.; Plin. Nat. Hist. v. 30.

3 See below, p. 159.

4 Plutarch, Vit. Alex. sec. 7 ; Gellius, Noc. Att. xx. 5. 
the purpose of systematic instruction. For in the fourth year of this period, ${ }^{1}$ we find Philip during an expedition to Byzantium leaving his son sole and absolute regent of the kingdom. Some barbarian subjects having revolted, Alexander undertook an expedition in person against them, and took their city, which he called after his own name, Alexandropolis. From this time he was continually engaged in business, now leading the decisive charge at Chæronea, and now involved in court intrigues against a party who endeavoured to gain Philip's confidence, and induce him to alter the succession. ${ }^{2}$ It is clear, therefore, that all instruction in the stricter sense of the word, must have terminated. Yet that a very considerable influence may have been Aristotle's still exerted by Aristotle upon the mind of Alexander, is not only in influence itself probable, but is confirmed by the titles of some of his writings ander. which are now lost. Ammonius, in his division of the works of the philosopher, mentions a certain class ${ }^{\mathbf{3}}$ as consisting of treatises written for the behoof of particular individuals, and specifies among them those books "which he composed at the request of Alexander of Macedon, that 'On Monarchy,' and 'Instructions on the Mode of establishing Colonies.' " The titles of these works may lead us to conjecture that the distinguishing characteristics of Alexander's subsequent policy, the attempt to fuse into one mass his old subjects and the people he had conquered, the assimilation of their manners, especially by education and intermarriages, the connexion of remote regions by building cities, making roads, and establishing commercial enterprises, may be in no small measure due to the counsels of his preceptor. A modern writer, indeed, has imagined an analogy between this assimilative policy of the conqueror, and the generalizing genius of the philosopher. ${ }^{*}$ And there really does seem some ground for this belief, in spite of an observation of Plutarch's, ${ }^{5}$ which is at first sight diametrically opposed to it. After speaking of the Stoical notions of an universal republic, he says, that magnificent as the scheme was, it was never realized, but remained a mere speculation of that school of philosophy; and he adds that Alexander, who nearly realized it, did so in opposition to the advice of Aristotle, who had recommended him to treat the Greeks as

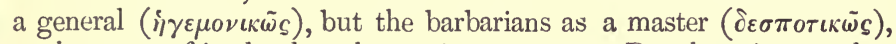
- the one as friends, the other as instruments. But there is no other authority than Plutarch for this story; and it seems far from impro-

${ }^{1}$ Plutarch, Vit. sec. 9 ; Diodorus, xvi. 77. See Clinton, Fast. Hell. a. 340, 339.

2 Plutarch, Vit. sec. 9, 10.

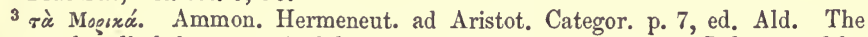
two works alluded to are cited by the anonymous author of the Life printed by Buhle in his edition of Aristotle, pp. 60-67, under the titles $\pi \varepsilon \rho^{i} \beta \alpha \sigma_{i} \lambda \varepsilon^{\prime} \alpha_{s}$ and

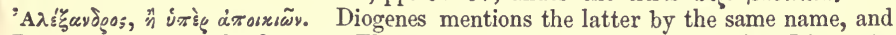

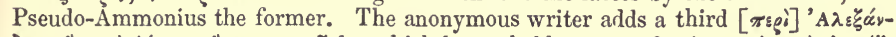

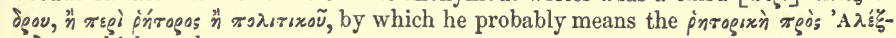
aydeoy, which we have.

4 Joh. von Mueller, Allgemeine Geschichte, i. p. 160.

${ }^{5}$ De Virt. et Fort. Alexandri, p. 329. 
bable that it is entirely built upon certain expressions used by Aristotle

His views respecting slavery.

Misrepresented.

Exculpated. the general principles inculcated by his master. ${ }^{2}$ As far as concerned the barbarians, with whom alone the Greeks previously to Alexander's expedition had been brought into contact, the neighbours of the Greek cities in Asia Minor and the Propontis, the savage hordes of Thrace, or the Nomad races inhabiting the African Syrtis, Aristotle's position was a most reasonable one. Christianity seems the only possible means for the mutual pacification of races so different from one another in every thought, feeling, and habit, as these and the polished Greeks were : and Christianity itself solves the problem not by those modifications of social life through which alone the statesman acts, or can act; but by awakening all to the consciousness that there exists a common bond higher than all social relations; it does not aim at obliterating national peculiarities, but it dwarfs their importance in comparison with the universal religious faith. If we would really understand the opinions of a writer of antiquity, we must understand the ground on which he rests, and must rest. We have no right to require of a pagan philosopher three centuries before Christ, that in his system he should take account of the influences of Christianity; and they who scoff at the importance which he attaches to the difference of race, would do well to point out any instance in the history of the world of a barbarous people becoming amalgamated with a highly-civilized one by any other agency.

Stagirus rebuilt.

in the first book of his 'Politics.' In that place he recognizes the relation between master and slave as a natural one; and he also main-
tains the superiority of Greeks over barbarians to be so decided and permanent as to justify the supremacy of the one over the other. Of the latter he argues that they have not the faculty of governing in them, and that, therefore, the state of slavery is for them the natural and proper form of the social relation. But it should not be overcitly distinguishes between a slave de facto and a slave de jure, and that he grounds his vindication of slavery entirely on the principle that such a relation shall be the most beneficial one to both the parties congoverned is susceptible of a higher order of government, he distinctly maintains that the relation is a false and unnatural one. If therefore, his experience had brought him into contact with the highly-cultivated and generous races of upper Asia to which Alexander penetrated, he must in consistency with his own principle, that every man's nature is to be developed to the highest point of which it is capable, have advised that these should be treated on the same footing as the Greeks, and Alexander's conduct would only appear a natural deduction from If Aristotle might reasonably feel proud of the talents and acquire-

1 Paley, Moral and Political Philosophy, c. v. p. 12.

2 From this point of view too, the assertion of Plutarch, quoted above (p. 123), acquires a plausibility, which otherwise we could never allow it. 
ments of his pupil, his gratification would be yet more enhanced by the nature of the reward which his services received. We have mentioned above the unhappy fate of Stagirus, Aristotle's birthplace. Although his own fortunes were little affected by this calamity, his patriotism, if we may believe the account in Plutarch, induced him to demand as the price of his instructions, the restoration of his native town. It was accordingly rebuilt, such of the inhabitants as were living in exile were restored to the home of their infancy, such as had been sold for slaves were redeemed, and in the days of Plutarch strangers were shown the shady groves in which the philosopher had walked, and the stone benches whereon he used to repose. ${ }^{\text {I }}$ 'The constitution under which the new citizens lived was said to be drawn up by him, ${ }^{2}$ and long afterwards his memory was celebrated by the Stagirites in a solemn festival, and, it is said, one month of the year (perhaps the one in which he was born) called by his name. ${ }^{\mathbf{3}}$ There is every reason to believe that during the latter part of his connexion with Alexander, when the more direct instruction had ceased, the newly-built town furnished him with a quiet retreat, and that he then and there composed the treatises we have mentioned above, for the use of his absent pupil. While their personal communication lasted, Pella, the capital of Macedonia, was probably his residence, ${ }^{4}$ as it is scarcely probable that Philip would have liked to trust the person of the heir-apparent out of his dominions.

We shall conclude the account of this portion of Aristotle's life by Fellowthe mention of three other remarkable persons who probably all shared with Alexander in the benefit of his instructions, although this is only pupils of Alexander. positively stated of the last of them. ${ }^{5}$ The first of these was Callis-

${ }^{1}$ Plutarch, Vit. Alex. sec. 7. In this matter the accounts are confused. Elian (Var. Hist. iii. 17 ; xii. 54), Diogenes (v. 4), and Pliny (vii. 29), attribute the restoration to Alexander. If it took place at the commencement of the regency, these may be reconciled with Plutarch. But the testimony of Valerius Maximus (v. 6) would refer both the destruction and rebuilding of Stagirus to Alexander, and that too at a time when Aristotle was very old and residing in Athens. The gentlest mode of reconciling this inaccurate epitomizer with possibilities, is to suppose that he has confounded Stagirus with Eressus, the birthplace of Theophrastus, of whom Diogenes and Pseudo-Ammonius relate a somewhat similar story.

2 Plutarch, adv. Colot. extr.

3 Pseudo-Ammon. and Vit. Lat. The name "Stagirites" shows the very late rise of this feature of the story. It may be built, however, on a true foundation.

4 This has been by Stahr (Aristotelia, i. p. 104) inferred from the expression Bogßópov iv rgoxoais in Theocritus's Epigram, quoted above, p. 114, note. The Macedonians, he says, called the river, on whose banks Pella stood, by the name Bó,Bo@os. We cannot find any authority except Plutarch for this assertion; and should be inclined to recognize in the expression in question a moral rather than a physical allusion.

S Suidas, v. Marsyas. That Callisthenes and Theophrastus were together pupils of Aristotle appears from Diogenes (Vit. Theoph. sec. 39); and the Macedonian connexions of both would incline us to believe that it was in that country that this relation existed. Theophrastus was personally known to Philip, and treated with distinction by him. (Elian, Var. Hist. iv. 19.) And if Callisthenes had been Aristotle's pupil at Athens, his character would surely have been sufficiently 
thenes, a son of Aristotle's cousin, who afterwards attended Alexander in his Asiatic expedition, and to whom we shall have occasion to revert in the sequel. The second was, Theophrastus, Aristotle's successor in the school of the Lyceum some years afterwards; and the third was one Marsyas, a native of Pella, brother to the Antigonus, who, after the death of Alexander, when the generals of the monarch divided their master's conquests among them, became King of Lycia and Pamphylia. He was a soldier and a man of letters; and one work of his 'On the Education of Alexander' is, perbaps, as great a loss to us as any composition of antiquity which could be named.

Aristotle returns to Athens. B.c. 335 -4.

On Alexander commencing his eastern expedition, Aristotle, leaving his relation and pupil Callisthenes to supply his own place as a friendly adviser to the youthful monarch, whom he accompanied in the ostensible character of historiographer, ${ }^{1}$ returned to Athens. Whether this step was the consequence of any specific invitation or not, it is difficult to say. Some accounts state that he received a public request from the Athenians to come, and conjointly with Xenocrates to succeed Speusippus. ${ }^{2}$ But these views appear to proceed upon the essentially false opinion that the position of teacher was already a publicly recognized one, and besides to imply the belief that Xenocrates and Aristotle were at the time on their travels together; whereas we know that the latter was in Macedonia till B. C. 335 , and that the former had four years before this time succeeded Speusippus, not by virtue of any public appointment, but in consequence of his private

Why. wish. ${ }^{3}$ If any more precise reason be required for the philosopher's change of residence than the one which probably determined him at first to visit Athens, namely, the superior attractions which that city possessed for cultivated and refined minds, we should incline to believe that the greater mildness of climate was the influencing cause. ${ }^{4}$ His health was unquestionably delicate; and, perhaps, it was a regard for this, combined with the wish to economize time, that induced him to deliver his instructions (or at least a part of them) not sitting or standing, but walking backwards and forwards in the open air. The extent to which he carried this practice, although the example of Protagoras ${ }^{5}$ in Plato's Dialogue is enough to show that he did not originate it, procured for his scholars, who of course were obliged to conform to Peripatetics. this habit, the soubriquet of 'Peripatetics,' or 'Walkers backwards and

developed eleven years afterwards to exhibit his unfitness as an adviser of Alexander to any eye, certainly to the sharp-sighted one of Aristotle. Besides, it is not likely that Alexander would have chosen one whom he was not already acquainted with, to attend him in such a capacity as Callisthenes did.

1 Arrian, iv. 10.

2 Pseudo-Ammon. Vit. Lat.

3 Diog. Laert. iv. 3.

4 This seems to be the true interpretation of the expression of Aristotle cited by

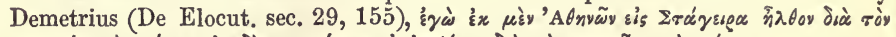

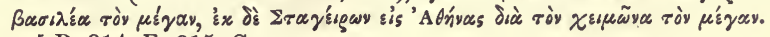

5 P. 314 , E. 315 , C. 
forwards." From a neighbouring temple of Apollo Lyceus, his school was commonly known by the name of the Lyceum ; and here every morning and evening he delivered lectures to a numerous body of scholars. Among these he appears to have made a division. The Division of morning course, or, as he called it from the place where it was deli- his scholars. vered, the morning walk ( $\dot{\varepsilon} \omega \theta_{\iota}$ òs $\left.\pi \varepsilon \rho i \pi \alpha \tau o s\right)$, was attended only by the more highly-disciplined part of his auditory, the subjects of it belonging to the higher branches of philosophy, and requiring a systematic attention as well as a previously-cultivated understanding on the part of the scholar. In the evening course ( $\delta \varepsilon \iota \lambda \iota v o$ s $\pi \varepsilon \rho i \pi a \tau o s)$ the subjects as well as the manner of treating them were of a more popular cast, and more appreciable by a mixed assembly. Aulus Gellius, ${ }^{3}$ who is our sole authority on this matter, affirms that the expressions acroatic

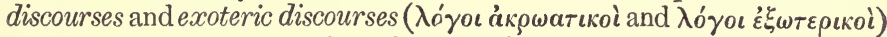
were the appropriate technical terms for these instructions: and he further says that the former comprised theological, physical, and dialectic investigations ; the latter rhetoric, sophistic (or the art of disputing), and politics. We shall in another place examine thoroughly into the precise meaning of these celebrated phrases, a task which would in this place too much break the thread of the narrative. We may, however, remark that the morning discourses were called acroatic or subjects of lectures, not because they belonged to this or that branch, but because they were treated in a technical and systematic manner; and so the evening discourses obtained the name of exoteric or separate, because each of them was insulated, and not forming an integral part of a system. It is obvious that some subjects are more suitable to the one of these methods, and others to the other; and the division which Gellius makes is, generally speaking, a good one. But that it does not hold universally is plain, not to mention other arguments, from the fact that the work on 'Rhetoric' which has come down to us is an acroatic work, and that on 'Politics' the unfinished draught of one; while, on the contrary, a fragment of an exoteric work preserved by Cicero in a Latin dress is upon a theological subject.

The more select circle of his scholars Aristotle used to assemble at Their constated times on a footing, which without any straining of analogy we vivial meetmay compare to the periodical dinners held by some of the literary clubs of modern times. Their object obviously was to combine the advantages of high intellectual cultivation with the charms of social intercourse ; to make men feel that philosophy was not a thing separate from the daily uses of life, but entered into all its charities, and was mixed up with its real pleasures. These reunions were conducted

${ }^{1}$ Cicero, Academ. Post. i. 4. Cicero translates the word $\pi$ s lare. Hermippus explained it by ávaxá $\mu \pi \tau s ı$. Diogenes Laertius (v. 2) attributes the origin of this practice with Aristotle to a regard, not for his own health, but for that of Alexander.

${ }^{2}$ Before the Peloponnesian War it had been used as a gymnasium, and was said to have been built by Pisistratus. See Aristoph. Pac. 355, and the Scholiast.

${ }^{3}$ Noct. Att. xx. 5 . 
according to regular rules, ${ }^{1}$ of which we know enough to see that the cynicism or pedantry, which frequently induces such as would be accounted deep thinkers to despise the elegancies or even the decencies of life was strongly discountenanced. ${ }^{2}$ In these days, especially in England, where so many different elements combine to produce social intercourse in its highest perfection, it is difficult to estimate the important effect which must have been brought about by a custom such as that just mentioned. "To enjoy leisure gracefully and creditably," is not easy for any one at any time, but for the Athenian in the days

Athenian social inter course. of Aristotle was a task of the greatest difficulty. Deprived of that kind of female intercourse which in modern social life is the great instrument for humanizing the other sex, softening, as it does, through the affections, the disposition to ferocity and rudeness, and checking the licentious passions by the dignity of matronly or maidenly purity, the youth of ancient Greece almost universally fell either into a ruffianly asceticism, or a low and vulgar profligacy. Some affected the austere manner and sordid garb of the Lacedæmonians, ${ }^{8}$ regarding as effeminate all geniality of disposition, all taste for the refinements of life, everything in short which did not directly tend to the production of mere energy: while others entirely quenched the moral will and the higher mental faculties in a debauchery of the coarsest kind. ${ }^{4}$ To open a new region of enjoyment to the choicer spirits of the time, and thus save them from the distortion or corruption to which they otherwise seemed doomed, was a highly-important service to the cause of civilization. The pleasure and utility resulting from the institution was very generally recognised. Xenocrates, the friend of Aristotle, adopted it. Theophrastus, his successor, left a sum of money in his will to be applied to defraying the expenses of these meetings; and there were in after times similar periodical gatherings of the followers of the Stoic philosophers, Diogenes, Antipater, and Panætius. ${ }^{5}$ If some of these, or others of similar nature, in the course of time degenerated into mere excuses for sensual indulgence, as Athenæus seems to hint, no argument can be thence derived against their great utility while the spirit of the institution was preserved.

Their public Another arrangement made by Aristotle in the management of his exercises. instructions appears particularly worthy of notice. In imitation, as some say, of a practice of Xenocrates, he appointed one of his scholars

1 Athenæus, p. 186.

$2{ }^{2}$ 'A

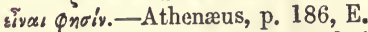

3 That the Aarwvopuvía so admirably hit off by Aristophanes (Av. 1729, et seq.) lasted long after his time is clear, not to mention other arguments, from the evident prevalence of the views which Aristotle takes so much pains to controvert.

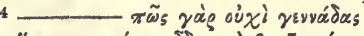

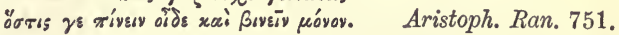

The manners of the latter comedy, as preserved in Terence's plays, are a sufficient evidence that this sarcasm was little less applicable at Athens throughout the fourth century before the Christian era.

5 Athenæus, p. 186. 
to play the part of a sort of president in his school, holding the office for the space of ten days, after which another took his place.' This peculiarity seems to derive illustration from the practice of the universities of Europe in the middle ages, in which, as is well known, it was the custom for individuals on various occasions to maintain certain theses against all who chose to controvert them. A remnant of this practice remains to this day in the 'Acts' (as they are termed), which are kept in the University of Cambridge by candidates for a degree in either of the Faculties. It is an arrangement which results necessarily from the scarcity of books of instruction, and is dropped or degenerates into a mere form when this deficiency is removed. While information on any given subject must be derived entirely or mainly from the mouth of the teacher,-as was the case in the time of Aristotle, no less than that of Scotus and Aquinas,- the most satisfactory test of the learner's proficiency is his ability to maintain the theory which he has received against all arguments which may be brought against it. We shall probably be right in supposing that this was the duty of the president $\left(a \rho_{\rho} \chi \omega \nu\right)$ spoken of by Diogenes. He was, in the language of the sixteenth century, keeping an act. He had for the space of ten days to defend his own theory and to refute the objections (ámóoı which his brother-disciples might either entertain or invent, the master in the meantime taking the place of a moderator, occasionally interposing to show where issue must be joined, to prevent either party from drawing illogical conclusions from acknowledged premises, and, probably, after the discussion had been continued for a sufficient time, to point out the ground of the fallacy. This explanation will also serve to account for a phenomenon, which cannot fail to strike a reader on the perusal of any one of Aristotle's writings that have come down to us. The systematic treatment of a subject is continually broken by an apparently needless discussion of objections which may be brought against some particular part. These are stated more or less fully, and are likewise taken off; or it sometimes happens that merely the principle on which the solution must proceed is indicated, and it is left to the ingenuity of the reader to fill up the details. To return to our subject, it is quite obvious that such a discipline as we have described

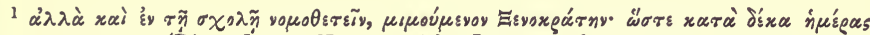

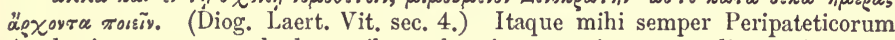
Academiæque consuetudo de omnibus rebus in contrarias partes disserendi non ob eam causam solum placuit, quod aliter non posset, quid in quâque re veri simile esset, inveniri; sed etiam quod esset ea maxima dicendi exercitatio: quâ princeps usus est Aristoteles, deinde, eum qui secuti sunt. (Cicero, Tusc. Qu. ii. 3.) Sin aliquis extiterit aliquando, qui Aristoteleo more de omnibus rebus in utramque partem possit dicere, et in omni causâ duas contrarias orationes, præceptis illius cognitis, explicare ; aut hoc Arcesilæ modo et Carneadi, contra omne quod propositum sit disserat; quique ad eam rationem adjungat hunc rhetoricum usum moremque dicendi,-is sit verus, is perfectus, is solus orator." (Cicero, De Orat. iii. 21.) The passage from Quintilian (i. 2, 23), quoted by Menage in his note on Diogenes (loc. cit.), refers to an essentially different kind of discipline, arising out of other grounds and directed to other ends.

[G. R.P.] 
must have had a wonderful effect in sharpening the dialectical talent of the student, and in producing-perhaps at the expense of the more valuable faculty of deep and systematic thought-extraordinary astuteness and agility in argumentation. Indeed, if we make abstraction of the subject-matter of the discussions, we may very well regard the exercise as simply a practical instruction in the art of Disputation,that which formed the staple of the education of the Sophists. And

Gellius's account explained.

Effect of this discipline on the subjectmatter of philosophy. now we may understand how Gellius, ${ }^{1}$ writing in the second century after Christ, should place this art among the branches which Aristotle's evening course embraced, although in the sense in which the Sophists taught it, he would have scorned to make any such profession. ${ }^{2}$ In what other light could this compiler have viewed the fact, that insulated topics arising out of a subject which they had heard systematically

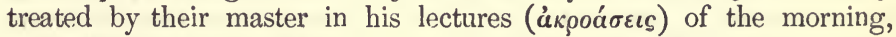
were debated by Aristotle's more advanced scholars, in the presence of the whole body, in the evening, the master being himself present and regulating the whole discussion.

It is evident that in this species of exercise it is not the faculty of comprehending philosophic truth that plays the most prominent part. As regards the subject-matter of such debates, nothing which is at all incomplete, nothing unsusceptible of rigid definition is available. Consequently the whole of that extensive region, where knowledge exists in a state of growth and gradual consolidation,- the domain of halfevolved truths, of observations and theories blended together in varying proportions, of approximately ascertained laws, in the main true, but still apparently irreconcilable with some phenomena,-all this fertile soil, out of which every particle of real knowledge has sprung and must spring, will be neglected as barren and unprofitable. Where public discussion is the only test to be applied, an impregnable paradox will be more valued than an imperfectly-established truth. ${ }^{3}$ And it is not only by diverting the attention of the student away from the profitable fields of knowledge, that a pernicious effect will be produced. He will further be tempted to give, perhaps unconsciously, an artificial roundness to established facts by means of arbitrary definitions. In nature everything is shaded off by imperceptible gradations into something entirely different. Who can define the exact line which separates the animal from the vegetable kingdom, or the family of birds from that of animals? Who can say exactly where disinterestedness in the individual character joins on to a well-regulated self-love?-or where On the phi- fanaticism ends and hypocrisy begins? But the intellect refuses to aplosopher.
1 Noct. Att. xx. 5. See p. 127.

2 See, for instance, the contempt with which he speaks of the sophistical principle- the one on which Isocrates taught rhetoric. Rhetoric. i. init.

3 “ Sapientis hanc censet Arcesilas vim esse maximam, Zenoni assentiens, cavere ne capiatur; ne fallatur, videre." (Cicero, Academ. prior. ii. 21.) Who can fail to recognise the disputatious habit of mind which gave birth to this principle? Compare sec. 21. "Si ulli rei sapiens assentietur unquam, aliquando etiam opinabitur: nunquam autem opinabitur ; nulli igitur rei assentietur." 
prehend what is not clear and distinct. Hence a continual tendency to stretch nature on the Procrustes-bed of logical definition, where, with more or less gentle truncation or extension, a plausible theory will be formed. If one weak point after another be discovered in this, a new bulwark of hypothesis will be thrown up to protect it, and at last the fort be made inipregnable,-but, alas! in the meantime it has become a castle in the air. Should, however, the genius of the disputant lie less in the power of distinguishing and refining, than in that of presenting his views in a broad and striking manner, should his fancy be rich and his feelings strong,- -above all, should he be one of a nation where eloquence is at once the most common gift and the most envied attainment,- -he will call in rhetoric to the aid of his cause; and, in this event, as the accessory gradually encroaches and elbows out that interest in whose aid it was originally introduced,as the handling of the question becomes more important, and the question itself less so,- - there will result, not, as in the former case, a scholastic philosophy, but an arena for closet orators, who will' abandon the systematic study of philosophy, and varnish up declamations on set subjects. Such results, doubtless, did not follow in the time of Aristotle and Xenocrates. Under them, unquestionably, the original purpose of this discipline was kept steadily in sight; and it was not suffered to pass from being the test of clear and systematic thought to a mere substitute for it. But the transition must have been to a considerable extent effected when an Arcesilaus or a Carneades could deliver formal dissertations in opposition to any question indifferently, and when Cicero could regard the rhetorical practice as co-ordinate in importance with the other advantages resulting to the student. ${ }^{2}$ In the very excellence and reputation then of this peculiar discipline of the founder of the Peripatetic school, we have a germ adequate to produce a rapid decay of his philosophy, and we have no occasion to look either to external accidents or to the internal nature of his doctrines for a reason of the degeneracy of the Peripatetics after Theophrastus. 'The importance of this remark will be seen in the sequel.

It was probably in the course of this sojourn at Athens, which Aristotle's lasted for the space of thirteen years, that the greater number of Aris- prosperity. totle's works were produced. His external circumstances were at this time most favourable. The Macedonian party was the prevalent one at Athens, so that he needed be under no fears for his personal quiet; and the countenance and assistance he received from Alexander enabled him to prosecute his investigations without any interruption from the scantiness of pecuniary means. The conqueror is said in Athenæus to

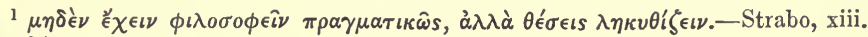
p. 124.

${ }^{2}$ See the passage cited above, p. 129, note ${ }^{1}$. Compare also Acad. Prior. ii. 18. "Quis enim ista tam aperte perspicueque et perversa et falsa secutus esset, nisi tanta in Arcesila, multo etiam major in Carneade, et copia rerum, et dicendi vis fuisset." Yet the eloquent Arcesilaus and Carneades left nothing behind them written.-Plutarch, De Fort. Alex. p. 323, ed Paris. 
have presented his master with the sum of eight hundred talents (about two hundred thousand pounds sterling) towards the expenses of his ' History of Animals," and enormous as this sum is, it is only in proportion to the accounts we have of the vast wealth acquired by the plunder of the Persian treasures. ${ }^{2}$ Pliny also relates that some thousands of men were placed at his disposal for the purpose of procuring zoological specimens, which served as materials for this celebrated treatise. The undertaking, he says, originated in the express desire of Alexander, who took a singular interest in the study of natural history. ${ }^{3}$ For this particular object, indeed, he is said to have received a considerable sum fiom $\mathrm{Philip}$, so that we must probably regard the assistance afforded him by Alexander (no doubt after conquest had enlarged his means) as having effected the extension and completion of a work begun at an earlier period, previous to his second visit to Athens. ${ }^{*}$ Independently, too, of this princely liberality, the profits of his occupation may have been very great, ${ }^{5}$ and we have before seen reason to suppose that his private fortune was not inconsiderable. It is likely, therefore, that not only all the means and appliances of knowledge, but the luxuries and refinements of private life, were within his reach, and having as little of the cynic as of the sensualist in his character, there is every probability that he availed himself of them. Indeed, the charges of luxury which his enemies brought against him after his death, absurd as they are in the form in which they were put, appear to indicate a man that could enjoy riches when possessing them, as well as in case of necessity he could endure poverty.

A ristotle retires to Chalcis in Eubce.

B. c. 322 .

But fortune, proverbially inconstant, was even more fickle in the days of Aristotle than our own. At an earlier period of his life, we have seen the virulence of political partizanship rendering it desirable for him to quit Athens. The same spirit it was which again, in his old age, forced him to seek refuge in a less agreeable but safer spot. The death of Alexander had infused new courage into the anti-Macedonian party at Athens, and a persecution of such as entertained contrary views naturally followed. Against Aristotle, the intimate friend and correspondent of Antipater (whom Alexander on leaving Greece had left regent), a prosecution was either instituted or threatened for an alleged offence against religion. ${ }^{6}$ The flimsiness of this pretext for

1 Athenæus, p. 338, e.

${ }^{2}$ See the authorities on this subject collected by Ste. Croix. Examen Historique, pp. $428-430$.

3 Hist. Nat. viii. 17.

4 Elian, Var. Hist. iv. 19.

5 See the beginning of the Hippias Major of Plato for the profits of the sophists, which there is no reason to suppose were greater than those of their more respectable successors. Hippias professes to have made, during a short circuit in Sicily, more than six hundred pounds, although the celebrated Protagoras was there as a competitor (sec. 5). Hyperbolus's instructions in oratory cost him a talent, or two hundred and fifty pounds. (Aristoph. Nub. 874.) But there is no means of deciding whether Aristotle's teaching was or was not gratuitous.

6 Phavorinus, ap. Diog. Laert. Vit. sec. 5; Elian, Var. Hist. iii. 36; Athenæus, 
crushing a political opponent-or rather a wise and inoffensive man, whose very impartiality was a tacit censure of the violent party spirit of his time-will appear at first sight of the particulars of the charge. Eurymedon the hierophant, assisted by Demophilus, accused him of the Frivolously blasphemy of paying divine honours to mortals. He had composed, it impiety. was said, a pæan and offered sacrifices to his father-in-law Hermias, and also honoured the memory of his deceased wife Pythias with libations such as were used in the worship of Ceres. This poean is the Scolium 'A $\rho \varepsilon \tau \dot{\alpha} \pi o \lambda v \mu o \chi \theta \dot{\varepsilon}, \& c$. , which we have described above (p. 118), and although we cannot tell what the circumstance was which gave rise to the latter half of the charge, we may reasonably presume that it as little justified the interpretation given to it as the ode does. That ignorance and bigotry, stimulated by party hatred, should find matter in his writings to confirm a charge of impiety founded on such a basis was to be expected; and he is related to have said to his friends, in allusion to the fate of Socrates, "Let us leave Athens, and not give the Athenians a second opportunity of committing sacrilege against philosophy." He was too well acquainted with the character of " the many-headed monster" to consider the absurdity of a charge as a sufficient guarantee for security under such circumstances, and he retired with his property to Chalcis in Euboa, ${ }^{1}$ where at that time Macedocian influence prevailed. In a letter to Antipater he expresses his regret at leaving his old haunts; but applies a verse from Homer in a way to intimate that the disposition that prevailed there to vexatious and malignant calumnies was incorrigible. ${ }^{2}$ It is not improbable that his new asylum had before this time afforded him an occasional retreat from the noise and bustle of Athens. ${ }^{3}$ Now, however, he owed to it a greater obligation. He was out of the reach of his enemies, and enabled to justify himself in the opinion of all whose judgment was valuable by a written defence of his conduct, ${ }^{4}$ and an exposure of the absurdities which the accusation involved. "Was it likely," he asks, His_defence. " that if he had contemplated Hermias in the light of a deity, he should have set up a cenotaph to his memory as to that of a dead man? Were funeral rites a natural step to apotheosis?" Arguments like p. 696; Origen, c. Celsum, i. p. 51, ed. Spencer; Demochares, cited by Aristocles (ap. Euseb. Præp. Ev. xv. 2).

${ }^{1}$ Apollodorus, ap. Diog. Vit. sec. 10. Lycon, the Pythagorean, cited by Aristocles (ap. Euseb. Præp. Ev. xv. 2), grounds a charge of luxury on the number of culinary utensils which were passed at the custom-house in Chalcis.

${ }^{2}$ Pseudo-Ammon; Elian, Var. Hist. iii. 36 (compare xii. 52); Phavorinus (ap. Diog. Vit. sec. 9).

${ }^{3}$ Diog. Vit. Epicuri, sec. 1 ; Strabo, x. p. 325, ed. Tauchnitz.

4 Athenæus (p. 697) quotes a passage from this work, to which he gives the title of $\dot{\alpha} \pi 0 \lambda o \gamma^{\prime} \alpha \dot{\alpha} \sigma \epsilon \beta \epsilon i \alpha s$, but at the same time mentions a suspicion that it was not genuine. It might very well be written by one of his scholars in his name, and embody his sentiments, just as the Apology of Plato does those of Socrates. This is the more likely, as Aristotle at this time appears to have been in a very weak

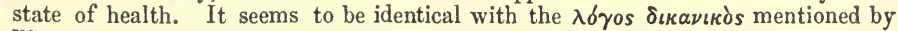
Phavorinus (ap. Diog. Vit. sec. 9), and to be so called because written in that form, although probably never intended to be recited in court. 
these, reasonable as they are, were not likely to produce much effect upon the minds of his enemies. The person of their victim was beyond their reach ; but such means of annoyance as still remained were not neglected. Some mark of honour at Delphi, probably a statue, had been on a former occasion (perhaps the embassy alluded to above) Insult passed decreed him by a vote of the people. This vote seems to have been upon him. at this time rescinded, an insult the more mortifying, if, as appears likely, it was inflicted on the pretext that he had acted the part of a spy in the Macedonian interest. ${ }^{1}$ In a letter to Antipater he speaks of this proceeding in a tone of real greatness, perfectly free from the least affectation of indifference. He alleges that it does not occasion him great uneasiness, but that he still feels hurt by it. ${ }^{2}$ It is impossible to find expressions more characteristic of an unaffectedly magnanimous nature, or which better illustrate the description of that disposition given by himself in one of his works. ${ }^{3}$

Coolness

towards him on the part of Alexander.

Callisthenes.

A subject which it is likely occasioned him during the latter years of his life far greater pain than anything which the fickle public of Athens could think or do, was the coolness which had arisen between himself and his illustrious pupil. It seems to have been closely connected with the conduct of Callisthenes, whom we have mentioned above (p. 126), who had accompanied Alexander into Asia by his particular recommendation. This individual possessed a cultivated mind, a vigorous understanding, and a bold and fearless integrity, combined with a strong attachment to the homely virtues and energetic character of the Macedonians, and a corresponding hatred and contempt for the Persian manners which had been adopted by Alexander after his successes. Unfortunately no less for those whom it was his desire to reform than for himself, the sterling qualities of his mind were obscured by a singular want of tact and discretion. ${ }^{4}$ He had no talent for seizing the proper moment to tell an unwelcome truth, and so far from being able to sweeten a reproof by an appearance of interest and affection for the party reproved, he often contrived to give his real zeal

Aristotle's advice to him the colouring of offended vanity or personal malice. Aristotle is said to have dreaded from the very first that evil would follow from these defects in his character, and to have advised him to abstain from frequent interviews with the king, and when he did converse with him, to be careful that his conversation was agreeable and goodhumoured. ${ }^{5}$ He probably judged that the character and conduct of Callisthenes would of itself work an effect with a generous disposition like Alex-

1 Demochares, cited by Aristocles.--Euseb. Præp. Ev. xv. 2.

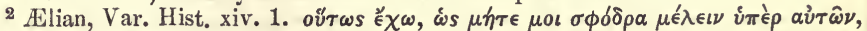
$\mu \eta \dot{\tau} \tau \epsilon \mu \eta \delta \hat{\epsilon} \nu \mu \epsilon \in \lambda \epsilon \iota \nu$. Pausanias (vi. 4, 8) speaks of a statue at Olympia said to be his: but it had no name, nor was it known who had placed it there.

${ }^{3}$ Nicom. Ethic. iv. p. 1123, col. 1, line 34.

4 Aristotle himself said of him, on hearing of his behaviour at court, that he was

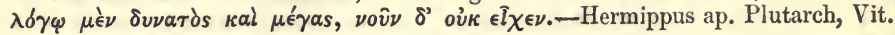
Alex. sec. 54.

${ }_{5}$ Valerius Max. vii. 2. 
ander's, and that its influence could not be increased, and would in all probability be much diminished, by the irritation of personal discussion, producing, almost of necessity, altercation and invective. Callisthenes, however, did not abide by the instructions of his master ; and, perhaps, the ambition of martyrdom contributed almost as much as the love of truth to his neglect of them. The description of Kent, which Shakspeare puts into the mouth of Cornwall, ${ }^{1}$ would certainly not do him justice; but it is impossible to shut our eyes to the fact that he made it " his occupation to be plain." Disgusted at the ceremony of the salaam, and the other oriental customs, which in the eyes of many were a degradation to the dignity of freeborn Greeks, he did not take the proper course, namely, to withdraw himself from the royal banquets, and thus by his absence enter a practical protest against their adoption; but, while he did not cease to attend these, he took every opportunity of testifying his disapprobation of what he Hisdislike of saw, and his contempt of the favours which were bestowed on such the Persian as were less scrupulous than himself. One of these, who appears to have particularly excited his dislike, was the sophist Anaxarchus,'an unprincipled flatterer, who vindicated the worst actions and encouraged the most evil tendencies of his master $;^{2}$ and perhaps a jealousy of this miscreant, and an unwillingness to leave him the undivided empire over Alexander's mind, was one reason which prevented him from adopting what would have been probably the most effectual as well as the most dignified line of conduct. Some anecdotes are related by Plutarch, which exhibit in a very striking manner both the mutual

1 This is some fellow,

Who, having been praised for bluntness, doth affect

A saucy roughness, and constrains the garb

Quite from his nature: He cannot flatter, he!

An honest mind and plain!- he must speak truth:

An they will take it, so : if not, he's plain.

These kind of knaves I know, which in this plainness

Harbour more craft, and more corrupter ends,

Than twenty silly ducking observants

That stretch their duties nicely!

King Lear, act ii. sc. 2.

${ }^{2}$ When Alexander, after having slain his friend Clitus in a fit of drunken passion, threw himself upon the earth, overwhelmed with remorse, deaf to the solicitations of his friends, and obstinately refusing to touch food, Callisthenes and Anaxarchus, the philosophers of that day standing in the place of the priests of this, were sent to offer him spiritual consolation. 'The latter, wise in his generation, determined to sear the conscience which he could not heal, and entered the tent with an expression of indignation and surprise. "What!" he cried, "is this Alexander, on whom the eyes of the whole world are bent? Is this he lying weeping like a slave, in fear of the reproaches and the conventional laws of men, when he ought to be himself the law and the standard of right and wrong to them ?-Why did he conquer the world but to rule and command it; surely not to be in bondage to it and its foolish opinions?" "Dost thou not know," he continued, addressing the un-

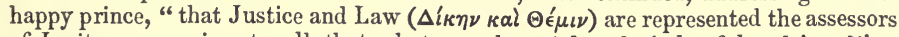
of Jupiter, as a sign to all that whatever the mighty do is lawful and just ?"Plutarch Vit. Alex. sec. 52. 
hatred of the philosophers breaking out in defiance of all the decencies of a court, and the rude bluntness of Callisthenes's manners. On one occasion, a discussion arose at supper-time, as to the comparative severity of the winters in Macedonia and in the part of the country where they then were. Anaxarchus, in opposition to his rival, strongly maintained the former to be the colder. Callisthenes could not resist the temptation of a sneer at his enemy. "You, at least," said he, " should hardly be of that opinion. In Greece you used to get through the cold weather in a scrubby jacket ( $\dot{\varepsilon} \nu \tau$ roi $\beta \omega \nu \iota)$; here, I observe, that you cannot sit down to table with less than three thick mantles

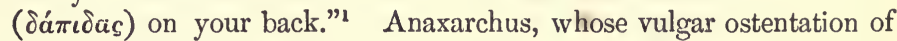
the wealth which his low servilities had procured him was observed and ridiculed by all, could not turn off this sarcasm; but the meanest animal has its sting, and he took care not to miss any opportunity for lowering the credit of Callisthenes with Alexander, a task which the unfortunate wrong-headedness ${ }^{2}$ of the other rendered only too easy. On the occasion of another royal banquet, each of the guests, as the cup passed round, drank to the monarch from it, and then, after performing the salaam, received a salute from him,-a ceremony which was considered as an especial nark of royal favour. Callisthenes, when his turn arrived, omitted the salaam, but advanced towards Alexander, who, being busy in conversation with Hephæstion, did not observe that the expected act of homage had been omitted. A courtier of Anaxarchus's party, however, Demetrius, the son of Pythonax, determined that their enemy should not benefit by this casualty, and accordingly called out, "Do not salute that fellow, sire, for he alone has refused to salaam you." The king, on hearing this, refused Callisthenes the customary compliment; but the latter, far from being mortified, exclaimed contemptuously as he returned to his seat, "Very well, then I am a kiss the poorer!"3 Such gratuitous discourtesy as this could hardly fail to alienate the kindness of a young prince, whose mere taste for refinement-leaving entirely out of consideration the intoxication produced by unparalleled success and the flatteries which

His popularity with the Greek party. follow it-must have been revolted by it. ${ }^{4}$ It, however, gained him great credit with the Macedonian party, who were no less jealous of the favour which the Persian nobles found with the conqueror than disgusted with the adoption of the Persian customs. He was considered as the mouth-piece of the body, and as the representative and vindicator of that manly and plain-speaking spirit of liberty which they

1 Plutarch, Vit. Alex. sec. 52.

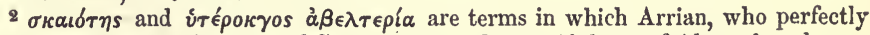
appreciates the manly spirit of Callisthenes, and is no idolater of Alexander, characterises his manners.-De Exped. Alex. iv. c. 12.

3 Plutarch, Vit. sec. 54 ; Arrian, iv. 12.

4 "Do not the Greeks seem to you," said he, on the occasion of Clitus's outrageous behaviour to two of his friends, "compared with the Macedonians, like demigods among brute beasts?"-Plutarch, Vit. sec. 51 . 
regarded as their birthright $;^{1}$ and the satisfaction which his vanity received from this importance, combined with a despair of reconquering the first place in Alexander's favour from the hated and despised Anaxarchus, probably determined him to relinquish all attempts at pleasing the monarch, and to adopt a line which might annoy and injure himself, but could hardly benefit any one. When an account was brought to Aristotle in Greece of the course pursued by his relation, his sharpsightedness led him at once to divine the result. In a line from the Iliad :- ${ }^{2}$

Ah, me! such words, my son, bode speedy death !

he prophetically hinted the fate which awaited him. Indeed the latter himself appears not to have been blind to the ruin preparing for him ; but this conviction did not produce any alteration in his conduct, or, if anything, it perhaps induced him to give way to his temper even more than before. At another banquet, the not unusual request was made to him, that he would exhibit his talents by delivering an extemporaneous oration, and the subject chosen was a panegyric upon the Macedonians. He complied, and performed his task so well as His indisto excite universal admiration and enthusiastic applause on the part of cretion. the guests. This circumstance appears to have nettled Alexander, whose affection for his old fellow-pupil had probably quite vanished, and he remarked in disparagement of the feat, in a quotation from Euripides, that on such a subject it was no great matter to be eloquent. "If Callisthenes wished really to give a proof of his abilities," said he, "let him take up the other side of the question, and try what he can do in an invective against the Macedonians, that they may learn their faults and reform them." The orator did not decline the challenge:- his mettle was roused, and he surpassed his former performance. The Macedonian nation was held up to utter scorn, and especial contempt heaped upon the warlike exploits and consummate diplomacy of Alexander's father Philip. His successes were attributed to accident or low intrigue availing itself of the dissensions which existed at that time in Greece; and the whole was wound up by the Homeric line-

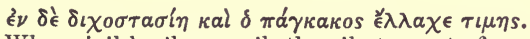

When civil broils prevail, the vilest soar to fame !

The effect of this course was such as might have been expected. Alexander fell into a furious passion, telling the performer, what was not far from the truth, that his speech was an evidence not of skill, but of malerolence; and the latter, perhaps conscious that he had now struck a blow which would never be forgiven, left the room, repeating as he went out a verse from the Iliad, which seems to be an allusion to the death of Clitus, and an intimation that he expected to be made the second victim to his sovereign's temper. ${ }^{3}$

1 Plutarch, Vit. sec. 53; Arrian, iv. 12.

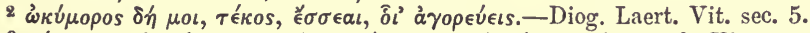

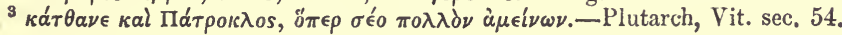


His ruin. A victim he was destined to be, although not in the way in which he appears to have expected. A practice had been introduced by Philip, similar to that which prevailed in the courts of the feudal sovereigns in the Middle Ages, that the sons of the principal nobles should be brought up at court in attendance on the person of the Conspiracy king. Of these pages, esquires, or grooms of the bedchamber (for of the pages. their office appears to have included all these duties ${ }^{1}$ ), who attended Hermolaus a on Alexander, there was one named Hermolaus, a youth of high
friend of Callisthenes. spirit and generous disposition, who was much attached to Callisthenes, and took great pleasure in his society and conversation. The philosopher appears to have considered his mind as a fit depository for the manly principles of Grecian liberty, which the tenets of Anaxarchus and the corrupt example of the monarch threatened utterly to extinguish, and, in the inculcation of these, to have made use of language and of illustrations, which, considering the circumstances of the case, were certainly dangerous, although in reference to the then prevailing tone of morality we shall scarcely be justified in censuring them. Harmodius and Aristogiton having, with the sacrifice of their own lives, been fortunate enough to bring about the freedom of their country, had been canonized as political saints, and were held up to all the youth of the free states of Greece for admiration and imitation; and Callisthenes can hardly deserve especial blame for participating in this general idolatry, or for regarding the glory of a tyrannicide as surpassing that of a tyrant, however brilliant the fortunes of the latter might be. Neither can we at all wonder that he should delight in depreciating the " pride, pomp, and circumstance" of greatness in comparison with dignity of character and manly energy, and in exposing the impotence of externals to avert any of " the ills to which flesh is heir." Such topics have been in all ages, and ever will be, the staple both of philosophy and of the sciolism which is its counterfeit; and the necessity for dwelling upon them must to Callisthenes have appeared the greater in order to counterbalance the habits of feeling which Persian manners and sophistry like that of Anaxarchus were calculated to spread among the Macedonian youth. $\mathrm{He}$ is said indeed to have continually professed that the only motive which induced him to accompany Alexander into Asia was that he might be the means of restoring his countrymen to their fatherland, as true Greeks as they went out, uncorrupted by the manners or the luxury of the barbarians $;^{2}$ and he seems unquestionably to have succeeded in putting a stop, at least for a time, to the ceremony of the salaam, of all eastern customs the most galling to Macedonian pride. $^{3}$ In an evil day, however, to Callisthenes, it happened that Hermolaus was out boar-hunting with Alexander, when the animal

1 Arrian, iv. c. 23.

2 Plutarch, Vit. sec. 53.

3 Plutarch, Vit. sec. 54. Compare Arrian, iv. 14, where Hermolaus is said to

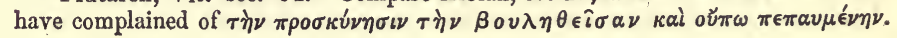


charged directly towards the king. The page, influenced probably more by the ardour of the chase, and his own youthful spirits, than by any just apprehension for his sovereign's safety, struck the creature a mortal wound before it came up to him. Alexander, the keenest of huntsmen, balked of his expected sport, in the passion of the moment, ordered Hermolaus to be flogged in the presence of his brother pages, Insulted by and deprived him of his horse (apparently the sign of summarily Alexander. degrading him from his employment). Such an insult to a Greek could only be washed out in the blood of the aggressor, and Hermolaus found ready sympathy among his compeers. It was agreed amrong them to assassinate Alexander while asleep, and the execution Plots his of the design was fixed for a night on which Antipater, the son of death. Asclepiodorus (whom Alexander had made lord-lieutenant of Syria), was to be the groom in waiting. It so happened that on that night Alexander did not retire to bed at all, but sat at table carousing until the very morning; whether by accident, or in consequence of the advice of a Syrian female, to whom in the character of a soothsayer he paid great respect, is not agreed by the contemporary historians. But this circumstance, whatever was the cause of it, saved the king and led to the detection of the plot. The next day, Epimenes, one of the conspirators, mentioned the matter to an individual who was strongly attached to him. This person spoke of it to Eurylochus, the brother of Epimenes, perhaps considering that his relationship was a sufficient guarantee for secrecy. Eurylochus, however, at once laid an information before Ptolemy Lagides, subsequently the first of the Greek dynasty in Egypt, and then one of the guard of lionour in attendance on Alexander. He reported to the king the names of Is detected. those who he had been told were concerned in the affair: they were arrested, and on being put to the torture confessed their crime and gave up the names of others who were participators. ${ }^{1}$ So far all accounts agree as to the substantial facts of this story, but here a great discrepancy commences. Ptolemy and Aristobulus ${ }^{2}$ both asserted Inculpation that the pages named Callisthenes as the instigator of their design. of CallisThis, however, was denied by the majority of contemporary writers on the subject, who related that the ill-will towards Callisthenes previously existing in the mind of Alexander, united with the intimacy between Hermolaus and the former, furnished ample means to his

${ }^{1}$ Arrian, iv. 13, 14.

${ }^{2}$ Aristobulus was one of Alexander's generals, and wrote an account of his campaigns. He did not, however, commence this work till his eighty-fourth year (Lucian, De Macrob.), long enough, therefore, after the transaction in question, to allow us to suppose that by a slip of the memory he may have confused circumstantial with direct evidence. Moreover, as there was nothing which made Alexander so unpopular as the execution of Callisthenes (Quintus Curtius, De rebus gestis Alex. viii. c. 3), so there was nothing which his biographers took so much pains to extenuate. See Ste. Croix, p. 360, et seq.; Arrian (iv. 14, fin.), at the same time that he speaks of the opportunities of knowledge possessed by Ptolemy and Aristobulus, and of their general fidelity, yet remarks that their accounts of the details of this affair differ from one another. 
enemies to raise a strong suspicion against him.' They alleged, that to a question from Hermolaus, "How a man might make himself the most illustrious of his species?" he replied, "By slaving him that is most illustrious;" and that to incite the youth to the rash act he bade him " not be in awe "of the couch of gold, but remember that such a one often holds a sick or a wounded man;" also, that when Philotas had asked him whom the Athenians honoured most of all men, he replied, "Harmodius and Aristogiton, the tyrannicides ;" and when the querist expressed a doubt whether such a person would at the existing time find countenance and protection anywhere in Greece, he replied, "That if every other city shut its gates against him, he would certainly find a refuge in Athens ;" and in support of this opinion quoted the instance of the Heraclidæ who there found protection against the tyrant Eurystheus. ${ }^{2}$ It requires but little penetration to see how, under circumstances of such peculiar irritation, the words of Callisthenes might, with very little violence and with the greatest plausibility, be interpreted in a treasonable sense, although they were nothing more than Macedonian principles expressed in a strong and antithetical manner. Indeed, the very admixture of legendary history in the instance of the sons of Hercules seems to betray the commonplaces of the rhetorician. And that this account of the matter, to which Arrian, following the majority of contemporary accounts, inclines, is the true one, seems proved beyond all doubt by two letters of Alexander himself, which are cited by Plutarch. In the former of these, written immediately after the event to his general, Craterus, he states, "that the pages on being put to the torture confessed their own treason, but denied that any one else was privy to the attempt." $\mathrm{He}$ wrote to Attalus and Alcetas to the same effect. But afterwards in a letter to Antipater, he says, "the pages have been stoned to Inculpation death by the Macedonians; but as for the sophist, I intend to punish of Aristotle. him, and those too who sent him out, and also the cities which harbour conspirators against me." In the latter part of this phrase, according to Plutarch, he alludes to Aristotle, as being the great-uncle of Callisthenes, and him by whose advice he had joined the court. It seems plain that in the interval between the writing of these letters, Alexander's mind had been worked upon by those whose interest it was to identify the cause of manliness and virtue with that of disloyalty and treason, by Anaxarchus and the crew of court sycophants whose practice he sanctioned by his example, and attempted to justify by his philosophy. The tide of hatred, however, was setting too strong against Callisthenes for him to stem it. He was placed under confinement, and according to accounts, which there is too much reason to fear are true, cruelly mutilated. It is said to have been Alexander's intention to bring

1 Arrian, loc. cit.

2 Plutarch, Vit. sec. 55; Arrian, iv. 10. This Philotas is not the son of Parmenio, put to death, together with his father, on a former occasion, but a page, the son of Carcis, a Thracian. See Arrian, iv. 13. 
him to a trial in the presence of Aristotle on his return to Greece; but the unfortunate man, after remaining in his deplorable situation for a considerable time, died from the effects of ill-treatment.

Whatever prejudices against his old master may have been raised in Ineffective the mind of Alexander on the score of Callisthenes, and whatever ill during the consequences might perhaps have followed if the conqueror had lived Alexander. to revisit Europe, intoxicated with his military successes, and hardened by the influence of those flatterers who, after Callisthenes's death, reigned supreme at court, it is explicitly stated by Plutarch, that while he lived, his estrangement never led him to injure Aristotle in the slightest degree. Mortification, therefore, at the degeneracy of his pupil, and sorrow at the loss of an affection in which he doubtless took both pride and pleasure, were the only evils which the latter during his remaining days had to endure. But a few vears after the death of both, a story began to be circulated which at last grew into a form in the highest degree detrimental to his character. It is impossible to Report which arose after the doubt that Alexander died from the fever of the country, caught imdeath of mediately after indulgence in the most extravagant excesses. At the time no suspicion to the contrary was entertained. ${ }^{1}$ But some time afterwards, the ambitious and intriguing Olympias, who had long indulged a bitter hostility towards Antipater (a hostility which the successful establishment of the latter in the government of Macedonia after her son's death had inflamed into a fiendish hatred), seized the opportunity which Alexander's rapid illness afforded, to throw the suspicion of poisoning him upon her enemy, whose younger son Iolaus had been his cupbearer. It was not till the sixth year after the fatal event that this story was set on foot; and it seems to have originated in nothing but Olympias's desire of vengeance, which then first found a favourable vent. The bones of Iolaus, who had died in the interim, were torn from their grave, and a hundred Macedonians, selected from among the most distinguished of Antipater's friends, barbarously butchered..$^{2}$ The accusation of poisoning the king seems at first to at first vague; have been vaguely set on foot, the only circumstantial part of the story being the point necessary to justify Olympias's malignity, namely - that Iolaus was the agent in administering the poison. But in afterwards process of time the minutest details of the transaction were supplied. detailed. We give them in the last form which they assumed. The fears of Antipater, it was said, arising from the growing irritation of Alexander incessantly stimulated by Olympias, induced him, on hearing that he was superseded by Craterus and ordered into Asia with new levies, to plot against his master's life. A fit means for this purpose was pointed out to him by his friend Aristotle, who dreaded the personal consequences to himself which seemed likely to follow from Alexander's anger against Callisthenes. ${ }^{3}$ The nature of this is quite in

${ }^{1}$ Plutarch, Vit. sec. $77 . \quad 2$ Diodorus, xix. 11; Plutarch, loc. cit.

8 Although Callisthenes had been put to death five years before, $i_{0} e$. in B. C. 328 ! See Clinton, Fast. Hel. ii. p. 376. 
keeping with the other features of the narrative. It was no other than the water of the river Styx, which fell from a rock near the town of Nonacris in Arcadia, and which, according to a local superstition which is not extinct to this day, ${ }^{1}$ possessed not only the property of

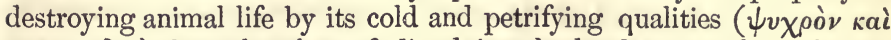
$\pi a \gamma \varepsilon \tau \tilde{\omega} \delta \varepsilon s)$, but also that of dissolving the hardest metals, and even precious stones. One substance alone was proof against its destructive influences-the hoof of a Scythian ass! In a vessel made out of this, a small portion of the fluid was conveyed by Cassander, Iolaus's elder brother, into Asia, and, on the occasion of the debauch at which Alexander was taken ill, administered to him by the latter. Iolaus was stimulated to the act by the desire of revenging an outrage upon himself committed by the king, and attachment to him induced Medius, a Thessalian, at whose palace the debauch took place, to be an accomplice in the treason. The assassin, according to the author of the 'Lives of the 'Ten Orators,' falsely attributed to Plutarch, ${ }^{2}$ was rewarded by a proposition of the demagogue Hyperides at Athens, to confer public honours upon him as a tyrannicide, and the horn cup in which the fatal draught had been conveyed from Greece deposited in the temple of Delphi.

Its refutation The absurdity of this account is glaringly manifest to readers of the present day, of whom nine out of every ten are probably better acquainted with the nature and operation of petrifying springs than the best informed of the Greek naturalists were. The ancients were not in possession of the touchstone for the discovery of falsehood which modern science affords; but even they were long before they attached any credence to the calumny. "The greater part of the writers on the subject," says Plutarch," "consider the whole matter of the alleged poisoning a mere fiction; and in confirmation of this view they quote the fact, that although the royal remains lay for several days unembalmed in consequence of the disputes of the generals-and that too in a hot and close place-they exhibited no marks of corruption, but remained fresh and unchanged." Arrian ${ }^{5}$ too, who, as well as Plutarch, derives his account of the king's illness and death from the court gazettes (' $\dot{\phi} \eta \mu \varepsilon \rho i \delta \varepsilon s)$, and confirms the statements of these by the

1 See Col. Leake's Travels in the Morea, vol. iii. pp. 165-9. The natives say that the water, which they call $\tau \dot{\alpha} \mathbf{M} \alpha \nu \rho \alpha-\nu \epsilon ́ p \iota \alpha$ (the black waters), and $\tau \dot{\alpha} \Delta \rho \alpha \kappa o-$ $\nu$ épı (the terrible waters), is unwholesome, and also that no vessel will hold it. It is a slender perennial stream falling over a very high precipice, and entering the rock at the bottom, which is said to be inaccessible, from the nature of the ground. Col. Leake quotes the phrases of Homer, $\kappa \alpha \tau \epsilon \iota \beta \delta \mu \epsilon \nu o \nu \Sigma \tau \tau v \gamma \delta s \delta \delta \omega \rho$, and $\Sigma \tau v \gamma \delta s$

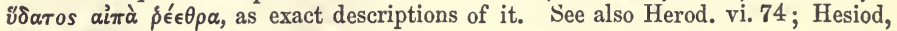
Theog. $785,805$.

2 P. 849. The same is stated by Photius, Biblioth. p. 496.

${ }^{3}$ Epigr. ap. Alian, De Nat. Animal. x. 40. That it should have been deposited there, as the Epigram states, by Alexander himself, is a circumstance which will not add much, in the opinion of modern critics, to the incredibility of the story.

4 Vit. Alex. ult. 5 vii. 27. 
narratives of Ptolemy and Aristobulus, says of the charge of poisoning, which he afterwards mentions, that he has alluded to it merely to show that he has heard of it, not that he considers it to deserve any credit. In fact, the sole source of the story in its details appears to have been one Hagnothemis (an individual of whom nothing else is known), who is reported to have said that he had heard it told by king Antigonus. ${ }^{1}$ But its piquancy was a strong recommendation to later writers ; and it is instructive and amusing to observe how their statements of it increase in positiveness, about in proportion as they recede Its gradual from the time in which the facts of the case could be known. Dio- growth. dorus Siculus and Vitruvius, living in the time of the two first Cæsars, merely mention the rumour that Alexander's death was occasioned by poison through the agency of Antipater, but do not pretend to assert its credibility. Quintus Curtius, writing under Vespasian, considers the authorities on that side to preponderate. The epitomizer of a degenerate age, Justin, flourishing in the reign of Antoninus Pius, slightly alludes to the intemperance which he allows had been assigned as the cause of Alexander's death, but adds that, in fact, he died from treason, and that the disgraceful truth was suppressed by the influence of his successors. And finally Orosius, in the fifth century, states broadly and briefly that he died from poison administered by an attendant, without so much as hinting that any different belief had ever even partially obtained. ${ }^{2}$ But it is remarkable that, of all these writers, not one mixes up Aristotle's name with the story; and it is probable that the foolish charge against him, mentioned (and discountenanced) by Plutarch and Arrian, fell into discredit very soon after it arose, and perhaps was only remembered as a curious piece of scandalous history, until the half-lunatic Caracalla thought proper to revive it, in order to gratify at once the tyrant's natural hatred for wisdom and virtue, and his own morbid passion for idolizing the memory of Alexander. It is recorded of him that he persecuted the Aristotelian sect of philosophers with singular hatred, abolishing the social meetings of their body, which appear to have taken place in Alexandria, confiscating certain funds which they possessed, and even entertaining the

1 Plutarch, Vit. Alex, loc. cit.

2 Diodorus, xvii. 117; Vitruvius, viii. 3 ; Q. Curtius, x. 10 ; Justin. xii. 14; Orosius, iii. 20. It is possible that some readers may quote Tacitus (Annal. ii. 73) as opposing the view we have given in the text of the gradual progression of credulity. But the exception is only apparent. Tacitus does not give his own view, but merely that of those who chose to draw a parallel between the circumstances of Germanicus's life and those of Alexander ; for which purpose this version of the death of the latter was necessary, and, perhaps, to this it owed much of its subsequent popularity. With respect, too, to the silence respecting Aristotle, it is to be remarked that the expressions of Pliny ("magnâ Aristotelis infamiâ excogitatum," Hist. Nat. xxx. ult.), if they are genuine, do not imply a belief, either on his own part or that of people in general, that the philosopher was guilty of abetting Antipater. But they seem more likely to be a marginal note, implying that " the story of the poisoning by such water was a figment that had done Aristotle's character much harm." 
design of destroying their master's works, on no other ground than that Aristotle was thought to have aided Antipater in destroying Alexander.

Its possible origin.

To attempt to account for the origin of so absurd a charge as that we have been discussing may perhaps appear rash. We cannot, however, resist the temptation to hazard a conjecture that while the intimacy of Aristotle with Antipater undoubtedly furnished a favourable soil for the growth of the story, the actual germ of it is to be looked for at Delphi. The cup in the treasure-house there, which the epigram we have quoted above represents as presented by Alexander, was probably of onyx, a stone of which the coloured layers, resembling as they do the outer coats of a hoof, procured it the name by which it goes. Now, it is obvious that in the time of which we are speaking, when the merchant who sold the wares was, for the most part, himself a traveller in distant countries, marvellous tales would be related respecting the strange commodities which he imported. The onyx might to the admiring Greek be represented as the solid hoof of some strange animal, with no less plausibility than in the fourteenth century a cocoa-nut could be sold as a griffin's egg-a long univalve shell represented as the horn of a land animal-or the ammonites of Malta regarded as serpents changed into stone by St. Paul. ${ }^{2}$ And although the more extensive communication with the East, which commenced after Alexander's expedition, would, in process of time, spread more correct views on the subject of natural productions, the old legends would linger in the temples; handed down traditionally by the attendants, who showed the curiosities to strangers, and were expected to be provided with a story for every relic. ${ }^{3}$ If any one of these Ciceroni ('绿 $\left.\eta \gamma^{\prime} \tau a \iota\right)$, aware of

1 Xiphilinus, Epitom. Dionis. pp. 329,330. Caracalla wore arms and used drinking cups which had belonged to Alexander, erected a great number of statues to him both in Rome and at the several military stations, and raised a phalanx of Macedonians, armed all after the manner of five centuries back, which he named after the Conqueror of the East. [In his wish to destroy the philosopher's works

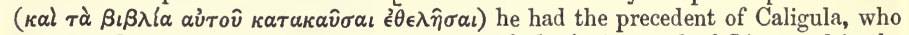
threatened to do the same with the works of the jurists and of Livy, and in the case of the latter carried his threat out to a considerable extent.--Suetonius, Vit. Calig. 34.] See also Dio Cassius. Ixxvii. 7.

${ }_{2}$ Compare, for instance, the stories related by Herodotus (iii. 102-111) of the way in which gold-dust and the various spices brought from the East were procured. The account which he gives of cinnamon is confirmed, with a little variation in the details, by Aristotle, Hist. Anim. ix. 13, p. 616, col. 1, Bekk. Theophrastus (Hist. Pl. iv. 7, 8) represents various corals as plants growing in the Indian Ocean. The Madrepora muricata is termed by him "stone thyme." The informant of Herodotus was no doubt some one of the travelling merchants which came by the caravans to Egypt.

${ }^{3}$ It has been remarked by Heeren, that Herodotus's account of the history of Egypt is derived entirely from local narrations connected with public monuments. (Manual of Ancient History, pp. 52, 53, Eng. transl.) This remark admits of far wider application. It would not be difficult to show that almost all the early events recorded by that author rest on the same basis. For instance, the history of the Lydian kings in the first book is obviously entirely made up of stories connected with offerings in the temples of Apollo at Delphi and Miletus. This is plain from the fact that every narrative at all circumstantial of any of these 
the intimate friendship which subsisted between Aristotle and Antipater, and also of the rumour that Alexander had been poisoned through the ageney of the latter, had either chanced to stumble himself, or to be directed by a more learned visitor to a passage in a work of Theophrastus (Aristotle's favourite scholar and successor), at that time extant, which stated " that in Arcadia there was a streamlet of water dropping from a rock, called the water of Styx, which those who wished for, collected by means of sponges fastened to the end of poles; and that not only was it a mortal poison to whoever drank it, but it possessed the property of dissolving all vessels into which it was put, except they were of horn," he must have possessed much less fancy, and a much greater regard for historical accuracy than the rest of his countrymen, if he did not, when the next pilgrin visited the temple, add at least a conjecture or two as to the connexion which the relic in question had with a story possessing so much interest to all. It should not be forgotten, in reference to that part of the account which represents Aristotle as the descoverer of this peculiar property of the "Stygian water" - that Theophrastus is the earliest authority for its possessing it, and that if Aristotle had been aware that such a belief existed, we

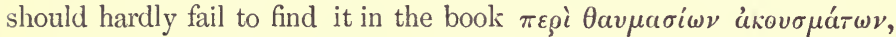
in the 121st chapter of which there is an account of a pestilential fountain in 'Thrace, the water of which was said to be clear and sparkling, and to the eye like any other, but fatal to all who drank of it.

We must now return from the discussion of the imputed share of Death of Aristotle in the death of his illustrious pupil, to the narrative of his Aristotle. own. He did not long survive his departure from the city in which he had spent so large a portion of his life. He retired to Chalcis in the year of Cephisodorus's archonship (в. C. 323-322), and early in that of his successor Philocles died (as we are justified by Apollodorus's authority in stating positively ${ }^{2}$ ) from disease. At nearly the same time the greatest orator that the world ever saw, the leader of that party whose influence had expelled Aristotle from Athens, was driven to have recourse to poison to escape a worse fate. There are not wanting accounts that the philosopher also met a violent death. That he poisoned himself to aroid falling into the hands of his varions accusers is the view of Suidas and the anonymous author of his Life. ${ }^{3}$ accounts.

monarchs terminated with a reference to one of these temples. The historians before him, with, perhaps, the exception of Hellanicus, made use even of the topographical form of composition.

${ }_{1}$ Theophrastus, ap. Antigonum Carystium, Hist. Mirab. sec. 174. Pausanias, where he describes the water and its singular effects, speaks of the story of Alexander having been destroyed by it as one which he had heard, but not as if it had been told him at the place. Beckmann (ap. Antig. Caryst. loc. cit.) supposes that a part of the legend is due to the fact that the water contained a volatile acid which exercised a corrosive effect upon metallic cups.

2 Ap. Diog. Vit. sec. 10, and Dionys. Hal. Ep. Amm. p. 728.

3 They appear to follow one Eumelus, whom Diogenes (Vit. Arist. sec. 6) cites and contradicts. He related that Aristotle died by drinking hemlock, at the age of seventy, and had become a pupil of Plato at that of thirty. See p. 104.

[G. R. P.] 
But independently of the superior authority of Apollodorus, and the evidence which Aristotle's own opinions, expressed in more than one place, on the subject of suicide, afford, in contradiction of this story, the fact of Chalcis being then under Macedonian influence, and, consequently, a perfectly secure refuge for any one persecuted for real or supposed participation in Macedonian politics, is quite enough to induce us to reject this story. A yet more absurd one is repeated by some of the early Christian wiiters. Mortification, according to them, at being unable to discover the cause of the Euripus ebbing and flowing seven times every day, induced him to throw himself headlong into the current. ${ }^{1}$ Of this story it is scarcely necessary to say more than that the phenomenon which produced such fatal consequences to the philosopher does not really exist. The stream constantly sets through the narrow channel between Eubœa and the mainland from north to south, except when winds blowing very strongly in an opposite direction produce for a time the appearance of a current from south to north. ${ }^{2}$ But instead of wasting time upon the refutation of these foolish accounts, we shall perhaps please our readers better by bringing together a few circumstances which appear to confirm the statement of Apollodorus, to which independently of them we should not be justified in refusing belief.

Confirmation Aulus Gellius ${ }^{3}$ relates that Aristotle's scholars, when their master of A pollodorus's statement.

had passed his sixty-second year, and being in a state of extremely bad health, gave them but little hopes that he would survive for any length of time, entreated him to appoint some one of their body as his successor, to keep their party together and preserve the philosophical views which he had promulgated. There were at that time, says Gellius, many distinguished men among his disciples, but two preeminently superior to the rest. Menedemus (or, as some suppose it should be written, Eudemus), a Rhodian, and Theophrastus, a native Aristotle's of Eresus, a town in the island of Lesbos. Aristotle, perhaps unappointment of a successor which a selection, however judicious, might produce, contrived to avoid the invidious task, and at the same time to convey his own sentiments on the subject. He replied, that at the proper time he would satisfy their wishes; and shortly afterwards, when the same persons who had made the request happened to be present, he took occasion to complain that the wine which he usually drank did not agree with him, and to beg that they would look out for some sort which might suit him better-for instance, said he, some Lesbian or Rhodian; two

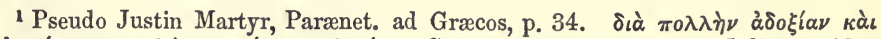

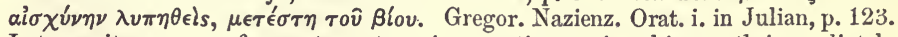
Later writers go so far as to put various sentiments into his mouth immediately before the perpetration of this rash act. Elias Cretensis (Comm. in S. Greg. Orat. iv.) attributes to him the words "Quoniam Aristoteles Euripum non cepit, Aristotelem Euripus habeat."

2 Tanaquil Faber, Epp. Critic. i. 14.

3 Noct. Att. xiii. 5. 
wines which, as is notorious, were beyond almost any others celebrated in antiquity. When a sample of each had been brought to him, he first tasted the latter, and praised it for its soundness and agreeable flavour. Then trying the Lesbian, he seemed for a time to doubt which he should choose, but at last said, "Both are admirable wines, but the Lesbian is the pleasanter of the two." He never made any further allusion to the matter of a successor, and the disciples universally concluded that this observation relative to the Rhodian and Lesbian vintages was meant as an answer to their question, Theophrastus the Lesbian being a man singularly distinguished for suavity both of language and manners; and accordingly, on the death of Aristotle, they unanimously acknowledged him as the chosen successor. That this anecdote implies the belief that a disease of some duration was the cause of the philosopher's death is quite obvious; and there is some ground for supposing that this disease was an affection of the intestines, from which he had long suffered. This affection, says another ancient author, ${ }^{1}$ which he bore with the His prohable complaint. greatest fortitude, was of such a nature that the wonder is that he contrived to prolong his life to the extent of sixty-three years, not that he died when he did. For complaints of this kind warm fomentations of oil applied to the stomach were recommended in the medical practice of antiquity. ${ }^{2}$ Now Lycon the Pythagorean, ${ }^{3}$ a bitter calumniator of Aristotle, grounded a charge of inordinate luxury against him upon the assertion that he indulged himself in the habit of taking baths of warm oil : an assertion which, if we should fail at once to recognise it as a misrepresentation of the medical treatment alluded to, will be unequivocally explained by the more accurate description of another writer, ${ }^{4}$ who obviously alludes to the same circumstance.

Diogenes Laertius, as we have mentioned in an earlier part of this His will. essay, speaks of having seen Aristotle's will, and proceeds to give the substance of it. ${ }^{5}$ That this is not an abstract of the authentic document is obvious from the circumstance that no mention whatever is made in it of his literary property, which was very considerable, and which we know from other sources came to Theophrastus. ${ }^{6}$ Neither, however, does there seem to us any well-grounded suspicion that the account of Diogenes is either a forgery, or the copy of a forgery. The whole document bears the stamp, in our judgment, of a codicil to a previously-existing will, drawn up at a time when the testator was dangerously ill, and had but little expectation of recovery. Thus, at the very commencement, Antipater, the regent of Macedonia, is

1 Censorinus, cited above, p. 6.

2 Celsus, ii. 17, iii. ult.

${ }^{8}$ Cited by Aristocles, ap. Euseb. loc. cit. He adds, that his avarice induced him to sell the oil after this use had been made of it.

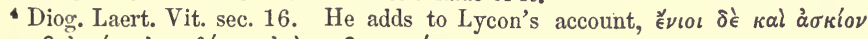

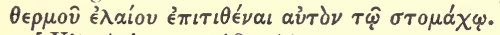

5 Vit. Arist. sec. 12-16.

${ }^{6}$ Strabo, xiii. p. 124. 
appointed the supreme arbiter and referee, and four other persons besides Theophrastus, "if he be willing and able," are directed to administer, until Nicanor, the son of Proxenus - to whom he gives his orphan daughter in marriage and the guardianship of his orphan son Nicomachus, together with the whole management of his pro-

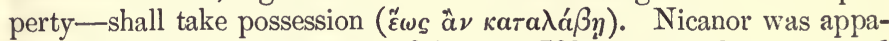
rently abroad on some service of danger. If he escapes, he is directed by the codicil to erect certain statues of four cubits in height in Sta-

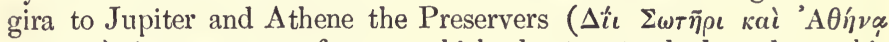
$\sigma \omega \tau$ ri $\rho$ n), in pursuance of a vow which the testator had made on his account. If anything should happen to Nicanor before his marriage, or after his marriage before the birth of children, and he should fail to leave instructions, Theophrastus is to take the daughter, and stand for all purposes of administration in the place of Nicanor. Should he decline to do so, the four provisional trustees are to act at their own. discretion, guided by the advice of Antipater. Besides these arrangements, all which seem adapted to meet a sudden emergency, such as that of a man dying away from the person in whom he put the most confidence, and in doubt whether the one whom he next trusted would be able to act, we find legacies to more than one individual which apparently imply a former bequest, ${ }^{1}$ and a trifling want of arrangement in the latter part, quite characteristic of a document drawn up under the circumstances we have supposed. 'Thus, he orders statues to be erected to Nicanor, and Nicanor's father and mother; also to Arimnestus (his own brother), " that there might be a memorial of him, he having died childless." A statue of Ceres, vowed by his mother, is to be set up at Nemea or elsewhere. Then, as if the mention of one domestic relation had suggested another, he commands that wherever he should be buried, the bones of his deceased wife should be taken up and laid by his side, according to her desire; and after this he again reverts to the subject of statues to be set up, and gives directions for the fulfilment of the vow which he had made for the safety of Nicanor.

Aristotle's descendants.

Aristotle left behind him a daughter named after her mother, Pythias. She is said to have been three times married; first, to Nicanor, the son of Aristotle's guardian Proxenus, and his own adopted child; secondly, to Procles, a descendant-apparently son or grandson-of Demaratus, King of Lacedæmon, by whom she had two

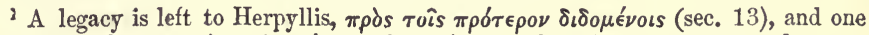
Simus is to have $\chi \omega \rho l s \tau o \hat{v} \pi \rho \delta \tau_{\epsilon} \rho \nu \nu$ á $\rho \gamma \nu \rho i o v$, another slave, or money to buy one (sec. 15). The battle of Cranon took place in August, B. C. 322; but it is very probable that it could not be safély conjectured till some time after what course Greek politics would take. If now Theophrastus was in Athens, and not with Aristotle at Chalcis, as seems far from improbable (see Diog. Laert. Vit. Theophrasti, see. 36), Aristotle might reasonably fear that he, perhaps, would not be able to act as his executor. Thus, too, when he directs a house and furniture to be provided for Herpyllis, he selects Chalcis and Stagira, both places where she would be safe from Athenian hatred, for her to choose between as a residence (sec. 14). 
sons named Procles and Demaratus, scholars of Theophrastus; and, thirdly, to Metrodorus, an eminent physician, to whom she bore a son named after his maternal grandfather.' He also left behind him an infant son, named after his paternal grandfather, Nicomachus, by a female of the name of Herpyllis, of whom it is very difficult exactly Herpyllis. to say in what relation she stood to him. To call her his mistress would imply a licentious description of intercourse which the name by which she is described $(\pi \alpha \lambda \lambda a \kappa \eta)$ by no means warrants us in supposing, and which the character of Aristotle, the absence of any allusion to such a circumstance in the numerous calumnies which were heaped upon him, and the terms of respect in which she is spoken of in his will, ${ }^{2}$ would equally incline us to disbelieve. It seems most probable that he was married to her by that kind of left-handed marriage which alone the laws of Greece and Rome permitted between persons who were not both citizens of the same state. The Latin technical term for the female in this relation was concubina. She was recognised by the law, and her children could inherit the sixth part of their father's property. Mark Antony lived in this kind of concubinage with Cleopatra, and Titus with Berenice. 'The two Antonines, men of characters the most opposite to licentiousness, were also instances of this practice, which indeed remained for some time after Christianity became the religion of the state, and was regulated by two Christian emperors, Constantine and Justinian. ${ }^{3}$ The Greek term is not used so strictly in a technical sense, and may be said to answer with equal propriety to either of the Latin words pellex and concubina. Where, however, the legal relation was denoted, there was no other word selected in preference ; ${ }^{*}$ and we may safely say that this, in the case

1 Stahr. Aristotelia, p. 164.

${ }^{2} \mathrm{He}$ provides amply for her, and enjoins his executors, if she should desire to marry, to take care that she is not disposed of in a way unworthy of him, remind-

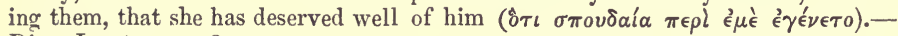
Diog. Laert. sec. 13.

3 Taylor, Elements of the Civil Law, p. 273. The terms "semi-matrimonium" and "conjugium inæquale" were applied to this connexion, which was entered into before witnesses ("testatione interpositâ") and with the consent of the father of the woman. Both contracting parties, too, were obliged to be single. See Gibbon, vol. v. c. xliv. pp. 368-370.

4 The author of the oration against Neæra thus uses it in the distinction which he

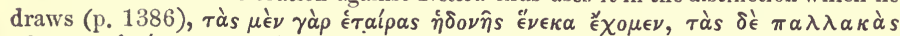

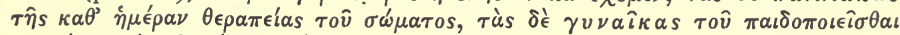

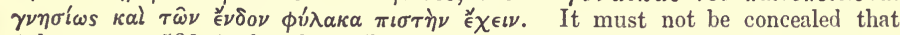
Athenæus, p. 589 (and perhaps Hermippus, whom he quotes), called Herpyllis by

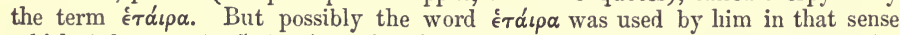
which Athenæus (p. 571, c.) speaks of. And even if Herpyllis had been originally an adventurer of the same description as Aspasia, we shall not necessarily think the worse of Pericles for marrying the latter, or Aristotle the former, when we consider that everything which elevates marriage above a faithful intercourse of this kind is due to the religious sanction and the religious meaning which it derives from Christianity. In Paganism the superiority of the one to the other was purely legal and conventional. The wife was the housekeeper and the breeder of citizens, and nothing whatever more. 
before us, is the probable interpretation, although there is no positive authority that it is the true one. The son Nicomachus was brought up by Theophrastus, and if we are to credit Cicero's assertion, that the Nicomachean Ethics which are found among Aristotle's works, were by some attributed to him, must have profited much by his master's instructions. It seems, however, more likely that Aristocles's account of him is the correct one, who relates that he was killed in battle at a very early age. ${ }^{1}$

Fate of Aristotle's u orks.

Straho's account.

The works of Aristotle are said to have met with a most singular mischance. They are related to have been buried some time after his death, and not to have been recovered till two hundred years afterwards. This story is so curious in itself, and of such vital importance in the history of philosophy, that we shall make no apology for investigating it thoroughly, in spite of the length to which this article has already been extended.

The main authority for the opinion is Strabo, in a passage of his geographical work, ${ }^{2}$ where, having occasion to speak of Scepsis, a town in the Troad, he mentions two or three persons of eminence who were born there. One of these is Neleus, the son of Coriscus, a person who was a scholar both of Aristotle and Theophrastus, and who succeeded to the library of the latter, in which too was contained that of the former. "For Aristotle," Strabo goes on to say, " made over his own library to Theophrastus (to whom he also left his school), and was the first that I know of who collected books and taught the kings in Egypt to form a library. Theophrastus made them over to Neleus; he took them over to Scepsis, and made them over to his heirs ( locked up without any care. When, however, they observed the pains which the kings of the Attalic dynasty (in whose dominions the town was) were at to get books to furnish the library at Pergamus, they buried them under ground in a sort of cellar, and a long time

1 Áristocles, ap. Eüseb. loc. cit.; Cicero, De Fin. v. 5.

2 Geogr. xiii. p. 124, ed. Tauchnitz. We have translated the whole of this celebrated passage as it stands in the text of all the printed editions. But besides the

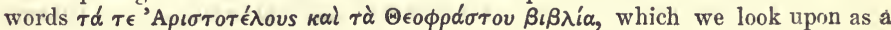
marginal note that has crept into the text, there appears to us to be unquestionably a corruption in the latter part. In default of the authority of MSS., a conjecture can only be received with great caution; but still we should be inclined to think,

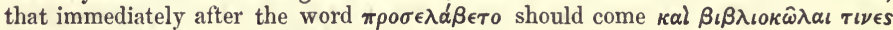
.....'A $A \epsilon \xi \alpha \nu \delta \rho \epsilon i \alpha$, and that after $\beta \iota \beta \lambda \iota 0 \theta \eta \kappa \eta s$ probably followed something like

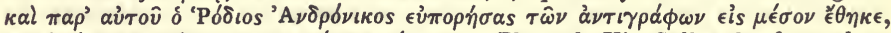

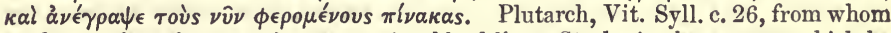
we have laken these words, unquestionably follows Strabo in the account which he gives of this affair. He cites him by name almost immediately afterwards, as is remarked by Schneider. (Præf. ad Aristot. H. A. p. lxxx.) It was, however, scarcely the Geography, but the Historical Memoirs of Strabo, which was his authority through the life of Sylla. Hence the slight divarication of the two narratives: in the topographical work the circumstances of the story which are most connected with Scepsis are principally dwelt upon; in the other those connected with Sylla. 
after, when they had received much injury from damp and worms, the representatives of the family sold them to Apellicon of Teos-the books both of Aristotle and of Theophrastus-for a very large sum. Apellicon was more of a book-collector than a philosopher; and the result was that, in an attempt to supply the gaps on the transcription of the text in new copies, he filled them up the reverse of well, and sent the books abroad full of mistakes. And of the Peripatetic philosophers, the more ancient who immediately succeeded Theophrastus, as in fact they had no books at all, except a very few, and those chiefly of the exoteric class, were unable to philosophize systematically, but were obliged to elaborate rhetorical disquisitions $\left(\mu r_{i} \delta \dot{\varepsilon} \nu\right.$

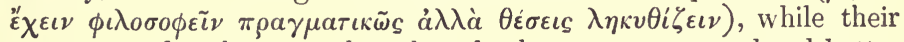
successors after the time when these books came out, speculated better and more in Aristotle's spirit than they, although they too were forced

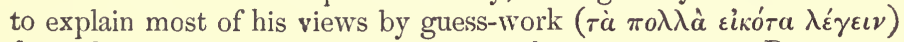
from the multitude of errors. And to this inconvenience Rome contributed a large share. For immediately after the death of Apellicon, Sylla, having taken Athens, seized upon the library of Apellicon; and after it had been brought here, Tyrannio the grammarian, who was an admirer of Aristotle, had the handling of it ( $\left.\hat{o}_{\varepsilon} \chi \varepsilon \iota \rho i \sigma \alpha \tau 0^{1}\right)$ by the favour of the superintendent of the library ; and [so had] some booksellers, who employed wretched transcribers, and neglected to verify the correctness of the copies, an evil which occurs in the case of all other authors too when copied for sale, both here ${ }^{2}$ and in Alexandria."

Plutarch, in his biography of Sylla, ${ }^{3}$ confirms a part of this account, I'lntarch's and adds a feature or two which is wanting here. His authority is account. obviously Strabo himself in another work now lost, and he is, therefore, not to be reckoned as an additional witness, but as the representative of the one last summoned, again recalled to explain some parts of his own testimuny. From him we learn that Sylla carried the library of Apellicon, containing the greater part of the books of Aristotle and Theophrastus, with which up to that time most people had no accurate acquaintance, to Rome. "There," he continues, "it

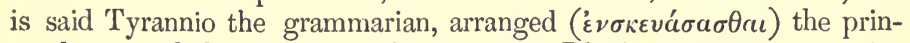
cipal part of them, and Andronicus the Rhodian, obtaining copies from him, published them, and drew up the syllabuses (rivakas) which are now current." He confirms the account of Strabo that the early Peripatetics had neither a wide nor an accurate acquaintance with the works of Aristotle and Theophrastus, from the circumstance of the property of Neleus, to whom Theophrastus bequeathed his books, falling into the hands of illiterate and indifferent persons; but of the story of burying the books he says nothing, nor yet of the endeavours of Apellicon to repair the damaged manuscripts.

1 In the parallel narrative of Plutarch the term $\epsilon^{\nu} \nu \sigma \kappa \epsilon v a ́ \sigma \alpha \sigma \theta \alpha \iota$ is used.

2 For the carelessness of transcribers at Rome, see Cicero, Epp. Fam. iii. 5; and Martial, ii. 8.

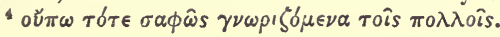


General helief of the story.
Athenaus statement.

Our readers have here the whole anthority ${ }^{1}$ which is to be found in the writers of antiquity for this celebrated story, which has been transmitted from one mouth to another in modern times without the least question of its truth until very lately. And not only has it been accepted as a satisfactory reason for an extraordinary and most important fact, the decay of philosophy for the two centuries preceding the time of Cicero, but editors and commentators of the works of Aristotle have resorted to it without scruple for a solution of all the difficulties which they might encounter. They have allowed themselves the most arbitrary transpositions of the several parts of the same work, and acknowledged no limit to the number or magnitude of gaps which might be assumed as due to the damp or worms of the cellar at Scepsis. ${ }^{2}$ Of late years, however, as the critical study of the Greek language has increased, and the attention of scholars been more drawn towards the philosophical department of antiquity, the inadequacy of this story to account for the state in which Aristotle's writings have come down to us has become more and more apparent; notices have been found which are quite incompatible with it; and at the present time it may safely be said that the falsity of the account Unwarranted in the main is completely proved. We will endeavour to give our readers some idea of the laborious researches which have led to this result. They have been carried on chiefly, if not entirely, by German philologers, the pioneers in this as in almost every other uncleared region of antiquity. ${ }^{3}$ But we must first call their attention to some other circumstances which would, antecedently to the investigations of which we speak, dispose us to look with some suspicion on the tale, unless very considerably qualified.

The work of Athenæus, to which we are indebted for so much fragmentary information on matters of antiquity, is cast in a form which had particular attractions for the readers of the time in which the author lived-the reigns of Marcus Aurelius and Commodus. A wealthy Roman is represented as hospitably entertaining several persons eminent for their acquaintance with literature and philosophy ; and the most curious notices imaginable from a multitude of writers,

\footnotetext{
1 The account of Suidas (v. $\Sigma \dot{v} \lambda \lambda a s$ ) is obviously extracted from the passage in Plutarch.

2 Thus Antonius Scainus interpolated the serenth and eighth books of the Politics between the third and fourth. Conringe, who followed him, made up for a scrupulous abstinence from this course by indulging himself freely in hypothesized lacunce, to such an extent that Goettling somewhat facetiously observes, Asteriscis suis interpositis noctem Aristoteliam quasi stellis illustrare sategit.Pref. ad Arist. Polit. p. 6.

${ }^{3}$ Brandis, Ueber die Schicksale der Aristotelischen Buecher, und einige Kriterien ihrer Aechtheit, in Niebuhr's Rheinisches Museum, vol. i. Kopp, Nachtrag zur Brandisischen Untersuchung, \&c. in the same work, vol. iii. Fabricius (Biblioth. Græca, iii. c. v.) mentions a French author who, in a work entitled Les Aménités de la Critique, published at Paris in 1717, impugns the story of Strabo. Of the two German writers, the former has contributed by far the more important investigations of this subject. Stahr (Aristotelia, Zweiter Theil) has availed himself of both, but has added little of his own.
} 
and upon all subjects, are woven ingeniously into the conversation of the guests. Nearly in the beginning of the work, the author, who himself is one of them, enlarges on the splendid munificence, the literary taste, and the accomplishments of the host. Among other things he praises the extent and value of his library. "It was of such a size," he says, "as to exceed those of all who had gained a reputation as book-collectors,-Polycrates the Samian, Pisistratus the tyrant of Athens, Euclid (also an Athenian), Nicocrates of Cyprus, ay, the kings of Pergamus too, and Euripides the poet, and Aristotle the philosopher,

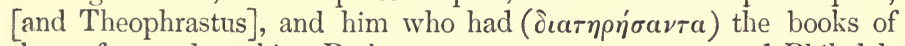
these, from whom king Ptolemy my countryman, surnamed Philadelphus, bought the whole, and carried them away, together with those he got from Athens and those from Rhodes, to the fair city of Alexandria." It is obvious that the author here follows an account very different from Strabo's, one which represented Neleus's library including the costly collections of Aristotle and Theophrastus as forming, together with some others, the basis of the famous collection at Alexandria. Now it is utterly inconceivable that if Ptolemy bought the whole library of Neleus, he should have been satisfied to leave the works of Aristotle and Theophrastus only behind in the hands of men so ignorant of their value, and careless of what became of them as Neleus's heirs are represented to have been, if no other copies of these works existed; and even supposing it possible that he should have done so, would not so singular an incident of literary history have been mentioned by some author of antiquity? Should we not find some record of it in Cicero, Silence of from whom we learn so much of the history of Greek philosophy? $\mathrm{He}$ even mentions the degeneracy of the Peripatetic school after Theophrastus in strong terms $:^{1}$ is it conceivable that if it had been attributable to the want of their founders' works, he should either have not heard of this, or should not think it worth mentioning? Could such a story have escaped the anecdote collectors under the empire, Elian, Phavorinus, and a host of others? Would Diogenes Laertius, who relates how many cooking utensils Aristotle passed at the Eubœan custom-house, have neglected so interesting an anecdote as this? Such considerations, combined with the notice in Athenæus, must prevent an impartial judge from attaching more than a very small degree of credit to that part of Strabo's narrative, which denies the publication of the works of Aristotle to any considerable extent before the time of Sylla. And this scepticism will not be diminished when we consider, that the greater part of Aristotle's works are so closely connected with Close coneach other that if any were published all or nearly all must have been nexion of so. He continually refers from the one to the other for investigations works.

1 De Finibus, v. 5. "Simus igitur contenti his [i.e. Aristotele et Theophrasto] namque horum posteri, meliores illi quidem meâ sententiâ quam reliquarum philosophi disciplinarum; sed ita degenerarunt, ut ipsi ex se nati esse videantur." It is strange that the words in italic characters should not have opened the eyes of men to look for a general cause of a general deterioration. Could they suppose that all the schools had lost all their books? 
which are necesssary to the argument which he has in hand. And although these references may be, and probably often are, due to a later hand, still this objection cannot he made in all cases, - in those, for instance, where the special work referred to is not named, but described in such a way that it is impossible not to identify it. ${ }^{1}$

But, after all, these arguments are little else than negative, and although they lead to a probability of a very high order against the truth of Strabo's narrative, they are not absolutely conclusive. In fact, the work of disproof is a most difficult one, from the circumstance of Destruction the whole of the literature of the two centuries after Theophrastus, of literature. enormous as its extent was, having been swept away, except such scanty fragments as are found here and there imbedded in the work of some grammarian or compiler. This will be strikingly evident from the consideration, that if the works of Aristotle, which have come down to us, had been lost, and a similar story had been related of Plato's works to that which we read in Strabo respecting those of Aristotle and Theophrastus, its refutation would be quite as difficult as that of the one about which we are at present concerned. But the difficulty of the problem did not damp the ardour of the German scholars we have spoken of above. They have searched through the works of the voluminous commentators upon Aristotle, which the learned eclecticism of the third, fourth, and fifth centuries of the Christian era produced, some of them still only existing in manuscripts, ${ }^{8}$ with an untiring diligence, and have detected in the works of much more modern scholiasts extracts from their predecessors, which prove to demonstration that the notice in Athenæus is in all probability true, and that certainly so much of Strabo's account as is incompatible with it is false.

1 Ritter, Geschichte der Philosophie, vol. iii. p. 35, gives a list of the passages in which the philosopher alludes to his own writings. Against many of these the objection we have noticed may be made. A more conclusive one is Poetic. p. 1454, col. 2, line 18 (quoted by Stahr, Aristotelia, ii. p. 296), from which it is certain that an Ethics-not, however, necessarily the Nicomachean-was published at the time the passage was written. But. unfortunately (supposing the work alluded to to be the Nicomachean Ethics), there is, perhaps, no one of Aristotle's writings so independent of all the rest.

$\checkmark$ The Royal Academy of Berlin were induced, by the advice of Schleiermacher, to publish a complete edition of Aristotle's works, based upon the collation of as many manuscripts as could be made available for the purpose. The execution of this work was placed under the superintendence of two most distinguished men; the one, Immanuel Bekker, the celebrated editor of Plato, Thucydides, and the Greek Orators-a scholar whose piercing intuition into the genius of the Greek language can only be compared to that of Newton into the laws of the universe, or that of Niebuhr into the institutions of antiquity; the other, Christian Brandis, the friend of Niebuhr, and guardian of his orphan children. The former fulfilled his portion of the task in 1831, by publishing the text of Aristotle's works from the collation of more than a hundred manuscripts, in two volumes, quarto. The latter, to whom the task of collecting and arranging the Greek commentators, and of elucidating the philosophy, devolved, published one volume of those (some from hitherto unedited manuscripts) in 1836, and promised in the preface a second, with prolegomena, as soon as the pressure of bad health would allow. 
We have seen that, according to the authorities on which the story rests, a very considerable impulse was given in the first century before the Christian era to the study of the Peripatetic philosophy. Andro- Ancient nicus the Rhodian is mentioned as the principal promoter of this commentarevival, having rearranged the works of Aristotle in a way which was totle. generally received in the time of Strabo, and which formed the basis of the present division. Contemporary with Andronicus, although younger than him, was Athenodorus of Tarsus ; and in the next generation to Athenodorus, Boëthus of Sidon, both celebrated for their acquaintance with the doctrines of Aristotle, and for their investigations of the literary questions connected with them. Now, although the works of all these writers have perished, ${ }^{1}$ they were not lust until they had furnished materials to Adrastus and Allexander of Aphrodisias, in the second century, and the Eclectic philosophers, Ammonius, Saccias, Porphyry, Ammonius the son of Hermias, Simplicius, and David the Armenian, in the third, fourth, and fifth; and of most of these considerable remains have come down to the present time, ${ }^{2}$ so that we are enabled, with very great precision, to ascertain the views

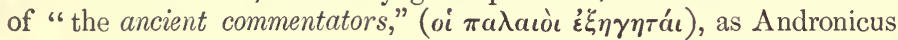
and his contemporaries are called by their more modern followers, on several particulars, and among others, on some having a direct bearing upon the story of Strabo.

We find, for instance, that a point which occupied much of the snme of their attention of the "ancients," was to determine between the claims of views still rival works, bearing the same name, and upon the same subject, to be reputed the genuine productions of Aristotle. Andronicus questioned

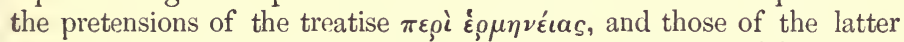
part of the 'Categories." Adrastus found two editions (if we may use the expression) of the latter work, differing very considerably from each other. The same was stated by him of the seventh book of the 'Physical Lectures.' Cicero mentions it as a question which could not be decided, as to whether a work on Ethics (apparently that which

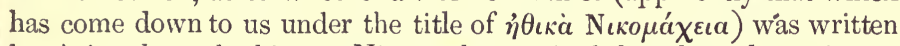
by Aristotle, or by his son Nicomachus. And that the only evidences on the one side or the other were merely internal, is obvious from the remark in which he expresses his inclination towards the latter opinion, " that he does not see why the style of the son should not bear a close resemblance to that of the father." Another question which occasioned considerable perplexity, was the arrangement of the several works which were held to be genuine. The present distribution is entirely based upon an arrangement which goes no further back than the time of Andronicus, and is entirely different from the one or more known.

1 The Paraphrase of the Nicomachean Ethics, which has come down to us under the name of Andronicus's, is generally considered to be of a later date.

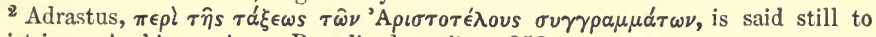
exist in an Arabic rersion. Brandis, loc. cit. p. 253.
${ }^{3}$ Brandis, p. 241.
4 Brandis, loc. cit.
5 De Fin. v. 5. 
which appear to have prevailed before him. There are at this day three known catalogues of the writings - the first is the one given by Diogenes Laertius in his life, the second that of the anonymous Greek biographer published by Menage. These resemble one another very much, and bear every appearance of having been derived, probably, however, through secondary channels, from the same source, which has been conjectured with great plausibility to be Hermippus of Alexandria's work, ${ }^{1}$ of which we have spoken in the early part of this essay. But it is impossible to imagine a greater difference than is found between these lists and the works which have come down to us. The names are so completely unlike, and there are so many reciprocal omissions, that a scholar of the sixteenth century was able, with the aid of a mortal antipathy to the Aristotelian philosophy, to succeed in persuading himself that everything which has come down to us under the name of the great Stagirite, was, with very slight exceptions, spurious. ${ }^{2}$ The third catalogue is found only in Arabic, and is said to much more nearly correspond with our own $;^{3}$ and, indeed, a great part of the difference between this and the two former is explicable from the fact that the same work is often referred to under more names than one, not merely by subsequent commentators on Aristotle, but also by the philosopher himself. ${ }^{4}$ But such differences, independently of positive testimony, abundantly show that many pieces which now form the component parts of a larger treatise were not left by the author in such an order, or, at least, that no authentic documents from which any given arrangement could be decidedly inferred, came to the

Andronicus possessed no authentic copy. knowledge of Andronicus and his brethren. If they had,-if, that is, the manuscripts of Apellicon had been, as they are represented, a genuine copy of all or most of Aristotle's works, never till then known, the task of these critics would have been a most easy one. There would have been no occasion for discussions of the internal evidence to determine between various readings of the text, different systems of arrangement, or contending claims as to authorship. A simple reference to a primitive copy would at once have settled all. And what shall we say to the letter of Alexander to Aristotle, complaining that he had published his acroamatic works, and thus put the world on a footing with his most highly-instructed pupil? It is of no avail to urge that the letter is not genuine: it very likely may not be so, but it was

1 Brandis, pp. 249, 262.

2 Patritius, Discussiones Peripateticæ, i. p. 16, et seq. His only exceptions were the Mechanics, and the treatise on the doctrines of Xenophanes, Zeno, and Gorgias. Some years afterwards a yet more extravagant opinion was propounded, that the present Greek manuscripts of Aristotle were translations from the Arabic. Philippe Cattier (quoted by Harles on Fabricius, Bib. Gr. vol. iii. p. 207) mentions it as the belief of some.

${ }^{3}$ Brandis, p. 262.

4 Brandis, p. 261. Petiti (Observatt. Miscell. iv. 9) and Buhle (Commentationes Societatis Reg. Gottingensis, vol. xv. p. 57), quoted by Brandis, give several instances of this identity; as also Brandis himself (Diatribe de perditis Arist. libris De Ideis et De Bono, p. 7). 
extracted by Gellius from the book of the very Andronicus whom this tale represents as the first publisher of these, and therefore proves his belief at any rate that some of them had been published long before. ${ }^{1}$

This evidence seems to prove incontrovertibly that the part of Strabo's and Plutarch's narrative which relates to the extraordinary treasure first made available by Andronicus, cannot be true. By another chain of testimony, equally elaborate, Brandis has shown that many of the works of Äristotle, of the highest and most recondite character, that we now possess, were actually in the hands of the Peripatetic school, whose degeneracy has been attributed to the loss of them. It is well known that the successors of the great philosopher in several instances composed works on the same subject (and sometimes identical in title also), with existing treatises of their founder. ${ }^{2}$ For, indeed, the spirit of dogmatism, which is often imputed to the Aristotelian philusophy by persons who are only acquainted with the schoolmen's modifications of it in the fifteenth and sixteenth centuries, is really so alien to it, that it would be difficult to find in the history of civilization an example of a more vigorous and healthy independence of thought, and a greater ardour for investigation than is afforded by the earlier disciples of the Lyceum. ${ }^{3}$ Although the works in question have long since been lost, Brandis has succeeded in eliciting from the notices which remain of them in the commentators we have referred to, very many particulars, which show in some instances that the author actually followed the course of the Aristotelian parallel work, and in more, that he made use of it. Under the first of these two classes are brought, by decisive arguments, the 'Physical Lectures' and the first book of the 'Former Analytics ;' and there is a considerable probability that the second book of the 'Former Analytics' and the fifth of the 'Metaphysics' may be added to these. ${ }^{4}$ Under the second we may number the 'Latter Analytics,' the 'Categories,' perhaps the treatise $\pi \varepsilon \rho$ ' $\varepsilon \rho \mu \eta \nu \varepsilon i a c$, the 'Topica,' the treatises 'On the Heavens,' ' On Growth and Corruption,' ' On the Soul,' and the 'Me-

${ }^{1}$ Aulus Gellius, Noct. Att. xx. 5 .

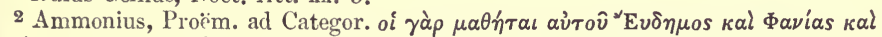

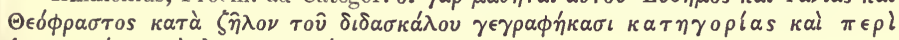

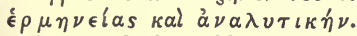

${ }^{3}$ Aristotle himself is especially noticed for having modified some of his views, which had been attacked by other philosophers, with perfect readiness, and without attempting any vexatious resistance or exhibiting any annoyance: $\stackrel{\epsilon}{\epsilon} \nu l \alpha \tau \hat{\omega} \nu \pi \rho \delta \sigma \theta \epsilon \nu$ à̃oois (besides Aristotle, Democritus and Chrysippus are spoken of ), à $\rho \epsilon \sigma \delta \nu^{\prime} \sigma \omega \nu$

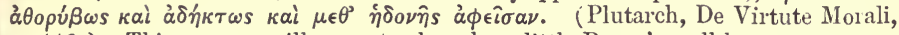
p. 448.) This passage will serve to show how little Bacon's well-known representation of him as one who "bore, like the Turk, no brother near the throne," is founded on fact. But, in truth, the great father of modern science imputed to Aristotle all the positiveness and dogmatism of the modern Aristotelians : his disgust at the idolaters was extended to the object of their idolatry. Somewhat simi-

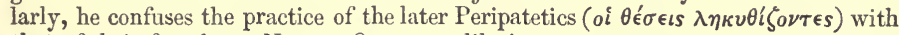
that of their founder.-Novum Organum, lib. i. sec. 71.

${ }^{*}$ Brandis, pp. 266-269, 281, 28:. 
teorologica.' $\quad$ Further researches on the principle here indicated may very probably add to the lists, but a very small part of either would be sufficient to demonstrate-when we consider that almost every one of these treatises would involve the possession of some others in order to be itself intelligible - that it was not the want of acroamatic works that produced the decay of the Peripatetic school.

Also to the Stoics.

Also to the A lexandrian scholars.
To make an objection to the inference which these facts allow us to draw against the correctness of Strabo's story, on the ground that Theophrastus may possibly have chosen to keep the works of Aristotle, as well as his own, in his own possession, and communicate the use of them only to the more favoured of his scholars, would be a most arbitrary proceeding; as there is not the slightest historical ground for such an hypothesis. But Brandis has precluded even this step. He has shown that Chrysippus the Stoic (who, in his dialectical work, quoted by Plutarch, ${ }^{2}$ speaks in the highest terms of the cultivation of that branch of science by the Academics down to Polemo, and the Peripatetics down to Strato inclusive), in several of his particular doctrines had an especial reference to the former treatment of the same by Aristotle, Eudemus, and Theophrastus. ${ }^{3}$ His discussion of the idea of Time is entirely based upon that of Aristotle, and exhibits an unworthy endeavour to conceal the similarity. ${ }^{4}$ Nay, the ancient commentators of highest reputation maintained that the whole of the Stoics' logical science, on which they prided themselves much, was nothing more than a following out of Aristotle's principles, and, in particular, that their doctrine of Contraries ( $\tau \dot{\alpha} \varepsilon \dot{\varepsilon} \nu \alpha$ ' $\nu \iota \alpha)$ was entirely

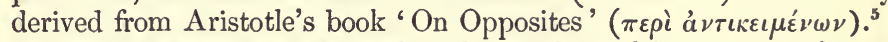

But it was not only to philosophers either of his own or of rival sects that the works of Aristotle were known at the time when they are reported to have been lying in the cellar at Scepsis. Aristophanes of Byzantium, the celebrated grammarian of Alexandria in the early part of the second century before Christ, made an abridgement of his Zoological works, ${ }^{6}$ and also wrote commentaries apparently on these, or some other of his works relating to Natural History. ${ }^{7}$ But before his time, Antigonus of Carystus, under Ptolemy Euergetes (B. c. $247-$ 222), in his 'Collection of Wonderful Stories,' quoted largely both from these and from the works of Theophrastus on similar subjects. Kopp says that he used not only these, but also the work on Foreign Customs ( $\beta a ́ \rho \beta a \rho a$ vó $\mu \mu \alpha)$, and that the same is probable both of

${ }^{1}$ Brandis, pp. 270, 272-275.

2 De Stoic. Repugn. p. 1045, fin.

3 Brandis, pp. $246,247$.

4 To the passages illustrative of this position collected by Baguet, De Chrysippi Vitâ, Doctrinâ, et Reliquiis, pp. 170, 181, Brandis adds Aristol. Phys. Ausc. iv. $10-14$.

5 Simplicius ap. Brandis, p. 247, note 30.

${ }^{6} \tau \dot{\alpha} \pi_{\pi \in \rho l} \phi \dot{v} \sigma \epsilon \omega s \zeta \omega \omega \nu$. Hierocles cited by Schneider, Præf. ad Hist. Arist. p. xviii.

7 Artemidorus, Oneirocr. ii. c. 14, on which see Schneider, p. xix. 
Callimachus and Nicander, ${ }^{1}$ and he acutely remarks, that the reason that the works on the Parts of Animals and the Generation of Animals are not so often cited as the History, is that the latter furnished far more materials for works that would possess a general interest, whereas the former necessarily implied a certain knowledge of physiology in the reader. But that they could not have remained unknown while the latter was published, is evident from the circumstance that in it the author frequently refers to them. Nor were the writings which related to physical phenomena the only ones which we are sure reached Alexandria. Andronicus related, that in the great library there were found forty books of 'Analytics' and two of 'Categories,' professedly the work of A ristotle. Of the former of these four only, of the latter one-in both instances those which we have-were decided upon by the ancient critics to be genuine. ${ }^{2}$. Besides which, the "Alexandrian writers, who formed canons of classical poets, historians, and philosophers, included Aristotle among the last, surely not on the strength either of his mere reputation, or only of his exoteric works.

But what, after all, was the nature of these exoteric writings; for Nature of the we are now obviously come to a point at which the accurate determi- exoteric nation of this question, which the continuity of the narrative has hitherto prevented, becomes necessary. We shall endeavour to be as brief as possible in our answer.

If we apply to Aristotle himself for information, we shall find Aristotle's nothing at all in his writings to confirm the popular opinion of a divi- division. sion of his doctrines into two classes, the one of which was communicated freely, while the other was carefully reserved for those disciples whose previously-ascertained character and talents were a security for their right appreciation of them. Wherever the term exoteric occurs, it is with reference to a distinction, not of readers, or hearers, but of questions treated on. It signifies little or nothing more than extrinsic, separate, or insulated. That facility of comprehension as regards the main subject-matter was not necessarily a characteristic of such works, appears from a passage in the 'Metaphysics,' ${ }^{3}$ in which the writer excuses himself from touching upon the doctrine of ideas (or constituent forms) any more than the order of his work demanded, assigning as a reason, that his views on this particular "were for the most part farniliar from the exoteric discourses." It is notorious that this was one of the deepest and most difficult questions of the ancient philosophy, being, in fact, the point where the schools of the Academy and the Lyceum diverged, and, consequently, if any part of Aristotle's views had been confined to a chosen few, -if there had been such a thing as an esoteric coterie,--here would have been proper matter to

1 Rheinisches Museum, vol. iii. pp. 95-98. He also says that Aratus, in his Prognostics, made use of the meteorological works of Aristotle.

2 Ammonius, Simplicius, and David the Armenian, cited by Brandis, p. 250.

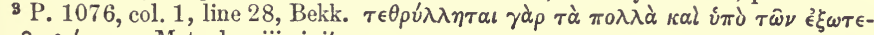

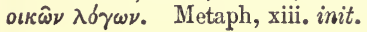


be reserved for them. Similarly, in the Nicomachean Ethics, ${ }^{1}$ he refers his readers to "the exoteric discourses" for an analysis of the human mind. The law of subordination among the parts of a composite whole, as, for instance, the law of harmony in music, is another subject which he considers as " rather proper for an exoteric investigation. " In "the exoteric discourses," he discussed the philosophy of life, the relative importance of the several elements which go to make up happiness, and the conditions which the social relation imposes on a mani. ${ }^{3}$ And in the same he proposes that an examination of the idea of Time should be gone into. ${ }^{4}$ Here then we have ample evidence that the most abstruse subjects, physical, metaphysical, and moral, were treated of somehow or other in discourses bearing the name of exoteric, a name to which modern usage has almost indissolubly attached the notion of shallowness, if not something like fraud also. Of anything like freemasonry, anything amounting to a severance of knowledge into two distinct spheres, the one to be inhabited by the vulgar, the other by choicer spirits, there is not a vestige. If any acroamatic work by Aristotle has come down to us, the Nicomachean Ethics is one. Yet in it is nothing requiring such profundity of reflection or sobriety of mind as would be demanded by the psychological discussion in the exoteric work to which the author refers. And as for the terms by which Plutarch and Clement of Alexandria denote that class of works which they place in contradistinction to the exoteric, they are in part not used by Aristotle at all, and in part used in a totally different sense. ${ }^{5}$ The phrases by which he designates such

1 P. 1102, col. 1, line 26, Bekk.

2 Politic. i. p. 1254, col. 1, line 33, Bekk. ка! yà

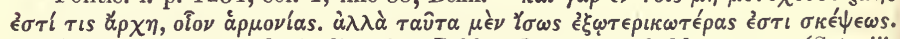

${ }^{3}$ Politic. p. 1323, col. 1, line 22, Bekk. In a remarkable passage (Sat. iii. 67-72) the Stoic Persius sums up all the great questions with which the philosophy of his school engaged. The parts printed in italics would all have been handled by Aristotle in the exoteric discourses to which he in this passage refers:causas cognoscite rerum;

Quid sumus; et quidnam victurigignimur; ordo

Quis datus; aut metæ quam mollis flexus, et unde;

Quis modus argento; quid fas optare; quid asper

Utile nummus habet; patrio, carisque propinquis

Quantum elargiri deceat; quem te Deus esse

Jussit; et humanâ quâ parte locatus es in re.

It is apparently to this work of Aristotle that Cicero refers. Acad. ii. 42; De Fin. ii. sec. 13 , iv. $18,20,26$; and probably De Offic. iii. 8.

${ }^{4}$ Phys. Auscult. p. 217, col. 2, line 31, Bekk.

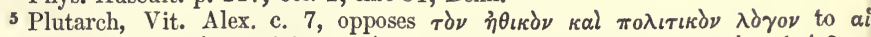

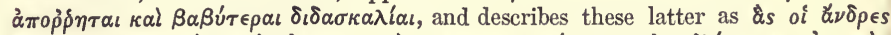

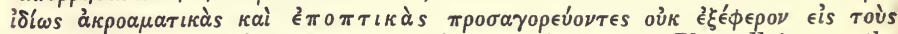

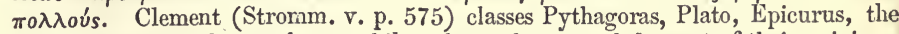
Stoics, and Aristotle together as philosophers who concealed a part of their opinions.

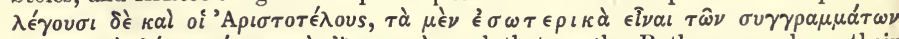

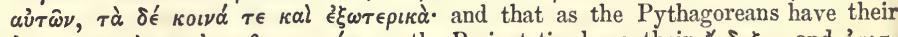

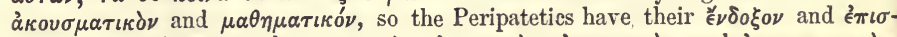

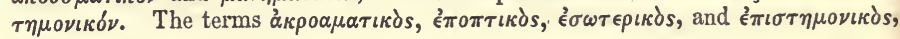


works as appear to stand in opposition to the exoteric, are $\lambda$ ó you

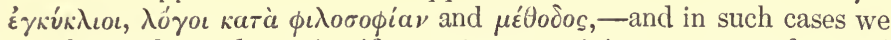
are always directed to scientific treatises containing a system of several parts methodically arranged and organically cohering, such in short as would be formed by the outline of a continuous course of lectures on some main branch of philosophy. And that the works included under the name acroamatic or acroatic by the philosophers since the time of Andronicus Rhodius, were of this description, seems most probable, Division of not only from the appearance presented by those which have come down to us, but fron the fact that, at the time when Greek philosophy was first imported into Rome, the word ápóaseıs had become the technical term for such productions. Crates Mallotes, who came to Rome on an embassy between the second and third Punic wars, is spoken of by Suetonius in terms which seem to show that a similar distinction to that which obtained in Aristotle's works, prevailed also in his. ${ }^{1}$

If now we keep steadily in view this distinction which it is plain Primary chathat Aristotle himself made in his discourses, the distinction between racteristics. cyclical, methodical, scientific productions, and insulated, independent essays, we shall perceive at once from the nature of the case, that, without any premeditated design on the part of the author, the former would ouly be appreciable by genuine disciples, those who were able and willing to afford a steady and continuous application to the development of the whole, while the latter might be understood by those who brought no previous knowledge with them, but merely attended to the matter in hand $;^{2}$ - that the one required a severe and rigid logic to preserve all parts of the system in due coherence, the other readily admitted of the aid which the imagination affords to the elucidation of single points, but which often becomes mischievous when they are to be combined; that to the first the demonstrative form of exposition would alone be appropriate, to the second any one, narrative or dialogic, or any other, which might be most fit for placing the one matter are never used by Aristotle, and the word ámó $\hat{\rho} \hat{\rho} \eta \tau$ os only in the ordinary classical

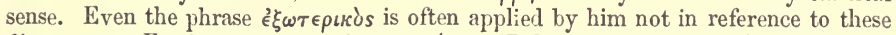

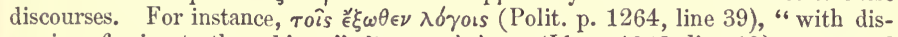

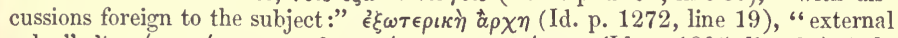

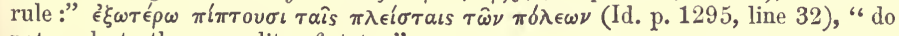
not apply to the generality of states."

1 Suetonius, De Cl. Grammat. cap. 2, "plurimas acroases subinde fecit, assidueque disseruit." - Here is obviously a distinction intended between the dissertations which he continually delivered, and the lectures which he gave from time to time.

${ }^{2}$ An illustration may, perhaps, be useful in clearing up what we apprehend to have been the real division. For the demonstration of Pythagoras's celebrated theorem (the forty-seventh proposition of the first book of Euclid) the whole of the preceding part of the book is requisite. This, then, is an example of a $\lambda$ b́ $\phi i \lambda o \sigma o \phi i \alpha \nu$. But in the particular case of a square, the property of the square of the diameter being equal to twice the square of the side, may be directly shown to a person ignorant of geometry, as it is hy Socrates in Plato's dialogue, Meno. This

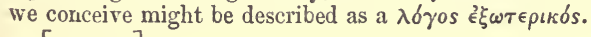

[G. R.P ] 
to be illustrated in a striking light. But we must be very careful not to confuse these resulting distinctions with the primitive one from which they flowed, and still more not to suppose that they were the cause of it; for we shall see presently that want of attention to this caused in later writers first of all most inaccurate expressions as to the nature of this celebrated division, and, finally, an utterly erroneous view of it, and of the spirit in which it originated.

Cicero's

Cicero, in two of his letters to Atticus, ${ }^{1}$ speaks of having composed imitations. two works in the manner of Aristotle's exoteric ones. The points of comparison which these two treatises (the 'De Finibus' and the 'De Republicâ) offer, consist in the dialogic form in which they are written, and the prefaces which serve to introduce the dramatis personce who carry on the discussion to the reader. The objections interposed by some of these to the view which it is the design of the author to elucidate are turned into a means of bringing it out in stronger and bolder relief. This mode of treatment in the hands of a master obviously offers many advantages. The dramatic interest keeps the attention of the reader from flagging; and the peculiar obstacles which the differences of individual temperament not unfrequently interpose to the reception of any doctrine may be in this way most clearly set forth and most easily removed. The dialogues of Plato are an obvious example of this. But if we consider the 'De Oratore,' 'De Finibus,' and 'De Republicâ' of Cicero to represent with tolerable accuracy the character of the Aristotelian Dialogues, we see at once a very considerable change. The genial productive power of the artist has given way to the systematic reflection of the philosopher. The personages introduced are not living and breathing men, with all their feelings, prejudices, and individual peculiarities, they are mere puppets which speak the opinions entertained by those whose name they bear. These opinions may be fairly and lucidly stated, they may be backed by all the pomp and power of rhetoric, as they are in Cicero, and as they probably were in Aristotle, but the speakers have no life, the scene no reality; and in spite of the pains taken by the author to prevent it by allusions to particular times, places, and circumstances, we rise from the perusal with our opinions more or less modified, but with no more distinct recollection of the parties by whom the discussion has been carried on than if they had been distinguished by the letters of the alphabet instead of the names of known characters. ${ }^{2}$ But what these produc-

1 Ad Attic. iv. 16. Hanc ego de Republicâ, quam institui disputationem in Africani personam et Phili et Lælii et Manilii contuli : adjunxi adolescentes, Q. Tuberonem, P. Rutilium, duo Lælii generos, Scævolam et Fannium. Itaque cogitabam, quoniam in singulis libris utor proœmiis, ut Aristoteles in iis, quos $\epsilon^{\prime} \xi \omega \tau \epsilon-$

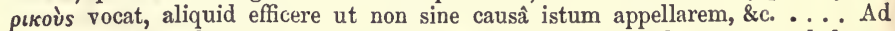
Attic. xiii. 19. Quæ autem his temporibus scripsi, Aristoteleum morem habent; in quo ita sermo inducitur ceterorum, ut penes ipsum sit principatus. Ita confeci quinque libros $\pi \epsilon \rho l \tau \epsilon \lambda \hat{\omega} \nu$, \&c. On the same principle he had composed his books De Oratore, Epp. Attic. iv. 16, Epp. ad Famil. i. 9, sec. 23.

2 Bishop Berkeley's Hylas and Philonous and Minute Philosopher make no pre- 
tions have lost as works of art, they have gained as works of science. The distinct and explicit exposition of a principle which prevents them from being the former, is a merit in them as the latter. And as the dialogic form, even where it fails in producing the dramatic impression Dialogic form that we receive from Plato, admits to the fullest extent of all the assistance which rhetoric can afford, it is not wonderful that it sh suld have been selected by Aristotle as an appropriate one for many or even most of his exoteric treatises. ${ }^{1}$

Neither in those cases in which he adopted this form can we be Style of the surprised that Aristotle should have made use of a style, which, exoteric
works. however unfit for the purposes of a rigidly scientific investigation, is not at all inappropriate to compositions such as we have described. A few relics (and unfortunately a very few) have come down to us of them; about thirty lines in the original Greek are quoted by Plutarch ${ }^{2}$ from one of the most celebrated, and Cicero has in a Latin dress preserved two other small fragments. ${ }^{3}$ The first of these is part of a treatise either addressed to Eudemus, Aristotle's disciple, or written on the subject of his death, and from the nature of the extract, no less than from the name it bore, ${ }^{4}$ seems to be upon the subject of the immortality of the soul, and the miserable condition of man while imprisoned in the body, as compared with that which preceded and will follow the present life. Our existence on earth is regarded as a punishment inflicted upon us by the gods; and in support of this opinion an appeal is made to the experience of the human race manifesting itself to that effect in proverbs and mythological tales. The dead are represented as dwelling in a higher sphere of being than the living, and as dishonoured by any expressions or feelings on the part of the latter which involve an opposite opinion. The language in tension to dramatic effect. The very names of the collocutors indicate the principles which they profess. In our opinion, Berkeley has acted wisely, but would have done better still to have dropped the dialogic form. Harris's three treatises are an attempt to come much nearer to the Platonic dialogue, and, in our judgment, a signal failure.

${ }^{1}$ Cicero, although he does not expressly say that the exoteric works were all dialogues, speaks of them as if they were nearly caextensive. So too Ammonius (Introd. ad Categ. sec. 2) divides the regular treatises of Aristotle into two heads,

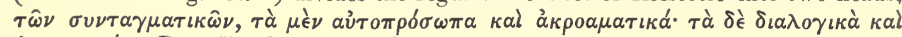
$\epsilon^{e} \xi \omega \tau \epsilon \rho \iota \alpha \dot{\alpha}$. But Simplicius and Philoponus prevent us from construing their

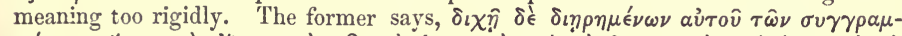

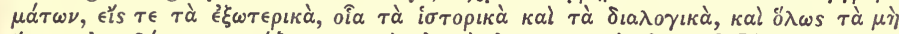

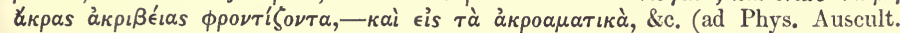
init.), and the latter, speaking of the exoteric writings, says, among which are the Dialogues, of which the Eudemus is one (ad Arist. De Animâ, i. 138).

${ }^{2}$ De Consolat. ad Apollon. p. 115. He also alludes to the same work in his Life of Dion, cap. 22.

${ }^{3}$ De Naturà Deorum, ii. 37; De Officiis, ii. 16.

${ }^{4}{ }^{\nu} \mathrm{E} v \delta \eta \mu s^{*}$ मे $\pi \in \rho \grave{\imath} \psi v \chi \hat{\eta} s$. It is probably this treatise which is referred to in the Nicomachean Ethics, p. 1102, col. 1, line 26, and which was quoted by Cicero in his Dialogue Hortensius (ap. Augustin. c. Julian. vol. x. p. 623, ed. Benedict). The fragment is given by Orelli in the seventh volume of his edition of Cicero's works, pp. $485,486$. 
which these sentiments are embodied is of proportionate dignity to the theme: it is totally unlike the dry and jejune style in which the works which have come down to us are written; on the contrary, it is rather diffuse and ornamented, and fully enables. us to understand the expression of Cicero, "Aristotle, with his golden flood of language," which, judging from his rigidly demonstrative works alone, we should deem singularly inappropriate. One of the passages preserved in Cicero is even more gorgeous and eloquent than the one in Plutarch, and for the sake of the subject we will endeavour to give some notion of its rhythm and structure, although, of course, a translation twice removed from the original can do this but very inadequately. The argument is the common one of natural theology, the evidence which the wonders of the universe afford of the existence of an intelligent Creator. Aristotle's reasoning appears to be directed against those who asserted that such an inference was the result of a traditional belief handed down from generation to generation, and interpreting all phenomena into an accordance with itself. He attempts by an illustration to show that this is not the case, but that it proceeds from the natural conviction of the human mind, unswayed by any particular bias, as soon as its attention is roused to these objects. "Suppose there to exist," says he, " a race of beings, who had always inhabited a region in the heart of the earth, dwelling in fair and lordly mansions adorned by statues and pictures, and provided with all the appliances of luxury in which those whom the world envies abound, but who never had visited the surface. Now, if these had heard by rumours and hearsay that there was a certain Divine power, living and acting; and then at some time the jaws of the earth were to open and allow them to quit their obscure dwelling-place and come forth into the region which we inhabit, - then, when all at once they beheld earth, sea, and sky, the enormous clouds, the mighty winds, - when they gazed on the suil, and perceived how vast, how beautiful it was, how potent in its operation, how, by diffusing its light through the whole of the heaven, it was the cause of the day;-when, again, after night had veiled the earth in darkness, they observed the whole firmament studded and lit up with stars, the moon with her varying phases, now increasing, now waning, and all rising, and setting, and running on their courses steadily and unvaryingly for an eternity of ages ; surely, when they beheld all this they would believe both that there were gods, and that these mighty works were from their hand!" The passage in the 'De Officiis' appears rather to be a summary of Aristotle's expressions in his own words than a translation like the above; but even there the reader will easily recognise an oratorical structure quite unlike what is to

1 Veniet, flumen orationis aureum fundens. (Aristoteles, Acad. Pr. ii. 38.) In another passage, Torquatus alleges that his adversary is prepossessed against E curus, because his writings are deficient in those "ornaments of style" which he finds in Plato, Theophrastus, and Aristotle. (De Fin. i. 5.) To the scientific works this description is about as applicable as to the Elements of Euclid. 
be found in any of the philosopher's works which have come down to us.

From these few and meagre specimens of the exoteric works of Popularity of Aristotle, we may observe without any difficulty that in every respect the exoteric they were calculated in a rhetorical and superficial age, such as that of the successors of Theophrastus was, to supersede the others. Literature became fashionable in high places. Philosophers thronged to the courts of an Antigonus, a Ptolemy, or an Attalus, and exerted themselves in making royal roads to knowledge for the sake of their patrons. A general acquaintance with the doctrines of the school to which they attached themselves was all that these latter could pretend to, and the instructor soon found out that very little more would be sufficient for himself. Why should he bestow time and labour on what would not be available to his purposes? Why should he trouble himself with thinking out the results which he could find ready provided to his hand? Above all, why should he neglect works which supplied food to his fancy and grace to his style, agreeably and lucidly written, and generally acceptable in literary society, for the dry and laborious systematic treatise, whose only merit was its rigidly logical connexion. The very discipline of the Lyceum, as we have shown in an earlier part of this essay, contributed its share to the work of deterioration, by producing an unconscious indifference to the truth of opinions provided only they were plausible and coherent; and the vanity of possessing a multifarious knowledge lost the only check which could have restrained it. The age of thought gave way to an age of mere accumulation of learning; and in such a one what could attract any man to works like Aristotle's scientific ones? In the time of Cicero a considerable impulse had certainly been given to philosophy. Yet how instructive is the story which he relates in the introduction to his 'Topica!' His friend 'Trebatius had stumbled while looking over lis library upon the 'Topica' of Aristotle, of which he had never heard, and on learning from Cicero the nature of the work was seized with a strong desire to read it. The obscurity of the book repelled him, and an eminent rhetoriciall to whom he applied for assistance told him that of those works of Aristotle he knew nothing. "This I was by no means surprised at," says Cicero, "that a rhetorician should know nothing of a philosopher, of whom philosophers themselves, with the exception of a very few, knew nothing."' And although Cicero deservedly prides himself upon being the introducer of Greek philosophy among his countrymen, it is extremely questionable whether, with the exception of those works which have a direct application to oratory, his knowledge of Aristotle was not confined to the exoteric writings. It is certainly these which he takes as his model and his basis in his own philosophical works.

Where a writer's opinions are studied rather than his principles and

1 Topica, i. 1. So, too, in a fragment in Nonius, voce contendere, he says, Magna etiam animi contentio adhibenda est explicando Aristoteli. 
Imputed variance between Aristotle's views.

method, where readers do not take the trouble to put themselves upon his standing-ground, to enter into his thoughts, and follow them out through the ramifications of his system, there will often appear a want of harmony between the results at which he arrives. 'There is a point from which all these will appear in their true perspective; but this point is on an eminence which it requires both time and labour to ascend. Such a want of agreernent in his results was imputed to Aristotle at an early period, before the time of Cicero, who notes it and gives a partial explanation of it. "On the subject of the chief good," says he, "there are two kinds of works, the one written in a popular manner, and termed by them exoteric, the other worked up with greater care (limatius), which they left in the form of notes (quod in commentariis reliquerunt). This makes them thought not always to say the same thing; although in the upshot there is no variation at all, in those at least whom I mentioned [Aristotle and Theophrastus], nor do the two differ the one from the other."' Here Cicero only speaks of those works which the author kept by him and continually made additions to, a class of works which did not form a Exoteric and large proportion of the scientific ones. ${ }^{2}$ But it is quite plain that the esoteric doc- remark might be extended to the whole of these latter: in every one
trine. of them might be found instances where Aristotle might "appear not to say the same thing" as in his more popular publications, but where at the same time "in the upshot there would be no variation at all." Now here we have the fact which formed the basis of the subsequent opinion that Aristotle had an inner and an outer doctrine, an opinion which gathered strength and distinctness as it passed from one hand to another, and is in modern times repeated with a confidence that would lead one to suppose that it rested on the explicit assertion of the author himself. Neither in Strabo, Plutarch, nor Gellius, is there any hint of a wilful suppression of sentiments on the part of Aristotle, ${ }^{3}$ although all three of these authors allude to a division of his works into two classes adapted to different mental qualifications in the readers. Growth of In Clement of Alexandria appears the first trace of any such notion, this notion. and the expressions which he makes use of are hardly sufficient to

${ }^{1}$ De Finibus, v. 5.

2 Aminonius (Introd. ad Arist. Categ.) describes those writings which he calls

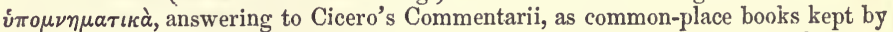
Aristotle for his own use, some of them devoted to one subject, some miscellaneous.

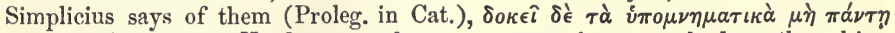

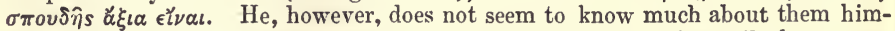
self, for he quotes Alexander Aphrodisias as his authority. But all the ancient commentators are agreed in making the acroamatic works a separate and more important class than the hypomnematic.

${ }^{3}$ The word ${ }^{\alpha} \pi \delta \dot{\rho} \hat{\rho} \eta \tau \alpha$ may seem opposed to this statement (Plut. Vit. Alex. sec. 7), but it seems only intended to indicate those writings which were not published, and which were kept secret, not because they contained peculiar doctrines, but from the same reasons which prevent any man from showing a work yet growing under his hands to any but his particular friends. One of these works was the Rhetoric, as has been remarked by Niebuhr in a note to the History of Rome, vol. i. p. 19, Eng. Trans. 
justify us in concluding that he had any decided opinion on this score.' But it was a view which would not fail to be caught hold of in an age singularly attached, as the declining Roman empire was, to mystical orgies and secret associations. Before Clement, indeed, Lucian had taken advantage of it for the purposes of a jest, where, in his 'Sale of Philosophers,' he puts Aristotle up to auction as a double man $;^{2}$ but obviously this is only a ludicrous version of the fact that his works were of very different kinds, stated, as very likely the later Aristotelians would themselves be fond of doing, in a paradoxical form. Nay, even when we get down to the close of the fourth century, to the rhetorician Themistius, a very great allowance must be made for the conceits of his affected style, before we form our estimate of his real sentiments. No one can dream of taking in their literal sense such phrases as those of "Aristotle shutting up and fortifying his meaning in a rampart of obscure phraseology, to secure it from the ravages of uninitiated plunderers;" 3 or " considering that knowledge was like food and drugs, one sort proper for the healthy, another for the sick," and therefore "involving his meaning in a wall of cloud, the doors of which two guardians, Perspicuity and Obscurity, like the Homeric Hours, stood ready to open to the initiated and close upon the profane." " But after making all proper allowance, there is no question that in the time of Themistius the opinion of a double meaning of EstablishAristotle was widely received. ${ }^{5}$ Ammonius in the fifth century thinks ment of the it necessary to state, apparently in opposition to the popular belief, Aristotle's " that the Dialogues of Aristotle differ very much from the direct duplicity.

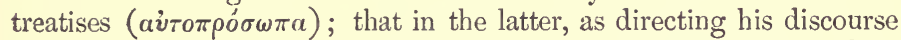
to genuine students, he not only delivers his real opinions, but employs the severest methods, such as people in general cannot follow; while in the latter, as they are written for general use, he delivers his real opinions, but employs methods not rigidly demonstrative, but of the kind that the generality of people are able to follow." 6 But his scholar Simplicius no longer swims against the tide; he asserts that in the " acroamatic works Aristotle aimed at obscurity, in order" through it

1 Stromm. loc. supra cit. After speaking of double doctrines of the Pythago-

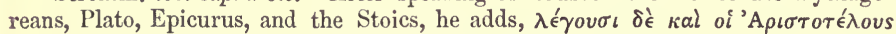

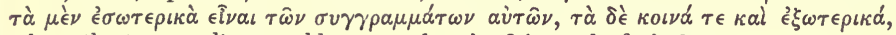

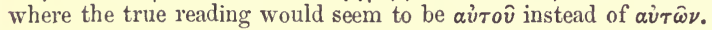

2 Vol. iii. p. 112, ed. Bipont.

3 Orat. xxiii. p. 294.

4 Orat. xxvi. p. 319 . The allusion is to Iliad, v. 750 ; and there are some others in the context, equally tasteless and'strained, to the marshalling of the Median army by Cyaxares (Herod. i. 98), and to the palace of Agbatana with its concentric sevenfold walls. (Herod. i. 98.)

5 One great reason of this. no doubt, was the desire of reconciling him with Plato, which is observable in Themistius, and was by his time the great object of philosophers. See especially Orat. xx. pp. 235, 236. Utterly unable to ascend to the point which would enable them to appreciate both, they endeavoured to establish a spurious agreement by the help of fictions like this.

${ }^{6}$ Ammonius, loc. supra cit. 
to repel the more indolent from him."1 The wit of the satirist and the flourishes of the rhetorician were thus translated into plain prose; and from this time forward the duplicity of Aristotle's doctrines may be considered as reckoned among the most indisputable facts.

Qualification of Strabo's narrative.

Character of Apellicon the Teian.
Having now thoroughly satisfied ourselves that the narrative of Strabo requires much qualification, we may inquire whether there is any part of it which is consistent with what from other sources we know really was the case. And there seems nothing to prevent us from believing that Neleus's heirs really possessed some books which had belonged to Aristotle and Theophrastus,- - that Apellicon purchased these, and that they were brought by Sylla to Rome, and there first made known to people in general. But that these were works of any great importance we have seen could not be the case; nor was the decay of the Peripatetic school owing to the want of them. A part of the story relates to matters of fact, for which Strabo is a most respectable witness; a part to a matter of opinion, on which he is no authority whatever. The one half is reconcilable with the fact that the principal acroamatic works of Aristotle were in the hands of his successors and in the library at Alexandria, during the interval between Neleus and Apellicon; it is in accordance with the notice of Athenæus that Ptolemy bought the libraries of Aristotle and Theophrastus; and with various other stories which, having a less obvious bearing upon the question, we have omitted for the sake of brevity in their proper place, but which will be found stated shortly below in the note. ${ }^{2}$ The other is inconsistent with these and many other facts, and may be rejected without invalidating the reputation of Strabo either for veracity or accuracy as regards matters which came within his knowledge-a reputation which we should be the last persons to desire to destroy. What then was the nature of these documents, the preservation of which was the foundation for so remarkable a story? We can only guess an answer, but we will nevertheless make the attempt.

Athenæus, ${ }^{3}$ quoting from the work of Posidonius the historian, a contemporary of Pompey the Great, gives a sketch of the character of Apellicon, which will, perhaps, throw a light upon this question. A

${ }^{1}$ Ad Auscult. Physic. fol. 2, 6, line 22.

2 I. Dionysius of Halicarnassus mentions it as a prevalent opinion that Demosthenes owed his skill in oratory to the study of Aristotle's Rhetoric, and takes some trouble to prove, by quotations in that work from Demosthenes, that all his famous Orations (the twelve Philippics, as they were called) were delivered before that work was written. (Ep. i. ad Ammæum.) II. Theophrastus corresponded with Eudemus concerning certain errors in the copies of the fifth book of the Physical Lectures (Andronicus Rhodius, ap. Simplicium, quoted by Brandis, p. 245). III. Valerius Maximus relates that Aristotle first of all gave his Rhetoric to a favourite scholar, Theodectes, and that it was published under his name; but that his greediness for reputation afterwards induced him to claim it for himself, by quoting from it in another work as his own production (viii. 14).

3 Athenæus, v. cap. liii. pp. 214, 215. 
man of vast wealth and restless disposition, and an adopted citizen of Athens, he appears to have alternately plunged himself into the turbulent politics of his time, and cultivated literature in a spurious kind of way. His taste for letters was a mere bibliomania, and brought him into trouble. He purchased, while the fit for philosophy was upon him, " the Peripatetic books and the library of Aristotle, and a great many others, being a man of large property. Moreover he surreptitiously obtained possession of the ancient original decrees of the Assembly, which were preserved in the temple of the Mother of the Gods, and from the other cities too he got hold of whatever was ancient and curious." This theft obliged him to save his life by flying the country: in the troublous times, however, which soon after succeeded, he contrived to procure his recall by joining the party of the demagogue Athenion. This individual had induced his countrymen to take a part in the confederacy which Mithridates had organized against the power of Rome. In an evil hour Apellicon quitted bookcollecting for military service. He took the command of an expedition against Delos, which was occupied by Orbius the Roman prætor; but displayed such utter ignorance of the commonest duties of a commander that his enemy soon found an opportunity of attacking him unawares, destroyed or captured the whole of his troops, and burnt all the machines which he had constructed for storming the city. The unfortunate dilettante escaped with his life, but died, in what way is not known, before Sylla stormed Athens, and seized on the library which had cost him so dear. ${ }^{1}$ It seems almost certain from this account of Apellicon, that it was the possession not of the works but of the autographs of them which was the attraction to him. Can we then conceive that it was the original autographs of Aristotle and Theophrastus which he purchased from the representatives of Neleus's family?-Autographs of what works? Not of the exoteric: for these were so generally known that he would have had no difficulty in filling up the gaps which the damp and worms had caused in his copy. Nor of the systematic treatises; for if the original manuscript of these had existed, Andronicus would have had no difficulty in determining what was by Aristotle, and what not, in the various cases where that question arose. Of neither of these classes of writing then can we imagine that the story of Strabo is to be understood. But if we suppose Aristotle to have left behind him, as every literary man whose energies last to the end of his life will do, collections on various subjects, rough draughts of future works, common-place books, some of a miscellaneous nature, some devoted to particular matters, containing, it may be, extracts from other writers, references to their opinions, germs of thoughts hereafter to be worked out, lines of argument merely indicated;-it is very conceivable that these documents, so long as a healthy and lively philosophical spirit existed in the Peripatetic school, would receive very little attention. If they

I Stahr, Aristotelia, ii. p. 119.

His passion fur curiosities 
were too fragmentary and unsystematic for publication they would remain in the possession of 'Theophrastus and Neleus, ${ }^{1}$ too curious to destroy, too unfinished to make any use of; and if the heirs of Neleus were illiterate men, they would see nothing in them but so many slovenly and disjointed scrawls, and not dream of putting them among the sumptuous collection of books which they sold to king Ptolemy. But in the time of Apellicon, the state of things was changed. The relics of the founder of the school would have acquired a sacred character; and unsaleable as they might have been to Ptolemy, who appears to have been a real lover of literature and not a mere book-fancier, would fetch a good price with the purchaser of stolen records. And it is not at all inconsistent with this view, that a person whose acquaintance with philosophy was of such a kind, should mistake the nature of the documents he had got hold of,- " attempt to supply the gaps when he transcribed the text in new copies,- - fill these up the reverse of well,-and send the books out into the world full of mistakes."

Such is the theory which, it appears to us, will reconcile the varying accounts respecting Aristotle's writings, and which, while it sweeps away all that is adventitious in the statement of the Greek geographer, will leave his testimony substantially unimpaired. And this theory is, in fact, confirmed by the state in which some of the works of

Reconciliation of the several notices on the subject.

Aristotle have come down to us. For some of these are not merely books kept by the author, and continually worked at, like the ' Rhetoric,' and Theophrastus's ' History of Plants,' nor are they mere notes for lectures, a dry skeleton of the subject, complete in themselves, and only requiring the illustration and development which would be supplied by the extemporaneous efforts of the instructor. Neither of these two descriptions will explain all the phenomena which strike the reader in the 'Poetics' and the 'Politics,' as these two treatises are Nature of the found in our manuscripts. Neither of them complete the discussion 'Politics' and of the range of topics which they promise; and it is impossible to receive as a satisfactory explication of this fact that they are only fragments of complete works of which the remainder has been lost. This is quite incompatible with what we find in them, namely, redundancies - whole paragraphs recast, and standing together with those for which they seem meant as a substitute. ${ }^{3}$ Such appearances are only to be understood on the supposition that the work in which they

1 Parts of some of them may very likely have been incorporated by Theophrastus, Strabo, and others in works of their own - a proceeding which, in those days, would not have been considered a plagiarism. Such, too, was doubtless the case with all

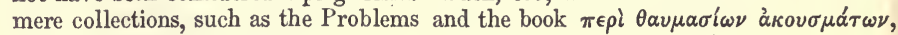
which, as we have it now, probably contains additions from several hands.

2 Strabo, loc. supra cit.

${ }^{3}$ A remarkable instance of this is Politic. iii. p. 1287, col. 1, line 1, col. 2, line 36 , which the passage p. 1285 , col. 2 , line 37 , p. 1286 , col. 2 . line 40 , is obviously intended to supersede. The latter is a more digested and orderly arrangement of the topics in the former. 
occur was an interleaved draught of a future treatise, itself never published (nor yet intended for publication) by the author. In such a case we should expect to find what we do find here, and certainly not, to the same extent, in any other work,- - scholia containing archæological or historical notes inserted in the midst of metaphysical divisions, imperfect analyses, defective enumerations, tacit references to writings of others or to opinions current at the time, allusions to questions treated on by the author in the work, which are nowhere to be found, gaps where obviously something was to be inserted, and expressions so slovenly as to be almost or wholly ungrammatical. To give instances of all these incongruities would extend this article to a much greater length; and therefore we must oblige our readers to take the assertion on our credit, assuring them that an attentive perusal of the works will supply them with several instances of each. ${ }^{1}$ And if we suppose them to be note-books devoted to the particular subjects on which they treat, kept by the author until the materials they contained had been worked up and published in a complete form, and then discarded by him, we shall see in what relation they probably stood to the works read by Cicero, ${ }^{2}$ and named in the catalogues of Diogenes Laertius and the anonymous biographer, ${ }^{3}$ and understand what kind of writings those in all probability were, which descended with the rest of Aristotle's library to Theophrastus, and from Theophrastus to Neleus, which were neglected by the librarians of Ptolemy Philadelphus, and emerged from their obscurity in the vault of Scepsis to be purchased by the antiquarian Apellicon. Only in making this estimate we must not forget the different importance which such writings possess for us, deprived for ever of those which were formed out of them,- and for their author and his immediate successors, to whom they would appear in no other light than the scaffold, by the aid of which the catherlral has been erected, does to the architect. And perhaps we may properly imagine that the greater

${ }^{1}$ We must stipulate, however, that the investigator shall not make use of any text previous to that of Bekker for this purpose. The former editors, partly from the want of MSS., and partly from ignorance of the style of thought and language peculiar to their author, have made strange havoc with these writings.

${ }^{2}$ De Legg. iii. 6 ; De Divin. ii. 1 ; Epp. ad Quint. Frat. iii. 5.

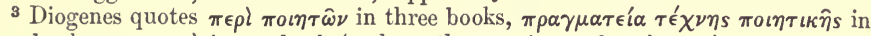
two books, $\pi$ oı $\tau \tau \iota k \grave{\alpha}$ in one book (perhaps the treatise we have), $\pi \epsilon \rho l \tau \rho \alpha \gamma \omega \delta i \hat{\omega} \nu$ in

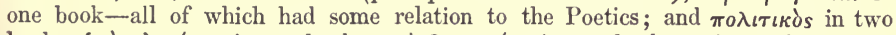

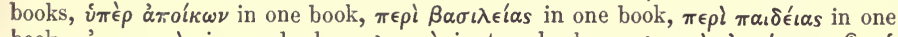

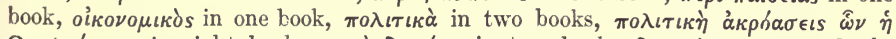

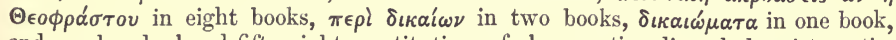
and one hundred and fifty-eight constitutions of democratic, oligarchal, aristocratic, and monarchical states, all having some bearing on the Politics. To these, perhaps, may be added, from the anonymous writer, $\pi \epsilon \rho l \in \dot{j} \gamma \in \nu \in \epsilon^{\prime} \alpha s$ in one book, $\pi \epsilon \rho i \sigma v \sigma-$

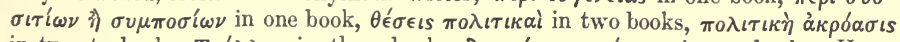

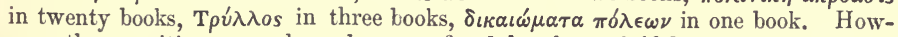
ever these writings may have been confused by the unskilful epitomizers of Hermippus, it is quite plain that Aristotle wrote a great deal more on both these subjects than has come down to us. 
fulness of these procured their preservation after they were recovered, while many others of the same kind, but yet further removed from completeness, were suffered to perish.

Literary notice of the existing writings of Aristotle.

We will conclude this memoir by a brief literary notice of the works published under the name of Aristotle, in the order in which they are given in the edition of the Berlin Academy.

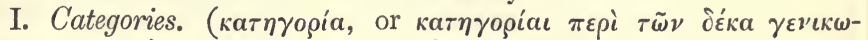
$\tau \dot{\alpha} \tau \omega \nu \gamma \varepsilon \nu \tilde{\omega} \nu$.) The genuineness of this work was much disputed in the time of the old commentators. Adrastus found a work on the same subject, bearing the name of Aristotle, and, singularly enough, consisting of exactly the same number of lines. It was, however, determined to be genuine by them, with the exception of the last part, which treats on what the Latin logicians term the 'Postprædicamenta.' This extends from the tenth chapter to the end. The work of Harris, called 'Philosophical Arrangements,' is an exposition, very much in the manner of the old commentators, of this treatise. A short but most masterly critique on it will be found in Kant's 'Kritik der reinen Vernunft,' p. 79. Adrastus wished to call the work $\tau \dot{\alpha} \pi \rho \grave{o} \tau \tilde{\omega} \nu$ $\tau о \pi \iota \kappa \tilde{\omega} \nu$, considering it as merely an introduction to the 'Topics,' a proposition which Porphyry disapproves of.

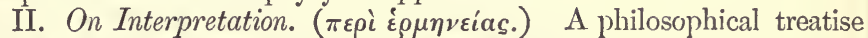
on grammar, as far as relates to the nature of nouns and verbs. Some of the old commentators from its obscurity imagined it to be a mere collection of notes, and Andronicus considered it not to be Aristotle's. Alexander of Aphrodisias, however, and Ammonius, prove it to be his, and to have been used by Theophrastus in a treatise of the same name which he wrote.

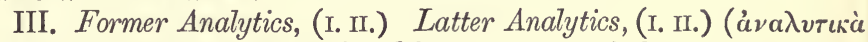

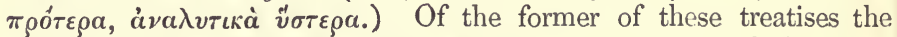
true and ancient title was $\pi \varepsilon \rho \grave{i} \sigma v \lambda \lambda \rho \gamma\llcorner\sigma \mu o \tilde{v}$, and that of the latter

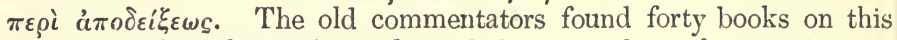
subject, professedly by Aristotle, and determined on the genuineness of these only, rejecting all the rest. Their subject is that which in modern times is especially termed logic, but would be more properly called dialectics, that is, an examination of the possible forms in which an assertion may be rnade, and a conclusion established.

Theoplirastus, Eudemus, and Phanias, scholars of Aristotle, wrote treatises on the same subjects as these three of their master, and called by the same name, a circumstance which probably had some connexion with the number of 'Analytics' ascribed to him.

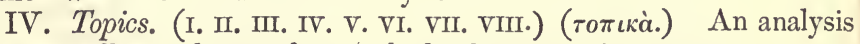
of the different heads from which demonstrative arguments may be brought. It was considered by the ancient commentators as the easiest of all Aristotle's systematic works. The Romans, however, as Cicero tells us in the preface to his work of the same name, found it so difficult as to be repelled by it, although he himself praises it no less for its language than for its scientific merits. His own work is 
an epitome of it, made by himself from memory, during a sea voyage from Velia to Rhegium.

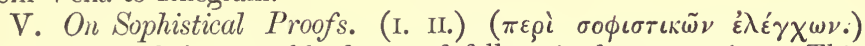
An analysis of the possible forms of fallacy in demonstration. This work has a natural connexion with the 'Topics,' as Aristotle himself remarks in the beginning of the last chapter of the second book.

The preceding works taken together complete Aristotle's logical writings, and with Porphyry's Introduction to the 'Categories,' have gone generally in modern times by the name of the 'Organum,' from

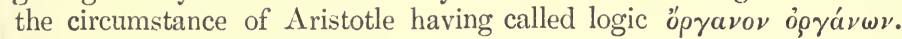
The philosopher gave this name to the art, because of all others it is the most purely instrumental, that is, the most entirely a means to something else, and the least an end to be desired for its own sake. The term, however, was in subsequent ages misapplied to mean that it was the best of all instruments for the discovery of truth, as opposed to the observation of facts, and the art was correspondently abused.

VI. Physical Lectures. (I. II. III. IV. V. VI. VII. VIII.) ( $\phi v \sigma \iota \eta^{\prime}$

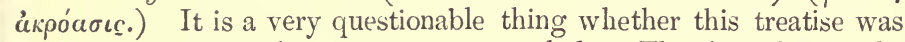
published by the author as one organic whole. The three last books probably formed a treatise by themselves under the name $\pi \varepsilon \rho i$ $\kappa \iota v i \mid \sigma \varepsilon \omega \varsigma,{ }^{1}$ and the first five another under that of $\phi v \sigma \iota \kappa^{\prime}$. Again of these the first one is quite independent of the rest, and is devoted to the discussion of the first principles ( $\dot{a} \rho \chi a i),{ }^{2}$ to which everything in nature may be resolved. This book is extremely valuable for the history of philosophy before the time of Aristotle. He discusses in it the theories of Melissus, Parmenides, Anaxagoras, Empedocles, and others. The second is taken up with an examination of the ideas of Nature, Necessity, and Chance; and the next three with the properties of Body, or rather with the analysis of those notions of the understanding which are involved in the idea of Body. Of this work ab-

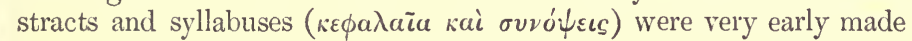
by the Peripatetic school, ${ }^{3}$ and these keeping their attention fixed upon the connexion of a system of dogmas, contributed perhaps much to divert them from the observation of nature, and to keep up that confusion between laws of the Understanding and laws of Nature which pervades the whole of the ancient physical speculations.

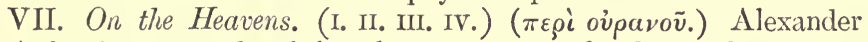

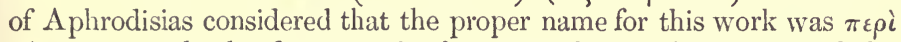
$\kappa o ́ \sigma \mu o v$, as only the first two books are really on the subject of the heavenly bodies and their circular motion. The two last treat on the

1 Simpl. ad. Phys. Auscult. f. 216. Diogenes, however, gives a work ( $\pi \in \rho i$ $\kappa \iota \nu \eta \tilde{\sigma} \epsilon \omega s)$ in two books. This is not conclusive against the opinion quoted in the text. See below, the notice respecting the Rhetoric.

${ }^{2}$ Perhaps it is to this book that the title $\pi \epsilon \rho l \alpha \hat{\alpha} \rho \chi \hat{\eta} s$, in Diogenes' Catalogue, refers.

${ }^{3}$ Simplicius, Introd. ad Phys. Ausc. vi. and rii. 
four elements and the properties of gravity and lightness, and afford much information relative to the systems of Empedocles and Democritus.

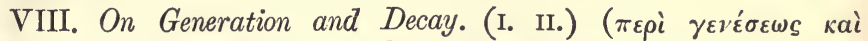
$\phi \theta 0 \rho \tilde{c} s$.$) This work treats on those properties of bodies which in our$ times would be considered to be the proper subject of physiological and of chemical science. Many other notions, however, of a metaphysical nature are mixed up with these, and it is only for its illustration of the history of philosophy that this work, like the rest of the physical treatises, is of any value to the modern student.

IX. Meteorology. (I. II. III. IV.) ( $\mu \varepsilon \tau \varepsilon \omega \rho о \lambda о \gamma ı$ кá.) The first of these books was by some in the time of the old commentators held not to be genuine; and Ammonius and others considered that the fourth should immediately follow the second of the last treatise, with which the subjects on which it treats, the changes effected in bodies by heat and cold, moisture and dryness, \&c., are certainly more connected.

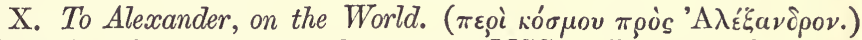
The titles of this tract in the various MSS. differ much from one

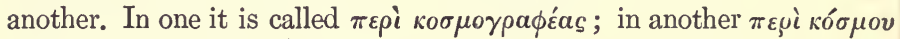

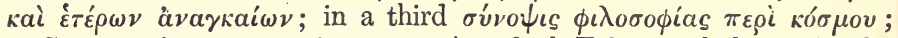
in Stobæus $\varepsilon \pi \iota \sigma \tau o \lambda \dot{\eta} \pi \varepsilon \rho \grave{\imath} \tau o \tilde{v} \pi a \nu \tau \grave{s}$, which Fabricius holds to be the true title. He considers the work to be genuine, contrary to the opinion of Scaliger, Salmasius, Casaubon, Voss, and Buhle. Fabricius's opinion has been taken up by Weisse, but the spuriousness of the piece is glaring. Stahr ('Aristoteles bei den Roemern,' p. 165, et seq.) has, as we think, satisfactorily shown that it is in all probability a composition of very late date, based upon Apuleius's work 'De Mundo,' which has sometimes been taken to be a translation of it.

XI. On the Soul. (I. II. III.) ( $\pi \varepsilon \rho i \psi v \chi \tilde{\eta} s$.$) In the first of these$ books are discussed the opinions of preceding philosophers upon this subject; in the second, the Soul in its sensible relations; in the third, in its rational ones. A celebrated dialogue of Aristotle's, to which we have before referred, ${ }^{1}$ bore this same title; and such as consider that the exoteric works were all in the form of dialogues, imagine that in the Nicomachean Ethics he alludes to it. At the same time there are parts of the third book of this treatise which seem apt for his purpose in that place; and although the work serves to make up that system of Aristotle's to which the preceding physical treatises, as well as the following belong, it is sufficiently independent of them to allow of its being perfectly understood without their perusal; a character which, in our opinion, is the only essential one of an exoteric writing.

XII. Eight tracts on physical subjects, namely,

(a.) On Perception and Objects of Perception. ( ai $\sigma \theta \eta \tau \tilde{\omega} \nu$.)

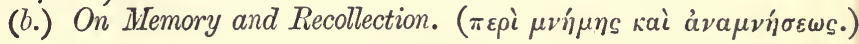
1 P. 163. 


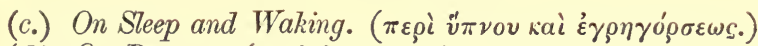

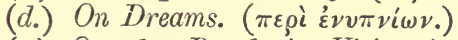

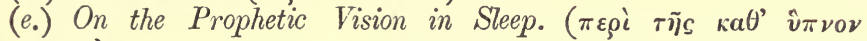

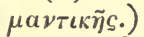

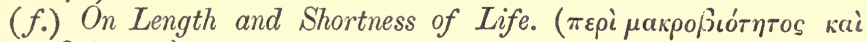

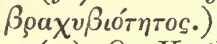

(g.) On Youth and Age, Life and Death. (

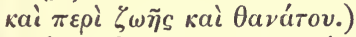

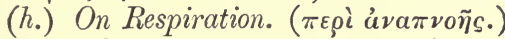

XIII. On Breath. ( $\left.\pi \varepsilon \rho i \tau o \tilde{v} \pi \nu \varepsilon v_{\mu} \mu a \tau o s.\right)$ This treatise, of which the subject is the same as that of the last mentioned, except that there is more reference in it to the lower animals, has been considered by many not to be by Aristotle. Sylburg considers the style to point to Alexander of Aphrodisias as its author. Meursius thought it probably to be by Theophrastus, and Patritius by Strato, principally because such a book is mentioned by Diogenes among the writings of these. Fabricius considers it to be Aristotle's, because Aristotle himself, in his treatise 'On the Motion of Animals,' appears to allude to it, and Galen quotes it as his. But neither of these two passages are quite conclusive.

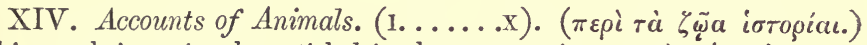

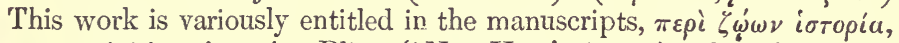

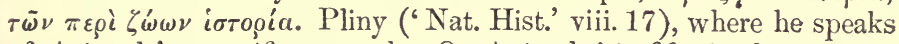
of Aristotle's magnificent work 'On Animals,' in fifty books, appears to include together with this all the treatises on natural history which follow it (and indeed are naturally connected with it), as well as some on comparative anatomy, now lost. The same may be said of Cicero's notice of them ('De Fin.' v. 4.) This work was illustrated by diagrams of the several parts of animals, which, together with the necessary explanations, perhaps formed a treatise by themselves. They are

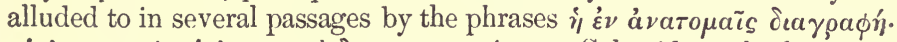

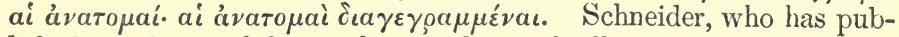
lished an edition of this work, most learnedly illustrated as régards the subject, not perceiving in it any traces of the injury which Aristotle's works, according to Strabo's account, received, was induced to consider it as one of the exoteric publications. But, in fact, the whole of the works on natural history are as closely connected with one another as the several parts of the 'Organum,' and it would be difficult to assign any reason why the one class should be regarded as exoteric and the other not so.

XV. On the Parts of Animals. ( $\left.\pi \varepsilon \rho i \zeta \zeta_{\iota} \omega \nu \mu \rho \rho i \omega \nu.\right)$ (I. II. III. IV.)

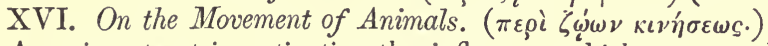

A curious tract investigating the influences which operate $a b$ extra upon animals. This treatise, together with the one following, and that ' On Breath,' are often put together with the eight tracts before mentioned (No. XII.), and make up what is called the 'Parra Naturalia.' 


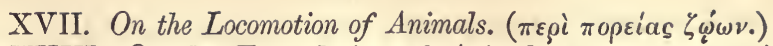

XVIII. On the Engendering of Animals. (I. II. III. IV. V.) ( $\pi \varepsilon \rho i$

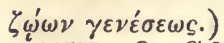

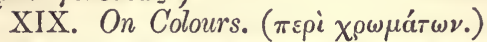

This has been considered by some critics to be the work of Theophrastus. Plutarch speaks of a treatise by Aristotle of the same name in two books.

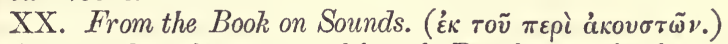

Apparently a fragment; although Porphyry, who has preserved it in his commentary on the 'Harmonicon' of Ptolemy, says that he has given the whole work.

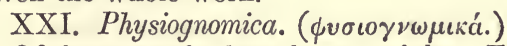

Of this tract the last chapter of the 'Former Analytics' is a sort of compendium. Buhle considers it spurious. It is not mentioned by any of the old commentators, but is by Stobæus and by Diogenes Laertius in his catalogue.

XXII. On Plants. (I. II.) ( $\pi \varepsilon \rho \grave{\phi} \phi v \tau \tilde{\omega} \nu$.

Aristotle wrote two books on plants, but not these which we have. They are a translation into Greek from the Latin; and even this version was considerably removed from a Greek original, having been made by some Gaul from an Arabian version, which, again, was only derived from a more ancient Latin translation. The original of all these, according to Scaliger, was only a cento of scraps, taken partly from Aristotle, and partly from the first book of Theophrastus's 'History of Plants.' Aristotle's work was already lost in the time of Alexander of Aphrodisias.

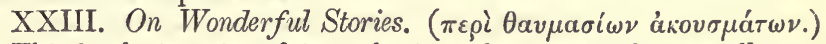

This book, in spite of its title, is nothing more than a collection of strange accounts, nor does it appear to have formed a part of a larger work of at all a different description. The latter part is obviously spurious, and with respect to the remainder various opinions have been held. Dodwell considers Theophrastus to have been the author; Scaliger, Aristotle. Buhle regards the whole as a patchwork of extracts from the works of the latter. Our opinion is that the germ of the work is to be looked for in one of those note-books' or $\dot{v} \pi o \mu \nu \eta$ $\mu a \tau a$ which were appropriated to collections, and from which supplies were occasionally drawn for more systematic works; and that this was in its transmission down to our times added to by several hands, and some of these most unskilful ones. See our notice of the "Problems' below. (No. XXV.)

XXIV. Mechanics. (

The first part of this work touches upon the principles of mechanics, and is followed by a number of questions, which are resolved by a reference to them. This latter part is probably only a few of the $\pi \rho \circ \beta \lambda \dot{\eta} \mu \alpha \tau a \dot{\varepsilon} \gamma \kappa \dot{v} \kappa \lambda \iota a$, or questions on the whole cycle of science, which we find mentioned as a work of Aristotle's, in two books, by Diogenes Laertius, and which is quoted by Aulus Gellius. 
XXV. Problems. (

This is a collection of questions on various subjects, in thirty-eight divisions, of which the first relates to medical, the fifteenth to mathematical, the eighteenth to philological, the nineteenth to musical, the twenty-seventh and three following to ethical, and the rest mainly to physical and physiological matters. Theophrastus is also said to have compiled a collection of problems; and Pliny quotes him as the authority for a circumstance which we find mentioned in this work.' In his treatises, too, $\pi \varepsilon \rho \grave{i} \kappa{ }^{\prime} \pi \omega \nu$ and $\pi \varepsilon \rho \grave{\imath} i \delta \rho \dot{\omega} \tau \omega \nu$, there are several coincidences with the 'Problems' of Aristotle; and hence some have held him really to be the author of these, while others have considered those works to be nothing more than a patchwork of Aristotle's 'Problems.'

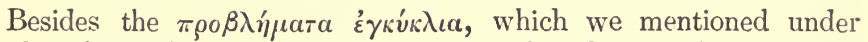

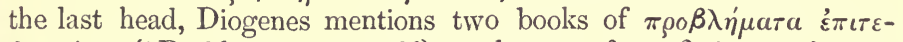

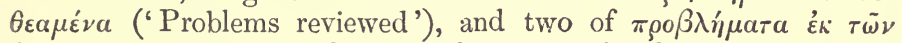

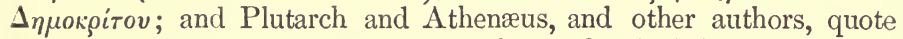

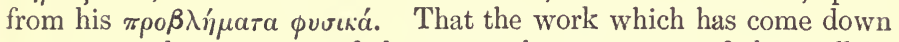
to us is neither any one of these, nor the aggregate of them all, is certain. Sylburg, in his preface, points out several instances in which Aristotle himself speaks of questions discussed in them, which will be looked for in vain in the present treatise. Neither do we find some of the quotations made by Aulus Gellius, Macrobius, Apuleius, and Alexander of Aphrodisias. On the other hand, some citations

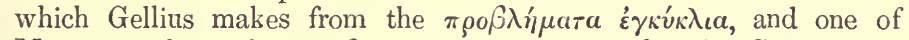
Macrobius from the $\pi \rho 0 \hat{\jmath} \lambda \dot{\eta} \mu a \tau \alpha \phi v \sigma u \dot{a}$, are found. So are two citations by Cicero, and one by Galen, quoting generally from the 'Problems.' These circumstances indicate that the work has been very much changed since it came from Aristotle's hands; and the most plausible hypothesis seems to be that the nucleus of the work is a selection ${ }^{2}$ of the collections of Aristotle, and that Theophrastus. added to it in its course down to us. There are many repetitions to be found in it, some even three times over with the change of only a few words; there is a great difference of style observable in several parts ; in many of the more ancient manuscripts parts are omitted and others differently arranged; and as regards the philosophy, it is impossible to suppose that a part could proceed either from Aristotle or Theophrastus, or from any philosopher of an undegenerate age. $A$ great deal is no doubt due to the bookmakers under the Roman empire: it was a work particularly well suited to the manufacture of such miscellanies as the taste of that time delighted in, and, with the exception of the works on natural history, appears to have been by far the most generally known of any of the Aristotelian writings at that time. These circumstances render it necessary for the historian of

${ }^{1}$ Prob. xxxiii. 12 ; Plin. Hist. Nat. xxviii. 6.

2 Aristophanes, the Alexandrian grammarian, epitomized or otherwise abridged Aristotle's collection of Proverbs.

[G.R.P.] 
philosophy to be extremely cautious how he infers the opinions of Aristotle upon any subject from it.

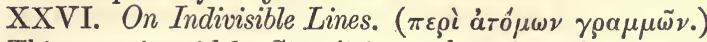

This tract is said by Simplicius to have been by some of the ancient commentators ascribed to Theophrastus.

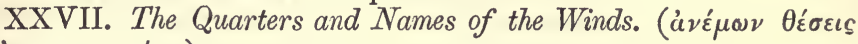

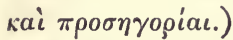

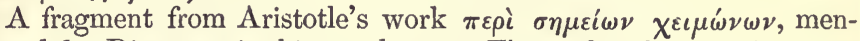
tioned by Diogenes in his catalogue. This is found in some manuscripts of Theophrastus's work, but Salmasius considers it to be Aristotle's.

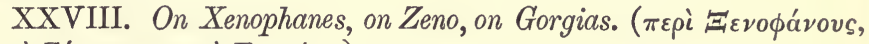

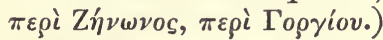

This fragment, according to Brandis, is the only one of all the works which have come down to us under the name of Aristotle's, which presents the least indication of that treatment which the manuscripts are said to have met with at the hands of Apellicon. This, too, and the 'Mechanics,' are the only works which Patritius allowed to be genuine. It is singular that one of the manuscripts ascribes

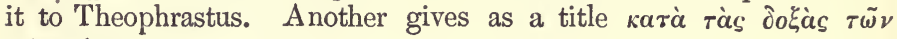
$\phi \iota \lambda o \sigma o ́ \phi \omega \nu$.

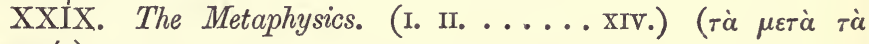
$\phi v \sigma \iota \kappa a ́$.

This collection of treatises is said to have been called by Andronicus by this name, because when he endeavoured to group the works of Aristotle together systematically, these remained after he had completed his physical cycle, and he had no better resource than to put them together after it. Harris ${ }^{1}$ gives a different account of the names, which he grounds on a passage in a manuscript work of Philoponus. Men, he conceives, were led to the study of the highest causes by an ascent from the contemplation of the lower or physical. Hence the first philosophy which treats of them was, from being subsequent in time to these physical inquiries, called Metaphysical. Brandis ${ }^{2}$ relates from a manuscript commentary of Asclepius (a writer of no great value), that Aristotle had during his lifetime committed the several treatises, the aggregate of which goes by this name, to his scholar Eudemus, who considered that they were not in a fit state for publication; but that after his death subsequent Peripatetics (oi $\mu \varepsilon \tau a \gamma \varepsilon \nu \varepsilon \dot{\sigma \tau \varepsilon \rho \circ}$ ) endeavoured to work them up into a whole, supplying what was deficient from other works of their founder. Whatever may be the truth of this story, it is unquestionable that the arrangement of the several books is merely arbitrary; and several variations have been proposed, among others one by Petiti, which we annex, with the addition of those works named by Diogenes Laertius in his catalogue, which he conceived to be identical with the several parts of

1 Additional note to the second of The Three Treatises, pp. 364, 365.

${ }^{2}$ Rhein. Mus. i. p. 242, note (19). 
this work. In the Greek manuscripts, the first book is denoted by the letter (A); the second, not by the letter (B), but by $(\alpha)$; the third by $(B)$; the fourth by $(\Gamma)$; and so regularly on to the fourteenth.

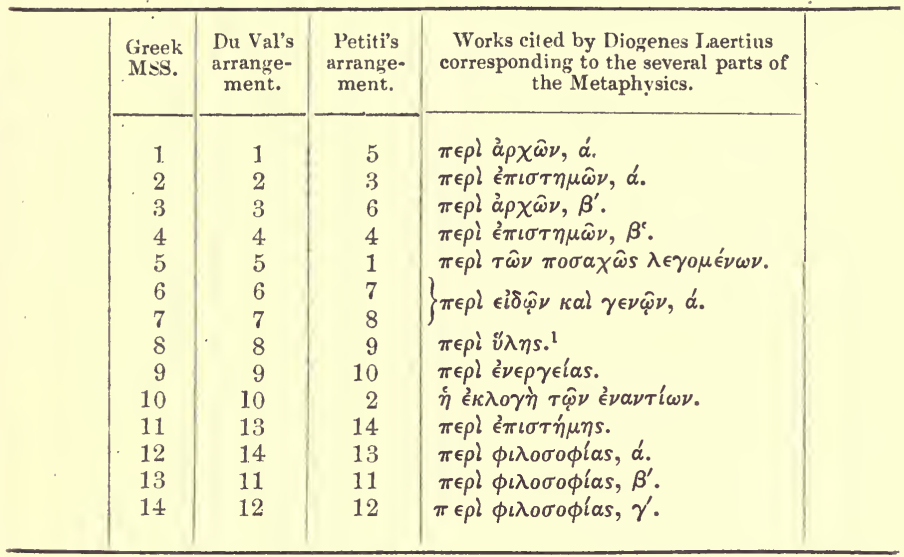

The thirteenth and fourteenth bocks are not found in the old Latin version, or that of Argyropylus. The second book ( $\boldsymbol{\alpha}$ of the Greek MSS.) was considered by some of the ancient commentators to be the work of Pasicrates the Rhodian, brother of Eudemus. Alexander of Aphrodisias says that it is by Aristotle, but is mutilated. Others have held that it is a sort of scholium, and that its proper place is as a preface to the second book of the 'Physical Lectures.' And the circumstance of its being denoted by so singular a mark in the manuscripts would lead us to conclude that some opinion of this sort was widely received.

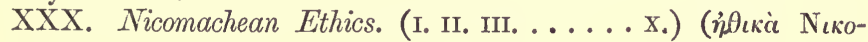
$\mu a \chi \varepsilon \tilde{\varepsilon} a$.)

'This is one of the most perspicuous, as well as most valuable, of the works of Aristotle which has come down to us. Although in a scientific form, there is a reference throughout to practical utility; and Aristotle himself seems to avow that he has sacrificed some of the rigidness of his method to this consideration. It is, however, unequalled to this day as a treatise on morals. On the subject of the name different accounts are given. Most of the ancient commentators assert that it was so called by Aristotle because inscribed to his son Nicomachus. Cicero appears, as we have seen, to consider the son the author. Petiti endeavours to show that the treatise was written at a time when Nicomachus was not born. It was probably, like the 'Rhetoric,' worked at by the author after having been published,

1 These are not mentioned by Diogenes. 
and this will account for some of those passages which he considers to be interpolations by him.

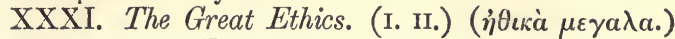

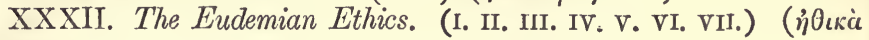
Eं่ $\eta \mu \varepsilon \iota$.)

This work was in ancient times attributed to Theophrastus or Eudemus. The third and three following books agree considerably, both in subject and style, with the fifth, sixth, and seventh of the ' Nicomachean Ethics.' Some of this agreement may be artificial, and arise from the transcribers interpolating the one work from the other. But it seems highly probable that both this treatise and the 'Great Ethics,' are books made up from the notes of Aristotle's scholars. They, particularly the last named, which, contrary to what its name would lead us to expect, is by far the shortest, seem to stand in very much the same relation to the 'Nicomachean,' as the little book 'Anweisung zur Menschen-und-Weltkenntniss' (which was published by a scholar of Kant's from notes of a course of lectures delivered by him) does to the work 'Anthropologie in pragmatischer Hinsicht,' which the philosopher himself published.

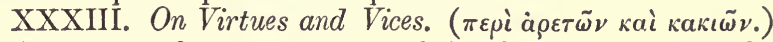

A spurious fragment, preserved by Stobæus. The author is by some scholars supposed to be Andronicus of Rhodes; but others think it should rather be attributed to a platonizing eclectic of later times.

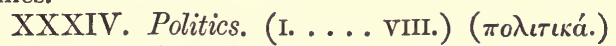

Of this work we have given our opinion in an earlier part of the article (p. 107).

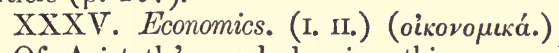

Of Aristotle's work bearing this name, Diogenes Laertius only mentions one book; and of these it seems quite evident that both are not by the same author. Erasmus held the first to be Aristotle's, but to be only a fragment; but Niebuhr considers that lately-discovered authorities prove it incontestably to be by Theophrastus.

If the second book is Aristotle's, it is probably a collection made by him when collecting materials for his historical and philosophical writings on government. It is chiefly a string of instances of oppression exercised by one people upon another, or by tyrants upon their subjects.

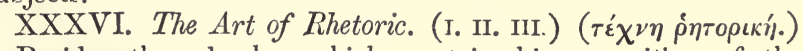

Besides these books, which contain his exposition of the art, Aristotle wrote one other which contained a history of it and of its professors from the earliest times to his own. Of this Cicero speaks ${ }^{1}$ in the highest terms, but it is unfortunately lost. The division into three books is ingeniously conjectured by $\mathrm{Stahr}^{2}$ to be due to Andro-

1 De Invent. ii. 2. Compare De Orat. ii. 38.

${ }^{2}$ Aristoteles bei den Roemern, p. 30 . 
nicus of Rhodes. Some of the MSS. collated by Bekker mark this division as peculiar to the manuscripts of the Latin arrangement. The Greek one terminated the first book with the end of the ninth chapter, and made our second book the third. Jonsius conjectures that the treatise mentioned by Diogenes in his catalogue, under the title $\pi \varepsilon \rho i \sigma \sigma \nu \beta o v \lambda i a s$, is the sixth and seventh chapters of the first book of this work. That this work is a different one from that which Aristotle is said to have made over to his scholar Theodectes, ${ }^{1}$ appears from a passage ${ }^{2}$ in which he quotes that treatise. Hence it would seem that, independently of the 'Rhetoric to Alexander,' the author of which is uncertain, Aristotle published three distinct works on this subject, which certainly accords with what Cicero says, ${ }^{3}$ that the Peripatetics boasted "that Aristotle and Theophrastus not only wrote better, but wrote much more on the subject of oratory than all the professed masters of the science."

But it seems to us more probable that the work which he cites was one by Theodectes, his own scholar, and that Valerius Maximus mistook for an act of envy what was more probably meant and taken for a flattering encouragement. The first sketch of the 'Rhetoric' was, as is remarked by Niebuhr, published long before it was worked up into the form we have it in now, and in this interval Theodectes, of whom Cicero speaks as a writer on the subject, probably published his book. It will be observed that Aristotle does not cite the treatise as his own; but this was overlcoked by Valerius, or the authority whom he followed, and the tale we have mentioned above was coined to illustrate the passage. It may also be remarked that the double publication of the 'Rhetoric' will serve to account for the growth of that story which Dionysius of Halicarnassus takes so much pains to refute. ${ }^{4}$ No one could have hazarded such a fiction with all the quotations from Demosthenes under his very eyes. It must have originated with some one who used a copy of the early edition; while Dionysius in his refutation used the later.

XXXVII. The Rhetoric to Alexander. ( $\delta \rho o v)$.

This treatise is not mentioned by Diogenes Laertius in his catalogue of Aristotle's works ; and the dedicatory preface at the beginning is a solitary instance, if it be a writing of Aristotle's, of such a proceeding. Quintilian appears to quote it as the prouluction of Anaximenes of Lampsacus, a contemporary of the Stagirite. Neither the style nor the treatment of the subject accords with the character of the last work; and perhaps what most contributed to procure its ascription to Aristotle is the circumstance that the writer claims the authorship of

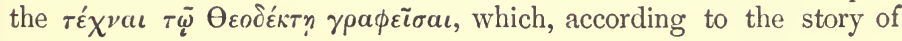

1 See above, p. 168, note 2, and compare Cicero, Brut. 64.

2 P. 1410, col. 2, line 2, ed. Bekker.

${ }^{3}$ De Oratore, i. 10.

- See above, p. 168 , note 2. 
Valerius Maximus, spoken of in the last article, could only belong to Alexander's preceptor. In spite of this, Victorius and Buhle have attributed the work to Callisthenes. We should be inclined to consider it the performance of a sophist of a very late date, and should regard the allusion to Theodectes as a confirmation of the opinion.

XXXVIII. On the Poetic Art. (

On the subject of this work we have already given our opinion. It has been considered by some a fragment of the two books 'On Poets,' which Macrobius quotes, but it hardly seems possible to consider it in this light. If it is derived in any way from a published work, it must have been by a process of epitomizing and selecting, and that not very skilfully. 


\section{EPICURUS.}

BY

ANDREW FINDLATER, A.M. 



\section{EPICURUS.}

FROM B. C. 341 TO B. C. 270 .

\section{PART I.-LifE.}

EPICURus was born in the third year of the hundred and ninth Olym- Epicurus, piad, seven years after the death of Plato. His birthplace was the ${ }_{\text {B.c. } 341 .}^{\text {born }}$ island of Samos, to which his father had removed as a colonist from Athens. This did not prevent Epicurus from being considered an Athenian by birth, and as belonging to the deme Gargettus and the tribe Ageis. Although the family would seem to have been origi- His parents. nally not without distinction, his parents were in rather indigent circumstances. His father, Neocles, is said to have been a schoolmaster, and his mother, Chœrestrate, to have practised arts of magic. It was afterwards made a matter of reproach to Epicurus that while young, when his mother went about among the cottages performing purifications, he had accompanied her and read the formula of incantaton; and that he had assisted his father to keep a school at very low ter ms. He had three brothers, Neocles, Chœredemus, and Aristobulus, w hom Plutarch cites as models of the rarest fraternal affection.

Epicurus lived at Samos and Teos to the age of eighteen, when he Visits repaired to Athens. Xenocrates was then teaching in the Academy, and Theophrastus, the successor of Aristotle, in the Lyceum, and it is probable that Epicurus may have been a pupil of one or both; for we His masters are told that he had begun the study of philosophy at the age of in philofourteen, and had received lessons in Samos from Pamphilus, a Platonist. A number of other philosophers are mentioned, by various authors, as having been at one time or other his instructors; but he himself used to boast that he was self-taught. Of the older philosophers he was most attached to Anaxagoras and Democritus. The writings of Democritus are said to have first attracted him to the study of philosophy; and his system of physics is evidently built upon the atomic speculations of Democritus.

His stay at Athens on this occasion was short: the troubles in Attica that followed the death of Alexander caused him to remove first to Colophon, and then to Mitylene and Lampsacus. It was at opens schonl Mitylene, in his thirty-second year, that he first opened a school ; and at Mitylene, there and at Lampsacus he taught for five years.

Epicurus now returned to Athens, E. c. 306, and there founded Returns to that school which ever after was called by his name. The followers Athens. of Plato occupied the Academy, those of Aristotle the Lyceum, the 
Cynics the Cynosargus, and the Stoics the Portico; Epicurus established his school in a garden which he purchased for 80 minæ (about 350l.), and laid out for the purpose. From this circumstance his followers were called the philosophers of the garden.

His

friendship with his pupils.
Manner of life. his enemies,

In this garden he and his pupils lived in a state of friendship to which, if the accounts given are to be trusted, there have been few parallels. Pythagoras had made his followers throw their property into a commoll stock, saying that the possessions of friends should be held in common; Epicurus disapproved of this, as implying a distrust of one another inconsistent with real friendship. The friendship of Epicurus and his pupils has been extolled by Cicero in the highest terms. ${ }^{1}$

Although Epicurus laid down the doctrine that pleasure is the chief good, the life that he and his friends led was one of the greatest temperance and simplicity. 'They were content, we are told, with a small cup of light wine, and all the rest of their drink was water. And an inscription over the gate promised to those who might wish to enter no better fare than barley-cakes and water. 'The chastity of Epicurus was so incontestable that Chrysippus, one of his principal opponents, in order to deprive him of all merit on the score of it, ascribed it to his being without passions.

Many stories, it is true, of an opposite character were put in circulation. The Stoics, whose system he chiefly set himself against, hated him bitterly, and broached all manner of calumnies on his mode of life; which, as he professed himself the advocate of pleasure, would naturally find ready belief with those who did not know him. Timocrates, who had been his pupil but abandoned him, represented Epicurus as gluttonous and licentious, reporting that he spent a mina (above 4l.) a-day on the luxuries of the table, and was in the habit of vomiting twice a-day from surfeit; and that many immodest women lived in his garden with him and his friends. Diotimus, the Stoic, carried this system of persecution so far, as to publish a set of obscene letters and attribute them to Epicurus.

refuted. Diogenes Laertius, who relates all these stories, declares his utter disbelief of them; and, besides citing direct testimonies to the contrary, appeals to the universal esteem in which he was held by his friends and pupils, and to the public statues which were erected to him by his countrymen after his death. If the reports in question had been generally believed in Athens, that could hardly have taken place; and that they were disbelieved in a city where slander against eminence was always so readily listened to, is a strong proof that they were without foundation.

His success as a teacher.

The success of Epicurus as a teacher was signal. Great numbers flocked to his school from all parts of Greece, and from Asia Minor. The attractiveness of his leading doctrine-the very name pleasuremight have considerable effect in bringing together hearers; but it 1 De Fin. i. 20. 
required something more to produce that steady adherence for which the school was remarkable. While many left other teachers to join Epicurus, only two instances were on record of Epicurus being deserted by a pupil. This could arise only from the ascendency which his character was calculated to acquire. That ascendency must have been due partly to the force of intellect which is otherwise manifest in his speculations; but partly also to the amiability and benevolence for which he was distinguished. He is said to have had so many friends, " that they could not be contained in whole cities." It says as much, perhaps, for the personal character of Epicurus as for his doctrines, that his three brothers were adherents of his system, and also one of his slaves, Inus, whom he made free at his death. Epicurus never married: according to his theory of happiness, marriage was not consistent with prudence; but in the important relations of a son, a brother, and a friend, he was confessedly most exemplary.

He continued to conduct a flourishing school till his death, in the His death, seventy-second year of his age, thirty-six years after he had settled as B.c. 270 . a teacher in Athens. He died of the stone, after a fortnight's illness. Writing to his friend Idomeneus during this illness, he says, that the violence of his sufferings were such that nothing could be added to it. " But the joy of mind arising from the habitual recollection of all my philosophical speculations, counterbalances all these afflictions." Diogenes Laertius gives us a glimpse, as it were, of his last moments. Finding his end approaching, "he entered a warm bath, called for a cup of pure wine and drank it, and having recommended his friends to remember his doctrines, he expired."

He left his house and garden for the use of the adherents of his philosophy, and appointed Hermarchus of Mitylene as his first successor. Metrodorus, to whom of all his followers he was most attached, died seven years before him; and Epicurus at his death made generous provision for the children of his friend. His will, His will. which we fortunately possess, is an interesting document, and gives us much more genuine insight into the affectionateness and generosity of Epicurus's character, than any of the third-hand reports that we are obliged to content ourselves with on other points concerning him. The following are extracts:-

"Out of the income which is derived from that property, which is here bequeathed by me to Amynomachus and Timocrates (the executors), I will that they, consulting with Hermarchus, shall arrange in the best manner possible the offerings to the manes in honour of the memory Appoints of my father, and mother, and brothers, and myself; and that my memory of birth-day may be kept, as it has been in the habit of being kept, on his parents. the tenth day of the month Gamelion; and that the reunion of all Hishirth-day the philosophers of our school, established in honour of Metrodorus and myself, may take place on the twentieth day of every month. They shall also celebrate, as I have been in the habit of doing myself,

1 Quoted from the translation in Bohn's Classical Library. 
the day consecrated to my brothers, in the month Poseideon; and the day consecrated to the memory of Polyænus, in the month Metageitnion.

Makes

provision for

the children

of two

friends.

"Amynomachus and Timocrates shall be the guardians of Epicurus, the son of Metrodorus, and of the son of Polyænus ; *** also of the daughter of Metrodorus; and when she is of marriageable age, they shall give her to whomsuever Hermarchus shall select of his companions in philosophy, provided she is well-behaved and obedient to Hermarchus. And Amynomachus and Timocrates shall, out of my income, give them such a sum for their support, as shall appear sufficient, year by year, after due consultation with Hermarchus. $* * *$ And as for the dowry for the girl, when she is come to marriageable age, let them take for the purpose such a sum from my property as shall seem to them, in conjunction with Hermarchus, to be reasonable. And let them also take care of Nicanor, as we ourselves have done; in order that all those who have studied philosophy with us, and who have assisted us with their means, and who have shown great friendship for us, and who have chosen to grow old with us in the study of philosophy, may never be in want of anything as far as our power to Emancipates prevent it may extend.-Of my slaves, I hereby emancipate Inus and his slaves. Nicias, and Lycon: I also give Phædrium her freedom."

\section{PART II.-Doctrines.}

The writings Epicurus was a most voluminous writer. According to Diogenes of Epicurıs. Laertius, he left three hundred volumes; " and in the whole of them there is not one citation from other sources, but they are filled wholly with the sentiments of Epicurus himself." Among others, he had thirty-seven books on Natural Philosophy; a treatise on Atoms and the Vacuum; one on Love; one on Choice and Avoidance; another on the Chief Good; four essays on Lives; one on Sight; one on Touch; another on Images; another on Justice and the other Virtues, \&c. Almost all these works are lost: the only writings of Epicurus that have come down to us are three letters, and a number of detached sentences, or sayings, preserved by Diogenes Laertius, in his life of the philosopher. Sources Some knowledge of the doctrines of Epicurus may be gathered knowledge of his doctrines. from scattered notices in several ancient writers, among others in Cicero 'De Finibus,' and 'De Nat. Deorum, and in Seneca. The poem also of Lucretius, 'De Rerum Natura,' contains substantially the philosophy of Epicurus. But the principal and only direct source are the letters and the sentences above mentioned. These - letters were written for the express purpose of giving to some of his friends an epitome of what he had taught in his discourses and books. In attempting, therefore, to give some account of the philosophical system of Epicurus, we mean to confine ourselves, for the most part, to this direct source; and as it has been the fate of 
Epicurus, perhaps more than any other philosopher, to be misrepresented and maligned, we will leave him, as far as possible, to speak for himself, only giving such hints as to put the reader in the point of view necessary for seeing the drift of the argument.

We shall not stop to point out the errors and deficiencies of the system-even though that were necessary. Our business is not to criticise the Epicurean philosophy, but to give our readers an idea of object of what it was; and for this purpose they are not to be put into a following hostile attitude, but rather led to look at it, for a time, with Epicurus's eyes. The worthlessness of most of the physical speculations, as regards positive science, will be readily enough apparent; and an appreciation of the moral doctrines will be found in another volume of this series. ${ }^{1}$

Are we to look upon Epicurus as a natural, or as a moral philo- Is Epicurus sopher? Judging by the comparative space that these two kinds of a natural speculation severally occupy in Epicurus's own epitome, one would philosopher? suppose that he held physical science to be more important than ethical. And we are still more liable to form this impression from a cursory reading of Lucretius's poetical version of the Epicurean philosophy; for to expound the nature and causes of physical and psychological phenomena seems the grand aim of that work, and moral reflections appear to be only incidental. It is really, however, the very reverse. The end of all philosophy, according to Epicurus, is to teach men how to live happily. If he appears chiefly occupied in speculating on the material world, it is because he looks upon a knowledge of that as the chief road to happiness; and all philosophy that does not seem to him to bear upon a happy life, he holds in the utmost contempt.

We shall fail, however, to appreciate rightly the Epicurean system Epicurus's of natural philosophy, unless we bear in mind how Epicurus conceived view of the physical science to affect human happiness. We seek for knowledge physical because it is power; we explore the laws of nature, that we may control the material world, and thus avert physical evils, and extract for ourselves the means of enjoyment. This view of the end of physical inquiry had hardly been distinctly conceived in ancient times by any school of philosophers ; in fact there was, as yet, scarcely any science of a nature sufficiently positive and exact to be turned to practical account. At all events this was not Epicurus's view of the use of natural philosophy. According to him, the great evil that afflicted men-the incubus on human happiness-was fear; fear of the gods, and fear of death. To get rid of these two fears and thus secure the negative, and, in his view, the chief condition of happiness, was the ultimate aim of all Epicurus's speculations on nature. This he prided himself on having effected; and his disciple, Lucretius, points to this service as his chief clain to our gratitude and admiration :-

${ }^{1}$ Vol. X. Maurice's 'Moral and Metaphysical Philosophy.' 
The

subjective

use of

science the chief.

The chief destroyers of human happiness.
Them [men] long the tyrant power Of SUPERSTITION swayed, uplifting proud Her head to heaven, and with horrific limbs Brooding o'er earth; till he, the man of Greece, Auspicious rose, who first the combat dared, And broke in twain the monster's iron rod.

* * * * And, hence, we,

Triumphant too, o'er Superstition rise,

Contemn her terrors, and unfold the heavens. ${ }^{1}$

He even goes so far as to profess his belief that, for delivering mankind from these and other disturbers of the soul, Epicurus has done more for their happiness, and is better entitled to divine honours at their hands, than Ceres and Bacchus who gave them corn and wine, or Hercules who delivered them from so many monsters. ${ }^{2}$

The use of pliysical theories, then, according to Epicurus, is subjective and not objective; and unless we advert to this at every step, not only will most of his reasonings and opinions appear trifling and ridiculous, but he will often seem to speak nonsense-as his commentators and translators not seldom make him to do. If we look at his explanations of phenomena from his own point of view, we shall be able to discern "a method in the madness" of even the wildest of them.

That we are not misrepresenting the view with which Epicurus philosophised, the following passages from his letters will prove :-

"You are striving, you say in your letter, to store up in your memory those opinions and speculations that tend to a happy life.

"In seeking a knowledge, then, of the phenomena of the heavens -and it is the same with every other science we are to propose no other end than freedom from perturbation of mind and firmness of belief.

"The leading disturber of men's souls and destroyer of their happiness is the belief that the stars are happy and immortal beings, with whose wills the wills and actions of men may not be in accordance; they also torment themselves with looking forward to fabulous eternal evils, and suffer by anticipation the insensibility of death. ** Tranquillity of mind consists in being delivered from all such myths, and in knowing and remembering the general laws of the world.

"If no anxious suspicions about the heavenly bodies, or about death troubled us, and if the limits and mode of regulation of the

${ }^{1}$ Good's Translation of Lucretius, i. 62 :-

Humana ante oculos fæde cum vita jaceret

In terris oppressa gravi sub religione,

Quæ caput a cæli regionibus ostendebat

Horribili super aspectu mortalibus instans,

Primum Graius homo mortalis tendere contra

Est oculos ausus primusque obsistere contra.

Quare religio pedibus subjecta vicissim

Opteritur, nos exæquat victoria cœlo.

2 Lucr. v. 14. 
desires were understood, we should have no need of physical science

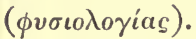

"It would not be possible to banish fear about the most important things, if we continued ignorant of the nature of the universe, or if any suspicion lurked of there being truth in the myths."

We learn from Diogenes Laertius that Epicurus divided philosophy Divisions of into three parts, the canonical, the physical, and the ethical. $\mathrm{He}$ plilosophy. rejected dialectics as superfluous and trifling. Language in itself, and the mere arts of reasoning and disputing, he seems to have despised. In his treatise on rhetoric, the one point he laid stress on was clearness, and this was the only thing he attended to in his own writings. To one department of language, indeed, he urges assiduous attention, that of general names; by observant exercise of the senses we are to form for ourselves clear and determinate notions of the things that correspond to such names, as foundations and tests of all other knowledge.

The canonical division of Epicurus's philosophy treated of the Sources and primary sources of knowledge, or, as he calls them, the criteria of criteria of

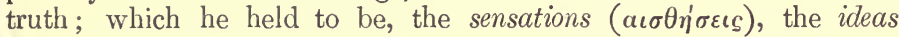
$\left(\pi \rho 0 \lambda \eta^{\prime} \psi \varepsilon \iota s\right)$, and the feelings or passions $\left(\pi \dot{c}^{\prime} \theta \eta\right)$. The senses were pronounced to be independent of reason, and incapable of memory. Their testimony must be received without question, for there is nothing that can decide upon it. One sense even cannot judge another : and reasoning, instead of establishing the truth of the sensations must be founded upon them. Ideas ${ }^{1}$ are defined to be, recollections of external things previously perceived by the senses. When the word man, for instance, is pronounced, a form of him is perceived by the mind, owing to previous operations of the senses. These ideas furnish us with direct and certain truth, no less than the senses do. The passions or feelings are two, pleasure and pain, affecting every living thing. Their testimony also is direct and certain, and by it are to be tried all questions as to what is to be chosen and what is to be avoided.

In opposition to knowledge derived from these three sourcés, which Deductive was considered self-evident and certain, was placed the knowledge knowledge. that is arrived at by inference or reasoning. This must always be founded on self-evident knowledge, and is suggested by scme analogy or resemblance, or results from combination. What is thus arrived at

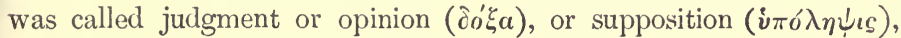
and might be either true or false ; true, if supported by testimony (of the criteria) or not contradicted by testimony ; false, if not supported, or if contradicted.

In accounting for the origin of error, Epicurus seems in some passages Origin or to admit a sort of active initiative on the part of the intellect itself - error. something not unlike the spontaneous creative powver attributed to it by some modern psychologists. This doubtless breaks in upon the

${ }^{1} \pi \rho \circ \lambda \eta \dot{\psi} \epsilon \iota s-$ absurdly rendered by the Latin word anticipatio, or the English preconception. 
simplicity and apparent sureness of his method; just as the admission of irregular deviations from the straight line in the motion of atoms, disfigures his physical theory.

Such then, according to Diogenes Laertius, were the canons or rules of method laid down by Epicurus in his treatise called 'The Canon.' This, therefore, was not so much a separate division of philosophy, as an introduction to the other two. The physics, or natural philosophy, is discussed in the first two of the letters before mentioned; the one being occupied with the constitution of the world in general, and the other with the phenomena of the heavens. His moral philosophy is delineated, briefly, in the third letter; and the select sentences contain maxims on both subjects. We will now present such a series of extracts from these authentic documents, preceded by necessary explanations, as to give some idea of Epicurus's leading dogmas, and of the sort of reasoning on which he founded them. We take no more liberty with the original than is necessary to render the passages intelligible to a modern reader.

\section{Physics. - The Universe.}

After enjoining attention to the exact import of names, and to the primary knowledge that we get from the three sources above mentioned, Senses, Ideas, and Passions, he proceeds :-

"Having ascertained all this, we may then proceed to the study of things depending on indirect evidence. And first to the truth, that

Nothing springs from nothing.

Everything is corporeal.

The universe infinite, both as to matter and space. Nothing is produced from what does not exist; for otherwise, everything would be produced from everything, without the necessity of seed. Again, if what disappears were so destroyed as to be nonexistent, then all things would perish, the elements into which they are resolved no longer existing. But in truth this All, this universe, was always such as it is now, and will always be such. For there is nothing into which it may change; for there is nothing besides the All, which, entering into it, could effect a change.

"The All or universe is body (corporeal). For it is by sensation that the existence of palpable objects is perceived, and it is by analogy with these that what cannot be directly observed, must be proved. (Now in this way we make out legitimately the existence of space). For if what we call vacuum, or space, or the intangible nature, did not exist, bodies would not have where to exist or move, as we see that they do. (Thus we get a knowledge of two kinds of existence, of bodies and of the vacuum). But besides these two, we can arivive at no notion, either through direct perception or by analogy to things perceived, of anything which we can conceive as a separate existence, and not as a property or accident of body or space.

"The universe is infinite. For that which is finite has an extreme, and an extreme implies something else beyond. (But something else than 'the All' ( $\tau \dot{0} \pi \tilde{a} \nu$ ) is an absurdity; the universe therefore has no extreme). So that having no extreme, it is infinite. And it is in- 
finite both in respect of the number of bodies that compose it, and of the extent of the vacuum or space. For if space were infinite and the bodies were limited in number, the bodies would be able to remain in no place, but would be carried hither and thither, and scattered through the infinitude of space, not supporting and keeping one another in their places. On the other hand, if space were limited, and the bodies infinite, the bodies would have nowhere to exist."

\section{Atoms.}

"Of bodies some are compounds, and some are elements of which Bodies the compounds are formed. These elements are indivisible (áro $\mu a, \begin{aligned} & \text { composed } \\ & \text { of indestruc- }\end{aligned}$ atoms) and unchangeable, being 'full' and admitting nowhere and no- tible atoms. how of dissolution. This is absolutely necessary to prevent the disintegration of bodies from ending in the annihilation of all things."

Among other properties, these atoms are stated to be of various Atoms are of shapes, this being necessary to account for the observed differences of various stzes bodies; for the sanie reason they are assumed to be of various magnitudes. In this respect, however, there are limits, otherwise we should be meeting with visible atoms, which is never the case; nor in fact can we conceive such a thing possible. On the other hand, we are to guard against the notion of unlimited smallness, or infinite divisibility. There is a great deal of elaborate argument in disproof No infinite of this notion, none of it very cogent. Perhaps this attempt at a reductio ad absurdum is the best. "For when one has once said that there are in any object an infinite number of particles, it is manifestly impossible to think any longer of that object as finite in magnitude." Atoms, then, have some determinate magnitude. 'They possess none of the changeable properties of bodies; but only the essential properties of form, magnitude, and weight.

The grand problem in the Epicurean cosmogony was: Given How were infinite space and an infinite number of atoms, to account for the the objects formation and continued existence of things as we see them. This the world initiatory part of the system is so briefly noticed in the 'Epitome,' that to understand it we must have recourse to Lucretius, where it is seen in a more expanded form. In solving the problem, Epicurus has faithfully adhered to his rule of explaining things beyond the reach of observation, only by the analogy of things that are observed. This corresponds in so far to the modern maxım, that requires us to call in to the explanation of phenomena no causes but such as we know to exist. The other part of that axiom-to call in no more causes than are necessary - has nothing expressly answering to it in the Epicurean canon; but his grand aim, to get rid, namely, of the gods, supplies the place of a positive rule, and makes him very sparing of principles.

To account for the formation of bodies, for their observed motions, Atoms and for most of their changeable properties, it is assumed that atoms with are endowed with an inherent motion, and that this motion, when inherent not interfered with, is always in one uniform direction downwards. motion. 
This is thought to be in strict analogy with what happens to palpalole bodies; and atoms, having weight like them, are assumed to follow the same law.

Of up and down in the infinite.

No centre.

Do atoms overtake one another?

They meet by deflection from the straight line.
Epicurus has been accused of absurdity in speaking of a downwards and an upwards in relation to infinite space. But from his point of view there is no absurdity. To him the earth was a fixed plain; and all motions of falling bodies, on whatever parts of the earth's surface and at whatever times, were parallel to one another, and therefore in one uniform fixed direction, which men knew by the name of "downwards."

He rejects, for many, to him, strong reasons, the notion of a centre towards which all things are in motion; a notion entertained by those philosophers who held that there is only one, and that a finite, world. This would have been contrary to the canon; for such convergent motions are nowhere observable: drops of rain, for instance, fall parallel—so at least thought Epicurus.

Suppose then the atoms moving like drops of rain across the vacuum, how are they ever to come together to form the world? Are we to assume that they have different velocities, and that one atom overtakes another? Epicurus had observed with sufficient accuracy the motions of bodies in free space, not to admit that supposition; and argues acutely enough against the idea that heavy bodies move faster than light ones.

At this rate atoms could never have combined. It only remained then to suppose that some of them deviated from the straight line.

This, too, regard intent; that primal seeds

When down direct their potent path they urge,

In time uncertain, and uncertain space,

Oft from the right decline. ${ }^{2}$

According to Cicero, " " this supposition is mere puerility; for he

1 The translator of Lucretius, in Bohn's Classical Library, after noticing this assumed absurdity (page xiii), accuses his author of afterwards contradicting himself, when lie says that nil est funditus imum. 'There is, however, no more contradiction in the one case than there is absurdity in the other. Lucretius holds, following Epicurus, that there is an up and a down, but denies that there is an upmost or a downmost; there is a downwards, but no bottom.

The translator of Diogenes Laertius, from the same misapprehersion of this part of the Epicurean physics, makes Epicurus actually contradict himself: "Moreover, we must not say (while speaking of the infinite) that such a point is the highest point of it, or the lowest. For height and lowness nuust not be predicated of the infinite." The sentence in italics is in direct contradiction of what Epicurus says immediately after. But the sentence in question has nothing corresponding to it in the original; it is a gloss of the translator, thinking to explain the preceding position. Epicurus again and again asserts that the motion caused by weight is always from high to low; he only cautions against thinking of any points in these two opposites as the highest or the lowest.

2 Illud in his quoque te rebus cognoscere aremus, Corpora cum deorsum rectum per inane feruntur, Ponderibus propriis incerto tempore ferme Incertisque loci spatiis decellere paulum. Lucr. ii. 216.

${ }^{3}$ Quæ res tota ficta est pueriliter; nam et ipsa declinatio ad libidinem fingitur 
introduces the deviation arbitrarily, making some atoms decline from the straight course without cause; and he also takes way from atoms, without cause, that natural motion from above downwards, which he himself had ascribed to all heavy bodies; but to say that anything takes place without a cause, is the most repugnant of all things to a natural philosopher."

Undoubtedly, this is the weak point in Epicurus's cosmogony ; and yet, if his canon is to be depended upon, the assumption is defensible. It seems, he might argue, to be contradicted by the testimiony of the senses, since heavy bodies, when they fall, move, as far as we can see, in straight lines and parallel to one another. "But who can discern that they do not deviate in the very slightest degree?"-which is all that is asked.

Thus, if not supported, the theory is at least not contradicted by the senses. The support or positive testimony is found in a quarter where we should little have looked for it-in the freedom of the will. We turn aside and alter our motions, nothing urging us thereto; this is an analogy to what is assumed of atoms, and authorises the assumption :-

The free-born mind

Acts or forbears, spontaneous ; its own time,

Its place, alike uncertain : these the will,

Doubtless, alone determines. ${ }^{1}$

Hence firm maintain we, primal seeds some cause

Must feel of rising motion unbestowed

By weight, or blow reactive, whence alone

Upsprings this secret power by man possest :

Nought forming nought, as reason proves precise. ${ }^{2}$

Thus, these fitful deflections of atoms from the straight course are inferred from, and then serve to account for, the self-originating movements of the human will.

When the atoms are once by this expedient brought into collision, The clashing innumerable motions in all directions are produced by their mutual re- of atoms actions; and, after infinite clashing and whirling, the result is-the the world. world we see :-

Primordial seeds

* * ever changing, ever changed and vext,

(ait enim declinare atomum sine causa; quo nihil turpius physico quam fieri sine causa quidquam dicere); et illum motum naturalem omnium ponderum, ut ipse constituit, e regione inferiorem locum petentium, sine causa eripuit atomis.-Cicero, de Fin. i. 6.

1 Declinamus item motus nec tempore certo

Nec regione loci certa, sed ubi ipsa tulit mens.

Nam dubio procul his rebus sua cuique voluntas

Principium dat.

Lucr. ii. 259.

${ }^{2}$ Quare in seminibus quoque idem fateare necessest,

Esse aliam præter plagas et pondera causam

Motibus, unde hæc est nobis innata potestas;

De nilo quoniam fieri nil posse videmus.

Lucr. ii. 284. 
From earliest time, through ever-during space,

With ceaseless repercussion, every mode Of motion, magnitude, and shape essayed;

At length th' unwieldy mass the form assumed Of things created. ${ }^{1}$

Cohesion dispensed with.

Their existence possible.

Their necessity.

Images produce hearing.
Perception by images or emanations.

Epicurus's notion of the constitution of matter is thus essentially different from ours. Instead of bodies owing their consistency to the mutual attraction of their particles, he considered them as held together by the shocks and resistance of surrounding atoms. We can thus understand the earnestness with which he labours to prove the infinite extension of matter, and the horror with which an Epicurean looked upon the heresy of one finite world, and of any space altogether empty of matter :-

For once to act, when primal atoms fail, Fail where they may, the doors of death are ope, And the vast whole unbounded ruin whelms. ${ }^{2}$

\section{Images.}

A prominent feature in Epicurus's philosophical system is the doctrine of perception by images $(\varepsilon \hat{\varepsilon} \delta \omega \lambda \alpha)$. Their nature and the proofs of their existence are thus stated :-

"There exist forms of solid objects, similar to those objects in shape, but differing from them much in the thinness of their substance. For there is no impossibility in such emanations existing in the air, or in there being a capacity in bodies for forming such hollow, thin spectra, or in the emanations retaining the unbroken disposition and structure that they had in the solids. To these forms we give the name of images."

'These images move with inconceivable rapidity, owing to the tenuity of their substance, which encounters little or no resistance in space. They are incessantly streaming off from the surface of all bodies, and are necessary to bring us into rapport with the world without.

"For external things could not impress upon us their nature, as to colour and shape, through the medium of the air between us and them, or through rays or any other emanations proceeding from us to them; so that perception must take place as it were through certain forms, of the same colour and shape, and of proportionate size, coming from the objects, and making their way with great rapidity to the eye or the mind."

In like manner sounding bodies throw off emanations, by which we

1

Primordia rerum * *

* quia multa modis multis mutata per omne

Ex infinito vexantur percita plagis,

Omne genus motus et coetus experiundo

Tandem deveniunt in talis disposituras,

Qualibus hæc rerum consistit summa creata.

Lucr. i. 1021.

2 Nam qua cumque prius de parti corpora deesse

Constitues, hæc rebus erit pars janua leti :

Hac se turba foras dabit omnis materiai.

Lucr. i. 1111. 
are brought into sympathy with them; mere pulses of the air could not be conceived to effect this. Perception by the smell takes place in the same way.

\section{Psychology.}

In Psychology, Epicurus is a decided materialist: he thus lays down the nature of the soul:-

"From the facts of sensation and passion, we infer with the utmost The soul is certainty that the soul is a bodily substance, composed of subtile par- ${ }^{\text {corporeal. }}$ ticles, disseminated through the whole frame, and having a great resemblance to spirit $\left(\pi \nu v^{\prime} v \mu a\right)$, with a mixture of heat. From the subtilty of its particles it has great capacity of change and displacement, and can thus enter into more perfect sympathy with the rest of the structure."

For the rest, the soul is principally concerned in sensation, but Relation of receives that faculty from being enveloped in the hody. Neither body soul and nor soul has any sensation by itself; the body loses sensation when sensation. the particles composing the soul are dissipated, and when the body is dissolved the soul is dissolved, and retains neither motion nor sensation.

"They who say that the soul is incorporeal utter nonsense. The The soul only incorporeal existence that we can form any notion of is the vacuum, incorporeal. which can neither act nor suffer. If the soul, then, were incorporeal, it could neither act nor suffer; but we have indisputable evidence that it does both, therefore, \&c."

We are told that Epicurus, in another of his works, distinguished The two in the soul the irrational part, which is diffused through the body soul, where generally, from the rational part, which is located in the breast, as is located. manifest from the feelings of fear and joy. This corresponds to the distinction made by Lucretius between anima and animus.

\section{Astronomy.}

In considering that part of Epicurus's system that treats of Astronomy and Meteorology, it is particularly necessary" to bear in mind the object with which he speculates. He seeks to understand the phenomena of the heavens for no practical purpose, but solely for subjective satisfaction-to enable the mind to account for them to itself, without the necessity of imagining any supernatural agency at work.

He conceives this class of appearances as peculiarly removed from Certainty direct observation by their distance, and therefore that a knowledge of not to be them can be arrived at only by inference-by the suggestions of the fancy as tested by the analogy of familiar facts. Absolute truth and certainty, therefore, are not to be looked for, nor are they necessary. Of various explanations, all equally conformable to the analogy of things around us, any one is satisfactory to the mind, and therefore as good as true.

"The phenomena of the heavens admit of various causes being Phenomena assigned for their production, equally conformable to the facts learned 
Descriptive astronomy useless.

Size of the sun and stars.

Causes of

Causes of
their motion.

Source of the moon's light.

Appearance of a face in the moon.

Eclipses.

Clouds.

Moral philosophy. from the senses. If, then, in thinking of any appearance, we suppose it brought about by the same cause that produces another appearance which gives no alarm or uneasiness, we are as much delivered from uneasiness as if we saw that such is the cause of it. At all events, whatever way we may suppose them to take place, they have clearly no connection with any immortal happy intelligences-a supposition introducing conflict and perturbation."

It was only the knowledge of the causes of the movements-what we call physical astronomy-that Epicurus considered worthy of pursuit; descriptive and historical astronomy he despised.

"As to a mere description or historical record of risings and settings of stars, and tropical movements and eclipses, and such like, that has no tendency to promote happiness; on the contrary, those that are occupied with these things, but remain ignorant of the causes, are perhaps more exposed to fear and perturbation than others."

We shall now be prepared to read a few specimens of Epicurus's explanations of particular phenomena without a smile; worthless and puerile as science, from his point of view they have a meaning and a value.

" The magnitude of the sun and of the other stars is, as regards us, such as it appears to be. If their magnitude were diminished by their distance, much more would their brilliancy.

"As to their motions, we may conceive them as owing to the revolution of the whole heaven, or that the heaven stands still and the stars move, according to a necessity generated in them at the birth of the world, their motion being kept up by the tendency of fire to advance towards its aliment.

"Again, it is admissible that the moon may have light of herself, and it is admissible that she may receive it from the sun; for we behold around us many bodies having light of themselves, and many receiving it from other bodies. So that the heavenly phenomena present no difficulties, when we bear in mind that they may be caused in many ways.

"The appearance of a face in the moon may be viewed as arising either from an alteration in the structure of the parts, or from something interposed, or in any way that is in accordance with things that we know with certainty.

"Eclipses of the sun and moon may be caused by extinction-a fact familiar to us, - or by the interposition of something else, such as the earth, or the heaven, or anything of that kind.

"Clouds may have many causes; they may be condensations of the air, compressions of the winds, conglomerations of atoms of a special kind, or emanations from the earth and the waters."

\section{Morai Philosophy.-The Gods.}

It remains to sketch briefly those doctrines of Epicurus that bear more directly on moral subjects. His physical speculations pave the 
way for his moral teaching: they furnish the negative conditions of happiness, by enabling him to allay all vain terrors and perturbations. The chief source of those terrors is the belief in supernatural agents. Epicurus's cosmogony and natural philosophy enable him to dispense with all such agency in the physical world as unnecessary; and he considers this as the starting point in proceeding to lay down the rules of life.

Epicurus does not deny that there are gods. The fact that we have The gods, a notion of such beings proves to him their existence. He believes how kno.n. that the visions of sleep have real objects corresponding to then, being produced by images of those objects floating about in the air. In a similar way we come by our ideas of the gods. Images or ernanations thrown off from them flow in upon us, accompanied with the most pleasurable feelings, and thus give us a conception of what a perfectly happy and incorruptible being is. ${ }^{1}$ The perfect happiness and un- Their perfect changeableness of the gods he assumes as an indisputable fact, and happiness makes it the foundation of his reasoning respecting them. Hence his ruptibility. famous maxim: "A happy and imperishable being neither has trouble itself, nor causes trouble to any other being." He had in his physics obviated the necessity of employing the gods in creating or moving the machinery of the world, and he now deprecates the very thought as impious.

"First of all, believe that God is a being imperishable and happy, Their as the common conception of God dictates; and attach to that con- freedom from ception nothing incompatible with incorruptibility and happiness. ${ }^{*} *$ all emotion. Beware of attributing the revolutions of the heaven, and eclipses, and the rising and setting of stars, either to the original contrivance or continued regulation of such a being. For business, and cares, and anger, and benerolence, are not accordant with happiness, but arise from weakness, and fear, and dependence upon others. Nor must we imagine that these fiery globes are themselves happy beings, moving by their own volition. But we must observe reverence in all that we utter on such subjects.

" There are gods; for our knowledge of them is direct and certain. Popular But they are not in all respects as the multitude think of them; for notions most of the actions and functions commonly attributed to the gods, impious. violate the fundamental notion of these happy existences. So that the impious man is not he that denies the gods of the multitude, but

1 Epicurus has been less explicit upon this point in his letters than we could have wished. The above account of his theory is derived from Cicero's report of it (De Nat. Deo. i. 19). "Epicurus autem, qui res occultas et penitus abditas non modo viderit animo, sed etiam sic tractet, ut manu nos dncat, docet eum esse vim et naturam deorum, ut primum non sensu, sed mente cernatur, nec soliditate quadam, nec ad numerum; ut ea, quæ ille propter firmitatem $\sigma \tau \epsilon \rho \epsilon ́ \mu \nu \iota a$ appellat, sed imaginibus similitudine et transitione perceptis : deinde cum infinita simillimarum imaginum species ex innumerabilibus individuis exsistat et ad nos affluat cum maximis voluptatibus, in eas imagines mentem intentam infixamque nostram intelligentiam capere, quæ sit et beata natura et æterna." 
he that attaches the fancies of the multitude to his idea of the gods. For the multitude judge of the virtues of the gods by their own, and attribute to them, alike the greatest evils that befall the wicked and the prosperity that accrues to the good."

Presages. While trying to account for the belief in presages or omens, drawn from the flight of birds and other circumstances connected with animals, Epicurus ridicules the idea of a divine being sitting aloft watching the motions of the animals, and taking his cue from that as to how he shall regulate the machinery of the world. He would not set any living thing, whose lot he meant to be tolerable, to such a dotard task; much less a being endowed with supreme felicity. Lucretius even hints the serious displeasure of the gods-if the gods could be angry - against those who assign them any such ignoble employment as at all interfering with this world and the concerns of men.
These notions if thou chase not, driving far
Thoughts of the gods unworthy, and adverse
To the pure peace they covet, thou wilt oft
Foretaste the heavenly vengeance that thou dread'st.
Not that the majesty of powers like these
Rage e'er can violate, or dire revenge
Rouse into action; but that thou thyself
Hence thy own ease wilt shipwreck with the storms
Of passions fierce and foul; nor e'er approach
With hallowed heart the temples they possess,
Nor deeply musing mark with soul serene
The sacred semblances their forms emit,
Traced by the spirit, thus of gods assured.
Judge, then, thyself, what life must hence ensue. ${ }^{1}$

\section{Death and Pain.} The fear of Epicurus next proceeds to cut off the other great source of disquiet - the fear of death. For this he had prepared the way in his physiology, when he proved that the dissolution of the body involves that of the soul.

how got

"The most terrible of all evils, death, is nothing to us ; since when we are, death is not; and when death is, we are not. It is nothing then to the dead or the living; for to the one class it is not near, and the other class are no longer in existence. The wise man does not fear not-being-alive, or think it an evil; for the question is not between

1 Quæ nisi respuis ex animo longeque remittis

Dis indigna putare alienaque pacis eorum,

Delibata deum per te tibi numina sancta

Saepe oberunt; non quo violari summa deum vis

Possit, ut ex ira poenas petere inbibat acris,

Sed quia tute tibi placida cum pace quietos

Constitues magnos irarum volvere fluctus,

Nec delubra deum placido cum pectore adibis,

Nec de corpore quæ sancto simulacra feruntur

In mentes hominum divinæ nuntia formæ

Suscipere hæc animi tranquilla pace valebis.

Inde videre licet qualis jam vita sequatur.

Lucr. vi. 78. 
being-alive and not-being-alive; but, as in choosing food, we prefer, not that which is most in quantity, but that which is most pleasant, so we value time not for its length, but for its agreeableness."

Having thus taken away the terrors of death by a syllogism, he addresses himself to the kindred subject of bodily pain.

"Continuous bodily pain is not of long duration: extreme pain Pain of short lasts very short time indeed; where there is an excess of pain over pleasure at all, it never continues many days; and when disorders are of long continuance, pleasurable feeling predominates over painful."

\section{The Chief Good.}

The chief disturbers of happiness being thus banished, tlie next step is to determine its positive elements. In what does happiness consist? in other words, what is the chief good? Pleasure, answers Pleasure the Epicurus. And, according to his canon, he could not have answered otherwise. The sources and tests of all ethical truth are the feelings $\left(\pi \dot{\alpha}^{\prime} \theta \eta\right)$, and these are two, pleasure and pain. Now all animals from the moment of their birtl delight in pleasure and are offended with pain, by their very nature and without reason; and they are prompted instinctively to seek the one and avoid the other. Since the feelings then are the criteria in all such questions, pleasure is the only good and pain is the only evil, and every action is to be judged by its effect in producing the one or the other.

But what is pleasure? Here Epicurus differed from Aristippus, what is who also held that pleasure is the chief good. According to Aris. pleasure? tippus and his school, before there is pleasure, there must be positive delightful sensations amounting to excitement and emotion. They also held that bodily pain was worse than mental. Epicurus, on the contrary, teaches that freedom from disquiet and pain, from cold, It is freedom hunger, and thirst, and from unsatisfied desires, is, of itself, pleasure. from uneasiness. Positive excitement may be necessary for joy and delight, but for pleasure tranquillity is enough. He also maintains that the sufferings of the mind are incomparably worse than those of the body; for flesh suffers only from present pain, but the soul suffers from the past, the present, and the future.

The tone of Epicurus's moral system is thus quietistic, and, his definition of pleasure being of a negative kind, he is able to arrive at practical precepts, which even his enemies could not find fault with. But we will let him speak for himself.

"For a correct theory of the desires leads us to settle all questions Ease of as to what we are to choose and what avoid, by a reference to the body and health of the body and the tranquillity of the soul; since this is the of mind are end of the art of living. For whatever we do, we do it for the pur- the chief pose of avoiding pain or perturbation; and that effected, the tempest, as it were, of the soul is allayed; the restless cravings of vital instinct no longer urge it abroad in quest of something felt to be necessary to complete the good of body and soul." 
That this negative state is actually pleasure, he makes out by a sort of verbal juggle not uncommon in ancient dialectics.

Freedom from pain proved to be pleasure.

Every pleasure not to be chosen.

Why contentment is good.

Sensual pleasure not meant.

Limit of bodily pleasure. The desires.

Is pleasure ever an ovil?

"For we are in want of pleasure, when, from pleasure not being present, we are in pain; but when we are not in pain, then we are not in want of pleasure. And for this reason we call pleasure the beginning and end of the art of living. Not that every pleasure is to be chosen; on the contrary, we avoid many pleasures when a preponderance of inconvenience would attend them, and many pains we count better than pleasures, when a greater pleasure will follow the suffering.

"Every pleasure is in itself good, but every pleasure is not to be chosen; just as every pain is an evil, and yet every pain is not, because it is so, to be avoided. For in every case this must be determined by comparison, and by a regard to what is upon the whole suitable and unsuitable.

"We call contentment a great good; not as if it were a thing in itself desirable to have little of the means of life; but that, if much be not our lot, we may be able to enjoy little: convinced that those men enjoy luxury most, who can most readily do without it.

"When we say that pleasure is the end of life, we do not mean the pleasures of the debauchee or sensualist, as some fiom ignorance or from malignity represent, but freedom of the body from pain and of the soul from anxiety. For it is not continuous drinkings and revellings, nor the society of women, nor rare viands and other luxuries of the table, that constitute a pleasant life; but sober contemplation that searches out the grounds of choice and avoidance, and banishes those chimeras that harass the mind.

"When once the pain arising from a want is removed, bodily pleasure admits of no further increase; anything more only varies it.

"Of the desires some are natural and necessary, such as drink when one is thirsty; some are natural but not necessary, such as a desire for luxuries that only vary pleasure and do not remove pain ; others are neither natural nor necessary, but owe their origin to vain opinions, such as a passion for civic distinctions and honours.

"Those desires that do not end in pain when left unsatisfied, are not necessary ; and their craving is easily silenced, when their gratification is difficult, or they seem likely to produce mischief."

As the natural and necessary desires are easily satisfied, the means of a happy life are thus within the reach of all, without struggle or difficulty.

"No pleasure is in itself an evil, but the means" of procuring some pleasures are attended with consequences that are destructive of the pleasures.

"If the means to which sensualists owe their pleasures dispelled the anxieties of the mind-as well those connected with supernatural objects as with death and pain,-and if they enabled them to set limits to their desires, we should have no grounds to blame them for taking 
their fill of pleasure, wherever they could find it, provided it were attended with no pain or grief from any quarter; for that is the only evil."

The whole question of ethics, then, comes to a calculation and balancing of pleasures and pains; in other words, the cardinal virtue Prudence is prudence. This Epicurus lays down explicitly.

"The principle that guides all our decisions is prudence, the most valuable part of philosophy; for on it are grounded all the other virtues, teaching us that there is no living happily without living prudently, and honourably, and justly ; nor prudently, and honourably, and justly, without living happily. For the virtues are indissolubly connected with a happy life."

\section{Justice.}

The greater part of the ethical doctrines of Epicurus-as indeed of the ancient philosophers generally-have reference to the individual; in other words, it is chiefly personal morality that he looks to. Justice Justice is almost the only social virtue on which we have his opinions, at any fourded on length, in his own words; and that he rests on the same prudential basis as he does temperance. Injustice is an evil, because it exposes the individual to disquietude from other men; justice is a virtue, because it secures him from this disquietude. The doctrine is thus established :-

"Natural justice is an agreement of convenience to avoid injuring Has no and being injured. In the case of animals, which are incapable of existence entering into such contracts, there is no such thing as justice or injus- compact. tice. Justice would have no existence were it not for contracts having been made somewhere or other to abstain from mutual injury.

"Injustice is not an evil in itself; but becomes so from the fear How that haunts the injurer of not being able to escape the appointed injustice avengers of such acts. When a man does anything, however secretly, an evil, in violation of one of those agreements that mankind have entered into for the mutual preservation of their interests, he can never feel sure that he will go undetected, even though he may have already escaped ten thousand times; for until his death, it is always uncertain whether he will finally escape."

The duties of friendship and good fellowship are inculcated on the same grounds of security to the individual.

"The best way to secure one's self from molestation from other and men, is to make friends and allies of all that we can; and where we friendship cannot make friends, to avoid making enemies. They attain the greatest security who make their social intercourse the most pleasant to one another."

The great prudential principle, of avoiding everything that can entail anxiety and trouble, is rigorously carried out by Epicurus in every detail of conduct that he notices. He lays down, for instance, as The wise attributes of his 'wise man,' that he will take no part in politics, and take office, 
nor marry. that he will not marry, or bring up children. He adds, indeed, that circumstances may at times justify a departure from these rules; but this does not obviate the absurd consequences that evidently flow from them. Accordingly, this doctrine has been severely handled by several ancient philosophers, particularly by Cicero ${ }^{1}$ and Epictetus. ${ }^{2}$

\section{Successors.}

Successors The school of the Garden was presided over successively by Herof Epicurus. marchus, Polystratus, Dionysius, Basilides, and others, and the philosophy continued to attract numerous adherents. When Greek philosophy was introduced among the Romans, the system of Epicurus, though never so popular as Stoicism, was adopted by many distinguished men. Horace and Atticus were Epicureans, and the splendid poem of Lucretius must have recommended the system to many. Under the emperors, Pliny the Younger and Lucian of Samosata are known to have been followers of this school.

Modern

In modern times, Epicureanism was resuscitated in France by Pierre

Epicureans. Gassendi, one of the most distinguished scholars and philosophers of the seventeenth century, who published an account of the life, and defence of the character, of Epicurus (Lugd. Bat. 1647). He was the means of forming a sort of modern school, professing the doctrines of the Garden, and which, meeting at first in the salons of Ninon de L'Enclos in Paris, and afterwards at Auteuil, Seaux, and elsewhere, included the most celebrated men and women of that and the succeeding age; among others, Molière, Madame Scarron, Saint Evremont, the Count de Grammont, Madame de Mazarin, the Duke of Rochefoucault, Rousseau, Hamilton, St. Aulaire, Fontenelle, and Voltaire.

${ }^{1}$ Ep. ad Famil. vii. 12.

2 Epict. apud Arrianum. iii. 7. 


\section{I C E R 0.}

BY

\section{JOHN HENRY NEWMAN, B.D. \\ FORMERLY FELLOW OF ORIEL COLLEGE, OXFORD.}


[This article has already appeared in the volume on Roman Literature: as it gives an account, however, of the Philosophy of Cicero, it is inserted again in this place entire, it being found impossible to separate the Philosophy from the Literature.EDITOR.] 


\title{
MARCUS TULLIUS CICERO.
}

\author{
FROM U. C. 647 TO 711 ; A. C. 107 To 43.
}

WE now turn to consider the political character, oratorical talents, and philosophical writings of one who has already come before us in our poetical division.

Marcus Tullius Cicero was born at Arpinum, the native place of Marius, ${ }^{1}$ in the year of Rome 647, (A.c. 107,) the same year which gave birth to the Great Pompey. His family was ancient and of equestrian rank, but had never taken part in the public affairs of Rome, ${ }^{2}$ though both his father and grandfather were persons of consideration in the part of Italy to which they belonged. ${ }^{\mathbf{3}}$ His father, being himself a man of cultivated mind, determined to give his two sons the advantage of a liberal education, and to fit them for the prospect of those public employments which a feeble constitution incapacitated himself from undertaking. Marcus, the elder of the Birth and two, soon displayed indications of a superior intellect, and we are told education. that his schoolfellows carried home such accounts of his talents, that their parents often visited the school for the sake of seeing a youth who gave such promise of future eminence. ${ }^{4}$ One of his earliest masters was the poet Archias, whom he defended afterwards in his consular year: under his instructions he made such progress as to compose a poem, though yet a boy, on the fable of Glaucus, which had formed the subject of one of the tragedies of Eschylus. Soon after he assumed the manly gown, he was placed under the care of Scævola the celebrated lawyer whom he introduces so beautifully into several of his philosophical dialogues; and in no long time he gained a thorough knowledge of the laws and political institutions of his country. ${ }^{5}$

This was about the time of the Social war; and, according to the Roman custom, which made it a necessary part of education to learn the military art by personal service, Cicero took the opportunity of serving a campaign under the Consul Pompeius Strabo, father of Pompey the Great. Returning to pursuits more congenial to his Early natural taste, he commenced the study of philosophy under Philo the campaign. Academic, of whom we shall speak more particularly hereafter. ${ }^{6}$ But $\begin{gathered}\text { 4. c. } 6.69 . \\ \text { 89. }\end{gathered}$ his chief attention was reserved for oratory, to which he applied

1 De Legg. ii. 3.

${ }^{3}$ De Legg. ii. 1, 3, 16 ; de Orat. ii. 66.

${ }^{5}$ Middleton's Life, vol. i. p. 13, 4to; de Clar. Orat. 89.
2 Contra Rull. ii. 1.

4 Plutarch, in Vitâ.
- Ibid. 
himself with the assistance of Molo, the first rhetorician of the day; while Diodotus the Stoic exercised him in the argumentative subtleties for which the disciples of Zeno were so celebrated. At the same time he declaimed daily in Greek and Latin with some young noblemen who were competitors in the same race of honours with himself.

Of the two professions, ${ }^{1}$ which, from the existence of external and internal disputes, are inseparable alike from all forms of government, while that of arms, by its splendour and importance, secures the almost undivided admiration of a rising and uncivilised people, legal practice, on the other hand, becomes the path to honours in later and more civilised ages, from the oratorical accomplishments by which it is usually attended. The date of Cicero's birth fell precisely during that intermediate state of things, in which the exclusive glory of military exploits was prejudiced by the very opulence and luxury which they had been the means of procuring; he was the first Roman who found his way to the highest dignities of the state with no other

Choice of profession.

Defence of Roscius

Amerinus his first cause.

His travels.

Returns to Rome. U. C. 677 . A. C. 77.

Quæstor of Sicily.

recommendation than his powers of eloquence, and his merits as a civil magistrate. ${ }^{2}$

The first cause of importance he undertook was his defence of Roscius Amerinus; in which he distinguished himself by his spirited opposition to Sylla, whose favourite Chrysogonus was prosecutor in the action. This obliging him, according to Plutarch, to leave Rome on prudential motives, he employed his time in travelling for two years under pretence of his health, which, he tells us, ${ }^{3}$ was as yet unequal to the exertion of pleading. At Athens he met with $\mathrm{T}$. Pomponius Atticus, whom he had formerly known at school, and there renewed with him a friendship which lasted through life, in spite of the change of interests and estrangements of affection so commonly attendant on turbulent times. ${ }^{4}$ Here too he attended the lectures of Antiochus, who, under the name of Academic, taught the dogmatic doctrines of Plato and the Stoics. Though Cicero evinced at first considerable dislike of his philosophical views, ${ }^{5}$ he seems afterwards to have adopted the sentiments of the Old Academy, which they much resembled; and not till late in life to have relapsed into the sceptical tenets of his former instructor Philo. After visiting the principal philosophers and rhetoricians of Asia, in his thirtieth year he returned to Rome, so strengthened and improved both in bodily and mental powers, that he soon eclipsed in speaking all his competitors for public favour. So popular a talent speedily gained him the suffrage of the commons; and, being sent to Sicily as quæstor, at a time when the metropolis itself was visited with a

${ }^{1}$ Pro Muræna, 14 ; de Orat. i. 9.

${ }^{2}$ In Catil. iii. 6 ; in Pis. 3 ; pro. Sylla, 30 ; pro Dom. 37 ; de Harusp. resp. 23 ; ad Fam. xv. 4.

${ }^{4}$ Middleton's Life, vol. i. p. 42, 4to.

${ }^{3}$ De Clar. Orat. 91

5 Plutarch, in Vitâ.

- Warburton, Div. Leg. lib. iii. sec. 3 ; and Vossius, de Nat. Logic, c. riii. sec. 22. 
a scarcity of corn, he acquitted himself in that delicate situation with such address, as to supply the clamorous wants of the people without oppressing the province from which the provisions were raised.' Returning thence with greater honours than had ever been before decreed to a Roman governor, he ingratiated himself still farther in the esteem of the Sicilians, by undertaking his celebrated prosecution Prosecution ' of Verres; who, though defended by the influence of the Metelli and of Verres. the eloquence of Hortensius, was at length driven in despair into voluntary exile.

Five years after his quæstorship, Cicero was elected ædile, a post Edile. of considerable expense from the exhibition of games connected with it. $^{2}$ In this magistracy he conducted himself with singular propriety ${ }^{3}$ for, it being customary to court the people by a display of splendour in these official shows, he contrived to retain his popularity without submitting to the usual alternative of plundering the provinces or sacrificing his private fortune. The latter was at this time by no means ample; but, with the good sense and taste which mark his character, he preserved in his domestic arrangements the dignity of a literary and public man, without any of the ostentation of magnificence which often distinguishes the candidate for popular applause. ${ }^{*}$

After the customary interval of two vears, he was returned at the head of the list as prætor $;^{5}$ and now made his first appearance in the Prætor. rostrum in support of the Mamilian law, which will be found in the volume of this Encyclopædia containing the public history of Rome. About the same time he defended Cluentius. At the expiration of his prætorship, he refused to accept a foreign province, the usual reward of that magistracy $;^{6}$ but, having the consulate full in view, and relying on his interest with Cæsar and Pompey, he allowed nothing to divert him from that career of glory for which he now believed himself to be destined.

It may be doubted, indeed, whether any individual ever rose to power by more virtuous and truly honourable conduct; the integrity Different of his public life was only equalled by the correctness of his private estimates morals ; and it may at first sight excite our wonder, that a course so his contemsplendidly begun should afterwards so little fulfil its early promise. poraries and We have, in our memoir of Cæsar, contained in the volume above cited, traced his course from the period of his consulate to his prætorship in Cilicia, and found each year diminish his influence in public affairs, till it expired altogether with the death of Pompey. This surprise, however, arises in no small degree from measuring Cicero's political importance by his present reputation, and confounding the authority he deservedly possesses as an author, with the opinions entertained of him by his contemporaries as a statesman. From the consequence usually attached to passing events, a politician's celebrity

1 Pro Planc. 26 ; in Verr. v. 14.

${ }^{3}$ De Offic. ii. 17 ; Middleton.

5 In Pis. 1.
2 Ibid.

4 Pro Dom. 58.

6 Pro Murænâ, 20. 
is often at its zenith in his own generation; while the author, who is in the highest repute with posterity, may perhaps have been little valued or courted in his own day. Virtue indeed so conspicuous as that of Cicero, studies so dignified, and oratorical powers so commanding, will always invest their possessor with a large portion of reputation and authority; and this is nowhere more apparent than in the enthusiastic joy displayed on his return from exile. But unless other qualities be added, more peculiarly necessary for a statesman, they will hardly of themselves carry that weight of political consequence which some writers have attached to Cicero's public life, and which his own self-love led him to appropriate.

The advice of the oracle, ${ }^{1}$ which had directed him to make his own genius, not the opinion of the people, his guide to immortality (which in fact pointed at the above-mentioned distinction between the fame of a statesman and of an author), at first made a deep impression on his mind; and at the present day he owes his reputation principally to those pursuits which, as Plutarch tells us, exposed him to the ridicule and even to the contempt of his contemporaries as " a pedant and a trifler." But his love of popularity overcame his philosophy, and he commenced a career which gained him one triumph and ten thousand mortifications.

It is not indeed to be doubted that in his political course he was considerably influenced by a sense of duty. To many it may even appear that a public life was best adapted for the display of his particular talents; that, at the termination of the Mithridatic war, Cicero was in fact marked out as the very individual to adjust the pretensions of the rival parties in the commonwealth, to withstand the encroachments of Pompey, and to baffle the arts of Cæsar. And if the power of swaying and controlling the popular assemblies by his eloquence; if the circumstances of his rank, equestrian as far as family was concerned, yet almost patrician from the splendour of his personal honours; if the popularity derived from his accusation of Verres, and defence of Cornelius, and the favour of the senate acquired by the brilliant services of his consulate; if the general respect of all parties

His

Consulate.

U. c. 690 .

A. C. 63 . which his learning and virtue commanded; if these were sufficient qualifications for a mediator between contending factions, Cicero was indeed called upon by the voice of his country to that most arduous and honourable post. And in his consulate he had seemed sensible of the call: "Ita est à me consulatus peractus," he declares in his speech against Piso, " ut nihil sine consilio senatûs, nihil non approbante populo Romano egerim; utsemper in rostris curiam, in senata populum defenderim; ut multitudinem cum principibus, equestrem ordinem cum senatu conjunxerim. ${ }^{3}$

1 Plutarch, in Vitâ.

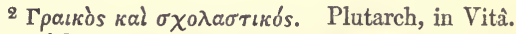

3 [" I have, throughout my consulship, so acted, that I have done nothing without the advice of the senate-nothing without the approval of the Roman people; that I have ever defended the senate in the rostrum, the people in the senate- 
Yet, after that eventful period, we see him resigning his high station Want of to Cato, who, with half his abilities, little foresight, and no aldress, ${ }^{1}$ political possessed that first requisite for a statesman, firmness. Cicero, on the contrary, was irresolute, timid, and inconsistent. ${ }^{2}$ He talked indeed largely of preserving a middle course ${ }^{3}$ but he was continually vacillating from one to the other extreme; always too confident or too dejected; incorrigibly vain of success, yet meanly panegyrizing the government of an usurper. His foresight, sagacity, practical good sense, and singular tact, were lost for want of that strength of mind which points them steadily to one object. He was never decided, never (as has sometimes been observed) took an important step without afterwards repenting of it. Nor can we account for the firmness and resolution of his consulate, unless we discriminate between the case of resisting and exposing a faction, and that of balancing contending interests. Vigour in repression differs widely from steadiness in meditation; the latter requiring a coolness of judgment, which a direct attack upon a public foe is so far from implying, that it even inspires minds naturally timid with unusual ardour.

His consulate was succeeded by the return of Pompey from the First Triumeast, and the establishment of the First Triumvirate; which, disap- virate. pointing his hopes of political greatness, induced him to resume lis ${ }_{\mathbf{A}}^{\text {v. c. c. } 60 .}$. forensic and literary occupations. From these he was recalled, after an interval of four years, by the threatening measures of Clodius, who at length succeeded in driving him into exile. This event, which, consider- His exile and ing the circumstances connected with it, was one of the most glorious return. of his life, filled him with the utmost distress and despondency. He A.c. 58 . wandered about Greece bewailing his miserable fortune, refusing the consolations which his friends attempted to administer, and shunning the public honours with which the Greek cities were eager to load him. ${ }^{4}$ His return, which took place in the course of the following year, reinstated him in the high station he had filled at the termination of his consulate, but the circumstances of the times did not allow him

house; that I hare ever associated the populace with the nobles, the equestrian order with the senate."-Editor.]

2 See Montesquieu, Grandeur des Romains, ch. xii.

1 Ad Atticum, i. 18, ii. 1.

3 Ad Atticum, i. 19.

${ }^{4}$ Ad Atticum, lib. iii. ; ad Fam. lib. xir.; pro Sext. 22 ; pro Dom. 36 ; Plutarch, in Vitâ. It is curious to observe how he conrerts the alleviating circumstances of his case into exaggerations of his misfortune: he writes to Atticus: "Nam quod me tam sæpe et tam rehementer objurgas, et animo infirmo esse dicis, quæso ecquod tantum malum est quod in meâ calamitate non sit? ecquis unquam ex tam amplo statu, tam in bonâ causâ, tantis facultatibus ingenii, consilii, gratiæ, tantis prasidiiis bonorum omnium, concidit?" ["You frequently and earnestly reprove me, and call me weak-minded. But tell me, what aggravation of misery is there which belongs not to my calamity? Has any man ever fallen from so high a position, in so good a cause, with such ample resources of ability, of judgment, of influence, with such powerful support of all good men?"-Editor.] iii. 10. Other persons would have reckoned the justice of their cause, and the countenance of good men, alleviations of their distress; and so, when others were concerned, he himself thought; pro Sext. 12. 
to retain it. We have elsewhere ${ }^{1}$ described his vacillations betwee the several members of the Triumvirate; his defence of Vatinius to please Cæsar ; and of his bitter political enemy Gabinius, to ingratiate himself with Pompey. His personal history in the meanwhile furnishes little worth noticing, except his election into the college of Augurs, a dignity which had been a particular object of his ambition.

Governor of His appointment to the government of Cilicia, which took place about Cilicia.

five years after his return from exile, was in consequence of Pompey's law, which obliged those senators of consular or prætorian rank, who had never held any foreign command, to divide the vacant provinces among them. This office, which we have above seen him decline, he now accepted with feelings of extreme reluctance, dreading perhaps the military occupations which the movements of the Parthians in that quarter rendered necessary. Yet if we consider the state and splendour with which the proconsuls were surrounded, and the opportunities afforded them for almost legalised plunder and extortion, we must confess that this insensibility to the common objects of human cupidity was the token of no ordinary mind. The singular disinterestedness and integrity of his administration, as well as his success against the enemy, are adverted to in our memoir of Cæsar. The latter he exaggerated from the desire universally felt of appearing to excel in those things for which nature has not adapted us.

His return to Italy was followed by earnest endeavours to reconcile Pompey with Cæsar, and by very spirited behaviour when Cæsar required his presence in the senate. On this occasion he felt the glow of self-approbation with which his political conduct seldom repaid him : "Credo," he writes to Atticus, "credo hunc (Cæsarem) me non amare; at ego me amavi: quod mihi jam pridem usu non venit." But this independent temper was but transient. At no period of his public life did he display such miserable vacillation as at the opening of the civil war. We find him first accepting a commission from the Republic $;^{3}$ then courting Cæsar; next, on Pompey's sailing for Greece, resolving to follow him thither; presently determining to stand neuter; then bent on retiring to the Pompeians in Sicily; and, when after all he had joined their camp in Greece, discovering such timidity and discontent, as to draw from Pompey the bitter reproof, "Cupio ad hostes Cicero transeat, ut nos timeat."

General con-

On his return to Italy, after the battle of Pharsalia, he had the battle of Pharsalia. mortification of learning that his brother and nephew were making their peace with Cæsar, by throwing on himself the blame of their opposition to the conqueror. And here we see one of those elevated

1 History of the Roman Empire, in the Encyclopædia Metropolitana.

2 [" I believe I have not his (Cæsar's) approval; but I have my own; which, for a long time, I have not been used to enjoy." - Editor.] Ad Atticum, ix. 18.

3 Ibid. vii. 11, ix. 6, 119, x. 8 and 9 , \&c.

"["I wish Cicero would go over to the enemy, that he may fear us." - Editor.] Macrobius, Saturnalia, ii. ?. 
points of character, which redeem the weaknesses of his political conduct; for, hearirig that Cæsar had retorted on Quintus the charge which the latter had brought against himself, he wrote a pressing letter in his favour, declaring his brother's safety was not less precious to him than his own, and representing him not as the leader, but as the companion of his voyage. ${ }^{1}$

Now too the state of his private affairs reduced him to great per- Private plexity; the sum he had advanced to Pompey had imporerished him, $\underset{\text { ments. }}{\text { embs- }}$ and he was forced to stand indebted to Atticus for present assistance. ${ }^{2}$ These difficulties led him to take a step which it lias been customary to regard with great severity-the divorce of his wife Terentia, Divorces though he was then in his sixty-second year, and his marriage with Terentia, and his rich ward Publilia, who was of an age disproportionate to his Publilia. own. ${ }^{3}$ Yet, in reviewing this proceeding, we must not adopt the modern standard of propriety, forgetful of a condition of society which reconciled actions even of moral turpitude with a reputation for honour and virtue. Terentia was a woman of a most imperious and violent temper, and (what is more to the purpose) had in no slight degree contributed to his present embarrassments by her extravagance in the management of his private affairs. ${ }^{4}$ By her he had two children, a His children. son, born the year before his consulate, and a daughter whose loss he was now fated to experience. To Tullia he was tenderly attached, firief at the not only from the excellence of her disposition, but from her love of loss of Tullia. polite literature; and her death tore from him, as he so pathetically A.c. 46. laments to Sulpicius, the only comforts which the course of public events had left him. ${ }^{5}$ At first he was inconsolable; and, retiring to a little island near his estate at Antium, buried himself in the woods, Secerles from to aroid the sight of man. ${ }^{6}$ His distress was increased by the un- public life. feeling conduct of Publilia; whom he soon divorced for testifying joy lirorces at the death of her step-daughter. On this occasion he wrote his Publilia. Treatise on Consolation, with a view to alleviate his mental sufferings ; and, with the same object, he determined on dedicating a temple to his daughter as a memorial of her virtues and his affection. His friends were assiduous in their attentions; and Cæsar, who had treated him with extreme kindness on his return from Egypt, signified the respect he bore his character, by sending him a letter of condolence from Spain, ${ }^{7}$ where the remains of the Pompeian party still engaged him. Cæsar had shortly before given a still stronger proof of his favour, by replying to a work which Cicero had drawn up in praise of Cato $;^{8}$ but no attentions, however considerate, could soften Cicero's vexation at seeing the country he had formerly saved by his exertions, now subjected to the tyranny of one master. His speeches, indeed, for Marcellus and Ligarius, exhibit traces of inconsistency; but for

${ }^{1}$ Ad Atticum, xi. 8, 9, 10 and 12.

3 Ad Fam. iv. 14; Middleton, vol. ii. p. 149.

5 Ad Fam. iv. 6.

7 Ibid. xiii. 20.
2 Ibid. xi. 13.

4 Ibid.

6 Ad Atticum, xii. 15, \&c.

8 Ibid. xii. 40 and 41 . 
the most part he retired from public business, and gave himself up to the composition of those works, which, while they mitigated his political sorrows, have secured his literary celebrity.

The murder of Cæsar, which took place in the following year, once ınore brought him on the stage of public affairs; but, as we intend our present paper to be an account of his private life and literary character, we reserve the sequel of his history, including his unworthy treatment of Brutus, his coalition with Octavius, his orations against Antonius, his proscription and death, for another department of our

His private virtues.

Apologies for his inconsistency in public life. work. On the whole, antiquity may be challenged to produce an individual more virtuous, more perfectly amiable than Cicero. None interest more in their life, none excite more painful emotions in their death. Others, it is true, may be found of loftier and more heroic character, who awe and subdue the mind by the grandeur of their views, or the intensity of their exertions. But Cicero engages our affections by the integrity of his public conduct, the correctness of his private life, the generosity, ${ }^{1}$ placability, and kindness of his heart, the playfulness of his temper, the warmth of his domestic attachments. In this respect his letters are invaluable. "Here we may see the genuine man without disguise or affectation, especially in his letters to Atticus; to whom he talked with the same frankness as to himself, opened the rise and progress of each thought; and never entered into any affair without his particular advice."

It must, however, be confessed that the publication of this correspondence has laid open the defects of his political character. Want of firmness has been repeatedly mentioned as his principal failing; and insincerity is the natural attendant on a timid and irresolute mind. On the other hand it must not be forgotten that openness and candour are rare qualities in a statesman at all times, and while the duplicity of weakness is despised, the insincerity of a powerful, but crafty mind, though incomparably more odious, is too commonly regarded with feelings of indulgence. Cicero was deficient, not in honesty, but in moral courage; his disposition too was conciliatory and forgiving; and much which has been referred to inconsistency, should be attributed to the generous temper which induced him to remember the services rather than the neglect of Plancius, and to relieve the exiled and indigent Verres. ${ }^{3}$ Much too may be traced to his professional habits as a pleader; which led him to introduce the licence of the forum into deliberative discussions, and (however inexcusably) even into his correspondence with private friends.

Some writers, as Lyttleton, have considered it an aggravation of Cicero's inconsistencies, that he was so perfectly aware of what was philosophically upright and correct. It might be sufficient to reply,

${ }^{1}$ His want of jealousy towards his rivals was remarkable; this was exemplified in his esteem for Hortensius, and still more so in his conduct towards Calvus. See Ad Fam. xv. 21.

2 Middleton, vol. ii. p. 525, 4 to.

3 Pro Planc.; Middleton, vol. i. p. 108. 
that there is a wide difference between calmly deciding on an abstract point, and acting on that decision in the hurry of real life ; that Cicero in fact was apt to fancy (as all will fancy when assailed by interest or passion,) that the circumstances of his case constituted it an exception to the broad principles of duty. As he eloquently expresses himself in his defence of Plancius: "Neque enim inconstantis puto, sententiam, tanquam aliquod navigium, et cursum, ex reipublicæ tempestate moderari. Ego vero hæc didici, hæc vidi, hæc scripta legi; hæc de sapientissimis et clarissimis viris, et in hac republicâ, et in aliis civitatibus, monumenta nobis literæ prodiderunt; non semper easclem sententias ab iisclem, sed quascunque reipublicæ status, inclinatio temporum, ratio concordiæ postularet, esse defendendas."

Thus he seems to consider it the duty of a mediator alternately ${ }^{2}$ to praise and blame both parties more than truth allows, if by these means it be possible either to flatter or to frighten them into an adoption of temperate measures.

But the argument of the objectors proceeds on an entire miscon- The Philoception of the design and purpose with which the ancients prosecuted sophy of the philosophical studies. The motives and principles of morals were not more specuso seriously acknowledged as to lead to a practical application of them lative than to the conduct of life. Even when they proposed them in the form of precept, they still regarded the perfectly virtuous man as the creature of their imagination rather than a model for imitation-a character whom it was a mental recreation rather than a duty to contemplate; and if an individual here or there, as Scipio or Cato, attempted to conform his life to his philosophical conceptions of virtue, he was sure to be ridiculed for singularity and affectation.

Even among the Athenians, by whom philosophy was, in many cases, cultivated to the exclusion of every active profession, intellectual amusement, not the discovery of truth, was the principal object of their discussions. That we must thus account for the ensnaring questions and sophistical reasonings of which their disputations consisted, has been noticed in our article on LoGIC $;^{3}$ and it was their extension of this system to the case of morals, which brought upon their sophists the irony of Socrates, and the sterner rebuke of Aristotle. But if this took place in a state of society in which the love of speculation pervaded all ranks, much more was it to be expected among the

1 C. 39. ["Nor do I regard it as any mark of inconsistency to regulate my opinions and my course, like a ressel, by the condition of the political weather. All that 1 have learned, witnessed, and read-all that has been recorder of the wisest and most illustrious men, both in our state and in other political communities, has taught me that the same man is not always to defend the same opinions, but rather those which the position of the state, the bias of the times, and the interests of peace may require."-Editor.]

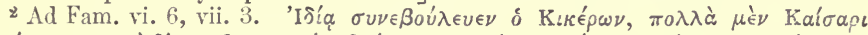

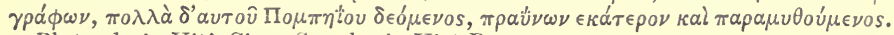
- Plutarch, in Vitâ Cic. See also in Vitâ Pomp.

${ }^{3}$ In the Philosophical division of the Encyclopædia Metropolitana. 
Romans, who, busied as they were in political enterprises, and deficient in philosophical acuteness, had neither time nor inclination for abstruse investigations; and who considered philosophy simply as one of the many fashions introduced from Greece, "a sort of table furniture," as Warburton well expresses it, a mere refinement in the arts of social enjoyment. ${ }^{1} \quad$ This character it bore both among friends and enemies. Hence the popularity which attended the three Athenian philosophers, who had come to Rome on an embassy from their native city; and hence the inflexible determination with which Cato procured their dismissal, through fear, as Plutarch tells us, ${ }^{2}$ lest their arts of disputation should corrupt the Roman youth. And when at length, by the authority of Scipio, ${ }^{8}$ the literary treasures of Sylla, and the patronage of Lucullus, philosophical studies had gradually received the countenance of the higher classes of their countrymen, we still find them, in consistency with the principle above laid down, determined in the adoption of this or that system, not so much by the harmony of its parts, or by the plausibility of its reasonings, as by its suitableness to the profession and political station to which they respectively belonged. Introduction Thus because the Stoics were more minute than other sects in inculof the Greek Philosophy to Rome.

cating the moral and social duties, we find the Jurisconsulti professing themselves followers of Zeno ${ }^{4}$ the orators, on the contrary, adopted the disputatious system of the later Academics $;^{5}$ while Epicurus was the master of the idle and the wealthy. Hence, too, they confined the profession of philosophical science to Greek teachers; considering them the sole proprietors, as it were, of a foreign and expensive luxury, which the vanquished might have the trouble of furnishing, but which the conquerors could well afford to purchase.

First applica- Before the works of Cicero, no attempts worth considering had been tion of the Latin lan. guage to philosophical subjects.

made for using the Latin tongue in philosophical subjects. The natural stubbornness of the language conspired with Roman haughtiness to prevent this application. ${ }^{6}$ The Epicureans, indeed, had made the experiment, but their writings were even affectedly harsh and slovenly $;^{7}$ and we find Cicero himself, in spite of his inexhaustible flow of rich and expressive diction, making continual apologies for his learned occupations, and extolling philosophy as the parent of everyCharacter of thing great, virtuous, and amiable.

Yet, with whatever discouragement his design was attended, he ultimately triumphed over the pride of an unlettered people, and the

1 Lactantius, Inst. iii, 16.

2 Plutarch, in Vitâ Caton. See also de Invent. i. 36.

3 Paterculus, i. 12, \&c. Plutarch, in Vitâ Lucull. et Syll.

4 Gravin. Origin. Juriscivil. lib. i. c. 44.

${ }^{5}$ Quinct. xii. 2. Auct. Dialog. de Orator. 31.

6 De Nat. Deor. i. 4 ; de Off. i. 1 ; de fin. Acad. Quæst., \&c.

7 Tusc. Quæst. i. 3 ; ii. 3 ; Acad. Quæst. i. 2 ; de Nat. Deor. i. 21 ; de Fin. i. 3 , \&c. ; de Clar. Orat. 35 .

${ }^{8}$ Lucullus, 2 ; de Fin. i. $1-3$; Tusc. Quæst. ii. 1, 2 ; iii. 2 ; v. 2 ; de Legg. i. $22-24$; de Off. ii. 2 ; de Orat. 41 , \&c. 
difficulties of a defective language. He was possessed of that first requisite for eminence, all enthusiastic attachment to the studies he was recommending. But occupied as he was with the duties of a states man, mere love of literature would have availed little, if separated from the energy and range of intellect by which he was enabled to pursue a variety of objects at once, with equally persevering and indefatigable zeal. "He suffered no part of his leisure to be idle, or the least interval of it to be lost; but what other people gave to the public shows, to pleasures, to feasts, nay, even to sleep and the ordinary refreshments of nature, he generally gave to his books, and the enlargement of his knowledge. On days of business, when he had anything particular to compose, he had no other time for meditating, but when he was taking a few turns in his walks, when he used to dictate his thoughts to his scribes who attended him. We find many of his letters dated before daylight, some from the senate, others from his meals, and the crowd of his morning levee." Thus he found time, without apparent inconvenience, for the business of the state, for the turmoil of the courts, and for philosophical studies. During his consulate he delivered twelve orations in the senate, rostrum, or forum. His treatises 'de Oratore' and 'de Republicâ,' the most finished perhaps of his compositions, were written at a time when, to use his own words, " not a day passed without his taking part in forensic disputes."2 And in the last year of his life, he composed at least eight of his philosophical works, besides the fourteen orations against Antony, which are known by the name of Philippics. Being thus ardent in the cause of philosophy, he recommended it to the notice of his countrymen, not only for the honour which its introduction would reflect upon himself (which itself was with him a motive of no inconsiderable influence), but also with the fondness of one who esteemed it " the guide of life, the parent of virtue, the guardian in difficulty, and the tranquillizer in misfortune." 3 Nor were his mental endowments less adapted to the accomplishment of his object, than the spirit with which he engaged in the work. Gifted with versatility of talent, with acuteness, quickness of perception, skill in selection, art in arrangement, fertility of illustration, warmth of fancy, and extraordinary taste, he at once seizes upon the most effective parts of his subject, places them in the most striking point of view, and arrays them in the liveliest and most inviting colours. His writings have the singular felicity of combining brilliancy of execution, with never-failing good sense. It must be allowed, that he is deficient in depth; that he skims over rather than dives into the various departments of literature; that he had too great command of the plausible, to be a patient investigator or a sound reasoner. Yet if he has less originality of thought than others, if he does not grapple with his subject, if he is unequal to a regular and lengthened disquisition, if he is frequently inconsistent in his opinions,
1 Middleton's Life, vol. ii. p. 254.
${ }^{2}$ Ad Quint. fratr. iii. 3.

3 Tusc. Quæst. v. 2. 
we must remember that mere soundness of thought, without talent for display, has few charms for those who have not yet imbibed a taste even for the outward form of knowledge, ${ }^{1}$ that system nearly precludes variety, and depth almost implies obscurity. It was this very absence of scientific exactness, which constituted in Roman eyes a principal charm of Cicero's compositions. ${ }^{2}$

Nor must his profession as a pleader be forgotten in enumerating the circumstances which concurred to give his writings their peculiar character. For however his design of interesting his countrymen in Greek literature, however too his particular line of talent, may have led him to explain rather than to invent; yet he expressly informs us it was principally with a view to his own improvement in oratory that he devoted himself to philosophical studies. ${ }^{3}$ This induced him to undertake successively the cause of the Stoic, the Epicurean, or the Platonist, as an exercise for his powers of argumentation; while the wavering and unsettled state of mind, occasioned by such habits of disputation, led him in his private judgment to prefer the sceptical tenets of the New Academy.

Here, then, before examining Cicero's philosophical writings, an opportunity is presented to us of redeeming the pledge we gave in our memoir of Plato, by considering the system of doctrine which the reformers (as they thought themselves) of the Academic school introduced about 300 years before the Christian era.

The New Academy.

Arcesilas.

We have already traced the history of the OLD ACADEMY, and spoken of the innovations on the system of Plato, silently introduced by the austere Polemo. When Zeno, however, who was his pupil, advocated the same rigid tenets in a more open and dogmatic form, the Academy at length took the alarm, and reaction ensued. Arcesilas, who had succeeded Polemo and Crates, determined on reverting to the principles of the elder schools $;^{5}$ but mistaking the profession of

${ }^{1}$ De Off. i. 5, init.

2 Johnson's observations on Addison's writings may be well applied to those of Cicero, who would have been eminently successful in short miscellaneous essays, like those of the Spectators, had the manners of the age allowed it.

3 Orat. iii. 4; Tusc. Quæst. ii. 3; de Off. i. 1. præfat. Paradox. Quint. de Instit. xii. 2. Lactantius, Inst. iii. 16.

* Acad. Quæst. i. 10, \&c. ; Lucullus, 5 ; de Legg. i. 20 ; iii. 3, \&c.

5 Acad. Quæst. i. 4, 12, 13 ; Lucullus, 5 and 23 ; de Nat. Deor. i. 5 ; de Fin. ii. 1; de Orat. iii. 18; Augustin. contra Acad. ii. 6. Sext. Emp. adv. Mathem.

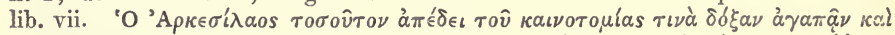

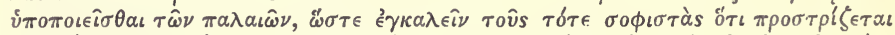

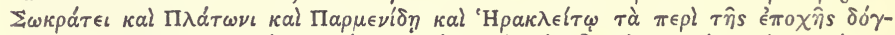

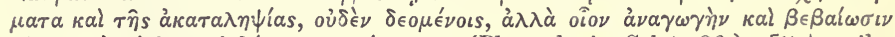

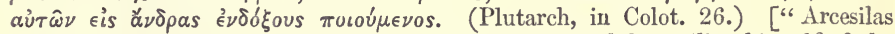
was so far from aiming at the reputation of originality while availing himself of the ancients, that the sophists of that time accused him of assenting implicitly to Socrates, and Plato, and Parmenides, and Heraclitus, in respect of his opinions on the suspension [of assent] and the incomprehensibility [of things], as to perfect authorities, and referring to them for confirmation as to persons of eminence.'-Editor.] 
ignorance, which Socrates had used against the sophists on physical questions, for an actual scepticism on points connected with morals, he fell into the opposite extreme, and declared, first, that nothing could be known, and therefore, secondly, nothing should be advanced.'

Whatever were his private sentiments (for some authors affirm his esoteric doctrines to have been dogmatic ${ }^{2}$ ), he brought forward these sceptical tenets in so unguarded a form, that it required all his argumentative powers, which were confessedly great, to maintain them against the obvious objections which were pressed upon him from all quarters. On his death, therefore, as might have been anticipated, his school was deserted for those of Zeno and Epicurus; and during the lives of Lacydes, Evander, and Hegesinus, who successively filled the Academic chair, being no longer recommended by the novelty of its doctrines, ${ }^{3}$ or the talents of its masters, it became of little consideration amid the wranglings of more popular philosophies. Carneades, ${ }^{4}$ Carneades. therefore, who succeeded Hegesinus, found it necessary to use more cautious and guarded language; and, by explaining what was paradoxical, by reservations and exceptions, in short, by all the arts which an acute and active genius could suggest, he contrived to establish its authority without departing, as far as we have the means of judging, from the principle of universal scepticism which Arcesilas had so pertinaciously advocated. ${ }^{5}$

The New Academy, ${ }^{6}$ then, taught with Plato, that all things in their own nature were fixed and determinate; but that, through the constitution of the human rnind, it was impossible for us to see them in their simple and eternal forms, to separate appearance from reality, truth from falsehood. ${ }^{7}$ For the conception we form of any object is altogether derived from and depends on the sensation, the impression,

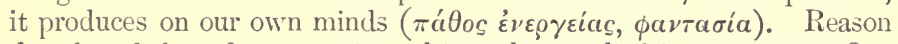
does but deduce from premises ultimately supplied by sensation. Our only communication, then, with actual existences being through the medium of our own impressions, we have no means of ascertaining Modified the correspondence of the things themselves with the ideas we enter- scepticism of tain of them; and therefore can in no case be certain of the fidelity Academy.

1 "Arcesilas negabat esse quidquam, quod sciri posset, ne illud quidem ipsum quod Socrates sibi reliquisset. Sic omnia latere censebat in occulto, neque esse quicquam quod cerni, quod intelligi, posset; quibus de causis nihil oportere neque profiteri neque affirmare quenquam, neque assertione approbare, \&c." (Acad. Quæst. i. 12.) ["Arcesilas affirmed that there was nothing that could be known, not even excepting what Socrates had reserved. He regarded all things as hid in obscurity, and nothing as capable of being perceived or understood; for which reasons he denied the right of any man to aver or affirm anything, or to confirm anything by assertion, \&c."-Editor.] See also Lucullus, 9 and 18 . They were countenanced in these conclusions by Plato's doctrine of ideas.-Lucullus, 45 .

2 Sext. Empir. Pyrrh. Hypot. i. 33 ; Diogenes Laertius, lib. iv. in Arcesil.

${ }^{3}$ Lucullus, 6.

5 Lucullus, 18, 24 ; Augustin. in Acad. iii. 39.

${ }^{6}$ See Sext. Empir. adv. Mathem. lib. vii.

7 Acad. Quæst. i. 13 ; Lucullus, 23, 38; de Nat. Deor. i. 5; Orat. 71. 
of our senses. Of their fallibility, however, we may easily assure ourselves; for in cases in which they are detected contradicting each other, all cannot be correct reporters of the object with which they profess to acquaint us. Food, which is the same as far as sight and touch are concerned, tastes differently to different individuals; fire, which is the same to the eye, communicates a sensation of pain at one time, of pleasure at another; the oar appears crooked in the water, while the touch assures us it is as straight as before it was immersed. ${ }^{1}$ Again, in dreams, in intoxication, in madness, impressions are made upon the mind, vivid enough to incite to reflection and action, yet utterly at variance with those produced by the same objects when we are awake, or sober, or in possession of our reason. ${ }^{2}$

It appears then that we cannot prove that our senses are ever faithful; but we do know they often produce erroneous impressions. Here then is room for endless doubt; for why may they not deceive us in cases in which we cannot detect the deception? It is certain they often act irregularly; is there any consistency at all in their operations, any law to which these varieties may be referred?

It is undeniable that an object often varies in the impression which it makes upon the mind, while, on the other hand, the same impression may arise from different objects. What limit is to be assigned to this disorder? is there any sensation strong enough to assure us of the presence of the object which it seems to intimate, any such as to preclude the possibility of deception? If, when we look into a mirror, our minds are impressed with the appearance of unreal trees, fields, and houses, how can we ascertain whether the scene we directly look upon has any more substantial existence than the former ? ${ }^{3}$

From these reasonings the Academics taught that nothing was certain,

1 “ $\mathrm{Tu}$ autem te negas infracto remo neque columbæ collo commoveri. Primum cur? nam et in remo sentio non esse id quod videatur, et in columbâ plures videri colores, nec esse plus uno, \&c." (Lucullus, 25.) ["You say that you are uninfluenced by the instances of the broken oar and the pigeon's neck. First, let me ask you why? for, in the case of the oar, I perceive that what appears is not; and, in the pigeon, that many colours are apparent, when there is but one, \&c."-Editor.]

${ }^{2}$ Lucullus, $16-18,26-28$.

3 “Scriptum est: ita Academicis placere, esse rerum ejusmodi dissimilitudines ut aliæ probabiles videantur, aliæ contra; id autem non esse satis cur alia percipi posse dicas, alia non posse ; propterea quòd multa falsa probabilia sint, nihil autem falsi perceptum et cognitum possit esse. Itaque ait vehementer errare eos qui dicant ab Academiâ sensus eripi, à quibus nunquam dictum sit aut colorem aut saporem aut sonum nullum esse; illud sit disputatum, non inesse in his propriam, quæ nusquam alibi esset, veri et certi notam. (Lucullus, 32.) ["It has been written thus :The Academics hold that there is in things that dissimilarity, that some appear probable, others the contrary; but that this is no sufficient reason for saying that some may be comprehended, others not; because many false impressions are probable, but no false impression can be the object of comprehension and knowledge. He affirms, therefore, that those are greatly mistaken who say that the Academics take away the existence of the senses; inasmuch as they have never denied that there are such things as colour, taste, and sound; but they contend that there is not in these things a peculiar mark of reality and certainty, not existing elsewhere."-Editor.] See also $13,24,31$; de Nat. Deor. i. 5 . 
nothing was to be known ( $\left.\kappa a \tau \alpha \lambda \eta \pi \tau \sigma^{\prime}\right)$. For the Stoics themselves,

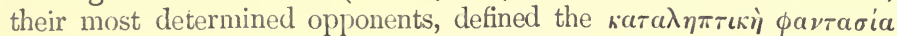
(or impression which involved knowledge'), to be one that was capable of being produced by no object except that to which it really belonged. ${ }^{2}$

Since then we cannot arrive at knowledge, we must suspend our decision, pronounce absolutely on nothing, nay, according to Arcesilas, never even form an opinion. ${ }^{3}$ In the conduct of life, however, probability ${ }^{4}$ must determine our choice of action; and this admits of different degrees. The lowest kind is that which suggests itself on

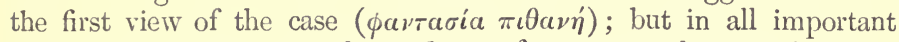
matters we must correct the evidence of our senses by considerations derived from the nature of the medium, the distance of the object, the disposition of the organ, the time, the manner, and other attendant circumstances. When the impression has been thus minutely considered, the $\phi a \nu \tau u \sigma i a$ becomes $\pi \varepsilon \rho \omega \delta \varepsilon v \mu \varepsilon \dot{\varepsilon} \nu$, or approved on circumspection; and if during this examination no objection has arisen to weaken our belief, the highest degree of probability is attained, and

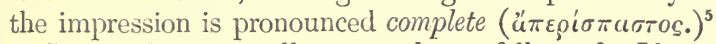

Sextus Empiricus illustrates this as follows: ${ }^{6}$-If on entering a dark room we discern a coiled rope, our first impression may be that it is

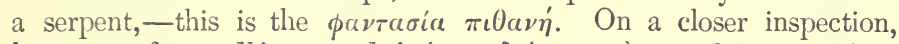

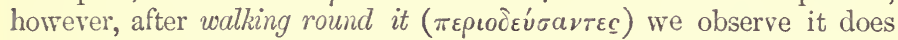
not move, nor has it the proper colour, shape, or proportions; and now we conclude it is not a serpent; here we are determined in our

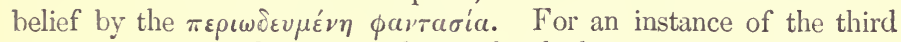
and most accurate kind, viz., that with which no contrary impression interferes, we may refer to the conduct of Admetus on the return of Alcestis from the infernal regions. He believes he sees his wife; everything confirms it; but he cannot acquiesce in that opinion; his

${ }^{1}$ O -Sext. Empir. Pyrrh. Hypot. iii. 25.

2 "Verum non posse comprehendi ex illâ Stoici Zenonis definitione arripuisse videbantur, qui ait id verum percipi posse, quod ita esset animo impressum ex eo unde esset, ut esse non posset ex eo unde non esset. Quod brevius planiusque sic dicitur, his signis verum posse comprehendi, quæ signa non potest habere quod falsum est." (Augustin, contra Acad. 2, 5.) ["They seemed to have caught their doctrine of the incomprehensibility of truth from that definition of the Stoic Zeno, who says that that may be perceived to be true which has been so impressed on the mind by the cause of its existence, as it could not have been by what was not the cause of its existence, which is thus more briefly and simply expressed: that truth may be comprehended by those marks which falsehood cannot possess." - Editor.] See also Sext. Empir. adv. Math. lib. vii. $\pi \in \rho l \mu \in \tau \alpha \beta o \lambda \hat{\eta} s$, and of Lucullus, 6 with 13.

${ }^{3}$ Lucullus, 13, 21, 40.

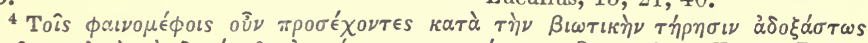

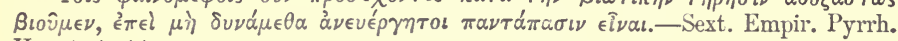
Hypot. 1, 11 .

s Cicero terms these three impressions, " visio probabilis; quæ ex circumspectione aliquâ et accuratâ consideratione fiat; quæ non impediatur."-Lucullus, 11.

${ }^{6}$ Pyrrh. Hypot. i. 33. 
mind is divided ( $\pi \varepsilon \rho \iota \sigma \pi \tilde{a} \tau \alpha \iota)$ from the impression he has of her death;

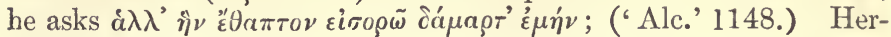

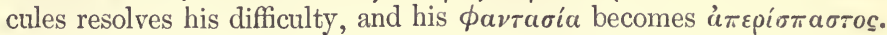

The suspension then of assent $(\dot{\varepsilon} \pi \circ \chi \grave{\eta})$ which the Academics enjoined, was, at least from the times of Carneades, ${ }^{1}$ nearly a speculative doctrine $;^{2}$ and herein lay the chief difference between them and the Pyrrhonists; that the latter altogether denied the existence of the probable, while the former admitted there was sufficient to allow of action, provided we pronounced absolutely on nothing.

Causes which made the New Academy a school of Rhetoric.

Little more can be said concerning the opinions of a sect whose fundamental maxim was that nothing could be known, and nothing should be taught. It lay midway between the other philosophies; and in the altercations of the various schools it was at once attacked by all, ${ }^{3}$ yet appealed to by each of the contending parties, if not to countenance its own sentiments, at least to condemn those advocated by its opponents, ${ }^{4}$ and thus to perform the office of an umpire. ${ }^{5}$ From this necessity then of being prepared on all sides for attack, ${ }^{6}$ it became as much a school of rhetoric as of philosophy, ${ }^{7}$ and was celebrated among the ancients for the eloquence of its masters. ${ }^{8}$ Hence also its reputation was continually varying: for, requiring the aid of great abilities to maintain its exalted and arduous post, it alternately rose and fell in estimation, according to the talents of the individual who happened to fill the chair. ${ }^{9}$ And hence the frequent alterations which took place in its philosophical tenets; which, depending rather

${ }^{1}$ Numen. apud Euseb. Præp. Evang. xiv. 7.

2 Lucullus, 31, 34 ; de Off. ii. 2; de Fin. v. 26 ; Quint. xii. 1.

${ }^{3}$ Lucullus, 22, et alibi ; Tusc. Quæst. ii. 2.

4 See a striking passage from Cicero's Academics, preserved by Augustin, contra Acad. iii. 7, and Lucullus, 18.

5 De Nat. Deor. passim; de Div. ii. 72. "Quorum controversiam solebat tanquam honorarius arbiter judicare Carneades."-Tusc. Quæst. v. 41.

${ }^{6}$ De Fin. ii. 1 ; de Orat. i. 18 ; Lucullus, 3 ; Tusc. Quæst. v. 11 ; Numen. apud Euseb. Præp. Evang. xiv. 6, \&c. ; Lactantius, Inst. iii. 4.

7 De Nat. Deor. i. 67; de Fat. 2; Dialog. de Orat. 31, 32.

${ }^{8}$ Lucullus vi. 18 ; de Orat. ii. 38, iii. 18; Quint. Inst. xii. 2; Plutarch, in vitâ Caton. et Cic.; Lactantius, Inst.; Numen. apud Euseb.

9 “ Hæc in philosophiâ ratio contra omnia disserendi nullamque rem apertè judicandi, profecta à Socrate, repetita ab Arcesilâ, confirmata à Carneade, usque ad nostram viguit ætatem; quam nunc propemodum orbam esse in ipsâ Græciâ intelligo. Quod non Academiæ vitio, sed tarditate hominum arbitror contigisse. Nam si singulas disciplinas percipere magnum est, quanto majus omnes? quod facere iis necesse est, quibus propositum est, veri reperiendi causâ, et contra omnes philosophos et pro omnibus dicere."-De Nat. Deor. i. 5. ["This principle in philosophy, of arguing against all propositions, and openly determining nothing, originated by Socrates, renewed by Arcesilas, and confirmed by Carneades, has been in force up to our own day, but is now, I understand, even in Greece, almost destitute of an advocate. This, I apprehend, is not ascribable to any fault of the Academy, but to the dullness of individuals. For, if it is a great task to acquire the philosophy of any one school, how much greater to attain those of all? which, nevertheless, is necessary for those who, for the investigation of truth, would be prepared to dispute for and against all the philosophical sects."-Editor.] 
on the arbitrary determinations of its present head, than on the tradition of settled maxims, were accommodated to the views of each successive master, according as he hoped by sophistry or concession to orercome the repugnance which the mind ever will feel to the doctrines of universal scepticism.

And in these continual changes it is pleasing to observe, that the interests of virtue and good order were uniformly promoted; interests to which the Academic doctrines were certainly hostile, if not necessarily fatal. Thus, although we find Carneades, in conformity to the plan adopted by Arcesilas, ${ }^{1}$ opposing the dogmatic principles of the Stoics concerning moral duty, and studiously concealing his private views even from his friends; ${ }^{*}$ yet, by allowing that the suspense of judgment was not always a duty, that the wise man might sometimes believe though he could not know ; ${ }^{4}$ he, in some measure, restored the authority of those great instincts of our nature which his predecessor appears to have discarded. Clitomachus pursued his steps by innovations in the same direction $;^{5}$ Philo, who followed next, attempting Philo and to reconcile his tenets with those of the Platonic school, ${ }^{6}$ has been accounted the founder of a fourth Academy-while, to his successor Antiochus, who embraced the doctrines of the Porch, ${ }^{7}$ and maintained the fidelity of the senses, it has been usual to assign the establishment of a fifth.

We have already observed, that Cicero in early life inclined to the systems of Plato and Antiochus, which, at the time he composed the bulk of his writings, he had abandoned for that of Carneades and Philo. ${ }^{8} \quad$ Yet he was never so entirely a disciple of the New Academy, as to neglect the claims of morality and the laws. He is loud in his protestations, that truth is the great object of his search :- "Ego enim," Mixed he says, "si aut ostentatione aliquâ adductus, aut studio certandi, ad Philosophy hanc potissimùm philosophiam me applicavi; non modo stultitiam meam, sed etiam mores et naturam condemnandarn puto . . . I Itaque, nisi ineptum putarem in tali disputatione id facere quod, quùm de republicâ disceptatur, fieri interdum solet, jurarem per Jovem deosque Penates, me et ardere studio veri reperiendi, et $\propto$ sentire quæ dicerem."9 And, however inappropriate this boast may appear, he at

1 De Nat. Deor. i. 25 ; Austin. contra Acad. iii. 17 ; Numen. apud Euseb. Præp. Evang. xir. 6.

2 De Fin. ii. 13, v. 7 ; Lucullus, 42 ; Tusc. Quæst. v. 29.

3 Lucullus, 45.

${ }^{4}$ Lucullus, xxi. 24. For an elevated moral precept of his, see de Fin. ii. 18.

5 'A $\tau \iota \kappa \hat{n} \kappa a \grave{~} \Sigma \tau \omega \ddot{\imath} \kappa \hat{n}$. -Diogenes Laertius, lib. iv. sub. fin. ["A man versed in the three schools-the Academic, the Peripatetic, and the Stoic."-Editor.]

6 " Philo, magnus vir, negat in libris duas Academias esse; erroremque eorum qui ita putârunt coarguit."-Acad. Quæst. i. 4. ["Philo, a great man, denies in his writings that there are two Academies; and refutes the error of those who have entertained that opinion."-Editor.]

7 De Fin. v. 5 ; Lucullus, xxii. 43. ${ }^{8}$ Acad. Quæst. i. 4 ; de Nat. Deor. i. 7.

${ }^{9}$ Lucullus, 20 ; see also de Nat. Deor. i. 7 ; de Fin. i. 5 . ["For my own part, 
least pursues the useful and the magnificent in philosophy; and uses his academic character as a pretext rather for a judicious selection from each system, than for an indiscriminate rejection of all. ${ }^{1}$ Thus, in the capacity of a statesman, he calls in the assistance of doctrines, which, as an orator, he does not scruple to deride ; those of Zeno in particular, who maintained the truth of the popular theology, and the divine origin of augury, and (as we noticed above) was more explicit than the other masters in his views of social duty. This difference of sentiment between the magistrate and the pleader is strikingly illustrated in the opening of his treatise 'de Legibus;' where, after deriving the principles of law from the nature of things, he is obliged to beg quarter of the Academics, whose reasonings he feels could at once destroy the foundation on which his argument rested. "Ad respublicas firmandas, et ad stabiliendas vires, sanandos populos, omnis nostra pergit oratio. Quocirca vereor committere, ut non bene provisa et diligenter explorata principia ponantur: nec tamen ut omnibus probentur (nam id fieri non potest), sed ut iis, qui omnia recta atque honesta per se expetenda duxerunt, et aut nihil omnino in bonis numerandum nisi quod per se ipsum laudabile esset, aut certè nullum habendum magnum bonum, nisi quod verè laudari suâ sponte posset." And then apparently alluding to the arguments of Carneades against justice, which he had put into the mouth of Philus in the third book of his 'de Republicâ,' he proceeds : “ Perturbatricem autem harum omnium rerum Academiam, hanc ab Arcesilâ et Carneade recentem, exoremus, ut sileat. Nam, si invaserit in hæc, quæ satis scitè nobis instructa et composita videntur, nimias edet ruinas. Quam quidem ego placare cupio, submovere non audeo."

if I have applied myself especially to this philosophy, through any love of display or ambition of excelling, I not only hold my folly amenable to condemnation, but my very character and nature; and, therefore, if I did not consider it absurd, in an argument like this, to do what is sometimes done in political discussions, I would swear by Jupiter and the gods Penates that I burn with an earnest desire of discovering the truth, and believe all that I say."-Editor.]

1 " Nobis autem nostra Academia magnam licentiam dat, ut, quodcunque maximè probabile occurrat, id nostra jure liceat defendere."-De Off. iii. 4. ["Our Academy, however, grants us considerable licence, so that we may defend, by our own right, whatever occurs to us as most probable."-Editor.] See also Tusc. Quæst. iv. 4, v. 29 ; de Invent. ii. 3.

2 ["All our argument is directed to the consolidation of states, the stability of their power, the sound condition of their population. Accordingly, I dread any failure in laying down well-considered and carefully-examined principles: not such, indeed, as shall meet universal approval (for that is impossible), but such as shall commend themselves to those who hold all upright and honourable objects to be in themselves deserving pursuit, and regard nothing as good which is not of itself praiseworthy; or, at least, nothing as eminently good which is not intrinsically an object of just commendation."-Editor.]

${ }^{3}$ De Legg. i. 13. ["But let us entreat the Academy-this new Academy I mean, the school of Arcesilas and Carneades-the disturber of all these things-to be silent. For should that school attack our arguments, skilfully as they seem to us to be framed and arranged, too much havoc would ensue. I would wish, then, to conciliate the Academy; remore it I dare not."-Editor.] 
And as, in questions connected with the interests of society, he thus uniformly advocates the tenets of the Porch, so in discussions of a physical character, we find him adopting the sublime and kindling sentiments of Pythagoras and Plato. Here, however, having no object of expediency in view to keep him within the bounds of consistency, he scruples not to introduce whatever is most beautiful in itself, or most adapted to his present purpose. At one time he describes the Deity as the all-pervading soul of the world, the cause of life and motion. ${ }^{1}$ At another $\mathrm{He}$ is the intelligent preserver and governor of every separate part. ${ }^{2}$ At one time the soul of man is in its own nature necessarily eternal, without beginning or end of existence $;^{3}$-at another it is represented as reunited on death to the one infinite Spirit; ${ }^{4}$-at another it is to enter the assembly of the gods, or to be driven into darkness, according to its moral conduct in this life; ${ }^{5}$-at another the best and greatest of mankind are alone destined for immortality ${ }^{6}$ - which is sometimes described as attended witl consciousness and the continuance of earthly friendships ; ${ }^{7}$ sometimes, as but an immortality of name and glory $;^{8}$ more frequently, however, these separate notions are confused together in the same passage. ${ }^{9}$

Though the works of Aristotle were not given to the world till His acquaintSylla's return from Greece, Cicero appears to have been a considerable ance with proficient in his philosophy, ${ }^{10}$ and he has not overlooked the important aid it affords in those departments of science which are alike removed from abstract reasoning and fanciful theorising. 'To Aristotle he is indebted for most of the principles laid down in his rhetorical discussions, ${ }^{11}$ while in his treatises on morals not a few of lis remarks may be traced to the same acute philosopher. ${ }^{12}$

The doctrines of the Garden alone, though some of his most intimate His abhorfriends were of the Epicurean school, he regarded with aversion and rence of contempt; feeling no sort of interest in a system which cut at the very root of that activity of mind, industry, and patriotism for which he himself both in public and private was so honourably distinguished. ${ }^{13}$

Such, then, was the New Academy, and such the variation of opinion,

1 Tusc. Quæst. i. 27 ; de Div. ii. 72 ; pro Milon. 31 ; de Legg. ii. 7.

2 Fragm. de Rep. 3; Tusc. Quæst. i. 29 ; de Univ.

3 Tusc. Quæst. i. passim ; de Senect. 21, 22 ; Somn. Scip. 8.

4 De Div. i. 32, 49 ; Fragm. de Consolat.

3 Tusc. Quæst. i. 30 ; Somn. Scip. 9; de Legg. ii. 11.

${ }^{6}$ De Amic. 4 ; de Off. iii. 28 ; pro Cluent. 61 ; de Legg. ii. 17 ; Tusc. Quæst. i. 11 ; pro Sext. 21 ; de Nat. Deor. i. 17.

7 Cat. 23.

9 Ibid. 11, 12 ; ad Fam. v. 21, vi. 21.

${ }^{8}$ Pro Arch. 11, 12; ad Fam. v. 21, vi. 21.

10 He seems to have fallen into some misconceptions of Aristotle's meaning. De Invent. i. 35, 36, ii. 14. See Quint. Inst. v. 14.

11 De Invent. i. 7, ii. 51, et passim; ad Fam. i. 9 ; de Orat. ii. 36.

12 De Off. i. 1 ; de Fin. iv. 5 ; ad Atticum.

${ }^{13}$ De Fin. ii. 21, iii. 1; de Legg. i. 13; de Orat. iii. 17 ; ad Fam. xiii. 1; pro Sext. 10. 
which, in Cicero's judgment, was not inconsistent with the profession of an Academic. And however his adoption of that philosophy may be in part referred to his oratorical habits, or the natural cast of mind, yet, considering the ambition which he felt to inspire his countrymen with a taste for literature and science, ${ }^{1}$ we must conclude with Warburton, ${ }^{2}$ that, in acceding to the system of Philo, he was strongly influenced by the freedom of thought and reasoning which it allowed to his compositions; the liberty of developing the principles and doctrines, the strong and weak parts of every Grecian school. Bearing then in mind his design of recommending the study of philosophy, it is interesting to observe the artifices of style and manner which, with this end, he adopted in his treatises; and though to enter minutely into this subject would be foreign to our present purpose, it may be allowed us to make some general remarks on the character of works so eminently successful in accomplishing the object for which they were undertaken.

His form of dialogue.

The most obvious peculiarity of Cicero's philosophical discussions is the form of dialogue in which most of them are conveyed. Plato, indeed, and Xenophon had, before his time, been even more strictly dramatic in their compositions; but they professed to be recording the sentiments of an individual, and the Socratic mode of argument could hardly be displayed in any other shape. Of that interrogative and inductive conversation, however, Cicero affords but few specimens $\mathbf{;}^{\mathbf{3}}$ the nature of his dialogue being as different from that of the two Athenians, as was his object in writing. His aim was to excite interest; and he availed himself of this mode of composition for the life and variety, the ease, perspicuity, and vigour which it gave to his discussions. His dialogue is of two kinds: according as his subject is, or is not, a controverted point, it assumes the shape of a continued treatise, or a free disputation; in the latter case imparting clearness to what is obscure, in the former relief to what is clear. Thus his practical and svstematic treatises on rhetoric and moral duty are either written in his own person, or merely divided between several speakers who are the organs of his own sentiments; while in questions of a more speculative cast, on the nature of the gods, on the human soul, on the greatest good, he uses his academic liberty, and brings forward the theories of contending schools under the character of their respective Advantages advocates. The advantages gained in both cases are evident. In of it. controverted subjects he is not obliged to discover his own views, he can detail opposite arguments forcibly and luminously, and he is allowed the use of those oratorical powers in which, after all, his great strength lay. In those subjects, on the other hand, which are uninteresting because they are familiar, he may pause or digress before the mind is weary and the attention begins to $\mathrm{flag}$; the reader is

${ }^{1}$ De Nat. Deor. i. 4 ; Tusc. Quæst. i. 1, v. 29; de Fin. i. 3, 4; de Off. i. 1 ; de Div. ii. $1,2$.

2 Div. Legg. lib. iii. sec. 9.

${ }^{3}$ See Tusc. Quæst.'and de Republ. 
carried on by easy journeys and short stages, and novelty in the speaker supplies the want of novelty in the matter.

Nor does Cicero discover less skill in the execution of these dialogues, Beauty of than address in their design. It were idle to enlarge upon the beauty, execution. richness, and taste of compositions which have been tlie admiration of every age and country. In the dignity of his speakers, their high tone of mutual courtesy, the harmony of his groups, and the delicate relief of his contrasts, he is inimitable. The majesty and splendour of his introductions, which generally address themselves to the passions or the imagination, the eloquence with which both sides of a question are successively displayed, the clearness and terseness of his statements on abstract points, the grace of his illustrations, his exquisite allusions to the scene or time of the supposed conversation, his digressions in praise of philosophy or great men, his quotations from Grecian and Roman poetry; lastly, the melody and fulness of his style, unite to throw a charm round his writings peculiar to themselves. To the Roman reader they especially reconmended themselves by their continual and most artful references to the heroes of the old republic, who now appeared but exemplars, and (as it were) patrons of that eternal philosophy, which he had before, perhaps, considered as the short-lived reveries of ingenious, but inactive men. Nor is there any confusion, harshness, or appearance of effort in the introduction of the various beauties we have been enumerating, which are blended together with so much skill and propriety, that it is sometimes difficult to point out the particular causes of the delight left upon the mind.

In proceeding to enumerate Cicero's philosophical writings, ${ }^{1}$ it may be necessary to premise that our intention is rather to sketch out the plan on which they are conducted than to explain the doctrines which they recommend; for an account of which the reader is referred to our articles on the schools by which they were respectively entertained. ${ }^{2}$

The series of his rhetorical works has been preserved nearly com- Rhetorical plete, and consists of the 'De Inventione,' ' De Oratore,' ' Brutus sive de works. claris Oratoribus,' 'Orator sive de optimo genere Dicendi,' ' De partitione Oratoriâ,' 'Topica de optimo genere Oratorum.' The lastmentioned, which is a fragment, is understood to have been the proem to his translation (now lost) of the speeches of Demosthenes and Aschines, 'De Coronâ.' These he translated with the view of defending, by the example of the Greek orators, his own style of eloquence, which, as we shall afterwards find, the critics of the dav censured as too Asiatic in its character ; and hence the preface, which still survives, is on the subject of the Attic style of oratory. This composition and his abstracts of his own orations ${ }^{3}$ are his only rhetorical works now extant, and probably our loss is not very great.

${ }^{1}$ See Fabricius, Bibliothec. Latin.; Olivet. in Cic. op. omn.; Middleton's Life.

${ }^{2}$ History of Greek and Roman Philosophy, in this Encyclopædia.

${ }^{3}$ Quint. Inst. x. 7. 

'Treatise on 'The 'Treatise on Rhetoric,' addressed to Herennius, though edited

with his works, and ascribed to him by several of the ancients, is now generally attributed to Cornificius, or sorne other writer of the same period.

These works consider the art of rhetoric in different points of view, and thus receive from each other mutual support and illustration, while they prevent the tediousness which might else arise from sameness in the subject of discussion. Three are in the form of dialogue; the rest are written in his own person. In all, except perhaps the 'Orator,' he professes to have digested the principles of the Aristotelic and Isocratean schools into one finished system, selecting what was best in each, and, as occasion might offer, adding remarks and precepts of his own.' 'The subject is considered in three distinct lights ${ }^{2}$ with reference to the case, the speaker, and the speech. The case, as respects its nature, is definite or indefinite; with reference to the hearer, it is judicial, deliberative, or descriptive ; as regards the opponent, the division is fourfold-according as the fact, its nature, its quality, or its propriety is called in question. The art of the speaker is directed to five points: the discovery of persuasives (whether ethical, pathetical, or argumentative), arrangement, diction, memory, delivery. And the speech itself consists of six parts: introduction, statement of the case, division of the subject, proof, refutation, and conclusion.

'De Inventione.'

His treatises 'De Inventione' and 'Topica,' the first and nearly the last of his compositions, are both on the invention of arguments, which he regards, with Aristotle, as the very foundation of the art; though he elsewhere confines the term eloquence, according to its derivation, to denote excellence of diction and delivery, to the exclusion of argumentative skill. ${ }^{3}$ The former of these works was written at the age of twenty, and seems originally to have consisted of four books, of which but two remain. ${ }^{4}$ In the first of these he considers rhetorical invention generally, supplies common-places for the six parts of an oration promiscuously, and gives a full analysis of the two forms of arguments, syllogism and induction. In the second book he applies these rules particularly to the three subject-matters of rhetoric, the deliberative, the judicial, and the descriptive, dwelling principally on the judicial, as affording the most ample field for discussion. This treatise seems nearly entirely compiled from the writings of Aristotle, Isocrates, and Hermagoras $;^{5}$ and as such he alludes to it in the opening of his 'De Oratore' as deficient in the experience and judgment which nothing but time and practice can impart. Still it is an entertaining, nay useful, work; remarkable, even among Cicero's writings, for its uniform good sense, and less familiar to the scholar,

1 De Invent. ii. 2 et 3 ; ad Fam. i. 9.

2 Confer de part. Orat. with de Invent.

3 Orat. 19.

${ }^{4}$ Vossius, de Nat. Rhet. c. xiii.; Fabricius, Bibliothec. Latin.

5 De Invent. i. 5, 6 ; de Clar. Orat. 76. 
only because the greater part has been superseded by the compositions of his riper years. His 'Topica,' or treatise on common-places, 'Topica.' has less extent and variety of plan, being little else than a compendium of Aristotle's work on the same subject. It was, as he informs us in its proem, drawn up from memory on his voyage from Italy to Greece, soon after Cæsar's murder, and in compliance with the wishes of Trebatius, who had sometime before urged him to undertake the translation. ${ }^{1}$

Cicero seems to have intended 'his 'De Oratore,' 'Brutus,' and 'De Oratore. 'Orator,' to form one complete system. ${ }^{2}$ Of these three noble works, the first lays down the principles and rules of the rhetorical art; the second exemplifies them in the most eminent speakers of Greece and Rome; and the third shadows out the features of that perfect orator, whose superhuman excellences should be the aim of our ambition. The 'De Oratore' was written when the author was fifty-two, two years after his return from exile; and is a dialogue between some of the most illustrious Romans of the preceding age on the subject of oratory. The principal speakers are the orators Crassus and Antonius, who are represented unfolding the principles of their art to Sulpicius and Cotta, young men just rising at the bar. In the first book, the conversation turns on the subject-matter of rhetoric, and the qualifications requisite for the perfect orator. Here Crassus maintains the necessity of his being acquainted with the whole circle of the arts, while Antonius confines eloquence to the province of speaking well. The dispute, for the most part, seems verbal ; for Cicero himself, though he here sides with Crassus, yet, elsewhere, as we have above noticed, pronounces eloquence, strictly speaking, to consist in beauty of diction. Scævola, the celebrated lawyer, takes part in this preliminary discussion; but, in the ensuing meetings, makes way for Catulus and Cæsar, the subject leading to such technical disquisitions as were hardly suitable to the dignity of the aged augur. ${ }^{3}$ The next morning Antonius enters upon the subject of invention. which Cæsar completes by subjoining some remarks on the use of humour in oratory; and Antonius, relieving him, finishes the morning discussion with the principles of arrangement and memory. In the afternoon the rules for propriety and elegance of diction are explained by Crassus, who was celebrated in this department of the art; and the work concludes with his treating the subject of delivery and action. Such is the plan of the 'De Oratore,' the most finished perhaps of Cicero's compositions. An air of grandeur and magnificence reigns throughout. The characters of the aged senators are finely conceived, and the whole company is invested with an almost religious majesty, from the allusions interspersed to the miserable destinies for which its members were reserved.

His treatise 'De claris Oratoribus,' was written after an interval of 'De claris nine years, about the time of Cato's death, and is conveyed in a Oratoribus.

1 Ad Fam. vii. 19.

2 De Div. ii. 1.

${ }^{3}$ Ad Atticum, iv. 16. 
dialogue between Brutus, Atticus, and himself. He begins with Solon, and after briefly mentioning the orators of Greece, proceeds to those of his own country, so as to take in the whole period from the time of Junius Brutus down to himself. About the same time he 'Orator.' wrote his 'Orator;' in which he directs his attention principally to diction and delivery, as in his 'De Inventione' and 'Topica' he considers the matter of an oration. ${ }^{1}$ This treatise is of a less practical nature than the rest. ${ }^{2}$ It adopts the principles of Plato, and delineates the perfect orator according to the abstract conceptions of the intellect, rather than the deductions of observation and experience. Hence he sets out with a definition of the perfectly eloquent man, whose characteristic it is to express himself with propriety on all subjects, whether humble, great, or of an intermediate character $;^{3}$ and here he has an opportunity of paying some indirect compliments to himself. With this work he was so well satisfied, that he does not scruple to declare, in a letter to a friend, that he was ready to risk his reputation for judgment in oratory on its merits. ${ }^{*}$

'De partitione ')ratoriâ.'

Moral and Physical writings.

- De Republicâ.'

Recent discovery of additional fracments of his Treatises.

The treatise 'De partitione Oratoriâ,' or on the three parts of rhetoric, is a kind of catechism between Cicero and his son, drawn up for the use of the latter at the same time with the two preceding. It is the most systematic and perspicuous of his rhetorical works, but seems to be but the rough draught of what he originally intended. ${ }^{5}$

The connexion which we have been able to preserve between the rhetorical writings of Cicero will be quite unattainable in his moral and physical treatises; partly from the extent of the subject, partly from the losses occasioned by time, partly from the inconsistency which we have warned the reader to expect in his sentiments. In our enumeration, therefore, we shall observe no other order than that which the date of their composition furnishes.

The earliest now extant is part of his treatise. 'De Legibus,' in three books; being a sequel to his work on Politics. Both were written in imitation of Plato's treatises on the same subjects. ${ }^{6}$ The latter of these ('De Republicâ') was composed a year after the 'De Oratore," and seems to have vied with it in the majesty and interest of the dialogue. It consisted of a series of discussions, in six books, on the origin and principles of government, Scipio being the principal speaker; but Lælius, Philus, Manilius, and other personages of like gravity taking part in the conversation. Till lately, but a fragment of the fifth book was understood to be in existence, in which Scipio, under the fiction of a dream, inculcates the doctrine of the immortality of the soul. But in the year 1822, Monsignor Mai, librarian of the Vatican, published considerable portions of the first and second books, from a palimpsest manuscript of St. Austin's 'Commentary on

1 Orat. 16.

4 Ad Fam. vi. 18.

6 De Legg. i. 5.
2 Ibid. 14, 31.

3 Ibid. 21, 29.

5 See Middleton, rol. ii. p. 147,4 to.

7 Ang. Mai, præf. in Remp. Middleton, vol. i. p. 486. 
the Psalms.' In the part now recovered, Scipio discourses on the different kinds of constitutions and their respective advantages; with a particular reference to that of Rome. In the third, the subject of justice was discussed by Lælius and Philus; in the fourth, Scipio treated of morals and education; while in the fifth and sixth, the duties of a magistrate were explained, and the best means of preventing changes and revolutions in the constitution itself. In the latter part of the treatise, allusion was made to the actual posture of affairs in Rome, when the conversation was supposed to have occurred, and the commotions excited by the Gracchi.

In his treatise 'De Legibus,' which was written two years later 'De Legibus.' than the former, and shortly after the murder of Clodius, he represents himself as explaining to his brother Quintus, and Atticus, in their walks through the woods of Arpinum, the nature and origin of the laws, and their actual state, both in other countries and in Rome. The first part only of the subject is contained in the books now extant; the introduction to which we have had occasion to notice, when speaking of his stoical sentiments on questions connected with state policy. Law he pronounces to be the perfection of reason, the eternal mind, the divine energy, which, while it pervades and unites in one the whole universe, associates gods and men by the more intimate resemblance of reason and virtue, and still more closely men with men, by the participation of common faculties, affections, and situations. He then proves, at length, that justice is not merely created by civil institutions, from the power of conscience, the imperfections of human law, the moral sense, and the disinterestedness of virtue. He next proceeds to unfold the principles, first, of religious law, under the heads of divine worship; the observance of festivals and games; the office of priests, augurs, and heralds; the punishment of sacrilege and perjury; the consecration of land, and the rights of sepulchre; and, secondly, of civil law, which gives him an opportunity of noticing the respective duties of magistrate and citizens. In these discussions, though professedly speaking of the abstract question, he does not hesitate to anticipate the subject of the lost. books, by frequent allusions to the history and customs of his own country. It may be added, that in no part of his writings do worse specimens occur, than in this treatise, of that vanity which was notoriously his weakness, which are rendered doubly odious by the affectation of putting them into the mouth of his brother and Atticus. ${ }^{1}$

Here a period of eight years intervenes, during which he composed little of importance besides his orations. He then published the 'Brutus' and 'Orator;' and the year after, his 'Academicæ Quæs- 'Academicæ tiones,' in the retirement from public business to which he was driven Quæstiones.' by the dictatorship of Cæsar. This work had originally consisted of two dialogues, which he entitled 'Catulus' and 'Lucullus,' from the 
names of the respective speakers in each. These he now remodelled and enlarged into four books, dedicating them to Varro, whom he introduced as advocating, in the presence of Atticus, the tenets of Antiochus, while he himself defended those of Philo. Of this most valuable composition, only the second book ('Lucullus') of the first edition, and part of the first of the second are now extant. In the former of the two, Lucullus argues against, and Cicero for, the Academic sect, in the presence of Catulus and Hortensius; in the latter, Varro pursues the history of philosophy from Socrates to Arcesilas, and Cicero continues it down to the time of Carneades. In the second edition, the style was corrected, the matter condensed, and the whole polished with extraordinary care and diligence. ${ }^{2}$

'De Finibus.' The same year he published his treatise 'De Finibus,' or the chief good, in five books, in which are explained the sentiments of the Epicureans, Stoics, and Peripatetics on the subject. This is the earliest of his works in which the dialogue is of the disputatious kind. It is opened with a defence of the Epicurean tenets, concerning pleasure, by Torquatus; to which Cicero replies at length. The scene then shifts from the Cuman villa to the library of young Luculius (his father being dead), where the Stoic Cato expatiates on the sublimity of the system which maintains the existence of one only good, and is answered by Cicero in the character of a Peripatetic. Lastly, Piso, in a conversation held at Athens, enters into an explanation of the doctrine of Aristotle, that happiness is the greatest good. The general style of his treatise is elegant and perspicuous; and the last book in particular has great variety and splendour of diction.

We have already, in our memoir of Cæsar, observed that Cicero was about this time particularly courted by the heads of the dictator's party, of whom Hirtius and Dolabella went so far as to declaim daily at his house for the benefit of his instructions. ${ }^{2}$ A visit of this nature to his Tusculan villa, soon after the publication of the 'De Finibus,' gave rise to his work entitled 'Tusculanæ Quæstiones,' which professes to be the substance of five philosophical disputes between himself and friends, digested into as many books. He argues throughout on Academic principles, even with an affectation of inconsistency; sometimes making use of the Socratic dialogue, sometimes launching out into the diffuse expositions which characterise his other treatises. ${ }^{3}$ He first disputes against the fear of death; and in so doing he adopts the opinion of the Platonic school, as regards the nature of God and the soul. The succeeding discussions on enduring pain, on alleviating grief, on the other emotions of the mind, and on virtue, are conducted for the most part on Stoical principles. ${ }^{4}$ This is a highly ornamental composition, and contains more quotations from the poets than any other of Cicero's treatises.

1 Ad Atticum, xiii. 13, 16, 19.

3 Tusc. Quæst. v. 4, 11.

2 Ad Fam. ix. 16, 18.

4 Ibid. iii. 10 ; v. 27. 
We have already had occasion to remark upon the singular activity of his mind, which becomes more and more conspicuous as we approach the period of his death. During the ensuing year, which is the last of his life, in the midst of the confusion and anxieties consequent on Cæsar's deatl, he found time to write the 'De Naturâ Deorum,' ' De Divinatione,' 'De Fato,' 'De Senectute,' ' De Amicitiâ,' 'De Officiis,' and 'Paradoxa,' besides the treatise on Rhetorical Common Places above mentioned.

Of these the first three were intended as a full exposition of the opposite opinions entertained on their respective subjects; the 'De Fato,' however, was not finished according to this plar.. ${ }^{1}$ His treatise 'De Naturâ Deorum,' in three books, may be reckoned the most ‘ De Naturâ magnificent of all his works, and shows that neither age nor disappointment had done injury to the richness and vigour of lis mind. In the first book, Velleius, the Epicurean, sets forth the physical tenets of his sect, and is answered by Cotta, who is of the Academic school. In the second, Balbus, the disciple of the Porch, gives an account of his own system, and is, in turn, refuted by Cotta in the third. The eloquent extravagance of the Epicurean, the solemn enthusiasm of the Stoic, and the brilliant raillery of the Academic, are contrasted with extreme vivacity and humour. While the sublimity of the subject itself imparts to the whole composition a grander and more elevated character, and discovers in the author imaginative powers, which, celebrated as he justly is for playfulness of fancy, might yet appear more the talent of the poet than the orator.

His treatise 'De Divinatione' is conveyed in a discussion between 'De his brother Quintus and himself, in two books. In the former, Quintus, after dividing Divination into the heads of natural and artificial, argues with the Stoics for its sacred nature, from the evidence of facts, the agreement of all nations, and the existence of gods. In the latter, Cicero questions its authority, with Carneades, from the uncertain nature of its rules, the absurdity and uselessness of the art, and the possibility of accounting from natural causes for the phenomena on which it was founded. This is a curious work, from the numerous cases adduced from the histories of Greece and Rome, to illustrate the subject in dispute. .

His treatise 'De Fato' is quite a fragment; it purports to be the 'De Fato.' substance of a dissertation in which he explained to Hirtius (soon after consul) the sentiments of Chrysippus, Diodorus, Epicurus, Carneades, and others, upon that abstruse subject. It is supposed to have consisted at least of two books, of which we have but the proem of the first, and a small portion of the second.

In his beautiful compositions 'De Senectute' and 'De Amicitiâ,' 'De SenecCato the censor and Lælius are respectively introduced, delivering their tute et de, sentiments on those subjects. The conclusion of the former, in which

${ }^{1}$ Je Nat. Deor. i. 6 ; de Div. i. 4 ; de Fat. 1. 
Cato discourses on the immortality of the soul, has been always celebrated; and the opening of the latter, in which Fannius and Scævola come to console Lælius on the death of Scipio, is as exquisite an instance of delicacy and taste as can be found in his works. In the latter he has borrowed largely from the eighth and ninth books of Aristotle's 'Ethics.'

'De Officis.' His treatise 'De Officiis' was finished about the time he wrote his second Philippic, a circumstance which illustrates the great versatility of his mental powers. Of a work so extensively celebrated, it is enough to have mentioned the name. Here he lays aside the less authoritative form of dialogue, and, with the dignity of the Roman consul, unfolds, in his own person, the principles of morals, according to the views of the older schools, particularly of the Stoics. It is written, in three books, with great perspicuity and elegance of style; the first book treats of the honestum, the second of the utile, and the third adjusts the claims of the two, when they happen to interfere with each other.

'Paradoxa, His 'Paradoxa Stoicorum' might have been more suitably, perhaps, stoicorum.' included in his rhetorical works, being six short declamations in support of the positions of Zeno; in which that philosopher's subtleties are adapted to the comprehension of the vulgar, and the events of the times. The second, fourth, and sixth, are respectively directed against Antony, Clodius, and Crassus. They seem to have suffered from time. ${ }^{1}$ The sixth is the most eloquent, but the argument of the third is strikingly maintained.

Besides the works now enumerated we have a considerable fragment of his translation of Plato's ' Timæus', which he seems to have finished about this time. His remaining philosophical works, viz.: the 'Hortensius,' which was a defence of philosophy ; 'De Gloriâ,' ' De Consolatione,' written upon Platonic principles on his daughter's death ; 'De Jure Civili,' 'De Virtutibus,' 'De Auguriis,' ' Chorographia,' translations of Plato's 'Protagoras,' and Xenophon's ' Economics,' works on Natural History, Panegyric on Cato, and some miscellaneous writings are, except a few fragments, entirely lost.

Epistles. His Epistles, about one thousand in all, are comprised in thirty-six books, sixteen of which are addressed to Atticus, three to his brother Quintus, one to Brutus, and sixteen to his different friends; and they form a history of his life from his fortieth year. Among those addressed to his friends some occur from Brutus, Metellus, Plancius, Cælius, and others. For the preservation of this most valuable department of Cicero's writings, we are indebted to Tyro, the author's freedman, though we possess, at the present day, but a part of those originally published. As his correspondence with his friends belongs to his character as a man and politician, rather than to his powers as an author, we have already noticed it in the first part of this memoir.

${ }^{2}$ Sciopp. in Olivet. 
His poetical and historical works have suffered a heavier fate. The Poetical and latter class, consisting of his commentary on his consulship, and his Historical history of his own times, is altogether lost. Of the former, which consisted of the heroic poems 'Halcyone,' 'Cimon,' ' Marius,' and his Consulate, the elegy of 'Tamelastes,' translations of Homer and Aratus, epigrams, \&c., nothing remains, except some fragments of the 'Phænomena' and 'Diosemeia' of Aratus. It may, however, be questioned whether literature has suffered much by these losses. We are far, indeed, from speaking contemptuously of the poetical powers of one who possessed so much fancy, so much taste, and so fine an ear.' But his poems were principally composed in his youth; and afterwards, when his powers were more mature, his occupations did not allow even his active mind the time necessary for polishing a language still more rugged in metre than it was in prose. His contemporary history, on the other hand, can hardly have conveyed more explicit, and certainly would have contained less faithful, information than his private correspondence; while, with all the penetration he assuredly possessed, it may be doubted if his diffuse and graceful style of thought and composition was adapted for the depth of reflection and condensation of meaning, which are the chief excellences of historical composition.

The orations which he is known to have composed amount in all orations. to about eighty, of which fifty-nine either entire or in part are preserved. Of these some are deliberative, others judicial, others descriptive; some delivered from the rostrum or in the senate; others in the forum or before Cæsar; and, as might be anticipated from the character already given of his talents, he is much more successful in pleading or in panegyric than in debate or invective. In deliberative oratory, indeed, great part of the effect depends on the confidence placed in the speaker; and though Cicero takes considerable pains to interest the audience in his favour, yet his style is not simple and grave enough; he is too ingenious, too declamatory, discovers too much personal feeling, to attain the highest degree of excellence in this department of the art. His irvectives again, howerer grand and imposing, yet, compared with his calmer and more familiar productions, have a forced and unnatural air. Splendid as is the eloquence of his Catilinarians and Philippics, it is often the language of abuse rather than of indignation; and even his attack on Piso, the most brilliant and imaginative of its kind, becomes wearisome from want of ease and relief. His laudatory urations, on the other hand, are among his happiest efforts. Nothing can exceed the taste and beauty of those for the Manilian law, for Marcellus, for Ligurius, for Archias, and the ninth Philippic, which is principally in praise of Servius Sulpicius. But it is in judicial eloquence, particularly on subjects of a lively cast, as in his speeches for Cælius and Muræna, and against 
Cæcilius, that his talents are displayed to the best advantage. To botl kinds his amiable and pleasant character of mind imparts inexpressible grace and delicacy; historical allusions, philosophical sentiments, descriptions full of life and nature, and polite raillery, succeed each other in the most agreeable manner, without appearance of artifice or effort. Of this nature are his pictures of the confusion of the Catilinarian conspirators on detection ; ${ }^{1}$ of the death of $\mathrm{Me}$ tellus $;^{2}$ of Sulpicius undertaking the embassy to Antonius $;^{3}$ the character he draws of Catiline $;^{4}$ and his fine sketch of old Appius frowning on his degenerate descendant Clodia. ${ }^{5}$

General dis- These, however, are but incidental and occasional artifices to divert tribution. and refresh the mind, as his orations are generally laid out according to the plan proposed in rhetorical works; the introduction, containing the ethical proof; the body of the speech, the argument, and the peroration addressing itself to the passions of the judge. In opening his case, he commonly makes a profession of timidity and diffidence, with a view to conciliate the favour of his audience; the eloquence, for instance, of Hortensius, is so powerful, ${ }^{6}$ or so much prejudice has been excited against his client, ${ }^{7}$ or it is his first appearance in the rostrum, ${ }^{8}$ or he is unused to speak in an armed assembly, ${ }^{9}$ or to plead in a private apartment. ${ }^{10}$ He proceeds to entreat the patience of his judges ; drops out some generous or popular sentiment, or contrives to excite prejudice against his opponent. He then states the circumstances of his case, and the intended plan of his oration; and here he is particularly clear. But it is when he comes actually to prove his point, that his oratorical powers begin to have their full play. He accounts for everything so naturally, makes trivial circumstances tell so happily, so adroitly converts apparent objections into confirmations of his argument, connects independent particulars with such ease and plausibility, that it becomes impossible to entertain a question on the truth of his statement. This is particularly observable in his defence of Cluentius, where prejudices, suspicions, and difficulties are encountered with the most triumphant ingenuity; in the antecedent probabilities of his 'Pro Milone ;" in his apology for Muræna's public, ${ }^{12}$ and Cælius's private, life, ${ }^{13}$ and his disparagement of Verres's military services in Sicily $;^{14}$ it is observable in the address with which the Agrarian law of Rullus, ${ }^{15}$ and the accusation of Rabirius, ${ }^{16}$ both popular measures, are represented to be hostile to public liberty ; with which Milo's impolitic unconcern is made an affecting topic ${ }^{17}$ and Cato's attack upon the crowd
1 In Catil. iii. 3.
2 Pro Cæl. 10.
4 Pro Cæl. 3.
6 Pro Quint. and pro Verr. 5.
${ }^{8}$ Pro Leg. Manil.
9 Pro Milon.
11 Pro Milon. 8-10.
12 Pro Muræn. 4.
14 In Verr. v. 2, \&c.
15 Contra Rull. ii. 9.
17 Pro Milon. init. et alibi.
3 Philipp. ix. 3.
5 Ibid. 6.
7 Pro Cluent.
10 Pro Deiotar.
13 Pro Cæl. 6.
16 Pro Rabir. 3. 
of clients which accompanied the candidate for office, a tyrannical disregard for the feelings of the poor. ${ }^{1}$ So great indeed is his talent, that (as we have before hinted) he even hurts a good cause by an excess of plausibility.

But it is not enough to have barely proved his point; he proceeds, either immediately, or towards the conclusion of his speech, to heighten the effect by exaggeration. ${ }^{2}$ Here he goes (as it were) round and round his object; surveys it in every light; examines it in all its parts; retires, and then advances; turns and returns it; compares and contrasts it; illustrates, confirms, enforces his view of the question, till at last the hearer feels ashamed of doubting a position which seems built on a foundation so strictly argumentative. Of this nature is his justification of Rabirius in taking up arms against Saturninus $;^{8}$ his account of the imprisonment of the Roman citizens by Verres, and of the crucifixion of Gavius ; ${ }^{4}$ his comparison of Antonius with Tarquin; ${ }^{5}$ and the contrast he draws of Verres with Fabius, Scipio, and Marius. ${ }^{6}$

And now, having established his case, he opens upon his opponent a discharge of raillery, so delicate and good-natured, that it is impos sible for the latter to maintain his ground against it. Or where the subject is too grave to admit this, he colours his exaggeration with all the bitterness of irony or vehemence of passion. Such are his frequent delineations of Gabinius, Piso, Clodius, and Antonius ; ${ }^{7}$ particularly his vivid and almost humorous contrast of the two consuls, who sanctioned his banishment, in his oration for Sextius. ${ }^{8}$ Such the celebrated account (already alluded to) of the crucifixion of Gavius, which it is difficult to read, even at the present day, without having our feelings roused against the merciless prætor. But the appeal to the gentler emotions of the soul is reserved (perhaps with somewhat of sameness) for the close of his oration; as in his defence of Cluentius, Muræna, Cælius, Milo, Sylla, Flaccus, and Rabirius Postumus; the most striking instances of which are the poetical burst of feeling with which he addresses his client Plancius, ${ }^{9}$ and his picture of the desolate condition of the Vestal Fonteia, should her brother be condemned. ${ }^{10}$ At other times, his peroration contains more heroic and elevated sentiments; as in his invacation of the Alban groves and altars in the peroration of the 'Pro Nilone,' the panegyric on patriotism, and the love of glory in his defence of Sextius, and that on liberty at the close of the third and tenth Philippics. But we cannot describe his oratorical merits more accurately than by extracting his own delineation of a perfect orator: "Sic igitur dicet ille, quem expetimus, ut verset sæpe multis modis eandem et unam rem; et hæreat in eadem, commoreturque sel1tentia : sæpe etiam ut extenuet aliquid, sæpe ut irrideat: ut declinet a

1 Pro Muræn. 14.

3 Pro Rabir. 5.

5 Philipp. iii. 4.

2 De Orat. partit. c. viii. 16, 17.

4 In Verr. v. 65, \&c., and 64, \&c.

${ }^{6}$ In Verr. v. 10.

7 Pro Redit. in Senat.; pro Dom.; pro Sext. Philipp.

8 Pro Sext. 8-10.

9 Pro Planc.

10 Pro Fonteio. 
proposito deflectatque sententiam : ut proponat quid dicturus sit: ut, cum transegerit jam aliquid, definiat: ut se ipse revocet: ut, quod dixit, iteret: ut argumentum ratione concludat: . . . ut dividat in partes: ut aliquid relinquat ac negligat: ut ante præmuniat: ut in eo ipso, in quo reprehendatur, culpam in adversarium conferat: . . . . ut hominum sermones moresque describat: ut muta quædam loquentia inducat: ut ab eo, quod agitur, avertat animos; ut sæpe in hilaritatem risumve convertat: ut ante occupet quod videat opponi : ut comparet Similitudines : ut utatur exemplis : . . . ut liberius quod audeat: ut irascatur etiam : ut objurget aliquando: ut deprecetur, ut supplicet; ut medeatur; ut a proposito declinet aliquantulum: ut optet, ut execretur; ut fiat iis, apud quos dicet, familiaris." 1

Character of his style.
Difference between the Greek and Latin languages.

But by the invention of a style, which adapts itself with singular felicity to every class of subjects, whether lofty or familiar, philosophical or forensic, Cicero answers even more exactly to his own definition of a perfect orator, ${ }^{2}$ than by his plausibility, pathos, and brilliancy. It is not, however, here intended to enter upon the consideration of a subject so ample and so familiar to all scholars as Cicero's oratorical diction, much less to take an extended view of it through the range of his philosophical writings, and familiar correspondence. Among many excellences, the greatest is its suitableness to the genius of the Latin language; though the diffuseness thence necessarily resulting has exposed it, both in his own days and since his time, to the criticisms of those who have affected to condemn its Asiatic character, in comparison with the simplicity of Attic writers, and the strength of Demosthenes. ${ }^{3}$ Greek, however, is celebrated for copiousness in its vocabulary and perspicuity in its phrases; and the consequent facility of expressing the most novel or abstruse ideas with precision and elegance. Hence the Attic style of eloquence was plain and simple, because simplicity and plainness were not incompatible with clearness, energy, and harmony. But it was a singular want of judgment, an ignorance of the very principles of composition, which induced Brutus, Calvus, Sallust, and others to imitate this terse and severe beauty in their own defective language, and even to pronounce

1 Orat. 40. [" Our model orator then will often turn one and the same subject about in many ways; dwell and linger on the same thought; frequently extenuate circumstances, frequently deride them; sometimes depart from his object, and direct his view another way: propound what he means to speak; define what he has effected; recollect himself; repeat what he has said; conclude his address with an argument; distribute into parts ; leave and neglect something occasionally ; guard his case beforehand; cast back upon his adversary the very charges brought against him; describe the language and characters of men; introduce inanimate objects speaking; avert attention from the main point ; turn a matter into jest and amusement; anticipate an objection; introduce similes; employ examples; speak with boldness and freedom, even with indignation; sometimes with invective; implore and entreat; heal an offence; occasionally decline a little from his object; implore blessings; denounce execrations; - in a word, put himself on terms of familiarity with the people whom lie addresses."-Editor.]

${ }^{2}$ Orat. 29. $\quad 3$ Tusc. Quæst. i. 1; de clar. Orat. 82, \&c.; de opt. gen. Dic. 
the opposite kind of diction deficient in taste and purity. In Greek, indeed, the words fall, as it were, naturally, into a distinct and harmonious order; and, from the exuberant richness of the materials, less is left to the ingenuity of the artist. But the Latin language is comparatively weak, scanty, and unmusical, and requires considerable skill and management to render it expressive and graceful. Simplicity in Latin is scarcely separable from baldness; and justly as Terence is celebrated for chaste and unadorned diction, yet, even he, compared with Attic writers, is flat and heavy. ${ }^{1}$ Again, the perfection of strength is clearness united to brevity; but to this combination Latin is utterly unequal. From the vagueness and uncertainty of meaning which characterises its separate words, to be perspicuous it must be full. What Livy, and much more Tacitus, have gained in energy, they have lost in perspicuity and elegance; the correspondence of Brutus with Cicero is forcible indeed, but harsh and abrupt. Latin, in short, is not a philosophical language, not a language in which a deep thinker is likely to express himself with purity or neatness. "Qui à Latinis exiget illam gratiam sermonis Attici," says Quintilian, " det mihi in eloquendo eandem jucunditatem, et parem copiam. Quod si negatum est, sententias aptabimus iis vocibus quas habemus, nec rerum nimiam tenuitatem, ut non dicam pinguioribus, fortioribus certè verbis miscebimus, ne virtus utraque pereat ipsâ confusione. Nam quo minus adjuvat sermo, rerum inventione pugnandum est. Serısus sublimes variique eruantur. Permovendi omnes affectus erunt, oratio translationum nitore illuminanda. Non possumus esse tam graciles? simus fortiores. Subtilitate vincimur? valeamus pondere. Proprietas penes illos est certior? copiâ vincamus." ${ }^{2}$ This is the very plan on which Cicero has proceeded. He had to deal with a language barren and dissonant; his good sense enabled him to perceive what could be done, and what it was in vain to attempt; and happily his talents answered precisely to the purpose required. Terence and Lucretius had cultivated simplicity; Cotta, Brutus, and Calvus had attempted strength; but Cicero rather made a language than a style; yet not so much by the invention as by the combination of words. Some terms, indeed, his philosophical subjects obliged him to coin $;^{3}$ but his great

1 Quint. x. 1.

2 ["Let him who demands from Latin writers that peculiar charm of the Attic style grant me the same sweetness of expression, and equal copiousness of language. If this, as it is, is denied us, then we must express ourselves in such words as we have, and not introduce confusion, by endeavouring to discuss subtile arguments in language which, not to call it too heavy, is yet too strong; lest both excellences (perspicuity and elegance) perish by their very commixture. For the less our language will assist us, the more we must labour to effect by the invention of matter, Let us aim at extracting from our subject sentiments of sublimity and variety. Let us appeal to every feeling, and adorn our style with metaphorical embellishments. We cannot attain the elegance of the Greeks; let us exceed them in vigour. Do they excel us in subtilty?-let us surpass them in force. Are they superior in exactness?-let us outstrip them in copiousness of detail."-Editor.]

${ }^{3}$ De Fin. iii. 1 and 4 ; Lucull. 6 ; Plutarch, in Vitâ. 
art lies in the application of existing materials, in converting the very disadvantages of the language into beauties, ${ }^{1}$ in enriching it with circumlocutions and metaphors, in pruning it of harsh and uncouth expressions, in systematizing the structure of a sentence. ${ }^{2}$ This is that "copia dicendi" which gained Cicero the high testimony of Cæsar to his inventive powers, ${ }^{3}$ and which, we may add, constitutes him the greatest master of composition the world has ever seen. If the comparison be not thought fanciful, he may be assimilated to a skilful laudscape-gardener, who gives depth and richness to narrow and confined premises, by taste and variety in the disposition of his trees and walks.

Roman eloyuence.

Orators before Cicero.

Such, then, are the principal characteristics of Cicero's oratory ; on a review of which we may, with some reason, conclude that Roman eloquence stands scarcely less indebted to his compositions than Roman philosophy. For, though in his 'De claris Oratoribus' he begins his review from the age of Junius Brutus, yet, soberly speaking (and as he seems to allow in the opening of the 'De Oratore'), we cannot assign an earlier date to the rise of eloquence among his countrymen, than that of the same Athenian embassy which introduced the study of philosophy. To aim, indeed, at persuasion, by appeals to the reason or passions, is so natural, that no country, whether refined or barbarous, is without its orators. If, however, eloquence be the mere power of persuading, it is but a relative term, limited to time and place, connected with a particular audience, and leaving to posterity no test of its merits, but the report of those whom it has been successful in influencing. "Vulgus interdum," says Cicero, " non probandum oratorem probat, sed probat sine comparatione, cùm à mediocri aut etiam à malo delectatur; eo est contentus : esse melius sentit: illud quod est, qualecunque est, probat."4

The eloquence of Carneades and his associates made (to use a familiar term) a great sensation among the Roman orators, who soon split into two parties; the one adhering to the rough unpolished manners of their forefathers, the other favouring the artificial graces which distinguished the Grecian style. In the former class were Cato and Lælius, ${ }^{5}$ both men of cultivated minds, particularly Cato, whose opposition to

1 This, which is analogous to his address in pleading, is nowhere more observable than in his rendering the recurrence of the same word, to which he is forced by the barrenness or vagueness of the language, an elegance.

2 It is remarkable that some authors attempted to account for the invention of the Asiatic style, on the same principle we have here adduced to account for Cicero's adoption of it in Latin; viz., that the Asiatics had a defective knowledge of Greek, and devised phrases, \&c., to make up for the imperfections of their scanty vocabulary. See Quint. xii. 10.

3 De clar. Orat. 72.

4 De clar. Orat. 52. ["Sometimes the multitude bestow their approval on an orator who does not deserve it, and are pleased with one of mean or no talent: they are sensible that something better exists; but they are content, and approve what they have, such as it is."-Editor.]

5 De clar. Orat. 72. Quint. xii. 10. 
Greek literature was founded solely on political considerations. But, as might be expected, the Athenian cause prevailed; and Carbo and the two Gracchi, who are the principal orators of the next generation, are related to have been learned, majestic, and harmonious in the character of their speeches. ${ }^{1}$ These were succeeded by Antonius, Crassus, Cotta, Sulpicius, and Hortensius; who, adopting greater liveliness and variety of manner, form a middle age in the history of Roman eloquence. But it was in that which immediately followed, that the art was adorned by an assemblage of orators, which even Greece will find it difficult to match. Of these Cæsar, Cicero, Curio, Ciceronian Brutus, Cælius, Calvus, and Callidius, are the most celebrated. The splendid talents, indeed, of Cæsar were not more conspicuous in arms than in his oratory, which was noted for force and purity. ${ }^{2}$ Cælius, who has come before us in the history of the times, excelled in natural quickness, loftiness of sentiment, and politeness in attack ; ${ }^{3}$ Brutus in philosophical gravity, though he sometimes indulged himself in a warmer and bolder style. ${ }^{4}$ Callidius was delicate and harmonious; Curio bold and flowing; Calvus, from studied opposition to Cicero's peculiarities, cold, cautious, and accurate. ${ }^{5}$ Brutus and Calvus have been before noticed as the advocates of the dry sententious mode of speaking, which they dignified by the name of Attic; a kind of eloquence which seems to have been popular from the comparative facility with which it was attained.

In the Ciceronian age the general character of the oratory was dignified and graceful. The popular nature of the government gave opportunites for effective appeals to the passions; and, Greek literature being as yet a noveity, philosophical sentiments were introduced with corresponding success. The republican orators were long in their introductions, diffuse in their statements, ample in their divisions, frequent in their digressions, gradual and sedate in their perorations. ${ }^{6}$ Under the emperors, however, the people were less consulted in Decline of state affairs; and the judges, instead of possessing an almost inde- loman pendent authority, being but delegates of the executive, from interested under the politicians became men of business; literature, too, was.now familiar Government. to all classes; and taste began sensibly to decline. The national appetite felt a craving for stronger and more stimulating compositions. Impatience was manifested at the tedious majesty and formal graces, the parade of arguments, grave sayings, and shreds of philosophy, ${ }^{7}$ which characterized their fathers; and a smarter and more sparkling kind of

${ }^{1}$ De clar. Orat.; pro Harusp. resp. 19.

2 Quint. x. 1 and 2. De clar. Orat. 75.

+ Ibid. ad Atticum, xiv. 1.

6 Dialog. de Orat. 20 and 22 Quint. x. 2.

7 " It is not uncommon for those who have grown wise by the labour of others, to add a little of their own, and overlook their master."-Johnson. We have before compared Cicero to Addison as regards the purpose of inspiring their respective countrymen with literary taste. They resembled each other in the return they experienced. 
oratory succeeded, ${ }^{1}$ just as in our own country, the minuet of the last century has been supplanted by the quadrille, and the stately movements of Giardini have given way to the brisker and more artificial melodies of Rossini. Corvinus, even before the time of Augustus, had shown himself more elaborate and fastidious in his choice of expressions. $^{2}$ Cassius Severus, the first who openly deviated from the old style of oratory, introduced an acrimonious and virulent mode of pleading. ${ }^{3}$ It now became the fashion to decry Cicero as inflated, languid, tame, and even deficient in ornament ; ${ }^{4}$ Mecænas and Gallio followed in the career of degeneracy ; till flippancy of attack, prettiness of expression, and glitter of decoration prevailed over the bold and manly eloquence of free Rome.

\section{MSS., EDITIONS, \&c., OF MARCUS TULLIUS CICERO.}

\section{PHILOSOPHICAL WORKS.}

Editt. Princc. :-

Collected Philosophical Works. Sweynheym and Pannartz. Romæ, 1471.

De Officiis, De Amicitiâ, De Senectute, Somnium Scipionis, Paradoxa, Tusculanæ Quæstiones, without name or date, but known to be published by Gering, Crantz, and Friburger. Paris, about 1471.

De Legibus, Academica, De Finibus. Görenz. Lips. 1809-13. (This edition was intended to comprise the whole of the Philosophical works.)

1. Rhetorical Philosophy :-

Ed. Princ. Alexandrinus and Essulanus. Venet. 1485. Containing De Oratore, Orator, Topica, Partitiones Oratoriæ, De Optimo Genere Oratorun. Reprinted at Venice, 1488 and 1495.

First complete edition. Aldus. Venet. 1514.

Schütz. Lips. 1804.

Wetzel (Opera Rhetorica Minora). Lignitz, 1807.

Beier and Orelli (Orator, Brutus, Topica, de Optimo Genere Oratorum). Turici, 1830.

\section{PARTITIONES ORATORIE.}

Ed. Princ. Fontana. Venet. (?) 1472.

(Two other undated editions are supposed by bibliographers to be earlier. One is known to have been printed at Naples by Moravus).

Gryphius. Lugd. Bat. 1545.

Camerarius. Lips. 1549.

Sturmius. Strasb. 1565.

Minos. Paris, 1582.

Majoragius and Marcellinus. Venet. 1587.

Hauptmann. Lips. 1741.

Subsidium:-

Reuschius de Ciceronis Partitionibus Oratoriis. Helmst. 1723.

DE ORATORE.

The first perfect MS. of this work was found at Lodi, hence called Codex Laudensis. It is now lost.

Ed. Princ. Sweynheym and Pannartz. At the monastery of Subiaco, between 1465 and 1467.

1 Dialog. 18.

3 Ibid. 19.
2 Ibid.

4 Ibid. 18 and 22. Quint. xii. 10. 
Pearce. Lond. 1795.

Wetzel. Brunsv. 1794.

Harles. Lips. 1819 (embracing Pearce).

Müller. Lips. 1819.

Heinischen. Hafn. 1830.

Subsidia :-

Ernesti De Præstantiâ Librorum Ciceronis de Oratore Prolusio. Lips. 1736.

Matthiæ Prolegomen zu Cicero's Gesprächen rom Redner. Francof. 1812.

Schott, Commentarius quo Ciceronis de Fine Eloquentiæ Sententia examinatur. Lips. 1801.

Gierig, Von dem ästetischen Werthe der Bücher des Cicero's rom Reduer. Fuld. 1807.

Schaarschmidt de Proposito Libri Ciceronis de Oratore. Schneeberg. 1804.

Trompheller, Versuch einer Characteristik der Ciceronischen Bücher rom Redner. Coburg, 1830.

\section{BRUTUS.}

MS. The Laudensian above mentioned.

Ed. Princ. Sweynheym and Pannartz. Romæ, 1469.

Ellendt. Künigsberg, 1826.

ORATOR.

Ed. Princ. same as Brutus.

Meyer. Lips. 1827.

Subsidia :-

Ramus, Brutinæ Quæstiones in Oratorem Ciceronis. Paris, 1549.

Perionius, Oratio pro Cic. Oratore contra P. Ramum. Paris, 1547.

Majoragius, In Oratorem Cic. Commentarius. Basil. 1552.

Junius, In Oratorem Cic. Scholie. Argent. 1585.

Burchardus, Animadv. ad Cic. Oratorem. Berolin. 1815.

$$
\text { DE OPT, GEN. ORATORUM. }
$$

Ed. Princ. annotante Achille Statio. Paris, 1551 and 1552.

Saalfrank (cum Topicis et Partitionibus). Ratisb. 1823.

\section{TOPICA.}

Ed. Princ. without name or date; supposed, Venet. 1472.

The Commentaries of Boethius, G. Valla, Melancthon, J. Visorius, Hegendorphinus, Latomus, Goveanus, Talvus, Curio, Achilles Statius, are contained in the editions printed at Paris by-

Tiletanus, 1543.

David, 1550.

Vascosanus, 1554 .

Richardus, 1557 and 1561.

RHETORICA AD HERENNIUM.

Ed. Princ. in Ciceronis Rhetorica Nova et Vetus. Jenson. Venet. 1470.

Burmann, edited by Lindemann. Lips. 1828.

Subsidia :-

Van Heusde, De Elio Stilone. Utrecht, 1839.

Regius, Utrum Ars Rhetorica ad Herennium Ciceroni falsò inscribatur. Venet. 1492.

2. Political Philosophy :-

\section{DE REPUBLICA.}

MS. The work was supposed to have been altogether lost, until the year 1822 when Angelo Mai restored about one-fourth of it from a palimpsest in the Vatican. 
Ed. Princ. Mai. Romæ, 1822.

Villemain. Paris, 1823.

Creuzer and Moser. Francof. 1826.

Subsidia :-

Wolf. Obss. Critt. in M. Tull. Cic. Oratt. pro Scauro et pro Tullio, et librorum de Rep. Fragm. 1824.

Zachariä Staatswissenschaftliche Betrachtungen uiber Ciceros neu aufgefundenes Werk vom Staate. Heidelb. 1823.

DE LEGIBUS.

Ed. Princ. in the Philosophical Works. Sweynheym and Pannartz. Romæ, 1471. Davis. Cantab. 1727, 1728.

Görenz. Lips. 1809.

Moser and Creuzer. Francof. 1824.

Bake. Lugd. Bat. 1842.

\section{Moral Philosophy :-}

\section{DE OFFICIIS.}

Ed. Princ. with the Paradoxa. Fust and Schöffer. Mainz. 1465 and 1466.

One without date or name, but supposed to be from the press of Ulrich Zell. Colon. 1469.

Another, generally referred to the following year, supposed to be by Ulrich Han, of Rome.

Sweynheym and Pannartz. Romæ, 1469.

Vindelin de Spira. Venet. 1470.

Eggesteyn. Strasb. 1470.

Heusinger. Brunsv. 1783.

Gernhard. Lips. 1811.

Beier. Lips. 1820, 1821.

Subsidia :-

Buscher, Ethicæ Ciceronianæ libri ii. Hamb. 1610.

Rath. Cic. de Officiis in brevi conspectu. Halæ, 1803.

Thorbecke, Principia Philosophiæ Moralis e Ciceronis Operibus. Lugd. Bat. 1817.

Ed. Princ. :-

$$
\text { CATO MAJOR (DE SENECTUTE). }
$$

This treatise is in the philosophical works printed by Sweynheym and Pannartz, but five previous editions had appeared at Cologne. They are undated. The first three were by Ulrich Zell, the next by Winter de Hornborch, the last by Arnold Therhoernen.

Germhard (with the Parodoxa). Lips. 1819.

Otto. Lips. 1830.

Ed. Princ. Guldenschaff. Colon.

\section{LELIUS (DE AMICITIA).}

Ulrich Zell. Colon.

These have no date, but Guldenschaff's is the earlier, and both are older than the edition of the philosophical works by Sweynheym and Pannartz.

Gernhard. Lips. 1825 .

Beier. Lips. 1828.

\section{Metaphysical Philosophy :-}

\section{ACADEMICA.}

Ed. Princ. Sweynheym and Pannartz (in the philosophical works).

Davis. Cantab. 1725.

Görenz. Lips. 1810.

Orelli. Turici, 1827. 
DE FINIBUS BONORUM ET MALORUM.

Ed. Princ. without name or date. Believed to be from the press of Ulrich Zell, at Cologne, and about 1467.

Joannes ex Coloniâ. Venet. 1471.

Davis. Cantab. 1728.

Rath. Hal. Sax. 1804.

Görenz. Lips. 1813.

Otto. Lips. 1831.

Madvig. Hafn. 1839.

\section{TUSCULANE QUESTIONES.}

Ed. Princ. Ulrich Han. Romæ, 1469.

There are several other editions in the 15 th century.

Davis. Cantab. 1709.

Rath. Hal. 1805.

Orelli et Variorum. Turici, 1829.

Kühner. Jenæ, 1829.

Moser. Hannor. 1836-37 (the most complete).

PARADOXA.

Ed. Princ. (with the De Officiis). Fust and Schöffer. Mainz. 1465. Reprinted by Fust and Gernshem, 1466.

Published with the De Officiis, De Amicitiâ, and De Senectute, by Sweynheym and Pannartz. Romæ, 1469.

The same, with the Somnium Scipionis, by Vindelin de Spira. Venet. 1470.

There are many editions of the 18th century.

Wetzel. Lignitz, 1808.

Gernhard. Lips. 1819.

Borgers. Lugd. Bat. 1826.

5. Theological Philosophy :-

\section{DE NATURA DEORUM.}

Ed. Princ. in the philosophical works by Sweynheym and Pannartz.

Davis. Cantab. 1718.

Moser and Creuzer. Lips. 1818.

Ed. Princ. as above.

DE DIVINATIONE.

Davis. Cantab. 1721.

Rath. Hal. 1807.

Creuzer, Kayser, and Moser. Francof. 1828.

DE FATO.

Published together with "De Divinatione."

\section{SUBSIDIA ON THE PHILOSOPHY OF CICERO.}

Brucker, Historia Critica Philosophiæ. Vol. II. pp. 1-70.

Sibert, Examen de la Philosophie de Ciceron.

(Mem. de l'Acad. des Inscr. Vols. XLII. and XLIII.)

Ritter, Geschichte der Philosophie. Vol. IV. pp. 76-168.

Waldin, De Philosophiâ Ciceronis Platonicâ. Jena. 1753.

Zierlein, De Philosophiâ Ciceronis. Hal. 1770.

Brieglieb, Programma de Philosophiâ Ciceronis. Cob. 1784.

Fremling, Philosophiâ Ciceronis. Lund. 1795.

Hulsemann, De Indole Philosophiæ Ciceronis. Luneb. 1799.

Gedıcke, Historia Philosophiæ Antiquæ ex Ciceronis scriptis. Berol. 1815.

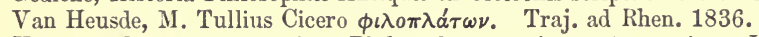

Kühner, M. Tullii Ciceronis in Philosophiam et ejus partes merita. Hamb. 1825. 


\section{SPEECHES.}

Ed. Princ. Sweynheym and Pannartz. Romæ, 1471.

Valdarfer. Venet. 1471.

Ambergau. Venet. 1472.

There is also an edition without name or date, supposed to be the true Editio Princeps.

Roigny. Paris, 1536.

Grævius. Amstel. 1695-1699. (Variorum Edition.)

Klotz. Lips. 1835.

The editions of separate speeches are very numerous.

III. LETTERS.

Ed. Princ. Sweynheym and Pannartz. Romæ, 1470. Jenson. Venet. 1470.

Aldus adnotante Minucio. Venet. 1548.

Schütz. Hal. 1809-1812. (This edition omits the letters to Brutus.)

Subsidium :-

Abeken. Cicero in seinen Briefen.

\section{COMPLETE WORKS.}

Ed. Princ. Minutianus. Mediol. 1498.

Manutius and Naugerius. Venet. 1519 -1523 .

Ascensius. Paris, 1522.

Cratander. Basil. 1528.

Hervagius. Basil. 1534.

Junta. Venet. 1534-1537.

C. Stephanus, Paris, 1555.
Lambinus. Paris, 1566.

Gruter. Hamb. 1618.

Gronovius. Lugd. Bat. 1691.

Verburgius. Amst. 1724.

Olivet. Genev. 1743-1749.

Ernesti. Hal. Sax. 1774-1777.

Schütz. Lips. 1814-1823.

Orelli. Turici. 1826-1837. 


\section{SENECA.}

THE STOICAL PHILOSOPHY.

BY

\section{WILLIAM LOWNDES, Esq., M.A., Q.C.,}

BRAZENOSE COLLEGE, OXFORD;

LATE JUDGE OF THE COUNTY COURT, LTVERPOOL.

REPRINTED FROM THE ORIGINAL EDITION. 
CrNIOS :-

ANTisthenes - $\quad$ - $\quad$ - $\quad$ - BORN B. C. 420

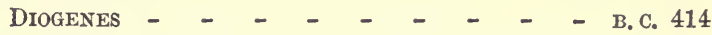
ONESICRITUS, Monimus, Crates, contemporaries with Diogenes.

\section{STOICS :-}

ZENO - - - - - - - - - B. C. 362

Cleanthes - - $\quad$ - $\quad$ - $\quad$ - - B. C. 320

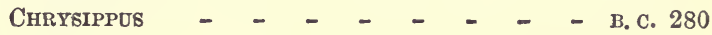

Panetius - - - _ - _ - - Died B. C. 236

Posidonius - - $\quad$ - $\quad$ - $\quad$ - - BORN B. C. 135

Seneca - - - - - - - - BORN B. C. 8

Dion Pruseus, contemporary with Seneca.

Epictetus - - _ - _ _ _ - DIED A. C. 161

Marcus Aurelius - - - began to Reign A. C. 170 


\section{LUCIUS ANNAUS SENECA.-THE STOICAL PHILOSOPHY.}

FroM B. C. 420 TO A. C. 170 .

\section{STOICISM IN GREECE.}

THE Stoical Philosophy, though of Greek origin, found in Rome the Progress of people to whose disposition and character it was best adapted; and in Rome. it was only among them, and at a comparatively late period, under the empire, that it attained the height of its development. In the early days of the Republic many glorious examples of Stoical virtue were displayed; and Cicero, in illustrating the paradoxes of the sect, reverts with patriotic triumph to those memorable instances of practical Stoicism. But such developments of character were rather the result of natural temperament, operated upon by circumstances, than the effect of system or discipline. It was at a later period that the Stoical philosophy may be said to have truly flourished at Rome; after the literature of Greece had been introduced, and when, according to the habits of individuals, or the temper of the times, the different systems of philosophy prevailed in succession. The manliness of the Roman character for a long time gave the preference to the doctrines of the Porch. Pomponius, indeed, amidst the convulsions attending successive usurpations, cultivated the milder and more soothing sentiments of Epicurus; but the delicacy of his nature and of his studies was looked upon as scarcely of a Roman mould, and his Attic surname was but an ambiguous compliment to his refinement. Although the practice of Academic disputation captivated the youthful imagination of Cicero, and opened an attractive field for the display of his inexhaustible treasures of eloquence, yet the practical morality of the Stoics seems always to have commanded his respect, and to have had a latent ascendency in his heart. It certainly advanced in his esteem in his declining years; and his treatises on the Duties of Life, and on the Paradoxes of the Stoics, show an affectionate anxiety to extricate a school, so eminent for virtuous practice, from some of its theoretical extravagances, and if possible to reconcile the dogmas of visionaries to the circumstances of society and the real exigencies of life.

The Stoical philosophy, hardy and severe as it was in its discipline, Cynicism the traced its descent from a sect still more austere and repulsive $;^{1}$ and parent of $_{\text {stoism. }}$ though many of the writers in the Stoical school attempted to ingraft on it the doctrines of other sects, as was the case with Seneca; or

$1 \mathrm{Ab}$ Antisthene, qui patientiam et duritiam in Socratico sermone maxime adamârat, Cynici primum, deinde Stoici manârunt. Cic. de Or. 3, 17 ; and Diog. Laert. vi. 103. 
gave way to the suggestions of common sense and humanity, as may be instanced in Panætius and Antoninus; yet Stoicism, as such, always bore strong traces of its Cynical origin. It will be necessary, therefore, in developing the doetrines of the Porch, to premise a short account of the parent school, that of the Cynics. Antisthenes. Antisthenes, the founder of this sect, was born in the year 420 B.C.
B. c. 420 .

at Athens, of a Thracian mother. In his early youth he studied the art of eloquence under Gorgias ; but his admiration of the independence and severe morality of Socrates, induced him to quit the rhetorician, that he might become a pupil of the philosopher. That love of singularity and perverse ambition, which formed a remarkable trait in the character of Antisthenes, and which attempted to disguise itself under the show of mortification and peculiar homeliness of apparel, did not escape the observation of his new master. "I can spy," said he, " the wearer's pride peeping out through the holes of those ragged garments." It does not appear whether he quitted Athens on the occasion of the death of Socrates, as other disciples of that philosopher did ; but a sarcasm of his is recorded, as having contributed to accelerate the punishment of those who effected that judicial murder. Some foreigners, unapprised of the event, are said to have asked Antisthenes where they could find Socrates' house: he assured them that Socrates was not worth inquiring after, but that he could refer them to a far superior and more accomplished personage; and he directed them accordingly to the house of Anytus. Soon after his master's death, Antisthenes seems to have given full scope to the peculiarities of his own character; and whether he happened to select a place which had been previously called the Dogs from some incident now unknown, ${ }^{1}$ or that he first obtained the name of $\mathrm{dog}$, and that the place was so called in honour of his Academy, certain it is, that he inveighed and scoffed in 'Cynosarges;' and that his adherents and imitators were with great propriety termed Cynics, or the School of Barkers. Little more is known of the particulars of his history. It cannot be doubted that his own conduct must have been irreproachable, and that he must have had a robust sort of satirical wit, to have atoned for, and sanctioned, the absurdities and extravagances of his outward demeanour. $\mathrm{He}$ was a man in many respects superior to the generality of his followers. Instead of decrying science and literature, he was himself an author; and he is said to have left behind him ten volumes of his works, though they have all now perished. We learn from Cicero, that he maintained the unity of the Supreme Being, in opposition to the polytheism of the vulgar, ${ }^{2}$ and that his writings were valuable, as monuments rather of his sagacity than of his erudition. ${ }^{3}$ It is probable that some of the tales related of him by the followers of his school are mere fictions; and, in fact, only descriptions of a Cynical model,

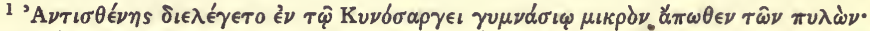

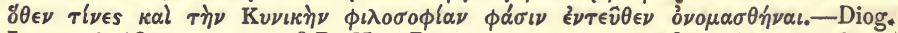
Laert. vi. 13. 2 De Nat. Deor. i. 13.

- 3 Ad Att. xii. 38.
} 
according to their own notions. It is not likely, for instance, that one, who had himself been a pupil of Socrates, and who was certainly a man of sense as well as humour, should have treated Diogenes, when he expressed himself willing to come under his tuition, as if he already had been really a dog; and should have done his best to beat him away with his large staff, and that the novice only prevailed by his resolute perseverance and endurance of honest blows. ${ }^{1}$

Diogenes, as has been the case with many others, rushed from the Diogenes. one extreme of licentiousness to the contrary one of asceticism, and sought to retrieve the dissoluteness of his youth, by the mortification and moroseness of his later years. His temperament is represented by all writers, as fervid and enthusiastic; his humour was coarse, homely, and caustic; and the specimens of it which have been preserved, exhibit a tartness in which it is difficult to say whether the character of sagacity or of scurrility most predominates. His predecessor was, by constitution, hardy and temperate; and observation of the world had confirmed him in his opinion of the dangerous nature of the passions. His lectures, therefore, and declamations against pleasure, were those of a humane, though an austere and rugged monitor. Diogenes, on the contrary, was of a nature altogether impetuous and excitable; his humour of restraint had as little relation to any rational purpose as his previous indulgences. He did not attempt to instruct, but professed to reprove others. He gave no lessons of prudence or severity; but disgorged his spleen, or envy, in bitter and insolent contumelies. His own uncomfortable feelings found vent in his taunts on all around him; and, by assuming a sort of misanthropy on principle he furnished abundant exercise to all the malignity of his wit. Such satirists and ribalds, by profession, are perhaps necessary characters in the great theatre of the world, and may serve well as the antidotes to parasites and sycophants, but they have little claim to be canonized amongst philosophers and moralists.

The following are, perhaps, amongst the happiest of the recorded sarcasms uttered by this accredited scoffer :-

"He often found it necessary in life," he said, "to have ready an answer or a rope."

He was indignant at people for praying to the gods for health, and at the same time doing what they could to destroy it by feasting.

Calling out once, "Men, come hither ;" and numbers flocking about him, he beat them all away with a stick, saying, "I called for men, and not varlets."

Dining one day at a common eating-house, he saw Demosthenes pass by, and invited him in. Demosthenes refusing, "What," said Diogenes, "should you be ashamed to dine here, when your master does so every day?"

"Against fortune," said he, "we must oppose courage; against nature, law; against passion, reason."

1 Hieron. adv, Jovin. 
Being asked, what animals were most dangerous in the bite? "Of wild animals," he replied, "a detractor ; of tame, a flatterer."

Seeing some women hanged upon an olive-tree, "I wish," remarked he, "that all trees bore the same fruit!"

To one who reproached him with living in dirty and discreditable places, "The sun," replied he, "can shine upon kennels, without disparagement to himself!"

Upon seeing an old woman painted, he observed, "If you do this to gratify the living, you are mistaken in the effect; if it is for the dead, lose no time in joining them."

Onesicritus. Among the friends of Diogenes are mentioned Onesicritus, Monimus, and Crates; the first of these, however, did not continue in the school of the Cynics at Athens, but attended the army of Alexander the Monimus. Great in his Indian expedition. Monimus seems to have been possessed with much of the extravagance of his friend and model Diogenes; and a saying of his is preserved, which is at once very suitable to his character as a man of lively and changeful impressions, and very remarkable as containing the germ of the Sceptical system. It is recorded to have been his doctrine, that there is no such thing as reality; but that all objects are the conceptions and creations of our own mind producing fantastic illusions, or semblances of external

Crates. objects; and that the whole is but a dream or show. Crates was a philosopher of a very different cast, and seems to have aimed at moral instruction under the guise of levity and petulance. He was not at all of a saturnine complexion; but made it his aim to give much oblique reproof, and to qualify many salutary but offensive reflections, with the appearance of ridicule and humour. The real good nature and kindness of his purpose were duly appreciated by his fellowcitizens; and whilst he was admired by strangers for his festive wit, and for the poignancy and vivacity of his sallies, he was frequently used as an umpire by his fellow-townsmen in their mercantile or family disputes; and his good sense and impartiality gave authority to his verdicts. He was the last, and, with the exception, perhaps, of Antisthenes, the most creditable teacher in the school of derision; and, indeed, his good sense and his constitutional vivacity seem so much to have modified his character, that if he was a Cynic by system and profession, he was in practice such a philosopher as might have belonged to any age, and as any school might have been proud to own.

Such was the course of the Cynical school among the Greeks. Its prevailing characters were a contempt of pleasure, a disregard to the distinctions of society, and an utter insensibility to decorum.

Review of the Cynical doctrines.

With regard to pleasure, moralists of all sects have concurred in admitting, that it is not, in its vulgar sense, to be made an ultimate object of pursuit; that first impressions are to be distrusted; and that mere prudence and self-regard will point out the superiority of the intellectual and moral enjoyments, over the hollow gratifications of 
sense; and that it is an equally gross fallacy in calculation, as it is a deviation from propriety, to prefer a personal pleasure to a social duty. But it is surely a strange error to suppose that pleasure, as such, must be an object of aversion to rational beings. When limited by prudence as to ourselves, and by a proper regard to the rights of society, a gratification of our own desires, and a sympathy in the enjoyments of others, are things innocent and commendable. Asceticism and mortification, for the sake of misery without any reference to utility, are the virtues of a misanthropic disposition or of a deranged intellect.

As to the distinctions of society, the Cynics of antiquity showed much more of spleen than sense, in their insolent disregard of them. Industry can never be encouraged effectually without permanent security to property; nor can any means be devised for giving such security which will not, in the end, produce an unequal distribution of wealth. Differences in the conditions of men are inevitable, as long as there are" differences in their capacities, the degree of exertion which they employ, and the extent of their industry. The accumulation of wealth, and the rights of inheritance, cannot be prevented or interfered with, without reducing the bonus of industry, and taking away the stimulants to exertion. Orders which are not open to merit, and privileges which benefit particular classes to the oppression of the community, are indeed abuses which should be removed wherever they exist; but some distinction of classes is inevitable in the course of national advancement: abilities and services must procure power and consideration, and wealth will always command influence. The Cynics, who derided these arrangements in society, did not so much exhibit any magnanimity of character, as they exposed their ignorance and contracted views. In their indiscriminate scoffing at what they termed ambition, they little perceived how much they injured the cause of virtue, by repressing every spirited exertion, by extinguishing the flame of worthy emulation, by deadening that enthusiasm without which nothing good and great was ever accomplished. Whilst they decried vanity, they rooted up at the same time much of that regard for the feelings and opinions of others; much of that social affection, which is in some instances the guarantee of propriety, as it is in others the incentive to virtue. When Diogenes trod upon Plato's robe, and exclaimed, "I trample under foot the pride of Plato," the sage's reply to the Cynic seems not without its justice: "True, but it is with the greater pride of Diogenes."

In regard to the insensibility of the Cynics to decorum, several of their outrages upon public manners are enumerated by Sextus Empiricus; and, perhaps, there may be some exaggeration in the descriptions given by this avowed enemy to them, and to their derivative sect the Stoics. But other particulars in the history of the Cynics, show that they were not slow or timid in illustrating by their example the doctrines which they promulgated; and if, as it is agreed, it was one of their leading principles, that time and place 
could make no difference in the morality of actions, and that no expression could be improper which related to transactions which were proper, ${ }^{1}$ it is easy to imagine what extravagances of conduct these philosophical caricaturists may have exhibited, and in what licentiousness of language they may have indulged. These aliens and obtruders into civilized society, when they treated shame as a factitious sentiment, and decried modesty and self-respect, showed a systematic perverseness which has provoked the reprehension of Cicero for its profligacy, ${ }^{2}$ and the opposition even of the licentious Mandeville, from the ignorance which it implies in the principles of human nature.

The Stoics. We proceed, however, to a history of the scion school of the Stoics; and we may premise, that the characters of the individuals belonging to it varied so materially from one another, and so materially also influenced the doctrines which they promulgated, that the system of the Stoics, as delivered by Zeno, can scarcely be recognised in the ostentatious pretensions and quibbling paradoxes of Chrysippus; and that it requires something like chemical art to detect any remnant of the same ingredients, when the compound has been filtered by the good sense of Panætius, or sublimed into the gasconade of Seneca.

After detailing, therefore, a few particulars in the life of Zeno, we shall subjoin a brief summary of the physical and moral doctrines of the Stoics, as they appear to have been expounded by him; and shall interweave in the narrative of his successors those prominent points in which they extended or deviated from the notions of their founder.

Zeno. Zeno was born at Citium, a town on the coast of Cyprus. His B. c. 362. father was a merchant, and in his voyages to Athens, brought home some of the pieces written by the pupils of Socrates. The young Zeno was charmed with the style of these philosophical productions. At the age of thirty-two he visited Athens, and from that time forwards devoted himself exclusively to philosophy. He attached himself at first to the Cynic Crates, and then for ten years placed himself under the tuition of Stilpo. He afterwards listened to Xenccrates

The Porch. and to Polemo. After this long course of discipline, he ventured to open his own school, and selected the Portico, a public building, ornamented with the paintings of Polygnotus, Myco, and Pandamus, the brother of Phidias. This place was, it seems, before his time one of general resort, and was, from these paintings and from its statues, denominated the Painted Porch; but the lectures and discussions of which it became the theatre, soon imparted to it a celebrity sufficient to distinguish it from other buildings of the same nature; and the

1 Non audiendi sunt Cynici, aut siqui fuerunt Stoici pænè Cynici, qui reprehendunt et irrident, quod ea, quæ turpia re non sint, nominibus ac verbis flagitiosa dicamus: illa autem, quæ turpia sint, nominibus appellemus suis. Latrocinari, fraudare, adulterare, re turpe est; sed dicitur non obscœnè : liberis dare operam, re honestum est, nomine obsconum: pluraque in eam sententiam ab eisdem contra verecundiam disputantur.-Off. 1,35 .

${ }^{2}$ Cynicorum vero ratio tota est ejicienda. Est enim inimica verecundiæ sine quâ nihil rectum esse potest, nihil honestum.-Off. 1,41 . 
followers of Zeno have been long handed down in history, as the philosophers of The Porch. The regularity of Zeno's life, as well as the severity of his doctrines, and the keenness of his logic, ensured to him the respect and admiration of the Athenians. The keys of the city were delivered into his custody. A golden crown was presented to him, and a statue of brass raised to his honour. Antigonus Gonatas, the king of Macedon, whenever he visited Athens, attended his lectures, and was anxious to prevail on him to come to the Macedonian court. Zeno's fame seems to have continued increasing to the end of his life, and in his latter days excited the jealousy, or at least incurred the reprehension, of Epicurus He died at the age of ninety-eight, after having presided many years in the Porch. He was tall in stature, thin in person, abstemious, with a countenance somewhat repulsive and scowling. He wrote a work on the Commonweal, in which he animadverted on the errors of Plato with much acrimony. Of this work nothing remains, except some few passages incidentally cited by ancient authors.

The Stoics considered the present system of the world as wrought His doctrines out of an original chaos; but they distinguished between the rude materials and the vivifying principle. From the materials they held that the different elements were produced by the operation of that mighty and pervading principle, which existed prior to their production, and which will survive their decay. The Stoical masters System of differed in their account of the process by which the elements were the world. divided from one another. Zeno seems to have considered that the earth was separated by its own gravity and adhesion; that the water consisted of such fluid particles as were not solid enough so as to conglomerate into earth, and yet were of too settled a nature to evaporate altogether into air; that the air itself was produced by exhalation; and that fire was produced from the air by flashes or coruscations.

Zeno seems to have had a tolerably distinct notion of the universality Centripetal of a centripetal force. He maintained that all things which exist by force. themselves are moved towards the middle of the whole, and likewise of the world itself, and that there is the same cause of the rest of the world in infinite space, and of the rest of the earth in the world, in the midst of which it is constituted as a point. It is true tliat Zeno stated that heavy bodies are principally influenced by this propensity, but he at the same time insisted that the lighter elements, as air and fire, did in some respect tend towards the centre of the world.

As the Stoics considered water to be, in one sense, the basis of all Phænomena the elements, and fire itself to be produced from water after having of Nature. been previously refined into air, it is not surprising that they defined the sun to be a self-guiding or intelligent mass of fire, gathered and kindled originally and still constantly nourished by exhalations from the great ocean; and that they deemed the moon to be nourished in the like manner from the exhalations of fresh water. Thev traced 
the variations of the seasons to the approach or remoteness of the sun. The rainbow they considered as a reflection of the sun's rays from a humid cloud.

The following were the principal arguments advanced by the Stoics, in proof of the existence of the Supreme Being. ${ }^{1}$

Supreme

Being.

If anything exists in nature which it would surpass the ingenuity, the wisdom, and the capacity of man to produce, the power which did produce such things must surpass the nature of man. But man could not form and arrange the heavenly bodies and the mighty system of the universe. The Being, therefore, who produced these must be something superior to human intelligence or power; and what can we term such a superior Being, otherwise than a Divinity?

Everything in nature seems to admit of gradations. In the parts of creation which appear inanimate, there are different degrees of utility, of completeness, and of beauty; there are greater or lesser approaches towards perfection. In the animated world there are all the varieties of susceptibility; rising from the merest torpor to the most exquisite sensation, and to the most lively and accurate instinct. But in reason, man stands alone; and is it to be supposed that this intelligence, which in his nature is coupled with a frame so full of impressions and infirmities, should not exist in some higher degree, and be able to exercise its operations in some nobler mould, in some form less fettered by incumbrance, and less exposed to casualty? It is probable, surely, that man, high as he stands, and far transcending all mere animals, may yet be but the lowest and most imperfect of rational and intelligent beings.

The universe is not a confused mass of unconnected and isolated materials. It is coherent. It is organized. It is a system. In every system there is some pre-eminent point, some spring of nourishment, some centre of vitality, in dependence upon which all the other parts exercise their functions, and in reference to which they act. From this all the supplies of the machinery are drawn, to this they all seem to revert. In the vegetable kingdom, the roots are considered the grand and primary organs; in the animal, the heart or the brain. Can such an anomaly then be supposed, as that the system of the universe itself is without a centre of life, and motion, and intelligence? Must it not be inferred, that there is some sovereign principle or sensorium of the universe, from the ocean of whose beauty all the energies of nature are derived, and into which, after having refreshed every part of the system with their tides of health and beauty, they will eventually be reabsorbed? The Stoics, however, at the same time that they maintained the unity of the pervading principle, accommodated themselves to the prevailing Polytheism. superstitions, by adopting them in a modified sense. They considered the popular divinities as figurative representations of the various powers of nature; and all the idle fables connected with the ${ }^{1}$ Cic. de Nat. Deor. ii. 6, 12, and 13; 7, 38, 45, and 46. 
vulgar polytheism were resolved into allegories, and treated as treasures of mysterious wisdom. ${ }^{1}$

In considering the moral doctrine of the Stoics, it will be only Morals. necessary to advert to those peculiarities by which they were distinguished from the other philosophical sects of antiquity. In opposition to the Epicureans, instead of resolving reason into instinct, and considering the pursuit of happiness as a quest of pleasure on a more enlarged scale, they proceeded to the other extreme, and maintained that the first impulses of nature are evidences of an inherent and connatural self-love. They argued that the first gleams of desire, as they are directed to things appropriate and conducive to welfare, are scintillations of an innate reason and prudential faculty. Since the natural desire of infants in their earliest moments are directed to things beneficial, and their aversions are calculated to guard them from things that would be injurious, this school stontly maintained that these particular affections imply a deliberate preference of what is good for the whole nature, and that those movements which have the appearance of senseless organic impulse, are the evolutions of an inherent prudence, and of a native self-love. They argued further, that the seminal principle of self-preservation must ke the ground of all original appetite and aversion, and not any pursuit of pleasure as such, or any declination from pain as such; for that pleasure and pain are merely the result and consequences of certain actions; now these consequences cannot be anticipated before experience, and therefore cannot originally, in the first instance, be the ground of the actions themselves. In the inanimate creation, where pleasure cannot be felt, there is still some inherent principle which directs the roots of trees to feel their way into appropriate layers of soil or moisture, and their branches to shoot upwards into the congenial atmosphere. In the lower orders of animals, life and health are preserved by some salutiferous influence of the same kind. If in human nature these original motives to action were mere animal propensities to the blind quest of pleasure, nature, which in other instances is so vigilant and conservative, would in the case of man often impel to injury and destruction. So far, therefore, from reason being resolved into blind appetite, what is termed instinct in the earliest impulses of the human frame ought to be exalted into a modification of reason.

The Stoics further argued, that though utility is a great object of desire, and a great test of the morality of actions, it is not the only consideration which impels to action; that all knowledge is desirable on its own account, without reference to the practical benefits wlich it produces; that the curiosity of children is an indication of a character inseparable from the human mind; and that, however disguised or counteracted by circumstances, a thirst for information and a yearning after truth are constituent parts of our nature. The gratification of these intellectual longings and aspirations was therefore held by them

$$
{ }^{1} \text { Cic. de Nat. Deor. iii. } 24 .
$$

[G. R. P.] 
to be in itself an ultimate object of desire; and as we have seen, that they considered the appetites merely as modes of self-love, or expressions of the endeavour after perfection, it was in perfect consistency with such principles, that they held the virtues, and the acquisitions of science, to be desirable in themselves, without reference to the benefits resulting from them to the individual, or to the community.

The great excellence of the Stoical morals consisted in the elevation which they gave to the sense of duty. When the understanding once ascertained what was proper to be done, the dictates of an enlightened conscience were, in their estimation, the universal and invariable rule of conduct. Their moral rules, though they may sometimes sound as if they had a speculative cast, were all applied to, and intended for, sound practical use. They considered the conclusions of experience respecting the happiness of mankind, as the voice of nature announcing the destinations and duties of individuals. No progress can be made towards the perfection, scarcely any even to the development, of the human faculties, without society. Society, therefore, is the natural state of man ; the nature of his body and his mind as clearly indicating, that it was interided by Providence that he should live in a social state, as the structure of other animals shows them to be adapted to the peculiar elements in which they live. The faculty of reasoning and language prove that man was intended for intercourse of this kind, as clearly as the construction of his lungs indicates that he was calculated for the atmosphere which he respires. The moment that the social nature of man is recognised by the understanding, the duties which that condition involves are implicitly comprehended as matters of paramount importance. The process by which, in general, the affections extend themselves from the individual to his home, his country, and mankind at large, is indeed somewhat reversed in the reflective and unimpassioned system of the Stoics; and the pupils of that school are taught rather to know their duties, by applying the conclusions of their reason to their particular situation, than to feel them by having their sympathies gradually expanded. But the coincidence between these deductions of the understanding, and the natural suggestions of the heart, is mutually illustrative of both.

Ideal perfec- The character which the Stoics have given of a wise man has been tion of the occasion of much misrepresentation. It was their aim to describe character. such a being as should be a constant model for the admirers of virtue to mould their own characters by, as far as human infirmities would permit. So far were the pupils of the Stoical school from pretending that they had attained such a degree of perfection themselves, that they expressly declared that their great masters, Zeno, Cleanthes, and Chrysippus, were themselves far deficient, and that although worthy of all veneration, they did not attain to the ideal of human excellence. The Stoic masters in their description of the wise man have, as might be expected, concurred in accumulating such qualities as tend to make a man at once most independent and most useful to others; thus 
they attributed to him an absolute command over his passions, and a mind so well acquainted with the course of nature, as not to be surprised at its apparent deviations and irregularities. There was indeed some variation in the notions of their different masters, whilst some regarded independence of mind, and others usefulness, as the great object of pursuit. Thus Chrysippus urged, that a wise man ought to apply himself to some office in the commonwealth, whilst Apollodorus maintained that a wise man ought to imitate the Cynics. It is a striking proof of the superstition of the Stoics, that amongst the qualities of their ideal character, they attributed to him the spirit of prophecy and divination; they held that he must know those signs which are communicated by gods and dæmons in the relations of human life; that he must be able to interpret dreams, and be versed in the mystery of augury. They not only held that their wise man would on adequate occasions willingly sacrifice his life for his country and friends, but they held that he would destroy himself when subjected to the torture of continued and racking pain, or afflicted by some lingering and incurable disease.

As far as the Stoics endeavoured to raise themselves, by the con templation of a perfect character, to something above humanity, their design was good and likely to be beneficial. On the other hand, the perpetual contrast between these strange and exaggerated notions, associated as they were with the name of Stoicism, was calculated to estrange the pupils of that school from the ordinary habits and feelings and affections of society. Whilst they revolved in their imagination the perfections of the wise man, they felt an additional disgust or a sanctified pity for the prejudices, the errors, and the delusions of those around them. Though they expressly disavowed the presumption, yet they unconsciously identified themselves with the model of their admiration. When they considered their imaginary wise man exempt from the failings and infirmities of nature, and that in the satisfaction of his own mind he concentrated all the honours which power and dignity seemed to bestow, the young aspirants would often feel a cynical aversion from the conflicts of life, and rest contented with that superiority which vanity easily generates in the fancy. They were taught to consider their wise man as a character mighty, elevated, and possessed of great power, yet at the same time void of all pride; he was the only person qualified to be a king or magistrate; and in accordance with their model, the conceit of their own importance was often disguised from others, and sometimes concealed from themselves, by the appearance of a rough independence or a virtuous humility.

But from this general criticism on the doctrines of Zeno, we must turn to pursue the history of his school, and to glance at the modifications introduced by his successors. Cleanthes was a native of Assus, Cleanthes. a city in Eolia. He was originally a wrestler, and he preserved B. c. 320 . through life that vigour and hardiness of frame which qualified him for his first profession. His poverty was extreme; and whilst attending 
the school of Zeno in the daytime, he was compelled to work for his subsistence during the greater part of the night, as a common carrier and drawer of water. It is related, that his healthy appearance, whilst he was apparently without any means of support, excited the attention of the police; and when he was summoned to give an account of his means of providing a livelihond, the gardener under whom he drew water, and a woman for whom he ground flour, came forward to attest his extraordinary industry. His faculties were not quick, but his application compensated for the defects or peculiarities of his natural disposition. Zeno admired him for his zeal and perseverance, and instituted him his successor. He wrote fifty-six volumes, all of which are lost. But Cicero has noticed one of his illustrations, and Diogenes Laertius and Stobæus have preserved a few of his memorable sayings. The illustration given by Cicero is this: "To place in a conspicuous point of view the impropriety of considering pleasure as the ultimate object of pursuit, and virtue as merely subservient and subsidiary, Cleanthes desired his hearers to suppose a fair tablet placed before their sight, in which pleasure was represented enthroned in majesty, with the virtues ministering to her as attendants upon her state, whispering to her that they were born to do her service, and that their only end and aim in existence was to show her honour by waiting in her train, or executing her commands."

Chrysippus was a native of Solis, a town of Cilicia, but early in life devoted himself to philosophy, and, fixing his residence in Athens, attended the school of Cleanthes. He soon distinguished himself by that logical subtilty, and that faculty of quick discrimination, which constituted at once the strength and the foible of his character. His ingenuity and address were inexhaustible; and as he pressed keenly and without reserve upon the weak points of his antagonist's arguments, spoke without reference to any system on his own part, and seemed regardless of everything except the point immediately under discussion, he was found to be a most redoubtable and vexatious disputant, and his character stood high as a leader in that warfare of words in which the Athenians so much delighted. To him the stoical philosophy owes that store of perverse and exaggerated conceits, with which it was embarrassed and disfigured. It procured applause for Chrysippus, and amazed the bystanders, when he advanced that all crimes were of equal magnitude, because all were equally deviations from right; or maintained that the virtuous man alone was possessed of absolute power, and was incapable of error. To show his logical skill, he adopted and insisted upon many of the most absurd and revolting of the Cynical notions; and we must refer to Sextus Empiricus for details which may prove Chrysippus to have been a hardy controversialist, but which cannot impress any one with a favourable opinion of him, either as a champion of good sense or as a friend of virtue. 


\section{Storcism among the Romans.}

After Chrysippus, Panætius and Posidonius supported the character Panætius, of the Stoical school, and indeed did much to retrieve it from his ${ }_{\text {в. с. } 136 .}^{\text {obit }}$ extravagances. But the philosophy of Greece was naturalized at Rome Posidonius, by Cicero. The opinions of the Stoics were a favourite study of the nat. в. c. 135 . Roman lawyers in particular; and it has been said, that some of those terse maxinis of the Roman code, which have been incorporated into the general law of Europe, may be traced as having originated in that school. By the Roman poets, too, the doctrines of Stoicism were Stoicism much cultivated; and Lucan has condensed into a few lines the lead-introduced ing principles of the sect, when giving the character of Cato. ${ }^{1}$ But Seneca, Epictetus, and Antoninus, are the three principal names which supported the glory of Stoicism under the Roman emperors; and we shall proceed to speak of their several characters and merits somewhat compendiously, since, considering the limits of our general work, we have perhaps already expatiated somewhat too largely in developing the peculiarities of stoicism.

Lucius Annæus Seneca was born at Cordova, in the eighth year Seneca. before Christ. His father was Marcus Annæus Seneca, a rhetorician of eminence, some of whose productions have come down to us. His mother's name was Helvia. He had tivo brothers, Marcus Annæus Novatus and Lucius Annæus Mela. Seneca was of a delicate frame of body, and was during the early period of his life much afflicted with ill health. He commenced his studies under his father; but lectures Education. on the media of proof, and on the modes of awakening the passions, served rather to stimulate than to satisfy his curiosity. He was anxious to inquire deeper into the nature of man, and to learn what could be known about the system of the universe. For this purpose he commenced his studies under Sotio the Pythagorean, a man whose exemplary habits at once sanctified and illustrated the doctrines which he expounded. But the ardour of Seneca's mind was such as not to allow him to acquiesce in the system inculcated by Sotio, to the exclusion of further research. He was initiated by Attalus in the peculiarities of the Stoical doctrine. He studied the Peripatetic philosophy under Papirius Fabian; and he learned, as far as an institution which despises all learning can be taught, the whimsies of the Cynics from Demetrius. This latitude of inquiry, and rejection of exclusive partialities, continued with Seneca through life; and to this habit we may attribute the characteristic excellences, as well as some of the peculiar blemishes, of his writings. His intercourse with Demetrius ripened into intimacy; and in his progress in the world, when fortune had heaped honours upon him, the courtier and the favourite did not abate his esteem or his familiarity with the Cynic. But the system of the Stoics was, upon the whole, the favourite with Seneca.

By his father's advice he then mixed in the active concerns of life, 1 Lib. ii. 380 . 
His appearance as a pleader.

and commenced his exertions as a pleader at the bar. At Rome, the pursuits of a lawyer and of an advocate were kept much more distinct than they usually have been in modern times. It required the labour of many years to qualify a man to practise as a jurist; and the continued and tedious comparison of texts, and cases, and precedents, was preliminary to the formation of that character of an authorised and solemn expositor of law, which is most nearly expressed by the modern term of a chamber-counsel. A few hours' study, on the contrary, such as could give a smattering of the terms of art, and a sketch of the general principles of law, was all that was thought necessary by the ancient Romans for the qualification of an advocate or pleader at the bar.

We are informed by the unknown author of the 'Dialogue on the Causes of the Decline of Eloquence,' that Seneca distinguished himself during the short period whilst he practised at the bar, by the weight and pointedness of his remarks; but that he was as deficient in his pleadings, as he afterwards showed himself to be in his writings, in" that uniform progression and flow of thought, which is almost inseparable from the character of eloquence. His success, however, was such, that he became desirous of advancing himself in public. $\mathrm{He}$ Quæstor. discharged the duties of the quæstorate, and became at length a distinguished favourite in the court of Claudius. But in consequence of an imputed familiarity with Julia, the daughter of Germanicus, he, with some others, fell into disgrace, and was banished to the island of

Banishment. Corsica. His conduct during exile deserves to be remarked, as illustrative of the tendency of that philosophy which he advocated and professed. In his letters to his own friends, he boasts of the opportunities now allowed him for retirement and study, and makes an ostentatious display of the means of wisdom and independence which were afforded him by solitude and retreat; he vaunted that his happiness was independent of external circumstances, and that a wise man could find a home and a country in any quarter of the earth. In his letters to the emperor, however, his submissions are abject; and his solicitations for leave to return are unqualified, spiritless, and pitiful. Lord Bolingbroke, in his 'Reflections on Exile,' has adopted the spirit and the style of Seneca's Stoical letters ; and we know that the magnanimity of this modern courtier and philosopher was on a par with that of his ancient prototype. Cicero, on the contrary, though the occasion of his banishment reflected honour rather than disgrace upon his character, instead of playing off the idle jargon of words, or making any hypocritical boast, or affecting an indifference to the regard and esteem of his countrymen, gave way too much to the painfulness of an exile which was unjustly inflicted upon him; and indulged in expressions of sensibility, which, however natural, and however amiable, have been reflected upon as amongst the blemishes of his character. Cicero, however, with whatever frankness he may have unbosomed his own feelings of weakness during exile, was recalled by the unsolicited and spontaneous 
summons of his own free countrymen. Seneca, whilst affecting to the world to pride himself in his compulsory seclusion, procured a remission of his sentence by undignified and unmanly entreaties to a tyrant. Besides his own direct submissions, his return is said to have been accelerated by the mediation of Agrippina, the mother of Nero. After his return, Seneca was engaged first as the tutor of Nero, and after- Tutor and wards as his minister; in both capacities he seems to have deserved minister of well of his pupil and of the Roman people, but in neither of them did his conduct escape obloquy. As a tutor it is said, that he sanctioned the excesses of his pupil ; whilst, in fact, he probably only modified irregularities which he could not restrain. As a minister, he has been made responsible for several of the outrages of his sovereign; though he may, perhaps, deserve the credit of repressing, rather than the imputation of instigating such perversions of power. Certain it is, that that part of Nero's reign in which Seneca participated in the administration of government, is not marked by atrocities so numerous or so intolerable as those which disgraced the latter part of it. The amplitude of Seneca's fortune, whilst minister, is another particular which has been objected to him by the censurers of his character. But, however inconsistent it may be with some of his Stoical eulogies upon poverty, and Cynical tirades against wealth and luxury, the acquisition of opulence cannot be otherwise a reproach to him; since extortion, or any dishonourable practice, is not imputed to him. Still less can there be any serious charge brought against him from his mode of enjoying his property. His own personal habits are admitted to have been temperate, and even abstemious; and if he delighted in the elegance of his gardens, or gratified himself by the number and extent of his villas, such indulgences were suitable to his condition and circumstances, though not to his pretensions to austerity; and were a rational and creditable mode of enjoyment. Umbrage, however, was given to Nero, by some particutar in Seneca's conduct; and the tyrant made Piso's conspiracy a pretext for the destruction of the philosopher. The particulars of Seneca's death are recorded with much minuteness by His death. Tacitus. That author mentions the frivolous circumstances by which Nero endeavoured to entrap him into an acknowledgment of his familiarity with the conspirators, as well as the dignified answer of Seneca; in which, after explaining his own refusal to see Piso on one occasion, as being unwell, and having no reason to prefer another man's welfare to his own, "Cæsar himself," he added, "knew that he was not a man of compliment, having received more proofs of his freedom than of his flattery." This answer of Seneca's was delivered to Nero in the presence of Poppæa and Tigellinus, his infamous favourites. Nero inquired whether it could be collected from Seneca's manner, that he had any intention of suicide. The tribune answered, that Seneca was so little discomposed by his visit, that he afterwards continued a story which he happened to be relating at the time. Nero sent him back, with peremptory orders for Seneca to put himself to death. The tribune, 
who himself had been engaged in Piso's conspiracy, had not resolution enough to be the bearer of such a message; and therefore despatched one of his officers with it. Seneca, upon receiving the command, expressed his desire to make some alterations in his will ; but the officer refusing to allow him access to his papers, he turned to his friends, and told them, that, since nothing else was left to him, he could at least bequeath to them the picture of his life; and intimated that some of the features of his own character were the best model for them on the present occasion. When some of them gave way to their feelings of grief, he rebuked them for their want of fortitude, or of foresight: "Where now," said he, "is our boasted philosophy; or of what avail is it, if it fails us when the most required? We cannot any of us have been unaware of the character of Nero: after the murder of his mother and his brother, it was scarcely to be expected that he would spare his preceptor." The death of Seneca was a lingering one, from the exhausted and the emaciated state of his frame. He opened the veins in his arms, in the presence of his wife, and other friends, and afterwards those in his legs. Finding this course ineffectual, he persuaded his wife to quit the room, and procured a draught of poison to be administered to him. As this, too, seemed to fail in its influence, he desired to be removed into a warm bath; and, as he entered, he sprinkled those who stood near him, saying, "I offer this libation to Jupiter the deliverer." His life-blood then gushed forth, and he speedily expired.

His works. Seneca's works consist of separate treatises, on 'Anger ;' 'Consolation;' 'Providence;' 'Tranquillity of Mind;' 'Constancy ;' 'Clemency;' 'The Shortness of Life ;' 'A Happy Life;' 'Retirement;' 'Benefits ;' of one hundred and twenty-four 'Epistles ;' and of seven books of questions in 'Natural Philosophy and History.' As a philosopher, Seneca is certainly not entitled to very high respect, either for the consistency or the temperateness of his opinions. His general principles are those of the Stoics; but his fondness for display and exaggeration, makes him caricature even some of their paradoxes. He thus maintains, in one place, that the wise man of the Stoics is not an ideal figment; but, that it has been realised in many individuals of the sect, and that it is such a model, as it is expected others should attain to. In another place he proposes Bion's insensibility as a model of Stoical wisdom, when after the loss of his wife and children in the course of a siege, he boasted that he was consummately happy, because he had escaped himself: for a wise man has no concern about any thing else; his own person is the whole of his property.

But Seneca does not scruple to adopt any notion, however inconsistent with the leading principles of Stoicism, if it gives him an opportunity of showing some of his turns and niceties of diction. $\mathrm{He}$ is, indeed, to be considered rather as a moral declaimer, than as a philosopher of any sect. As a moralist, his theory inclined to the asperities and singularities of Cynicism. His love of effect, and con- 
stant affectation of brilliant sentences, naturally carried him to such an extreme.

As a writer, Seneca may be commended for occasional felicities; and as he was always striving to add wit to reason, and to express something weighty and solid in a striking manner, it is not to be wondered, that he should sometimes have succeeded. But he is justly termed the grand corrupter of Roman eloquence; and his style, brilliant as it is, is the more dangerous on account of the author's abilities. ${ }^{1}$ It is a perpetual succession of efforts; and in the range of antitheses, of points, of figures, prettinesses and exaggerations, the reader finds himself without intermission, amused, surprised, dazzled, baffled, and fatigued. There is no repose in the composition, and thoughts and expressions which singly might make some impression, are lost in the crowd of others which are protruded with equal ostentation, and with the same glare. A sentiment which, in the pages of Tully, we should find reflected in one continued impression, as from a clear mirror, is dealt out to us in the sentences of Seneca, as from a glass fantastically cut into a thousand spangles.

Contemporaneous with Seneca flourished Dio of Prusa, surnamed Dion Pruseus Chrysostom. His character is handed down as that of a severe and unsparing censurer of the follies and vices of his time. His speeches which remain to us are rather remarkable for their abruptness and affected importance, than for any genuine vigour or eloquence.

Epictetus was the great ornament of the Stoic school during the reigns of Domitian and Hadrian. Born a slave, and maimed in person, he obtained his manumission by the excellence of his conduct; and not only instructed the age in which he lived, by his irreproachable example and illustrious doctrine, but has edified succeeding ages by those precepts which his pupil and admirer Arrian collected into a manual of moral wisdom, and illustrated with a commentary. No philosopher has surpassed Epictetus in urging the claims of virtue to independence. His maxims are terse and pregnant with sense, and his exhortations earnest and affectionate. Though there is much severity of discipline recommended, there is no sternness in the manner of the teacher. He speaks, perhaps, with some degree of injustice of the world at large; and too often describes virtue as necessarily in a state of persecution. But no production of any heathen writer is better adapted than the manual which is inscribed with the name of Epictetus, to summon virtue to a proper steadiness and reliance upon itself, or to arm a wavering mind with resolution amidst the occasional discouragements and untoward circumstances of life.

Next in succession to this illustrious slave among the ornaments of Marcus the Stoic school, appears the emperor Marcus Aurelius Antoninus. It Aurelius is unnecessary here even to glance at those victories on the Euphrates

Epictetus, obiit circiter A. C. 161 .

${ }^{1}$ Quintilian has very justly sketched the character of Seneca (x. 125). "Abundat dulcibus vitiis," is one of the terse and closely applicable strokes by which he portrays him. 
and on the Danube, by which the philosophic monarch protected the boundaries and ensured the subsequent tranquillity of the Roman empire. His reign forms part of the happy period in which the vast extent of that empire has been characterised, as having " been governed by absolute power under the guidance of virtue and wisdom." The predilection of Antoninus for the Stoical system displayed itself early in his life. At the age of twelve years he commenced that discipline of patience and self-restraint, which in after-life enabled him to be the master of himself, whilst he was the sovereign of the world. Throughout life his self-command was complete and exemplary. In his youth he was not a slave to the fervour of his passions, nor was he the plaything of ambition in his maturer age. In his palace he preserved the strictness and system of a general. In his camp he composed a great part of those philosophical meditations which will immortalize his name. Even his own favourite sect never carried him away captive from good sense, or led him to indulge in their extravagant pretensions and paradoxes. His character is a bright example of the best influence of the Stoical tenets, operating upon a mild temper and amiable disposition; and supplying that firmness and energy which are most required for, but are rarely found combined with such a nature. 


\section{SEXTUS EMPIRICUS.}

\section{THE SCEPTICAL PHILOSOPHY.}

BY

JAMES AMIRAUX JEREMIE, D.D.,

REgICS ProfESSOR OF DIVINITY, CAMBRIDGE. 



\section{SEXTUS EMPIRICUS.-THE SCEPTICAL PHILOSOPHY.}

FLOURISHED circiter A. C. 190.

The Sceptical Philosophy, as developed in the writings of Sextus Empiricus, forms one of the most curious portions in the history of the human mind, and it is on this account that we have separated his name from those of the other writers who flourished under the Antonini. To mark by what process and through what gradations an entire deviation from the general opinions and feelings of mankind was effected, is in itself a study neither destitute of interest, nor unproductive of utility. But in a trork intended to exhibit in one distinct and comprehensive view the rise and advancement, and multifarious relations of science, it is peculiarly necessary to describe the nature of that system which attempts to overthrow the fundamental principles of universal knowledge. To little purpose indeed have we laboured to sketch the magnificent structure which the genius of ages has raised and adorned, if it be but an unsubstantial fabric, which vanishes at the approach of scrutiny.

The causes, from which a tendency to perpetual doubt was first Causes of derived, have been variously sought, in the affectation of superior acuteness; in the confusion of ill-directed studies; in the habit of sophistical disputation; in the attractions of brilliant paradox; and, above all, in the extreme difficulty of separating truth from falsehood, strangely as they are intermixed and scattered in a mass of diversified opinions. But most commonly excessive scepticism springs, as by a kind of reaction from excessive dogmatism. "If a man will begin with certainties, he shall end in doubts," is an observation of the great reformer of learning, in his examination of the different disorders which have checked its growth and perverted its application. ${ }^{1}$ And Socrates has shown, ${ }^{2}$ with that simplicity and clearness with which he unfolded the most complicated operations of the mind, that, as an unnatural aversion to mankind arises in general from a detection of treachery in those persons in whom confidence had been reposed, so a settled distaste for all reasoning originates in a discovery of unsoundness in those arguments on which reliance had been placed. It is in- Probable deed impossible to consider that singular union of ignorance, presump- effects of tion, and obstinacy, which characterised the ancient dogmatists, without

1 Lord Bacon, Of the Advancement of Learning, book i. p. 31.

2 In Phædon. 
feeling that, antecedently to experience, it must have been most probable, that some more candid, as well as more intelligent, reasoner, impressed with a sense of our intellectual weakness, and disgusted with unmeaning propositions,- however magisterially delivered, and however disguised under a variety of pompous technicalities,-would at length draw the mortifying contrast between the boundless extent of science, and the circumscribed powers of our understanding. It might also have been expected, that his indignation would rise in propcrtion as he saw more fully the effects of a system which substituted conjecture for experiment and authority for proof ; or, as he observed more frequently the efforts of its defenders in maintaining the most palpable absurdities with as much pertinacity and violence, as if they were contending for the most evident and the most important demonstrations. It might also have been naturally supposed, that the vivacity of impatient genius might lead him, in his zeal against learned despotism, to sacrifice strong arguments indiscriminately with weak, and to sink from sober caution into a morbid state of complete distrust. But it could hardly have been foreseen, that a sect would arise, the avowed object of which would be to evince, by a long train of reasoning, that all reasoning is fallacious, and to establish as its principle, that all the principles of human knowledge are too dubious to command the slightest degree of assent. That one man should be so perplexed by cavils, and so confounded by difficulties and contradictions crossing him in all the paths of literary or scientific research, as to deny at once the evidence of his senses, is no extraordinary circumstance; but that a body of men should systematically profess to doubt, and labour to persuade others to doubt, whether truth be discovered or discoverable, rnust be regarded as one of the most striking phenomena which the annals of philosophy present.

Such, however, was that class of philosophers of whom we shall endeavour succinctly to trace the rise and progress, and to delineate the features and character, in connexion with our biographical notice of the celebrated disciple who has collected their arguments, and illustrated their method.

History of

From the earliest ages of philosophy we may remark a frequent expression of doubt, bordering on despondency, in the language of its most distinguished followers.' They seem nearly all, at some time, to have made the melancholy confession, that "whatever we look upon within the amplitude of heaven and earth is evidence of human ignorance." To imagine, however, that such reflections materially influenced their opinions and pursuits, is to deny the tenour of their general reasoning. We are far, therefore, from supposing, what Huet has laboured to prove, ${ }^{2}$ that a system of scepticism existed in the most ancient times : his conclusions are drawn from a few partial facts, hastily recorded by writers who were more anxious to enliven their meagre

1 See Diog. Laert. in Vit. Pyrrhon.

2 Traité Philosophique de la Foiblesse de l'Esprit Humain. 
narratives, than to ascertain and deliver the truth. It cannot be denied, however, that some philosophers proceeded to considerable lengths in throwing doubt on the most common maxims; and that both the minute controversies of the sophists, and the embarrassing objections of Socrates, operated in a powerful manner in unsettling the notions of subsequent inquirers. Without reverting to remote periods, or renewing the details which we have already given of the AcADEMIC sects, we shall content ourselves with some observations on those who are strictly called the members of the Sceptic or Pyrrhonic school.

Pyrrho was a native of Elis, and flourished about the CXth Olym- Pyrrho. piad. Even from the scanty details of his life which have been B.c.340. transmitted to us, we can perhaps trace, with a considerable degree of probability, the source of that entire scepticism on all points of moral evidence and of abstract reasoning, for which he was peculiarly distinguished. We learn, that after having abandoned the study of painting, to which he had applied himself in early youth, and having devoted his time to philosophical pursuits, he directed his attention principally to the works of Democritus, and received the instructions of Anaxarchus, whom he accompanied in the expedition of Alexander the Great into India, where he conversed with the magi and gymnosophists. ${ }^{1}$

Now we know that Democritus expressed in most positive terms his opinion of the uncertainty of human knowledge, and the impossibility of finding truth, which he was in the habit of describing as sunk in some deep well $;^{2}$ we know, too, that from the school of Democritus came Metrodorus the Chian, who placed in the very beginning of one of his works the maxim, That we are ignorant of all things, and even of the truth of this very assertion; ${ }^{3}$ and that among the disciples of Metrodorus was Anaxarchus, the tutor of Pyrrho. When to these circumstances we add the fact mentioned by Strabo, that the Brachmans, a branch of the sect of Indian gymnosophists, maintained that nothing was in its nature good or bad, but was only such in appearance, ${ }^{4}$ we possess some of the principal points which, if considered in conjunction with the effects of natural disposition, enable us in a great measure to account for that tendency to scepticism in Pyrrho, which was no doubt increased and elicited by the overbearing arrogance of

${ }^{1}$ Diog. Laert. in Vit. ; Aristocl. ap. Euseb. de Præpar. Evang. lib. xiv. c. 18 ; Lucian, in Bis Accusat.; Suid. in $\Pi v \dot{\rho} \dot{\rho} \omega \nu$.

2 Democritus (pronunciat) quasi in puteo quodam sic alto ut fundus sit nullus veritatem jacere demersam. Lactant. Instit. lib. iii. c. 27. Comp. Cic. Acarlem. Quæst.; Dicg. Laert. lib. ix. sec. 72.

${ }^{3}$ Cic. Academ. Quæst. lib. i. Chius Metrodorus initio libri qui est de Naturâ : Nego, inquit, scire nos, sciamusne aliquid, an nihil sciamus; ne id ipsum quidem nescire, aut scire, scire nos ; nec omnino, sitne aliquid, an nihil sit. See also Diog. Laert. in Vit. Anaxarch. lib. ix. sec. 58.

${ }^{4}$ Strab. lib. $\mathrm{xv}$. Sects of men who professed universal doubt, seem to have flourished in many other nations, e.g. the Hairetis among the Turks, the Medabberim among the Arabians, \&c. 
the dogmatic teachers. When, however, his biographers proceed to relate, that he adopted in practice those principles which he defended in theory, it is, we think, sufficiently manifest that they have mistaken for authentic anecdotes the satirical inventions of his enemies, whose design was, probably, to prove that, whatever might be the triumphs of Pyrrhonism in the shade of the schools, the slightest occurrence in real life dispelled the illusion, and left the refined caviller precisely in the same situation as vulgar mortals. ${ }^{1}$ What, indeed, can be more ridiculously absurd than the idle tales of Antigonus Carystius, ${ }^{2}$ that Pyrrho would not stir a step to avoid a chariot or a precipice, and was frequently indebted to the kind assistance of the friends who attended him, for the preservation of his life! ${ }^{3}$ The honours which were paid to him, may be deemed a proof that the tenour of his conduct was not at variance with the received customs of society,customs which he considered as causing, by their arbitrary decision, the only difference between right and wrong.

In conformity with existing prejudices, he suffered himself to be appointed one of the priests of a religion, "the truth of which his own opinions must have led him to question, if not to deny. This circumstance will, however, excite no surprise in those who have attended to the peculiar train of thinking, with respect to the political utility of polytheism, which pervades the writings of the ancient philosophers, and appears to have produced the same effect on the least scrupulous as on the most superstitious sects. Impressed with a conviction of the vanity of earthly pursuits, Pyrrho is said to have constantly repeated the well-known lines, in which Homer compares the race of men to leaves, "now green in youth, now with'ring to the ground," and from which he probably passed, by an easy transition, to reflections on the vicissitudes of fortune, the fluctuations of fashion, and the mutability of opinion. The remaining instances, intended to illustrate his manner of life, which may be found in the ill-connected, but entertaining collections of Diogenes Laertius, are trivial and contradictory: at one time he is represented as secluding himself even from his nearest relations, whilst at another he is described as joining his family in the management of their domestic affairs, and as performing the meanest duties with cheerfulness and indifference. From the general language of his biographers, however, we may conclude that both the

1 See Hume's Essays, vol. ii. pp. 183-186. Having observed, that " the great subverter of P'yrrhonism is action and employment, and the occupations of common life," he allows, that even the determinate Sceptic will "be the first to join in the laugh against himself, and to confess, that all his objections are mere amusement, and can have no other tendency than to show the whimsical condition of mankind, who must act, and reason, and believe; though they are not able, by their most diligent inquiry, to satisfy themselves concerning the foundation of these operations, or to remove the objections which may be raised against them."

2 Quoted by Diog. Laert. in Vit. Pyrrhon.

3 Comp. La Mothe le Vayer, De la Vertu des Payens, p. 243 ; Bayle, Dict. Hist. art. Pyrrhon.

4 Diog. Laert. in Vit.; Hesych. Miles. 
powers of reasoning which he displayed in his discourses, and the remarkable composure which he evinced in the midst of danger and suffering, attracted the notice and commanded the respect not merely of the multitude, but of his philosophical opponents.

Of his disciples, scarcely any facts of importance are related; the Disciples of most eminent among them was Timon the Phliasian, a philosopher $\begin{gathered}\text { Prrnho. } \\ \text { Timon. }\end{gathered}$ who joined to an indolent and unobtrusive disposition a keen and sarcastic veill of humour, which manifested itself in numerous poems, dramas, and dialogues against the Dogmatists. Fragments of his chief work, entitled 'Silli,' in which he attacked his adversaries with caustic ridicule, are found interspersed in many subsequent writers. From the saying of a Peripatetic philosopher, that "as the Scythians shot flying, so Timon gained disciples by shunning them," "we may infer that he was not without followers; yet no regular successor seems to have transmitted the principles of the Pyrrhonic school, which, perhaps, by being identified with the later Academics, was considered as extinct in the time of Cicero. ${ }^{2}$ It had been renewed, however, by Ptolemy the Cyrenæan; and was defended at Alexandria about the very period when the Roman philosopher thought it no longer in existence, by Fnesidemus, who wrote eight books of Pyrrhonian discourses.

From this last author, the tenets of the Sceptics were taught by a succession of masters, of whom little, but the name, is recorded, till the age of Sextus Empiricus, a writer of considerable learning and ingenuity, in whose works, replete with a curious variety of recondite knowledge, which would otherwise have been totally lost, the method, principles, and design of his sect are copiously detailed, and systematically explained. Of his life scarcely any account is to be found in succeeding writers, or to be extracted by inferential reasoning from his extant treatises. Conjectures have been resorted to as substitutes for facts, and have perplexed, rather than infurmed, the historical examiner.

Suidas identifies Sextus Empiricus with Sextus Chæronensis, ${ }^{3}$ a whether the nephew of Plutarch, and one of the tutors of Marcus. Antoninus. same as This account is rejected by Salmasius, ${ }^{4}$ Rualdus ${ }^{5}$ Jonsius, ${ }^{6}$ Casaubon, ${ }^{7}$ chæro-

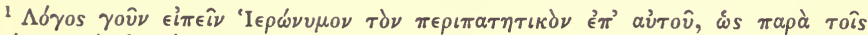

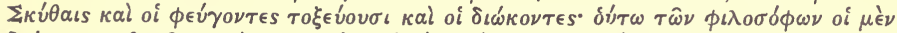

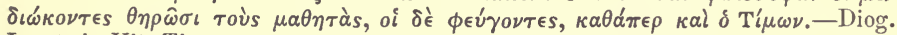
Laert, in Vit. Timon.

2 De Finib. lib. ii.

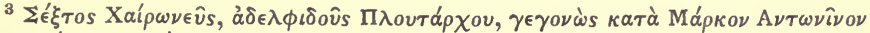

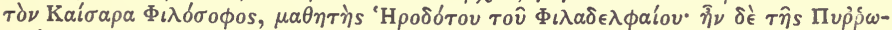

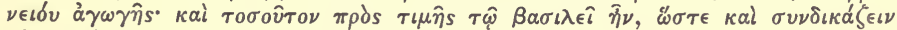

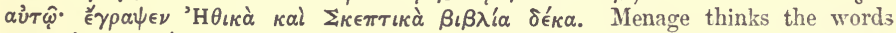

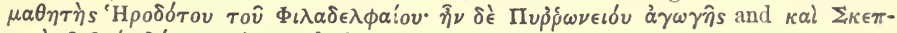

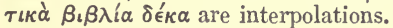

- In Not. ad Capitolin.

6 De Script. Hist. Phil. lib. iii. c. 12.

7 In Not. ad Capitolin., though he adopts a different opinion in Not. ad Diog. Laert. 
Kuster, ${ }^{1}$ Menage, ${ }^{2}$ and Fabricius $;{ }^{3}$ and defended by Hervetus, ${ }^{4} \mathrm{G}$. Vossius, ${ }^{5}$ and Huet in his sceptical treatise on "The Weakness of the Human Mind.' The chief argument in its favour is drawn from the circumstance, that the names of both philosophers, and also that of their preceptor, Herodotus, are the same : to which it is easy to reply, that several learned men, the two Zenos for instance, have borne the same name, and that this very coincidence, by perplexing the interpreters, may have led them to assert that one Herodotus was master to both. And, not to insist on the difference of their sirnames, the rules of conduct which the philosophic emperor acknowledges he had received from Sextus Chæronensis, ${ }^{6}$ rather tend to confirm the opinion of those commentators who infer from a passage, somewhat ambiguous, in Capitolinus, ${ }^{7}$ that he was a Stoic, and certainly seem less likely to have formed the main subject of a Sceptic's instructions. Sextus belonged to that sect in medicine called Empirics, who, judging Nature to be incomprehensible, followed experience in preference to reasoning. ${ }^{8}$ His country is unknown: his works refute the assertion of Suidas, that he was a native of Libya, ${ }^{9}$ and indeed rather enable us to discover where he did not, than where he did, live. His age may perhaps be referred to the reign of the Emperor Commodus. ${ }^{10}$

Works of Sextus.

The extant works of Sextus consist of three books of Pyrrhonic Institutes or Sketches, and ten, or, according to a different arrangement, eleven books against the mathematicians, by which word are meant all who profess any kind of knowledge. The former treatise is designed to be a summary of the principles, method, and end of Scepticism. In pursuance of our plan, therefore, we shall present such an outline of its contents as may assist the reader in forming some idea of the instruments employed by the ancient Pyrrhonists, when they attempted to destroy the basis of reasoning, and in discovering the stamina of those modern systems which, in a more expanded shape, have been maintained with the most refined subtilty and address.

Sextus begins his 'Institutes' by dividing the ancient philosophers

1 Ad Suid. tom. iii. p. 299.

${ }^{3}$ Biblioth. Græc. tom. v. p. 527.

5 In Libr. de Phil. p. 99.

7 Audivit et Sextum Chæronensem Plutarchi nepotem, Junium Rusticum, Claudium Maximum, et Cinnam Catulum, Stoicos.

8 Sextus, indeed, maintains that the Methodic sect in medicine was more favourable to Pyrrhonism than the Empirical (Pyrrh. Hyp. lib. i.), whence Marsilius Cognatus contends that he belonged to the former; in which opinion he is seconded by D. Le Clerc (Hist. Med. part ii. p. 378); but it is justly observed by Fabricius, that the Sceptics never professed to follow their maxims in common life, and therefore not in the practice of medicine (Bibl. Græc. ed. Harles. tom. v. p. 527).

9 In lib. iii. sec. 213, of his Pyrrh. Instit., he contrasts the customs of his country with those of the Libyans.

10 Fabr. Bibl. Græc. tom. v. p. 527. Menage places Sextus Empiricus about the time of 'Trajan and Adrian. (Obs. in Diog. Laert. p. 1.) Brucker refers his age to the third century, in the reign of the emperor Severus. (Hist. Crit. Philos. p. 636.) 
into three classes: the Dogmatists, such as were the Peripatetics, the Analysis of Epicureans, and the Stoics, who asserted that they had discovered his Pyrrhonic truth; the Academics, who denied the possibility of such a discovery; and the Sceptics, who neither asserted nor denied, but doubted. $\mathrm{He}$ then proceeds to explain the character and arguments of the latter sect. Scepticism is defined to be, the art of comparing in every way Definition of sensibles and intelligibles, - the reports of our senses and the concep- Scepticism. tions of our minds. The end of this comparison is to find as strong reasons for the rejection as for the admission of any point whatever. The great principle on which the whole system is allowed to rest, is, Fundathat to every proposition a contrary proposition possessing equal mental prinweight may be opposed. This maxim, however, was not laid down as incontrovertible. The Sceptic perceived the inconsistency of asserting that no assertion is true, and therefore consented to doubt even whether he doubted. He agreed, moreover, with the mass of mankind respecting appearances; but he hesitated to receive opinions founded on them, with regard to the real nature of things. His conduct was consequently regulated in compliance with the state of established usages and institutions. In theory, he withheld his assent from the most general maxims of physics and of morals, because he did not see any infallible criterion by which he could distinguish truth from falsehood; in practice, he followed the instinct of nature, the bent of passion, the laws of society, and the common rules of art and science. His speculations, however, though confessedly not productive of any alteration in the employments of life, were represented as leading to results of a most important nature. The entire suspension of judg- End of ment $(\dot{\varepsilon} \pi \circ \chi \grave{\eta})$ induced by the impossibility of discerning reality from illusion, in our internal thoughts and external impressions, was said to beget a state of perfect indifference and tranquillity, a total freedom from the fretful variety of cares and sorrows which agitate the human breast. The Sceptic pursues not with feverish anxiety what cannot be shown to be really good; he shuns not in perpetual alarm what cannot ke proved to be essentially evil. The process by which this

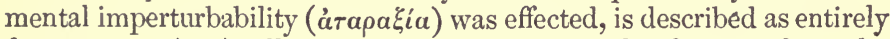
fortuitous. As Apelles, despairing to imitate the foam in his celebrated picture of a horse, flung against it his sponge, still stained with the different colours which he used, and thus, by a fortunate accident, produced that exact effect which the most exquisite skill was incapable of accomplishing: so the Seeptic, who had attempted the separation of truth from falsehood, with a view of releasing his mind from the troubles which oppressed it, unable to attain this object, suffered his judgment to remain suspended by the equal force of contrary reasons, and through this very suspension eventually obtained that tranquillity which he sought in vain from another source.

In order to maintain this desirable indecision, the Sceptic resorted to Sceptical a variety of methods, which were dexterously opposed to the several methods of arguments of the Dogmatists. He endeavoured to show, that the

Scepticism, and method by which it is obtained. 
evidence derived from our perceptions was, considered under every Difference point of view, fallacious. For, in the first place, since animals, arising among animals. from different species and in different manners, possess a different conformation of the organs of sense, they cannot be affected in the same way by the same external objects. But, as the parts of the material world seem to us of different colours, in consequence of the jaundice or a suffusion, and of different figures, according as we press the sides of the eye, or as we view them in convex or concave mirrors; so it is possible that animals, some of whom have the eye red, some white, some narrow, some oblique, some prominent, some depressed, receive impressions from objects dissimilar from those which they convey to man. And the same remark is equally applicable to the remaining senses. Even as digested food becomes veins, arteries, bones, or sinews, according to the difference of the recipient parts, or as water, when poured on plants, becomes bark, boughs, or fruits; so he concludes that objects are variously felt, according to the constitution and temperament of the animal creation. Indeed, it must be in consequence of the incongruity of their sensations, that the same substance is eagerly desired by some, and utterly loathed by others; and that what is wholesome to one class is deadly to another. If, therefore, the question be put to the Sceptic, whether hemlock be nourishment or poison, he will answer,- that it is the former to quails, the latter to men; but he will cautiously avoid pronouncing that it is either the one or the other, in the nature of things. For man, being an interested party, cannot be qualified to judge between his own sensations and those of animals, in order to decide to which the preference ought justly to be given. Nor can any demonstration be adduced; for though the demonstration be apparent to us, to determine on that account that it is true, is to assume the very point which it was meant to prove.

Diversity of The Sceptic, having thus far reasoned to show that man has no men. right to pretend that his own perceptions are more correspondent with the real nature of things than those of animals termed irrational, is willing to argue even on the supposition that men have the exclusive privilege of discerning truth, and to evince that a suspension of judgment is even then altogether necessary. So various are the corporeal frames and constitutions of mankind, that the same objects produce different effects upon different persons, and it is impossible to be certain that our particular apprehension is entitled to superior credit. We cannot, he will add, place confidence in all men, for we should thus admit the most palpable contradictions; we cannot discover, by a review of the universe, on what side the majority of mankind in any question ought to be ranked; and if we are required to follow a few, we must immediately ask, who are these few? the Platonists will refer us to Plato, the Epicureans to Epicurus; and, amidst this contrariety, the Sceptic will rest in his usual indecision.

After having thus argued on the concession, that men in general 
have the power of judging, he will consent to meet his adversaries Diversity of even by granting, that there may be some one individual on whom senses in the reliance might possibly be placed, and he will merely ask, to which of the senses of this individual must credit be attached? For different organs present things in different modes. Painting sets forth to the sight some objects as standing out, others as sinking backwards, but to the touch the picture presents no inequalities. Honey, which is luscious to the palate, is offensive to the eye ; and balm, which is delightful to the organs of smell, is repulsive to those of taste. It is, besides, impossible to ascertain, whether substances have all the qualities which they appear to possess; or only one quality, which seems different, owing to the diversity of our senses ; or many more qualities than our limited number of senses is capable of perceiving. And if our senses cannot comprehend external objects, neither can our intellectual faculties arrive at the knowledge of their real nature, and suspension is again requisite.

But still the Sceptic is content to pursue the discussion, and to Different grant to his adversary, for the sake of argument, that we can confide in one sense of one individual; yet, again, this one sense will be states of the same senses. variously disposed, according as its possessor is young or old, in health or in sickness, asleep or awake, sated or hungry, or, in short, agitated by one or more of the numerous passions, orving to which the senses give different reports, and the understanding forms different deductions. All, therefore, that can be asserted of anything is, that it appears to us in a certain manner, at a certain period of life, and under certain circumstances; but that we know not whether it be really such in its nature. For, continues the Sceptic, by introducing one of his favourite cavils, it cannot be proved that one of these states is preferable to another, unless we have some criterion which itself can only be made credible by a demonstration. But how can the demonstration be judged to be true but by a criterion? The demonstration, therefore, will require a criterion to confirm it, while the criterion requires a demonstration to prove it true.

Thus the Sceptic having, with an air of triumph, destroyed by his alternate method both the demonstration and the criterion, by which alone one sensation can he shown to be preferable to another, finds an additional reason for his boasted suspension. He proceeds, however; to confirm it by several other commonplaces. He urges the dissimi- Situation and larity of objects in consequence of distance, place, and position : the distance of same tower from afar seems round, from a nearer point square; the same oar under water seems broken, above water straight; the same light in the sunshine is dim, in darkness bright; the same image, which when laid flat, seems smooth, when inclined, seems uneven; the same feathers on the dove's neck assume various hues, according as they are variously turned. ${ }^{1}$ Now, since there is nothing which is

${ }^{1}$ Compare Senee. Nat. Quæst. lib. i. c. 5, and Tertullian, de Anim. c. 17. The arguments of the latter have been sketched by Bishop Kaye, with great perspicuity, 
not in some position and place, and at some distance, the absolute nature of things is undiscoverable, and their appearance only can be determined according to these three points.

Mixtures in the objects which present them. selves to the senses.

Quantity and constitution of subjects.

Relation.

Frequency or rareness of occurrence.

Variety of laws, institutions, fables, persuasions, \&c.

He derives another argument from the mixtures in the objects which present themselves to our senses. The images which proceed from surrounding objects reach us not in a pure and uncompounded state, but they are blended and modified by the medium through which they pass ; for the same thing will wear a different aspect, as the impressions take place through a medium which is warm or cold, dry or moist, curved or straight, broad or narrow, - -hence the varieties of sounds, smells, and colours. And that, too, without mentioning the coats and humours of the eye, through which the images of objects, with all their external admixtures, are conveyed. And as the senses err, so also will the intellect, which is guided by them, err. Indeed it is possible, that the intellect itself produces an alteration in what it receives from the senses, in consequence of the humours which exist in its material seat.

But, besides this, the Sceptic will urge the confusion which arises from the quantity and constitution of the subject. For instance, the shavings of goat's horn seem white, though the horn itself seems black; and filings of silver seem black, though silver itself seems white; grains of sand, which are rough and uneven, when viewed singly, are smooth and plane, when viewed jointly ; the same medicine, which, in a small quantity, refreshes and heals, in a larger, oppresses and destroys. All, therefore, that can be asserted of an object is, that it appears in a certain manner, when in a certain quantity, and in a certain state; but not that it is such in its nature.

He will contend, moreover, that all things are relative:-relative to the thing which judges, namely, the animal, the man, the sense, and the state of the sense; relative to things seen with it, to the composition, quantity, and position of objects; relative also as genus and species, as like and unlike, as equal and unequal. And of this relation alone can we be assured.

He likewise draws an argument from frequency and rareness of occurrençe: comets attract more attention than the sun, because seen less often; gold is more prized than water, because more rarely found : but let the novelty alter, and language will alter; the sun will be more admired than comets, and water more valued than gold; so that there is no fixed measure by which we can determine the intrinsic merit of anything.

But the Sceptic borrows his most powerful argument from the acknowledged variety of laws, customs, institutions, fabulous creeds, and dogmatic opinions. By constantly opposing all these with promp-

in his excellent analysis of the Treatise De Animâ (Eccles. Hist. of the Second and Third Centuries, illustrated from the writings of Tertullian, p. 200). The reasoning of the Sceptic drawn from the dereptibility of the senses is ridiculed by Epictetus. (Ap. Arrian, lib. ii. Diss. c. 20.) 
titude and address, and by showing them to be repugnant and destructive one to another, he learns to repeat with additional confidence the necessity of a complete indecision.

It were unnecessary to detail all the other methods, however in- other genious, which Sextus has enumerated. It is sufficient to observe, methods of that by their means the Pyrrhonist was furnished with a kind of panoply of cavils against every species of reasoning. If an hypothesis was made, he would counterpoise it by some contrary hypothesis ; if Reduction ad a proof was offered, he would ask how the proof itself was demon- infinitum. strated; and, if an additional proof was given, he would require this additional proof to be proved, and so on ad infinitum.

But why, it may be asked, such subtile definitions of terms, if all observations is equally uncertain? Why such careful attempts to avoid confusion, ${ }_{\text {Pyrrhonic }}^{\text {on the }}$ if all is equally confused? Why pretend to understand the systems Philosophy. of the Dogmatists, if nothing can be understood? Why determine contradicthat their proofs are weak, if man is not qualified to determine any-tions. thing? Why style those who mistake his object ignorant, unless the Sceptic himself possess some knowledge of which they are exempt? How can one hypothesis be opposed to another, unless that other be comprehended? How is it ascertained that contrary reasons of equal force can be raised against other reasons, unless equality of force can be inferred? And, if as many and as valid arguments may be urged in favour of any one proposition as against it, what shadow of use can all his own reasoning possess? Might not the Dogmatist turn round on the Sceptic, and accuse him of obstinate dogmatism-of believing everything - of asserting everything; and when the disciple of Pyrrho replied, "Nay, but I assert nothing, I believe nothing ;" might not the same Dogmatist exclaim, "I maintain that you are one of my sect, and to every argument you may bring to show the contrary, I will affirm that a contrary argument of as much weight may be opposed to it; things seem to me different from what they seem to you, and you have no right to suppose your own senses are superior to mine: nay, be not indignant, if you attempt to give me a proof that you are not a Dogmatist, on your own principles I will require a proof of that proof, and so on without end."

Indeed the great body of the Pyrrhonian philosophy seems to have Consideradepended on no better assertion than the following: some things are tions on its false, therefore, perhaps, all things are false; some men differ in opinion, therefore, perhaps, no man's opinion is correct. But the Pyrrhonist urged, that the effects of his system were an unvaried state of internal tranquillity. It requires but little knowledge of human nature to be convinced of the falsehood of this assertion. There will always be the reaction of a natural propensity to belief against the pressure of adopted doubt, and this struggle will necessarily destroy the mental equipoise. The truth of this fact is abundantly exemplified in the history of man: Sylla, Tiberius, Louis XI. of France, not

${ }^{1}$ See the objections more fully stated in Crousaz's Examen du Pyrrhonisme. 
to mention other instances, will prove that the disbeliever in religion is often a believer in divination and astrology. And even in the works of professed Sceptics, in Sextus Empiricus, ${ }^{1}$ in La Mothe le Vayer, in Huet, in Glanvile, we discern an extreme facility in admitting reports, which would have been rejected with pointed ridicule by men but little inclined to indulge in unreasonable doubts. But if perfect Scepticism were really attainable, still the conflict of our passious and our opinions would disturb and poison the sources of enjoyment; or, even granting that the appearances of pain would be then incapable of inflicting pain, the Sceptic must admit, by parity of reasoning, that the appearances of pleasure would be unable to excite pleasure; and if our hopes must be sacrificed with our fears, and our joys with our sorrows-if all our feelings, in short, must be deadened into a state of torpid lethargy, it can hardly be supposed that the happiness of life would be eventually promoted. Such are the obvious faults of excessive Pyrrhonism.

Objections against the Dogmatists.

Observations on the last two Books of Pyrrhonic Institutes.
It cannot be denied, however, that when the Sceptic expatiated on our total ignorance of the essence of matter, and when he laboured to prove that the sensible qualities of bodies are not inherent, but only secondary and relative to the perceptions of the mind, his arguments were no less ingenious than forcible and just. It must also be remarked, that though he often resorted to puerile devices in order to elude the sober arguments of common reasoners, yet he sometimes stated objections to the distempered theories of the Dogmatists, which seem worthy of the better Scepticism introduced in after times by Descartes, as a necessary preparative to philosophical investigation. He discarded with profound contempt the prevalent practice of suffering the mind to be preoccupied by hypothesis; of alleging reasons neither self-evident nor demonstrated; of ascribing to one single cause phenomena which might arise from several joint causes ; of attributing a series of regular effects to the operation of unconnected and unobserved causes; of drawing a false analogy between the visible and the invisible world; of offering explanations inconsistent with their own principles; and of seeking reasons for facts before they were well assured of the facts themselves.

It would be inconsistent with our plan to enter into a detailed account of the last two books of this singular work, it will be sufficient to state their general design. The second book treats chiefly of dialectics : it is employed in proving, in opposition to the opinions of the logicians, that there is no method by which truth can be discovered. Sextus returns continually to his favourite objection: there is no

1 The works of Sextus teem with tales which would hardly be equalled by the anecdotes of the most credulous: $e . g$. that Demophon was cold in the sunshine and warm in the shade; that the Tentyrites in Egypt are not hurt by crocodiles; that the elephant flies from the ram, the lion from the cock, and whales from the crackling of bruised beans, \&c. (book i. c. 13 and 14). Sir Thomas Brown might have enriched his Treatise on Vulgar Errors by having added Sextus to the writers whom he consultew. 
criterion, and all demonstration, by which the existence of such a criterion is to be shown, requires itself another demonstration, and so on for ever. We cannot trust our senses - they deceive us; we cannot confide in advisers - they differ. And here it may be remarked, that the cavils of Sextus are not, like the dexterous subtilties of Bayle, adroitly insinuated in some lively anecdote, curiously wrought into some brilliant train of reasoning, and unexpectedly introduced in various historical articles which in themselves possess intense interest; but they are methodically and heavily brought out; with tedious and insipid repetition. He argues, that there is no such thing as a demonstration, because it would consist of connected propositions, and this connexion can never be proved. The Stoic objected with great acuteness, You must allow that there may be a demonstration, if you can, as well as if you cannot, prove the contrary: if you cannot, you have no right to deny it; and if you can, your reasoning is a demonstration. All the Sceptic could answer was, that maxims which destroy others destroyed themselves also; that the medicine passed away with the disease which it removed. ${ }^{1}$ He felt that the maxim, "all is false," is self-contradictory; for if it be true, all is not false. Sextus proceeds to attack syllogisms-a mode of reasoning unquestionably liable to objection,- -and afterwards produces the following cavil against definitions: "Either you Definitions. know what you are defining, before you define it, or you do not; if you do not, you cannot define; if you do, you need not: but, you will answer, I define for the use of others ; but if you understood the point without a definition, why should not they?": As if a definition were not the result of a gradual succession of ideas, linked together and developed in a manner useful to ourselves by the simplification, and, for the same reason, still more useful to others. He objects, that a definition, in consequence of the limited nature of our knowledge, may perhaps never embrace all the qualities of the subject; but such reasoning would rather tend to show it to be incomplete, than dangerously false. He objects also, that wrong definitions have been often given; but does it follow that none are true? is it because some men have defined light to be the act of a luminous body, that no definition of light can ever be given?

After having next examined the various divisions of logic, he devotes Existence of his third book to the consideration of physics, and begins with its the Deity. most important branch, - the existence of the Deity-premising, however, that in practice he conformed to the established religion, and admitted the necessity of worshipping the gods. And it is fortunate for the happiness of mankind, that the arguments by which he endeavours to contradict the voice of universal nature are as feeble as they are trite: they are derived from the impossibility of comprehending his essence; of forming any defined idea of his substance; and from the diversity of opinions respecting his form and nature. And

${ }^{1}$ Sext. c. Mathem.; Aristocl. ap. Euseb.; Diog. Laert. lib. ix. sec. 76. 
if we know not his essence, says the Sceptic, we cannot know his attributes. As well might he argue, that because we are utterly ignorant of the essence of matter and of spirit, that we are therefore ignorant of their properties and their operations. It cannot but excite a smile to observe the ridiculous contradictions into which the habit of cavilling will lead even men of considerable penetration : it is impious, says Sextus, to believe in God, because it is impious to allow, as we must, in consequence of such a belief, allow, that he has either not the will, or not the power to remedy existing evils; but what is the meaning of impiety? is it not want of reverence towards the Deity, which is an assumption of his existence ? ${ }^{1}$ If there be no Deity, there can be no impiety; and if there be, it cannot be impiety to assert his existence.

Puerile sophisms.
Treatise: against the Mathematicians.
But these sophisms are plausible in comparison with many which occur in other parts of the work, and which were, surely, rather intended as playful means of tormenting the Dogmatists, than as serious objections. For instance, his arguments against a cause: a cause cannot be posterior to its effect, neither can it be anterior, for it would then be a cause before it produced an effect, that is, a cause without being a cause, since it is a cause only, inasmuch as it produces an effect:- or, his arguments against motion : if a thing be moved, it is either moved in the place in which it is, or in that in which it is not; but not in the place in which it is; for if it be in it, it continues in it; nor in the place in which it is not, for where a thing is not there it cannot act or be acted upon.

After having urged a variety of cavils not very dissimilar from the egregious trifling which we have just noted (and which we should have passed over with the contempt it merits, were it not calculated to give a view of ancient Pyrrhonism), on our notions of augmentation, diminution, subtraction, addition, generation, corruption, place, time, and number, Sextus examines the grounds of the ethical part of philosophy, and attempts to annihilate the essential difference between right and wrong, by showing that there is notbing in itself good, bad, or indifferent. His arguments are nearly the same as those which modern writers have urged as disproving the existence of a moral sense, and are replete with a rich variety of facts, illustrative of the customs of antiquity, and of the sentiments of pagan philosophers. He concludes, by confessing that he has employed reasoning sometimes strong, and sometimes comparatively weak, in order to adapt himself to the capacities of mankind in his attempt to check the temerity, and to humble the arrogance of the Dogmatists.

The treatise against the mathematicians, or professors of any kind of knowledge, is a work of greater extent, containing a copious collection of extracts, explanatory of the systems of the different schools in every branch of ancient literature and science. Objections are successively directed against the grammarians, rhetoricians, geometers, arithmeti1 See Crousaz, Examen du Pyrrhonisme. 
cians, astrologers, musicians, and writers on physical and on ethical subjects.

The Pyrrhonic Institutes have been partially explained by M. Sorbiere in his 'Lettres et Discours,' and by Le Clerc in his 'Bibliothèque Ancienne et Moderne (tom. xiv. p. i.), and have been translated into English by Stanley, in his 'History of Philosophy.' The whole body of ancient and modern Scepticism has been reviewed with considerable attention by M. Crousaz in his ' Examen du Pyrrhonisme ;' a work in which the fallacies of perverse ingenuity are refuted with that soundness of reasoning which results from long discipline in habits of rigid logic and accurate research. It is melancholy, however, to reflect, that a keen insinuation, conveyed in one smart sentence, produces an effect on the mind which a folio of elaborate discussion can with difficulty remove. The lively versatility of Bayle is strikingly contrasted by the cautious, and often prolix, and tedious method of his more exact, but less able, opponent. The paradoxes of Sextus are more easily detected and exposed; but still the absence of that spirited attack, which, neglecting all subordinate errors, seizes at once on the most prominent, and strips them of their attractions with unrelenting severity, render his dissertation, not perhaps less intrinsically valuable, but less interesting and less popular. The first treatise of Sextus was Editions, sc. translated by Henry Stephens, and the second by Gentian Hervet: these $\begin{gathered}\text { of Sextus } \\ \text { Empiricus. }\end{gathered}$ translations contain some inaccuracies, arising chiefly from an inadequate acquaintance with the peculiarities of the Stoic dialectics. ${ }^{1}$ The best edition of the entire works of Sextus is undoubtedly the following: Sexti Empirici 'Opera. Græcè et Latinè.' 'Pyrrhoniarum Institutionum,' lib. iii. cum Henrici Stephani versione et notis. 'Contra Mathematicos, sive disciplinarum Professores,' lib. vi. contra Philosophos, lib. v. cum versione Gentiani Herveti.' Græca ex MSS. codicibus castigavit, versiones emendavit supplevitque, et toti operi notas addidit Io.' Albert. Fabricius, Lipsiensis, \&c. Lipsiæ, 1718, fol. Further information may be found in Morhoff, 'Polyhist.' tom. ii. 1. i. c. 6 ; and in Fabricii 'Bibliotheca Græca,' tom. v. p. 527, ed. Harles.

1 Menage, who passes the highest praise on the works of Sextus, seems to have been inclined to comply with the request of a learned friend, who urged him to write observations on them: it is to be regretted that he was prevented from executing a task for which his varied erudition rendered him eminently qualified. See his Obs. in Diog. Laert. lib. ix. sec. 116. 



\section{PLOTINUS.}

THE ECLECTICS, OR LATER PLATONISTS.

BY

JAMES AMIRAUX JEREMIE, D.D.,

REGIUS PROFESSOR OF DIVINITY, CAMBRIDGE. 


\section{THE ECLECTICS, OR LATER PLATONISTS.}

FotaMo - - FLOURISHED TOWARDS THE CLOSE OF THE SECOND CENTURY.

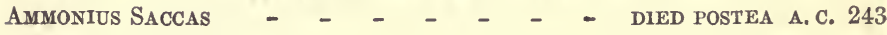

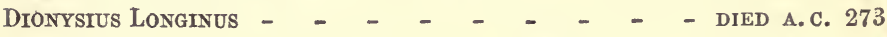
PORPHYRY - - _ _ _ _ _ BORN A. C. 233, DIED A. C. 304

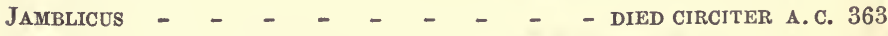
Hierocles - - - _ _ _ - FlOURISHEd CIRCITER A. C. 485 Proclus - - - _ - _ - - BORN A. C. 412, DIED A. C. 485 


\section{PLOTINUS.}

BORN A. C. 205 , DIED A. C. 270.

THE history of ancient philosophy may be divided into the age of invention and the age of illustration: the one gave birth to those earlier speculations, in which, amid all their incompleteness, the stamp of original genius is of too bold and brilliant a cast to be mistaken: the other was marked by general attempts to explain, to methodize, to expand, or to modify existing theories. In this latter period arose the singular system, or, more properly speaking, combination of systems, which forms the subject of the present rapid sketch.

Dogmatism, as we have already remarked, had produced, by a Rise of reaction natural to the human mind, its opposite, Pyrrhonism. ${ }^{1}$ But Eclecticism. the state of universal doubt into which many of the philosophers, who flourished in the first ages of the Christian era, had been thrown, was too unnatural to be long held even in theory, much less to be practised in the conduct of life. A desire, therefore, was soon felt to reject the most objectionable, and to select the most excellent, doctrines of the various schools, which divided the philosophic world in general, and Alexandria, the seat of motley disputants of all countries and characters, in particular. This amalgamation of dogmas was calculated to promote many objects. It associated the traditions of the East with the method of the Greeks; and, as a consequence of this union, ${ }^{2}$ the religious enthusiasm with which the Oriental spirit was deeply imbued, infused itself into every part of the new philosophy. Hence it disguised by allegorical ingenuity the deformities of polytheism, and borrowed many of the peculiarities of the Christian ethics, which were gradually imparting a more elevated tone to the morals of the time. Hence, too, it was distinguished by the vehemence with which, breaking beyond the limited range of reason into the mystical contemplation of abstract truths, it sought, in process of time, supernatural aid from the arts of theurgy. ${ }^{\text {a }}$ In this manner arose the school com-

I See above, SExtus Empiricus.

2 Cousin, Cours de l'Hist. de la Philosoph. tom. i. p. 317.

3 M. Degerando looks upon the school of the new Platonists as dividing itself into three branches: the school of Rome, that of Alexandria, that of Athens. In the first, the chiefs are Plotinus and Porphyry; in the second, Jamblicus and Hierocles; in the third, Plutarch and Syrianus : it is represented to us by Proclus, the only one well known to us. Ammonius Saccas is the common source. T'he School of Rome has this distinctive character, that it is essentially a philosophical eclecticism ; that it shows itself but little tinctured with Oriental traditions; that it does not yet invoke the services of the ancient mythology. The School of Alex- 
monly called Eclectic, ${ }^{1}$ and also, perhaps, with more propriety, by reason of its fundamental principles, $\mathrm{NeO}$-Platonic. Though experience soon showed the difficulty of forming a consistent whole frorn materials often discordant; and though it naturally followed, that the diversity of tastes and feelings which had occasioned an original difference of views and schemes, would operate to prevent an universal acquiescence in the propriety of subsequent rejection, or selection; still this strange system, conversant with themes which exalt the mind beyond "this dim spot which men call earth," attractive, too, by its pantheistic rature no less than by its spiritual ecstacies and theurgic pretensions, exerted extraordinary influence on the course of philosophic opinions.

Although the habit of uniting parts of different philosophical systems may be traced to much earlier times, and is particularly observable in the writings of Plutarch, Galen, and the learned of a later period, the first who instituted the Eclectic sect, at least the first who systematically introduced it into the Alexandrian school, is said to Potamo. have been Potamo, who appears to have flourished at the close of the second century. ${ }^{2}$ His works, one of which was a 'Commentary on the Timæus of Plato,' and another, a treatise entitled 'Elementary Science,' are lost; and the very meagre account of Diogenes Laertius is wholly insufficient to enable us to judge of his method of reasoning, ${ }^{8}$ which probably was not attended with distinguished success, hut it appears not from it that he made Platonism the basis of his new scheme.

Ammonius Saccas.

The first philosopher of importance who attempted a regular combination of the various elements of the different schools, especially the Platonic, was Ammonius, surnamed Saccas, who lived about the commencement of the third century. According to Porphyry, he passed from Christianity, in which he had been educated, to paganism: according to Eusebius he was converted from paganism to Christianity. The contradiction may perhaps be correctly solved by supposing that

andria, on the contrary, plunges deeply into mystic theology : it is a syncretism of philosophical and religious opinions. The School of Athens, he thinks, holds a middle course, adopting faith as a sort of medium between direct revelation and reason, and preferring to reascend to the sources of Greek wisdom: Orpheus is its hero.-Hist. Comp. des Syst. Pbil. tom. iii. p. 477, note m.

1 Almost the only sect with which the Alexandrian school could not coalesce, was the Epicurean, which was fundamentally different from the Platonic. It shrank from the contact of a scheme of morals which would degrade and deaden the feelings it was its aim to infuse, as well as from a system in which man is but

\section{— " the abandon'd orphan of blind chance \\ Dropp'd by wild atoms in disorder'd dance."}

2 Suidas places Potamo in the age of Augustus. But Diogenes Laertius, who wrote in the beginning of the third century, says that Potamo founded the Eclectic sect, $\pi \rho \partial$ ỏ $\lambda$ i $\gamma o v$, " a little before." Degerando thinks it probable that the Potamo mentioned by Porphyry is a different person.-Hist. Comp. des Syst. Phil. tom. iii. p. 151 .

${ }^{3}$ See, however, Diderot, Euvres, tom. ii. pt. i. p. 402. See also Glæchner, Dissert. de Potamon. Alexandrini Philosophiâ. Leips. 1745, in 4 to. 
the latter alludes to another Ammonius, who wrote a Harmony of the Gospels. From a fragment of Hierocles, preserved by Photius, it appears that Ammonius Saccas, disgusted with the scandal brought upon philosophy by the acrimonious disputes which existed among the Platonists, Aristotelians, and others, and which had even led them to corrupt the writings of their great masters, attempted, by the rejection of certain superfluous parts, to demonstrate that, in the main, the doctrines of Plato were in harmony with those of Aristotle. $\mathrm{He}$ had some eminent disciples, in which number are reckoned Herennius, Origen, Longinus, and Plotinus.

Of Herennius, nothing is known. Origen is, probably, not the same Herennius. . who acquired so distinguished a name in ecclesiastical history. Origen.

Dionysius Longinus, ${ }^{1}$ a native of Emesa, in Syria, is known to pos- Longinus. terity, not in consequence of his philosophical opinions, of which we have scarcely any extant memorials, but through his celebrated work 'On the Sublime;' which, occasionally fired with all the enthusiasm which the finished models of better days would naturally excite in a high and noble spirit, continues to charm and to instruct the great educated mass, while the barren speculations of his Platonic contemporary who refused to concede to him the title of philosopher, ${ }^{2}$ are confined to the closets of a few learned and meditative men.

His private history, too, is of a nature which interests our common feelings in a high degree. After having studied under the most distinguished masters, and visited the most noted seats of literature, and acquired so extensive a fame by the profundity of his erudition, as to be called the Living Library, he fell a victim to the fury of the Roman soldiery, at the downfal, and, perhaps, by the ingratitude, of Zenobia, Queen of Palmyra, whom he had assisted by his instructions and defended by his counsels. From the slight shreds still remaining of his philosophical works, it is gratifying to perceive that he rejected the sophistical hypotheses, which had transferred the properties of matter to the operations of spirit, and had resolved all mental phenomena into the effects of mere mechanical action.

But, undoubtedly, in philosophical history, the most celebrated fol- Plotinus. lower of Ammonius was Plotinus, from whom, as having completed the Eclectic system, that school afterwards took its name. He was born at Lycopolis, in Egypt, ${ }^{3}$ in the year 205. His family is not known, and the events of his early life are involved in obscurity.

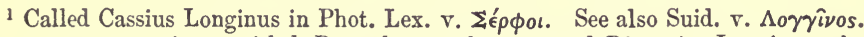
In a recent treatise, entitled Remarks on the supposed Dionysius Longinus, the author attempts to show that the work On the Sublime was written in the Augustan Age.

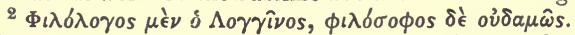

${ }^{3}$ Eunap. in Plotin. Plotinus himself would not tell the place of his birth or his family. On the same principle-contempt for his body-he refused to have his picture painted. "As if, forsooth, it were not enough," he said to Amelius, " to carry the image in which Nature has enclosed us; you think we should transmit to posterity, as a sight worthy of its attention, the image of an image!" And from the same cause, perhaps, he observed great abstemiousness, avoiding the flesh even of tame animals, and abstaining from baths,-Porphyr, in Plotin.

$[$ G. R. P. $]$ 
After having finished his grummatical studies at Alexandria, in his twenty-eighth year, he felt anxious to attend philosophical lectures, but the mixture of collateral knowledge on literary subjects, which entered into their composition, dissatisfied and saddened his mind, which yearned for pure metaphysical speculations. The method of Ammonius was far more congenial to his turn for mysticism; and the instant he heard that philosopher, he declared that he was the man whom he sought, and he continued to receive his instructions eleven years. The praises which this preceptor had lavished on the transcendental wisdom of the Magi and Brahmins, filled him with an ardent desire of visiting the East; and he availed himself of the opportunity of gratifying it which was presented by the expedition of Gordian against A. D. 243. the Persians. But, in consequence of the disastrous death of that emperor, he was forced to save himself by flight to Antioch, whence he proceeded to Rome. Here he observed for some time the secrecy which Ammonius had enjoined respecting the esoteric portion of his lessons; but, on learning that it had been violated by his fellow-pupils, Herennius and Origen, he considered himself released from all scruples on the subject. His lectures, during ten years, were only orally delivered ; but afterwards he committed parts of his precepts to writing, and communicated them to persons whose judgment he respected. At length the accession of Porphyry to the number of his disciples, induced him to write some works, in order to explain with greater accuracy the difficulties which occasionally arose. During the six years that Porphory studied under him, he wrote four-and-twenty books; before that disciple's arrival, he composed twenty-one; and after his departure, nine. The different ages at which they were written have been, perhaps fancifully, marked by the different style of these several parts-before it reached, when it fully possessed, and after it had passed its mature strength. His mind was trained to the difficult task of going through the plan or composition of a whole work with so much accuracy, that his sentences, when delivered, required no alteration, and casual interruptions were not known to disturb the thread of his meditations. To the badness of his handwriting, the incorrectness of his orthography, and more especially the neglect of revision on his part, may, perbaps, be ascribed in some degree the confusion which is still complained of in his works, notwithstanding the corrections of Porphyry.

Though the lectures of Plotinus were of too abstruse a nature to become very popular, they were attended by Romans of senatorian rank, and proved sufficiently powerful to induce some to resign their magisterial duties in order to indulge in a philosophic life. So deep was the respect which was entertained for his integrity, that numerous lawsuits were referred to his arbitration, and many persons on their deathbeds intrusted him with the guardianship of their children. The emperor Gallienus and the empress Salonina paid him marked regard ; and it is attributed to the opposition of malevolent courtiers, that he was unsuccessful in his plan to have a city in Campania rebuilt, to be 
peopled by philosophers, and goverued by the laws of Plato's ideal His intended commonwealth. Various illnesses and infirmities, occasioned, perhaps, Platonopolis, by his neglect of his health, filled with pain his latter days. When phical he felt his end drawing nigh, he said, in the language of his philosophy, "I strive to return the divine principle within me to the Divine Being who animates the universe." He died in the year 270, in his sixtysixth year. ${ }^{1}$

Longinus acknowledged that he could not understand many of the subjects treated of by Plotinus, but that he loved beyond measure and venerated his manner of writing, the variety of his knowledge, and the philosophical arrangement of his questions. ${ }^{2}$ His mind, naturally ardent and enthusiastic, appears to have been deeply tinged with fanaticism; and his ecstatic contemplations, or pretended visions of the Supreme Being, bear a resemblance to the wild extravagances of modern mystics. To express the most profound contempt for the corporeal prison in which the soul, an emanation from the Divine nature, is confined, and to aspire by a high degree of mental elevation and illumination to an union with the God who fills the universe, seems net to have been entirely peculiar to the later Platonists. "In all ages," as Locke remarks, "men, in whom melancholy has mixed with devotion, or whose conceit of themselves has raised them into an opinion of a greater familiarity with God, and a nearer admittance to His favour than is afforded to others, have often flattered themselves with a persuasion of an immediate intercourse with the Deity, and frequent communications from the Divine Spirit." ${ }^{\prime 3}$

The Plotinian school was propagated by many eminent men. Succession of Amelius (whose true name was Gentilianus), a Tuscan, in the year the Plotinian 246 , embraced the principles, and drew up in writing some of the in- Amelius. structions of Plotinus. One of the books which he wrote was to show A. D. 246. the difference between the doctrine of Numenius and that of Plotinus, in answer to the accusation brought against the latter of having borrowed from the former. But the most distinguished of its members Porphyry. was Porphyry (or in Syrian, Malchus), a Tyrian, born in the year

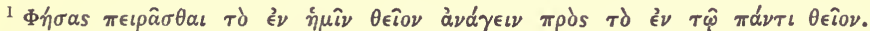
(Porphyr. Vit. Plotin.) The Life of Plotinus, by Porphyry, gives an account of his familiar spirit, and represents him as possessed of miraculous powers. See Bayle, Dict. Hist.

${ }^{2}$ Ap. Porphyr. Vit. Plotin. The only Latin translation of Plotinus is that of Marsil. Ficinus. The first Greek and Latin edition is that of P. Perna, 1580. A complete critical edition of his works, which is much wanted, has been undertaken by the learned Fred. Creuzer, professor at Heidelburg, who has already published an edition of the book De Pulchro, with a revised translation, notes, and a commentary.

${ }^{3}$ Essay on the Human Understanding, book iv. c. 19.

4 St. Jerome calls him Bataneotes. "Ce mot a fort tourmenté les interprètes. S'agit-il de Béten ou Basan en Palestine, comme le suppose Baronius ? Faut-il

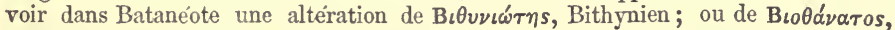

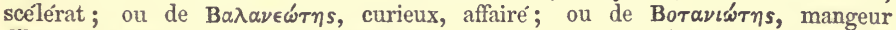
d'herbes, selon le régime de Pythagore, ou bien l'équivalent de nouveau Battus, et 
233, in the reign of Alexander Severus. His early education was first directed by a Christian preceptor, Origen, and afterwards in Athens by Longinus, to which latter philosopher we may, perhaps, in a great measure, ascribe the elegance of his style, the extent of his learning, ${ }^{1}$ and his adoption of the opinions of Plotinus, of whom we find him a disciple in Rome, about his thirtieth year. His attainments recommended him to the especial favour of his master, whose tenets he defended and explained, and whose writings he revised and corrected. The morbid turn of mind, in which he indulged, may be inferred from the circumstance which he relates, that Plotinus deterred him from a resolution which he had taken, in his thirty-sixth year, of releasing himself from the burthen of life. After the death of Plotinus, Porphyry, who had passed from Rome to Sicily, appeared as one of the most determined and formidable enemies of Christianity, against which he wrote fifteen different treatises, of which, as they were destroyed by the Emperor Theodosius, we have extant only such fragments as remain in ecclesiastical. writers. He was attacked with great zeal, particularly by Methodius, Apollinaris, and Eusebius. On his return to Rome, Porphyry publicly taught the tenets of his master, and pretended to have received Divine communications, with a confidence which is only to be ascribed to enthusiastical illusion, not unaccompanied, perhaps, with imposture. He died about the year 304, towards the end of Dioclesian's reign. ${ }^{2}$

d'expression de la battologie, de la prolixité reprochée quelque-fois à Porphyre? Ni cette dernière hypothèse, proposée par Gundling, ni les précédentes imaginées par Sirmond, Holstenius, Tannegui Lefebrre, Heumann, \&c., ne nous semblent assez plausibles; et nous trouverions une explication plus immédiate du terme employe par Saint Jérôme, dans ce qui dit Etienne de Bysance, d'un bourg de Syrie, appelé Batanea, et peuplé d'une colonée Tyrienne ; il se pourıit que, ne en ce lieu, Porphyre eat pris, pour se rehausser, ce nom de Tyrien, et que Saint Jérôme l'eut replacé dans son bourg natal.-Biog. Univ. Art. Porphyre.

${ }^{1}$ His learning was acknowledged. "Doctissimus philosophorum Porphyrius, quamvis Christianorum acerrimus inimicus."-S. August. de Civ. Dei, xix. 22 ; Comp. Euseb. Præp. Evang. V. 14, \&c.

2 The life of Porphyry was written by Eunapius, and, in modern times, by Lucas Holstenius, in his edition of Porphyry's Life of Pythagoras. Of the works of Porphyry, many of which are lost, his treatise De Abstinentiâ ab Esu Animalium; De Vitâ Pythagoræ; Sententiæ ad Intelligibilia ducentes; De Antro Nympharum, with a fragment, De Styge, found in Stobæus, were printed at Cambridge in 1655, $8 \mathrm{vo}$, with a Latin version. The Life of Pythagoras, of which the beginning and end are wanting, was published under the name of Malchus, by Conrad Rittershusius, in 1610 , by $\mathrm{J}$. Donatus in 1629 , and by Lucas Holstenius in 1630 . It was afterwards published by Kuster, at Amsterdam, in 1707, and also by M. Theoph. Keissling, together with that written by Jamblicus. The treatise On Abstinence from the Flesh of Animals, is one of the best works of Porphyry: he endeavours to prove that animal food is to be avoided, at least by those who aspire to a perfect life, as soliciting too strongly the senses; he treats of the origin and object of sacrifices, to answer the objection drawn from the immolation of animals; he maintains that animals are gifted with reason, and entitled to the same justice which is exercised by men one to another; and, lastly, he collects authorities, drawn from the examples of persons and nations famed for wisdom, in favour of his reasoning, and concludes by an exhortation to purity. (See the Abbé Ricard, Eurres Morales de 
The most distinguished disciple of Porphyry was Jamblicus, of Jamblicus. Chalcis, in Cœlo-Syria. He taught the Plotinian theories, if with less eloquence and learning, with even greater celebrity and success. Not content with the aim of his enthusiastic predecessor to elevate the mind to an ecstatic intuition of the Divinity, he laid claim to theurgic powers, pretending by certain forms and ceremonies to call down and command the assistance of supernatural beings. The fame of his miracles was so great, that he acquired the name of wonderful and divine teacher. His character seems to us more liable to the charge of studied imposture than of overheated fanaticism. But we are aware how unsafe it is to judge by the cold rules of ordinary life the conduct of such men as are born with intensely ardent imaginations, and with a sensibility more tremblingly alive to the varied impulses of nature, and, it may be, not untinged with hypochondriacal gloom.

His writings, though they evince much reading and throw light on the Alexandrian school, are destitute of clearness, method, and originality. ${ }^{2}$

Plutarque, tom. xiii.; Schoell, Hist. de la Littérature Grecque, tom. v.) The best edition is that of J. de Rhœur (Utrecht, 1767, in 4to). It has been joined in one volume to the edition of the work, On the Cave of the Nymphs, which had been published in 1765 by R. M. Van Goens. The Researches, or Questions respecting Homer ('О lished by J. Lascaris, at Rome, in 1518; by And. d'Asola, in 1521; by J. Bedout, in 1539; and are to be found in the editions of Homer by J. Camerarius and Micyllus (Bâsle, 1541, 1543, and 1551), and J. Barnes (Cambridge, 1714). His work, On Prosody, was published by Villoison (Anecdota Græca, vol. ii. p. 103).

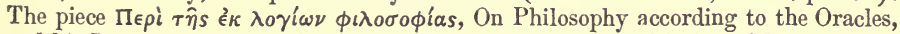
and his Letter to Marcella, his wife, were first published by M. Ang. Maius (Milan, 1816, in 8vo), and have been reprinted, with critical remarks, in the Gnomic Collection of J. C. Orelli, vol. i. See also some remarks on the Letter to Marcella, by Raoul-Rochette, in the Journal des Savans, Avril, 1817. For an account of his other extant works, and his treatise on the Categories of Aristotle, \&c., see Fabricius, Hist. Græc.; Schoell, De la Litt. Grecq. tom. v.; and his Life by M. Daunou, in the Biog. Univ. tom. $x x x v$.

${ }^{1}$ His first teacher had been Anatolius, who presided in a Peripatetic school at Alexandria. There is a fragment of Anatolius still extant, entitled, Of Sympathies and Antipathies, which was published with the version and notes of $\mathrm{J}$. Rendtorf, by Fabricius, in the old edition of his Biblioth. Græc. tom. iv. p. 295.

2 There is no entire collection of the works of Jamblicus. His Life of Pythagoras was edited by Theoph. Kiessling (Leips. 1813, 2 vols. 8vo). The piece $\Pi \in \rho l$

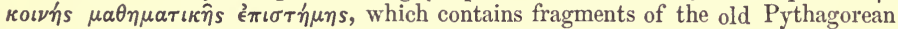
philosophers, was first published by Villoison, in his Anecdota Græca, vol. ii. p. 188, and reprinted by J. G. Firis. (Copenhagen, 1790, in 4to.) His commentary, On Nicomachus's Institutes of Arithmetic, was published by Sam. Tennulius, in 1667

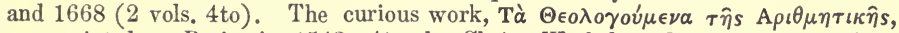
was printed at Paris, in 1543, 4to, by Christ. Wechel, and at Leipzig in 1817, 8 vo, with notes, by Fr. Ast. The treatise on the Mysteries of the Egyptians, which is, under the name of Abammon Magister, ascribed to Jamblicus, was edited by Th. Gale, Oxford, 1678, fol. Christ. Meiners thinks it is not a work of Jamblicus. It was composed in order to solve the difficulties proposed by Porphyry in his Letter to the Egyptian Anebo. (" Judicium de libro qui de Mysteriis Egypt. inscribitur," in Comm. Soc. Scient. Gotting. tom. iv.) His arguments are answered by Tennemann. Stobæus has preserved a fragment of the work of Jamblicus On the Soul, and also several parts of his Letters. 
Though the time and place of the death of Jamblicus are not known, it probably preceded that of Constantine, and may have taken place about the year 363 .

Under Constantine and Constantius.

Under

Julian.

Eusebius of Myndus, Adesius, \&c.

The Neo-Platonic a considerable diminution of influence from the ascendency which Christianity had gained over the declining cause of paganism during the reign of Constantine and Constantius. But on the accession of Julian, himself an enthusiastic philosopher and patron of philosophers, and the consequent restoration of the ancient superstitions which it had attempted by various allegoircal refinements to preserve, it resumed its importance, and exercised with renewed lustre the magical powers to which it presumptuously laid claim. Though Eusebius of Myndus strove to restore only the Platonic intuitive contemplation of intelligibles, Addesius of Cappadocia, and others, made numerous and successful experiments on the credulity of their followers. Maximus, Priscus, and Chrysanthius swell the list of philosophers, to whom the zealous Emperor extended his favour or his reverence.

Eunapius of Sardis, in the reign of Theodosius, recorded in his
Eunapius. 'Lives," still extant, the extravagances of a school, to which he was blindly devoted; and, towards the close of the fifth century, Hierocles, ${ }^{2}$ the advocate of Eclecticism, maintained in his treatise ' On Providence,' that the sentiments of Plato and Aristotle were reconcilable, and followed the same method in his 'Commentaries on the Golden Verses of Pythagoras." 3

School at

Athens.

Although Alexandria, where Pythagorico-Platonic notions found warm admirers, was the cradle of the Eclectic school, it was also established at Athens, in which ancient seat of learning the chair of philosophy was supported, at first, by imperial, and afterwards by Plutarch, son private, liberality. There Plutarch, the scn of Nestorius, and after, of Nestorius. him Syrianus, the author of a ' Ccmmentary on Aristotle's Metaphysics,' Syrianus. and ' On the Rhetoric of Hermogenes, ${ }^{, 4}$ still remaining, propagated the Alexandrian system.

1 See the edition of his works by M. Boissonade, 1807.

2 This is not the Hierocles of Bithynia, who wrote a work against Christianity, which was refuted by Eusebius.

3 The first edition of the complete works of Hierocles was published in Greek and Latin, by John Pearson, London, 1654 and 1655, in 2 parts, small 8vo. The first contains the Golden Verses, the Commentary, and the work called Facetiæ (A $\sigma \tau \in \hat{i} \alpha)$; the second, the abridgment of the work On Providence, with the extract of Photius, and the fragments preserved by Stobæus, together with the version of Curterius; and the notes of Sylburg, Lilius Gyraldus, and Merio Casaubon. The second edition is that of P. Needham, Cambridge, 1709, in 8vo. Rich. Warren published, at London, in 1742, a critical edition of the Commentary only. For further information, see Schoell, Hist. de la Litt. Grecq. tom. vii. p. 99 .

4 The Greek text of the Commentary on Aristotle has not yet been published. Jerome Bagotini has published the Latin translation of the part which relates to books iii. xiii. and xiv., Venice, 1558, 4to. The Commentary on Hermogenes may be found in the Aldine edition of the Greek rhetoricians. 
Proclus, a favourite disciple of the latter philosopher, holds a con- Procius. spicuous place in the new school. He was born in the year 412 at Constantinople, though, as his parents had inhabited Xanthus in Lycia, where he received the first elements of his knowledge, he is often called a Lycian. After having studied at Alexandria, and having learned from Olympiodorus ${ }^{1}$ to blend together the Aristotelian and Platonic doctrines, he visited Athens, where, by the successive instructions of Plutarch, the son of Nestorius, and of Syrianus ${ }^{2}$ he was introduced into the mysteries of their philosophy. So rapid was the progress which he made in these obscure pursuits, that at the age of twenty-eight he had composed, besides other pieces, his best work, a 'Commentary ${ }^{3}$ on the Timæus of Plato." The skill which he acquired in the theurgic art, as well as in the mysterious science of his school, pointed him out as worthy of filling the office of public professor. His lectures, full of dark mysticism, harmonized well with the taste of the age, and won him many followers. His very credulous, or very inventive, biographer and successor Marinus, ${ }^{5}$ relates that he prepared himself by abstinence from animal food, by long fastings and repeated prayers, for immediate intercourse with the Divine Being, and that he possessed the power of expelling diseases, and of commanding the elements. Proclus died of the gout in the year 485 .

His works, ${ }^{6}$ a strange mass of varied fanaticism, discover marks of a rich, but unchecked, fancy, and extensive, but misapplied, learning.

Marinus chose as his successor Isidorus, who soon after removed to Narinus. Alexandria, and left the Platonic chair at Athens to Zenodotus. The Isidorus. succession of the school at Athens ended with Damascius of Syria, Damascius. who suffered from the persecution of the Emperor Justinian. His 'Lives of Isidorus and others,' and some fragments of his philosophy, still remain.

${ }^{1}$ This is not the Olympiodorus who wrote commentaries on four dialogues of Plato, - the First Alcibiades, the Phædo, the Gorgias, and the Philebus.

2 The following modest epitaph is a testimony of the affection which Proclus felt for his master Syrianus :-

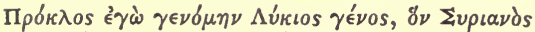

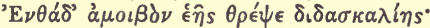

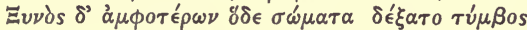

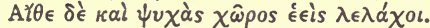 \\ Mar. Vit. Procl. 36, p. 29, ed. Boisson.}

${ }^{3}$ As this Commentary does not extend to the whole of the Timæus, it may be, perhaps, incomplete. It contains the work of Timæus the Locrian.

4 See an account of the life of Proclus, and an interesting notice of a manuscript containing some of his unpublished works by M. de Burigny, in Hist. de l'Académ. des Inscrip. tom. i. p. 139-153.

5 The work of Marinus was published by Fabricius (Hamburgh, 1700, 4to), and afterwards subjoined to the Biblioth. Latin. 1703, 8vo. The best edition is that of Boissonade. (Leips. 1814, in 8vo.)

${ }^{6}$ For an account of the editions of the various works of Proclus, see Schoell, Lit. Grecq. tom. vii. M. V. Cousin has published some of his works, hitherto unedited. Some of the works of Proclus have been translated into English by Mr. Thomas Taylor, an enthusiastic Platonist. 
Hypatia. One of the Alexandrian philosophers was Hypatia, the celebrated daughter of the able mathematician Theon. Her acquirements, both in literature and in science, were so remarkable as to qualify her in an eminent degree to become a public preceptress in the Plotinian School. In this capacity she undertook to reconcile Plato and Aristotle with an eloquence which flowed from a highly-cultivated genius, and which was regulated by a sober judgment. While the gracefulness of her address and lustre of her personal attractions were unobscured by vanity, the purity of her character continued untainted by suspicion. Among the crowd who enjoyed her acquaintance, and admired her talents and virtues, was Orestes, the Præfect of Alexandria, who had opposed the measures and incurred the enmity of Cyril, who filled the A. D. 415. patriarchal chair in that city. Orestes, insulted by a body of seditious monks, had put one of their leaders to death, and Cyril had buried him in the church, and caused his name to be registered among the martyrs. The partisans of the bishop extended their resentment to the unfortunate Hypatia. As she was one day returning home from the schools, an infuriated mob seized her, drew her from her chair, and dragged her to the church called Cæsarea, where, after having stripped off her garments, they killed her, and, with monstrous barbarity, consigned her mangled limbs to the flames. Cyril, violent and haughty, was reproached, perhaps not without foundation, as having connived in this atrocious murder. ${ }^{1}$

Many learned men, though not professed philosophers, embraced the new Platonic doctrines. Among the most noted was Macrobius. Macrobius, ${ }^{2}$ who lived in the reign of Honorius and Theodosius II., and wrote, among other books, 'A Commentary on Scipio's Dream, as described by Cicero,' and 'Saturnalia,' or conversations between the most eminent men of Rome; a curious work, full of critical and antiquarian lore, but written without much spirit or accuracy.

Themistius. Themistius may also be added, an orator, whose honest eloquence, which shines with a stronger glare on the darkened theatre of degenerate literature, procured for him the successive favours of Constantius, Julian, Valens, Gratian, and Theodosius. ${ }^{3}$

Ammianus

Marcellinus.

The historian, Ammianus Marcellinus, ${ }^{4}$ also speaks with much

1 Her life was written by the Abbe Goujet, in tom. v. of the Mémoires de Littérature, by Desmolets. See also Enfield's Hist. of Phil. vol. ii.

2 The best edition of Macrobius is that of Leyden (1676, in 8vo), with the Variorum notes. There is also a good edition published in London (1694, in 8vo).

3 The best edition of Themistius is that of Harduin, fol. Paris, 1684. See particularly the extracts from his Harangues or Panegyrics in Thomas, Essai sur les Eloges, c. xxi.

4 The style of Ammianus is harsh, inflated, and obscure. But it should be remembered that it is the style, not only of a soldier, but of a Greek, who wrote in Latin, at a period when most historical works were destitute of elegance. He thus concludes his history:-Hæc ut miles quondam et Græcus, à principatu Cæsaris Nervæ exorsus adusque Valentis interitum, pro virium explicavi mensurâ, opus veritatem professum nunquam (ut arbitror) sciens silentio ausus corrumpere vel mendacio. Scribant reliqua potiores ætate, doctrinis florentes. Quos id (si libuerit) 
respect of the Platonic philosophers. A few passages, in which Ammianus mentions Christianity in favourable terms, ${ }^{1}$ have been adduced to prove that he was himself a Christian. But it is surely one thing to approve of the morality, another to have embraced the doctrines, of a religion; it is one thing to contrast the intemperate conduct of certain Christians with the benevolent spirit of their professed principles, and another to have himself adopted those principles. A Jew not unfrequently appeals to Christian charity, yet it by no means follows that he is converted. The manner in which he ascribes sudden relief, in a moment of distress, to sacrifices offered in the temple of Castor, ${ }^{2}$ is, perhaps, of itself sufficient to show that the author was a pagan.

Some, who devoted their time chiefly to the illustration of the Aristotelian philosophy, may be, with more propriety, considered in the class of Peripatetic philosophers, such, for instance, were Olympiodorus, the preceptor of Proclus, and Simplicius.

Although the exalted conceptions of Plato had filled the minds of his Character of later followers with high and fervent aspirations, they appeared to have the Plotinian despaired of attaining to the magic of his inimitable style. The language of Plotinus, teeming with ideas, is yet confused, immethodical, and unadorned. It is a task, therefore, of considerable difficulty to develop arguments which are rather sketched than completed, and to present in a clear light the whole of a system, of which the parts are not only, separately considered, obscure, but, in their general relations, ill-connected. The labours of Porphyry, however, insufficient as we cannot but deem them, have doubtless prevented the confusion from being still greater than it is at present.

At the request of Plotinus, whose theories his habits of intimacy The enabled him to ascertain, he distributed his works into 'Enneades,' to Enneades of which he added some comments of his own. This work, one of the most curious of ancient monuments, is highly useful as an exposition, for such it is, rather than an elementary view, of the transcendental philosophy of his age. We shall endeavour to point out, though in a very concise manner, its most leading features.

Each of the six 'Enneades' is composed of nine books. 'The first,

aggressuros, procudere linguas ad majores moneo stylos. Of the thirty-one books, into which the History of Ammianus was divided, only the last eighteen, beginning after the death of Magnentius, in 353, are extant; though full of digressions, they are highly valuable for the information they contain, and the candour they evince. There is a good edition of Ammianus, with the notes of F. Lindenbrogius, Hen. and Hadr. Valesius, Jas. Gronovius, Th. Reinesius, and J. Augustin. Wagner, by C. Gottlob. Aug. Erfurdt, in 3 vols. 8vo, Leips. The Dictionnaire Bibliographique remarks: Il y a une traduction Française d'Ammien Marcellin dont j'ignore le nom de l'auteur, elle est en 3 vols. in-12, d'abord imprimée à Berlin, puis à Lyon en 1778 (tom. iv. p. 18). The author of the translation in question was M. de Moulines, who undertook it at the request of Frederick II.

1 Especially because he says of George, the bishop, "Professionis suæ oblitus, quæ nihil nisi justum suadet et lene, ad delatorum ausa feralia desciscebat" (lib. xxii.)

2 Lib. xix. c. 10. 
touching essentially on moral subjects, treats, among other points, of Man, of the Virtues, of Happiness, of Beanty, of the Chief Good, of the Origin of Evils, of the Emancipation of the Soul from the Body. The second, relating essentially to Physics, treats, besides other subjects, of the World, of Circular Motion, of the Action of the Stars, of the two kinds of Matter. The third treats of Destiny, of Providence, of each man's Demon, of Love, of Eternity and Time, and other general considerations on the Laws of the Universe. The fourth is on the Essence, the Nature, the Faculties, and the Immortality of the Soul; its descent into the body and its diversities. The fifth is on Intelligence - on the three principal Substances, on Unity, on Ideas, \&c. The sixth and last is a kind of recapitulation, treating on Being, Unity, Numbers, Ideas, Liberty, \&c. The six Enneades are composed of three divisions : the 1st contains the first three Enneades; the 2 d, the fourth and fifth; and the $3 \mathrm{~d}$, the sixth. ${ }^{1}$

The Plotinian doctrine has been defined "the theory of absolute unity, perfect and primordial, and the graduated relations by which variety proceeds."

The triads of Pythagoras and Plato, and the doctrines of the Christians, probably suggested the idea of three Principles.

The first principle. Absolute unity.

The second principle. Supreme intelligence.

The third principle. The soul.
The First Principle is above all things. From it all things proceed; without it nothing could be. It is One. It is simple. From it emanate motion and rest; but itself, having no place, has neither motion nor rest. It is infinite, not as matter is immense, but as being one, and as having nothing by which it can be limited. As there can be nothing better than that from which all things proceed, it is the best of all things. It is essentially good. It is the source and end of beauty. It is free, but its freedom, and its other attributes, must not be understood in the sense in which they are ascribed to other beings, but in a manner altogether inexplicable.

From this First Principle proceeds mind, or intellect, its lively image. It proceeds from it without action and without will, without altering or modifying the First Principle, even as light proceeds from the sun. Intelligence is at once the object conceived; the subject which conceives; the act of conceiving: these three things are identical. It contemplates itself incessantly; this contemplation is its essence.

The third Principle, subordinate to the two others, is the universal soul, the principle of life, subsisting, as well as intellect, of which it is the image, in the Divine essence. It is supramundane. It is the source of the principle which is diffused through and animates the world.

This procession is not operated in time; it is from all eternity. The three Principles, though forming a hierarchy in order and dignity, are contemporaneous. ${ }^{2}$

1 The ninth book of the second Ennead is Against the Gnostics. The object of Plotinus is to refute the theory of the two principles and that of successive emanations.

${ }^{2}$ Brucker thus describes the Plotinian Trinity. Plotinus, he says, taught, "Prin- 
Matter is considered merely as the receptacle of forms, the basis of Matter, \&c. qualities; itself has neither figure, quality, magnitude, nor place, and must, therefore, be defined negatively.

The intelligible world - unchangeable and eternal-alone embraces true essences, of which this visible world merely presents the appearance. The intelligible world, or plenitude of ideas, rules over and penetrates into all parts of the sensible world by the excellence and energy of its power.

Among celestial natures are different orders, possessing different gradations of excellence, gods, demons, genii, heroes.

The human soul, derived from the supramundane soul, is in this respect sister, as it were, to the soul of the world. Pre-existing before its union with the body, from which all its vices arise, it returns, after its separation, to the Divine source whence it emanated. Here below, the soul is not in the body, as in its place or receptacle, nor as a part of a whole, nor as form is united with matter, but it is present to the body as its animating principle. The human soul may unite itself with the Divine soul, and by this with the Divinity, whence it derives all its knowledge; for the most pure and exalted source of knowledge is in the contemplation of Divine forms. ${ }^{1}$ The soul perceives by

cipium omnium non esse omnia, sed super omnia et potestatem omnium, nempe super-ens; illud intellectualis vitæ causam esse, et infinitum modo singulari optimum sibi sufficientissimum, pulcherrimum, liberrimum, unum, ipsam essentiam; nec hoc in alia principia deducendum, sed hoc proposito intellectum deinde, quodve primo intelligit, mox animam post eum collocanda, et ita tria tantum in divinis principia ponenda esse. Hujus trinitatis centrum esse lucidissimum, lucem ex se scaturiens, atque divino modo generans; hinc maximum post illud, mentem esse, à Deo genitam, illi vero cohærentem, quæ sit imago Dei, ut lux solis; intellectum hunc generare animam. Intellectum istum multa (nempe objective) in se habere, et hinc esse multum et unum; ejus actionem esse intelligentiam, ipsum suo modo multiplicem esse, et compositum, nempe complecti res revera existentes, id est, intelligibilia et ideas pro conditione rationum seminalium in mundo : ideas autem istas ab intellectu non differre, sed actum tantum accedere, ut multa fiant in entibus. Mentem divinam per ideas in materiam agere intrinsece, non tamen eas esse, ut rerum irrationalium, sed præstantiori gradu. In cœlo incorporeo esse Deos duplices intelligibiles et intellectuales; illos ideas esse, hos intellectus omnes ætorna idearum contemplatione beatos. Animam mundi non mundanam tantum esse, sed et supramundanam. Veneremque duplicem, terrestrem et cœlestem. Hanc supramundanam esse essentiam ex essentiâ emanantem et existentem simul at minorem generante: $a b$ eo generari animas reliquas, licet unum totum sit ubique. Nunquam fuisse tempus, quo universum non animatum fuerit; neque materiam unquam informem potuisse existere. Nisi enim corpus sit, animam non fuisse progressuram ex lumine, eam cum umbram inveniret in extremis mundum fecisse, tanquam ædificium speciosum, non separatum ab effectore, at nec illi tamen commixtum. Quicquid attingat animam, sic inde perfici, prout essentia animæ naturaliter se habeat; ornatum vero esse ex animæ potestate; eum in rebus inanimatis non consopitam jacere, sed tendere in aliud; eam rotare omnia à summis ad una per circulum. Hæc de principiorum trinitate Plotinus tradidit, quæ cum Christianorum trinitate confundenda haud sunt." (Inst. Hist. Phil. p. 335.)

${ }^{1}$ In this system the human mind may also act, and receive knowledge in two ordinary ways; one by participating in intelligence, the other by forms: in the first, being in a manner filled and illuminated by intelligence, it feels and sees it 
means of the First Principle, even as the eye by means of light. The vision, or intuition of God, the great point of perfection and felicity, by which the mind, a link in the chain of intelligence, ascends, by the various steps of purification, to the great source of life and being, was the high object of the Plotinian school. Porphyry relates that Plotinus had four times during his life enjoyed an intimate communication with the Divine Being, and that he himself had attained that favour once. ${ }^{1}$

The liberation of the soul from its corporeal prison, was the end of the new Platonic morals, to attain which it was to pass through several degrees of human and divine virtues. ${ }^{2}$ The human virtues are physical, economical, and political ; they relate to the care of the body and the duties of private and public life. The Divine virtues are purgative, requiring abstinence and mortification; theoretic, comprising the intellectual exercise of contemplating intelligible natures ; and theurgic, lead-

immediately; in the other, it uses certain laws or characters engraven in us, for God has imprinted in the human mind the rational forms of things. But true knowledge is that in which the thing known is identical with the subject knowing: such is that which the understanding has of itself. (Enn. iv. lib. viii. c. 4 ; Enn. v. lib. iii. c. 4 ; Enn. iii. lib. viii.; Enn. vi. lib. i. c. 4.) The faculties of the soul are of two sorts; one, directing themselves above themselves, constitute reason; the others, descending to the lower regions, form sensibility and vegetation. Reason is, as it were, intermediate between the understanding and the senses, it acts not by means of corporeal organs, but by the sole force of intelligence. (Enn. v. lib. iii. c. 2 ; Enn. ii. lib. i. c. 7.) The understanding is never passive, it receives not forms from without; it is not even passive in sensation, as some philosophers suppose. In sensation, it is not modified by an impression reaching it; on the contrary, it acts and carries itself without. Light comes not from the object lighted, but from the luminous subject. (Enn. iii. lib. i. c. 10; lib. ii. c. 1; Enn.v. lib. v. c. 6.) In vision, the mind places, but at a distance, the object perceived, and attributes to it a size very different from that of which it has the image. (See Enn. iv. lib. vi. c. 1, 2, \&c.) Memory consists, not in the preservation or trace of received impressions, but, on the contrary, in a development of the energy of the soul, powerful in proportion as this energy is intense. (See Enn. iv. lib. iv. c. 3, \&c.) -Degerando, Hist. des Syst. Philos, tom. iii. c. 21.

1 There are three ways of elevating oneself to the First Principle. Harmony, love, wisdom; these are expressed by Plotinus when he distinguished three states, called the Musician, the Lover (E $\rho \omega \tau \iota k \delta s)$, and the Philosopher. The first is still placed in the midst of lower objects, but the admiration which is raised within him by the image of beauty reflected on them prepares his soul for truth: the second resides in a more exalted sphere; he is engaged in the love of immaterial things: the third soars, as if borne on wings, to the sphere sublime, to the contemplation of intelligibles in their very source. Plotinus recommends, therefore, his followers to prepare themselves by purifications, by prayers, by exercises, which adorn the mind, to ascend to the intellectual world, to nourish themselves with the celestial food which it contains; to raise themselves to that height where the spectacle becomes identical with the spectator; where the mind not merely sees itself in itself, but everything else; where essence is one with intelligence; where, confounded in a manner with the universality of beings, it embraces it not as being external, but as belonging to it.-Enn. vi. lib. vii. c. 36 ; Degerando, Hist. Comp. des Syst. Phil. tom. iii. p. 382.

${ }^{2}$ See the learned dissertation of Fabricius, De Gradibus Virtutum, secundùm quas Proclum laudat Marinus, in his Prolegomena to the Life of Proclus by Marinus. 
ing by immediate communications with superior beings, to obtain power over demons, and to attain to the enjoyment of the Divine vision.

It is evident that there is the greatest similarity between the Comparison mysticism of the Plotinian school and that of the Quietists in later between the times, who regarded an intense and undisturbed contemplation of the school and divine perfections as a means of obtaining an intimate union with the Deity. Indeed, it would be no uninteresting speculation to compare the Plotinian reveries with those of the Hesychasts and of the Illuminati, as well as with those of Molinos, Malaval, Mad. Guyon, and Fenelon -names which show (and it is the best lesson of charity) how often mistaken, and even dangerous, opinions may find admission into minds, to which it would be unjust to deny the praise of amiable and benevolent and pious feelings.

It is to be remarked that Plotinus not merely extended, but even Difference departed from, the doctrines of Plato. For instance, according to between the Plato, matter is coeternal with the Divinity, to whom he alone Plato and attributes those ideas, of which it imposes the forms on matter; according to Plotinus, all that is real is in the Divinity, emanates from it ; matter is only a vain appearance, a mere negation. According to Plato, the object of man is to draw near to God, to endeavour to resemble Him ; according to Plotinus, man may unite, and, as it were, identify himself with God. According to Plato, ideas are only present to the Supreme Intelligence $;^{1}$ according to Plotinus, they are substances identified with that intelligence. ${ }^{2}$

1 This Platonic doctrine has been described with exquisite beauty by one of our own poets, whose genuis, "warm from the schools" of Athens, and truly "enchanted with Socratic sounds," was peculiarly adapted to lend attractions no less to the philosophical than to the political sentiments of ancient Greece:-

Ere the radiant sun

Sprang from the East, or 'mid the vault of night

The moon suspended her serener lamp :

Ere mountains, woods, or streams, adorn'd the globe,

Or Wisdom taught the sons of men her lore-

Then lived the Almighty One, then, deep retired,

In his unfathomed essence, view'd the forms,

The forms eternal of created things;

The radiant sun, the moon's nocturnal lamp,

The mountains, woods, and streams, the rolling globe,

And Wisdom's mien celestial. From the first

Of days, on them his love divine he fix'd,

His admiration, till, in time complete,

What he admir'd and lov'd, his vital smile

Unfolded into being. Hence the breath

Of life, informing each organic frame;

Hence the green earth, and wild-resounding waves;

Hence light and shade, alternate warmth and cold,

And clear autumnal skies and vernal showers,

And all the fair variety of things.

Akenside-Pleasures of Imagination, book $i$.

It would be curious to compare the above systems with that of Malebranche.

${ }^{2}$ Degerando, Hist. Comp. des Syst. Phil. tom. ii. c. 21. The following may 
Manner in which the Eclectic philosophy was calculated to impede Christianity.

It is scarcely necessary to point out the consummate art with which the Eclectic philosophy was adapted to thwart and perplex the progress of revealed religion. By the help of allegory, of all devices the most accommodatingly flexible, it endeavoured to detect and trace the features of hidden wisdom in those monstrous fictions of paganism, which afforded so much scope to the sarcastic severity of the early advocates of Christianity. By adopting, too, the oriental theory of a scale of Divine emanations, and by representing those inferior spirits as mediators between the Supreme Deity and mankind, it justified and enjoined polytheistic worship. Moreover, by attempting to mould into accordance the chief tenets of various schools, it undertook to remove the objection to which philosophy was repeatedly exposed by the disputes of its most eminent professors on momentous questions. 'Again, by the elevated tone of morality and mysticism which it assumed, a strong effort was made to remove the stigma of inconsistency which rested on the character of a philosopher. And while many of the peculiarities of the new religion were adroitly introduced, in the disguise of expanded and embellished Platonism, every art of falsehood was taxed to maintain the pretensions of ineffable communications with, and miraculous control over, the powers of the invisible world. ${ }^{1}$

In brief, for our limits forbid us from entering into the obscurity of of the Neo-Platonic subtilties, the doctrines of Plotinus may be thus recapitulated. He considers the metaphysical generation of ideas as the type of the generation of beings, or rather he represents both generations as identical, for he admits no beings but spirits. ${ }^{2}$ Spirit in its turn is identical with its own ideas, it has no object out of itself; the intuition, immediate or reflex, is also the source of all knowledge, and as particular notions are, according to metaphysical order, comprised in the most general notion, the First Principle comprises all

serve as an instance of their manner of combining, or rather confounding, the opinions of different sects. After having explained the Plotinian cosmology, Brucker adds, "Luculenter ex hoc Plotinianæ physologiæ systemate constare potest, quo pacto æternitatem mundi Aristotelicam cum Platonis opinione, mundum à Deo factum esse, Plotinus conciliaverit. Intelligi autem ex eo quoque potest, quomodo Plotiniana secta eandem de rerum origine hypothesin Christianorum decretis, omnia ex nihilo esse producta, assimilaverit. Nam idem quoque dicere ausi sunt, sed significatione diversâ: nempe Deum omnia, ipsamque materiam non preexistentem et sibi subjectam habuisse, sed ex suo sinu libero voluntatis suæ actu, adeoque ex nullo preexistente subjecto eduxisse. Quod exemplum esse potest, quam turpiter horum hominum syncretismus decreta philosophorum, et ipsam veritatem cœlestem corruperit."-Instit. Hist. Phil. p. 282.

1 See Brucker, Instit. Hist. Phil. p. 275.

2 Tiedemann, in his work on the Spirit of Speculative Philosophy, regards the Plotinian system as gross Spinosism, because Plotinus considers all existing things as parts of the Divinity, and the Divinity itself as the first matter, which, by diverse transformations, reproduces itself under forms infinitely varied; and as subtle Spinosism, because he makes the Divinity the original subject of all the varied appearances which present themselves on the theatre of experience, and wishes to deduce all things from the sole notions of the understanding. 
realities; the first intelligence is at the same time the universal intelligence, and it contains necessarily all other intelligences. ${ }^{1}$

"Even the errors of great men are fruitful of truths;" and this one practical advantage at least may be derived from a survey, however brief, of philosophical errors that, in enabling us to trace, it teaches us to avoid, the source from which they have arisen, and the mazes through which they run. The history of the Plotinian school-of men who rendered profitless the high mental endowments they had received from nature, by substituting " ungrounded fancies" and mystical aspirations for those sober inquiries which lie within the reach of the human intellect-affords, we think, a useful exemplification of that species of error, which the great Bacon has placed among the "peccant humours" by which learning has been corrupted. It has proceeded "from too great a reverence and a kind of adoration of the mind and understanding of man, by means whereof men have withdrawn themselves from the contemplation of nature, and the observations of experience, and have tumbled up and down in their own reason and conceits. Upon these intellectualists, which are, notwithstanding commonly taken for the most sublime and divine philosophers, Heraclitus gave a just censure, saying, ' men sought truth in their own little worlds, and not in the great and common world;' for they disdain to spell, and so by degrees to read in the volume of God's works; and contrariwise, by continual meditation and agitation of wit, do urge and, as it were, invocate their own spirits to divine and give oracles unto them, whereby they are deservedly deluded."

Such is a faint and naturally very imperfect outline of the peculiar philosophy ${ }^{2}$ which, generally spread, exerted mighty influence from the third to the seventh century; which, after having reappeared in the middle ages, shone with great lustre in the fifteenth and sixteenth centuries $;^{3}$ and which, notwithstanding its wildness and extravagance,

1 Degerando, Hist. Comp. des Syst. Phil. tom. ii. c. 21.

${ }^{2}$ Of the Advancement of Learning, lib. i. c. 5.

${ }^{3}$ Our object having been merely to present a clear outline of the most prominent features of the Eclectic school, together with a succinct view of its most noted propagators, we have been obliged to avoid entering into a detail of its metaphysical and theological principles, or into notices of the long train of eminent men who have successively adopted and extended Platonic notions. Among the authors of a marked Platonic cast, who adorn the annals of English Literature, it is sufficient to mention the celebrated names of Theophilus Gale, of Henry More, and, above all, of R. Cudworth.

${ }_{4}$ Degerando, Hist. Comp. des Syst. Plil. Besides this able work, by which, together with the learned Brucker's Hist. Critic. Phil. tom. ii. and Enfield's Hist. of Phil. we have been chiefly guided, the reader will find additional information in the writings of Mather, Tiedemann, Tennemann, Buhle, and V. Cousin. See also Cudworth's Intellectual System, with Mosheim's valuable notes to his Latin translation; Mosheim de turbatâ per recentiores Platonicos Ecclesiâ ; Fabric. Biblioth. Græc. tom. ix. Ed. Harles; Creuzer's Letter to Wyttenbach, prefixed to his edition of the fragment of Plotinus, De Pulchro; to which may be added the following works, noticed by Degerando (tom. iii. note p, p. 478), Beausobre, Hist. de 
still perhaps may be destined to rise into new importance by the united efforts of learning in Germany and enthusiasm in France.

l'Eclectisme; Obarius, Dissert. de Eclecticis, prefixed to the German translation of Stanley; Erich's Commert. de Doctrinâ Platon, \&c.; Roth. Dissert. Trinit. Platonic.; Leder Müller, Dissert. de Theurgiâ, \&c.; Dicell. Majer, Series veterum in Schol. Alexandr. Doctor.; Rosler, De Commentitiis Phil. Ammonianæ fraudib. et noxis; Feussling, De tribus Hypostasibus Plotini; Habenftreet, Dissert. de Jamblic. Phil. Syr. Doctrin.; Hilscher, De Scholâ Alexandrin.; a Letter by M. de Ste. Croix, in a new edition of the Eclectics; a Dissertation by the son of Fichte, De Philosophiæ novæ Platonic. origine; Neander, Uber den Kaiser Julian and sein Zeitalter, \&c. 


\section{A R C II I II E D E S.}

GREEK MATHEMATICS.

BY

\section{WILLIAM WHEWELL, D.D., F.R.S.,}

master of trintty COLLEge, CAMBrIDGE;

PROFESSOR OF MORAL PHLOSOPHY IN THE UNIVERSITY OF CAMBRIDGE. 


\section{GREEK MATHEMATICIANS.}

\begin{tabular}{|c|c|c|c|c|c|c|c|c|c|}
\hline Thales & - & - & - & - & 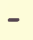 & 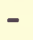 & - DIED & B. C. 546 & \\
\hline ANAXIMANDER & - & - & - & - & - & - & - & B. C. $547, \mathrm{AGED}$ & 72 \\
\hline Pythagoras & - & - & - & - & - & - & - & B. C. $507, \mathrm{AGED}$ & 98 \\
\hline EMPEDOCLES & - & - & - & - & - & - & - & B. C. 413, AGED & 60 \\
\hline ANAXAGORAS & - & - & - & - & - & - & - & B. C. $428, A G E D$ & 72 \\
\hline ARCHYTAS - & - & - & - & - & - & - & - & B. C. 360 & \\
\hline DEMOCRITUS & - & - & - & - & - & - & - & B. C. 361, AGED & 109 \\
\hline ZENODORUS & - & - & - & - & - & - & - & -- & \\
\hline HipPocrates & - & - & - & - & - & - & - & -- & \\
\hline ANTIPHON AND & BRYSON & - & - & - & - & - & - & -- & \\
\hline METON AND EUC & JCTEMON & - & - & - & - & & OURISHED & B. C. 438 & \\
\hline Plato & - & - & - & - & - & - & - DIED & B. C. 348, AGED & 81 \\
\hline MENechyus & - & - & - & - & - & - & - & -- & \\
\hline Dinostratus & - & - & - & - & - & - & - & - & \\
\hline EUdoxus - & - & - & - & - & - & - & - & -- & \\
\hline ARISTOTLE & - & - & - & - & - & - & - DIED & B. C. 322, AGED & 63 \\
\hline AUTOLYCUS & - & - & - & - & - & FL & OURISHED & B. C. 330 & \\
\hline EUCLID & - & - & - & - & - & - & - & B. C. 320 & \\
\hline ARISTILLUS AND & D TrMoc & IARIS & - & - & - & - & - & B. C. 280 & \\
\hline ARISTARCHUS & - & - & - & - & - & - & - & B. C. 281 & \\
\hline Aratus & - & - & - & - & - & - & - & -- & \\
\hline ARCHIMEDES & - & - & - & - & - & - & - DIED & B. C. 212, AGED & 75 \\
\hline CoNon & - & - & - & - & - & & OURISHED & B. C. 240 & \\
\hline ERATOSTHENES - & - & - & - & - & - & - & - DIED & B. C. 194, AGED & 82 \\
\hline APOLLONIUS & - & - & - & - & - & FI & OORISHED & B. C. 215 & \\
\hline Ctesibius & - & - & - & - & - & - & - & B. C. 150 & \\
\hline HERO & - & - & - & - & - & - & - & B. C. 140 & \\
\hline
\end{tabular}




\section{GREEK MATHEMATICS.}

AT the time when the state of eloquence and the arts among the Greek Greeks showed most strongly the extraordinary powers of their geometry. minds, they were employed in forming and advancing the singularly beautiful and intellectual structure of the GREek GEOMETry. This science, associated in its birth with their earliest philosophy, generally continued combined with their favourite speculations; and in its progress was more rapid, or at least more certain, than any of them. In the school of Prato it had already engaged in the most intricate and difficult researches; and when transferred to the college of Alexandria, it produced those profound investigations, on which the first intellects of later times have been content to employ themselves without hoping to add to its discoveries.

Among the names which the history of this subject offers, that of Archimedes has been, by the suffrage of all judges, considered as standing highest; and possessing the same pre-eminence in the ancient world with that of Newton in modern times. It will, therefore, be natural to combine with what can be collected of his biography, some account of the history, about that time, of the sciences which he cultivated. This sketch of what was then known, may be considered as the only view which we can give of that which is generally the most interesting part in the life of a mathematician, his education : for it is clear that Archimedes was familiar with all that had been done in mathematics up to his time. Without such knowledge, few have been fortunate enough to extend, as he did, the limits of their province in the world of science.

Thales of Miletus, the first of the Greeks who is mentioned as Thales. having turned his attention to geometry, is to be looked on as the B. c. 600 . father of their mathematical science, as indeed he appears to have been of the rest of their philosophy. The discoveries attributed to him are of the most elementary kind; but enough was done to give an impulse to the subject; and his followers in the Ionic school imitated him also in these researches. ANAximander is said to have Anaximanwritten an 'Introduction to Geometry.' Pythagoras was a scholar of der. Thales; and did much for the progress of mathematics, besides the discovery of his celebrated theorem, for which he is said, it must be acknowledged with little probability, to have sacrificed a hetacomb. The theories of which he was the author, and the reception which they met with, show the strong tendency of the Greeks to such inquiries. In his hands and those of his successors, music became a 
mathematical subject; the properties of numbers were pursued with an inquisitiveness which led to a curious spirit of mysticism; and the doctrine of the sphere was applied to the explanation of astronomical phenomena.

Under these circumstances geometry and its related sciences soon became of considerable extent. We have the titles of several treatises

Democritus. upon a variety of its branches by Democritus and others of the times before Pericles; and at the period of the Peloponnesian war, geometers had not only travelled over most elementary problems, but had, in some instances, struck against those limits which they have been ever since vainly struggling to pass. According to Anaxagoras. Plutarch, Anaxagoras, the friend of Pericles, employed himself B.c. 530. in his prison in investigations on the quadrature of the circle; and circle. steps of the same problem were also attempted by Antiphon and Bryson, whose reasonings Aristotle calls paralogisms, though it would Hippocrates. seem undeservedly with respect to the former. HiPPOCRATES, who was originally a merchant of Chio, and became a geometer at Athens, whither he had gone in consequence of pecuniary misfortunes, entered upon a train of research, which at first seemed to promise success, in measuring the circle. He went so far as to find the area of a space Lunes. comprehended between two circular areas, and called a lune, from its resemblance to the horned moon; but it was found impossible to extend this to a whole circle. Another problem, now also known to be impracticable by plane geometry, namely, the discovery of two mean proportionals, excited much interest about this time. It is Doubling the identical with the problem of doubling the cube, said to have been cube. proposed by the oracle at Delos; though this story is probably only one of those fictions in which mathematicians used often to present their questions. However that may be, it is certain that we have several solutions of this problem, purporting to be of the time of Plato, given by Eutocius in his commentary on Archimedes. Archytas. ARchYTas, a Pythagorean, the master of Plato, solved it by a somewhat complicated construction, in which a conical and cylindrical Menechmus. surface are made to intersect. Menechuus, a scholar of Plato, obtained the result by the intersection of two conic sections. Eudoxus. Eudoxus, another of Plato's scholars, is said to have applied to it в. c. 370. curve lines invented by himself. Plato himself devised a kind of parallel ruler, by means of which it might easily be mechanically executed. Indeed, the Greek geometry seems sometimes to have had a rather curious tendency to solve its problems by mechanical contrivances: of which practice, according to Plutarch, in his account of Archimedes, Plato strongly disapproved; notwithstanding the instance we have just given of his adoption of it. ${ }^{1}$

I Plutarch. in Marcello. Plutarch obviously confounds, as it was easy for a writer to do who was not a mathematician, the solution of problems by mechanical

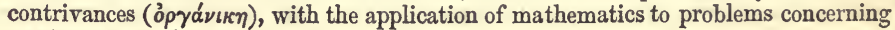
machines $(\mu \eta \chi \dot{\alpha} \nu เ \kappa \eta)$. 
The admiration of Plato for geometry is well known, from the in- Plato. scription which he is said to have placed over the door of the place where he taught: "Let no one enter who is without geometry." The acquisitions which are attributed to him and his school show how rapidly the science advanced; for the discoveries which we have now to notice are no longer particular propositions, but general methods, and long trains of investigation. We shall consider them in order.

It appears by what has been just said of Menechmus, that the Conics. conic sections had already been discovered. They are sometimes ascribed to Plato himself, and many of their properties were known soon after his time.

Plato is said to have invented the geometrical analysis; the method Analysis. by which, assuming a problematical result to be true, we reason backward to the other propositions which its truth presupposes, till we arrive at something which is known to be true or to be false; and thus establish or overturn the proposition assumed.

Another invention of this illustrious mathematical school was the Loci. doctrine of geometrical loci. By this proceeding, when a required point cannot be found by the intersections of straight lines and circles, some new curve is constructed, consisting of the places which the point might assume by leaving out one of the conditions; and in this curve the remaining condition enables us to determine the point de-

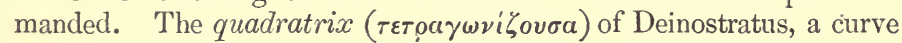
so called from the scholar of Plato, who invented it, or discovered its properties, and from its use in squaring the circle, was one of the first of these loci. It may also be used in another celebrated problem, the trisection of an angle. This problem, and that of the duplication of the cube, gave rise also to the loci constructed by succeeding mathematicians, and called the conchoid of Nicomedes, and the cissoid of Diocles. Besides these, which were called loci at a line, similar considerations led afterwards to the invention of loci at a surface, when Loci at a the possible positions of a point lay in a curved superficies.

To the active minds of Plato and his school we may attribute also solid the prosecution of 'Solid Geometry.' We bave a treatise by ZFxo- geometry. Dorus, who is supposed to have lived somewhat about this time, in which it is proved that the content of the sphere is greater than that of any other solid of equal surface. This is preserved by Theon in his commentary on the 'Almagest,' and is the oldest work on geometry extant. But the Platonists pursued this subject, and investigated the properties of the five regular solids, called from that cause the Platonic bodies. This branch could not previously have been much attended to, for Plato (Rep. lib. 7) "notes it defective," to use Lord Bacon's phrase in his 'Survey of Human Learning.'

In the passage of Plato just referred to, he divides mathematics Astronomy. into the doctrine of planes, or plane geometry; the doctrine of solids; and the doctrine of solids in motion. This last division is meant to describe the mathematical part of 'Astronomy,' viz., the doctrine of 
the appearances presented by the revolution of a sphere. Thales, or his immediate successors, had maintained the spherical form of the earth, and imagined and named the most important circles in the sphere of the heavens. After this, the application of geometry to determine the risings, settings, and motions of the stars was an obvious step, and seems to have been early made. It does not appear to have led to any very recondite consequences; and may be adequately judged of from the ancient and curious treatise on the sphere still extant, and Autolycus. written by Autolycus, who lived about the time of Alexander. For B. C. 300 . an account of this work, and of other early Greek astronomers, see the 'History of Astronomy.' 1 Of Eudoxus, one of the most eminent of them, we may further notice Delambre's opinion, that he possessed an artificial globe, such as we may conceive the skill of that time able to produce; and that having marked upon it the places of the stars, with no great exactness, he determined their risings and settings by means similar to what is now understood by " the use of the globes." The results of this method he published in a work which we may consider of great importance, as having given rise not only to the poetical paraphrase of Arctus, but to the valuable commentary of Hipparchus.

The other astronomical opinions of the Greek philosophers were less precise and correct. The true system of the universe had indeed been maintained by Pythagoras, but the minds, even of philosophers, were not yet ripe for it; and except that it was occasionally revived, as for instance by Aristarchus of Samos, a little before Archimedes, it slept till the time of Copernicus. Aristotle pretended to confute it; and Plato's opinions, though often borrowed from the Pythagoreans, have no tinge of that part of their philosophy. Yet he is said to have adopted in his old age the system which places the sun in the centre of the universe. He had also the merit of having recommended mathematics to the more particular attention of astronomers; but apparently this was done with the hope of discovering imaginary relations among the parts of the universe: such, perhaps, as afterwards haunted the mind of Kepler; and though unfounded in themselves, led him, by singular good fortune, to the true laws of the solar system. Eudoxus, already mentioned as the disciple of Plato, appears to be the author of that cumbrous hypothesis of crystalline spheres, which generally, but erroneously, has the name of Ptolemy attached to it. It is not to be found in the works of that great astronomer, though it was adopted by Aristotle and others of the ancients.

Cycle of nineteen years invented. B. C. 433 .

The most important practical result of the astronomy of those times

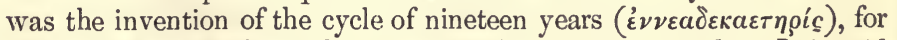
the purpose of making the solar and lunar year coincide. It is said (Geminus, c. 6) to have been produced for the approbation of the Athenians, by Meton and Euctemon, and adopted B. c. 433 ; and it so far answers its purpose, that it is still in use, under the name of 1 Page 334 of this volume. 
the golden number, to determine the new and full moons, on which moveable festivals depend.

The Pythagoreans had paid much attention to arithmetic, $i$. e., to Arithmetic. the properties of numbers ; indeed, they attributed to numbers a mystical meaning, which is not very intelligible. The Platonists also pursued this subject, and invented arrangements of numbers into various classes: thus they were called odd or even, perfect or imperfect, polygonal, which included triangular, square and pentagonal, pyramidal, \&c. Besides these speculations, which are not of very material consequence, the practical art of performing arithmetical operations had been carried to a considerable extent, as we shall see hereafter.

It has already been mentioned, that, from the time of Pythagoras, Music. music had become a mathematical science. Though there seems to be some error in the account of the inferences which that philosopher drew from the notes struck by the hammers on a blacksmith's anvil, the general fact is probably true, that he made the discovery that two musical strings which gave the most perceptible concord to the ear, exhibited also remarkable mathematical relations to each other in their lengths and tensions. This curious fact, connected with the great importance which the Greeks attached to music, soon led to a variety of speculations, derived from these mathematical proportions, which were assumed to be perfectly exact. This accuracy, however, though a proper subject for theory, is not the foundation of practical music: and though a mathematical exactness in concords is susceptible of being appreciated by the ear, it is rejected by the practice of modern music. Indeed, the unalterable properties of numbers, thus curiously connected with one of the most exquisite gratifications of the senses, make it impossible to preserve the perfect exactness of chords in every part of the musical scale. Therefore, though the ancients reasoned upon their concords as perfect, it is probable that in practice they used them imperfect. The latitude which this allows gives rise to the different expression of the different keys, as they are called, which probably correspond, at least to a considerable extent, with the various modes, Phrygian, Dorian, \&c., of the ancient music. It was also probably this capacity of the ear to adapt itself to concords slightly imperfect, which caused the separation into two sects of the ancient theorisers on this subject: of one of which sects Pythagoras was the founder, as Aristoxenus, a cotemporary of Aristotle, was of the other. While the former made the simplicity of the arithmetical relations regulate, as it were, the musical ones; the latter appealed more to experiment, and placed the tones at equal intervals in the scale; perhaps making, much in the same manner as is done in modern keyed instruments, their defects compensate each other. It seems requisite, in speaking of ancient mathematics, to say something of this difficult, and perhaps uninteresting portion of the science, as it was by them considered a most important branch; and many of their greatest 
mathematicians have written upon it treatises which are still extant. Their principal researches consisted in determining the value of the intervals between different notes of their scale, and arranging them into systems of four contiguous notes, which they called tetrachords: which, however, do not make the successions of the notes so clear as our arrangement of them in octaves. Any further discussion of this subject might be considered out of place; we shall only notice, that the scale above referred to was called the diatonic; that besides this they had the chromatic, in which all the half notes were introduced; the old enharmonic, which, according to Dr. Burney, resembled the Scotch scale; and the new enharmonic, which contained all the quarter notes, and to which we have nothing exactly corresponding. It appears certain that the music of the Greeks was confined to melody, or the pleasing succession of sounds; and that it was left for modern times to produce what we now call harmony; that effect of simultaneous sounds which may almost be considered as having a rightful claim to the reward offered for the discovery of a new sense of pleasure.

Mechanics. In the view of the state of mathematics in the time of Plato we can hardly enumerate the two sciences of mechanics and optics, which had scarcely then begun to exist, though they soon afterwards engaged some attention. The doctrine of motion, indeed, was not destined for the Greeks, for they never had any but the vaguest notions on the subject, and continued ignorant of the first law of motion, "that a moving body will go on uniformly, except so far as it is acted upon by external causes :" nor was any light thrown on this subject, till the time of Galileo. In the 'History of Astronomy' the reader may see the speculations of Aristotle; and a fragment on this subject, which is attributed to Euclid, contains nothing more definite or important. The doctrine of equilibrium, in which Archimedes made such extraordinary progress, seems to have been little better before his time. In Aristotle's mechanical problems, he thus accounts for the fact that, by means of the lever, a small weight may move a larger which is at the end of a shorter arm. The extremities of the arms describe circles, and the motion of a point in a circle is twofold; viz., a motion perpendicular to the radius, which is according to nature, and a motion towards the centre, which is contrary to nature. This unnatural motion is smaller in a larger circle, if the space described be the same; and hence in a larger circle a force will with equal ease move a body through a larger space. It is manifest that such reasoning as this can lead to nothing; and we do not know of anything better till the time of Archimedes.

optics. Optics was in a similar imperfect state at this time. The vagueness of Aristotle's speculations on the subject has been mentioned in the history of it given in another part of this volume, ${ }^{2}$ and the reader will there find an abstract of the remarkable treatise of Euclid; the earliest

1 Page 346 of this volume.

2 Page 353. 
which we have on this science. The hypothesis of vision which is there attempted to be proved is, that it does not take place by images coming from the objects and entering the eye, but by rays proceeding from the eye to the different points of the objects. It is evident that the mathematical results would be the same on either supposition.

The subjects which we have mentioned, geometry, plane and solid, and arithmetic, in the department of pure mathematics; astronomy, music, mechanics, and optics, in that of their application; formed the exact sciences cultivated by the ancients. To this division some of their authors added logistics and geodesy; the former indicating the application of arithmetic to questions respecting material objects; the latter, the mensuration of land by geometry: for which addition, however, there seems no necessity. At the time of Plato, some portion of these sciences seems to have formed a common part of a liberal education: see the dialogues 'Meno,' ' Erastæ,' and ' Theætetus.' It is not probable, however, that any extensive information on such subjects was popularly diffused. Thucydides seems to have been ignorant of the cause of a solar eclipse; and Aristophanes ridicules the geometricians and natural philosophers, under the character of Socrates in 'The Clouds,' and of Meton in 'The Birds.'

The preceding sketch shows how flourishing was the condition of the mathematics among the Greeks at the time when almost every other department of literature and art was at its greatest splendour. Their poetry, eloquence, and sculpture soon began to derline; but in the usual progress of the human mind the sciences continue to advance after these arts have become retrograde. In most countries a short period only of original excellence has been allowed to the literature which depends upon the imagination. The exercise of that faculty, like the liberty of a turbulent republic, seems to lead, after a few generations, to its slavery; but the reason, a better-governed kingdom, goes on making acquisitions which are imperishable and perpetually accumulating. The science and literature, of which Athens had been the metropolis, were transferred to the other coasts of the Mediterranean, and particularly fostered by the successors of Alexander. The encouragement of the Ptolemies produced no poets who are now considered as great; but royal patronage may be more successfully extended to men of science; and the mathematical school of Alex- School of andria exhibited an extraordinary succession of remarkable men. The Alexandria. cloistered walks, and public halls, and ample libraries of this Egyptian college, were for nearly a thousand years the resort of the most eminent of the men of science among the ancients; in whose hands the exact sciences, though often stationary, were sometimes advancing and never going back.

One of the principal founders of this school was EucLid, whose Euclid. 'Elements' form a groundwork of geometry, which the mathematical world has hardly yet been able to improve upon. Of his history we know little. Pappus, contrasting his character with that of Apol- 
lonius, describes it as kind and unassuming, and particularly disposed to encourage mathematical merit in others. He is said to have been attracted to Alexandria by the patronage offered to learned men under the first Ptolemy; and to that monarch, when he had expressed some dissatisfaction at the prolixity of the reasonings, through which the study required him to proceed, Euclid is reported to have represented, that "there was no royal road to geometry." Besides the celebrated 'Elements,' he was the author of mathematical works upon almost every branch of the science which we have mentioned. $\mathrm{He}$ wrote four books 'On Conics ;' a treatise 'On Loci at Surfaces ;' and one 'On Porisms,'a species of geometrical proposition, which, after being long involved in obscurity, was elucidated by Robert Simson, and after him by Professor Playfair. We have his data, and a 'Treatise on Divisions,' that is, on dividing a figure in a given ratio by lines drawn under certain conditions. Another work which Pappus praises much, was an arrangement and analysis of mathematical paralogisms. We have already referred to his Optics, of which science, mathematically considered, it is by no means improbable, from the nature of the treatise, that he was the inventor. We possess also a work on Music attributed to him, but which, Montucla thinks, consists of two parts, the first written by an Aristoxenian, and the second by a Pythagorean. In the latter capacity, Euclid is said to have been the person who first demonstrated that the Aristoxenian method of proceeding by tones and half tones, would necessarily give the octaves out of tune. We have already mentioned the fragment, referring to mechanics, which is ascribed to Fuclid; and arithmetic may be considered as the subject of the 7 th, 8 th, 9 th, and 10th books of the 'Elements.' In astronomy we have a work of his upon the doctrine of the sphere, entitled 'Phenomena.' This last science was one of those which Astronomy at occupied most, and most successfully, the Alexandrian mathematicians. Alexandria. Above all, the importance of observation began to be better under Aristillus and Timocharis. Aratus. stood. Aristillus and Timocharis for a long course of years made observations on the stars, many of which are preserved by Ptolemy. The poem of Aratus, so popular among the ancients, and which was translated by men of no less name than Cicero and Germanicus, was about this time written at the court of Antigonus Gonatas. And

Aristarchus. ARISTARCHUS of Samos, besides his method of determining the B. c. 281. distance of the sun by the dichotomy of the moon, mentioned in the 'History of Astrunomy,' ' made an observation of the solstice 281 B. C., and is remarkable as having attempted to revive the true doctrine of the universe which places the sun in the centre. This we learn

Archimedes. from ARCHIMEDES, of whose life we shall now collect what is known, and examine the improvements of which he was the author in the different branches of science.

This extraordinary man is said by Plutarch to have been a relation, as well as friend, to Hiero, king of Syracuse, and flourished under the 1 Page 335 of this volume. 
long and peaceful reign of that prudent monarch. Though the Sicilian prince reigned at the time when the contests of the Romans and Carthaginians were becoming a struggle for existence, and in the situation where the rival nations most naturally came in contact, he kept himself pretty well out of the vortex of wars and calamities, into which the violence of his neighbours might have drawn him; and the warlike machines which the great mathematician constructed, to prove to the king the resources of his art, found no employment during his reign. Archimedes appears to have been born B. c. 287, a little before Hiero's Archimedes accession to the crown. His youth corresponded with the time of born Ptolemy Philadelphus, under whom Alexandria, then the principal B. c. 287. seat of science, contained several of the mathematicians whom we have already mentioned. To this school he travelled, but at what precise time does not appear. He was probably too late to be a personal scholar of Euclid; but, among the other mathematicians with whom he became acquainted, he frequently in his works mentions Covor, with particular expressions of attachment. Conon is known to have resided in Egypt, under Ptolemy Euergetes, in honour of whose queen he formed the constellation of Berenice's Hair. It is said to have been for the purpose of raising water out of the canals of Egypt that Archimedes invented the machine, which yet has the name of his screw ; and the Arabian historian attributes to him the mounds and bridges, which are rendered necessary by the inundations of the Nile.

The greater part of his life, however, appears to have been spent at Syracuse; and his mathematical researches are given in "his beloved Doric dialect," as one of his ancient commentators calls it; the form of Greek which was spoken in Sicily, and with which the pastoral poets have made us associate something of picturesque simplicity. It was there that he pursued his investigations, and carried forwards the mathematical knowledge of his time by those wide advances, which we shall shortly mention.

It would appear that then, as in later times, mathematicians used to announce their discoveries in part, in such a manner as to challenge the ingenuity of their contemporaries by what they kept concealed. Archimedes had sent to Conon a long list of propositions on various subjects, of which he required the demonstrations; and, it would appear, that he employed the artifice of stating some false theorems along with the true ones: "In order," he says, "that if any assert themselves to have discovered the whole, and produce no demonstrations, they may be convicted, as pretending to have done what is impossible." These discoveries refer to the area of the parabola, the surface and solidity of the sphere and cylinder, the properties of spheroids, and of that spiral, which is called indifferently the spiral of Conon or of Archimedes. Conon, however, died before he had obtained the demonstration of these propositions, to the great grief of Archimedes. "If he had lived," he says, " he would have found out these, and invented more, and would have done much for the advance- 
ment of geometry; for I well know his uncommon talents, and his indefatigable industry in these studies." When Conon was dead, years elapsed without any one attempting the proposed theorems. 'The demonstrations were sent by Archimedes himself, at different times, to Dositheus, an Athenian, whom he knew, as he tells him, to be both a friend of Conon and a lover of mathematics; and who, after receiving a part, had pressed him much for the remaining portions. These successive epistles form his treatises 'On the Quadrature of the Parabola,' ' On the Sphere and Cylinder,' 'On Helices or Spirals,' and 'On Spheroids and Conoids.'

Quadrature The 'Treatise on the Quadrature of the Parabola,' was the first of parabola. instance in which a geometer had been able to determine the exact space bounded by a curve line; for though several before him had pretended to assign the area of the circle and of portions of it, their assumptions, as Archimedes asserts, were inadmissible: and their conclusions must have been false, since the problem, as we have already observed, is not soluble. The method which he employs is most remarkable for its ingenuity and novelty. He divides the parabola into an endless series of decreasing terms; and we may observe in his process the tendency to that passage from finite to infinite, by resolving a curve into its smallest portions, which, after assuming various forms in the hands of Barrow, Cavallerius, Newton, \&c., produced at last the differential and integral calculus. And though by means of these modern methods, a mere scholar in mathematics may now obtain the answers to such questions as that of which we are speaking, we cannot but regret, in the facilities of our technical rules, the elegance and evidence of the ancient geometry. Difficult as the problem appears in the way in which Archimedes has treated it, his only axiom is, that of two unequal spaces, the excess of the greater above the less, may be multiplied so as to exceed any given space; and from this he proves, by the strictest reasoning, that a parabola can be neither greater nor less than two-thirds of the parallelogram described about it.

Sphere and cylinder.

The speculations respecting the sphere and cylinder are those with which the author appears to have been most delighted, for he wished to have his grave marked by these solids, as some more recent mathematicians have had their discoveries engraved on their tomb-stones. Indeed, all who have the perception of geometrical beauty, must be struck both with his results and his methods. As he had been the first to find the area of a plane curve, he here finds the surface of a curvilinear solid; and determines the sphere to be two-thirds, both in content and in surface, of the cylinder which circumscribes it; with many other remarkable properties of these solids compared with each other and with the cone.

Spirals. The subject of spiral lines, was also, so far as we know, altogether new. In the one which he has examined he has discovered many remarkable properties with respect to its area, tangent, \&c. 
The conoids and spheroids are solids described by the revolution of Conoids and a conic section about its axis. These he considers, as also the sections spheroids. which are made in them by planes, the solid content of the parabolic conoid, \&c. This subject appears to have given him more trouble than the rest, for he informs his correspondent that he long kept back the proofs of his theorems on it, because he found some difficulty and doubt; "at least," he says, "going over them more carefully, I satisfied my scruples."

Besides these works which are addressed to Dositheus, we have his measurement of the circle; in which he determines the circumference to be between 3 and $3 \frac{1}{7}$ times its diameter. The method which he uses might easily be extended to greater accuracy by the assistance of a proper system of arithmetic.

The Greek arithmetic is the subject of his 'Psammites, or Number- Numbering ing of the Sand,' of which he thus explains the purpose to Gelo, the the sand. son of his king Hiero, and associated with him in the throne: "There are persons, king Gelo, who think that the grains of the sand are infifinite in number; I mean not merely the sands about Syracuse and the rest of Sicily, but those of the whole earth, inhabited and uninhabited. Others think that they are not infinite, but that no number can be expressed which shall exceed this multitude. Now, I shall attempt to show by geometrical proofs, which you will be able to follow, that among the numbers which I have expressed and published in my books to Zeuxippus, there are some which exceed, not only the multitude of the sands which would fill the earth, but of those which would fill the universe. You understand that by the universe is meant, by most astronomers, the sphere of which the centre is the earth, and the radius the distance of the sun from the earth." $\mathrm{He}$ then proceeds to some reasonings to establish that this distance is less than 10,000 of the earth's radii ; ${ }^{1}$ and to show that if we conceive a globe of this magnitude to be formed of grains of sand, the fortieth of an inch in diameter, their number may be reckoned. With our present mode of notation, there is no difficulty in increasing numbers to any magnitude whatever. But the Greek system, less perfect than the Arabic, though much superior to the numeration of other countries, required some contrivance to carry it to the requisite extent. The Greek geometer answered this purpose by dividing the figures into periods, the unit in each period being a myriad myriad, or ten million times the unit in the preceding. The Greeks could thus go on with their numbers as far as they might choose, though still their method did not afford them the same facilities which we derive from ours, in arithmetical operations.

Of the astronomical labours of Archimedes, none have reached our Astronomy.

1 It is, in fact, about 24,000 of the earth's radii; but this difference does not effect the reasonings of Archimedes. He founded his calculations on the supposition made by Aristarchus of Samos, that the sun's diameter was not greater than thirty times the earth's. 
times, if we except the method of determining the sun's apparent diameter, which has been extracted in the 'History of Astronomy.' The accuracy of his result is remarkable, if we consider, not only the imperfection of his means in other respects, but that he does not appear to have known any way of observing with one eye at a time, and is obliged to make allowance for the double vision of his two eyes. He was, as were all the mathematicians of that age, a diligent practical observer; and we are told, that he thought he had discovered the distances of the heavenly bodies from the earth, and from each other; but that his measures were rejected by the Platonists, as not following that imagined perfection of mathematical proportions, which, they asserted, must necessarily exist. Cicero speaks of an orrery, as we should call it, made by Archimedes, and exhibiting the motion of the sun, the moon, and the planets; which he uses as an argument against those who deny a Providence. "Shall we," says he, " attribute more intelligence to Archimedes for making the imitation, than to nature for framing the original ?"

Mechanics.

Perhaps the most remarkable part of his discoveries were those which he made in mechanics, and his applications of them to practice. We have already seen, that before his time, this branch of science did not exist. In his work on the equilibrium of bodies, he gives a proof of the fundamental properties of the lever, which has never yet been surpassed in simplicity and evidence; and applies his principles to find the centre of gravity of various spaces, with great ingenuity. In his work on the 'Floating of Bodies in Fluids,' he shows a complete insight into the nature of fluid equilibrium ; and determines the position in which bodies float in some cases, which can, by no means, be considered as easy, even to modern mathematics. Indeed, without any addition to the principles of Archimedes, the doctrine of equilibrium was capable of being carried to its utmost extent, though among the ancients it appears to have stopped with him. We are told by Pappus, that Hero, a little after his time, proved in what cases there could be an equilibrium in the five mechanical powers; viz., the lever, the wheel and axle, the polyspact or pulley, the wedge, and the screw; and that he reduced them all to one in principle; but we cannot be certain that these proofs were strict, for there is nothing satisfactory in the demonstrations given by authors before the time of Stevinus and Galileo; and an attempt made by Pappas himself to determine the mechanical advantage of the inclined plane is remarkably erroneous.

Mechanical nventions.
We read of many mechanical contrivances of Archimedes, some, probably, merely attributed to him from the celebrity of his name. For instance, an invention something like what are now called Chinese puzzles, in which certain angular pieces of ivory are to be put together, so as, by different arrangements, to produce the resemblance of various objects. But he seems to have turned much of his attention to the construction of machines of extraordinary powers; and he boasted of 1 Page 337 of this volume. 
the unlimited extent of his art in the well-known expression, "Give me a spot to stand on, and I will move the earth." The mechanicians of that time employed themselves, not merely in proving the possibility of making a given force move any weight, however large, but studied to combine the best material means for carrying it into effect. Athenæus describes a ship of extraordinary magnitude, which Hiero caused to be made with twenty ranks of rowers, and containing so enormous a space, as to have on board gardens, baths, walks, a gymnasium, a large library, \&c. This unwieldy mass, Archimedes is said, by means of some mechanical power, to have enabled Hiero to push into the sea, by his individual strength. We have already mentioned the screw of Archimedes, which is said, also, to have been used as the pump of this vessel.

Though the study of mathematics is generally considered dry and His habits. repulsive by persons not engaged in it, there seem to be few pursuits which have the power of exciting so strong and engrossing an interest in the student. Like our own Newton, when absorbed in the current of discovery, Archimedes is said to have required to be reminded of the common duties of eating and drinking by those about him; and while his servants were placing him in the bath, he employed himself in drawing mathematical diagrams in the ashes which were spread on the floor, or in the oil with which his skin was covered. "So that this abstraction made people say, and not unreasonably," Plutarch tells us, " that he was accompanied by an invisible siren, to whose song he was listening." A lively fancy might easily imagine a discoverer, in the enthusiasm of his speculations, to be absorbed in his attention to the voice, audible only to his ears, which reveals to him truths concealed from all the world beside.

Another story told of Archimedes, is that of Hiero's crown. King Hiero's Hiero sent to a goldsrnith a certain weight of gold, to be made into a crown. crown. The crown was sent home of the proper weight; but it was suspected that some silver had been substituted for a part of the gold, and Archimedes was asked to detect the quantity of the fraud. $\mathrm{He}$ had sought in vain for some time, the means of doing it; xwhen one day, going into the bath, the rising of the water as his body became more immersed, suggested a method, which he instantly saw to be infallible, and he immediately sprung out, exclaiming, "I have found

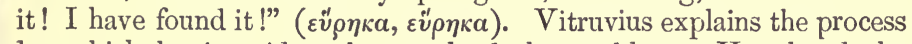
by which he is said to have solved the problem. He placed the crown, and a wedge of gold, and one of silver, each of equal weight, in a full vessel of water. In each case the quantity of water which ran over, gave the size of the mass; and by comparing these, he found the quantity of silver in the crown. The principles explained in his 'Equilibrium of Bodies in Fluids,' afford the means of a more accurate and scientific solution, which we should have been disposed to attribute to him, but for this testimony to the contrary.

We now come to the last and most remarkable events in the life of 
Siege of Syracuse. B.c. 212.
Archimedes, those connected with the siege of Syracuse, which ended B. c. 212. Hiero the friend of Archimedes had closed his reign a few years sooner. Gelo his son, and apparently the pupil of the mathematician, had died before his father. Hieronymus, the son of Gelo, succeeded to the throne, but not to the popularity of his grandfather; he shortly fell the victim of a conspiracy, and Syracuse became a prey to contending factions, who soon engaged her in a quarrel with the Romans. Marcellus by sea, and Appius by land, laid siege to the city, and it would probably have been soon taken had it not been for the extraordinary resources of mechanical skill which Archimedes produced in its defence. We have an account of them in Polybius, one of the most intelligent and scrupulous of historians, and who was born a few years only after the time. He says, that when the Roman fleet appeared sailing towards the city, it was assailed at a distance from the walls by powerful machines, which threw darts and stones: that when it got too near for the range of these, others were used so actively that Marcellus was obliged to approach the city, under protection of the night: and that when they were near it, such an artillery of arrows and other missiles was played upon them, that they were unable to make the assault and suffered great loss. To protect the besiegers from such attacks in their approaches, they built upon vessels, certain machines in use among the ancients, and called sambucæ. When these came near, there suddenly started above the walls large cranes carrying stones of ten talents and heavy masses of lead: these were brought over the sambucæ and then let fall, so as to break through the whole structure and nearly to sink the ships on which it was carried. Large levers were also made, to project over the walls, from which iron claws were suspended; by these the vessels were seized by the prows and hoisted half way out of the sea, and then let fall, with such violence, as to be sometimes dashed under water: so that, as Marcellus observed, Archimedes used his ships like buckets. By these contrivances the Roman soldiers suffered so much, that at last, the appearance of a rope or a pole above the walls, threw them into a panic, for fear of some new instrument of annoyance.

There does not seem to be any reason to doubt these statements, which are confirmed by the universal consent of historians. In fact, while modern artillery was unknown, much greater attention was paid to improving those instruments which were used; and the effects produced exceeded, in many cases, anything that we should think possible, without the use of gunpowder. The powers which were employed, were sometimes the elasticity of large beams of wood, of which a gigantic bow was made, and worked by machinery; and sometimes the forces of cords of different substances, which being violently twisted, were allowed to untwist, and thus to give motion to a lever inserted in them. We have descriptions of such machines, by Hero of Alexandria, who lived not long after Archimedes. With respect to the latter kind, he says that the best materials for the cords, are the 
muscles of the shoulders of various animals, of the legs of stags, and the necks of bulls. He also observes, that long female hair, having been saturated with essences, possesses a powerful elasticity for this purpose. And, in considering the effects ascribed to the other machines, we must recollect how much smaller the Roman vessels were than ours.

Another of the inventions ascribed to Archimedes at this siege are His burning the mirrors with which he is said to have burnt the Roman fleet, of mirrors. which relation the authenticity is more disputed. In the 'History of Optics, ' some account is given of the ancient authorities and modern experiments on this subject. The silence of Polybius and Livy on this point, while they give us other details of the siege, would lead us to imagine that if Archimedes did execute something of the kind, it was not rery important or decisive. And at the same time the distinctness of the latter evidence, and the demonstrated practicability of the fact, liardly allow us to suppose that it is entirely without foundation. Lucian in the second century says, that Archimedes by his mechanical skill burnt ( $\kappa a \tau \varepsilon \dot{ } \phi \varepsilon \xi_{\varepsilon}$ ) the Roman ships. Galen, a little later, alludes to it as a known fact. Anthemius, the architect of Saint Sophia, in the sixth century, says, that it is undeniable, and mentioned by numerous historians; and explains the method in which it might be executed as was afterwards done by Buffon and others. And the later authors, Zonaras and Tzetzes, mention it with an unusual distinctness of reference to the earlier historians Dio Cassius, Diodorus, \&c., as if to remove any doubt which might exist. So that, perhaps, we may come to the conclusion of Gibbon, who says, "Since it is possible, I an more disposed to attribute the act to the greatest mathematician of antiquity than to give the merit of the fiction to the idle fancy of a monk or a sophist."

By the ingenuity of Archimedes the siege of Syracuse was pro- Taking of tracted for some time; but at last the fortune of the Romans pre- Syracuse. vailed. They discovered a weak place in the fortifications; made an attack when the citizens had relaxed their vigilance in the celebration of a feast to Diana; and soon became masters of part of the city. Marcellus is said to have wept at the approaching ruin of this populous and opulent state, which, old in prosperity, and rich in historical recollections, was now tending to a catastrophe so different from that of its former great siege by the Athenians. After some difficulties and fluctuations of success, the unfortunate town was taken by the Romans, and given up to be plundered by the soldiers. Archimedes, who had so long been its safety, perished in the confusion of the capture. It is said that Marcellus had given strict orders to preserve a person of whose genius he had had such extraordinary proofs; but that these were disregarded in the licence of war. While the Romans were plundering from house to house, Archimedes, unaffected by the violence which surrounded him, was absorbed in the contemplation of 
a mathematical diagram; and, when a soldier burst into the room, refused to attend to him, till he had finished his demonstration: on which the man, with the carelessness of human life which such scenes produce, killed the venerable philosopher upon the spot. According to some, when about to be put to death, he pleaded, like Lavoisier in modern times, for a short respite to finish the philosophical inquiries on which he was engaged, which, as in that case, was also refused.

Death of

Archimedes, B. C. 212.

Thus died, at the age of seventy-five, one of the most extraordinary mathematical geniuses of any age or nation. Marcellus was grieved at the fruitlessness of his attempt to save him, and honoured his memory by liberality towards his surviving relations. A sepulchre was built for him on which was placed a sphere and a cylinder, figures which had been the subject of some of his most beautiful discoveries. But neither his mathematical fame, nor his defence of Syracuse, seem to have kept him long in the memory of his countrymen. When Cicero, travelling in Sicily less than 140 years afterwards, inquired for his tomb, he was told by the Syracusans that nothing of the kind existed. "I recollected," he says, "some verses, which I had understuod to be inscribed on his monument, which indicated that on the top of it there was a sphere and a cylinder. On looking over the buryingground (for at the gate of the city the tombs are very numerous and crowded), I saw a small pillar just appearing above the brushwood, with a sphere and a cylinder upon it, and immediately told those who were with me, who were the principal persons in Syracuse, that I believed that to be what I was seeking. Workmen were sent in with bills to clear and open the place, and when it was accessible we went to the opposite side of the pedestal : there we found the inscription, with the latter portions of the lines worn away, so that about half of it was gone. And thus one of the most illustrious cities of Greece, and one formerly of the most literary, would have remained ignorant of the monument of a citizen so distinguished for his talents, if they had not learnt it from a man of a small Samnite village."

Archimedes was incomparably the most inventive and original of ancient mathematicians, and seems to have possessed the power of applying his geometry to a greater diversity of subjects, and of overcoming difficulties of a more various kind. If he had had one or two successors of equal genius with hirnself, it is not easy to see to what extent or in what direction the science of the ancients would have advanced; but it must certainly have anticipated some of the discoveries of modern times, though probably by methods a good deal different from ours. The mechanics of equilibrium, hydrostatics, and catoptrics might have been brought nearly to perfection, for they were in possession of the principles on which these depend. In fact, however, no advance of consequence was made in mixed mathematics. In astronomy alone had they adopted the only source of knowledge, assiduous and accurate observation. And the discoveries of mathe- 
maticians from that time were made almost entirely in pure geometry, and even these are very limited, if we except what was done by Apollonius; and of his propositions it is said that he owed some to Archimedes, whose results were left unedited and fell into his hands.

In practical mechanics the ancients appear to have gone somewhat further than we have yet mentioned. Hero seems to have been well acquainted with the effects, if not with the theory, of the elasticity of the air; and we have a treatise of his called 'Pneumatica' or ' Spiritalia,' describing divers machines depending upon that property, and most of them containing the principle of the syphon. We have also a treatise by him 'On Automatons ;' his automatons, which are principally toys moved by very simple machinery. And besides several mechanicians who are remarked for their inventions of warlike machines, Cresibius, the master of Hero, who lived apparently about Ctesibius.

150 в. с. invented a pump which is yet considered of a very efficient construction.

In order to finish what relates to the great age of Greek geometry, we shall notice some of the eminent characters who flourished with, or immediately after, Archimedes. These all seemed to have belonged to the college of Alexandria. Eratosthenes was a cotemporary of Eratosthenes. the Sicilian mathematicians, and was a remarkable instance of great ${ }^{\text {B.c. }}{ }^{27 i-194}$. acquirements in very different branches of knowledge. He is generally called by the ancients "Eratosthenes the grammarian" or philologer; and though he comes under our notice as a great geometer and astronomer, he was also a poet and an antiquary. It is seldom that one person attempts to master so many subjects, without incurring the charge, and perhaps the danger, of being superficial. His enemies gave him the name of Beta, as occupying only the second place in his pursuits : his admirers called him the Pentathlete, thus comparing him to a person who at the public games had been victorious in all the subjects of emulation. He was appointed superintendent of the library of Alexandria, under the third Ptolemy (Euergetes 246-221 B. C.): and he had the merit of inducing that monarch to place in the vestibule of the museum the armillae, or combinations of graduated circles which were the principal instruments of observation among the ancients. These instruments were about 20 inches diameter, and the observations made with them are quoted in the 'Almagest.' The mode of observing was by placing a pin on one limb of the circle, so that its shadow might fall upon another at the opposite extremity of the diameter, and thus indicate the position of the sun. By this means Eratosthenes is said to have found, that the interval between the tropics was $\frac{1}{8} \frac{1}{3}$ of the circumference, which makes the obliquity of the ecliptic $23^{\circ} 51^{\prime} 19 \cdot 5^{\prime \prime}$. His measurement of the earth is remarkable and celebrated, and has been described in the 'History of Astronomy.' He also gave determinations of the magnitude and distance of the sun, which appear, from their discordance with 
each other, to be erroneously reported to us. Besides his astronomical merits, he was an eminent geometer. He turned his attention to conic sections; and we have his description of a mesolabium, or instrument for finding any number of mean proportionals, which is ingenious, though it is said to have been ridiculed by Nicomedes; who, probably soon after, invented the conchoid for a similar object. He is said to have written ' De locis ad medietates,' the subject of which treatise can only be a matter of conjecture; and he is also known for what is called his 'Sieve,' which is a method of finding prime numbers. We possess likewise his 'Catasterism,' which is a description of the constellations. After living to the age of eighty-three, he found his sight fail and his health decay, and came to the resolution that life was not worth preserving under such circumstances. He died by voluntarily abstaining from food, B. C. 194 .

The principal remaining name which offers itself to our notice in A pollonits the Alexandrian school, is the illustrious one of Apollonius, whom tlourished

antiquity distinguished by the name of "The Great Geometer," and who has been considered with corresponding admiration by some of the most profound of modern mathematicians. He was born at Parga in Pamphylia, in the time of Ptolemy Euergetes: was instructed in mathematics by those who had been the disciples of Euclid: and flourished at the museum under Philopater (221 to 204 B. c.). We learn from Pappus that he employed himself in what has been a favourite, but not very profitable, speculation of the most acute mathematicians, an attempt to prove the elementary axioms on which geometry is founded. The works of his which remain are a treatise on conic sections. The four first books of this, which were all that were known in Europe till 1658, contain the properties observed previously to his time; but the three following ones, which were brought from the East and translated from the Arabic, give his own discoveries. They are principally on the greatest and least lines which can be drawn from any point to the curve of a conic section. They show wonderful powers in the management of the ancient geometry, and though it might be imagined that the instrument was scarcely capable of such results, they lead to the borders of the modern theories of evolute curves and centres of osculation. ${ }^{1}$ Besides

1 The history of the recovery of these books is remarkable. Upon the syllabus given by Pappus of the lost books of Apollonius's conics, several persons had attempted to form a conjectural restoration, or divination, as it was called. In particular, Viviani had been for some time silently and laboriously engaged in this investigation, when it was discovered by Borelli (in 1658) that the fifth, sixth, and seventh books existed in Arabic in the Medicean library. Viviani saw himself on the point of losing the credit due to several years of research by this unexpected discovery. He, however, obtained from the Grand Duke an attestation of the state of forwardness in which his own MSS, then were, signed by his hand; and an injunction to Borelli to keep secret his translation till Viviani's book had been published. The Divinatio in V. Apollonii Conicorum appeared in 1659, and the 
this treatise, Apollonius wrote others on several very general and difficult problems of geometrical analysis, which he pursued into all their detail of cases. Their titles and subjects are given us by Pappus. Many of them have since exercised the ingenuity of the most skilful of modern mathematicians. For instance, the problem of ' Tactions,' of which the most difficult case is to draw a circle touching three given circles, has been solved by Vieta and Newton. 'The Section of Ratio' and 'The Section of Space' have been restored by Halley. This problem is to draw a line through a given point, cutting segment from two given straight lines: in the first place so that they may have a given ratio; in the next place so that they may contain a given rectangle. In 'The Determinate Section' it was required to find a point in a straight line, such that the rectangles of its distances from given points should have a given ratio: this was resolved by Dr. Simson. The problem of 'Inclinations' proposed to draw through a given point a straight line, so that a given portion of it should be intercepted between two given straight lines. Some of these problems had been solved by Euclid, and Pappus blames Apollonius for the harsh manner in which he speaks of the solution of his predecessor, which did not pretend to be complete.

Like the other mathematicians of his time he also applied to astronomy, as we learn from his having, like Eratosthenes, a sobriquet derived from a Greek letter. He was called Epsilon $(\varepsilon)$ from his perpetual attention to the moon, which resembled the form in which that letter was written. After his time, the principal progress of Greek mathematicians was made in astronomy. Either that the powers of the Greek geometry had reached their limit, or that inventive genius became more scarce, succeeding generations contented themselves almost entirely with commenting upon what had been done by the giants in geometry who were the first race. Thus Hypatia the daughter of Theon, Pappus, Serenus, and Eutocius wrote commentaries upon Apollonius; Eutocius also upon Archimedes; Theon upon Euclid: and it is from such of these as are still extant that much of the preceding information is derived. They had means of knowledge which have since been lost; and we might have been able to give a much more complete and accurate account of the extensive series of inventions which the old mathematics exhibited, if time had spared the histories of this science by Theophrastus and Eudemus, from which later writers seem to have drawn the light whose scattered rays reflected from them we have been attempting to collect.

translation from the Arabic in 1661. The comparison of the conjectural with the ancient Apollonius is to the credit of both. Viviani's propositions are more varied and extensive, but perhaps those of the ancient geometer are more recondite and difficult. 


\title{
GREEK PHYSICS.
}

\author{
BY \\ PETER BARLOW, EsQ., F.R.S.,
}

pRofessor at the ROYAl Militari aCADEMY, WOOLWiCh;

AND

The late Rev. FRANCIS LUNN, M.A., F.R.S.,

ST. JOHN'S COLLEGE, CAMBRIDGE.

REPRINTED FROM THE ORIGINAL EDITION. 
The Historical Introductions, prefixed by Professor Barlow to his Treatises on the Physical Soiences, contained in the Second Division of the Encyclopædia Metropolitana, are frequently referred to in Professor WHEwell's History of Greek Mathematics, which precedes this article: The following passages have, on that account, been extracted from those Treatises and appended here, for the sake of easy reference. The last of the six extracts is made from the 'History of Electricity,' by the late Rev. Francis LunN. The reader who desires further information than is afforded by the passages now cited, is referred to the History of Greek Physics, contained in the History of the Inductive Sciences, by Professor WhewelL.EDIToR. 


\section{GREEK PHYSICS.}

\section{ASTRONOMY.}

IT would be useless, if even the nature of our work would admit of it, General to attempt to trace the history of this science from its earliest state of view. infancy, which is probably nearly coeval with that of society itself; at least if we regard the rude observations of shepherds and herdsmen as exhibiting the first dawn of astronomy. A man must be strangely divested of the curiosity peculiar to his species, who, while exposed to the varying canopy of the heavens, through successive nights and seasons, could suffer such a brilliant spectacle to pass repeatedly before him, without noticing the fixed or variable objects there presented to his view ; and his attention, once drawn to a contemplation of the firmament, he would remark the invariable position of the greater number of those bodies with regard to each other; the irregular motion of others; and hence, by some denomination or other, we should have a distinction made between what we now call the fixed stars and the planets; while the sun and moon are, in their appearances, sufficiently distinct from the rest of the heavenly bodies, to have called for a farther distinguishing appellation, and to have claimed the particular regard of these rude observers.

Such was probably the origin of astronomy; and in this state, in all likelihood, it might remain for many ages, and in many countries unknown to and unconnected with each other. The length of the year, the duration of a lunar revolution, the particular rising of certain stars at certain seasons, and a few other common and obvious phenomena, might therefore be predicted with a certain degree of accuracy, long: before those observations assumed any thing like a scientific form, and long anterior to that time from which we date the origin of astronomy as a science, properly so called.

The honour of being the first inventors of this sublime study has Claims of the been attributed to various nations; the Chaldeans, the Egyptians, the chaldeans, Chilese, the Indians, have each had their advocates amongst our astronomical historians; and even a certain unknown people have been created by the enthusiasm of some writers, of whom all traces are supposed to have been long lost, but to whom all original knowledge of astronomy has been attributed. The more closely, however, we examine the claims of these actual or imaginary people, the more we shall be convinced that their astronomy consisted of little more than we have indicated above; viz., a tolerable approximation to certain periods, and to the reappearance of certain phenomena, that required nothing more than a continued and patient observation of stated occur- 
rences, which, as we have observed, could not long remain unnoticed even in the most infant state of society.

Egyptians. We may judge of the state of Egyptian astronomy from the circumstance of Thales having first taught them how to find the heights of the pyramids from the length of their shadows. It is true that they had some idea of the length of the year, and had, in a certain measure, approximated towards a determination of the obliquity of the ecliptic, or of the path of the sun, which they stated to be $24^{\circ}$. The Chaldeans appear to have made some rude observations on eclipses, but still little scientific knowledge can be attributed to this people; who, after observing these phenomena, were contented to explain them by tearhing that the two great luminaries of the heavens were only on fire on one side, and that eclipses were occasioned by the accidental turning of their dark sides towards us. And again, that these bodies were carried round the heavens in chariots, close on all sides except one, in which there was a round hole, and that a total or partial eclipse was occasioned by the complete or partial shutting of this aperture. Similar absurd and extravagant notions will be found amongst all the early pretenders to the study of astronomy; but we cannot concede to such knowledge and pretences the term science; they had, in fact, no science, they had amassed together a number of rude observations, and had been thus enabled to determine certain periods, and to predict some few phenomena; but we have no proof, nor even any reason whatever to imagine, from any facts that have been handed down to us, that these predictions rested upon any other basis than that of simply observing the repeated returns of these appearances within certain periods.

Astronomy as it was receiverl by the early Greeks.

Thales.

B. c. 600 .
If to the knowledge above indicated, we add an arbitrary collection of certain clusters or groups of stars into constellations; the division of the zodiac into twelve signs, corresponding to the twelve months of the year; into twenty-seven or twenty-eight hours, answering to the daily motion of the moon; an obscure idea of the revolution of the earth upon its axis, which was afterwards lost; a knowledge of five planets; and some contradictory notions respecting the nature and motion of comets, we shall have a pretty correct picture of the state of astronomy as it was received amongst the Greeks; from whom it first derived its scientific character. It is, therefore, only from this period that we shall commence our historical sketch.

Thales is generally considered as the founder of astronomy amongst the Greeks. This philosopher, who must have flourished about 600 years before the commencement of the Christian era, is said to have taught that the stars were fire, or that they shone by means of their own light; the moon received her light from the sun, and that she became invisible in her conjunctions, in consequence of being hidden or absorbed in the solar rays, which it must be acknowledged is but an obscure way of saying that she then turned towards us her unenlightened hemisphere. He taught farther that the earth is spherical, 
and placed in the centre of the world; he divided the heavens, or rather found them divided by five circles: the equator, the two tropics, and the arctic and antarctic circles. The year he made to consist of 365 days ; and determined "the motion of the sun in declination." What is meant by this expression is not very easy to comprehend; if it only means that he discovered such a motion, it can scarcely be considered as correct, as it must have been known prior to his time ; viz., to the first observers; and it cannot mean that he laid down rules for computing it, as we have every reason to know that the most simple principles of trigonometry were not propagated till many centuries after his time.

Thales is also said to have first observed an eclipse, and to have Predicts an predicted that celebrated one which terminated the war between the eclipse. Medes and the Lydians; an eclipse on which much has been written, but no very satisfactory conclusion arrived at. Herodotus says, "it happened that the day was changed suddenly into night, a change which Thales the Milesian had announced to the people of Ionia, assigning for the limit of his prediction, the year in which the change actually took place." Thales had therefore neither predicted the day nor the month; and, in all probability, he had no other principle to proceed upon, than the Chaldean period of eclipses already alluded to in the preceding part of this article.

The pointed declaration of the historian, that the limits assigned by the astronomer for the appearance of this phenomenon was the year in which it happened, is a pretty obvious proof of the low state of astronomical science at this time, and it would be of little importance whether the eclipse was itself partial or total; but as there is little doubt that such an event actually took place, it becomes a matter of high importance in chronology, to ascertain whether it was such as it is described, viz., a total eclipse; for no partial obscuration of the sun's light would accord with the description of Herodotus, of the day being suddenly changed into night; and such a phenomenon in any particular place being an extremely rare occurrence, it would, if correct, enable us to determine not only the year, but the very day and hour at which it happened, and thus furnish at least one indisputable period in chronology and history.

Various dates have been assigned to this eclipse. Pliny places it in Dates the fourth year of the forty-eighth Olympiad which answers to the assigned to year 585 B.c. ('Hist. Nat.' lib. 2, cap. 12); a similar opinion has been advanced by Cicero ('De Divinat.' lib. 1, § 49), and probably by Eudemus ('Clement. Alex. Strom.' lib. 1, p. 354); by Newton ('Chron. of Anc. Kings,' amended); Riccioli ('Chron. Reform,' vol. i. p. 228); Desvignoles, ('Chronol.' lib. 4, cap. 5, § 7, \&c.); and by Brosses ('Mém. de l'Acad. des Belles Lettres,' tom. xxi. Mém. p. 33).

Scaliger, in two of his writings ('Animad. ad Euseb.,' p. 89, and in ' $\mathrm{O} \lambda v \mu$. $\mathbf{a} \nu a \gamma \rho a \phi \eta ')$, has adopted also the opinion of Pliny; but 
in another work ('De Emen. Temp. in Can. Isag.' p. 321), he fixes the date of this eclipse to be the 1 st of October, 583 в. с. Calvisius states it in his 'Opus Chron.', to have taken place in 607 в. c. Petavius says it happened July 9 th, 597 в. с. ('De Doct. 'Temp.' lib. 10, cap. 1), which date has likewise been adopted by Marsham, Bouhier, Corsini, and by M. Larcher the French translator of Herodotus (tom. i. p. 335.) Usher is of opinion that it happened 601 B. c.; and Bayer, May 18, 603 B. C. ; which latter opinion has been supported by two English astronomers, Costard and Stukeley ('Phil. Trans.' for 1753). But Volney attempts to show, in his 'Chronologie d'Herodote,' that it could be no other than the eclipse which happened February 3rd, 626 B. C.

Mr. F. Bailly has examined with great care and labour the probability of these several statements, from which it appears, that most of the eclipses above alluded to happened under circumstances which render it absolutely impossible any of them should be that alluded to by Herodotus; most of them were not even visible in that country, which must necessarily have been the scene of action between the Medes and the Lydians, and none of them was total in those places. He has, therefore, with great perseverance, by means of the latest astronomical tables of the 'Bureau des Longitudes,' computed backward to find whether any eclipse of the sun actually happened within the probable limits of the event recorded by the historian, and the result of his research is, that on the 10th of September, 610 B. C., there was a solar eclipse, which was total in some parts of Asia Minor; and which, he therefore concludes, with great probability, was the identical one referred to by Herodotus. Admitting, therefore, the conclusion, we have one decided point of time to which we are enabled to refer with confidence, at which time, the state of astronomy is known to have been such as we have described. See 'Phil. 'Trans.' for 1811.

Anaximan-

der,

Anaximenes, A naxagoras.
B. c. $\$ 30$.

Pythagoras. B. c. 540 .
The successors of Thales, Anaximander, Anaximenes, and Anaxagoras, contributed considerably to the advancement of astronomy. The first is said to have invented or introduced the gnomon into Greece; to have observed the obliquity of the ecliptic; and taught that the earth was spherical, and the centre of the universe, and that the sun was not less than it. He is also said to have made the first globe, and to have set up a sun-dial at Lacedæmon, which is the first we hear of among the Greeks; though some are of opinion that these pieces of knowledge were brought from Babylon by Pherecydes, a contemporary of Anaximander. Anaxagoras also predicted an eclipse which happened in the fifth year of the Peloponnesian war; and taught that the moon was habitable, consisting of hills, valleys, and waters, like the earth. His contemporary Pythagoras, however, greatly improved not only astronomy and mathematics, but every other branch of philosophy. He taught that the universe was composed of four elements, and that it had the sun in the centre; that the earth was 
round, that we had antipodes; and that the moon reflected the rays of the sun; that the stars were worlds, containing earth, air, and ether; that the moon was inhabited like the earth; and that the comets were a kind of wandering stars, disappearing in the superior parts of their orbits, and becoming visible only in the lower parts of them. The white colour of the milky-way he ascribed to the brightness of a great number of small stars; and he supposed the distances of the moon and planets from the earth to be in certain harmonic proportion to one another. He is said also to have exhibited the oblique course of the sun in the ecliptic and the tropical circles, by means of an artificial sphere; and he first taught that the planet Venus is both the evening and morning star. This philosopher is said to have been taken prisoner by Cambyses, and thus to have become acquainted with all the mysteries of the Persian magi; after which he settled at Crotona in Italy, and founded the Italian sect.

About 440 years before the Christian era, Philolaus, a celebrated Philolaus. Pythagorean, asserted the annual motion of the earth round the sun; and soon after Hicetas, a Syracusan, taught its diurnal motion on its own axis. About this time also flourished Meton and Euctemon at Athens, who took an exact observation of the summer solstice 432 years before Christ; which is the oldest observation of the kind we have, excepting some doubtful ones of the Chinese. Meton is said to have composed a cycle of nineteen years, which still bears his name; and he marked the risings and settings of the stars, and what seasons they pointed out: in all of which he was assisted by his companion Euctemon. The science, however, was obscured by Plato and Aristotle, who embraced the system afterwards called the 'Ptolemaic,' which places the earth in the centre of the universe.

After Philolaus, the next astronomer we meet with of great repu- Eudoxus. tation is Eudoxus, who flourished 370 B. c. He was a contemporary with Aristotle though considerably older, and is greatly celebrated for his skill in this science. He is said to have been the first to apply geometry to astronomy, and is supposed to be the inventor of many of the propositions attributed to Euclid. Having travelled into Egypt in the early part of his life, he obtained a recommendation from Agesilaus to Nectanebus, king of Egypt, and by his means got access to the priests, who were then held to have great knowledge of astronomy; after which he taught in Asia and Italy. Seneca tells us, that he brought the knowledge of astronomy, $i$. e., of the planetary motions, from Egypt into Greece ; and according to Archimedes, his opinion was, that the diameter of the sun was nine times that of the moon. He was also acquainted with the method of drawing a sun-dial on a plane.

Soon after Eudoxus, we meet with Calippus, wlose system of the Calippus. celestial sphere is mentioned by Aristotle; but he is better known for B. C. 330 . a period of seventy-six years, containing four corrected Metonic periods, and which had its beginning at the summer solstice, in the year 330 B. c. And it was about this time, or rather earlier, that the Greeks 
having begun to plant colonies in Italy, Gaul, and Egypt, became acquainted with the Pythagorean system, and the notions of the ancient Druids concerning astronomy.

Autolycus.

B. c. 300 .

Passing over the names of various other astronomers of this period, who appear to have done very little towards the advancement of the science, we come to Autolycus, the most ancient writer whose works have been handed down to our time. He wrote two books, viz., ' Of the Sphere which moves,' and the other, 'On the Risings and Settings of the Stars.' These works were composed about 300 B. с.

We have now passed over a period of three handred years from the time of Thales, and, therefore, by making a few extracts from these works of Autolycus, we shall be enabled to form some idea of the progress of astronomy during this period. In the work on the moveable sphere, we have several propositions, of which the following are the most important:-

Earliest work

1. If a sphere move uniformly about its axis, all the points on its extant on astronomy. surface which are not in its axis, will describe parallel circles, having for their common poles, those of the sphere itself, and of which all the planes will be perpendicular to the axis.

2. All these points will describe, of their respective circles, similar arcs in equal times.

3. Reciprocally, similar arcs will indicate equal time.

4. If a great fixed circle, perpendicular to the axis, divide the sphere into two hemispheres, the one visible, the other invisible, and that the sphere turns about its axis, those points on the surface that are hidden will never rise, and those that are visible will never set. This is what we now denominate a parallel sphere; the great fixed circle corresponding with our equator.

5. If a great circle pass through the poles, all the points of the surface will rise and set alternately. This corresponds to our horizon, and to our right sphere.

6. If the great circle be oblique to the axis, it will touch two equal parallel circles; of which, that adjacent to the one pole will be always apparent, the other always invisible.

The first of these circles was called by the Greeks (although not by this author), as we still denominate it, the arctic circle, and the other the antarctic circle.

7. If the horizon be oblique, the circles, perpendicular to the axis, will always have their points of rising and setting in the same points of the horizon, to which they are all equally inclined.

8. The great circles which touch the arctic and antarctic circle, will, during the complete revolution of the sphere, twice coincide with the horizon.

9. In the oblique sphere, of all the points which rise at the same instant, those which are nearest to the visible pole will set last; and of the points which set at the same instant, those that are nearest the same pole will rise first. 
10. In the oblique sphere, every circle which passes through the poles, will be perpendicular to the horizon twice in the course of one complete revolution.

We omit some other propositions of this author, which are of less Remarks on importance than the above; and even those which we have given, are such as one would imagine could not have escaped the observation of any one who would think of employing an artificial sphere to represent the celestial motions; yet from the tenor of the work in question, it would seem, that if they were known, they were never before, at least, embodied in the form of a regular treatise.

Here, then, we may begin to date the first scientific form of astronomy; because in this work, however low and elementary, we have an application of geometry to illustrate the motions of the heavenly bodies; but we shall still find two other centuries pass away, before the same principles were applied to actual computation.

Contemporary with Autolycus was Euclid; whose elements of geo- Euclid. metry, after so many ages, still maintain their pre-eminence, and contain all the propositions that are necessary for establishing every useful theorem in trigonometry; yet it is perfectly evident that no ideas were yet conceived of the latter science. Neither Euclid nor Archimedes, great as were their skill and talents in geometry, had any idea of the method of estimating the measure of any angle by the arc, which the two lines forming it intercepted; nor does it appear that they knew of any instrument whatever for taking angles; a very convincing proof of which appears in the process adopted by the latter justly-celebrated philosopher, in order to determine the apparent diameter of the sun.

Passing over the poet Aratus, who is supposed to have embodied Aristarchus. in his poem all the astronomical knowledge of the time in which he wrote, viz., 270 в. c., but who had not himself made any observations, we come to Aristarchus, who has left us a work, entitled 'Of Magnitudes and Distances ;' in which he teaches, that the moon receives her light from the sun, and that the earth is only a point in comparison with the sphere of the moon. He likewise added, that when the moon is dichotomized, we are in the plane of the circle which separates the enlightened part from the unenlightened, which is the most curious and original remark of this author; in this state of the moon, he also observes, that the angle subtended by the sum and moon, is one-thirtieth less than a right angle; which, in other words, is saying, that the angle is $87^{\circ}$, whereas we now know that this angle exceeds $89^{\circ} 50^{\prime}$. In another proposition he asserts, that the breadth of the shadow of the earth is equal to two semi-diameters of the moon, whereas these are to each other as 83 to 64 . In his sixth proposition, he states the apparent diameter of the moon to be one-fifteenth part of a sign, or $2^{\circ}$; whereas we know that it is only about half a degree. Again, the disiance of the earth from the moon being assumed as unity, the distance of the moon from the sun was said to be $17 \cdot 107$, and the distance of the earth from the sun $19 \cdot 081$. Such was the astronomical 
knowledge in the time of Aristarchus, who lived about two hundred and sixty-four years before the Christian era.

Eratosthenes. In order of time we pass now to Eratosthenes, who may, perhaps, B. c. 230, with more propriety than Autolycus, be considered as the founder of astronomical science; particularly if it be true that he placed in the portico of Alexandria certain armillary spheres; of which so much use was afterwards made, and which, it is said, he owed to the munificence of Ptolemy Euergetes, who called him to Alexandria, and gave him the charge and direction of his library.

Ancient armillary sphere.

Determination of the equinoxes.

Magnitnde of the earth.
According to the description given of these armillaries by Ptolemy, they were assemblages of different circles; the principal one of which served as a meridian; the equator, the ecliptic, and the two colures, constituted an interior assemblage, which turned on the poles of the equator. There was another circle, which turned on the poles of the ecliptic, and carried an index to point out the division at which it stopped. The instrument of which the above appears to be the general construction was applied to various uses; amongst others, it served to determine the equinoxes, after the following manner:-The equator of the instrument being pointed with great care in the plane of the celestial equator, the observer ascertained, by watching the moment when neither the upper nor the lower surface was enlightened by the sun; or rather, which was less liable to error, when the shadow of the anterior convex portion of the circle completely covered the concave part on which it. was projected. This instant of time was evidently that of the equinox. And if this did not happen at a time when the sun shone, two observations were selected, in which the shadow was projected on the concave part of the circle in opposite directions; and the mean of the interval between these observations was accounted the time of the equinox. At this time we find enu-

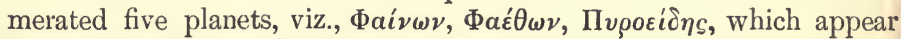
to indicate Jupiter, Saturn, and Mars; and to which were added Venus and Mercury.

Eratosthenes not only taught the spherical figure of the earth, but attempted to ascertain its actual circumference, by measuring, as exactly as could be done in his time, the length of a certain terrestrial arc, and then finding the astronomical arc in degrees intercepted between the zeniths of the two places. The segment of the meridian which he fixed upon for this purpose, was that between Alexandria and Syene. The measured distance of which was found to be 5,000 stadia. The angle of the shadow upon the scaphia, which was observed at Alexandria, was equal to the fiftieth part of the circle; and at Syene there was no shadow from this gnomon at noonday of the summer solstice. That this last observation might be the more accurately taken, they dug a deep well, which, being perpendicular, was completely illuminated at the bottom when the sun was on the meridian. The exact quantity which this philosopher assigned to the circumference of the earth is not known; at least, different opinions have been advanced: 
some state it at 250,000, and others at 252,000 stadia: the length of this unit of measure is also somewhat uncertain. It is, however, of small importance, as we may be pretty well convinced that, by such means as he employed, no very accurate conclusion could be expected; it is sufficient that he attempted the solution of the problem in a very rational manner, to entitle him to the honour of being one of the most celebrated of the Grecian astronomers.

Eratosthenes also observed the obliquity of the ecliptic, and made obliquity of it to consist of $\frac{1 \frac{1}{16} 6}{6}$ th of a circumference, which answers to about the ecliptic. $23^{\circ} 51^{\prime} 19 \cdot 5^{\prime \prime}$. This observation is commonly stated to have been made in the year 230 B. C.

Archimedes, the justly-celebrated geometer of Syracuse, was con- Archimedes. temporary with Eratosthenes; and although most conspicuous as a mechanic and geometrician, the great impulse which he gave to the sciences generally, will not admit of our passing him over in silence in this history. All that we have of this author with reference to astronomy, is found in his 'Arenarius,' a work which lias been translated into most modern languages; where he undertakes to prove, that the numerical denominations which he has indicated in his books to Zeuxippus, are more than sufficient to express the grains of sand that would compose a globe, not only as large as our earth, but as the whole universe. He supposes that the circumference of the earth is not more than three million stadia; that the diameter of the earth is greater than that of the moon, and less than that of the sun; that the diameter of the sun is 300 times greater than that of the moon; and moreover, that the diameter of the sun is greater than the side of the inscribed chiliagon, that is greater than $\frac{36}{1^{6} 0} 0$, or $21^{\prime} 36^{\prime \prime}$.

The manner in which he arrives at his conclusion is very interesting, Archimedes as showing the state of the sciences at this time, even in the hands of ascertains this great master:- - I have used," says he, "every effort to deter- diameter of mine, by means of instruments, the angle which comprehends the sun, and has its summit at the eye of the observer; but this is not easy; for neither our eyes nor our hands, nor any of the means which it is possible for us to employ, have the requisite precision to obtain this measure. This, however, is not the place to enlarge upon such a subject. It will suffice to demonstrate that which I have advanced, to measure an angle which is not greater than that which includes the sun's apparent diameter, and has its summit in our eyes; and then to take another angle which is not less than that of the sun, and which equally has its summit in our eyes. Having, therefore, directed a long ruler on a horizontal plane towards the point of the horizon where the sun ought to rise, I place a small cylinder perpendicularly on this ruler. When the sun is on the horizon, and we look at it without injury, I direct the ruler towards the sun, the eye being at one of its extremities, and the cylinder is placed between the sun and the eye in such a manner, that it entirely conceals the sun from view. I then remove the cylinder farther from the eye, until the sum begins [G. R. P.] 
to be perceived by a thin stream of light on each side of the cylinder. Now, if the eye perceived the sun from a single point, it would suffice to draw from that point tangential lines to the two sides of the cylinder. The angle included between these lines would be a little less than the apparent diameter of the sun; because there is a ray of light on each side. But as our eyes are not a single point, I have taken another round body, not less than the interval between the two pupils; and placing this body at the point of sight at the end of the ruler, and drawing tangents to the two bodies, of which one is cylindric, I obtained the angle subtended by the suns (apparent) diameter. Now the body, which is not less than the preceding distance (between the pupils), I determine thus: I take two equal cylinders, one white, the other black, and place them before me; the white further off, the other near, so near indeed as to touch my face. If these two cylinders are less than the distance between the eyes, the nearer cylinder will not entirely cover the one that is more remote, and there will appear on both sides some white part of that remote cylinder. By different trials, we may find cylinders of such magnitude, that the one shall completely conceal the other: we then have the measure of our view (the distance between the pupils), and an angle, which is not smaller than that in which the sun appears. Now, having applied these angles successively to a quarter of a circle, I have found that one of them has less than its 164th part, and the other greater than its 200 th part. It is therefore evident, that the angle which includes the sun, and has its summit at our eye, is greater than the 164th part of a right angle, and less than the 200th part of a right angle."

By this process, Archimedes found the sun's apparent diameter to be between $27^{\prime}$ and $32^{\prime} 56^{\prime \prime}$.

Singular accuracy in the result.

It is not a little remarkable, considering the obvious inaccuracy of the method, that the maximum limit thus obtained, differs only $\frac{1}{3}$ of a minute from $32^{\prime} 35^{\circ} 6^{\prime \prime}$, which is the largest angle actually subtended by the sun's diameter, and which is observed about the time of the winter solstice, when the sun is nearest to the earth. But this quotation from the 'Arenarius' is extremely curious also on other accounts. We may learn from it, first, that Archimedes, with all his fecundity of genius, and with all the variety of his inventions, had no means of diminishing the effect of the sun's rays upon his eyes, and therefore performed this interesting experiment when the sun was in the horizon, that the optic organ might sustain its light without inconvenience. It also proves to us, that there was not then any instrument known to Archimedes, which he thought capable of giving the diameter of the sun, to within four or six minutes; since he found it necessary to devise means at which he stopped, after an attempt not very satisfactory. We see, further, that he carried his angles, or their chords, over a quarter of a circle; but he does not say expressly that his arc had been divided; to render his language accurately, it is simply 
requisite to say, having carried one of the chords 200 times over upon the arc, he found it exhausted; and that the other chords could only be applied 164 times upon the quadrant.

We see, also, that Archimedes had not the means of computing the angle at the vertex of an isosceles triangle, of which he knew the base and the two equal sides. He was obliged to recur to a graphical operation as uncertain as the observation itself. Thus he was entirely ignorant even of rectilinear trigonometry, and he had not any notion of computing the chords of circular arcs.

We now come to the great father of true astronomy, Hipparchus; Hipparchus. but our limits will not admit of our entering very deeply into his discoveries and improvements. One of his first cares was to rectify the length of the year, which before his time we have seen had been made to consist of 365 days and 6 hours. By comparing one of his own observations at the summer solstice with a similar observation made 145 years before by Aristarchus, he shortened the year about 7 minutes; making it to consist of 365 days, 5 hours, 53 minutes; which, however, was not sufficient: but the cause of the mistake is said to have rested principally with Aristarchus and not with Hipparchus; for the observations of the latter, compared with those of modern times, give 365 days, 5 hours, 48 min. $49 \frac{1}{2}$ sec. for the duration of the year; a result which exceeds the truth very little more than a second. It is to be observed, however, that this is no very exact criterion, unless the same be compared with the observation of the more ancient observer; for supposing all the error on the side of Hipparchus, it is more divided by comparing it with others at the distance of 19 or 20 centuries, than in comparing it with one, where the distance of time is only 145 years.

One of the greatest benefits which astronomy derived from this Introduction philosopher was his enunciation and demonstration of the method of of trigonocomputing triangles, whether plane or spherical. He constructed a chords. table of chords, which he applied nearly in the same manner as we now do our tables of sines. As an observer, however, he rendered great service to the doctrine of astronomy, having made much more numerous observations than any of his predecessors, and upon far more accurate principles. He established the theory of the sun's Establishes motion in such a manner, that Ptolemy, 130 years afterwards, found the theory, no essential alteration requisite; he determined also the first lunar motion, inequality, and gave the motions of the moon's apogee and of its first lunar nodes, which Ptolemy afterwards very slightly modified. Hipparchus inequality. also prepared the way for the discovery of the second lunar inequality, and from his observation it was, that the fact of the precession of the equinoxes was first inferred. He employed the transit of the stars Hour of the over the meridian to find the hour of the night, and invented the $\begin{gathered}\text { night found } \\ \text { by the stars. }\end{gathered}$ planisphere, or the means of representing the concave sphere of the stars, on a plane, and thence deduced the solution of problems in spherical astronomy, with considerable exactness and facility. To him also we owe the happy idea of marking the position of towns and 
cities, as we do those of the stars, by circles drawn through the poles perpendicularly to the equator; that is, by latitudes and by circles parallel to the equator, corresponding to our longitudes. From his projection it is, that our maps and nautical charts are now principally constructed, and his method, by means of eclipses, was for a long time the only one by which the longitude could be determined.

Catalogue of Another most important work of Hipparchus, was his formation of the stars.

a catalogue of the stars. The appearance of a new star in his time, caused him to form the grand project of enabling future astronomers to ascertain whether the general picture of the heavens were always the same. This he aimed to effect, by attempting the actual enumeration of the stars. The magnitude and difficulty of the undertaking did not deter this indefatigable astronomer; he prepared and arranged an extensive catalogue of the fixed stars, which subsequently served as the basis of that of Ptolemy. So great, indeed, is the merit of this prince of Grecian astronomy, that the enthusiastic language in which Pliny speaks of him in his Hist. Nat. (lib. ii. cap. 26) may rather be admired than censured.

Ptolemy.

A. c. 120.

After Hipparchus, we meet with no astronomer of eminence amongst the Greeks till the time of Ptolemy, who flourished between the years 125 and 140 of the Christian era; a space of nearly three hundred years. There were, however, some astronomical writers, both Greeks and Romans in the course of this time, whom it may not be amiss to enumerate, although the little progress that the science made in their hands will exempt us from the necessity of entering minutely into an analysis of their several works : these were, Geminus, who lived about 70 years B. C., whose book is entitled 'Introduction to the Phenomena;' Achilles Tatius, of about the same period; Cleomedes, who lived in the time of Augustus; Theodosius, Menelaus, and Hypsicles, who are supposed to have written about the year 50 B. c. ; Manilius, Strabo, Posidonius, and Cicero, who were about half a century later; after which, we meet with no one to whom it is at all necessary even to refer, till we come to Ptolemy, who was born in the year of Christ 70; and who made, as we have stated above, most of his observations between the years 125 and 140 of our era.

Various

labours of

Ptolemy has rendered all succeeding astronomers indebted to him, Ptolemy. both for his own observations, which were very numerous, and his construction of various tables, but most of all for the important collection which he made of all astronomical knowledge prior to his time,

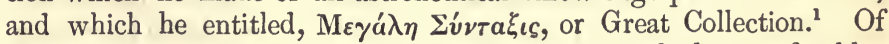
his own labours, we may mention his theory and calculation of tables of the planets, and his determination, with a precision little to be expected in his time, of the ratio of their epicycles to their mean distances; that is to say, in other terms, the ratio of their mean distances to the distance of the earth from the sun. This theory, imperfect as

1 Called by the Arabs, who translated it, the Almagest (from the Arabic art. al, and the Greek superlative megistos, greatest). 
it was, was adopted and generally admitted, for the space of fourteen centuries, during which time, it was transmitted to the Arabs, the Persians, and the Indians, with whom it is still held sacred.

To this celebrated Grecian we also owe the substitution of the Sines sines of arcs instead of their chords; as also the first enumeration of introduced some important theorems in trigonometry.

Ptolemy was the author of that system of astronomy which still Ptolemy's bears his name; or, if he did not entirely invent it (as there is great to prove the reason to suppose he did not), he enforced it by such arguments as led immobility to its establishment; and it was afterwards rendered sacred through the stupid bigotry and intolerance of the Romish church. He endeavours to prove the absolute immobility of the earth, by observing, "If the earth had a motion of translation common to other heavy bodies, it would, in consequence of its superior mass, precede them in space, and pass even beyond the bounds of the heavens, leaving all the animals and other bodies without any support but air; which are consequences to the last degree ridiculous and absurd." In the same place he adds, "Some persons pretend, that there is nothing to prevent us from supposing that the heavens remain immoveable, while the earth turns on its own axis from west to east, making this revolution in a day nearly; or that, if the heavens and the earth both turn, it is in a ratio corresponding with the relations we have observed between them. It is true, that as to the stars themselves, and considering only their phenomena, there is nothing to prevent us, for the sake of simplicity, from making such a supposition. But these people are not aware how ridiculous their opinion is, when considered with reference to events which take place about us; for if we concede to them that the lightest bodies, consisting of parts the most subtle, are not possessed of levity (which is contrary to nature), or that they move not differently from bodies of a contrary kind (although we daily witness the reverse); or, if we concede to them that the most compact and heaviest bodies possess a rapid and constant motion of their own (while, it is well known, that they yield only with difficulty to the impulses we give to them), still, they would be-obliged to acknowledge, that the earth, by its revolution, would have a motion more rapid than any of those bodies which encompass it, in consequence of the great circuit through which it must pass in so short a period; wherefore such bodies as are not supported on it, would always appear to possess a motion contrary to itself; and neither clouds, nor any projected bodies, nor birds in flight, would ever appear to move towards the east; since the earth, always preceding them in this direction, would anticipate them in their motion; and everything, except the earth itself, would constantly appear to be retiring towards the west."

If we did not feel convinced that, in certain cases, even the errors and false reasoning of such a man as Ptolemy, possess a greater interest than the more correct and refined arguments of minor 
philosophers, we should certainly not have laid before our readers this extract from the introduction to the 'Almagest;' but considering it as the defence of an hypothesis, which maintained its ascendency for fourteen centuries amongst all nations, and which is still held sacred throughout every part of Asia, it is impossible to divest it of its interest and importance.

Analysis of the Almagest.

Theorems in trigonometry.

Climates.

Length of the year, \&c.

The other part of this great work is more worthy of the talents of its author, and is more deserving of our attention; but the limits of this article will not admit of our giving more than a very concise abstract of its contents. The first book, beside what we have hitherto mentioned, exhibits a highly-interesting specimen of the ancient trigonometry; and the method of computing the chords of arcs, which, in fact, involves our fundamental theorems of trigonometry, though expressed in a manner totally different.

Ptolemy first shows, how to find the sides of a pentagon, decagon, hexagon, square, and equilateral triangle, inscribed in a circle, which he exhibits in parts of the diameter, this being supposed divided into 120. He next demonstrates a theorem equivalent to our expression $\sin (a-b)=\sin a \cos b-\sin b \cos a$; by means of which he finds the chord of the difference of any two arcs, whose chords are known. He then finds the chord of any half arc, that of the whole arc being given, and then demonstrates what is equivalent to our formula for the sine of two arcs; that is, $\sin (a+b)=\sin a \cos b+\sin b \cos a$; and by means of this he computes the chord to every half degree of the semicircle. These theorems it may be said belong rather to the history of trigonometry than to that of astronomy ; but we trust that the obvious dependence of the latter science upon the former, will be found to justify us in introducing them to the reader in this place.

We are next presented with a table of climates nearly equivalent to our nonagesimal tables, and it is not a little singular, that amongst them, we find none appertaining to the latitude of Alexandria; because, without such an auxiliary, Ptolemy must have contented himself with interpolations, which were not only difficult to make, but attended at the same time with great inaccuracy; a circumstance from which it has been concluded, that Ptolemy himself made few observations, or that he was not very particular concerning the accuracy of his calculations. The examination of this question would carry us too far out of our track to admit of our entering upon it in this place; but the reader may see it developed in all requisite detail, in the learned ' History of Astronomy,' lately published by Delambre.

Having passed over the above preliminary details, the author treats of the length of the year, the motion of the sun, the mean and apparent anomaly, \&c. \&c. The length of the year, according to the sexagesimal notation, he makes $365 \mathrm{~d} .14^{\prime} 48^{\prime \prime}$, which answers to 365 d. 5 h. $55^{\prime} 12^{\prime \prime}$; the diurnal motion of the sun is stated to be $0^{\circ} 59^{\prime} 8^{\prime \prime} 7^{\prime \prime \prime} 13^{\mathrm{iv}} 12^{\mathrm{v}} 31^{\mathrm{vi}}$, and the horary motion $2^{\prime} 27^{\prime \prime} 50^{\prime \prime \prime}$ $43^{\text {iv }} 3^{\mathrm{v}} 1^{\mathrm{vi}}$. To this is also added two tables, one of the mean 
motion of the sun,-and the other of the solar anomaly. 'The fourth book of the 'Almagest' is employed in treating of the motion of the moon, being prefaced by a few remarks respecting the observations which are most useful for that purpose: he then gives an abstract of all the lunar motions, with a table of them; in the first of which the motion is exhibited for periods of eighteen years : in the second for years and hours; and in the third for Egyptian months and days. Four other columns of the same table present the number of degrees which belong to each of the times indicated in the first column; viz. the second, the longitude; the third, the anomaly; the fourth, the latitude; and the fifth, the elongation.

The author next treats of various subjects connected with the Lunar lunar motion; as, for instance, its general anomaly ; its eccentricity ; the lunar parallax; the construction of instruments for observing the parallax ; the distance of the moon from the earth, which he states at $38 \cdot 4 \frac{1}{3}$ terrestrial radii, when in the quadratures; the apparent diameters of the sun and moon; the distance of the sun from the earth, which is stated at 1210 radii of the latter; and the relative magnitudes of the sun, moon, and earth. The diameters of these are stated to be to each other, as the numbers $18 \cdot 8,1$, and $3 \frac{2}{3}$; also their masses as $6644 \frac{1}{2}, 1$, and $39 \frac{1}{4}$.

The next book is entirely occupied with the doctrine of eclipses of the sun and the moon; the determination of their limits and durations; tables of conjunctions; and methods of computation and construction, \&c.

We cannot extend the analysis of this important work to a greater Particular length; but must content ourselves with a few remarks relative to deductions some of the deductions to which we have referred. We have seen that Ptolemy made the length of the year to be more than 365 days, $5 \mathrm{~h} .55 \mathrm{~m}$., which is about 6 minutes longer than it really is; but considering that the observations before his time, with the exception of those of Hipparchus, were very imperfect; and that the distance of time between these two celebrated astronomers, was not sufficient to determine such a question, with the means they possessed, to the greatest nicety, we may rather admire the near approximation to the truth, than be astonished at the difference between his result and that deduced from numerous and long-continued observations.

His researches on the theory of the sun and moon were, however, The evection attended with better success. Hipparchus had shown that these two discovered. bodies moved in orbits, of which the earth was not the centre; and Ptolemy demonstrated the same truths by new observations. $\mathrm{He}$, moreover, made another important discovery, which belongs exclusively to him, except so far as relates to the observations of Hipparchus, by a comparison of which with his own, his conclusion was deduced,we allude here to the second lunar inequality, at present distinguished by the term evection. It is known, generally, that the velocity of the moon in its orbit, is not always the same, and that it augments or 
diminishes, as the diameter of this satellite appears to increase or decrease ; we know, also, that it is greatest and least at the extremities of the line of the apsides of the lunar orbit. Ptolemy observed that from one revolution to ancther, the absolute quantities of these two extreme velocities varied, and that the more distant the sun was from the line of the apsides of the moon, the more the difference between these two velocities augmented; whence he concluded that the first inequality of the moon, which depends on the eccentricity of its orbit, is itself subject to an annual inequality, depending on the position of the line of the apsides of the lunar orbit with regard to the sun.

When we consider Ptoleny's system of astronomy, as founded upon a false hypothesis, the complication of his various epicycles, in order to account for the several phenomena of the heavenly bodies, and the rude state of the ancient astronomy, it is impossible to withhold our admiration of the persevering industry and penetrating genius of this justly-celebrated philosopher; who, with such means, was enabled to discover an irregularity which would seem to require the most delicate and refined aid of modern mechanics to be rendered perceptible.

The work of this author to which we have hitherto confined our remarks, is the "Almagest;" but Ptolemy also composed other treatises; which, if not equal to the above in importance, are still such as to be highly honourable to his memory and talents, particularly his geography.

Ptolemy's geography.

This work, although imperfect as to its detail, is notwithstanding founded upon correct principles; the places being marked by their latitude and longitude agreeably to the method of Hipparchus. As to the inaccuracies of their position, although they cannot be denied, they will readily be pardoned, when we consider that he had for the determination of the situation of cities and places of which he speaks, only a small number of observations, subject to considerable errors; and the mere report of travellers, whose observations we may readily grant were still more erroneous than those of his own. It requires many years to give great perfection to geography : even in the present time, when observations with accurate instruments have been made in every part of the globe, we are still finding corrections necessary ; a remarkable instance of which seems to have occurred lately (1818) to Captain Ross, in his voyage into Baffin's Bay, where he is said to have found some parts of the land laid down nearly a degree and a half out

1 The first printed edition of this celebrated performance was a Latin translation from the Arabic version of Cremoneus; which, however, abounds so much in the idiom of that language, as to render it nearly unintelligible, without a constant reference to the Greek text. This was published at Venice in 1515; and in 1538 the collection appeared in its original language, under the superintendence of Simon Grynaeus, at Basil, together with the eleven books of the Commentaries of Theon. The Greek text was again republished at the same place, with a Latin version, in 1541 ; and again, with all the works of Ptolemy, in 1551; and lastly, a splendid French edition, with the Greek text, by M. Halma, in three beautiful volumes, royal quarto, Paris, 1813. 
of their proper places. Many other minor pieces on astronomy and optics are also attributed to this author; but we have already extended our accounts of his works to a greater length than we had intended, and must now therefore pass on to his successors.

After the time of Ptolemy we find no Greek astronomers of Greeks eminence, although we have some few writers on this subject. The posterior to science of astronomy had now obviously passed its zenith, and began rapidly to decline. The Alexandrian school, it is true, still subsisted; but during the long period of five hundred years, all that can be said is, that the taste for, and the tradition of, the science was preserved, by various commentators on Hipparchus and Ptolemy ; of whom the most distinguished were Theon and the unfortunate Hypatia, his daughter. The latter is said to have herself computed certain astronomical tables, which are lost.

We now arrive at that period, so fatal to the Grecian sciences. Destruction These had for a long time taken refuge in the school of Alexandria ; ${ }_{\text {Alexandrian }}$ where, destitute of support and encouragement, they could not fail to school. degenerate. Still, however, they preserved, as we have said above, at least by tradition or imitation, some resemblance of the original ; but about the middle of the seventh century, a tremendous storm arose which threatened their total destruction. Filled with all the enthusiasm a military government is calculated to inspire, the successor of Mahomet ravaged that vast extent of country, which stretches from the east to the southern confines of Europe. All the cultivators of the arts and sciences who had from every nation assembled at Alexandria, were driven away with ignominy : some fell beneath the swords of their conquerors, while others fled into remote countries, to drag out the remainder of their lives in obscurity and distress. The places and the instruments which had been so useful in making an immense number of astronomical observations, were involved with the records of them, in one common ruin. The entire library, containing the works of so many eminent authors, which was the general depository of all human knowledge, was devoted to the devouring flames, by the Arabs; the caliph Omar observing, " that if they agreed with the Koran, they were useless; and if they did not, they ought to be destroyed :" a sentiment worthy of such a leader, and of the cause in which he was engaged. In the midst of this conflagration, the sun of Grecian science, which had long been declining from its meridian, finally set; never, perhaps, again to rise in those regions once so celebrated for the cultivation of every art and science that does honour to the human mind.

\section{MECHANICS.}

It is not our intention, in the present article, to enter upon the history of practical mechanics, but to confine ourselves exclusively to the theory of the science; we shall not, therefore, have to travel into those dark ages in which historical facts and fables are so blended, that it 
is nearly impossible to distinguish the one from the other. We learn Aristotle. at once from the writings of Aristotle, what the state of mechanical B. c. 330. theory was in his time: for we find him maintaining, that if one body have ten times the density of another, it will move with ten times the velocity, and that both being let fall from the same height, the one will fall through ten times the space that the other will in the same time; that the velocity of the same body, in different mediums, is reciprocally as their densities; and other equally absurd and inconsistent notions: and the difficulty which Galileo experienced in eradicating these false hypotheses, is a proof that, in the long interval between his time and that of the Stagirite, no theory of motion of a more intelligible and satisfactory description had appeared; although the doctrine of equilibrium had already begun to assume a scientific form in the hands of Archimedes and Pappus.

Archimedes. In the writings of Archimedes that are still extant, we find the B.c. 289. earliest attempt to reduce the laws of equilibrium to order and consistency. His work 'De Equiponderantibus' first unites and assimilates them with the pure principles of geometry. With this view, he began by considering the case of a lever or balance, supported on a fulcrum, and loaded with a weight at each extremity; then assuming it as an axiom, that when the two arms of the balance are equal, the two weights supposed in equilibrio are also necessarily equal, he demonstrated that if one of the arms of this lever be augmented in length, the weight applied to it in order to preserve the equilibrium must be reduced in the same ratio: and hence he concluded, that generally, when two weights suspended from the unequal arms of a lever are in equilibrio, these weights ought to be reciprocally proportional to the distance of their respective points of application from the centre of motion. He also observed, that each of these two weights produced the same pressure on the fulcrum or point of support as it would do if it were immediately applied at that point; he next proceeded to make this substitution mentally, and to combine the sum of the two weights with a third; thus attaining the same conclusion for an assemblage of the three weights as for the first two; and so on for any greater number. Hence he demonstrated, step by step, that there exists in every system of bodies, as well as in every single body, regarded as a system, a general centre, which we denominate the

Centre of gravity. centre of gravity. He then applied this theory to certain examples, and determined the centres of gravity in the parallelogram, the triangle, the trapezium, the area of the parabola, \&c. \&c.

This deduction, as we have above observed, was the first step towards establishing a rational theory of mechanics; and the surprise expressed by Hiero at the famous assertion of our philosopher, "Give me a place to stand on, and I will move the earth," shows at once the novelty of the doctrine, and the wretched state of mechanical knowledge prior to this discovery. To the same author has also been attributed the theory of the inclined plane, the pulley, and the screw; 
much doubt, however, remains upon this subject, and he is too rich in honours to render it desirable to increase them by any of uncertain authority. The machines which he constructed for the annoyance of the Roman army, during the siege of Syracuse, astonish even our present proficients in the science; but as no writings particularly descriptive of them have come down to us, we are in a great measure unacquainted with the nature of their powers: and while much of what is invaluable has been lost, much may have been exaggerated by succeeding writers, and little of scientific detail can be relied upon respecting them. No theory of mechanics, with the exception of what little is found in the collection of Pappus, and which is chiefly a repetition of the doctrines of Archimedes, appeared from the time of the latter philosopher, till near the end of the sixteenth century.

\section{HYDROSTATICS.}

We have seen, in the historical chapter prefixed to our treatise on Mechanics, that we are indebted to Archimedes for the first correct theoretical notions of the doctrine of statics; and it was the same celebrated philosopher who first established the fundamental laws of hydrostatics, or that branch of hydrodynamics which relates to the equilibrium of fluids.

With regard to the theory of the motion of bodies, whether solid or fluid, or the sciences of dynamics and hydraulics, they have had their birth wholly amongst the moderns; the former of these we have already noticed in the chapter above alluded to, and the latter will be introduced in its proper place in the present article.

According to some authors, the work which Archimedes composed Hydrostatics. on Hydrostatics, we owe, as it now exists, to a translation from the Archimedes. Arabic ; while others maintain that we have derived it from an immediate translation of the original Greek text. This work is entitled 'De Humido insidentibus,'- and is divided into two books. The basis on which this author founds his theory is this: that every particle of a fluid being supposed equal, and equally heavy, will remain in the place in which it is found; or that the whole mass will be in equilibrio when each particular particle is equally pressed in every direction. This equality of pressure, on which the state of equilibrium is made to depend, is demonstrated by experiment. The author afterwards examines the conditions which ought to obtain, in order that a solid homogeneous body, floating on a fluid, may take and preserve the situation of equilibrium: he shows that the centre of gravity of the body, and that of the part immersed, must be situated in the same vertical right line; that the weight of the body is equal to the portion of fluid displaced by it; that the body will be entirely immersed when its specific gravity is equal to, or exceeds that of the fluid; and other principles of the science of hydrostatics, which constitute the basis of the theory of present times. It appears, likewise, from his investigations, 
that two bodies of equal magnitude, both heavier than the fluid in which they are immersed, will lose equal parts of their weights ; and that reciprocally, when the weights lost in the same fluid are equal, the bodies are of equal magnitudes. The solution of the well-known problem of Archimedes, relative to the crown of Hiero, king of Syracuse, depends on the above principles.

Serew of Archimedes.

Besides the theoretical principles of Hydrostatics, we owe also to this philosopher, according to some authors, an ingenious hydraulic engine, called, from the name of its supposed inventor, the screw of Archimedes. It is employed in elevating water to small heights; and is very simple in its construction, and commodious in its application.

Diodorus asserts, that Archimedes invented this machine in his voyage to Egypt, and that the Egyptians afterwards employed it for the purpose of draining the marshes of that country; but Vitruvius, a contemporary of Diodorus, does not enumerate it amongst the discoveries of Archimedes, of whom he was nevertheless a great admirer; and Claudius Perrault, the translator and commentator of Vitruvius, adds, that the use Diodorus gives to this machine, namely, that it was employed to render Egypt habitable, by draining off the waters with which it was formerly inundated, makes it highly probable that the engine is of much earlier date than the time of the Syracusan philosopher. If this conjecture have any foundation, let us not mix with the legitimate claims of Archimedes, an invention which may be contested with him: he is too rich in other respects to render important the sacrifice of an equivocal right.

Ctesibiusand About a century after Archimedes, two mathematicians of the Hero.

Invention of the pump and siphon.

Alexandrian school, viz.: Ctesibius, and Hero, his disciple, invented the pump, the siphon, and the fountain of compression; the latter of which is to this day known under the appellation of Hero's fountain. We owe more especially to Ctesibius, a machine of the same kind, composed of a sucking and a forcing pump; so combined, that by their alternate action, the water is drawn and forced into a tube placed between them. The effects produced by these machines are in truth highly curious and interesting, and doubtless must have appeared very extraordinary to their original inventors, who, not knowing to what principle to attribute them, had recourse to their grand scheme of occult qualities, so commodious for explaining all the phenomena of nature. The water rose in the pumps, according to these philosophers, because nature abhorred a vacuum, and consequently the place abandoned by the piston was immediately supplied by the water: we know not whether at that time philosophers were aware of the limit to which the elevation of the water was confined; but we do know, that when this was pointed out to the great Galileo, the father of modern physics, he could only explain it by stating, that nature's abhorrence of a vacuum only extended to about thirty-three or thirty-four feet! Such were the illustrations of 
the ancients : their whole science consisted in the operations of secret and occult powers; they transferred from the moral to the physical world, the ideas of affection and hatred; both celestial and terrestrial bodies had their sympathies and antipathies; and philosophers considered that they had explained a phenomenon, when they had, after one manner or another, brought it under the influence of these chimerical agents.

The Clepsydra, or water-clock, may be considered as an hydraulic Clepsydra. machine, of which the invention is attributable to the Egyptians. This instrument indicated the hours by the successive elevations of the water which entered into a vessel, in quantities, regulated according to the proposed divisions of time, or by means of a hand, which the falling water caused to revolve on a graduated face or dial-plate. Ctesibius, and even some moderns, as Tycho Brahe, Dudley, and others, have not disdained to turn their attention to the improvement of this machine; the great perfection, however, that has been attained in the construction of clocks and watches, renders the clepsydra, in the present day, a mere matter of curiosity.

Water-mills, which must be classed amongst the most valuable Water-mills. hydraulic engines, were also an ancient invention, of the date of which we are ignorant. An epigram of the Greek Anthology seems to indicate that water-mills were first invented in the time of Augustus; but Vitruvius, who flourished under this prince, in his descriptions, does not speak of them as a recent invention; it is, therefore, highly probable that they were known long before that period. As to wind-mills, wind-mills. they were not employed in Europe till long after water-mills: some authors pretend, that the former were first invented by the French in the sixth century of the Christian era; while others assert that we owe them to the Crusaders, who brought them from the East, where they were even then very ancient; and generally preferred to watermills, in consequence of the sources of the rivers being much more rare and uncertain in those countries than in Europe. But whether they are the invention, or merely the adoption of Europeans, this is certain - that the progress of their improvement was very slow, and that we generally prefer the use of water-mills as more commodious and regular in their operation.

Bossut, when speaking of these ancient and important constructions, observes, "In viewing so many labours, so many monuments of human genius, the man, alive to gratitude, asks, to whom do we owe all these useful and sublime discoveries? What honours, what recompenses, have these benefactors of man received of their country, or of the world at large? history commonly answers nothing to these inquiries: while great pains are taken to transmit the names and the exploits of conquerors, who have ravaged the earth, and left traces of misery and destriction in all their steps."

It is, however, only the construction of certain hydraulic engines that we owe to the ancients; for they were wholly ignorant of any 
theoretical hydraulic principle: we may, therefore, easily conceive, that their first attempts were very rude and imperfect, and the defects of one machine were their only lessons for the construction of others less imperfect ; and it was thus, by successive attempts, and reiterated experiments and failures, that they were led by degrees to that state of perfection to which they ultimately attained.

Frontinus, To Sextus Julius Frontinus is commonly attributed the first theofirst theorist. retic notions of the motion of fluids. This author was inspector of the public fountains of Rome, under the emperors Nerva and Trajan, and he left, on this subject, a work entitled 'De aquæductibus urbis Romæ commentarius.'

In this treatise, the author first describes the aqueducts of Rome, cites the names of those which the Romans had constructed, and the dates of their constructions; he then fixes and compares with each other the measures of capacity which he employed at Rome for measuring the products of the adjutages. Thence he passes to a description of the means of distributing the waters of an aqueduct, or of a fountain. On these subjects he made several correct observations; for example, he showed that the quantity of water issuing from an adjutage, did not wholly depend upon its magnitude or superficies, but that the height of the reservoir above it must also be considered; a very obvious fact, but yet such an one as some more recent constructors have neglected to introduce into their investigations. He knew, also, that the tube designed to carry off part of the water of an aqueduct, ought to have, according to circumstances, a position more or less oblique with respect to the course of the fluid, \&c. Notwithstanding all this, however, he did not exhibit a mathematical precision on this subject; for he did not know the correct law which obtained between the velocity of the adjutage, and the height of the reservoir.

No other ancient author approximated in any manner towards a theoretical view of the principle of hydraulics; we are, therefore, completely justified in claiming the honour of the discovery of this science as wholly due to the moderns.

\section{PNEUMATICS.}

As the science of Pneumatics is in a great measure involved in the general doctrine of the theory of fluids, many branches of its history are so connected with that of hydrodynamics, that it is difficult to separate them from it; and, accordingly, many of the circumstances given under the latter head will equally apply to the former. There is, however, one important distinction: most of the properties of water are striking and obvious, while those of air are lidden and obscure; that water is a heavy body is a fact which must have been known from the earliest observations, but the gravitating properties of atmospheric air were by no means so evident, and therefore long remained a matter of doubt, even after the idea of its ponderability had been 
suggested. That some of the ancients had formed certain vague ideas of the gravitating power of the air, is obvious from many of their works still extant; but their notions were very confused, and involved in considerable obscurity. Thus Aristotle says, that all the elements Aristotle. have weight, with the exception of fire; adding, that a bladder inflated with air will weigh more than when it is quite empty. (De Cælo, lib. iv. c. i. op. tom. i. p. 485.) Plutarch and Stobæus quote Aristotle as teaching that the weight of air is between that of fire and earth; and the latter philosopher himself quotes Empedocles as attributing the act of respiration to the pressure of the air, by which it insinuates itself into the lungs. Again, Plutarch (De Placit., lib. iv. c. xxii. tom. ii. p. 903) expresses, in similar terms, the opinion of Asclepiades on this subject, and represents him as saying, that the external air, by its weight, opened its way by force into the breast. Hero of Alexandria, in his work 'Spiritalia,' applies the principle of Ctesibius and the elasticity of the air to produce and explain various effects, in such a way, as sufficiently to convince us that he was no stranger to several of the properties of atmospheric air ; and Ctesibius, adopting the principle of its elasticity, constructed wind-guns, which afterwards passed for modern inventions. There is, however, some difference between the ancient and modern air-gun: in that of Ctesibius, for example, the ball was not immediately exposed to the action of the air, but was impelled by the longer arm of a lever, while the air acted on the shorter; but the principle of operation is the same in both, and shows clearly that the elastic property of common air, if it could not be accurately measured, was at least known at that period. To this philosopher is also commonly attributed the invention of the sucking-pump.

Hero, to whom we have above referred, was a contemporary and scholar of Ctesibius; he describes in his treatise ' On Pneumatics,' a number of very ingenious inventions, a few of which are calculated for utility, but the greater part only for amusement; they are principally siphons, variously concealed and combined, fountains and water-organs, besides the syringe and fire-engine. This machine is said to agree in principle with the common engine of the present day; it consists of two barrels, discharging the water alternately into an air-veśsel; and it appears, from Vitruvius, that this was the original form in which Ctesibius invented the pump. Hero supposes the possibility of a vacuum in the intervals of the particles of a body, observing, that without it no substance could be compressible; but he imagined that a vacuum could not have existed throughout a perceptible space, and thence derives the principle of suction. The air contained in a given cavity, he says, may be rarefied by sucking out a part of it, and he describes a cupping instrument, which approaches very nearly to an imperfect air-pump.

It appears, therefore, that at this time, viz. (в. c. 100), many of the properties of air were fully understood, particularly its gravity and elasticity; but the followers of these philosophers, abandoning the 
opinions of their masters, maintained a different doctrine, and invented many absurd hypotheses to account for the operations of the various machines above alluded to.

\section{OP'TICS.}

It would be more easy to become the encomiast of this science than to trace its history; for there is no department of philosophy more deserving of our study, whether we consider its beauty or the multiplicity of its phenomena. Air, which serves as the medium of speech, and the vehicle of sound, enables us to carry on an intellectual intercourse with our fellow-creatures; but how considerably is that intercourse improved and facilitated by light, which brings before us their image - their image which tells us so much of their character and of their thoughts! The eye, so susceptible of multifarious impressions, conveys to the mind ideas of the forms by which bodies are limited, the colours by which they are adorned, their relative positions, and their motions. By a single look this admirable organ enables us to seize the indefinite modifications of the numerous objects that diversify our richest landscapes; and when it becomes aided by the instruments furnished by our knowledge of the laws of reflection and refraction, it contemplates the two kinds of infinity that would otherwise have remained unknown - that of animalculæ and of small inanimate objects, imperceptible by reason of their minuteness-and that of the celestial bodies, invisible by reason of their remoteness; thus opening to natural history a new field, to astronony a new heaven, and inviting us successfully to contemplate the universe of the poet:"Without bound,

Without dimension, where length, breadth, and height, And time and place are lost."

But our present employment must not be that of eulogy.

Mirrors.

The ancients for several centuries seem, as was naturally to be expected, to have had no knowledge of the theory of optics, and to have made no advances of consequence in the construction of optical instruments. The observance of a straight rod, partially immersed in water, would suggest to them the idea of refraction; and the sight of their own image, reflected from the smooth surface of a quiescent liquid, would naturally lead them to attempt the construction of artificial

mirrors. Accordingly, we find mention not merely of mirrors, but of metallic mirrors, in the earliest writings now extant, those of Moses. In Exodus xxxviii. 8, though Luther, and some few after him, translate the passage "He made the hand-bason of brass, and its stand also of brass, in the presence of the women who served before the door of the tabernacle;" yet they have been censured for this, since the Septuagint, the Vulgate, the English, and the Dutch Bibles, agree in translating "Beramoth' "of the mirrors," made, say many of the commentators, of polished brass. In the book of Job, too, now generally 
assigned by biblical critics to Moses as the author, we have (xxxvii. 18) in the address of Elihu to his afflicted friend, the inquiry:-

" Hast thou with him [God] spread out the heavens, Polished as a molten-mirror?"

Pliny assures $u^{1}$ that the pagan women, when attending the worship of their deities, were ornamented with metallic mirrors; and it seems extremely probable, as Cyril, of Alexandria, has affirmed, ${ }^{2}$ that the Israelitish women borrowed this custom from the Egyptians, and attempted to introduce it into their own worship. These early mirrors were flat, and so they appear to have been, generally, down to the time of Prasitelis, who lived in the reign of Pompey the Great.

His mirrors chiefly consisted of hammered plates of pure silver, as Prasitelis's we learn from the words of Pliny:-_ "Lamina duci et specula fieri mirrors. non nisi ex optimo (argento) posse creditum fuerat." But the silver was sometimes mixed with other metals:- "Id quaque jam fraude corrumpitur." Pliny further informs us, that "Specula quoque ex eo (stanno) laudatissima, Brundusii temperabuntur, donec argenteis uti cæpere et ancillæ." Highly-praised mirrors were manufactured at Brundusium, till the very maid-servants began to use silver ones. The monster, Nero, who it seems was short-sighted, employed as a mirror an emerald, reduced to a polished surface, on which he viewed by reflection, the combats of the gladiators. Here, however, is no optical science.

Aristotle is the earliest author whose writings on the subject of Aristotle. optics have reached our times; but, unfortunately, he has not been more successful in this branch of research than he was in reference to mechanics. His speculations on the nature of the rainbow, on the manner in which we perceive objects, and on different optical phenomena, are not merely crude, but generally erroneous; and in his

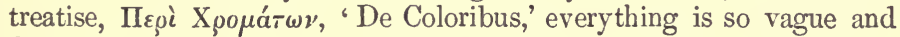
foreign from correctness of explication, that we should not hold ourselves justified in presenting any detail.

Soon after Aristotle, the celebrated geometer Euclid composed a Euclid. book on this subject. It appears under the title,'O $\pi \tau \iota$ à (neâter plural), and has been sometimes ascribed to another author bearing the same name. We are of opinion, however, that it fairly belongs to the geometrician, and that it is the 'Introduction' only which was written by another hand. As the deductions of Euclid, though founded upon a wrong hypothesis, are curious, considering the state of mixed mathematics at the epoch in which they appeared, we shall present a synopsis of them in this place.

Light propagates itself in right lines, as is shown by the shadows of Propositions. bodies, and by the passage of light through a door or window.

If the luminous object be equal to the object illuminated, the sections 
of the shadow are equal to the object, because the extreme rays are parallel. If the illuminated body be less than the luminous body, the shadow will gradually diminish: on the contrary, if the illuminated body be largest, the shadow will become gradually larger and larger.

Hypothesis. Visual rays issue from the eyes in diverging right lines, so as to form a pyramid, or cone, whose vertex is in the eye, and whose base encircles the object which we contemplate. Objects to which these rays are directed are seen by us; but we cannot see those towards which these visual lines do not point.

Objects appear larger, smaller, or equal, according as the angles under which we see them, are greater, less, or equal. The object is always seen in the direction of the visual ray; and those which are seen by the greatest number of rays are most distinct.

We never see the whole of an object. Of two equal objects, the nearest will be seen most distinctly. Every visible object becomes invisible at a certain distance.

Of equal parts of a right line, those which are most remote are seen under the smallest angle, and appear smallest.

Equal magnitudes, seen at unequal distances, appear unequal; that which is nearest will appear greatest.

Parallel lines, viewed from a distance, appear to converge.

If a horizontal surface be lower than the eye, the part which is most remote will appear to be elevated: if the horizontal surface be higher than the eye, the most remote portion will appear depressed.

A circle, viewed in the direction of its own plane, will appear as a right line.

When we look at a sphere with one eye, we never see so much as its half.

Viewed from a distance, a sphere appears as a circle.

When we look at a sphere with both eyes, if its diameter be equal to the distance between the two pupils, we see its half: if the interval between the pupils be greater, we see more than half; if the said interval be less, less than the sphere half will be seen.

If we look at a cylinder with one eye, we shall not see its half; as we approach nearer to it, we see less and less.

If the eye be in a line that passes through the centre of a circle perpendicularly to its plane, all the radii of the circle appear equal.

A circle, seen obliquely, appears flattened or contracted.

If several objects are in motion, and only one quiescent, that one will seem to move in a contrary direction.

If several bodies move with unequal velocities, and the eye is carried along in the same direction, those objects which have the same velocity as the eye will appear stationary; those which have greater velocities will appear to advance, while those which have less velocities will seem to recede.

If several objects have equal velocities, those which are most remote will appear to move most slowly. 
If the eye advance, distant objects will appear to be left behind.

If an object appear to augment, we judge that it is approaching towards the eye.

Objects unequally distant, which are not in a right line, may sometimes give the idea of a concave surface, and, at others, the idea of a convex surface.

These propositions relate to direct vision: there are a few which relate to reflection. Among these we find the problem, to find the Problem. height of an object by its shadow, or, in the absence of the sun, by means of a mirror, on the principle of the equality of the angles of incidence and reflection.

Euclid also attempts to determine the burning point of a concave spherical mirror, but errs in his conclusion; for he supposes that this point is the centre of the concavity, or the centre of the sphere.

How long this error in theoretical deduction remained uncorrected, it is not easy to say: it is well known that the ancients employed concave mirrors to rekindle the vestal fires. Plutarch, in his 'Life of Numa,' gives a description, not very distinct, however, of the $\sigma \kappa \alpha \phi \varepsilon i \alpha$, Numa. or dishes, which they thus employed. They seem to have been con- B.c. 710 . cave polished hemispheres, or segments nearly hemispherical; and Plutarch tells us, that the combustible matter was placed in their centre. This could not be; for the focus is at the distance of half the radius.

Imperfect, however, as the theory appears to have been, there can be no question that the practice of setting fire to substances by placing them in the foci of catoptric and dioptric instruments, was known some centuries before the Christian era. In addition to what is already socrates. adduced, we may cite a passage from the 'Clouds' of Aristophanes, in $\begin{gathered}\text { B... } 420 . \\ \text {. }\end{gathered}$ which he introduces Socrates as giving lessons to Strepsiades. The Aristophane object of the dramatist is to ridicule the philosopher. Strepsiades proposes an expedient by means of which he intends to pay his debts :-

"Strep. You have seen at the druggists that fine transparent stone with which fires are kindled.

"Soc. You mean glass, do you not?

"Strep. Just so.

"Soc. Well, what will you do with that?

"Strep. When a summons is sent to me I will take this stone, and, placing myself in the sun, I will, though at a distance, melt all the writing of the summons."

Writing, in those times, was traced on wax spread upon a more solid substance. Hence we see why Strepsiades should propose to melt the writing.

From this use of burning glasses, the transition to the mirrors, said Archimedes' to have been employed by Archimedes, is not either so extraordinary, burning or so difficult, as has been usually imagined. It has been repeatedly ${ }_{\text {B.c. }}$. 218 . affirmed, on the authority of Hero, Diodorus Siculus, Lucian, and 
Pappus, that Archimedes, by means of burning mirrors, set fire to the Roman fleet that was drawn up to besiege Syracuse. This, however, has been often denied. Descartes, and many after him, have regarded the thing as impossible. To the discussion of this question we cannot devote much space; it will be expected, however, that we do not pass it over in total silence.

Father Kircher, although he was among the incredulous, in reference to the Archimedean mirrors, concluded from an actual survey of the site of the town and harbour of Syracuse, that the distance to which the philosopher had to project the solar rays was not more than thirty paces. And whatever may have been the doubts formerly entertained on this subject, it is now well known, that the solar rays may, after reflection, be thrown to an effective focus at a much greater distance than this. Our deduction will not be speculative, but historical.

Zonaras.

Zonaras affirms, from the authorities above specified, that ArchiA.c. 1160. medes set fire to the Roman fleet by means of the solar rays collected

Proclus. A. C. 514 . and reflected by a polished mirror. He then adds, that Proclus, copying his example, burnt with mirrors of brass the fleet of Vitalian, who besieged Constantinople, under the emperor Anastasius, in the year 514 .

Tzetzes.

A. C. 1160 .

Tzetzes, who also quotes the same authorities, presents a particular explication of the mechanism of Archimedes' burning mirrors. "When Marcellus (says he), had removed his fleet out of the reach of the darts, Archimedes brought into play a hexagonal mirror, composed of several other smaller mirrors, each of which had twenty-four angles, and which could be moved by means of their hinges, and of certain plates of metal. He placed this mirror in such a position that it was in the midst of the meridional solar rays both in summer and in winter; so that those rays, being received on the mirror, were reflected by it, and kindled such a fire as reduced the Roman vessels to ashes." This is much such a description as might naturally be expected from a person not skilled in either optics or mechanics; and such a person was Tzetzes.

A very obscure hint, however, is sufficient to bring real genius into action; and it is highly probable, that the celebrated Napier, putting a happy construction upon the words of Tzetzes, recovered the admir-

Napier. able invention of Archimedes. In a paper of Napier's, bearing date A.c. 1596. June 2, 1596, and containing hints of secret inventions, we meet with the following:-

"The invention, proof, and perfect demonstration, geometrical and algebraical, of a burning mirror, which, receiving of dispersed beams of the sun, doth reflex the same beams altogether united, and concurring precisely in one mathematical point, in the which point most necessarily it engendereth fire; with an evident demonstration of their error, who affirm this to be made a parabolic section. The use of this invention serveth for the burning of the enemy's ships at whatsoever appointed distance. 
2ndly. "The invention and sure demonstration of another mirror which, receiving the dispersed beams of any material fire, or flame, yieldeth also the former effect, and serveth for the like use."

Long after this, viz., in 1726, M. Du Fay found that "at 200, 300, Du Fay. and even as far as 600 French feet (about 640 English), the rays of the sun received on a plane mirror, one foot square, and thence reflected to a concave one, 17 inches in diameter, consumed combustible bodies in the focus of the latter."

The success of this interesting experiment, doubtless, stimulated Buffon. Buffon to attempt the production of fire at a distance, after the manner of Archimedes, by one reflection only. In the year 1747 , after various trials with combinations of plane mirrors (in number sometimes amounting to 400), placed in a square frame, and brought to bear upon the object by means of screws, he succeeded in melting lead and tin at the distance of about 50 English yards; and in burning lighter substances, at the distance of 75 yards. This was affected in March and April. With summer heat, and a better apparatus, he expresses a certainty of producing combustion at more than 140 of our yards ; a distance, probably, double that at which Archimedes produced his conflagration. Since the publication of Buffon's results, the scepticism which prevailed in reference to the burning mirror of Archimedes has been rapidly wearing away. The philosopher had not to invent the apparatus for the purpose, but simply to apply what he had previously invented. With regard to the probable construction of Archimedes' apparatus, since this would not be the proper place to enter into detail, we refer to the speculations in Peyrard's edition of Archimedes, tom. Peyrard. ii., pp. $464-508$. We must now return to the point at which we A.c. 1808 . commenced this inquiry.

In the same century with Archimedes, lived Ptolemy Euergetes, Ptolemy celebrated by historians for causing to be placed on the tower of the Euergetes. Pharos at Alexandria, a mirror, which represented accurately all that was done on water or land within its scope; and by means of which, as some authors relate, an enemy's fleet was seen at the distance of 600,000 paces. We do not hold ourselves responsible for the truth of this. Father Abat, whose 'Amusemens Philosophiques' were published in 1763 , has an ingenious attempt to prove the probable existence of such a mirror at the time specified; and a copious abridgment of his arguments, by a very able writer, was given in the nineteenth volume of Tilloch's 'Philosophical Magazine.'

Among the writings which still remain of the celebrated Claudius Ptolemy the Ptolemy, the Alexandrian astronomer, is one on Optics. It is comprised in five discourses, or books, of which the first is lost ; most part of the remaining four are preserved, and have been carefully examined in the manuscripts, both by Delambre and by Venturi.

Although, as we have just remarked, the first book is wanting, we are not entirely ignorant of its contents, because each book commences with a recapitulation of what had been taught in the former. Thus 
we learn, that the first book treated of the relations between light and vision, of their resemblance and of their difference. It was probably a philosophical dissertation after the manner of Aristotle. Ptolemy supposes that vision is effected by means of a pyramid of visual rays, of which the vertex is at the eye, and the base at the object seen. This agrees with the notions of Euclid: some writers, earlier than either of these, taught, as the moderns do, that the rays of light proceed from the visible object; but this notion had few partizans, while the notions of Euclid and Ptolemy prevailed extensively. Vision by the axis of the pyramid is, according to Ptolemy, more correct and perfect than that by oblique rays. Vision makes bodies known, reveals their magnitude, colour, figure, rest, and motion; but all this requires light.

Shadows are not seen: we know them only by privation.

We can see better with two eyes than with one: with one only we do not see the object precisely at the same place as with two. We see the object simple, if the two axes of the pyramids are directed in the same manner upon the object; we see the same object double, if the axes are not directed naturally, and if the distance is a little less than that between the two eyes.

Colour makes part of bodies, it is the exterior crust. The eye perceives the direction of the visual ray which it sends towards the body; it perceives, in like manner, the length; it judges of the magnitude of the object, from the length of the pyramid combined with the magnitude of its base. If the humidity of the visual ray be promptly dissipated, bodies are seen better when near; if it be slowly dissipated, they are seen better at a distance.

That which causes certain persons to see better than others, is the abundance of the visual virtue; which, like all other faculties, fails in old men.

The moon has a colour which is peculiar to it, and which is only perceived in eclipses.

When we have long contemplated an object highly coloured, and then direct our eyes to another object, we attribute to that the colour of the former.

Things which we see by reflection partake of the colour of the mirror; as those which we see through a diaphanous, or transparent body, assume its colour.

When we observe a fire or a light at the horizon, beyond a pool of water, we perceive a long luminous train which follows our motion.

A sail seen from far, appears more curved than it is in fact; because the middle, which is seen directly, is perceived better than the edges, which appear to fly. Thus painters, when they would excite the idea of anything concave, give a less vivid tint to the middle than to the edges; and the contrary, if they would give the idea of convexity.

Similar to these are the remaining speculations in the second book.

In the third book Ptolemy proceeds to the subject of mirrors. The principal propositions are these:-In the plane mirror, the object is 
seen in the continuation of the perpendicular let fall from the object itself upon the plane, and as far behind the plane as the object is before it. This had been previously taught by Euclid; as had been the equality of the angles of incidence and reflection.

Ptolemy then recurs to the consideration of objects which appear in different places at the same time, though simple; and to those which, though more than two, appear in one and the same place. We cannot detail his speculations on these points, but must limit ourselves to one only, and that relating to astronomy. "It results (says he) from the preceding, that of things which are in the sky and subtend equal angles, those which are nearest the zenith ought to appear less, and those which are near the horizon appear greater; because we see the latter in a manner to which we are more accustomed. Elevated objects are seen in a way with which we are less familiar, and with difficulty of action." Thus, according to Ptolemy, the moon in the zenith appears smaller; because he who looks towards the zenith, is in a less natural position than when he looks at any object posited horizontally.

The author next returns to plane mirrors, and shows that in them objects are not disfigured; but that the right becomes the left, and vice versâ.

In concave mirrors, objects appear concave; in convex mirrors, they appear convex. In convex mirrors objects seem diminished. Thus, also, taught Euclid.

In a concave mirror, a curve line may, according to circumstances, appear either convex, concave, or rectilineal. In a convex mirror, objects appear on the side on which they really are; yet, by reason of our habit of judging, the right will seem to be on the left, and the left on the right.

Ptolemy's fourth book relates principally to concave mirrors.

$\mathrm{He}$ treats of the place of the image, and shows when it may be upon the surface of the mirror; when before that surface, when behind the eye, when behind the mirror.

When the image is behind the mirror, the distance of, the object from the mirror is less than that of the image.

When the image is between the eye and the mirror, the distance of the object from the eye, will be greater, equal, or less, than the distance of the image from the mirror, according to circumstances.

When the object is between the eye and the mirror, it appears in a different place from that in which it really is; and when we move it in one direction, it will appear to move in the contrary one.

Ptolemy next passes to the consideration of mirrors compounded of a plane and a concave, or of a convex and a concave; and explains the cases in which the image is direct or inverted, augmented or diminished; after which he traces the peculiarities of pyramidal mirrors with circular or polygonal bases, having the eye placed in the axis of the pyramid. In all this Ptolemy never determines the precise point 
of reflection, when the place of the eye and that of the image are known: he satisfies himself with showing, generally, that the object is before or behind the mirror, or the eye, or nearer to the mirror, or more remote than the eye ; the relations being not measured, but indicated vaguely.

Prolemy on refraction.

The fifth book of Ptolemy's 'Optics' contains his researches into the nature of refraction.

$\mathrm{He}$ explains the experiment of the piece of money so placed in a vessel that its edges render it invisible, until water is poured in, when the money is brought into sight, while it has remained quiescent. After this, he proceeds to a curious set of experiments, which we cannot here detail, in order to determine the relation between the positions of the incident and refracted ray, the media being air and water, for all degrees of incidence, varying by tens, up to $80^{\circ}$. The medium ratio of the sine of incidence to that of refraction, when the ray passes from air into water, is 4 to $3 \cdot 06936$ : according to the experiments of Newton, the ratio of these sines is 4 to $2 \cdot 99432$. When the ray passes from air into glass, the result of Ptolemy's experiments is, that the sines of incidence and refraction are as 3 to $2 \cdot 02158$. Newton gives for the ratio of these sines 3 to $1 \cdot 93048$. The correspondence between these respective ratios is greater than might reasonably have been expected, considering that the instruments employed by Ptolemy would not enable him to measure angles to nearer than half a degree. Newton employed rain water: Ptolemy has simply informed us that the water employed by him was always of the same density. Newton, again, employed common glass: Ptolemy calls his the purest glass: what that was we cannot say, because we know nothing of the glass manufactory among the Egyptians in the time of Ptolemy.

In the explication of astronomical refraction, Ptolemy proceeded in several respects as Cassini did in the last century. He, also, taught expressly, that the more a star is elevated, the less will be the difference between the true and the apparent place, and that this difference is nothing when the star is in the zenith, because the vertical ray does not undergo any flexure. This Ptolemy demonstrates by means of a figure; from which it appears, that in all cases the refraction carries the star towards the zenith.

Ptolemy afterwards describes different experiments connected with the subject of refraction; but his deductions from them are, in general, erroneous. Altogether, however, this fifth book of his 'Optics' is highly curious and interesting; and, indeed, the whole work is methodical and instructive; on which account, we have entered more fully into description of it than has been usual among the historians of optics.

It is an interesting inquiry, but by no means of easy determination, how far the ancients attempted to assist sight by dioptrical instruments. Roger Bacon, in his piece 'On the Secret Works of Nature 
and Art, and on the Nullity of Magic,' says, " transparent bodies may be so figured that things at the greatest distance may appear to be the nearest, and the contrary; so that, from an incredible distance, we may read the smallest letters, and number things, however minute: thus it is thought that Julius Cæsar, on the coast of Gaul, discerned, Julins Cæsar. by or through very large glasses, the disposition and situation of the camps and (coast) cities of Britannia Major." We here render per ingentia specula, by or through very large glasses, because the author is speaking of perspicua, transparent things. On what evidence he grounds his assertion we know not.

The ancients are well known to have used dioptric as well as catoptric burning-glasses; and it is not probable that they would employ the former thus, and yet remain ignorant of their magnifying power. The contrary, indeed, is plainly affirmed by Seneca: Literæ quamvis Seneca. minutæ et obscuræ, per vitream pilam aquâ plenam, majores clarioA. c. 64 . resque cernuntur. "Letters, though minute and obscure, appear larger and clearer through a glass bubble filled with water."' phenomenon, often observed, would naturally lead inquisitive men a few steps farther. But they could make no important advance (says Dr. Hook) without the art of grinding glass. This they had; so at least says Pliny. "Some glass is fashioned by blowing; some is Pliny. ground upon a wheel, or in a turning lathe; and some is engraved like silver. Sidon was celebrated for its glass-works, having also invented specula. Such was the ancient art of glass.", What were here meant by specula? The phrase "siquidem etiam specula excogitaverat," points evidently to some notable invention.

That glass was ground by the ancients is also fairly deducible from the language of Seneca. He tells us that prisms were in use among the virtuosi of Rome, in the days of Nero; and how could a glass prism be made by blowing? "A rod, or bar of glass (says he) is made with several angles; and if the rays of the sun pass through it, such colours are made as we see in the rainbow." Seneca also speaks of multiplying-glasses, the several faces of which must have been cut upon a wheel.

All this, however, brings us not to any such invention as that of telescopes. Nor are we aware of anything in antiquity that can indubitably be so interpreted. We have seen adduced, for this purpose, a passage from Pisidas, a Christian writer, who flourished at Constan- Pisidas.

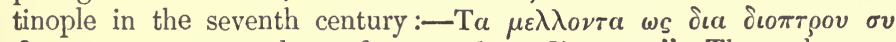
$\beta \lambda \varepsilon \pi \varepsilon \iota$; " you see things future as by a dioptrum." They who contend for the early invention of telescopes, say that this dioptrum was a prospective glass. But, if it were the same as the dioptrum employed by Hipparchus, and afterwards by Ptolemy, it was no other than a straight ruler of about four feet long, on which were fixed

1 Seneca, Nat. Quæst. lib. i. c. 7.

2 Plin. Nat. Hist. lib. xxxvi. c. 26.

3 Seneca, Nat. Quæst. lib. i. c. 7. 
three equidistnnt "sights," as they are technically called. A figure of it is given in M. Halma's edition of the 'Almagest.'

From what has been stated, then, it will be seen that the ancients had but little that deserved the name of optical science; that what they possessed was confined almost entirely to catoptrics, and was, even in reference to that department, extremely imperfect; that their instruments were chiefly catoptrical, some of which, however, they carried to very high perfection; and that we have no proof that their dioptric instruments went beyond single lenses, prisms, and multiplying glasses. In reference to refraction, the few researches which they had instituted, seem to have been ingenious and partially successful.

\section{ELECTRICITY.}

In attempting to give a short abstract of the history of that branch of Physics now universally termed Electricity, it will be perceived that a single fact observed in the earliest ages, and as far as our information can reach, at first recorded by the Greek philosophers, has by the subsequent addition of analogous phenomena, created and given name to a separate and important science.

Thales. B. c. 600 .

Theophrastus.

B. c. 321.

Thales of Miletus, who flourished about 600 years before the Christian era, is reported by subsequent writers to have described the power developed in amber by friction, by which it was enabled to attract bits of straw, and other light bodies; and an attempted explanation of this phenomenon is given as one of his philosophical dogmas. In the treatise of Theophrastus upon stones, we have the earliest de-

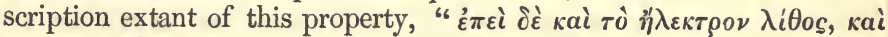

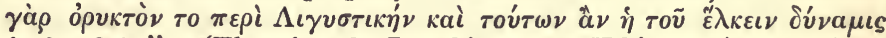

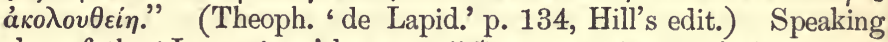

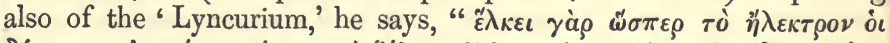

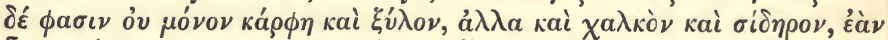

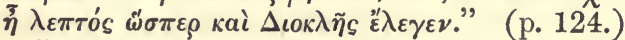

Pliny. It does not appear that Pliny's knowledge upon this subject exA. c. 70. tended beyond that of Theophrastus: he states of pieces of amber that "attritu digitorum acceptâ, vi caloris attrahunt in se paleas et folia arida, ut magnes lapis ferrum " (Plin. lib. xxxvii. cap. iii.); and "nec folia autem aut stramenta in se rapere, sed æris aut ferri laminas." Like Theophrastus, he also mentions the lapis Lyncurius as possessed of the same property. In the same chapter he adds, "In Syria quoque fœminas verticillos inde facere et vocare harpaga, quia folia, et paleas, vestium fimbreas ad se rapiat." Similar quotations might

Solinus.

A.c. 218. easily be adduced from the writings of Priscian and Solinus. Salmasius, in his commentary upon the latter author, asserts that karabe, the word by which amber was known among the Arabs, is said by Avicenna to be of Persian origin, and to signify the power of attracting straws. ('Hyl. Iat.') 
The ancient naturalists were well aware of another interesting electrical phenomenon in the shocks of the torpedo. Aristotle says that Aristotle. " this tish causes or produces a torpor upon those fishes it is about to B. C. 341 . seize, and having by that means got them into its mouth, feeds upon them." He further adds, that this fish " hides itself in the sand and mud, and catches those fish that swim over it by benumbing them, and of this some have been eye-witnesses: the same fish has also the power of benumbing men." Pliny says that " this fish, if touched by a rod or spear, even at a distance, paralyses the strongest muscles, and binds and arrests the feet however swift." ('Nat. Hist.' xxxii. ch. i.) Galen the physician has given a similar description (" $\mathrm{De}$ Locis Affect.') Oppian describes the organs by which the animal Oppian. produces this effect (lib. ii. ver. 62); and Claudian has a short poem claudian. upon the subject. The medical writers speak of applying the shocks A. C. 395 . of the torpedo for the cure of diseases. Scribonius Largus, (cap. xli.) Scribonius relates, that Anthero, a freedman of Tiberius, was by this means cured of the gout. Dioscorides advises the same remedy for inveterate pains of the head (lib. ii. art. Torpedo). Further notices of this application may be found in Galen, 'Simp. Medic.' lib. xi. Paulus Galen, \&c. Egineta, lib. vii. Such is a summary of the knowledge of the ancients upon electricity; but the curious reader will also find much interesting matter on this subject in a dissertation by Dr. Falconer, contained in the third volume of the "Memoirs of the Manchester Society,' wherein it is rendered exceedingly probable that the use of conductors for attracting lightning from the clouds, was not unknown even in these early times.

The scanty fragments of information which the literature of the middle ages affords on this and every other scientific subject may be passed over in silence; and it may fairly be asserted, that from the time of Pliny until the end of the fifteenth century no advance whatever took place in the branch of natural philosophy now before us. There is, however, mention made of more than one electrical phenomenon in the scholia upon Homer, by Eustathius, bishop of Thessalonica, about A. C. 1160; one of these passages, relating to. Walimer, the king of the Goths, who commenced his reign, according to $\mathrm{Du}$ Fresnoy, A. c. 415 , is too singular to be passed by unnoticed.

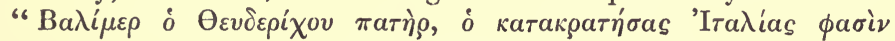

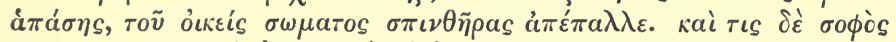

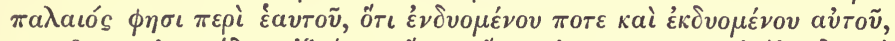

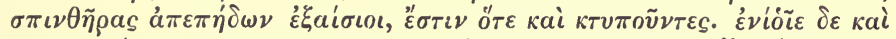

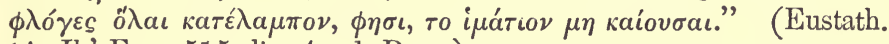
' in Il.' E. p. 515, lin. 4, ed. Rom.)

"Walimer, the father of Theodoric, (uncle, marpìs?) who conquered, as they say, the whole of Italy, used to emit sparks from his own body; and a certain ancient philosopher says of himself, that once when he was dressing and undressing himself, sudden sparks

A. c. 144. 
were emitted, occasionally crackling, and sometimes, he says, entire flames blazed from him, not burning his garment."

Although it is clear that philosophical speculations upon the natural properties of matter were by no means valued or pursued in what we should now call a truly scientific manner; yet the following singular passage from St. Jerome may afford a sufficient proof that the facts which had been before recorded, were neither lost nor forgotten. " "Arguit in hoc loco Porphyrius et Julianus Augustus, vel imperitiam historici mentientis, vel stultitiam eorum qui statim secuti sint Salvatorem, quasi irrationabiliter quemlibet vocentem hominem sint secuti: cum tantæ virtutes, tantaque signa præcesserint, quæ Apostolos antequam crederent, vidisse non dubium est. Certe fulgor ipse, et majestas divinitatis occultæ quæ etiam in humanâ facie relucebat, ex primo ad se videntes trahere poterat aspectu. Si enim in magnete lapide et succinis hæc esse vis dicitur, ut anulos et stipulam et festucas sibi copulent; quanto magis Dominus omnium creaturarum ad se trahere poterat quos vocabat." Sti. Hieronymi, Presb. lib. i. ' Com. in Matt.' cap. ix. 


\section{N D E X.}

Asop, birth, 4

-, a slave, 4

- , anecdotes, 5

- , liberation, 6

—, travels, 8

—, settles at Babylon, 9

$\longrightarrow$, precepts, 9

—

$\longrightarrow$, death, 12

Alexander's early masters, 120

_- obligations to Aristotle, 121

education, 122

fellow pupils, 125

- coolness to Aristotle, 134

Alexandrian school, destruction of, 345

Amelius, 291

Ammianus Marcellinus, 296

Ammonius Saccas, 288

Anaxagoras, birth, 21

—, doctrines, 23, 308, 332

Anaximander, birth, 19

, doctrines, 20, 307, 332

Anaximenes, 20, 332

Ancient commentators on Aristotle, 155

Ancient Theists and Atheists, 21

Antisthenes, 250

Apellicon the Teian, 168

Apollodorus' Summary of Aristotle's Life, 101

Apollonius, 324

Arcesilas, 218

Archelaus, 24

$\longrightarrow$, philosophy, 25

Archimedes, 315

- science and inventions, 314-321, 337, 346,347

— , birth, 315

- death, 322

Archytas, 308

Aristarchus, 314, 335

Aristillus, 314

Arithmetic, 311

Aristotle, 346, 351, 353, 363

—, early histories of, 96

—_, birthplace, 101

early education, 102
Aristotle comes to Athens, 103

- works, 105

— , reputed ingratitude to Plato, 108

- gives lectures, 113

- at the court of Hermias, 114

- flies to Mytilene, 116

marries Pythias, 117

is calumniated, 117

- goes to Macedon to educate Alexander, 123

—, influence over Alexander, 123

, misrepresented, 124

returns to Athens, 126

, division of his scholars, 127

—, their social meetings, 127

- $\quad$ their public exercises, 128

-, prosperity, 131

— returns to Chalcis, 132

- accused of impiety, 133

—, defence, 133

— advice to Callisthenes, 134

- death, 145

—, will, 147

- descendants of, 148

, fate of his works, 150

157

- , style of his exoteric works, 163

$\longrightarrow$, popularity of his exoteric works, 165

- difficulty of his scientific works, 165

—, imputed variance in his views, 166

- , literary notice of his existing writings, 172

-, Categories, 172

$\longrightarrow$, on Interpretation, 172

— Former Analytics, 172

— Topics, 172

- - on Sophistical Proofs, 173

-, Physical Lectures, 173

- , on the Heavens, 173

-

- Meteorology, 174

- , to Alexander, on the World, 174

$\longrightarrow$, on the Soul, 174

—, tracts on physical subjects, 174 
Aristotle, on Breath, 17

$\longrightarrow$, Accounts of Animals, 175

- on the Parts of Animals, 175

- on the Movement of Animals, 175

- , on the Locomotion of Animals, 176

- on the Engendering of Animals, 176

$\longrightarrow$, on Colours, 176

_ from the Book on Sounds, 176

-

—, on Plants, 176

—, on Wonderful Stories, 176

—, Mechanics, 176

_ Problems, 177

- , on Indivisible Lines, 178

, the Quarters and Names of the Winds, 178

, on Xenophanes, Zeno, and Gorgias, 178

—, the Metaphysics, 178

- Nicomachean Ethics, 179

-

- , the Eudemian Ethies, 180

-, on Virtues and Vices, 180

- Politics, 180

—, Economics, 180

, the Art of Rhetoric, 180

- , the Rhetoric to Alexander, 181

$\longrightarrow$, on the Poetic Art, 182

Astronomy, 307, 329

Athenæus's account of Aristotle's works, 153

Athenian social intercourse, 128

Autolycus, 310, 334

BUFFON, 357

Calippus, 333

Callisthenes, 134

Carneades, 219

Cephisodorus' book against Aristotle, 113

Chrysippus, 260

Cicero. Imitations of Aristotle, 162

- , birth and education, 207

_., Consulate, 209

- Triumvirate, 211

-

_ Governor of Cilicia, 212

—, Philosophical Writings, 216-227

-, Rhetorical Works, 227-230

_- Moral and Physical Writings, 230-234

_, Epistles, 235

$\longrightarrow$, Poetical and Historical Works, 235

, Orations, 235

MSS., editions, \&c., 242

Claudian, 363

Cleanthes, 259

Comparison between the Plotinian School and

Crates, 252 the Quietists, 301

Ctesibius, 323, 348, 351
Cynical Doctrines, review of, 252

Cynicism the parent of Stoicism, 249

Damascius, 225

Democritus, 21, 308

Destruction of ancient literature, 154

Dialectics, 32

Difference between the Greek and Latin lan-

Diogenes, 251 guages, 238

Diogenes Apolloniates, 24

Dion Prusæus, 265

Dogmatism, effects of, 269

Du Fay, 357

ECLECTICISM, rise of, 287

Eclectic Philosophy calculated to impede Christianity, 302

English translations of Plato, 90

Epictetus, 265

Epicurus, birth, 185

- visits Athens, 185

- opens school, 185

- , manner of life, 186

$\longrightarrow$, success as a teacher, 186

- , death, 187

$\longrightarrow$, will, 187

- emancipates his slaves, 188

$\longrightarrow$, doctrines, 188

-

-

- , divisions of his philosophy, 191

—, Physics-the universe, 192

-, atoms, 193

-

-, psychology, 197

-, astronomy, 197

—, Moral Philosophy - the gods, 128

—, death and pain, 200

$\longrightarrow$, the chief good, 201

$\longrightarrow$ justice, 203

- , successors of, 204

Eratosthenes, 323, 336

Eubulus, 115

Euclid, 313, 335, 353

Eudoxus, 308, 333

Eustathius, 363

FABLE, use of, 3

Frontinus, 350

GALEN, 363

Gellius's account of Aristotle, 130

Gorgias, 29

Greek Geometry, 307

- Mechanics, 312

- Music, 312 Optics, 312 
Herachitus, 57

Herennius, 289

Hermias, 114, 116

Hermolaus, a friend of Callisthenes, 138

Hero, 348, 351

Herpyllis, 149

Hiero's crown, 319

Hierocles, 294

Hipparchus, 339

Hippias, 30

Hippocrates, 308

Hostility between Aristotle and Isocrates, 112

Hypatia, 296

Hydrostatics, 347

IMMORTALITY of the soul, 56

Introduction of the Greek Philosophy to Rome, 216

Isocrates' hostility to Aristotle, 112

Isodorus, 295

JAMBLICUS, 293

LeONidas, 120

Leucippus, 21

Literature fashionable in Rome, 98

Longinus, 289

Lysimachus, 121

Macrobius, 296

Marcus Aurelius Antoninus, 265

Marinus, 295

Mechanics, 312, 345

Menechmus, 308

Modern Platonists, 89

Monimus 252

Music, 311

NAPIER, 356

Neo-platonic School, 294

New Academy (the), 218

Numa, 355

\section{ONESICRITUS, 252}

Oppian, 363

Optics, 312

Orators before Cicero, 240

Origen, 289

\section{Pamphila, 99}

Panætius, 261

Peripatetics, 126

Peyrard, 357

Phavorinus, 99

Phllip's acquaintance with Aristotle, 119

Philo and Antiochus, 223

Philosophy of the ancients, more speculative than practical, 215
Philosophy of the early poets, 15

- of Italy, 57

Philolaus, 333

Pisidas, 361

Plato, fables concerning, 53

—, birth, 53

- a disciple of Socrates, 54

, early writings, 54

retires to Megara, 55

composes the Phædo, \&c., 55

- visits Italy, 57

— visits Egypt, 59

- opens a school at Athens, 61

, Dialogues, 61

_ ridicules the Sophists, 61

visits Dionysius, 63

-

_- idea of a commonwealth, 64

- Cosmogony, 65

-

- , creation of living beings, 67

- , properties of matter, 67

- , system of Laws, 67

- , death, 68

-, spurious writings, 68

—, Philosophy, 71

- Politics, 76

—_, Natural Theology, 79

—_, Physical System, 79

_

-

$\longrightarrow$, successors, 89

-, admirers in Britain, 90

_- English translations of, 90

— sentiments towards Aristotle, 107

$\longrightarrow$, as a mathematician, 309

Pliny, 361, 362

Plotinian school, 291

- doctrines, 297, 301

Plotinus, 289

—, intended Platonopolis or philosophical colony, 291 works, 297

Plutarch, 355

$\longrightarrow$, account of Aristotle's works, 151

Pneumatics, 350

Porch, the, 255

Porphyry, 291

Posidonius, 261

Potamo, 288

Prasitelis, 358

Proclus, 295, 355

Prodicus, 29

Protagoras, 29

Ptolemy, 340, 357

Euergetes, 357

Pyrrho, birth of, 271 , disciples of, 273 
Pyrrhonism, causes of, 270

Pythagoras, 58, 307, 332

Pythias, wife of Aristotle, 117

Quietists, the, 301

Roman eloquence, 240

Sceptical Philosophy, 270

$\longrightarrow$, history of, 270

- account of, 275-283

School of Alexandria, 313

Scribon Largus, 363

Seneca, birth, 261

-, education, 261

-, banishment, 262

- , tutor of Nero, 263

$\longrightarrow$, death, 263 works, 264

Sextus Chæronensis, 273

Sextus Empiricus, 273

$\longrightarrow$, works of, 274, 283

Socrates, birth, 34

—, a student, 34

-, a soldier, 35

$\longrightarrow$, marriage with Xanthippe, 36

, poverty, 37.

—, method of teaching, 37

$\longrightarrow$, the 'Irony' of, 38

$\longrightarrow$, the 'Demon' of, 39

—, religion, 41

_, moral character, 42

- calumuies regarding, 43

$\longrightarrow$, doctrines, 44

$\longrightarrow$, precepts, 44
Socrates, politics, 45

$\longrightarrow$, accusation, 48

- , trial and condemnation, 48

- , death, 49

—_, sects founded by his followers, 50

Solinus, 362

Sophists, the, 26

$\longrightarrow$, effects of their teaching, 32

- ridiculed by Plato, 61

Stagirus built, 124

Stoical philosophy, 249

Stoicism introduced into Rome, 261

Strabo's account of Aristotle's works, 150

Superstition in Greece, 26

Thales, birth, 17

- doctrines, 18, 307, 330, 362

Themistus, 296

Theophrastus, 362

Timocharis, 314

Timon the Phliasian, 273

Tzetzes, 356

Uncongeniality of Plato and Aristotle, 110

WISE Men of Greece, 16

Xanthus, master of Esop, 4

Xanthippe, wife of Socrates, 36

ZENo, 254

$\longrightarrow$, his doctrines, $255-259$

Zenodorus, 309

Zenodotus, 295

Zonaras, 356 



\section{DAY USE}

RETURN TO DESK FROM WHICH BORROWED

\section{LOAN DEPT.}

This book is due on the last date stamped below, or

on the date to which renewed.

Renewed books are subject to immediate recall.

RKFI.FV

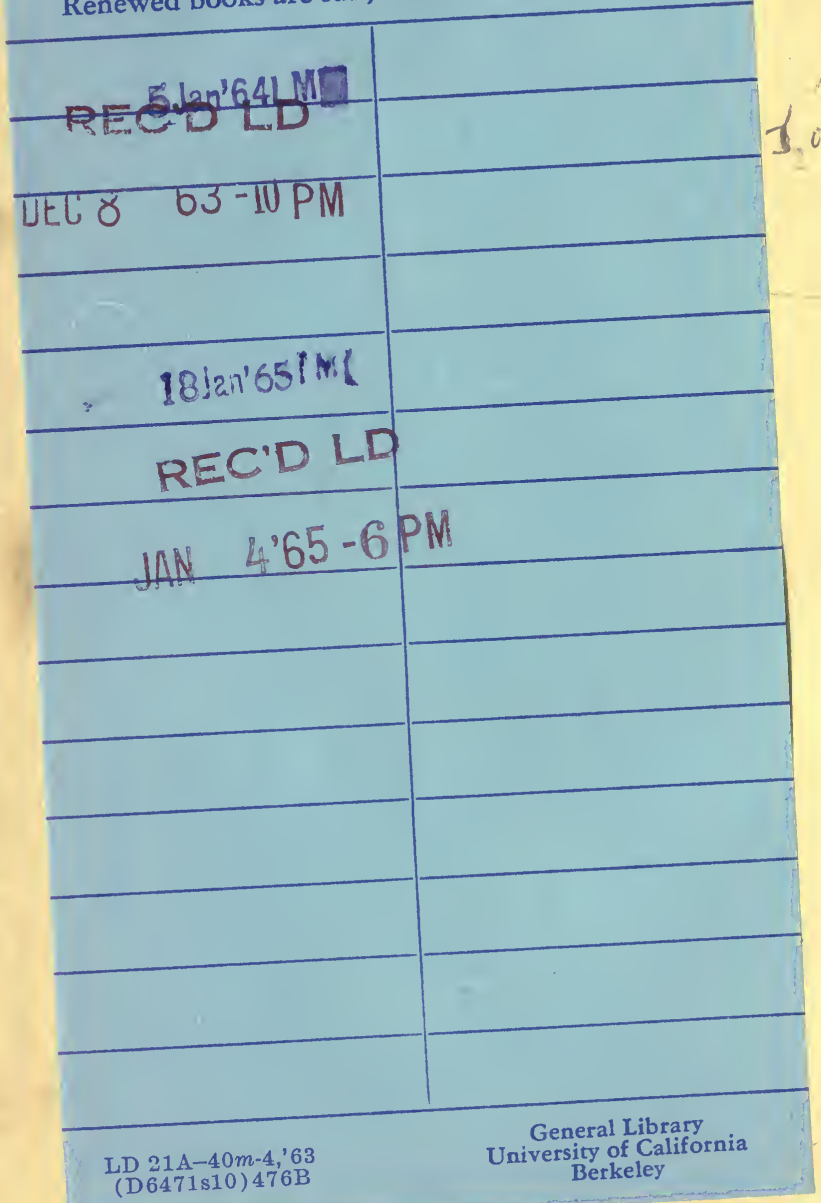




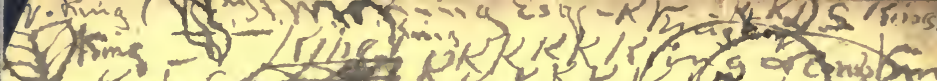

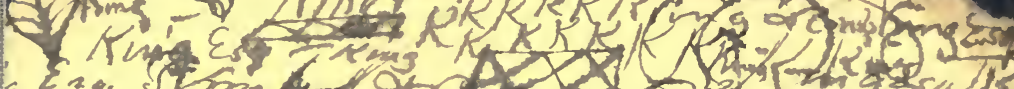

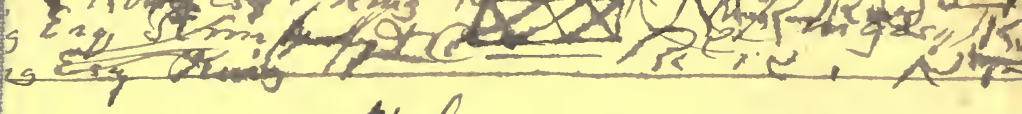
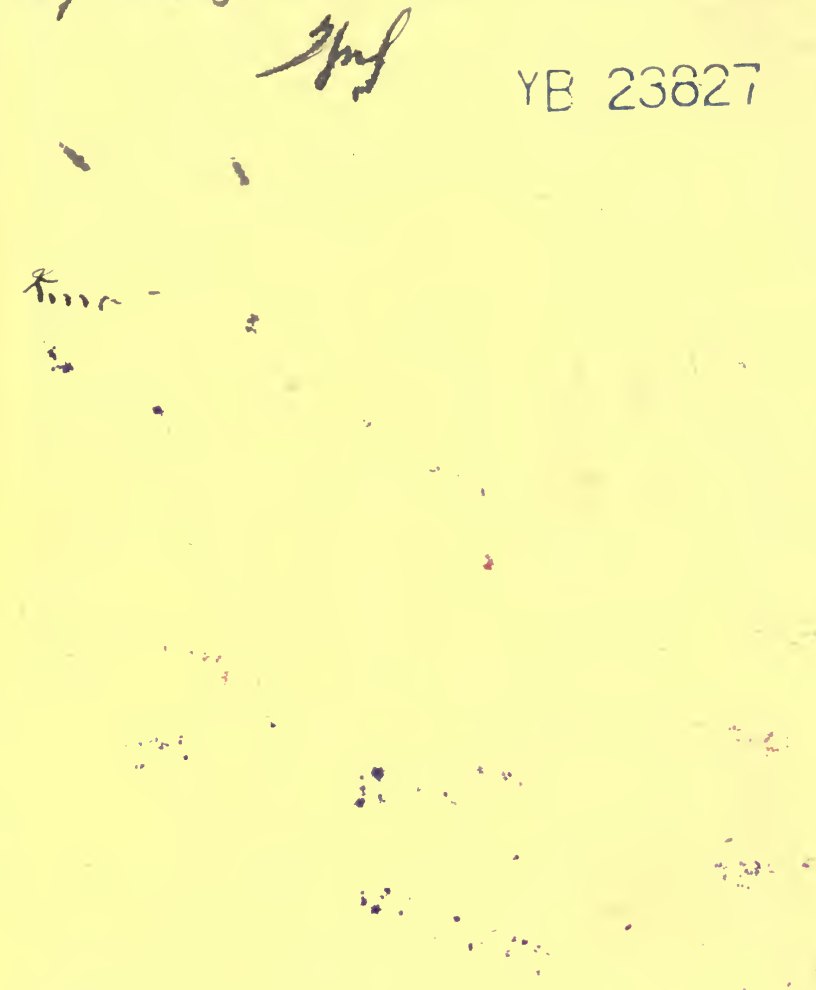

$\because \quad 6 \div 2 x^{2} x$ 


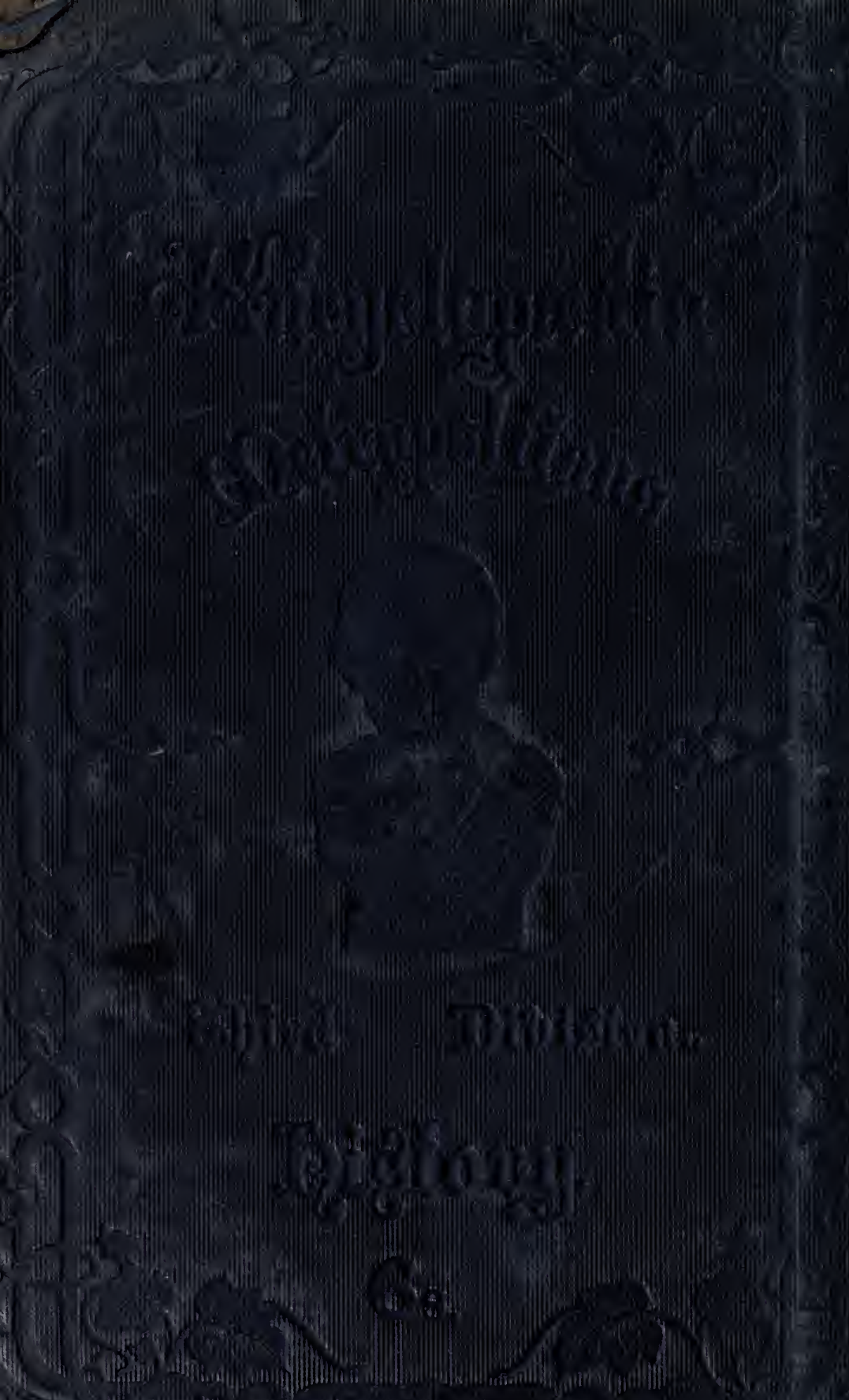

20 4 -

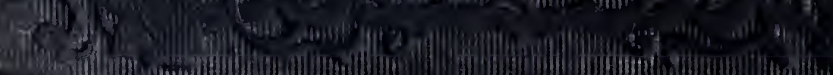

